\title{
Submarine Landslides: Selected Studies in the U.S. Exclusive Economic Zone
}

\section{U.S. GEOLOGICAL SURVEY BULLETIN 2002}

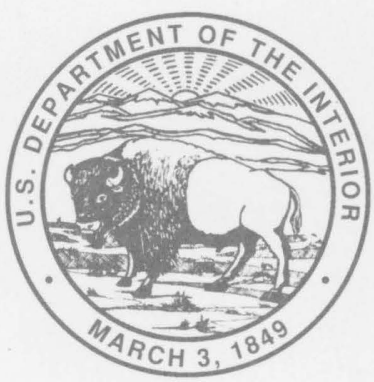




\section{Submarine Landslides: Selected Studies in the U.S. Exclusive Economic Zone}

Edited by W.C. SCHWAB, H.J. LEE, and D.C. TWICHELL 


\title{
U.S. DEPARTMENT OF THE INTERIOR BRUCE BABBITT, Secretary
}

\author{
U.S. GEOLOGICAL SURVEY
}

Dallas L. Peck, Director

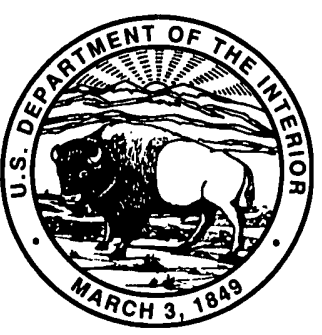

Any use of trade, product, or firm names in this publication is for descriptive purposes only and does not imply endorsement by the U.S. Government

For sale by

U.S. Geological Survey, Map Distribution

Box 25286, Bldg. 810, Federal Center

Denver, CO 80225

\section{Library of Congress Cataloging in Publication Data}

Submarine landslides : selected studies in the U.S. exclusive economic zone / U.S. Department of the Interior, Geological Survey; edited by W.C. Schwab, H.J. Lee, and D.C. Twichell.

p. $\quad \mathrm{cm}$. - (U.S. Geological Survey bulletin ; 2002)

Supt. of Docs. no.: 119.3:2002

1. Mass wasting-United States. 2. Marine sediments-United States.

I. Schwab, William C. II. Lee, Homa J. III. Twichell, David C.

IV. Series.

[QE598.5.U6]

$557.3 \mathrm{~s}-\mathrm{dc} 20$

[551.3'07]

91-33678 


\section{FOREWORD}

With each passing year, the United States becomes increasingly dependent upon resources from the oceans. Historically, the sea has provided food resources, recreational resources, and a defensive barrier in times of war. During the last few decades, we have turned to the sea to provide other resources such as oil, gas, and construction aggregate which had been almost exclusively extracted from onshore areas. With an ever-growing population demanding more resources to sustain a high quality of life, the United States will have to turn more frequently to the oceans to meet its increasing requirements for fresh water, energy minerals, industrial minerals, agricultural minerals, waste disposal, recreational diversions, military exercises, and other activities. All this must be accompanied and balanced with environmental concerns.

Recognizing the growing importance of the oceans to the future of the United States, President Reagan in 1983 expanded the United States to include those parts of the oceans extending 200 miles off our shores. This enormous new territory, the Exclusive Economic Zone (EEZ), is over 3 million square nautical miles in size which is about 30 percent large than the land area of the United States.

The United States Geological Survey (USGS) through its Offshore Geologic Framework program was directed by the President and the Congress to explore the sea floor of this new frontier. In partnership with colleagues from other Federal agencies, the States, academia, industry, and scientists from the international community, the USGS began a program in 1983 to map the EEZ. To date, these reconnaissance-scale studies have mapped approximately 2 million square nautical miles of the EEZ and unveiled a fascinating, but extremely complex, sea floor. These discoveries hold the promise of potential resources that ultimately will help meet the needs of all Americans. This promise will be realized, however, only through continued research, technology advancement, and informed decision making.

Although our studies discovered significant potential resources, they also identified geologic processes that not only threaten the availability of these potential resources but also threaten human life directly. This volume is dedicated to increasing the understanding of one such process-submarine landslides. The authors focis on documenting our new understanding of the geologic processes involved in submarine landslides and the consequences of these processes.

Submarine landslides fall within a general category marine geologists call geohazards. To evaluate fully the significance of any geohazard, it is necessary to develop an understanding of the basic geological processes involved as well as the geographic distribution, frequency of occurrence, scale, magnitude, and consequences of the processes. All these topics and more are covered as the authors share their insights into submarine landslides occurring in diverse geologic settings throughout the EEZ from New England to Hawaii, from the arctic to the tropics, and from shallow water to deep ocean basins.

Without question,. submarine landslides involve significant geologic processes which must be understood and documented for policy makers to make informed decisions as to when and how the marine resources within the United States EEZ are to be exploited. This volume is a substantial and unique contribution to expanding the knowledge base of submarine landslides. 


\section{CONTENTS}

Foreword III

Submarine Landslides: An Introduction 1

By H.J. Lee, W.C. Schwab, and J.S. Booth

U.S. Atlantic Continental Slope Landslides: Their Distribution, General Attributes, and Implications 14

By J.S. Booth, D.W. O'Leary, Peter Popenoe, and W.W. Danforth

Submarine Mass Movement, a Formative Process of Passive Continental Margins: The Munson-Nygren Landslide Complex and the Southeast New England Landslide Complex 23

By D.W. O'Leary

The Cape Fear Landslide: Slope Failure Associated with Salt Diapirism and Gas Hydrate Decomposition $\mathbf{4 0}$

By Peter Popenoe, E.A. Schmuck, and W.P. Dillon

Ancient Crustal Fractures Control the Location and Size of Collapsed Blocks at the Blake Escarpment, East of Florida $\mathbf{5 4}$

By W.P. Dillon, J.S. Risch, K.M. Scanlon, P.C. Valentine, and Q.J. Huggett

Tectonic and Stratigraphic Control on a Giant Submarine Slope Failure: Puerto Rico Insular Slope 60

By W.C. Schwab, W.W. Danforth, and K.M. Scanlon

Slope Failure of Carbonate Sediment on the West Florida Slope 69

By D.C. Twichell, P.C. Valentine, and L.M. Parson

Slope Failures in an Area of High Sedimentation Rate: Offshore Mississippi River Delta 79

By J.M. Coleman, D.B. Prior, L.E. Garrison, and H.J. Lee

Salt Tectonics and Slope Failure in an Area of Salt Domes in the Northwestern Gulf of Mexico 92

By B.A. McGregor, R.G. Rothwell, N.H. Kenyon, and D.C. Twichell

Slope Stability in Regions of Sea-Floor Gas Hydrate: Beaufort Sea Continental Slope 97

By R.E. Kayen and H.J. Lee

Mass Movement Related to Large Submarine Canyons Along the Beringian Margin, Alaska 104

By P.R. Carlson, H.A. Karl, B.D. Edwards, J.V. Gardner, and R. Hall

Comparison of Tectonic and Stratigraphic Control of Submarine Landslides on the Kodiak Upper Continental Slope, Alaska 117

By M.A. Hampton

Submarine Landslides That Had a Significant Impact on Man and His Activities:

Seward and Valdez, Alaska 123

By M.A. Hampton, R.W. Lemke, and H.W. Coulter

Processes Controlling the Style of Mass Movement in Glaciomarine Sediment:

Northeastern Gulf of Alaska 135

By W.C. Schwab and H.J. Lee 
Liquefaction of Continental Shelf Sediment: The Northern California Earthquake of 1980143

By M.E. Field

A Submarine Landslide Associated with Shallow Sea-Floor Gas and Gas Hydrates off Northern California 151

By M.E. Field and J.H. Barber, Jr.

Sur Submarine Landslide, a Deep-Water Sediment Slope Failure $\mathbf{1 5 8}$

By C.E. Gutmacher and W.R. Normark

Seismically Induced Mudflow in Santa Barbara Basin, California 167

By B.D. Edwards, H.J. Lee, and M.E. Field

Submarine Landslides in a Basin and Ridge Setting, Southern California 176

By M.E. Field and B.D. Edwards

Giant Volcano-Related Landslides and the Development of the Hawaiian Islands

By W.R. Normark, J.G. Moore, and M.E. Torresan

Submarine Slope Failures Initiated by Hurricane Iwa, Kahe Point, Oahu, Hawaii 197

By W.R. Normark, Pat Wilde, J.F. Campbell, T.E. Chase, and Bruce Tsutsui 
Edited by W.C. Schwab, H.J. Lee, and D.C. Twichell

\title{
Submarine Landslides: An Introduction
}

\author{
By H.J. Lee, W.C. Schwab, and J.S. Booth
}

\section{INTRODUCTION}

Consider these events: In the late afternoon of March 27, 1964, one of the most violent earthquakes of all time rocked southern Alaska. In the community of Valdez, shortly after the shaking began, a cargo ship unloading at the town dock began to toss violently, with vertical motion in excess of $10 \mathrm{~m}$ (meters) and rolls of $50^{\circ}$. Next, the docks vanished into turbulent water. The entire waterfront followed, along with warehouses, a cannery, heavy equipment, and 30 people. Ten-meter waves propagated back and forth across the bay on which Valdez is situated, surging over $500 \mathrm{~m}$ inland and flooding much of the town. For months following these catastrophic events, the shore area near Valdez continued to subside.

In August 1969, Hurricane Camille, one of the century's most intense hurricanes, struck the coast of Louisiana. At an oceanographic station near the South Pass portion of the Mississippi Delta, wave heights of 21 to $23 \mathrm{~m}$ were recorded before the instruments used to measure wave height failed. Three offshore drilling platforms were badly damaged or destroyed. Later, one of the platforms was found, half-buried in mud and displaced $30 \mathrm{~m}$ downslope.

On November 19, 1929, a major earthquake occurred on the continental slope south of the Grand Banks, off the eastern coast of the United States and Canada. During the earthquake, many submarine communications cables failed near the earthquake epicenter. For 13 hours following the earthquake, cables continued to fail in a systematic sequence: with the passage of time, cable breaks occurred farther and farther to the south.

On the Hawaiian island of Lanai, limestone-bearing gravel blankets the coastal slopes and extends to an altitude of $326 \mathrm{~m}$. The characteristics of the gravel show that it originally formed at sea level. The island is sinking so rapidly that the deposit could not have been deposited during previous worldwide highstands of sea level. Most probably, the deposit was placed by a giant wave.

These four examples share a common element: they all show the devastation that can result from submarine landslides, a general term used to refer to downslope movement of sea-floor material en masse (also termed

Manuscript approved for publication July 12, 1991. "mass movement"). At Valdez, a large portion of a submarine delta-front failed during the Alaska earthquake and slipped into the bay, carrying with it the town's waterfront and generating massive waves. During Hurricane Camille, the large waves generated by the storm loaded the weak sea-floor muds, causing them to fail and move downslope. On the Grand Banks, the magnitude 7.2 earthquake caused slope failures on the continental slope and rise. Some of these slope failures transformed into high-velocity turbidity currents that traveled over $720 \mathrm{~km}$ (kilometers) from the source area, breaking communication cables along the way. Off the coasts of the Hawaiian Islands, the remains of giant slope failures have been found using a modern side-looking sonar system. Some are more than $200 \mathrm{~km}$ long with volumes up to $5,000 \mathrm{~km}^{3}$. The great displacement of the landslide blocks from their original source suggests that some of the failures were cataclysmic events, capable not only of removing landmass from the islands' coastlines but also of generating tremendous sea waves. One of these giant landslides may have been the cause of the wave that carried gravel from sea level up to an elevation of $326 \mathrm{~m}$ on the island of Lanai.

Most submarine landslides are not so spectacular. In fact, most undersea slope failures probably occur without any person being aware of them, but as man reaches farther into the oceans to extract oil and gas and mineral resources, searches for environmentally safe areas to dispose of waste, and occupies more coastal areas, the potential impact of undersea landslides on humanity increases. Major loss of property and life has already occurred; more losses may occur in the future. Even when particular landslides have no direct impact on man's development, they are still of basic interest to geologists in understanding how sediment and rock are transported to deeper water. Mass instability acts as a fundamental process in the formation and modification of continental and insular margins. The occurrence of such features tells us about the environments in which they form and allows us to use fundamental geologic knowledge to exploit resources and increase our knowledge of the importance of environmental hazards such as earthquakes and hurricanes.

The purpose of this report is to introduce the subject of submarine landsliding through selected studies that have been partly or fully supported by the U.S. Geological 


\section{RECORD}

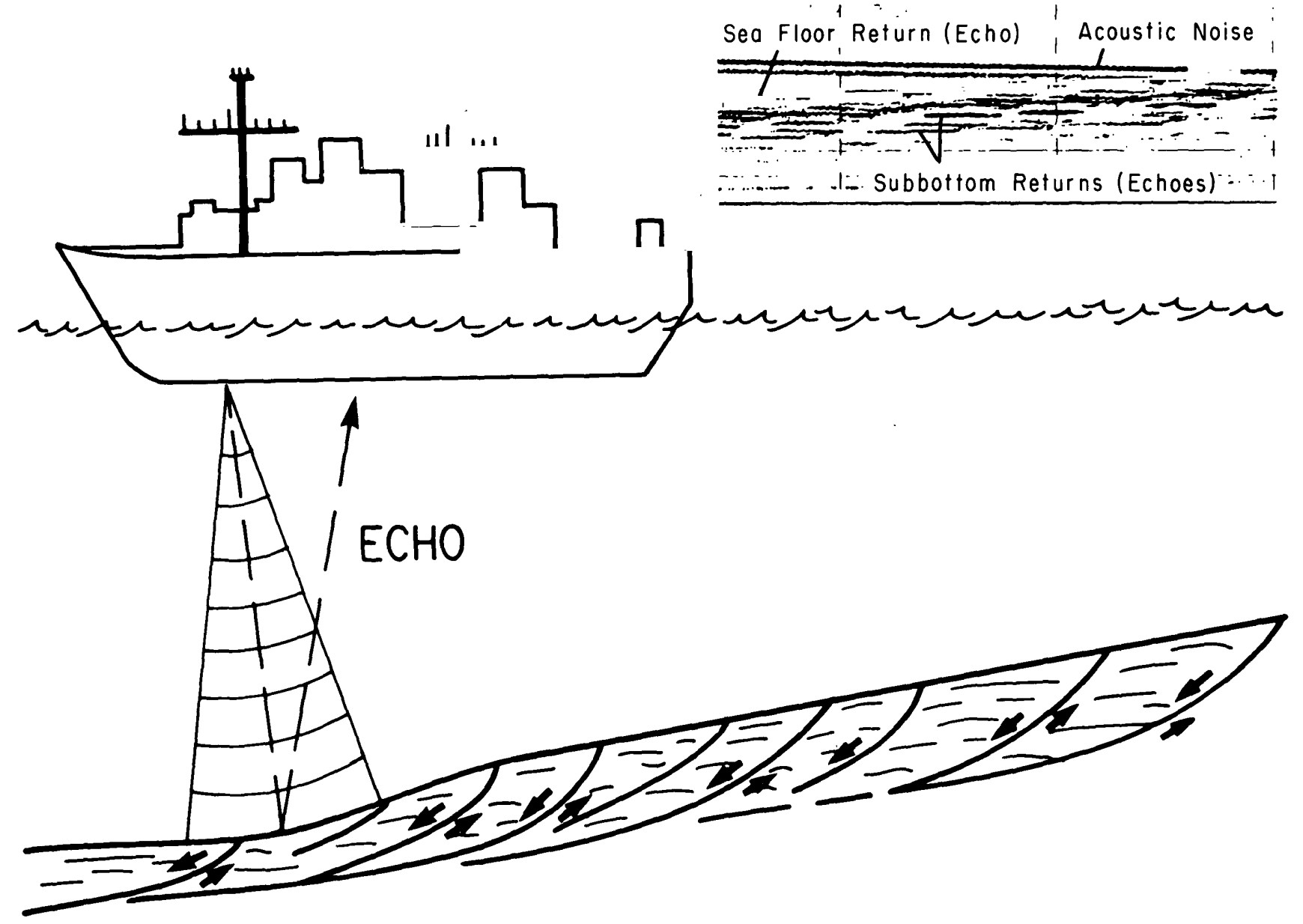

Figure 1. High-resolution profiling technique. The ship is crossing a series of slump blocks (arrows showing the direction of relative movement). The record in the upper right is a real profile showing what this idealized mass movement looks like on a seismic-reflection profile.

Survey. The report is not meant to be comprehensive but rather is an attempt to provide a cross section of the type of research going on within the academic, government, and ocean-engineering communities. The selected studies clearly demonstrate that marine investigators are just beginning to appreciate that submarine landslides are a common, widespread feature of the U.S. Exclusive Economic Zone (EEZ) and impose many constraints on the future of sea-floor utilization. The title of each section reflects the major point exemplified by the landslide being described. The sections are mainly visual in format and are intended for individuals with a general interest in the offshore areas of the United States, either from a basic scientific or from a seabed utilization point of view.

\section{METHODS FOR FINDING SUBMARINE LANDSLIDES}

Submarine landslides are occasionally recognized when they directly involve the shoreline. The catastrophic failure at Valdez is one of the best examples of this type. Other landslides disrupt or destroy offshore facilities, for example, the offshore platform lost during Hurricane Camille or the submarine cables broken off the Grand Banks. Some landslides are identified when major changes in water depth or sea-floor relief are observed, perhaps by fishermen or divers. The detection and recognition of most submarine landslides, however, relies on remote observation of seafloor and subbottom morphology. That is, does the sea floor have the appearance of slope failure? Are features observed that look like landslides that have been seen on shore?

Development in offshore remote-sensing technology over the last 3 to 4 decades (such as precision depth recorders, high-resolution seismic-reflection systems, and sidescan-sonar systems) has allowed marine investigators to determine the appearance of the sea floor accurately and map areas of landslides. The basic principle of seismicreflection techniques involves detection of sediment stratigraphy and structure as indicated by variations in acoustic- 
reflection characteristics (fig. 1). In general, the higher the frequency of the signal sent out by the shipboard seismic system, the higher the resolution and the smaller the depth of penetration below the sea floor. For example, a seismic system that uses an outgoing signal with a frequency of 12 $\mathrm{kHz}$ (kilohertz) is typically used as a precision depth recorder (high resolution with little, if any, subbottom penetration) while a $3.5-\mathrm{kHz}$ system, although yielding a slightly lower resolution, is capable of penetrating over $100 \mathrm{~m}$ of soft sediment and defining subbottom landslide geometry. High-power, low-frequency systems (for example, air guns and sparkers) can penetrate up to $15 \mathrm{~km}$ beneath the sea floor and resolve reflecting surfaces 100 to $200 \mathrm{~m}$ apart. .

Probably the most significant recent development in mapping sea-floor morphology is the evolution of sidescansonar systems (fig. 2). The principle of sidescan sonar is relatively simple. An instrument towed by a research vessel sends out two sound beams which are directed to either side of the towed vehicle. The sound beams are tuned to create a beam that is very narrow in the fore and aft direction but very broad in the across-track direction. The transmitted sound beams image, or "insonify," a narrow slice of sea floor perpendicular to the ship's track. The acoustic energy returned from the sea floor (acoustic backscatter) is then sensed, or "heard," by the instrument and transmitted to a shipboard recorder which displays the data in twodimensional form as an image. As the instrument is towed along, it insonifies adjacent slices of the sea floor and, in this way, builds an acoustic image. The level of acoustic backscatter is a function of, among other things, the sea-floor topography, roughness, and composition. Using computer-processing techniques, it is now possible to produce true-scale mosaics of large areas of sea floor similar in appearance to aerial photographs.

Conventional sidescan-sonar systems can insonify swaths of sea floor typically less than $1 \mathrm{~km}$ wide. These high-resolution systems are inappropriate for use as a reconnaissance tool because of the huge amount of time required to survey large areas. Two other systems, SeaMARC I (Sea Floor Mapping And Remote Characterization) and GLORIA (Geological LOng-Range Inclined Asdic) are able to obtain much broader swaths of the sea floor (up to $5 \mathrm{~km}$ for SeaMARC and $45 \mathrm{~km}$ for GLORIA). The GLORIA system is towed only $50 \mathrm{~m}$ below the sea surface at relatively fast speeds ( 8 knots) and can cover an area of as much as $27,700 \mathrm{~km}^{2}$ per day. Thus, GLORIA can obtain true large-scale reconnaissance views of the sea floor which are needed in assessing the extent and style of mass movement processes in the deep-water sections of the EEZ. Many examples of the use of both seismic-reflection and sidescan-sonar techniques in the investigation of submarine slope instability are presented in the sections of this report.

\section{HISTORY}

Our awareness of the importance and extent of submarine slope failure and mass movement has evolved over a long period. It has become apparent to marine geologists and ocean engineers that the largest landslides on Earth have occurred on the bottom of the sea. As recently as the 1960's, however, submarine landslides were thought to be rare in ocean basins except on steep slopes, on the soft sediment of river deltas, or in seismically active areas. The first evidence for large-scale submarine slope failure and mass movement came primarily from studies of anomalous sea-floor topography (for example, see Shepard, 1955; Moore, 1961; Inderbitzen, 1965) or displaced material (for example, see Heezen and Ewing, 1952, 1955) and from studies of ancient strata from many locations (Jones, 1937; Beets, 1946; Kuenen, 1949; van Straaten, 1949). Development of seismic-reflection, sidescan-sonar, and sea-floor sampling techniques since the 1950's coupled with increasing interest in the continental margins as a resource area has resulted in the accumulation of a large amount of data pertinent to the evaluation of submarine slope failure and mass movement. Large volumes of sediment and rock are involved in these slope failures, and they occur on seismically active and inactive submarine slopes of varied steepness (Dill, 1964; Heezen and Drake, 1964; Menard, 1964; Kelling and Stanley, 1970; Moore and others, 1970; Lewis, 1971; Booth and Dunlap, 1977; Carlson and Molnia, 1977; Embley and Jacobi, 1977; Hampton and Bouma, 1977; Embley, 1980; Booth and others, 1984).

\section{CAUSES OF SLOPE FAILURE AND ANALYSIS TECHNIQUES}

As recently as the mid 1970 's, the few actual observations of submarine slope failure in the literature were mainly qualitative, because slope stability analysis requires knowledge of the slope topographic profile, the shape of the major slip surface (failure plane), and a variety of engineering properties of the material that composes the sea floor-information that is seldom available in the case of submarine landslides. Early investigators recognized from qualitative studies that several mechanisms can induce or "trigger" submarine slope failure. Heezen (1956) suggested that "over-steepening" of the slope due to rapid deposition of sediment was responsible for submarine slope failure near the mouth of the Magdalena River in Colombia. Dill (1964) suggested that the generation of gas associated with the decomposition of organic matter could lead to slope failure. Submarine slope failure triggered by earthquakes first was recognized from qualitative observations (for example, see Gutenberg, 1939; Heezen and Ewing, 1952, 1955; Ryan and Heezen, 1965). Henkel (1970) showed that large storm waves could load the sea floor and cause slope 

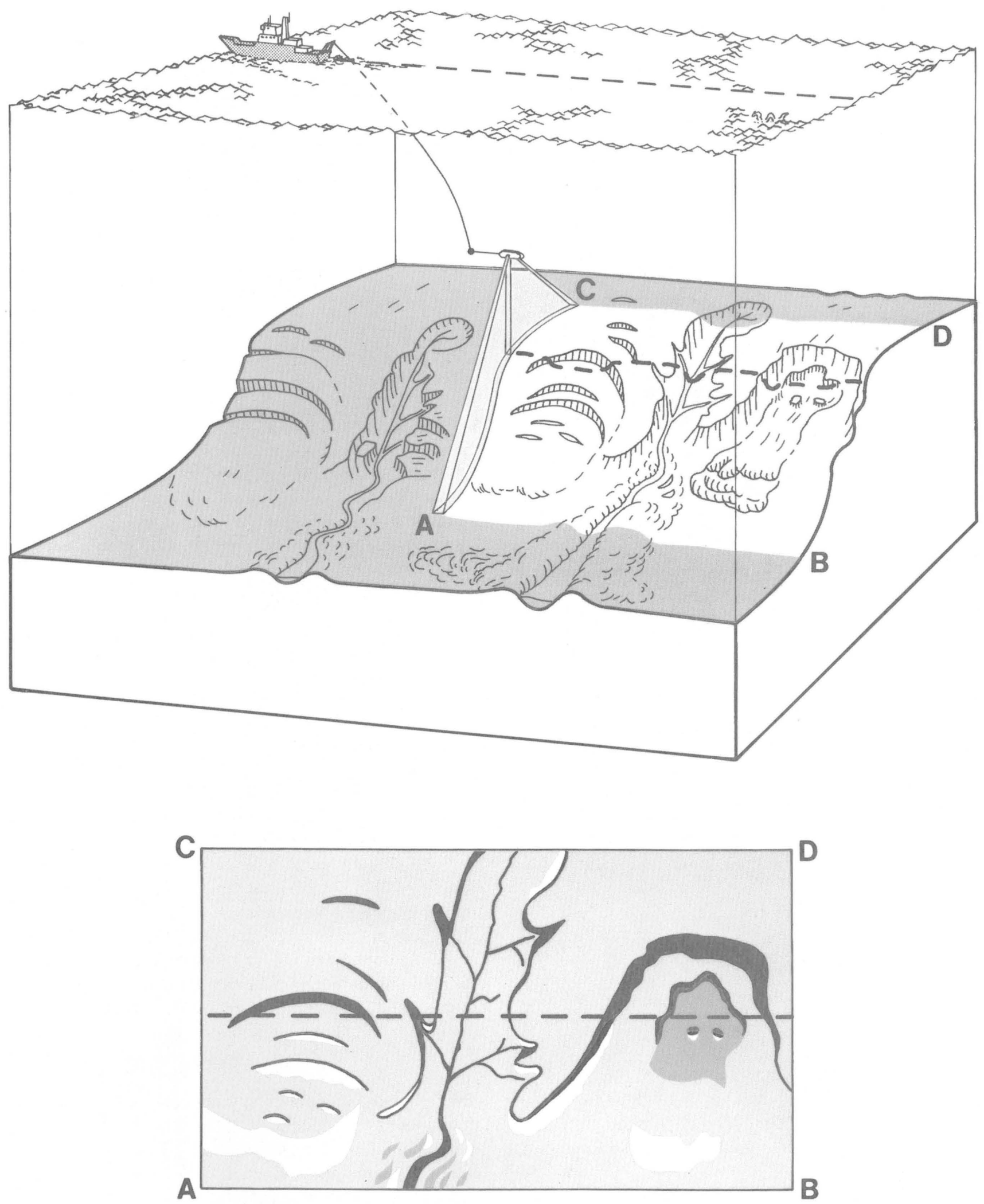

Figure 2. Principles of sidescan-sonar for mapping sea-floor landslide deposits. The top panel illustrates how sidescan sonar operates, and the bottom panel sketches the resulting sidescan-sonar image. 


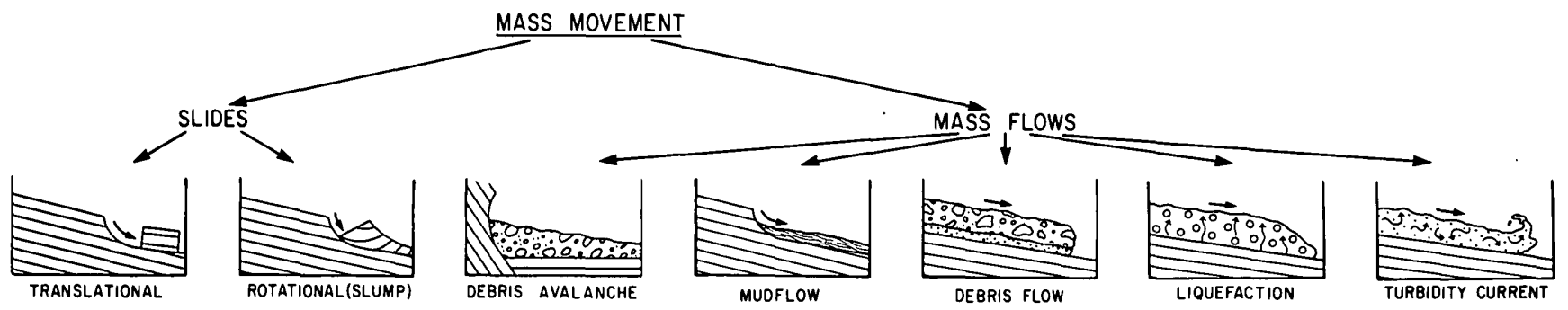

Figure 3. General landslide classification (modified from Varnes, 1958).

failure. This failure mechanism was observed clearly during the passage of Hurricane Camille (Bea and others, 1983).

Quantitative analysis of the mechanics of submarine slope failure requires making assessments of the strength of sediment and the magnitude of stresses acting downslope. An important quality of sediment is that the strength decreases as the excess pore-water pressure (that is, in excess of hydrostatic pressure) increases. Excess pore-water pressures commonly exist in deposits that are accumulating rapidly and can be evaluated using simplified sedimentation models (Terzaghi, 1956; Gibson, 1958). Excess pore-water pressures can also be caused by bubble-phase gas and by repeated loading from earthquakes or storm waves.

Downslope stresses result from gravity, earthquakes, or storm waves. Because, typically, so little is known about the properties and geometry of submarine slopes, investigators use analysis methods that are very simplified. The slopes are generally approximated by a tilted plane that extends for considerable distance in all directions (the so-called "infinite slope"). Earthquakes are represented by a constant lateral force that is proportional to the peak horizontal acceleration resulting from the shaking (Morgenstern, 1967). Wave-induced stresses are related to wave height, water depth, and other factors (Henkel, 1970; Seed and Rahman, 1978).

By evaluating the magnitude of downslope stresses relative to sediment strength, investigators have shown how steep slopes, high deposition rates, earthquakes, and storm waves can lead to slope failure (for example, Morgenstern, 1967; Almagor and Wiseman, 1977; Hampton and others, 1978; Schwab and Lee, 1983; Booth and others, 1984; and Lee and Edwards, 1986).

More sophisticated models for evaluating sediment deformation on slopes have also been developed. The quantitative accuracy of any deformation prediction is, however, limited by the quality of the sediment or rock stress-strain relation. Choosing the appropriate stress-strain relation for a seabed material poses major problems. For example, a significant change in the stress-strain behavior occurs when a sediment is subjected to repeated loading (Esrig, Ladd, and Bea, 1975; Anderson, 1976; Wright, 1976). Thus, the dominant influence of repeated loading (stresses associated with earthquakes or storm waves), along with other factors such as poor sample quality (Lee, 1985), severely limit the accuracy of these more advanced methods for offshore slope stability analysis, as a common practice. For site-specific studies, however, in which adequate resources are available for field borings, laboratory testing, and advanced computer modeling, accurate analyses of sea-floor deformations can be made using the finite-element approach (Arnold, 1973; Wright, 1976).

\section{TERMS USED TO DESCRIBE SUBMARINE LANDSLIDES}

Studies of sedimentary structures associated with slope failure and mass movement have shown that during and following slope failure, sediment can achieve a broad range of styles of mobility, from rigid block motion to turbulent flow. These styles of mobilization involving various types of material can be referred to by different terms. In this report, we follow the terminology recommended by. Varnes (1958) with some modification (fig. 3).

Slope failure occurs when the downslope driving forces acting on the material composing the sea floor are greater than the forces acting to resist major deformations. Following slope failure, the failed mass moves downslope under the influence of gravity and possibly other forces. Thus, mass movement (also known as mass wasting) is defined as the movement of the failed material driven directly by gravity or other body forces, rather than tractive stresses associated with fluid motion. If the moving sediment takes a form that resembles a viscous fluid, the process is termed mass flow. Such a failure has considerable internal deformation with innumerable invisible or shortlived internal slip surfaces. Slides are translational or rotational movements of essentially rigid, internally undeformed masses along discrete slip planes. In the literature, all forms of mass movement are occasionally referred to as slumps. Correctly, slumps are a special kind of slide in which blocks of failed material rotate along curved slip surfaces (rotational movement). In each of these types, movement can be fast or slow. Extremely slow movement is called creep.

Submarine slides can become mass flows as the sliding mass progressively disintegrates and continued downslope movement occurs (Morgenstern, 1967; Hampton, 1972). End-member products of disintegrating slides have been given special names. Debris flows are flows of 
sediment in which the sediment is heterogeneous and may include larger clasts supported by a matrix of fine sediment. Mudflows involve predominantly muddy sediment. Turbidity currents involve the downslope transport of a relatively dilute suspension of sediment grains that are supported by an upward component of fluid turbulence. Turbidity currents are often generated by the disintegration and dilution of slides or debris flows, although they may be generated independently from other mass-movement events. Liquefaction occurs when a loosely packed sediment collapses under an environmental load. Here, the grains temporarily lose most contact with one another, and the particle weight is temporarily transferred to the pore fluid. Excess porewater pressures are induced by this behavior. They eventually dissipate, although sometimes very slowly, and the material may flow downslope under the influence of gravity or spread laterally under the influence of stresses induced by earthquakes or perhaps storm waves.

Recent surveys using modern remote-sensing equipment have revealed truly giant submarine landslides that involve the failure of thousands of cubic-kilometers of rock and sediment (for example, see Moore and others, 1990). When these landslides have disintegrated into relatively smaller pieces (which may still be quite large) and have clearly moved rapidly, they are referred to as debris avalanches. Debris avalanches may occur on a smaller scale, too. In particular, when some sandy sedimentary deposits fail, most commonly as a result of slope oversteepening, they avalanche downslope as a thin grain flow.

\section{ENVIRONMENTS}

Submarine landslides are not distributed uniformly over the U.S. EEZ. Instead, they tend to occur most often where there are thick bodies of soft sediment, where the slopes are steep, and where the environmental loads are high. These conditions are met in fjords, deltas, and submarine canyons and on the continental slope.

\section{Fjords}

Of all the environments of U.S. EEZ, Alaskan fjords (and areas within Puget Sound, Washington) with high sedimentation rates are likely the most susceptible to slope failure, both in terms of the proportional areal extent of deposits that can become involved in mass movement and also in terms of the recurrence interval of slope failures at the same location. Fjords are glacially eroded valleys that have been inundated by the sea. They are typically fed by sediment-laden rivers and streams that drain glaciers. These factors lead to environmental conditions that are highly conducive to slope failure. The submerged sides of glacial valleys are commonly very steep and may extend to great depths, perhaps $1,000 \mathrm{~m}$ or more. There is typically a delta at the head of the fjord formed by streams that may drain the glacier that initially eroded the valley. These fjord-head deltas have beds that dip at $5^{\circ}$ to $30^{\circ}$ between 10 and $50 \mathrm{~m}$ water depth. In greater water depths, the submerged part of the delta dips at angles of $0.1^{\circ}$ to $5^{\circ}$ to the flat basin floor, typically at depths between 100 and $1,000 \mathrm{~m}$ (Syvitski and others, 1987). The glacial streams feeding these deltas carry rock flour and coarse sediment whose deposits easily lose strength when shaken by an earthquake. The sediment may also be deposited so rapidly that pore-water pressures cannot dissipate completely as sedimentation continues. The resulting underconsolidated state of the sediment causes abnormally low strength. Organic matter brought down with the glacial debris may be abundant, and it can decay and produce bubble-phase gas that also may lead to elevated pore-water pressure and low strength. Some fjorddelta deposits are so near instability that they fail during particularly low tides, during which the supporting forces of seawater are temporarily removed from the sediment. Some of these steep slopes with weak sediment fail seasonally or semicontinuously yielding numerous small-scale slope failures. Slope failures of a seasonal or semicontinuous nature have been reported in many fjords in Canada; for example, Bute Inlet (Syvitski and Farrow, 1983; Prior and others, 1986), Knight Inlet (Syvitski and Farrow, 1983), and North Bentinck Arm (Kostaschuk and McCann, 1983) and are probably common in Alaska, as well. Fjord-head delta slope failures occasionally produce catastrophic effects, such as occurred in Valdez (Coulter and Migliaccio, 1966; Hampton and others, this report), Seward (Lemke, 1967; Hampton and others, this report) and Whittier (Kachadoorian, 1965) in the 1964 Alaska earthquake or in Kitimat Arm, Canada (Prior, Bornhold, and others, 1982; Prior, Coleman, and others, 1982).

The sidewalls of fjords can also be unstable. Deposition of suspended sediment on the steep $\left(10^{\circ}\right.$ to greater than $90^{\circ}$ overhangs) submerged valley sides can frequently lead to small slope failures (Farrow, Syvitski, and Tunnicliff, 1983). Even more important are slope failures on side-entry deltas that build out rapidly onto the sidewall slopes. Failures in Howe Sound, Canada (Terzaghi, 1956; Prior and others, 1981), are of this type.

Finally, the deep fjord basins, which tend to have slopes of less than 0.1 , commonly receive failed sediment masses and flows from the side walls and fjord-head deltas. If these landslides incorporate enough water during their movement, they can progress through mass flows into turbidity currents. These mass flows and turbidity currents can be fed into and across the basins by channels (Syvitski and others, 1987).

Slope failures in fjords can generate large waves which cause major damage to coastal communities. During the 1964 Alaska earthquake, much of the damage and many of the fatalities in Valdez (Coulter and Migliaccio, 1966; Hampton and others, this report), Seward (Lemke, 1967; Hampton and others, this report) and perhaps Chenaga (Plafker and others, 1969) resulted from giant waves 
generated by submarine landslides in fjords. Waves $8.2 \mathrm{~m}$ in height were generated during the major sea-floor failure at Kitimat Arm, Canada, in 1975 (Murty, 1979).

Because fjords are found in rugged, mountainous terrain, the fjord-head deltas and side-entry deltas are frequently the only flat land available for development. These marginally stable to unstable locations become the sites of coastal developments. Not only do these developments become vulnerable to natural slope failure, which might occur frequently even if the developments were not present, but man's activities can also lead to additional slope failures. For example, a river channel stabilization program at Howe Sound (Terzaghi, 1956) caused rapid delta growth to be localized and probably contributed ultimately to slope failure.

\section{Active River Deltas on the Continental Shelf}

Active river deltas are the next most likely sites for slope instability in the U.S. EEZ. Many rivers contribute large quantities of sediment to relatively localized areas on the continental margins. Depending on a variety of environmental factors, including wave and current activity and the configuration of the continental shelf and coastline, thick deltaic deposits can accumulate fairly rapidly. These sediment wedges and blankets can become the locations of sediment instability and landsliding partly because of their thickness. To create large, deep-seated landslides, a thick deposit of comparatively low-strength sediment is needed. Because most of the continental shelves were subaerially exposed during the last glacial cycle, most sediment on the shelves from that time or before has been eroded or desiccated. Accordingly, the strengths of these older deposits are commonly high enough to resist downslope gravitational stresses on the gentle shelves, and all but the very greatest storm- and earthquake-induced stresses as well. Only in areas of continued modern deposition where significant thicknesses (tens of meters) of younger sediment have been deposited above the strong, old sediment do landslides occur. These younger deposits tend to have relatively low strength because of rapid deposition rates. In addition, decaying organic matter can produce bubblephase gas that can further reduce strength. These locations may fail under gravitational loading (due to the slope steepness alone) or during storms or earthquakes.

The locations of the major sedimentary depocenters provide some information on where undersea landslides might be expected on the continental shelf. For example, the Yukon River is a major source of sediment (60 million tons per year) in the northern Bering Sea. Although the prodelta is nearly flat, there are indications of localized liquefaction of sandy silt (Clukey and others, 1980) during large storms.

The occurrence of slope failures on active deltas of the continental shelf off southern Alaska is not surprising.
Glacially fed rivers debouching into the Gulf of Alaska or adjacent sounds and inlets contribute 450 million tons of sediment per year (Milliman and Meade, 1983). Slope failures have been identified in modern sediment all along the Alaskan margin (Reimnitz, 1972; Molnia and others, 1977; Carlson, 1978; Schwab and Lee, 1983, 1988, this report; Schwab and others, 1987; Lee and Edwards, 1986). The landslides are likely induced by either storm waves or earthquakes (Schwab and Lee, 1988, this report); the high incidence of landsliding arises because of the intensity of earthquake and storm-wave loading, the thickness of modern sediment, and the tendency of the glaciomarine sediment to lose strength when cyclically loaded.

The west coast of the United States has relatively short, steep rivers with small drainage basins. The sediment yield of these rivers can be high but is extremely variable (Milliman and Meade, 1983). There are indications of slope instability on some of the deltas, for example, that of the Klamath River (Field and others, 1982; Field, this report).

The Mississippi River contributes the most sediment to the EEZ of any single river within the United States (2 to $7 \times 10^{8}$ tons of sediment per year; Coleman and others, 1980; Milliman and Meade, 1983). Most of this sediment is deposited on the shelf fronting the modern bird-foot delta, a delta-lobe that has been in existence for only 600 to 800 years (Fisk and others, 1954). The distributary mouths of the modern delta build seaward at rates varying from 50 to $100 \mathrm{~m}$ per year. Offshore of these distributaries, the sediment accumulation rates are very high, ranging to $1 \mathrm{~m}$ per year or more (Coleman and others, 1980). The sediment deposited consists mostly of clay-sized particles and is also rich in organic matter that is rapidly degraded to gas (mainly methane and carbon dioxide). Rapid sedimentation and gas charging lead to high excess pore-water pressures and a state of extreme underconsolidation. Although the slopes of the delta-front are very low, less than $1.5^{\circ}$, evidence of slope failure is widespread. Submarine gullies were first described by Shepard (1955). More recently, sidescan sonar mosaics have shown extensive fields of sediment instabilities all along the delta-front (Coleman and others, 1980; Coleman and others, this report).

Elsewhere along the coast of the Gulf of Mexico and Atlantic Ocean, the rate of sediment accumulation on the continental shelf is low and landslide features are rare. Most modern deposition occurs in bays that formed when valleys were drowned by rising sea level after the most recent glacial cycle (ice age).

Deltas of some of the major rivers that deposit large amounts of sediment along the margins of the United States do not display geomorphic evidence of submarine landsliding. Such lack of evidence does not automatically preclude previous slope failure in these deposits because waves and burial can erase the failure effects. The lack of slope failure features likely indicates, however, that the occurrence of slope failure is less frequent or less extensive in these 
deltas. Most notable is the delta of the Columbia River (Nittrouer and Sternberg, 1981) whose surface appears to be devoid of failures. Evidently, a combination of circumstances is needed for slope failure to occur on the continental shelf. High sedimentation rates are needed so that a sufficiently thick bed of modern sediment can develop. Relatively low permeability (fine-grained sediment) can allow high pore-water pressures to be retained and produce low sediment strength. Also needed, however, are environmental factors, such as storms or earthquakes, that can generate stresses in the sediment that exceed the strength. These can be augmented by strength degradation during cyclic loading, such as seems to be particularly common with glacially derived sediment. Finally, the configuration of the continental shelf, including its slope, can influence the stability of deltas. The interaction of all of these factors, rather than one factor alone, ultimately determines whether mass movement will occur.

\section{Submarine Canyon and Deep-Sea Fan Systems}

Submarine canyon systems serve as conduits for passing large amounts of sediment from near the continental shelf to deep-sea fans. Although more active at times of lowered sea level during periods of extensive continental glaciation, the presence of extensive, thick sediment deposits on the continental rise surrounding the United States testifies to the importance of mass movement mechanisms associated with these systems. Mass movement mechanisms are capable of bringing sand-sized and even coarser particles to locations hundreds of kilometers from shore. Landsliding appears to be one system element that allows massive deposition on submarine fans to occur. According to one model (Hampton, 1972), sediment accumulations in canyon heads begin to move as coherent landslide blocks following some triggering event, such as an earthquake or storm. As the blocks move downslope, the resulting jostling and agitation cause disintegration and subsequent incorporation of ambient water. The debris flow produced displays increasingly fluidlike behavior. As the debris flow continues on its path, further dilution by surrounding water occurs, particularly as sediment is eroded from the front of the flow. Ultimately, a dilute turbulent cloud of sediment, or turbidity current, is created. The turbidity current has a density slightly greater than the surrounding seawater and can flow for long distances (up to hundreds of kilometers) at moderate to high velocities (1 to $8 \mathrm{~m} / \mathrm{s}$, Shepard, 1963; Bowen and others, 1984; Reynolds, 1987). When the turbidity current enters a depositional phase, it leaves deposits that have distinctive textural characteristics; namely sandy sediments at the base that decrease in grain size to silt and clays at the top of the deposit (Bouma, 1962; Middleton and Hampton, 1976).
Landsliding, particularly within submarine canyons (Carlson and others, this report), appears to be an important, if not essential, part of the process of building deep-sea fans, which are among the most extensive sedimentary features of the Earth's surface. The circumstances surrounding these slope failures and their subsequent conversion into turbidity currents are poorly understood, however. Storms cause sediment movement in canyons, perhaps by inducing slumping near the canyon heads (Marshall, 1978) or perhaps by introducing or resuspending enough sediment to form a density current directly (Shepard and Marshall, 1973; Reynolds, 1987). Earthquakes also cause landslides in canyon heads and subsequent turbidity current flow (Malouta and others, 1981; Adams, 1984), but details of this process are lacking. Major earthquakes and other shocks do not always cause canyon-head landslides (Shepard, 1951; Dill, 1969). Landsliding in canyon heads and turbidity current mobilization were likely more common during glacial cycles (Nelson, 1976; Barnard, 1978) because of lowered sea level, increased sediment supply and possibly, increased storm wave loading. Thus, many of these submarine canyons and deep-sea fans, unlike fjords and river deltas, are not active areas of slope failure today.

\section{The Open Continental Slope}

A final common environment for undersea landsliding in the U.S. EEZ is the area between submarine canyons on the continental slope. Landslides have been reported all around the U.S. margin along slopes removed from submarine canyon systems. Included are slopes off southern California (Buffington and Moore, 1962; Haner and Gorsline, 1978; Field and Clarke, 1979; Nardin, Edwards, and others, 1979; Nardin, Hein, and others, 1979; Ploessel and others, 1979; Field and Edwards, 1980; Field and Richmond, 1980; Hein and Gorsline, 1981; Thornton, 1986; Edwards, Lee, and Field, this report; Field and Edwards, this report), central and northern California (Field and others, 1980; Richmond and Burdick, 1981; Field and Barber, this report; Gutmacher and Normark, this report), off Alaska (Marlow and others, 1970; Hampton and Bouma, 1977; Carlson and others, 1980; Hampton, this report; Kayen and Lee, this report), in the Gulf of Mexico (Lehner, 1969; Woodbury, 1977; Booth, 1979; Booth and Garrison, 1978; Twichell, Valentine, and Parson, this report; and McGregor and others, this report), and along the Atlantic coast (Embley and Jacobi, 1977; McGregor, 1977; Knebel and Carson, 1979; McGregor and others, 1979; Malahoff and others, 1980; Booth and others, 1984, 1988; Cashman and Popenoe, 1985; O'Leary, 1986; Booth and others, this report; O'Leary, this report; Popenoe, Schmuck, and Dillon, this report; Dillon and others, this report). The failures are found near river mouths and far removed from them, as well as in both arid and humid 


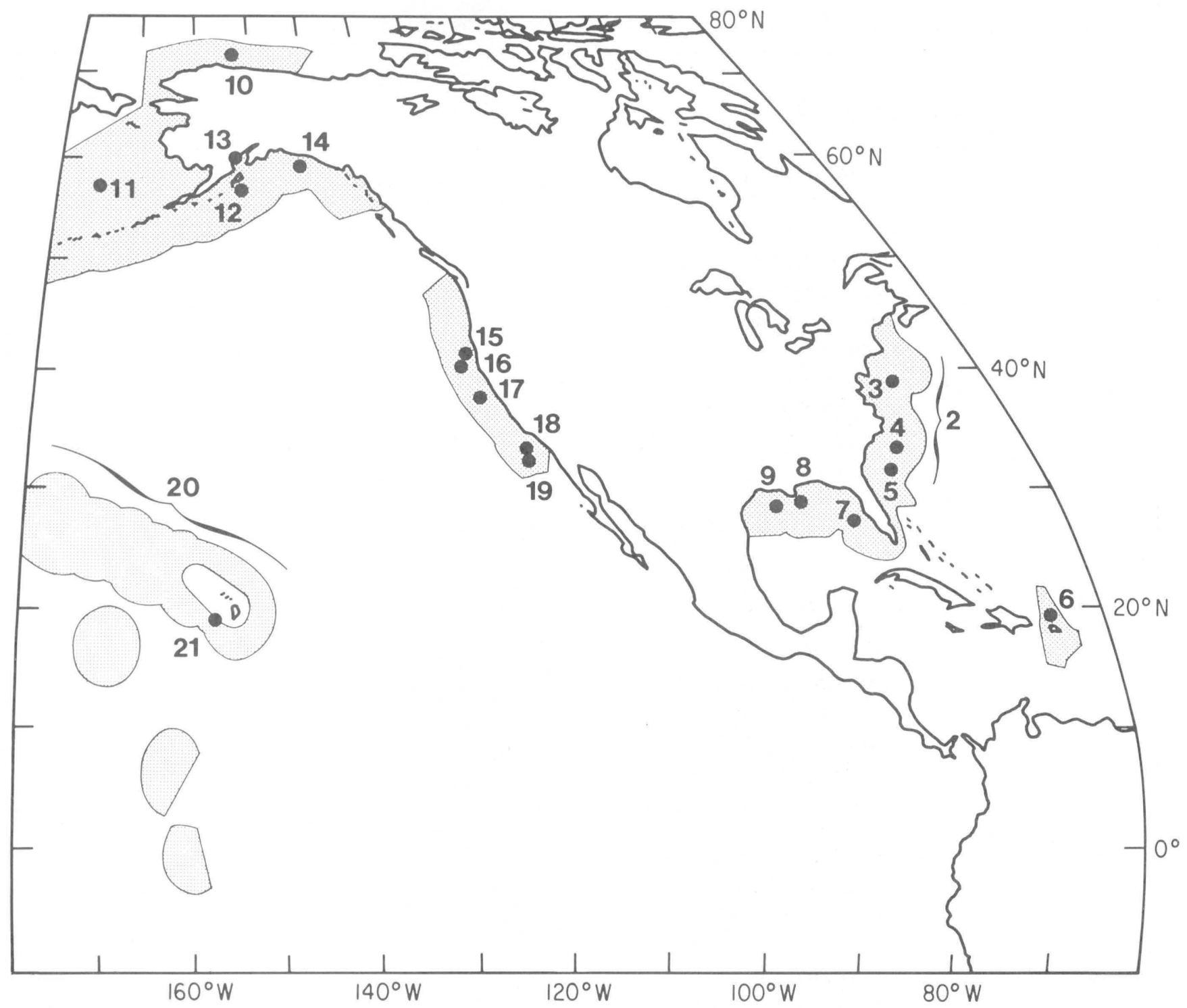

Figure 4. Locations of landslide studies described in this report. Numbers refer to sections listed in table 1. The shaded area is the U.S. EEZ.

climates. Ages of the slope failures are seldom known, so we cannot determine whether they occurred under glacial or interglacial conditions, nor can the recurrence interval be estimated with any degree of accuracy. Many were probably seismically induced because typical continental slopes have gradients of $5^{\circ}$ or less which would be expected to be statically stable. Storm-wave loading is seldom a major factor much below the shelf break (Lee and Edwards, 1986). Occurrence of slope failures seems to correlate with sedimentation rate, slope declivity, seismicity, and presence of bubble-phase gas and gas hydrate, but the relationship is complex (Field, 1981).

\section{SECTIONS IN THIS REPORT}

This report contains 20 sections that discuss landslides within the U.S. EEZ (fig. 4, table 1). The locations of these landslides are distributed fairly uniformly around the United States. This compilation is not exhaustive, however. Rather, the goal is to show the variety of landslides that have been found, the associations of the landslides with other features, methods that have been used to understand the causes and mechanisms of the landslides, and the potential that some of these features have as a hazard to coastal and offshore development. One of the 
Table 1. Sections included in this report

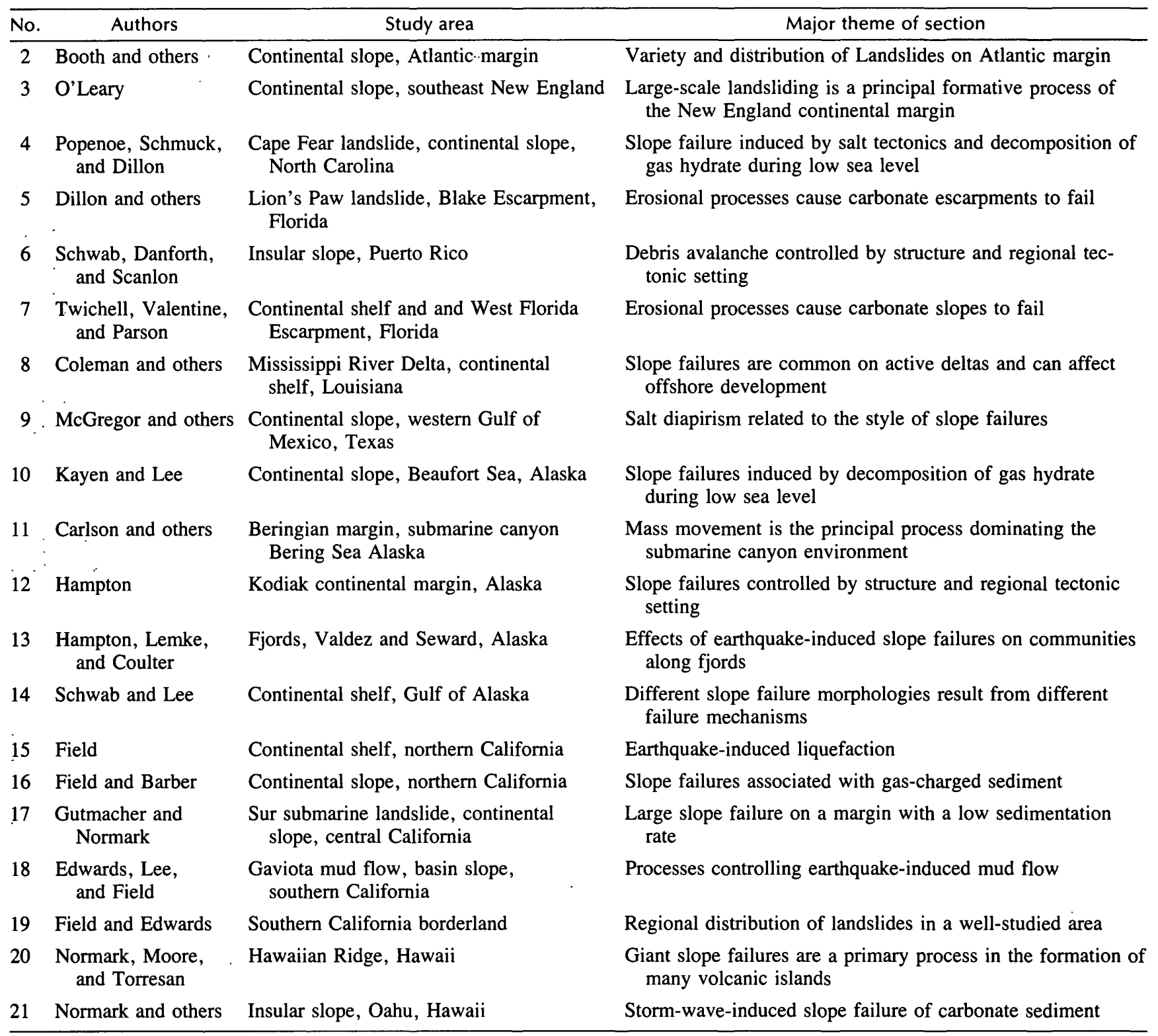

sections in this report-(Hampton, Lemke, and Coulter) considers sediment failures in fjords, three sections consider failures in rapidly deposited sediment on the continental shelf (Coleman and others; Field; Schwab and Lee), one section (Carlson and others) considers mass instability in submarine canyons, and the remaining fifteen sections are concerned with failures of varying size on continental, insular, or basin slopes. The slope environment is emphasized because the largest and most spectacular landslides occur here and more nearly complete coverage with sidescan-sonar mapping has been obtained during the U.S. Geological Survey EEZ-SCAN Project (Gardner, 1986). More landslide deposits are preserved in the slope environment through glacial stages when the continental shelves are subaerially exposed and coastal fjords are filled with gla- ciers. That is, more landslide deposits are preserved on continental and insular slopes even though the frequency of landslide recurrence may be much greater in deltaic deposits on the continental shelf and in fjords.

The sections in this report provide insights into the presence of mass movement features and processes that control submarine mass movement. Although marine researchers and engineers are attempting to resolve the problems associated with slope instability through the use of more quantitative methodologies, the results of recent sea-floor mapping surveys provide a constant reminder that there is much yet to be known. The marine researcher will be tasked with the responsibility to solve these unknowns in the 1990's and beyond as the economic significance of the sea floor increases. As many of the sections in this report 
suggest, however, marine research will not only provide solutions but will continue to reveal new mysteries.

\section{ACKNOWLEDGMENTS}

The authors wish to thank Monty Hampton and David Drake for their helpful reviews of the manuscript. All illustrations and photography were provided by Jeff Zwinakis and Dann Blackwood.

\section{REFERENCES CITED}

Adams, John, 1984, Active deformation of the Pacific northwest continental margin: Tectonics, v. 3, p. 449-472.

Almagor, Gideon, and Wiseman, Gdalyah, 1977, Analysis of submarine slumping in the continental slope off the southern coast of Israel: Marine Geotechnology, v. 2, p. 349-388.

Anderson, K.H., 1976, Behavior of clay subjected to cyclic loading: International Conference on Offshore Structures, Trondheim, Norway, Proceedings, p. 17-23.

Arnold, Peter, 1973, Finite element analysis-A basis for seafloor soil movement design criteria: Offshore Technology conference, 5th, Houston, Tex., Proceedings, v. 2, p. 743-752.

Barnard, W.D., 1978, The Washington continental slope: Quaternary tectonics and sedimentation: Marine Geology, v. 27, p. 79-114.

Bea, R.G., Wright, S.G., Sircar, Partha, and Niedoroda, A.W., 1983, Wave-induced slides in South Pass Block 70, Mississippi Delta: Journal of Geotechnical Engineering, v. 109, p. 619-644.

Beets, C.S., 1946, Miocene submarine disturbance of strata in northern Italy: Journal of Geology, v. 54, p. 229-245.

Booth, J.S., 1979, Recent history of mass wasting on the upper continental slope, northern Gulf of Mexico as interpreted from the consolidation states of the sediment, in Pilkey, O.H., and Doyle, L.J., eds., Geology of continental slopes: Society of Economic Paleontologists and Mineralogists Special Publication 27, p. 153-164.

Booth, J.S., and Dunlap, W.A., 1977, Consolidation state of upper continental slope sediments, northern Gulf of Mexico: Offshore Technology conference, 5th, Houston, Tex., Proceedings, Paper 3165, p. 1019-1028.

Booth, J.S., and Garrison, L.E., 1978, A geologic and geotechnical analysis of the upper continental slope adjacent to the Mississippi Delta: Offshore Technology conference, 10th, Houston, Tex., Proceedings, Paper 3165, p. 1019-1028.

Booth, J.S., O'Leary, D.W., Popenoe, Peter, Robb, J.M., and McGregor, B.A., 1988, Map and tabulation of Quaternary mass movements along the United States-Canadian Atlantic continental slope from $32^{\circ} 00^{\prime}$ to $47^{\circ} 00^{\prime} \mathrm{N}$. latitude: U.S. Geological Survey Miscellaneous Field Studies Map MF-2027, 3 sheets.

Booth, J.S., Silva, A.J., and Jordan, S.A., 1984, Slope-stability analysis and creep susceptibility of Quaternary sediments on the northeastern U.S. continental slope, in Denness, Bruce, ed., Seabed mechanics: International Union of Theoretical and Applied Mechanics/International Union of Geodesy and Geophysics Symposium Proceedings, London, Graham \& Trotman, p. 65-75.

Bouma, A.H., 1962, Sedimentology of some flysch deposits. A graphic approach to facies interpretation: Amsterdam, Elsevier, $168 \mathrm{p}$.
Bowen, A.J., Normark, W.R., and Piper, D.J.W., 1984, Modeling of turbidity currents on Navy Submarine Fan, California: Continental Borderland: Sedimentology, v. 31, p. 169-185.

Buffington, E.C., and Moore, D.G., 1962, Geophysical evidence on the origin of gullied submarine slopes, San Clemente, California: Journal of Geology, v. 71, p. 356-370.

Carlson, P.R., 1978, Holocene slump on continental shelf off Malaspina Glacier, Gulf of Alaska: American Association of Petroleum Geologists Bulletin, v. 62, p. 2412-2426.

Carlson, P.R., and Molnia, B.F., 1977, Submarine faults and slides on the continental shelf, northern Gulf of Alaska: Marine Geotechnology, v. 2, p. 275-280.

Carlson, P.R., Molnia, B.F., and Wheeler, M.C., 1980, Seafloor geologic hazards in OCS Lease Area 55, eastern Gulf of Alaska: Offshore Technology conference, 12th, Houston, Tex., Proceedings, v. 1, p. 593-603.

Cashman, K.V., and Popenoe, Peter, 1985, Slumping and shallow faulting related to the presence of salt on the continental slope and rise off North Carolina: Marine and Petroleum Geology, v. 2, p. $260-272$.

Clukey, E.C., Cacchione, D.A., and Nelson, C.H., 1980, Liquefaction potential of the Yukon prodelta, Bering Sea: Offshore Technology conference, 12th, Houston, Tex., Proceedings, p. 315-325.

Coleman, J.M., Prior, D.B., and Garrison, L.E., 1980, Subaqueous sediment instabilities in the offshore Mississippi River Delta, U.S. Bureau of Land Management Open-File Report $80-01,60 \mathrm{p}$.

Coulter, H.W. and Migliaccio, R.R., 1966, Effects of the earthquake of March 27, 1964, at Valdez, Alaska: U.S. Geolog ical Survey Professional Paper 542-C, 36 p.

Dill, R.F., 1964, Sedimentation and erosion in Scripps submarine canyon head, in Miller, R.L., ed., Papers in marine geology: New York, MacMillan, p. 232-248.

1969, Earthquake effects on fill of Scripps submarine canyon: Geological Society of America Bulletin, v. 80 , p. 321-328.

Embley, R.W., 1980, The role of mass transport in the distribution and character of deep-ocean sediments in the Atlantic: Marine Geology, v. 38, p. 23-50.

Embley, R.W., and Jacobi, R.D., 1977, Distribution and morphology of large submarine sediment slides and slumps on Atlantic continental margins: Marine Geotechnology, v. 2, p. 205-228.

Esrig, M.L., Ladd, R.S., and Bea, R.G., 1975, Material properties of submarine Mississippi Delta sediments under simulated wave loadings: Offshore Technology conference, 7th, Houston, Tex., Proceedings, v. 1, p. 399-412.

Farrow, G.E., Syvitski, J.P.M., and Tunnicliffe, Verena, 1983, Suspended particulate loading on the macrobenthos in a highly turbid fjord: Knight Inlet, British Columbia: Canadian Journal of Fisheries and Aquatic Science, v. 40 (supp. 1), p. 273-288.

Field, M.E., 1981, Sediment mass-transport in basins: Controls and patterns, in Douglas, R.G., Colburn, E.P. and Gorsline, D.S., Short course notes: Pacific section, SEPM, San Francisco, Calif., p. 61-83.

Field, M.E., and Clarke, S.H., 1979, Small-scale slumps and slides and their significance for basin slope processes, Southern California Borderland: Society of Economic Paleontologists and Mineralogists Special Publication 27, p. 223-230.

Field, M.E., Clarke, S.H., and White, M.E., 1980, Geology and geologic hazards of offshore Eel River basin, northern California continental margin: U.S. Geological Survey OpenFile Report 80-1080, 80 p. 
Field, M.E., and Edwards, B.D., 1980, Slopes of the southern California.borderland: A regime of mass transport, in Field, M.E., Bouma, A.H., Colburn, I.P., Douglas, R.G., and Ingle; J.C., eds, Proceedings, Quaternary depositional environments of the Pacific Coast: Pacific Coast Paleogeography, Symposium 4, SEPM, Pacific Section, p. 169-184.

Field, M.E.; Gardner, J.V., Jennings, A.E., and Edwards, B.D., 1982, Earthquake-induced sediment failures on a $0.25^{\circ}$ slope, Klamath River delta: California Geology, v. 10, p. 542-546.

Field, M.E., and Richmond, W.C., 1980, Sedimentary and structural patterns on the northern Santa Rosa-Cortes Ridge, southern California: Marine Geology, v. 34, p. 19-98.

Fisk, H.N., McFarlan, E.F., Jr., Kold, C.R.,' and Wilbern, L.J., Jr., 1954, Sedimentary framework of the modern Mississippi Delta: Journal of Sedimentary Petrology, v. 24, p. 76-99.

Gardner, J.V., 1986, Program EEZ-SCAN; a reconnaissance view of the Western U.S. Exclusive Economic Zone, in Clarke, S.H., ed., U.S. Geological Survey highlights in marine research: U.S. Geological Survey Circular 938, p. 125-132.

Gibson, R.E., 1958, The process of consolidation in a clay layer increasing in thickness with time: Geotechnique, .v. 8, p. $71-182$.

Gutenberg, B.A., 1939, Tsunamis and earthquakes: Seismological Society of America Bulletin, v. 29, p. 517-526.

Hampton, M.A., 1972, The role of subaqueous debris flow in generating turbidity currents: Journal of Sedimentary Petrology, v. 42, p. 775-793.

Hampton, M.A., and Bouma, A.H., 1977, Slope instability near the shelf break, western Gulf of Alaska: Marine Geotechnology, v. 2, p. 309-331.

Hampton, M.A., Bouma, A.H., Carlson, P.R., Molnia, B:F., Clukey, E.C., and Sangrey, D.A., 1978, Quantitative study of slope instability in the Gulf of Alaska: Offshore Technology conference, 10th, Houston, Tex., Proceedings, v. 4, p. 2307-2318.

Haner, B.E., and Gorsline, D.S., 1978, Processes and morphology of continental slope between Santa Monica and Dume submarine canyons, Southern California: Marine Geology, v. 28 , p. $77-87$.

Heezen, B.C., 1956, Corrientes de turbidez del Rio Magdalena: Sociedad Geografica de Columbia Buletin, v. 51-52, p. 135-143.

Heezen, B.C., and Drake, C.L., 1964, Grand Banks slump: American Association of Petroleum Geologists Bulletin, v. 48 , p. 221-225.

Heezen, B.C., and Ewing, Maurice, 1952, Turbidity currents and submarine slumps and the 1929 Grand Banks earthquake: American Journal of Science, v. 250, p. 849-873.

.. 1955, Orleansville earthquake and turbidity currents: American Association of Petroleum Geologists Bulletin, v. 19, p. 2505-2514.

Hein, F.J., and Gorsline, D.S., 1981, Geotechnical aspects of fine-grained mass flow deposits: California Continental Borderland, Geo-Marine Letters, v. 1, p. 1-5.

Henkel, D.J., 1970, The role of waves in causing submarine landslides: Geotechnique, v. 20 , p. $75-80$.

Inderbitzen, A.L., 1965, An investigation of submarine slope stability: Marine Technology Society and American Society of Limnology and Oceanography, Ocean Science and Ocean Engineering conference, 1965, Transactions, v. 2, p. 1309-1344.

Jones, O.T., 1937, On the sliding or slumping of submarine sediments in Denbighshire, North Wales, during the Ludlow Period: Quarterly Journal of the Geological Society of London, v. 93, p. 241-283.
Kachadoorian, Reuben, 1965, Effects of the earthquake of March 27, 1964, at Whittier, Alaska: U.S. Geological Survey Professional Paper 542-B, 21 p.

Kelling, G.A., and Stanley, D.J., 1970, Morphology and structure of Wilmington and Baltimore submarine canyons, Eastern United States: Journal of Geology, v. 78, p. 637-660.

Knebel, H.J., and Carson, Bobb, 1979, Small-scale slump deposits, Middle Atlantic continental slope, off Eastern United States: Marine Geology, v. 29, p. 221-236.

Kostaschuk, R.A., and McCann, S.B., 1983, Observations on delta-forming processes in a fjord-head delta, British Columbia: Sedimentary Geology, v. 36, p. 269-288.

Kuenen, Ph.H., 1949, Slumping in the Carboniferous rocks of Pembrokeshire: Quarterly Journal of the Geologic Society of London, v. 104, p. 365-386.

Lee, H.J., 1985, State of the art: Laboratory determination of the strength of marine soils, in Chaney, R.C., and Demars, K.R., eds., Strength testing of marine sediment: Laboratory and in situ measurements, ASTM STP883: Philadelphia, Pa., American Society for Testing and Materials, p. 181-250.

Lee, H.J., and Edwards, B.D., 1986, Regional method to assess offshore slope stability: Journal of Geotechnical Engineering, v. 112 , p. 489-509.

Lehner, Peter, 1969, Salt tectonics and Pleistocene stratigraphy on continental slope of northern Gulf of Mexico: American Association of Petroleum Geologists Bulletin, v. 53, p. 2431-2479.

Lemke, R.W., 1967, Effects of the earthquake of March 27, 1964, at Seward, Alaska: U.S. Geological Survey Professional Paper 542-E, 43 p.

Lewis, K.B., 1971, Slumping on a continental slope inclined $1^{\circ}-4^{\circ}$ : Sedimentology, v. 16, p. 97-100.

Malahoff, Alexander, Embley, R.W., Perry, R.B., and Fefe, C., 1980 , Submarine mass-wasting of sediments on the continental slope and upper rise south of Baltimore Canyon: Earth and Planetary Science Letters, v. 49, p. 1-7.

Malouta, D.N., Gorsline, D.S., and Thornton, S.E., 1981, Processes and rates of Recent (Holocene) basin filling in at active transform margin: Santa Monica Basin, California Continental Borderland: Journal of Sedimentary Petrology, v. 51, p. 1077-1095.

Marlow, M.S., Scholl, D.W., Buffington, E.C., Boyce, R.E., Alpha, T.R., Smith, P.J., and Shipek, C.J., 1970, Buldir Depression-A late Tertiary graben on the Aleutian Ridge, Alaska: Marine Geology, v. 8, p. 85-108.

Marshall, N.F., 1978, Large storm-induced sediment slump reopens an unknown Scripps Submarine Canyon tributary, in Stanley, D.J., and Kelling, G., eds., Sedimentation in submarine canyons, fans, and trenches: Stroudsburg, Pa., Dowden, Hutchinson and Ross, p. 73-84.

McGregor, B.A., 1977, Geophysical assessment of submarine slide northeast of Wilmington Canyon: Marine Geotechnology, v. 2, p. 229-244.

McGregor, B.A., Bennett, R.H., and Lambert, D.N., 1979, Bottom processes, morphology, and geotechnical properties of the continental slope south of Baltimore Canyon: Applied Ocean Research, v. 1, p. 177-187.

Menard, H.W., 1964, Marine geology of the Pacific: New York, McGraw-Hill, $271 \mathrm{p}$.

Middleton, G.V., and Hampton, M.A., 1976, Subaqueous sediment transport and deposition by sediment gravity flows, in Stanley, D.J., and Swift, D.J.P., eds., Marine sediment transport and environmental management: New York, John Wiley, p. 197-218. 
Milliman, J.D., and Meade, R.H., 1983, World-wide delivery of river sediment to the oceans: Journal of Geology, v: 91 , p. $1-21$.

Molnia, B.F., Carlson, P.R., and Bruns, T.R., 1977, Large submarine slide in Kayak Trough, Gulf of Alaska: Geological Society of America Reviews in Engineering Geology, v. 3, p. 137-148.

Moore, D.G., 1961, Submarine slumps: Journal of Sedimentary Petrology, v. 31, p. 343-357.

Moore, J.G., Clague, D.A., Holcomb, R.T., Lipman, P.W., Normark, W.R., and Torresan, M.E., 1990, Prodigious submarine slides on the Hawaiian Ridge: Journal of Geophysical Research, v. 94, p. 17465-17484.

Moore, T.C., van Andel, T.H., Blow, W.H., and Heath, G.R., 1970, Large submarine slide off the northeastern continental margin of Brazil: American Association of Petroleum Geologists, v. 54, p. 125-128.

Morgenstern, N.R., 1967, Submarine slumping and the initiation of turbidity currents, in Richards, A.F., ed., Marine geotechnique: Urbana, University of Illinois Press, p. 189-220.

Murty, T.S., 1979, Submarine slide-generated water waves in Kitimat Inlet, British Columbia: Journal of Geophysical Research, v. 84, p. 7777-7779.

Nardin, T.R., Edwards, B.D., and Gorsline, D.S., 1979, Santa Cruz Basin, California Borderland: Dominance of slope processes in basin sedimentation, in Doyle, L.J., and Pilkey, O.H., eds., Geology of continental slopes: Society of Economic Paleontologists and Mineralogists Special Publication 27, p. 209-221.

Nardin, T.R., Hein, F.J., Gorsline, D.S., and Edwards, B.D., 1979, A review of mass movement processes, sediment and acoustic characteristics, and contrasts in slope and base-ofslope systems versus canyon-fan-basin floor systems, in Doyle, L.J., and Pilkey, O.H., eds., Geology of continental slopes: Society of Economic Paleontologists and Mineralogists Special Publication 27, p. 61-73.

Nelson, C.H., 1976, Late Pleistocene and Holocene depositional trends, processes, and history of Astoria Deep-Sea Fan, northeast Pacific: Marine Geology, v. 20, p. 129-173.

Nittrouer, C.A., and Sternberg, R.W., 1981, The formation of sedimentary strata in an allochthonous shelf environment: The Washington continental shelf: Marine Geology, v. 42, p. 201-232.

O'Leary, D.W., 1986, The Munson-Nygren slide, a major lowerslope slide off Georges Bank: Marine Geology, v. 72, p. $101-114$.

Plafker, G., Kachadoorian, Reuben, Eckel, E.B., and Mayo, L.R., 1969, Effects of the earthquake of March 27, 1964, on various communities: U.S. Geological Survey Professional Paper 542-G, 50 p.

Ploessel, M.R., Crissman, S.C., Rudat, J.H.; Son, R.X., Lee, C.F., Randall, R.G., and Norton, M.P., 1979, Summary of potential hazards and engineering constraints, proposed OCS Lease Sale No. 48, offshore Southern California: Offshore Technology conference, 11 th, Houston, Tex., Proceedings; p. 355-363.

Prior, D.B., Bornhold, B.D., Coleman, J.M., and Bryant, W.R., 1982, Morphology of a submarine slide, Kitimat Arm, British Columbia: Geology, v. 10, p. 588-592.

Prior, D.B., Bornhold, B.D., and Johns, M.W., 1986, Active sand transport along a fjord-bottom channel, Bute Inlet, British Columbia: Geology, v. 14, p. 581-584.

Prior, D.B., Coleman, J.M., and Bornhold, B.D., 1982, Results of a known sea-floor instability event: Geo-Marine Letters, v. 2 , p. $117-122$.
Prior, D.B., Wiseman, W.J., and Gilbert, Robert, 1981, Submarine slope processes on a fan delta, Howe Sound, British Columbia: Geo-Marine-Letters, v. 1, p. 85-90.

Reimnitz, Erk, 1972; Effects in the Copper River delta, in The Great Alaska earthquake of 1964, v. 6: Oceanography and coastal engineering: Washington, D.C., , National. Research Council, National Academy of Sciences, p.: 290-302.

Reynolds, Suzanne, 1987 , A recent turbidity current event, Hueneme Fan, California: reconstruction of flow properties: Sedimentology, v. 34, p.129-137.

Richmond, W.C., and Burdick, D.J., 1981, Geologic hazards and constraints of offshore northern and central California: Offshore Technology conference, 13th, Houston, Tex., Proceedings, v. 4, p. $9-17$.

Ryan, W.B.F., and Heezen, B.C., 1965, Ionian Sea submarine canyons and the 1908. Messina turbidity current: Geological Society of America Bulletin; v. 76. p. 915-932.

Schwab, W:C., and Lee, H.J., 1983, Geotechnical analyses of submarine landslides in glạcial marine sediment, northeast Gulf of Alaska; in Molnia, B.F., Glacial marine sedimentation: New York; . Plenum Press, p. $145 \div 184$.

1988, Causes of two slope-failure types in continentalshelf sediment, northeastern Gulf of Alaska: Journal of Sedimentary Petrology, v. 58, p. 1-11.

Schwab, W.C., 'Lee, H.J., and Molnia, B:F., 1987, Causes of varied sediment gravity flow types on the Alsek prodelta, northeast Gulf of Alaska: Marine Geotechnology, v. 7, p. 317-342.

Seed, H.B.., and Rahman, M.S., 1978, Wave-induced pore pressures in relation to ocean floor stability of cohesionless soils: Marine Geotechnology, v. 3, p. 123-150.

Shepard, F.P.; 1951, Mass movements in submarine canyon heads: Transactions, American Geophysical Union, v. 32, p. $405-418$.

1955, Delta-front valleys bordering the Mississippi distributaries: Geological Society of America Bulletin; v. 66, p. 1489-1498.

1963, Submarine canyons, in Hill, M., ed., The sea: New York, John Wiley, p. 480-506.

Shepard, F.P., and Marshall, N.F., 1973, Storm-generated current in La Jolla Submarine Canyon, California: Marine Geology,:v. 15, p. M19-M24.

Syvitski, J.P.M., Burrell, D.C.; and Skei, J.M., 1987, Fjords: Processes and products: New York, Springer-Verlag, 379 p.

Syvitski, J:P.M., and Farrow, G.E., 1983, Structures and processes in bayhead deltas: Knight and Bute Inlet, British Columbia: Sedimentary Geology, v. 36, p. 217-244.

Terzaghi, Karl, 1956, Varieties of submarine slope failures: Texas conference on Soil Mechanics and Foundation Engineering, 8th, Proceedings, Texas University. Bureau Engineering Research Special Publication 29, p. 1-41.

Thornton, S.E., 1986, Origin of mass flow sedimentary structures in hemipelagic basin deposits: Santa Barbara Basin, California Borderland: Geo-Marine Letters, v. 6, p. 15-19.

van Straàten, L.M.J., .1949, Occurrence in Finland of structures due to sub-aqueous sliding of sediments: Bulletin of the Geological Commission of Finland, no. 144, $35 \mathrm{p}$.

Varnes, D.J., 1958, Landslide types and processes, in Eckel, E.D., ed., Landslides and engineering practice: Highway Research Board Special Report 29, p. 20-47.

Woodbury, H.O., 1977, Movement of sediments of the Gulf of Mexico continental slope and upper continental shelf: Marine Geotechnology; v. 2, p. 263-274.

Wright, S.G., 1.976, Analysis for wave-induced sea-floor movements: Offşhore Technology conference, 8th, Houston, Tex., Proceedings, v. 1, p. 41-53: 


\title{
U.S. Atlantic Continental Slope Landslides: Their Distribution, General Attributes, and Implications
}

\author{
By J.S. Booth, D.W. O'Leary, Peter Popenoe, and W.W. Danforth
}

\section{INTRODUCTION}

Because of its relatively gentle slopes and tranquil environment, the sea floor off the Atlantic coast was not considered a likely place for landsliding. In fact, many researchers associated with the offshore geologic studies that preceded the oil- and gas-lease sales of the 1980's believed that the continental slope would be shown to be basically inert-a quiescent environment which was gradually, over long periods or perhaps at rare intervals, undergoing some erosion but, in general, becoming increasingly more stable. Recent systematic surveys, culminating with a Geological LOng-Range Inclined Asdic (GLORIA) sidescan-sonar survey (EEZ-SCAN 87, 1991), and studies of geologic processes have revealed, to the contrary, that not only have there probably been hundreds of landslides on the U.S. Atlantic continental slope but that most of the mappable landslides have occurred in relatively recent geologic time.

Here, we focus on 179 individually mapped landslides on the U.S. Atlantic outer continental margin. Our purpose is to provide a qualitative overview and a statistical summary of the distribution and characteristics of these landslides and a brief analysis of observed tendencies, associations, trends, and correlations that may give insight into the causes and processes of marine landsliding. A complete listing of the data used in this chapter may be found in Booth and others (1988). The largest landslides and areas of extensive mass movement are shown on the GLORIA imagery (pl. 1, envelope inside the back cover).

\section{GEOLOGIC SETTING}

The continental slope off the Eastern United States is a relatively steep and narrow rampart between the Atlantic Ocean basin and the North American continent. In terms of water depth, it extends from the edge of the continental shelf ( 75 to 200 meters $(\mathrm{m})$ water depth) to approximately $2,000 \mathrm{~m}$, where it is bounded by the continental rise. From Georges Bank south to Cape Hatteras, the physiography of the continental slope is dominated by the presence of numerous canyons and canyon systems. South of Cape Hatteras, the slope's typical ramplike appearance is interrupted by the broad Blake Plateau, which separates the inner Florida-Hatteras slope from the Blake Escarpment (outer slope), thus giving the margin a stairstep appearance in this region.
This complex morphology is a reflection of a continental margin that has been extensively modified through time (see, for example, Schlee and others, 1979). Regional slope angles may be as low as $1^{\circ}$ or $2^{\circ}$, but they commonly approach $10^{\circ}$ (Keller and others, 1979) and may be greater than $15^{\circ}$, as on the Blake Escarpment (Emery and Uchupi, 1972). Locally, declivities frequently exceed $20^{\circ}$ and some canyon walls are practically vertical (see, for example, O'Leary and Twichell, 1981). In the Tertiary and Quaternary Periods (that is, the Cenozoic Era, or approximately the last 66 million years of Earth history), the slope experienced a series of transgressive-regressive cycles (gradual submergence then re-emergence of land areas in response to the relative rise and fall of sea level), during which it was subjected to progradation (building seaward) as well as large-scale net erosion.

Near the top of the continental slope, the Quaternary sedimentary section (which represents about the last 2 million years of Earth's history) typically is 200 to $300 \mathrm{~m}$ thick (Poag and Sevon, 1989). It is composed chiefly of muds (silts and clays) which were derived primarily from erosion of the adjacent land mass. Calcareous sediment (commonly composed or derived from shells and shell fragments) is locally dominant off parts of the Southern United States, whereas sands and gravels derived from melting glaciers or related processes are locally dominant off New England. The Quaternary sediment section, in general, thins and becomes more uniformly layered to seaward; in places on the lower slope, particularly in canyons, it is absent. Thus, viewed in cross section, the Quaternary sediment, which is frequently involved in slope failure and mass movement, is a tilted, wedge-shaped mass lying atop the Tertiary sediment beneath it.

The Tertiary sediment section is more varied in composition and stratification. Schlee and others (1979), Robb and others (1981), and Poag and Sevon (1989) have shown that the lower part of this approximately $3-\mathrm{km}$-thick section comprises mainly indurated chalk or limey clay. The sediment at this stratigraphic level also has a high silica content; in places it resembles porcelain. Higher in the Tertiary section, the sediment is more typically muddy, but sands containing a distinctive green mineral (glauconite) are present as well. Tertiary sediments are also involved in landslides.

\section{MAPPING METHODS AND LIMITATIONS}

A variety of data sources was used to identify and enumerate the landslides and related features. Primarily, 
high-resolution, seismic-reflection profiles and sidescansonar images served as the basis for our compilation (for a description of these techniques see Lee, Schwab, and Booth, this report). The many investigations (dating from 1952) used to compile the landslides data base encompass a considerable range in technology, navigational accuracy, acoustic resolution, and data-processing sophistication. Consequently, there are various degrees of data quality and confidence associated with the identification and interpretation of the previous studies. Furthermore, because much of the systematic survey work was conducted in areas of pending oil- and gas-lease sales, the coverage is regionally biased; that is, coverage of the continental slope is not uniform. The plotted distribution of landslides is, thus, not necessarily representative of the true distribution and areal extent of the largest landslides.

The spacing of the seismic-reflection profiles is another limitation. As examples, landslides that have dimensions considerably less than the grid spacing used in the surveys have a relatively low probability of detection, and the actual size (length and width) of the slope failure features are bracketed by the grid spacing rather than known precisely.

Although most data sources were used in the general compilation, the data base used for statistical description and analyses was limited to those values or interpretations that were judged to be of relatively high quality. Still, the accuracy or utility of the preponderance of the data used for the statistical work cannot be verified. Nonetheless, we assume that data used in our analyses is of acceptable quality and is the best data set available in any case (the reader is referred to Booth and others (1988) for more details on the methods, limitations, and data base).

\section{OVERVIEW OF LANDSLIDES}

\section{Distribution}

Evidence of landsliding exists across the entire breadth of the U.S. Atlantic continental slope (fig. 1). The data suggest that each of these landslides occurred within the last 2 million years and that almost all occurred within the last 200,000 years (Booth and others, 1988). Despite the inference created by the presence of landslide complexes, which to some extent reflect biased survey coverage, slope failures are apparently not limited to specific areas nor are they uniformly distributed. Also evident in figure 1 is the great extent of the largest landslides. Most of these major landslides comprise debris flow or other types of flow deposits, which extend $100 \mathrm{~km}$ or more out onto the continental rise. The larger landslides and landslide-related features have been outlined on the Atlantic U.S. Exclusive Economic Zone (EEZ) GLORIA sidescan-sonar imagery (pl. 1, in envelope). A more complete map of landslides and related features is presented in Booth and others (1988). Other maps showing the distribution of landslides have been published by Embley and Jacobi (1986) and Tucholke (1987).

Landslides have originated in all but the greatest water depths. Figure 2 shows their distribution with respect to bathymetry; it also shows that the mid-slope region $(800$ to $1,000 \mathrm{~m}$ water depth) is favored as an origination depth. Landslides have even originated at the base of the slope and at the top of the rise (2,000 to $2,200 \mathrm{~m}$ water depth); in fact, the Depth-of-Origin histogram (fig. 2) implies that there is a mode (increased tendency for landslides to originate) in these water depths. This is somewhat of a paradox. Intuitively, we would expect that landslides would terminate, rather than originate, at those depths because there is a pronounced reduction in slope angle at the top of the continental rise (from an average of $5^{\circ}$ to $6^{\circ}$ on the continental slope to less than $0.1^{\circ}$ farther out on the rise); that is, we would expect that landslides would tend to slow down and stop on the flatter surface of the rise. In fact, despite the slight tendency for landslides to originate at the slope-rise boundary, the data (fig. 2) show that a large mode in termination depth (depth of the toe of the landslide deposit) is, in fact, present at 2,000 to $2,200 \mathrm{~m}$. As is the case for origin depth, however, landslide termini have been mapped over the entire range of depths investigated, and as shown in figure 2 , another, broader mode is centered at about $1,100 \mathrm{~m}$.

\section{Dimensions and Declivities}

There is a considerable range in the dimensions of the areas affected by landslides. Measured lengths vary from 0.3 to $380 \mathrm{~km}$ (most common length: 2 to $4 \mathrm{~km}$ ); widths vary from 0.2 to $50 \mathrm{~km}$ (most common width: 1 to $2 \mathrm{~km}$ ). The thickness of the sedimentary section involved in the landslides (at or near its origin) varies from 10 to $650 \mathrm{~m}$. Given the stated limitations concerning survey line spacings and resolution of the acoustic data, there are probably many landslides areas even smaller or thinner than those measured. As shown in figure 3, landslide areas range from less than $0.1 \mathrm{~km}^{2}$ up to approximately $19,000 \mathrm{~km}^{2}$, which is roughly the size of New Jersey. Nearly two-thirds of all landslides, however, have an area of $10 \mathrm{~km}^{2}$ or less.

Numerically, most landslides have occurred at declivities of $4^{\circ}$ or less, there is a dramatic drop in landslide frequency at angles greater than $4^{\circ}$, and landslides on slopes greater than $10^{\circ}$ to $12^{\circ}$ are rare (fig. 4). Moreover, although landslides took place at slope angles of up to $30^{\circ}$, it is apparent that steep slopes are not necessarily associated with the slope failures despite the presence of the numerous submarine canyons, which tend to have steep sidewalls (the slight rise in landslide frequency at slope angles of $13^{\circ}$ and $14^{\circ}$ is, however, attributed to submarine canyons). 


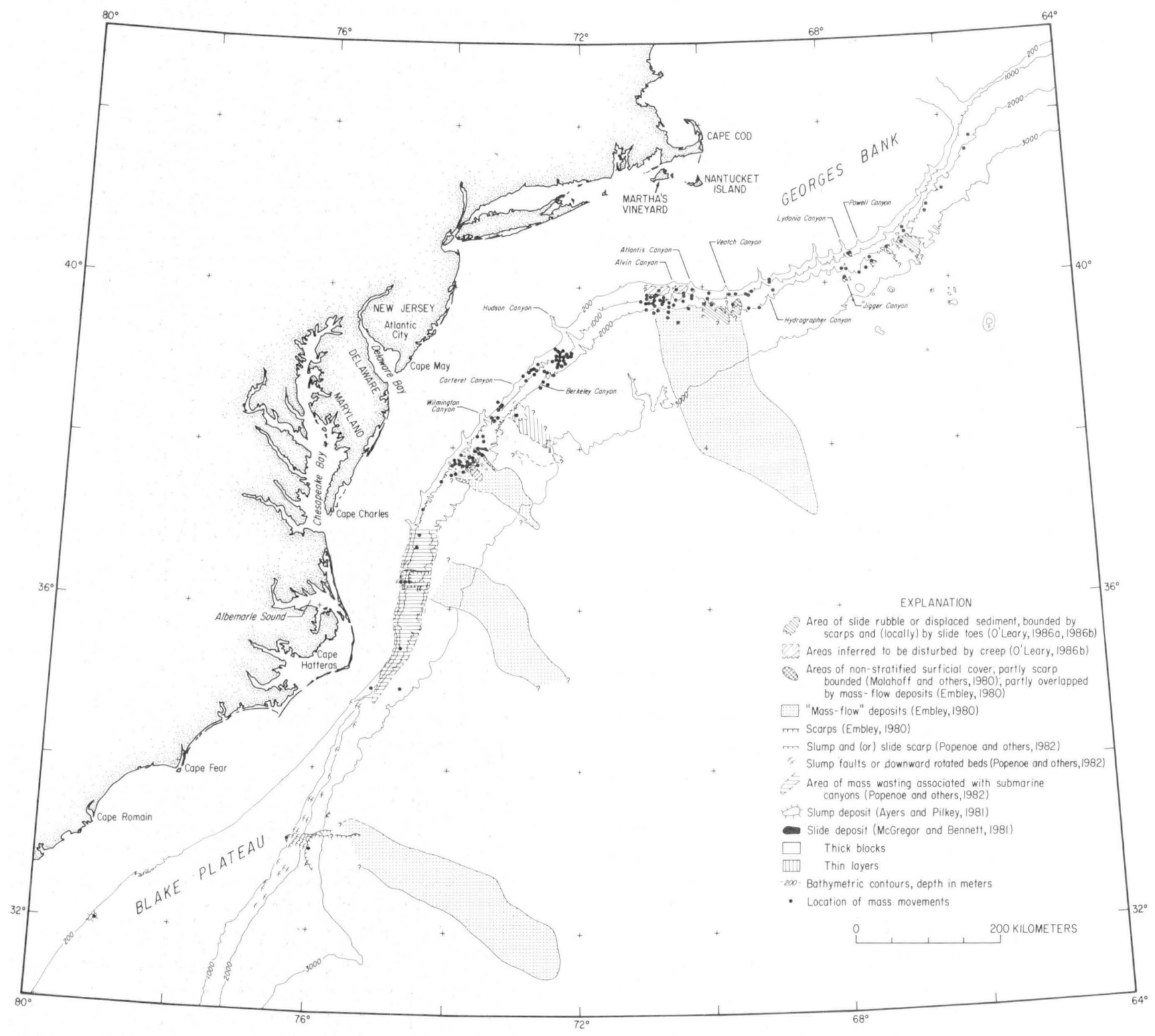

Figure 1. Distribution and style of landslides and related features (modified from Booth and others, 1988).

\section{Style}

The frequency distribution of the landslide types is shown in the histograms (fig. 5). The prevalence of the types of mass movements that involve a breakup or fragmentation of a sediment section indicates that once a slope failure has taken place, the failed section of slope tends to disintegrate into a structureless mass. To achieve this condition, the sediment must be in a "steady state." The concept of steady state and its relevance to disintegrative failures are presented in Schwab and Lee, this report. Despite the prevalence of disintegrative mass movements, slides and other varieties of landslides also are common (fig. 5), which suggests that slope failures are not restricted to or associated with a unique set of initial sediment conditions. In fact, the variety of styles shown probably suggests that landsliding has occurred in a variety of sediment types as well as under a variety of conditions. The modest dominance of translational (straight slip plane) over rotational (curved slip plane) failures (fig. 5) is not considered meaningful because of the uncertainties in data quality.

\section{Morphologic Setting}

Slope failures have occurred on gentle, smooth slopes; on steep walls of submarine canyons; on ridge crests; and on a variety of other topographic features, including mounds, alcoves, small gullies, slopes with rough terrains, and deeply embayed regions (fig. 6). Because each of the three major morphologic settings shown in figure 6 


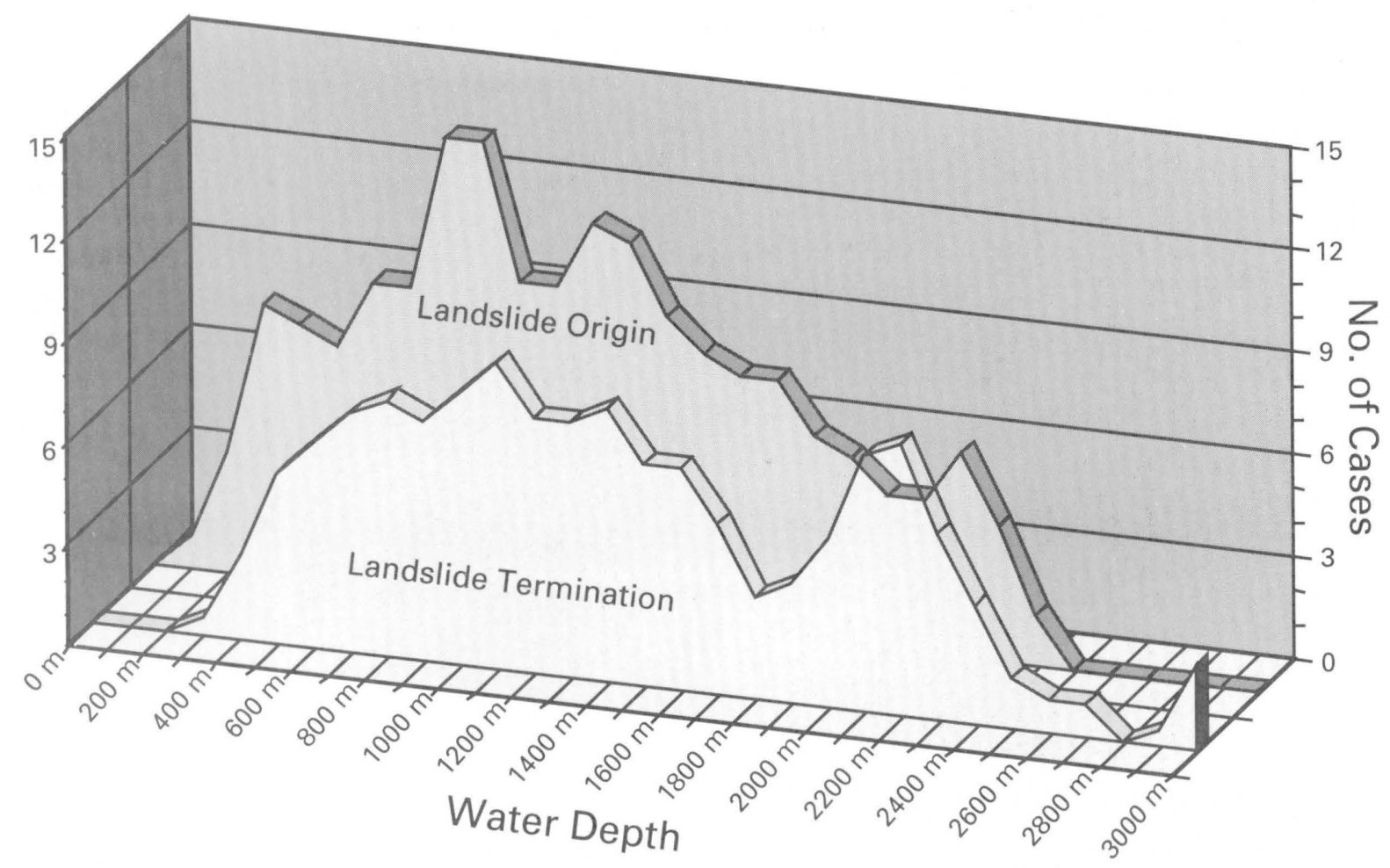

Figure 2. Origin and termination of landslides. Slope failures have occurred at all but the greatest depths shown but most commonly at about 900 meters. Note also the mode in origin below 2,000 meters. Termination depths of landslides (depth at

has experienced numerous landslides, we suggest that landsliding is not just ubiquitous but has happened with significant frequency in each setting. Canyons, because of their relatively steep sides, would intuitively seem to be the most likely site for landslides, but, as also indicated in figure 6 , at least on a numeric basis there have been more landslides on smooth, gentle slopes (hereafter called open slopes).

\section{Summary}

The occurrence of landslides on the U.S. Atlantic continental slope is widespread: landslides have taken place in all geographic areas, all water depths, and at all slope angles. They may be found associated with all types of topographic features, and they occur in a variety of styles or landslide types and range in size from virtually imperceptible to nearly $20,000 \mathrm{~km}^{2}$. Although the attributes of these landslides vary widely, some generalizations can be made. Table 1 is a tabulation of characteristics of a "typical" landslide.

\section{ASSOCIATION AND TRENDS}

Analysis of the data base shows that several variables either change systematically in association with other vari-

toe of landslides) have two primary modes: at mid-slope water depths (approximately 1,100 meters) and at the base of the continental slope (approximately 2,100 meters, where the slope angle is reduced).

ables or are somewhat constrained by the presence or absence of certain conditions. These relationships can reveal fundamental mechanisms that control landsliding (Lee, Schwab, and Booth, this report) and may provide insight into how and why landslides occur. Although a complete treatment of all the various tendencies is beyond the scope of this paper, we believe that two in particular are worthy of discussion: the relationship between slope angle, morphologic setting, and the size of the landslide; and the tendency for landslides to be disintegrative (that is, for the displaced mass of sediment to continue to lose its internal structure or change its shape).

Table 1. Characteristics of a "typical" landslide

\begin{tabular}{ll}
\hline Length & 2 to $4 \mathrm{~km}$ \\
Width & 1 to $2 \mathrm{~km}$ \\
Thickness & $50 \mathrm{~m}$ \\
Origin water depth & $900 \mathrm{~m}$ \\
Termination water depth & 1,100 and $2,100 \mathrm{~m}$ \\
Slope angle (at origin) & $4^{\circ}$ \\
Morphologic setting & Open slope \\
Style (type of landslide) & Mass flow generated from a \\
& translational failure plane \\
\hline
\end{tabular}




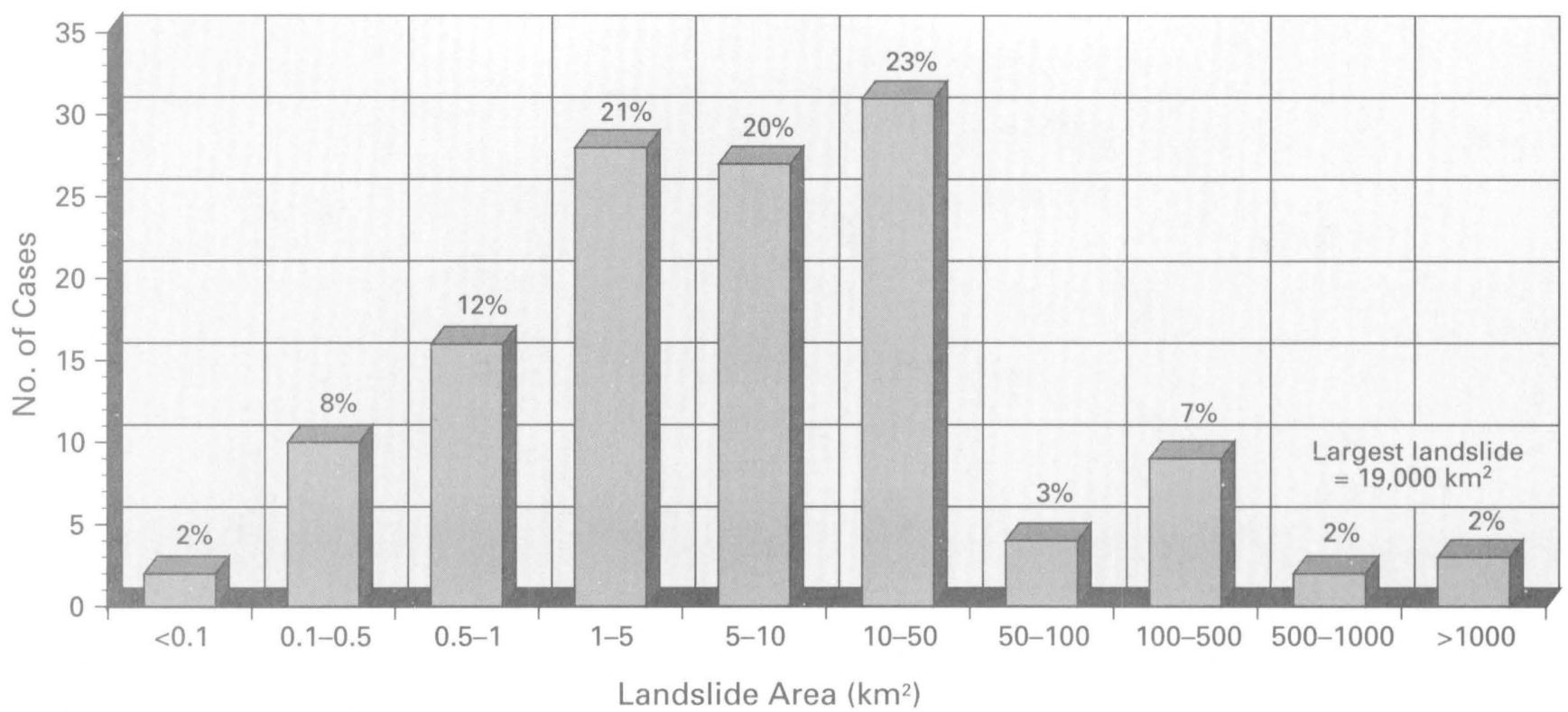

Figure 3. Landslide area frequency distribution. Because of survey methodology, highest frequency of occurrence may not be in the 10 to 50 square kilometers interval (as shown) but in a smaller size class. The largest (19,000 square kilometers) is equivalent in area to New Jersey. Values rounded to nearest whole percent.

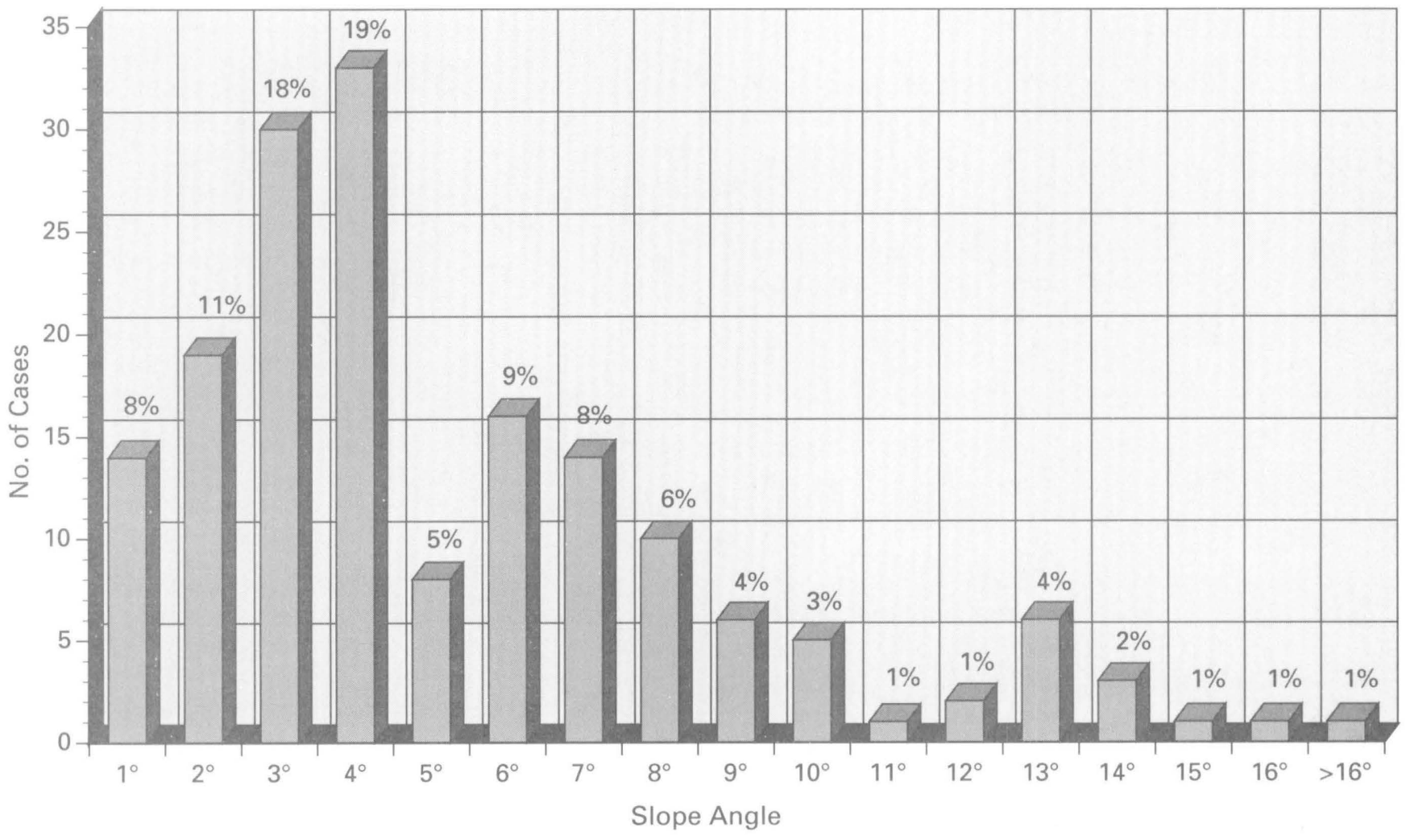

Figure 4. Slope angle frequency distribution at sites of landslide origin. Most occur at very low angles. Values rounded to nearest whole percent. 


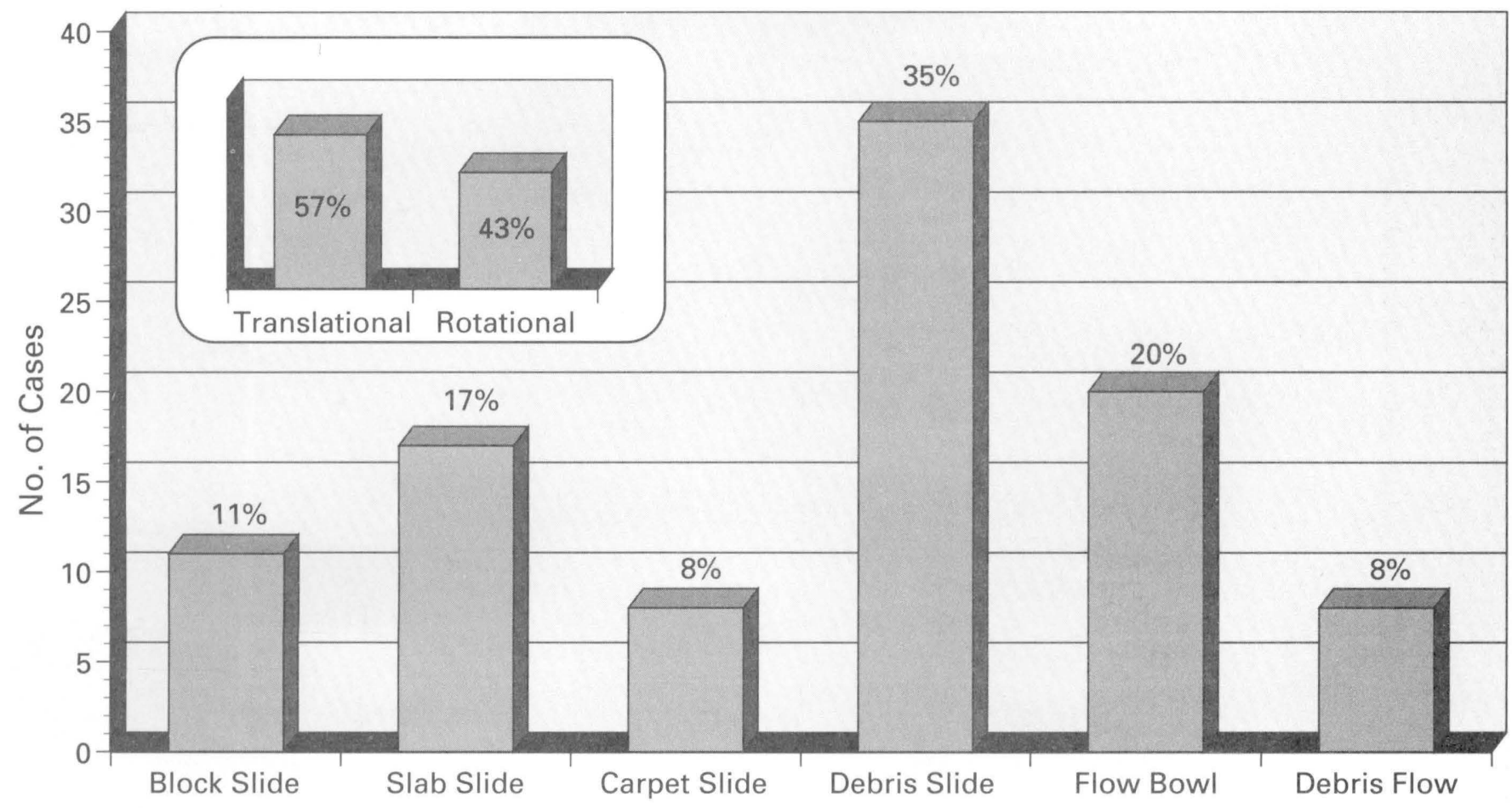

Figure 5. Frequency of occurrence of different styles or types of landslides (based on dominant characteristic). The percentages shown for each category reflect combined totals from both translational and rotational origin. Brief definitions: Block slide-displaced mass is structurally intact and cubical; Slab slide-displaced mass is structurally intact and tabular; Carpet slide-displaced mass is basically intact, typically tabular, and parts are folded or "wrinkled"; Debris slide-displaced mass consists of large rock fragments or rubble (similar to the

\section{Associations of Angle, Setting, and Size}

Comparison of landslides found on open slopes with those found in canyons shows that the average-sized openslope landslide $\left(\approx 100 \mathrm{~km}^{2}\right)$ tends to occur at lower slope angles and is much larger (by an order of magnitude) than the average canyon landslide $\approx 6 \mathrm{~km}^{2}$ ). Furthermore, regardless of morphologic setting or other characteristic, large-scale landslides (area greater than $100 \mathrm{~km}^{2}$ ) tend to be associated with gentle slopes (approximately $3^{\circ}$ to $4^{\circ}$ ). Similarly, small-scale landslides (average area less than 5 $\mathrm{km}^{2}$ ) tend to be associated with steep slopes (greater than or equal to $10^{\circ}$ ). The basic associations between area and slope angle for both open-slope landslides and canyon landslides are shown in figure 7 . Note that in contrast to the trend showing a decrease in area of open-slope landslides with increasing declivity, the area of canyon landslides remains fairly constant until the slope angle exceeds about $15^{\circ}$.

That the sizes of canyon landslides would be less than their open- slope counterparts is somewhat intuitive: canyons are relatively confined areas themselves. Moreover, the total area of the continental slope occupied by steep

debris avalanche defined in Lee, Schwab, and Booth, this report); Flow bowl-a depression associated with a sediment mass that has collapsed or liquefied at depth, or possibly throughout its entire thickness; Debris flow-a completely deformed, displaced mass that has moved as a viscous fluid. The insert shows the percentages of landslides that originated on straight (translational) and curved (rotational) failure planes. Values rounded to nearest whole percent.

slopes is likewise relatively small and mostly associated with canyons. On the other hand, if we focus on the open-slope data, it is evident from figure 7 that in addition to the apparent general correlation between slope angle and landslide area, there is also a pronounced difference in area between the landslides that occurred on slopes greater than or equal to $9^{\circ}$, which have areas $\approx 100$ to $1,000 \mathrm{~km}^{2}$, to those that took place on slopes of greater declivity $(\approx 1$ $\mathrm{km}^{2}$ ). In summary, the landslides that took place on open slopes not only were much more frequent in regions of low declivity but also tended to be greater than or equal to two orders of magnitude larger than in regions of high declivity.

\section{The Tendency Toward Disintegrative Landslides}

A second aspect of the landslides is that most landslide products are disintegrative in nature. After initial slope failure, whether it be translational or rotational, most landslide bodies tend to develop large strains, lose their internal structure, and consequently, flow, collapse, or generally break up into debris or rubble. As indicated on 


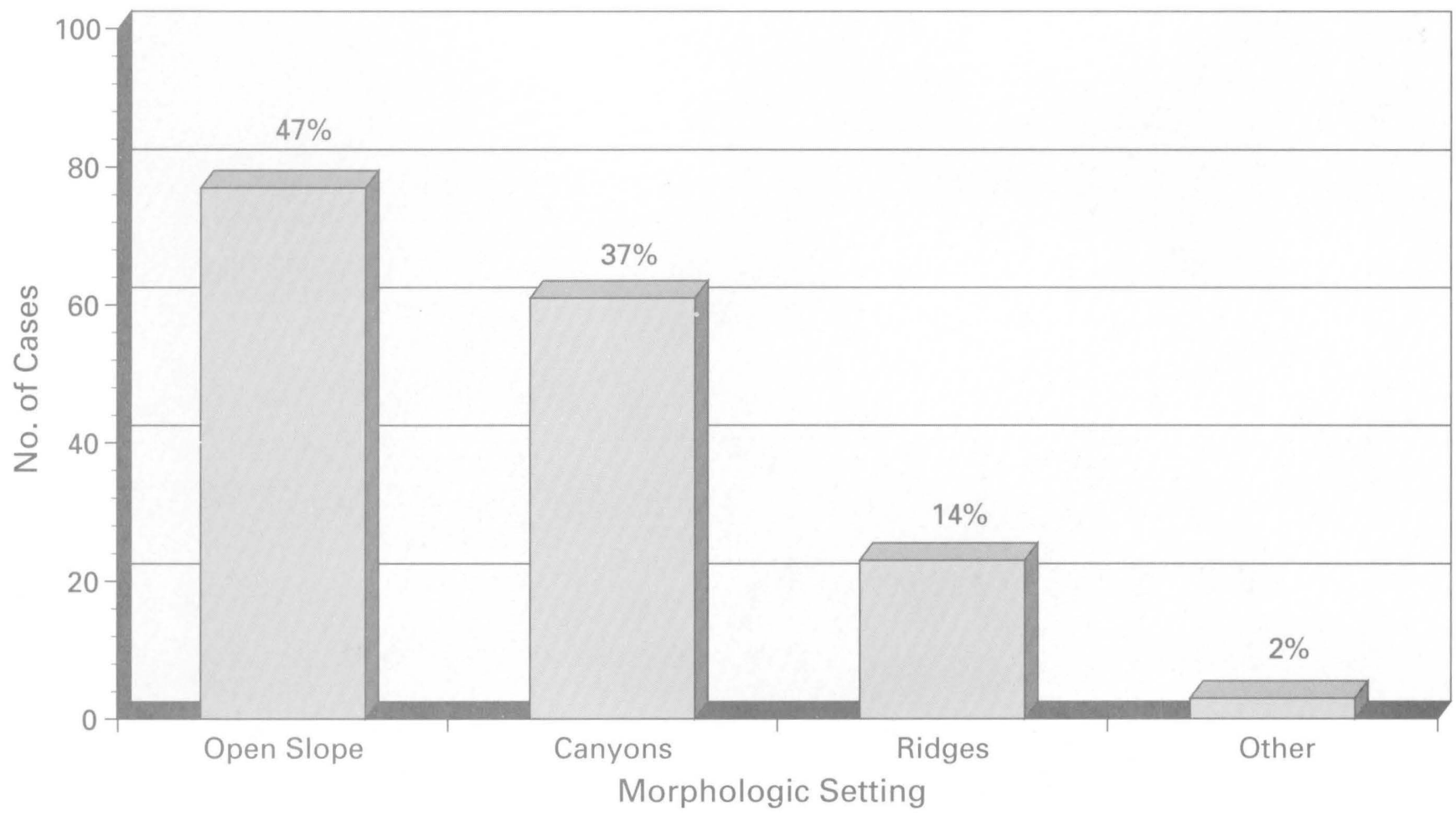

Figure 6. Common morphologic settings and the associatea rrequency ussurioution of Iandslides in each. Frequency determined on the basis of occurrence only; frequency on the basis of the area of each morphological feature not considered. Values rounded to nearest whole percent.

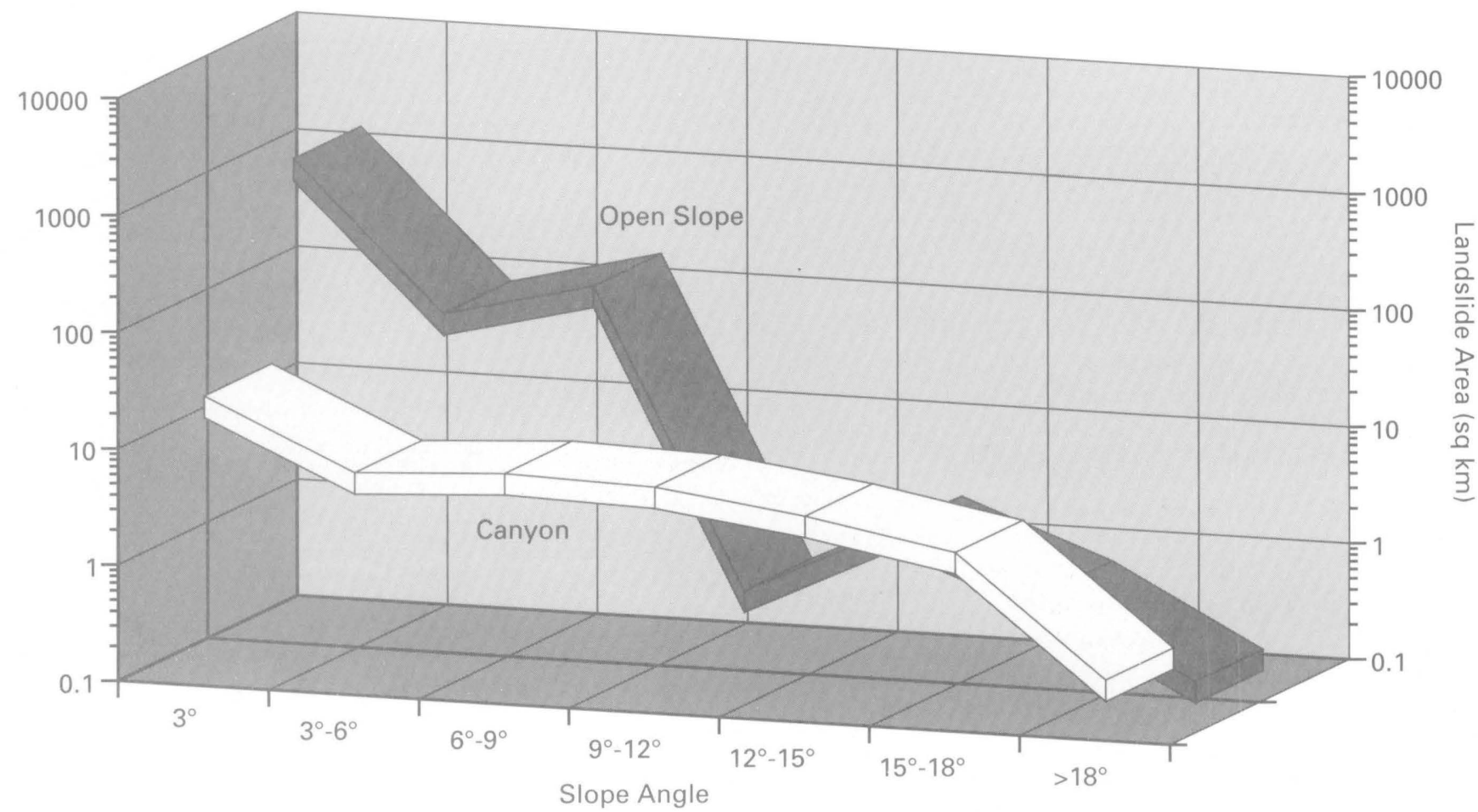

Figure 7. Association between landslide size and slope angle (ar site of landslide origin) for open slopes and canyon landslides. Areas shown within each $3^{\circ}$ interval are average values. 


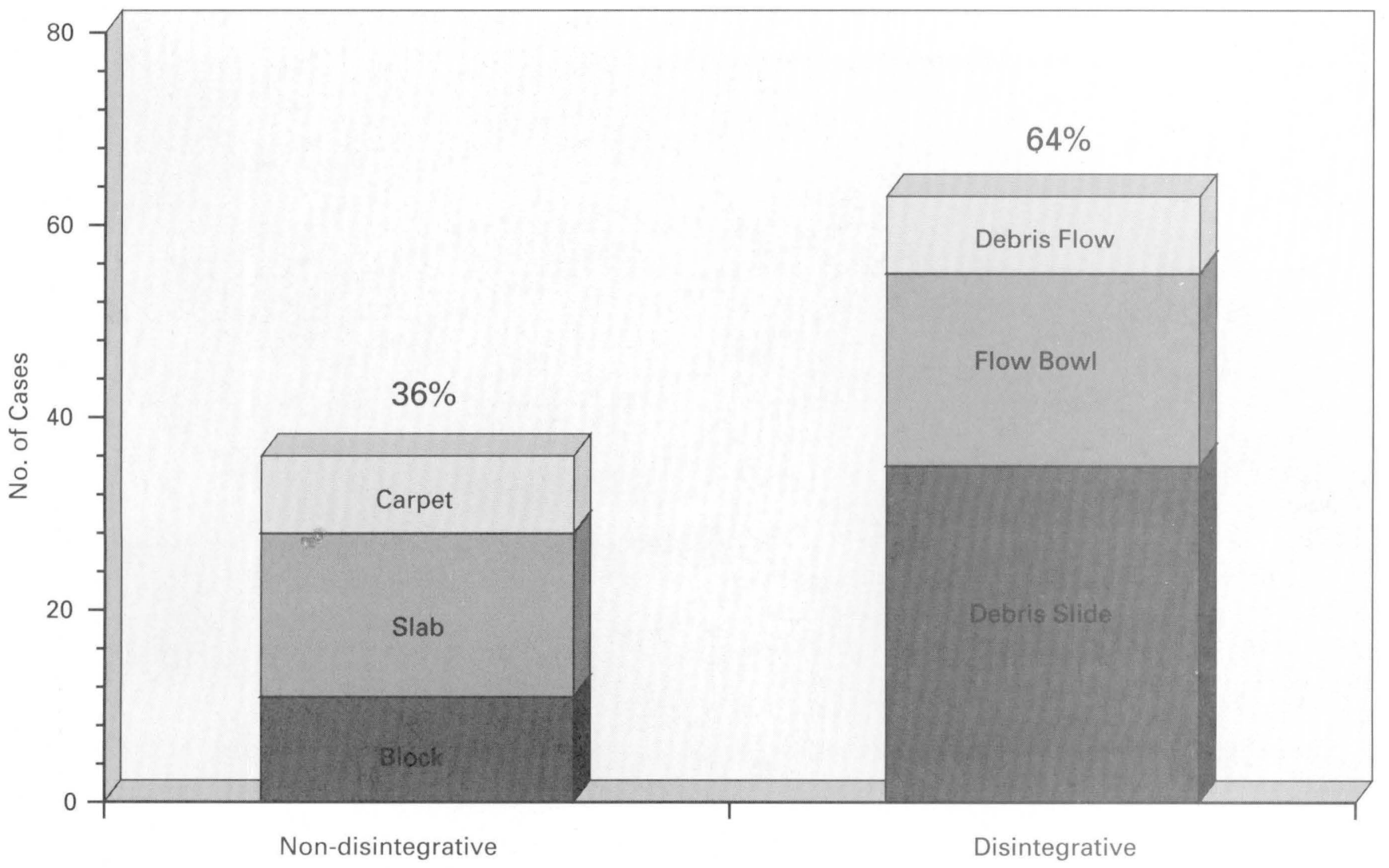

Figure 8. Individual and cumulative percentages of disintegrative landslides (that is, the displaced mass of sediment continues to lose its internal structure or change its shape at stresses less than those that caused the initial

slope failure) and non-disintegrative landslides (that is, the displaced mass of sediment retains its original shape and internal structure after the initial failure).

figure 8 , nearly two-thirds of the landslides have suffered this fate. This implies that the sediments tend to weaken considerably once they experience stresses greater than their natural strength can withstand. Such weakening can happen, in some cases, even if that excess stress is only momentary (that is, from an earthquake).

\section{SOME POSSIBLE CAUSES OF LANDSLIDES}

Both the relationship between angle, setting, and landslide size and the tendency for landslides to be disintegrative bear on landslide genesis. We consider the associations of low slope angles, large landslides, and open slopes to be significant. The occurrence of large-scale landslides on gentle slopes implies that regional, rather than local, factors have been dominant. Furthermore, slope angle, which is commonly an important factor controlling the initiation of a landslide, does not appear to be important for these landslides. In fact, the angles involved are well below those normally required to initiate landslides. Specifically, static forces alone at angles less than $10^{\circ}$ would not be enough to cause slope failures except in the most anomalously weak sediments; angles exceeding $15^{\circ}$ to $20^{\circ}$ would

be more typical. The fact that the landslides tend to be disintegrative is compatible with the assertion that regional mechanisms may be involved and may also suggest that a relatively rapid stress increase or strength reduction took place within the sediment column.

We have seen that (1) landslides are pervasive and that there are no apparent exclusionary factors based on location, slope angle, depth, or morphologic setting, (2) slope angles associated with the landslides are generally much less than those normally required to influence slope stability under static conditions, (3) the lower-angle landslides tend to be larger in area, and (4) the landslides tend to be disintegrative. Although it is evident that there has been a variety of causes for the landslides, transient forces (especially those that could affect large areas) likely played a significant role in producing many of the slope failures documented here. Earthquake loading is the most common transient force affecting these slopes.

The east coast continental margin, although not prone to as frequent or intense earthquakes as the Californian or Alaskan margins, is not aseismic. Large earthquakes that have occurred at Cape Ann, Mass. $(1638,1755)$, Charleston, S.C. (1886), and more recently, in the Grand Banks 
region off the Canadian Maritimes (1929) testify to this. Apparently, they would have approached or exceeded a magnitude of 7 on the Richter scale. The Cape Ann and Charleston earthquakes caused extensive damage locally. The Grand Banks earthquake caused a slope failure which was directly responsible for a series of breaks in transAtlantic cables on the sea floor. Moreover, since their relatively recent emplacement (around 1970), seismic stations have recorded many small tremors off the coast of the northeastern United States (for example, Yang and Aggrawal, 1981). These tremors may contribute, through ground shaking and a reduction in the strength of the sediment, to the development of an unstable condition on some sections of the continental slope or rise. Earthquakes can easily produce the levels of loading necessary to fail these lower-angle slopes (Morgenstern, 1967).

Accordingly, we hypothesize that earthquakes are a major cause of landslides on the continental slope. Earthquakes fit the implied criteria derived from the landslides data base. They can induce slope instabilities over broad, morphologically varied areas of low slope inclination; they promote disintegrative landslides; and they are sufficiently frequent on this "passive" continental margin to be a factor in numerous observed slope failures.

Gas may be abundant in frozen form (gas hydrates) beneath the southern part of the U.S. Atlantic outer continental margin (Popenoe, Schmuck, and Dillon, this report). If frozen gas were converted to free gas by a change in pressure, such as by a lowering of sea level during an ice age, it could trigger landslides by lowering sediment strength (Kayen and Lee, this report). We suggest, therefore, that gas hydrates also may have played a role in some of the observed slope failures.

\section{REFERENCES CITED}

Ayers, M.W., and Pilkey, O.H., 1981, Piston core and surficial sediment investigations of the Florida-Hatteras slope and inner Blake Plateau, in Popenoe, Peter, ed., Environmental geologic studies on the southeastern Atlantic Outer Continental Shelf, 1977-1978: U.S. Geological Survey Open-File Report 82-582A, p. 5-1 to 5-89.

Booth, J.S., O'Leary, D.W., Popenoe, Peter, Robb, J.M., and McGregor, B.A., 1988, Map and tabulation of Quaternary mass movements along the United States-Canadian Atlantic continental slope from $32^{\circ} 00^{\prime}$ to $47^{\circ} 00^{\prime} \mathrm{N}$. latitude: U.S. Geological Survey Miscellaneous Field Studies Map MF-2027.

EEZ-SCAN 87, 1991, Atlas of the U.S. Exclusive Economic Zone, Atlantic continental margin: U.S. Geological Survey Miscellaneous Investigations Series, v. 1-2054.

Embley, R.W., 1980, The role of mass transport in the distribution and character of deep-ocean sediments with special references to the North Atlantic: Marine Geology, v. 38, p. $23-50$.

Embley, R.W., and Jacobi, Robert, 1986, Mass wasting in the western North Atlantic, in Vogt, P.R., and Tucholke, B.E., eds., The Western North Atlantic Region: Boulder Colorado, Geological Society of America, The Geology of North America, v. M, p. 479-490.

Emery, K.O., and Uchupi, Elazar, 1972, Western North Atlantic Ocean: topography, rocks, structure, water, life, and sediments: American Association of Petroleum Geologists Memoir 17, $532 \mathrm{p}$.

Keller, G.H., Lambert, D.N., and Bennett, R.H., 1979, Geotechnical properties of continental slope sediments-Cape Hatteras to Hydrographer Canyon, in Doyle, L.J., and Pilkey, O.H., eds., Geology of the Continental Slopes: Society of Economic Paleontologists and Mineralogists Special Publication 27, p. 131-151.

Malahoff, Alexander, Embley, R.W., Perry, R.B., and Fefe, C.F., 1980, Submarine mass-wasting of sediments on the continental slope and upper rise south of Baltimore Canyon: Earth and Planetary Science Letters, v. 49, p. 1-7.

McGregor, B.A., and Bennett, R.H., 1981, Sediment failures and sedimentary framework of the Wilmington geotechnical corridor, U.S. Atlantic Continental Margin: Sedimentary Geology, v. 30, p. 213-234.

Morgenstern, N.R., 1967, Submarine slumping and the initiation of turbidity currents, in Richards, A.R., ed., Marine Geotechnique: Urbana, Ill., University of Illinois Press, p. 189220.

O'Leary, D.W., 1986a, Seismic structure and stratigraphy of the New England continental slope and the evidence for slope instability: U.S. Geological Survey Open-File Report 86-118, 7 maps.

1986b, The Munson-Nygren slide, a major lower slope slide off Georges Bank: Marine Geology, v. 72, p. 101-114.

O'Leary, D.W., and Twichell, D.C., 1981, Potential geologic hazards in the vicinity of Georges Bank Basin, in Grow, J.A., ed., Summary Report of the Sediments, Structural Framework, Petroleum Potential, and Environmental Conditions of the United States Middle and Northern Continental Margin In Area of Proposed Oil and Gas Lease Sale No. 76: U.S. Geological Survey Open-File Report 81-765, p. 48-68.

Poag, C.W., and Sevon, W.D., 1989, A record of Appalachian denudation in postrift Mesozoic and Cenozoic sedimentary deposits of the U.S. middle Atlantic continental margin: Geomorphology, v. 2, p. 119-157.

Popenoe, Peter, Coward, E.L., and Cashman, K.V., 1982, A regional assessment of potential environmental hazards and limitations on petroleum development of the southeastern United States Atlantic continental shelf, slope, rise, offshore North Carolina: U.S. Geological Survey Open-File Report 82-136, $67 \mathrm{p}$.

Robb, J.M., Hampson, J.C., Jr., and Twichell, D.C., 1981, Geology and potential hazards of the continental slope between Lindenkohl and South Toms Canyon offshore MidAtlantic United States: U.S. Geological Survey Open-File Report 81-600, 21 p.

Schlee, J.S., Dillon, W.P., and Grow, J.A., 1979, Structure of the continental slope off the eastern United States, in Dowle,L.J., and Pilkey, O.H., eds., Geology of the Continental Slope: Society of Economic Paleontologists and Mineralogists Special Publication No. 27, p. 95-118.

Tucholke, B.E., 1987, Submarine geology, in Milliman, J.D., and Wright, W.R., eds., Marine Environment of the U.S.Atlantic Continental Slope and Rise: Jones and Bartlett Publishers, Boston, p. 56-113.

Yang, Jih-Ping, and Aggarwal, Y.P., 1981, Seismotectonics of northeastern United States and adjacent Canada: Journal of Geophysical Research, v. 86, no. B6, p. 4981-4998. 


\title{
Submarine Mass Movement, a Formative Process of Passive Continental Margins: The Munson-Nygren Landslide Complex and the Southeast New England Landslide Complex
}

\author{
By D.W. O'Leary
}

\section{INTRODUCTION}

Evidence of extensive submarine mass movement along continental slopes rimming the Atlantic Ocean began to appear in the 1970's (Embley, 1976; Jacobi, 1976; Embley and Jacobi, 1977). High-resolution seismicreflection or echo-sounder profile data from that time shows irregular, disrupted stretches of sea floor and chaotic deposits upon, or not deeply buried beneath, the sea floor. This geophysical evidence has been confirmed by cores and photographs which show sediments at the sea floor with embedded fragments of rock far removed from their original sites of deposition.

During the time this evidence began to accumulate, the notion of a "passive continental margin" was developed (Burk and Drake, 1974). Continental slopes around the Atlantic (with the exception of the Caribbean region) were considered to be passive, which meant simply that geological processes conducive to sea-floor instability, such as subduction of oceanic crust, active faulting, and slope steepening, do not occur. Rather, passive margins are sites of more or less gradual subsidence in response to sediment deposition and crustal aging. To explain extensive mass movement on passive margins, geologists appealed to processes such as failure of unstable masses of deltaic sediment deposited on the upper part of the continental slope during times of low sea level (during ice ages), to oversteepening of the lower part of the slope by deep current erosion, to infrequent but major earthquakes, to gas generation, and even to bioerosion (Saxov and Nieuwenhuis, 1982; Lee, Schwab, and Booth, this report).

By the middle 1980's, marine survey data included sidescan-sonar images which showed that submarine landslides along the Atlantic margin are more common than previously thought and that some are of enormous extent (Kidd and others, 1985; Bugge and others, 1988; Booth and others, this report). The new data implied that mass movement might be an integral phenomenon in the evolution of passive continental margins.

The geological problem that large submarine slides represent in the passive margin setting is examined in this section with reference to two centers of mass movement located on the continental slope off New England: the southeast New England landslide complex and the Munson-
Nygren landslide complex (fig. 1). The descriptions of these submarine landslide complexes and their geological setting are based mainly on data obtained during a Geological LOng-Range Inclined Asdic (GLORIA) sidescan-sonar survey conducted in 1987 (O'Leary, 1988a); however, the search for an understanding of causes and processes depends on additional and more varied data, only some of which can be cited here and much of which still remains to be gathered.

\section{SUBMARINE LANDSLIDE COMPLEXES OFF NEW ENGLAND}

The southeast New England landslide complex and the Munson-Nygren landslide complex appear, on the basis of the GLORIA sidescan-sonar data, to be the only large $\left(>6,000\right.$ square kilometers $\left(\mathrm{km}^{2}\right)$ areas of mass movement along the continental slope off New England. Evidence of mass movement within the area of the southeast New England landslide complex was first recognized by Uchupi (1967); subsequent seismic-reflection surveys revealed that a wide area of the continental rise in this region is covered by mass-movement debris (MacIlvaine and Ross, 1979; Embley, 1982; Vassallo and others, 1984). Evidence of the Munson-Nygren landslide complex was first reported by O'Leary (1986).

It was clear from the earlier work that large masses of strata had been subject to slope failure within these two areas, but the spatial relationships of individual failures and mass-movement deposits that characterize each area were unknown until data were acquired by a GLORIA sidescansonar survey (O'Leary, 1988a). Sidescan-sonar images and seismic-reflection profiles show that small individual landslides as well as exceptionally large ones contribute to each landslide complex and that mass movement has recurred both within and adjacent to previous slope failures. Because of the apparent chronological and spatial complexity, the term landslide complex is applied to the two broad areas of mass movement.

\section{SOUTHEAST NEW ENGLAND LANDSLIDE COMPLEX}

The southeast New England landslide complex extends along the New England continental slope from 


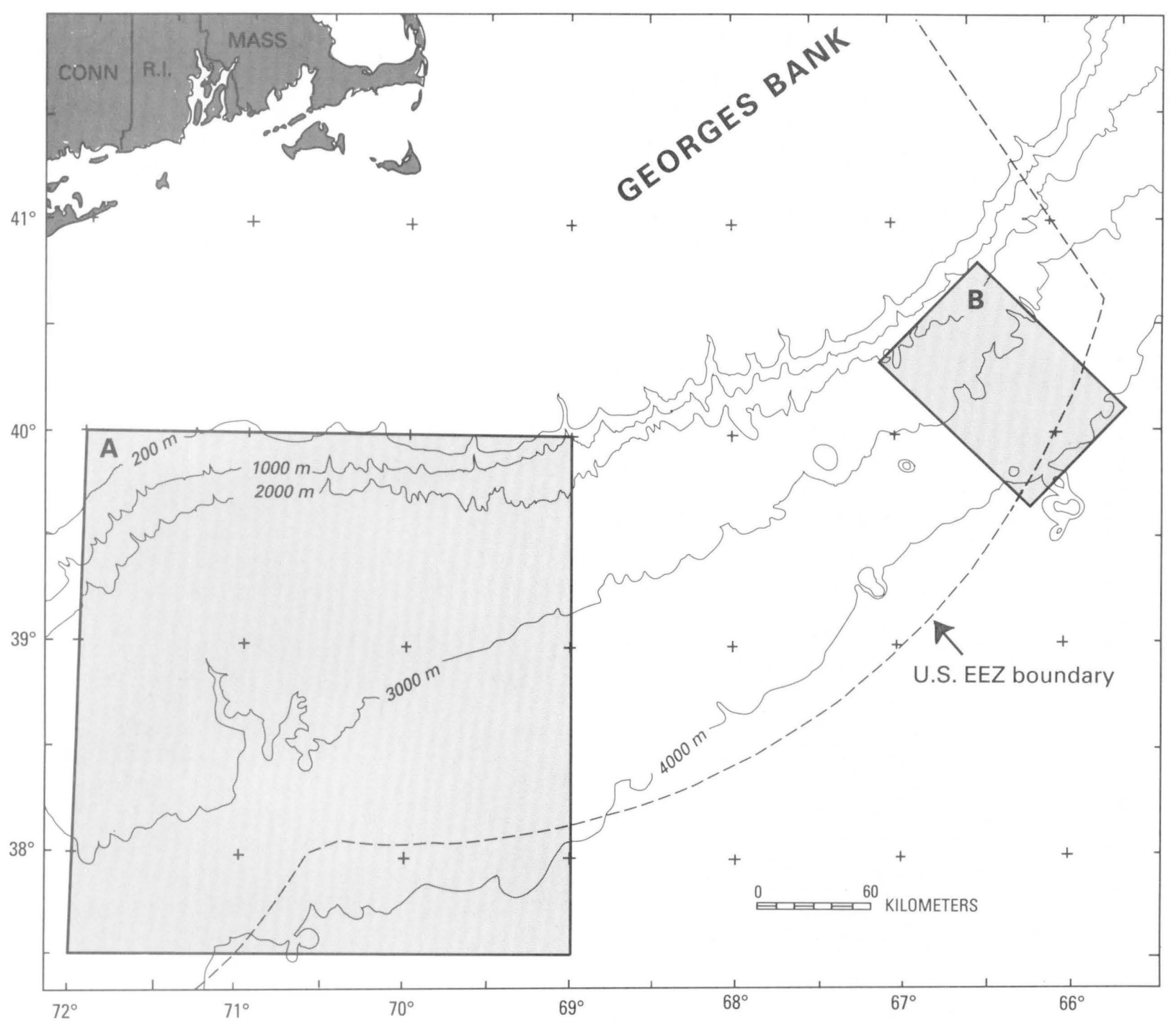

Figure 1. Areas of the New England continental slope and rise occupied by mass movement complexes: (A) Southeast New England landslide complex; (B) Munson-Nygren landslide complex.

Hudson Canyon east to $69^{\circ} 30^{\prime} \mathrm{W}$. (fig. 2), a distance of 200 kilometers $(\mathrm{km})$. The complex comprises four major landslides and numerous lesser areas of mass movement, as well as masses of sediment that have issued from canyons and that coalesce with the larger mass-movement deposits. The four major landslides (or centers of mass movement) within the southeast New England landslide complex, the Block Canyon landslide, the Atlantis Canyon landslide, the Nantucket Canyon landslide, and the Veatch Canyon landslide, are named for the largest canyons that seem to have been involved in or modified by each slope failure (fig. 2). Each landslide complex is represented along the upper rise by broad depressions bounded by scarps as much as 150 meters (m) in relief (fig. 3).

Slope failure generally originated on the continental slope in water depths greater than $750 \mathrm{~m}$. Evidence includes irregular scarps and cliffs that range in relief from 10 to 200 m (fig 4). Most strata of Pleistocene age $(10,000$ to 2 million years old) have been removed, along with an unknown amount of older strata. Chalky sediment of Eocene age (38 to 54 million years old) has been sampled from the sea floor below the landslide scarps (Gibson, 1965), and blocks of chalk have been sampled from debris on the rise, indicating that hard, deeply buried strata have been exposed by mass movement and, at least locally, involved in the transport.

Despite the gentle slope inclination $\left(4^{\circ}\right.$ to $\left.8^{\circ}\right)$, mass movement has been remarkably complete. The lower slope is nearly bare of rubble except for tongues of debris that have formed below some of the larger scarps, probably as a result of rockfalls or partial collapse of sections of scarp. There is no clear evidence of any large slabs that have survived transport across the slope nor any slabs that have been arrested close to the scarps, whereas the rise is 


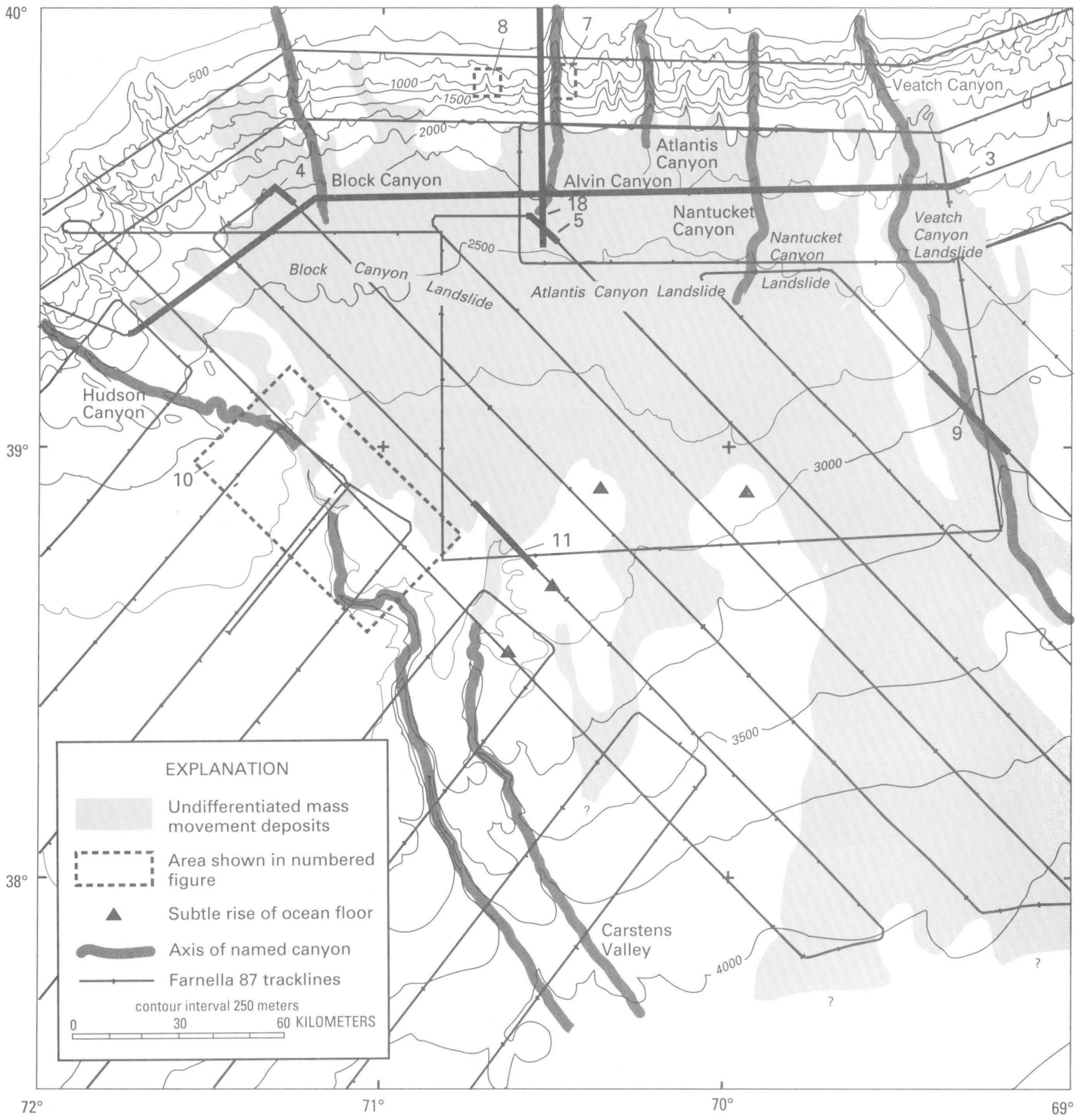

Figure 2. Generalized map of the southeast New England landslide complex. Numbered heavy line segments indicate locations of seismic-reflection profiles shown in corresponding figures.

blanketed by sheets of debris as much as $50 \mathrm{~m}$ thick and 50 $\mathrm{km}$ wide (figs. 2, and 5). Some mass-movement deposits are separated vertically from others by intervals of welllayered strata, suggesting geologically significant periods of quiescence and normal deposition between mass movements (fig. 5).
Debris from the landslides has spread across the upper rise to form broad, flared deposits which have sharply defined, irregular borders (figs. 2 and 6). The GLORIA images show the debris as light gray areas (areas of high acoustic backscatter intensity) and the undisturbed sea floor as dark gray (areas of low acoustic backscatter). The 


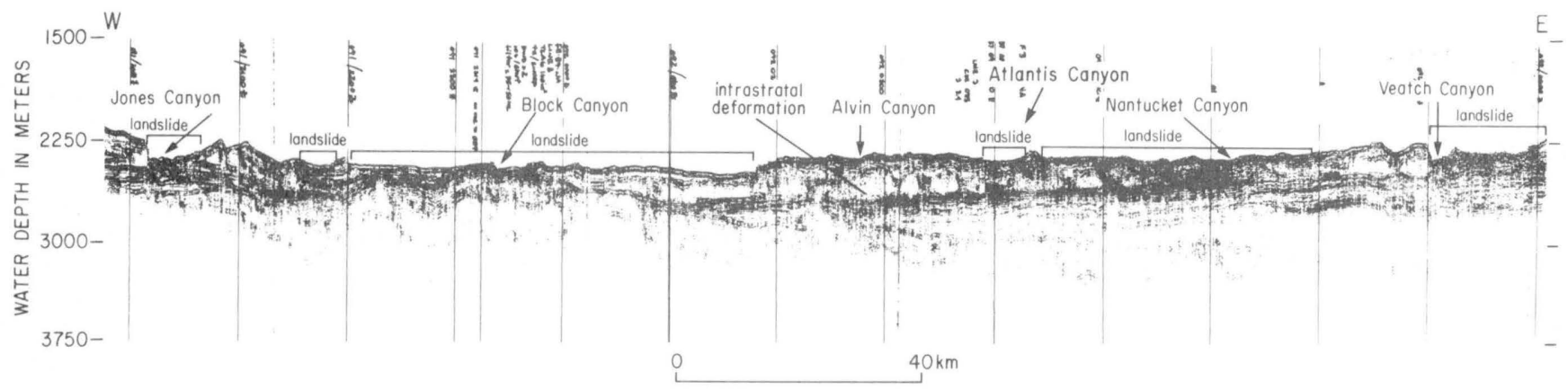

Figure 3. Seismic-reflection profile along the upper rise at water depths of about 2,250 meters shows relationships between landslide-complex depressions and canyons.

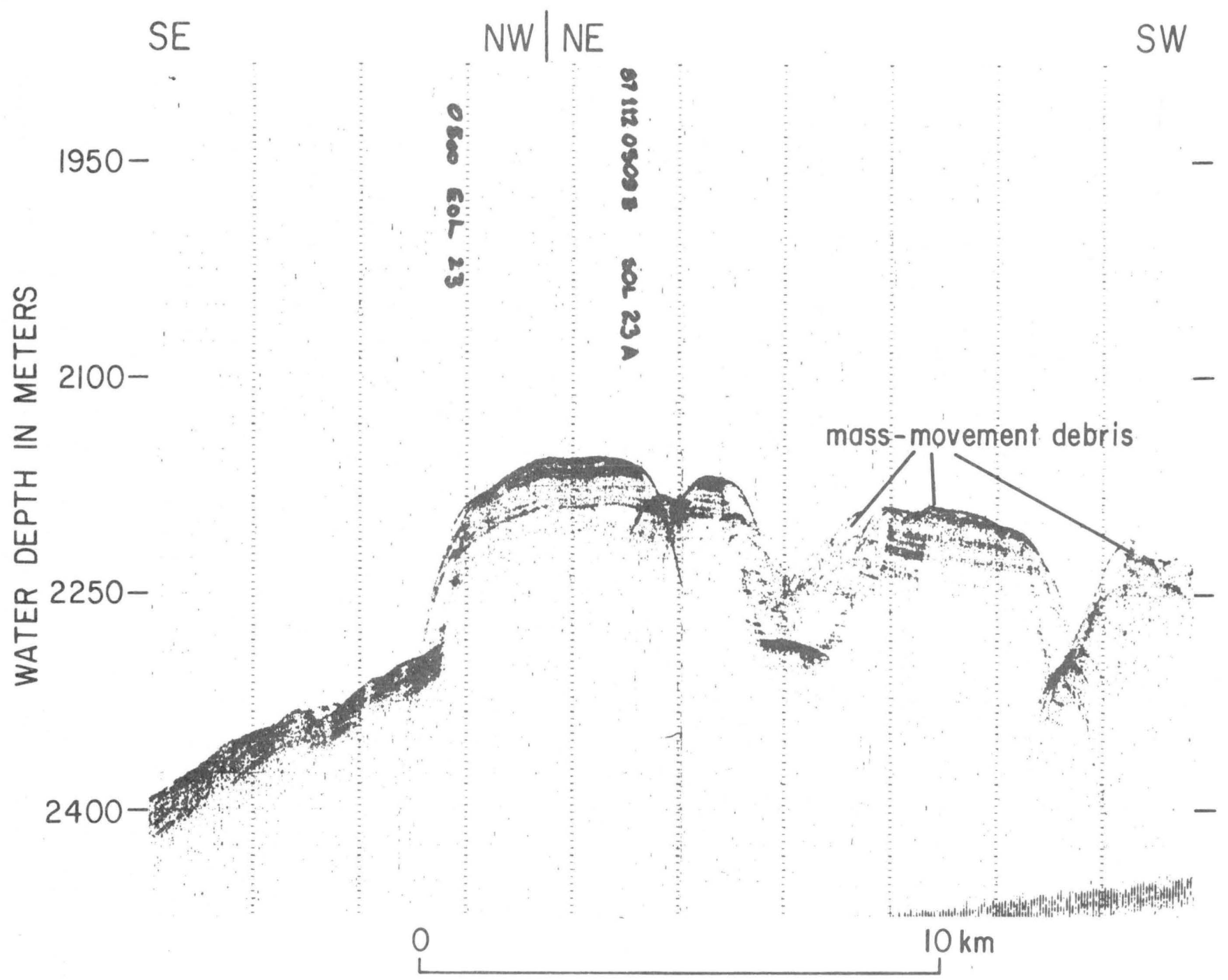

Figure 4. Part of the escarpment along the head of the southeast New England landslide complex. The features shown here, in a water depth of about 2,250 meters, have a relief of almost 100 meters. The central gap is choked with debris, and the two stacks at the right end of the profile segment are partly overridden with debris. 


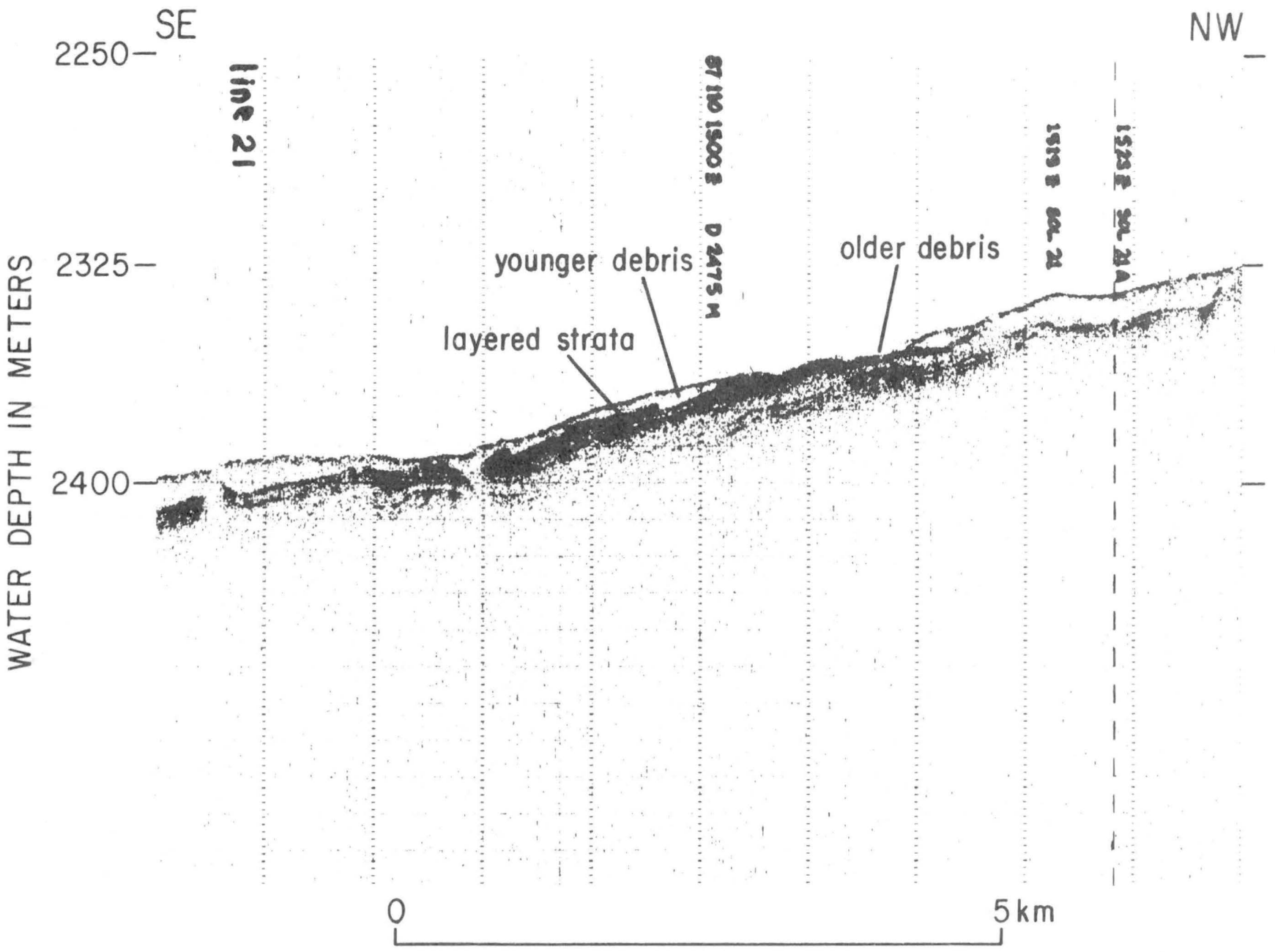

Figure 5. Echo-sounder profile shows two generations of mass-movement debris separated by remnant of normally layered sediment.

boundaries of the mass-movement deposits mapped from the GLORIA images show that transport of debris was halted or diverted by subtle rises of the ocean floor more than $100 \mathrm{~km}$ from the landslide heads (figs. 2 and 6). The debris typically pinches out at the contacts with little relief.

A number of submarine canyons feed into the southeast New England landslide complex. The larger canyons appear to predate mass movement, because some are evidently partly filled with debris, and sediment that drapes their upper walls has been partly removed by mass movement (fig. 7). Other canyons, however, clearly postdate the major mass-movement events, because they slice through some of the failure scarps on the slope (fig. 8). GLORIA images of the continental rise show that mass-movement debris partially dammed canyons. Veatch Canyon was actually overridden by debris of the Veatch Canyon landslide (fig. 9), whereas Hudson Canyon was partly filled by debris of the Block Canyon landslide that entered through alcoves along the east bank (fig. 10). Carstens Valley, which originates on the continental rise itself, was partly choked by the Block Canyon landslide debris; its head and upper region are nearly obscured by debris (fig. 11).

\section{MUNSON-NYGREN LANDSLIDE COMPLEX}

The Munson-Nygren landslide complex occupies the lower slope off Georges Bank between Munson and Nygren Canyons and just west of Munson Canyon (figs. 1 and 12). A sequence of at least three separate landslides has occurred between Munson and Nygren Canyons at a water depth of about $1,900 \mathrm{~m}$. Little is known about the oldest landslide; evidence of its existence consists of a rubble deposit shown in a seismic-reflection profile (fig. 13). This deposit is truncated by a 325-m-high scarp that represents a younger (and the major) landslide. The scarp that is associated with the second phase of mass movement forms a narrow alcove 6 to $10 \mathrm{~km}$ wide that extends $45 \mathrm{~km}$ downslope to where it opens on the continental rise and loses topographic definition (fig. 12). Displaced slabs as much as $250 \mathrm{~m}$ thick, and 


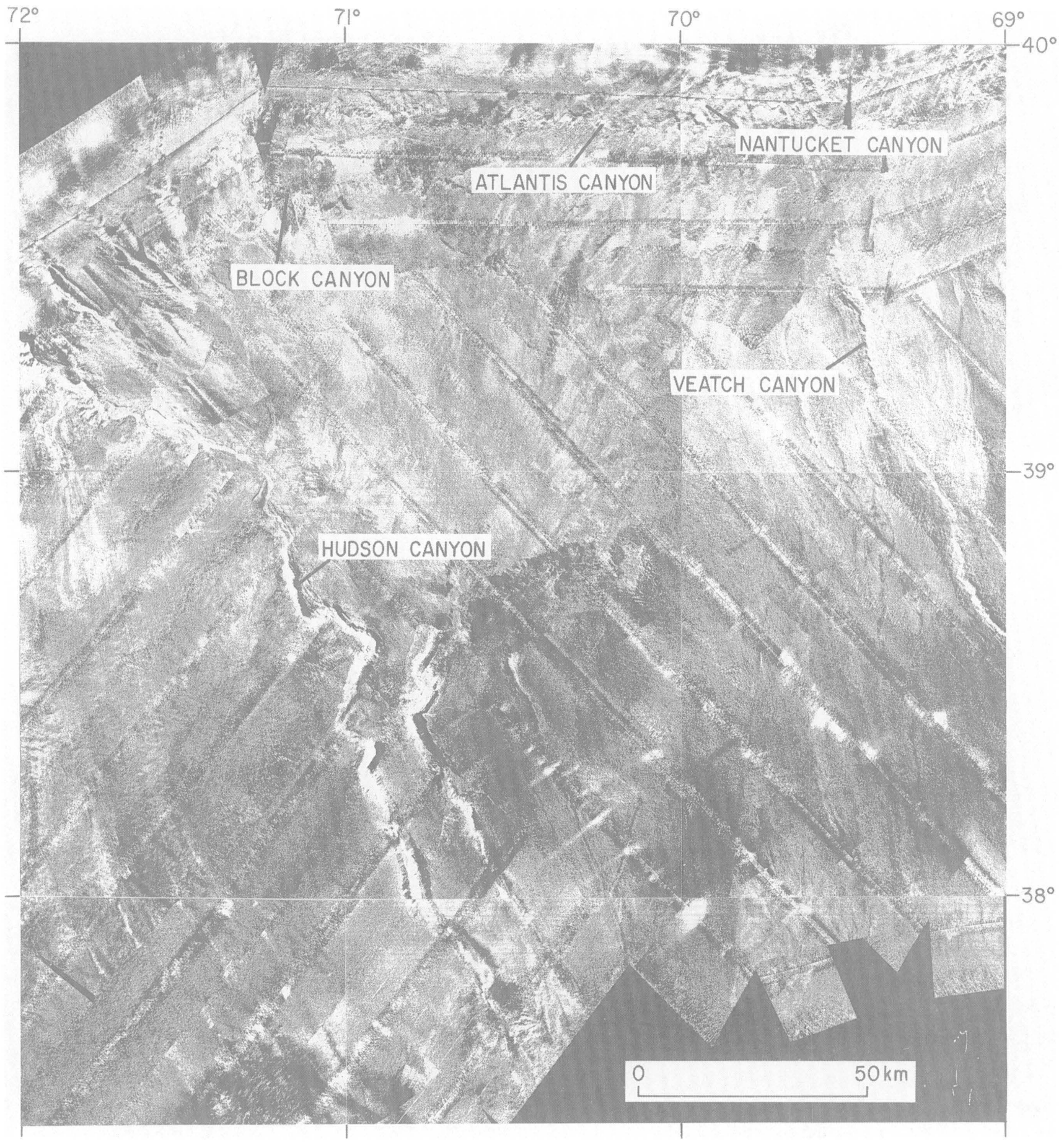

Figure 6. GLORIA sidescan-sonar imagery shows a broad distribution of debris within the southeast New England landslide complex (area A, fig. 1); debris shows as relatively light gray tones in the images. Wispy light and dark tones oriented north-south in eastern half of the image are debris flow lines. See figure 2 for further interpretation.

locally back-tilted blocks represent a third phase of landsliding toward the central Munson-Nygren landslide trough; the zone of these displaced slabs extends laterally for distances as much as 5 to $10 \mathrm{~km}$ back from the scarp (fig. 14) and apparently led to breaching of the east wall of Munson Canyon and to partial filling of the canyon with debris (figs. 15 and 16). The GLORIA images show that mass movement along the west flank of Munson Canyon constitutes a distinct landslide comparable in size to the Munson-Nygren landslide. It is called the Retriever landslide, because it spreads its debris directly downslope toward Retriever Seamount (fig. 12). 
S

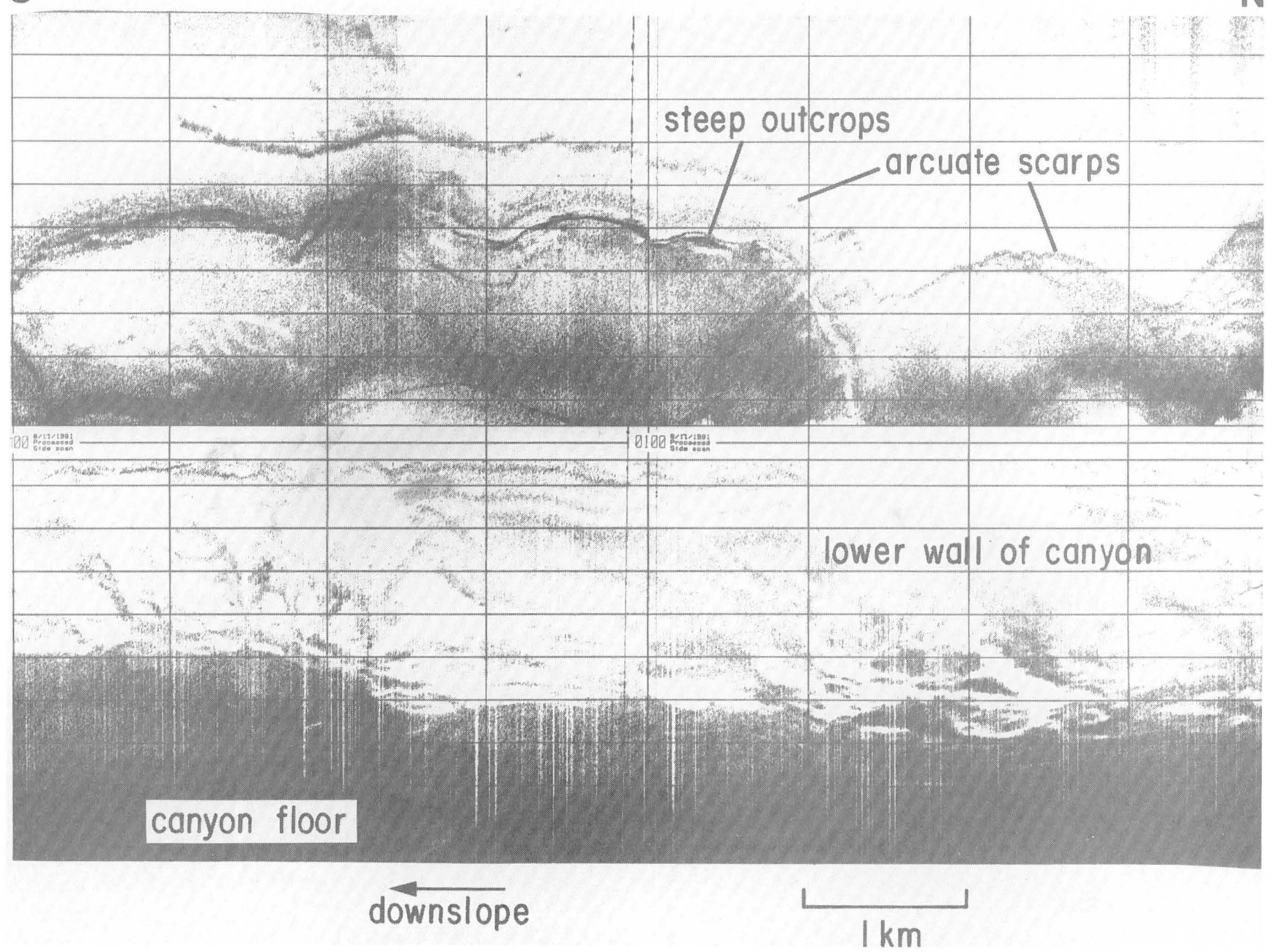

Figure 7. SeaMARC I sidescan-sonar image shows embayed, collapsed west wall of Atlantis Canyon. This image has been enhanced to emphasize the arcuate scarps forming the canyon rim as well as steep outcrops and cliffs along the wall. Dark tones indicate steep and (or) highly reflective surfaces.

Debris from the Retriever landslide seems to be older than sediment issued from Munson Canyon; whereas sediment from Munson Canyon merges rather completely with debris of the Munson-Nygren landslide, indicating coeval activity (fig. 17). Debris from the Munson-Nygren landslide complex extends across the rise for a distance of at least $200 \mathrm{~km}$ and over a width of sea floor as great as $80 \mathrm{~km}$ (fig. 12). The total combined debris sheet, not much thicker than about $35 \mathrm{~m}$, has flowed around Retriever seamount, partly burying it.

\section{COMPARATIVE FEATURES OF THE LANDSLIDE COMPLEXES}

The southeast New England landslide complex and the Munson-Nygren landslide complex share important similarities in structure and form, but there are significant differences in their physiographic settings and in the char- acter of the respective debris deposits. The similarities and the differences present interesting implications about origin and process.

In both areas, landsliding originated on the middle to lower part of the continental slope (the headwall scarps are at $750-\mathrm{m}$ to $1,900-\mathrm{m}$ water depths) and involved thick sections (less than or equal to $300 \mathrm{~m}$ ) of consolidated, well-bedded strata. Both areas of mass movement also show evidence of deformed layers deep in the sedimentary section (intrastratal deformation; figs. 3 and 14). Mass movement has been complex in both areas, involving multiple and sequential displacements that have cut into or occurred within older mass movement deposits.

In both areas, landsliding has been geologically recent; the youngest strata resolvable by echo-sounding, strata of late Pleistocene age (about 20,000 years old), have been cut. Landsliding in both areas also postdates the episode of major canyon cutting along the slope, although it 


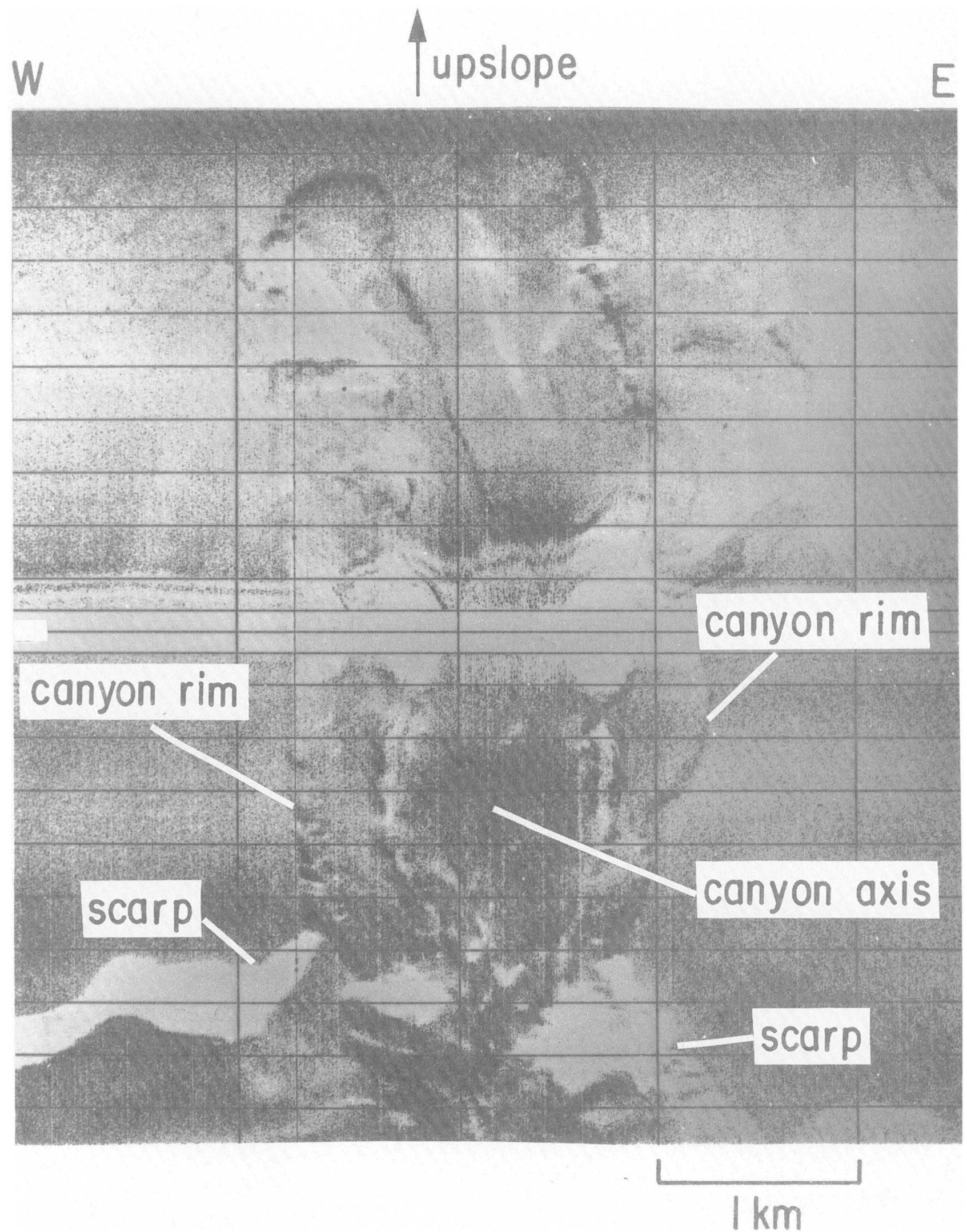

Figure 8. SeaMARC I sidescan-sonar image shows small canyon cut through a mid-slope head-wall scarp of the southeast New England landslide complex. The scarp faces downslope and is in acoustic shadow (white tone). 


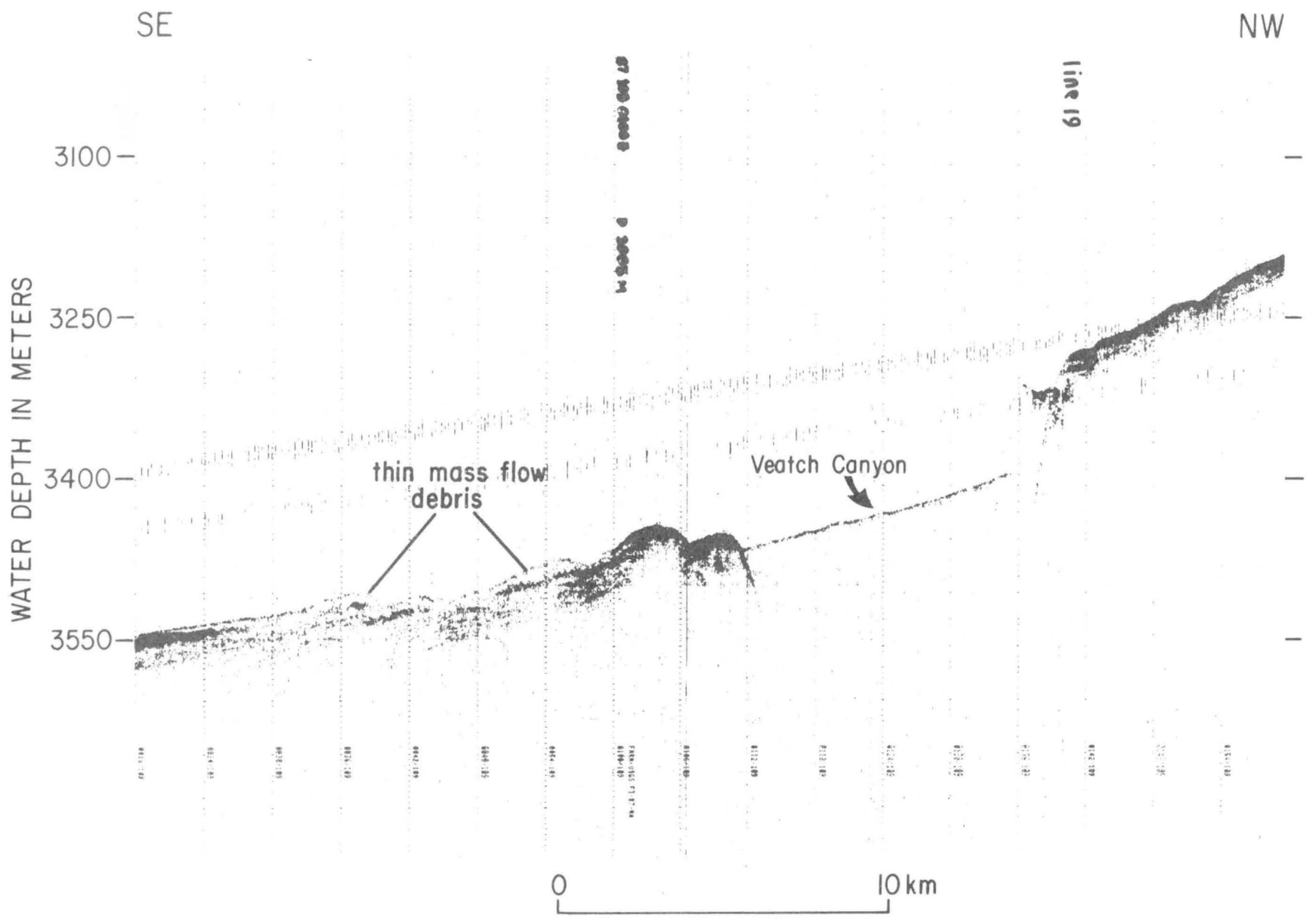

Figure 9. Echo-sounder profile shows Veatch Canyon nearly filled by debris of the Veatch Canyon landslide. The debris crossed the canyon from the north, partly filling it, and extended for some uncertain distance to the south.

is clear that in the southeast New England landslide complex, at least, some canyons have formed along with or following some of the mass movement, and Munson Canyon has been active following some deposition in the Munson-Nygren landslide complex (fig. 17).

In both areas, mass-movement debris is almost totally disintegrated; only small blocks of hardened sediment have survived transport. The strata subject to mass movement must have been unable to withstand the stress of movement and must have fragmented in the manner of subaerial landslides. The disintegrated debris was remarkably mobile. In both areas, it spread out, away from the landslide head across a sea floor inclined at less than a degree.

The two landslide complexes occupy distinctly different physiographic settings. The southeast New England continental slope is an area of mainly parallel stratification in which the lower slope steepens with depth and forms an abrupt contact with a more gently sloping continental rise surface (fig. 18). The Munson-Nygren landslide complex and the Retriever landslide occur along a segment of slope which is steepest above the headwall scarp (fig. 13) and which otherwise curves gradually into the continental rise. It is easy to see how slope steepness in the former setting controls the extent of mass movement and the location of the slope failure scarps of the southeast New England landslide complex. Given the more or less uniform physical properties and sediment type, however, it is difficult to understand how slope failure could occur in the latter setting, because failure has taken place on the more gently inclined and presumably more stable lower part of the slope. Most of the slope along Georges Bank (fig. 1), a distance of $350 \mathrm{~km}$, features physiographic characteristics typical of the Munson-Nygren area; near Munson and Nygren Canyons, there do not appear to be any distinctive environmental factors which could have localized recurrent mass movement. Most of the Georges Bank slope is deeply cut by canyon erosion, and although landsliding has occurred at many places along the Georges Bank slope, nowhere does it reach the proportions of the MunsonNygren landslide complex.

There are interesting differences as well in the gross aspect of the debris deposits. Compared to debris of the 

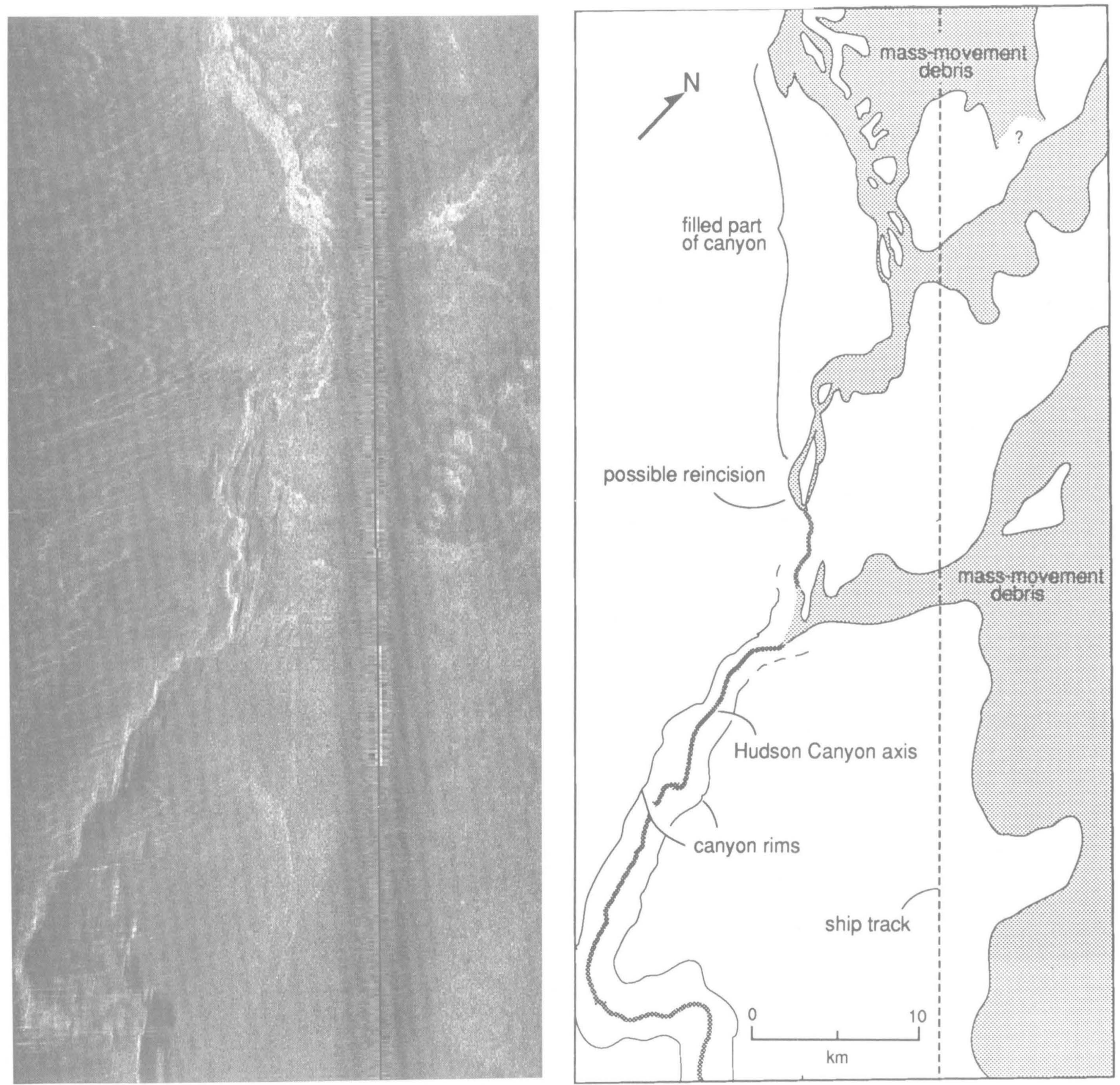

Figure 10. GLORIA sidescan-sonar image shows debris partly filling Hudson Canyon on the upper rise at a water depth of about 260 meters. Toward the south end of image the canyon has about 200 meters relief.

southeast New England landslide complex, debris of the Munson-Nygren landslide complex, as seen in the GLORIA images, does not have well-defined margins; debris of the Munson-Nygren landslide complex has a more flared distal aspect and a generally more homogeneous internal acoustic character. The less well-defined margins of the MunsonNygren debris deposit and the apparently deeper cuts into the sea floor suggest higher velocity transport with erosive powers. The more clearly defined and intricate borders of debris deposits of the southeast New England landslide complex, the existence of flow lines and patches of undisturbed strata beneath thin debris in this area implies a less destructive emplacement, perhaps involving lower velocities or less viscosity.

\section{SUMMARY OF INTERPRETATIONS AND CONTROVERSIES ON ORIGIN}

An explanation for the origin of one landslide complex must in some way account for the origin of the other, 


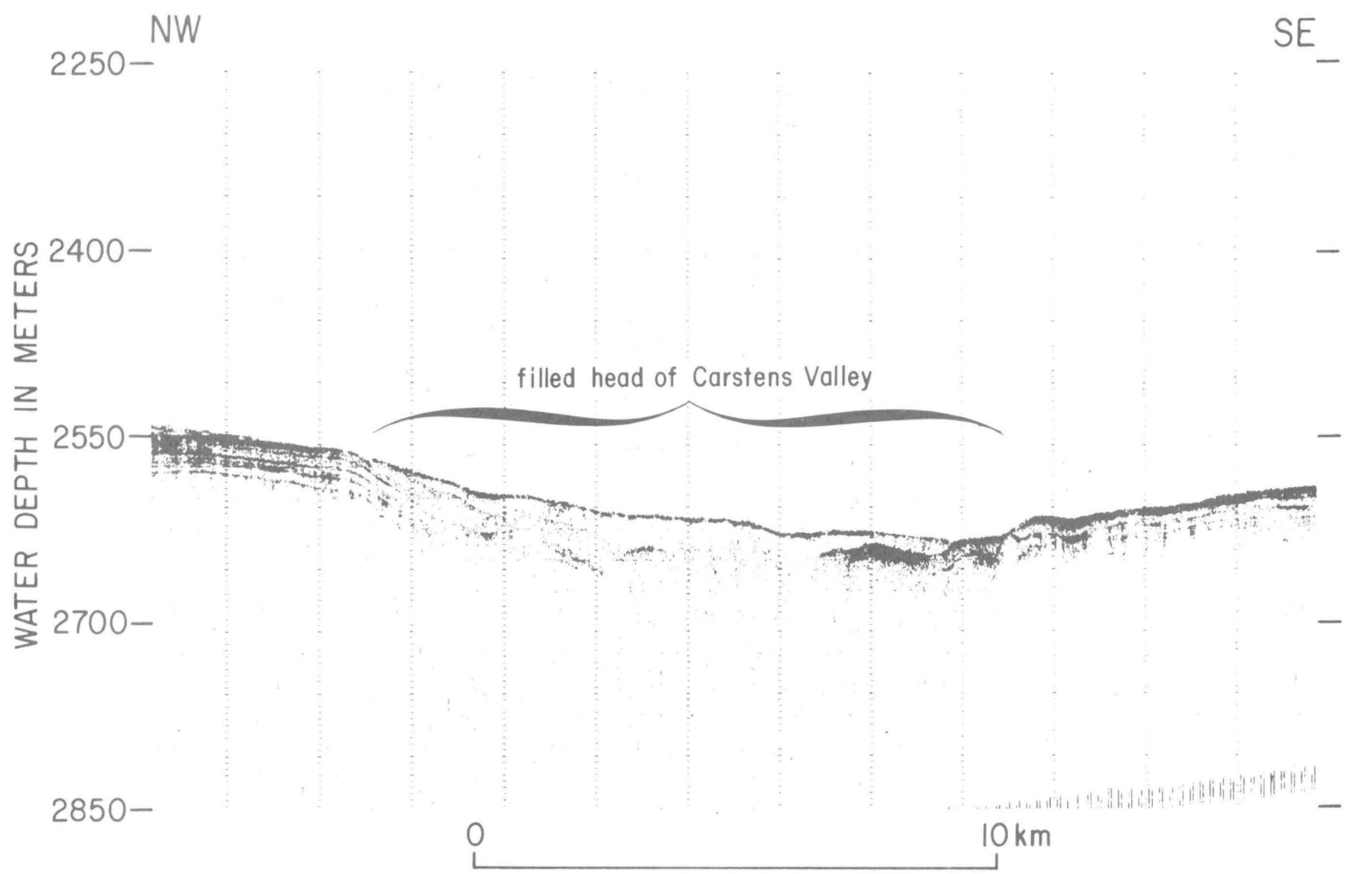

Figure 11. Echo-sounder profile shows mass-movement debris filling the head of Carstens Valley at water depths of about 2,600 meters.

since we wish to explain both the common features and the differences. Additionally, an acceptable explanation must conform to what we know about the geological histories of the two complexes. The accumulated geophysical data from the New England continental margin place strong constraints on any such explanation.

The concept of erosional undercutting of the lower continental slope by bottom currents is given no support by the GLORIA data off New England. The data show no evidence for any significant erosional or depositional features aligned along the New England slope, but they do show a nearly ubiquitous alignment of erosional and depositional features extending downslope and across the upper rise. The geological history of the New England continental slope, for the last 120,000 years at least, is dominated by sediment transport (mass movement) and erosion trending across the slope and rise rather than parallel to it (O'Leary, 1988b; Danforth and Schwab, 1990).

The concept of slope instability due to gas accumulation or to rapid sediment deposition on the upper slope is negated in the New England region by the fact that mass movement has occurred at water depths from $750 \mathrm{~m}$ to $2,000 \mathrm{~m}$, in stacks of strata tens to hundreds of meters thick, many of which had become compacted and indurated through time. Furthermore, these causal mechanisms are predicated on sea level having been lowered to at least the shelf edge, and while there is good evidence that such lowering did occur in Pleistocene time (O'Leary, 1988c), the data show that both canyon cutting and mass movement postdate any deposition that attended the latest drop in sea level. This means that shelf-edge deposition did not directly cause the slide complexes; shelf-edge deposits had attained stability before sliding occurred.

Likewise, "bioerosion" (Hecker, 1982) cannot account for failure of apparently stable stacks of strata tens of meters thick over areas of tens of hectares, because boring or digging organisms cannot penetrate deeply enough into the compacted strata. Bioerosion is, at most, a surficial process.

Of the various hypotheses put forward for mass movement along the New England slope, only earthquake shaking could account directly for the slide complexes. The case for earthquake-induced mass movement seems wellestablished for the Atlantic passive margin setting because of the widely cited 1927 Grand Banks earthquake, which is infamous for having set off mass flows that snapped a number of submarine cables sequentially downslope on the continental rise (Heezen and Ewing, 1952). Earthquake 


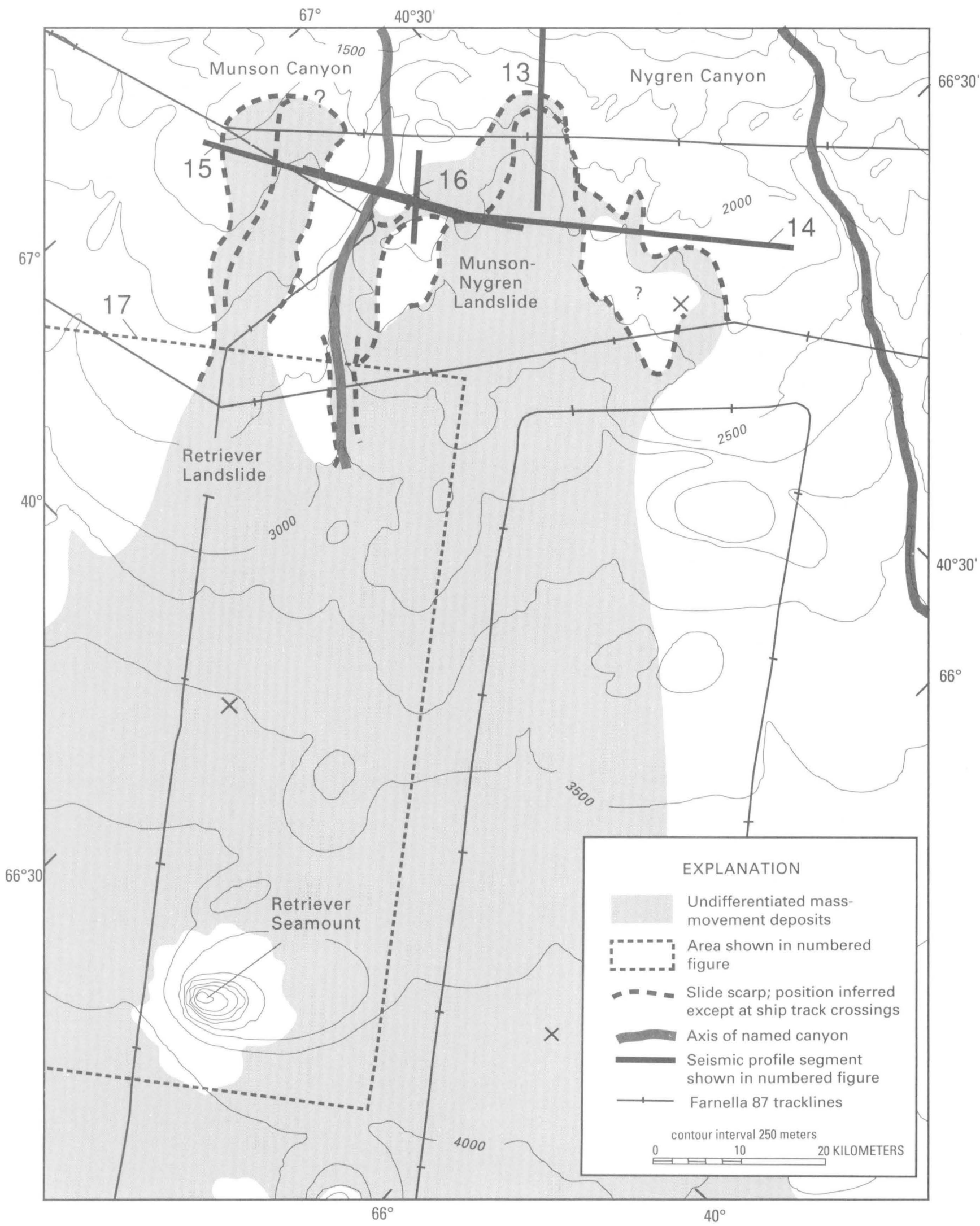

Figure 12. Generalized map of the Munson-Nygren landslide complex. Numbered heavy line segments indicate locations of seismic-reflection profiles shown in corresponding figures. 


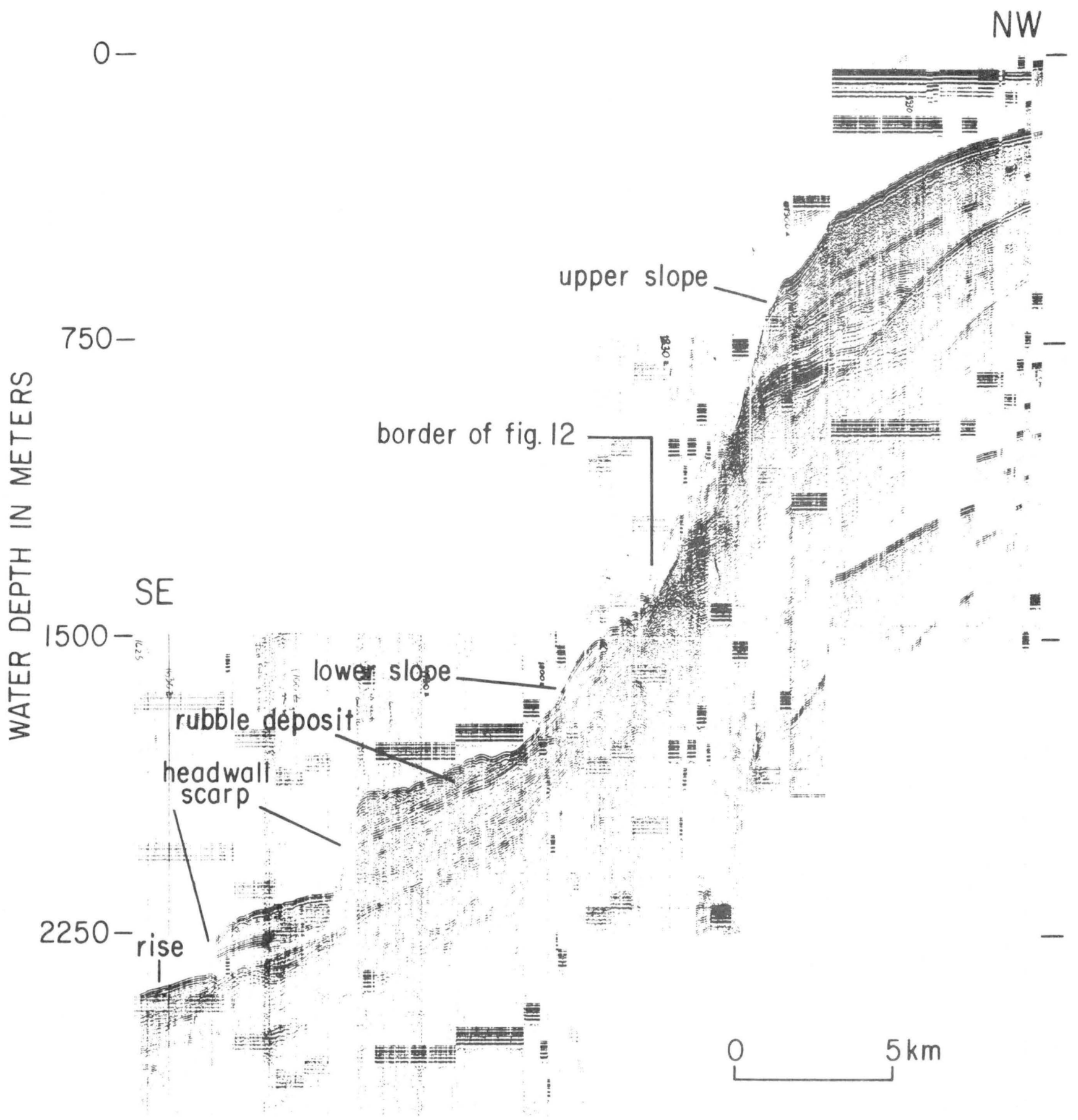

Figure 13. Seismic-reflection profile across the continental slope shows scarps and rubble associated with the Munson-Nygren landslide complex.

shaking is not necessarily the entire answer, however; there are other phenomena involved that must be explained. These phenomena include the involvement of slope canyons as debris conduits to the southeast New England landslide complex, the widespread intrastratal deformation, the recurrent mass movement at a particular spot and over an apparently short-and recent-interval of geologic time, and in the case of the Munson-Nygren landslide, the fact that mass movement occurred on a relatively gentle slope rather than on the steeper upper slope which we might expect would be more liable to fail.

The earthquake hypothesis could possibly be used to explain some of these difficulties. It is reasonable to suppose that short-lived episodes of seismicity have occurred, as part of the ongoing geological evolution of the Atlantic margin and that "swarms" of earthquakes have led to recurrent slope failure in localized areas (Woodcock, 1979), including recurrent or sustained collapse of canyon 


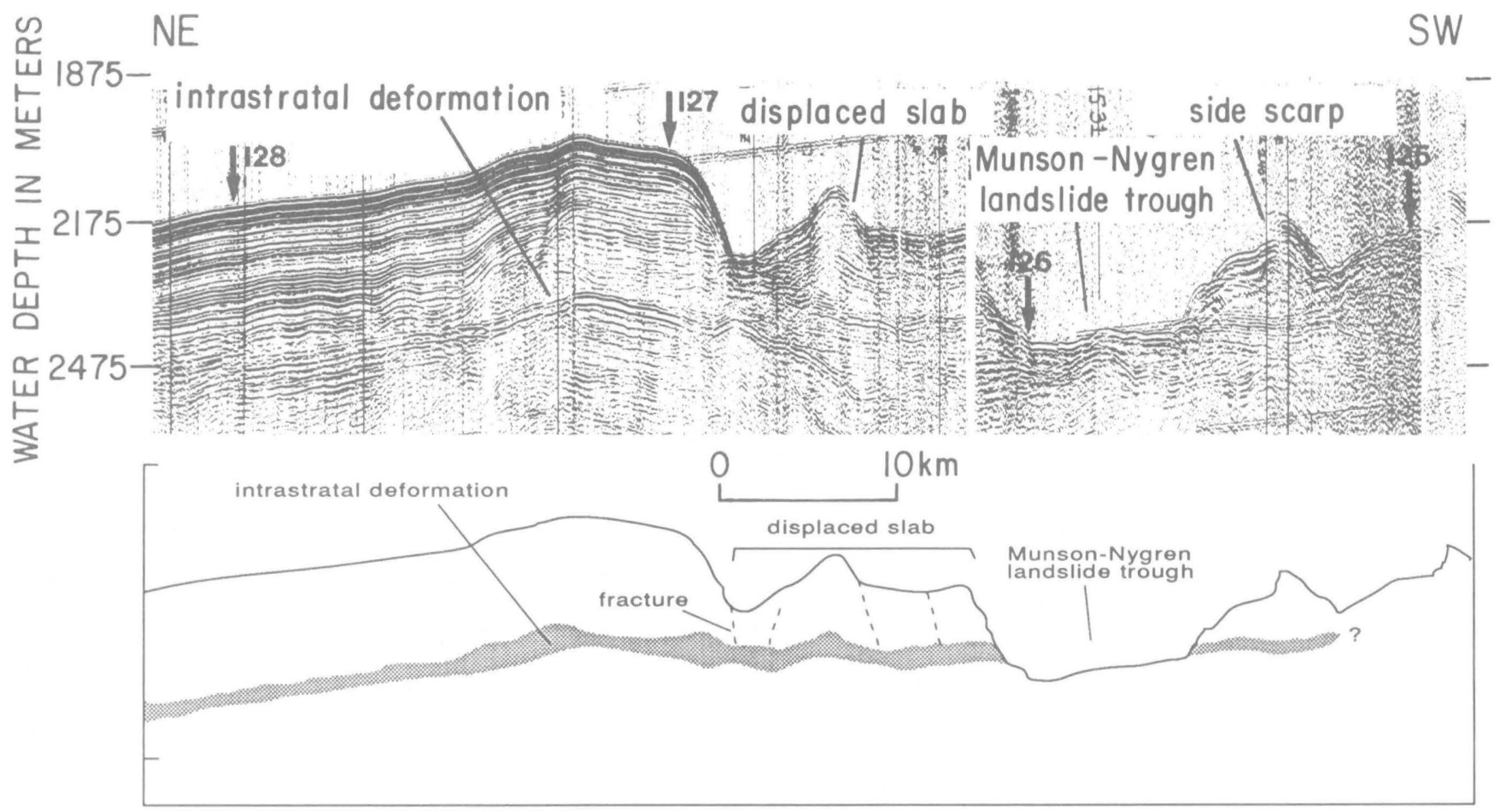

Figure 14. Seismic-reflection profile shows collapsed, displaced strata to either side of the main Munson-Nygren landslide.

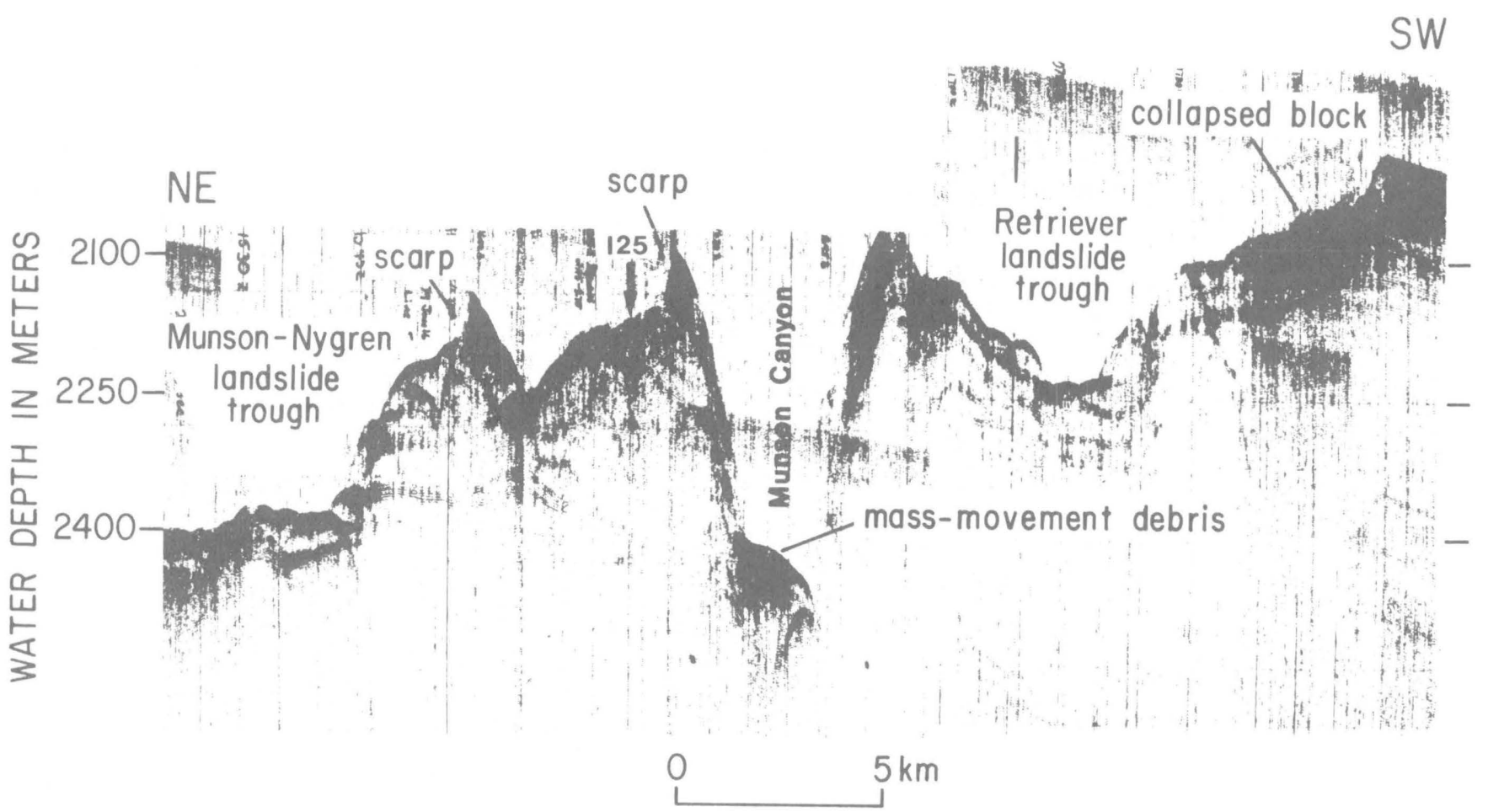

Figure 15. Seismic-reflection profile along lower slope shows location of Munson Canyon between Munson-Nygren landslide and Retriever landslide. Note the scarp that faces crossing position of profile I25 (fig. 16); the scarp backs the upper wall of Munson Canyon. 


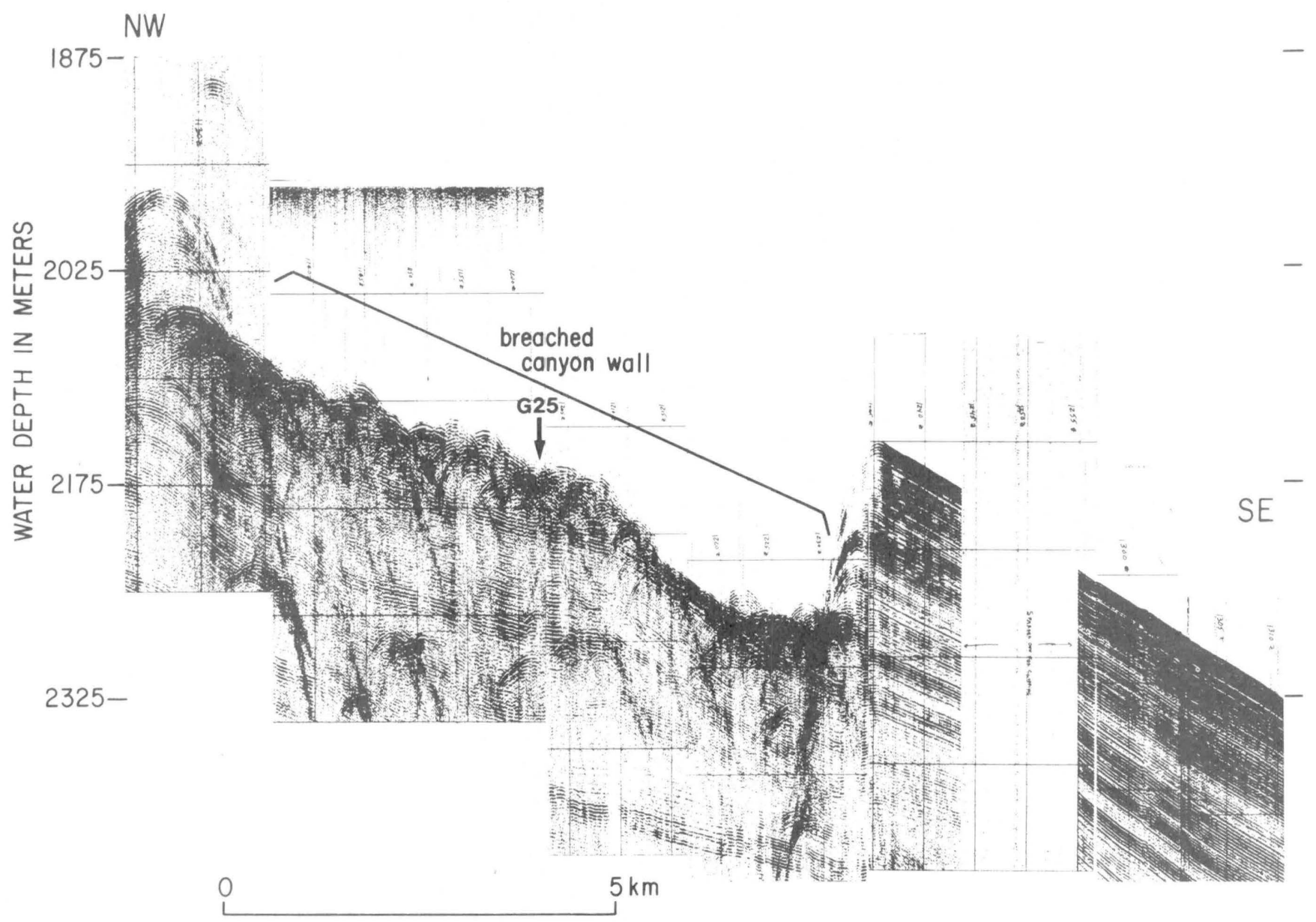

Figure 16. Seismic-reflection profile I25 extending along the upper east side of Munson Canyon shows that profile G25 (fig. 15) crosses a breach in the upper wall of Munson Canyon.

walls. It is even plausible to assert that some of the intrastratal deformation could be a consequence of ground shaking. Some unconsolidated, water-saturated layers may undergo strength loss and local failure during earthquake loading (Lee, Schwab, and Booth, this report). Other layers, deeper in the section, may weaken over a long period due to creep and a gradual loss of strength. Such layers may also be susceptible to earthquake shock. Little is known about this inferred weak-layer phenomenon, and the full story awaits results of ongoing research; however, failure of a laterally extensive weak layer could lead to nearly instantaneous collapse (liquefaction at depth within the strata) and disintegration of large slabs of strata. Such disruption is implied by the finely fragmented, thin debris strewn across the rise below the landslide scarps.

The contrast in depositional style between the Munson-Nygren landslide complex debris and the southeast New England landslide complex debris can be attributed, at least in part, to sediment composition. The southeast New England landslide complex is derived from a finer-grained, more clay-rich, probably more cohesive sediment
(O'Leary, 1988c); the debris may have regained some cohesive strength below a certain transport velocity, or the debris may have behaved more like a debris flow than a turbidity current. The Munson-Nygren landslide is derived from slightly coarser, less cohesive, more poorly sorted sediment that may have been more readily dispersed to form a turbid flow than debris of the southeast New England landslide complex.

\section{CONCLUSIONS}

The southeast New England landslide complex and the Munson-Nygren landslide complex are similar to large landslide complexes found elsewhere on continental slopes that rim the Atlantic Ocean basin. The landslide complexes show recurrent mass movement in stacks of strata that were otherwise stable for some time following deposition. Landsliding has resulted in nearly complete fragmentation of the failed strata and emplacement as thin sheets of debris over huge areas of the upper rise.

Mass movement of this nature seems to be a common feature of passive continental margins (Booth and others, 

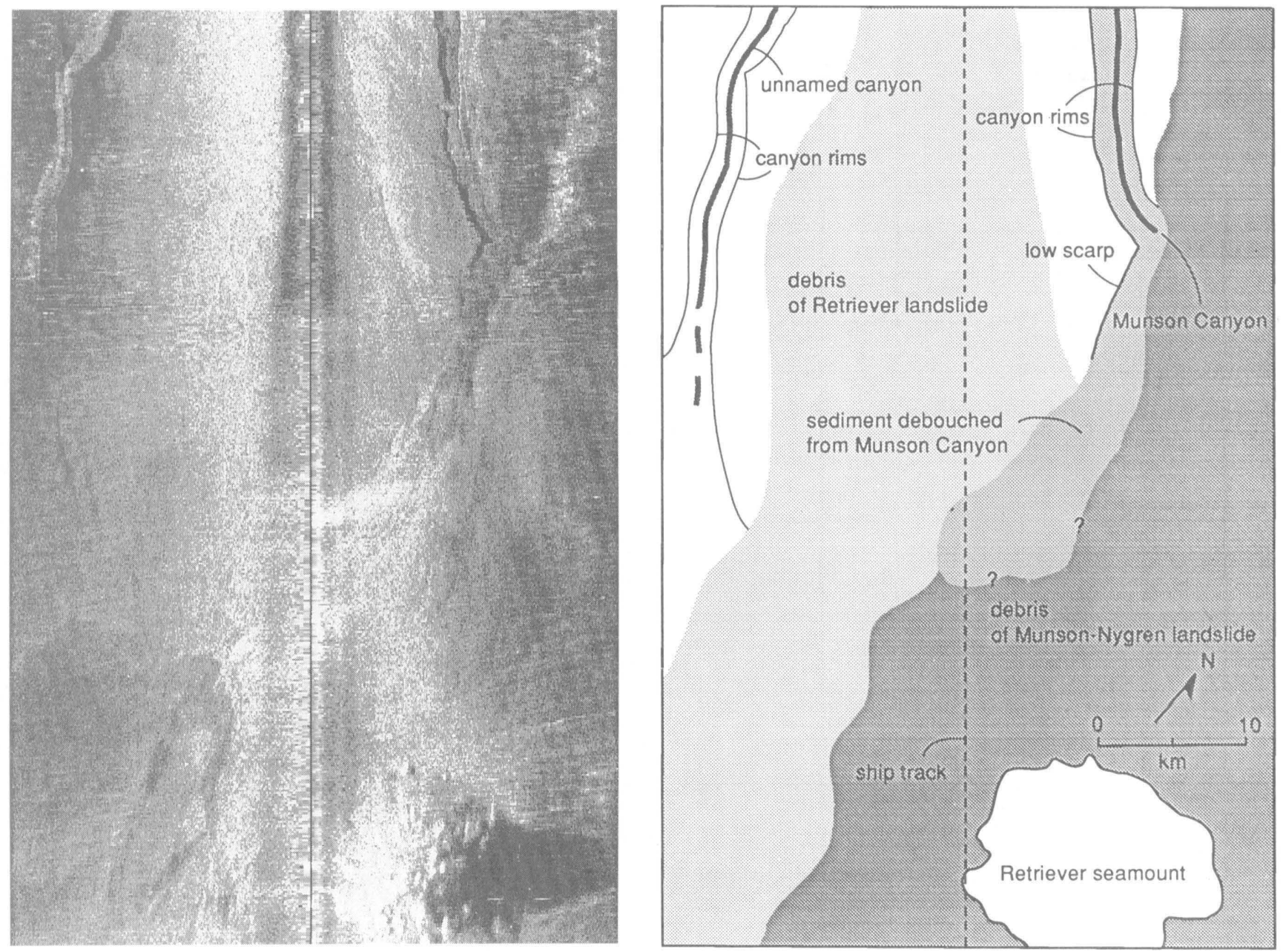

Figure 17. GLORIA sidescan-sonar image segment shows sea floor in the vicinity of Retriever seamount (water depth about 3,700 meters). Sediment debouched from Munson Canyon trends across the Retriever landslide debris field, but it seems to merge with, or perhaps be diverted by, the Munson-Nygren landslide debris.

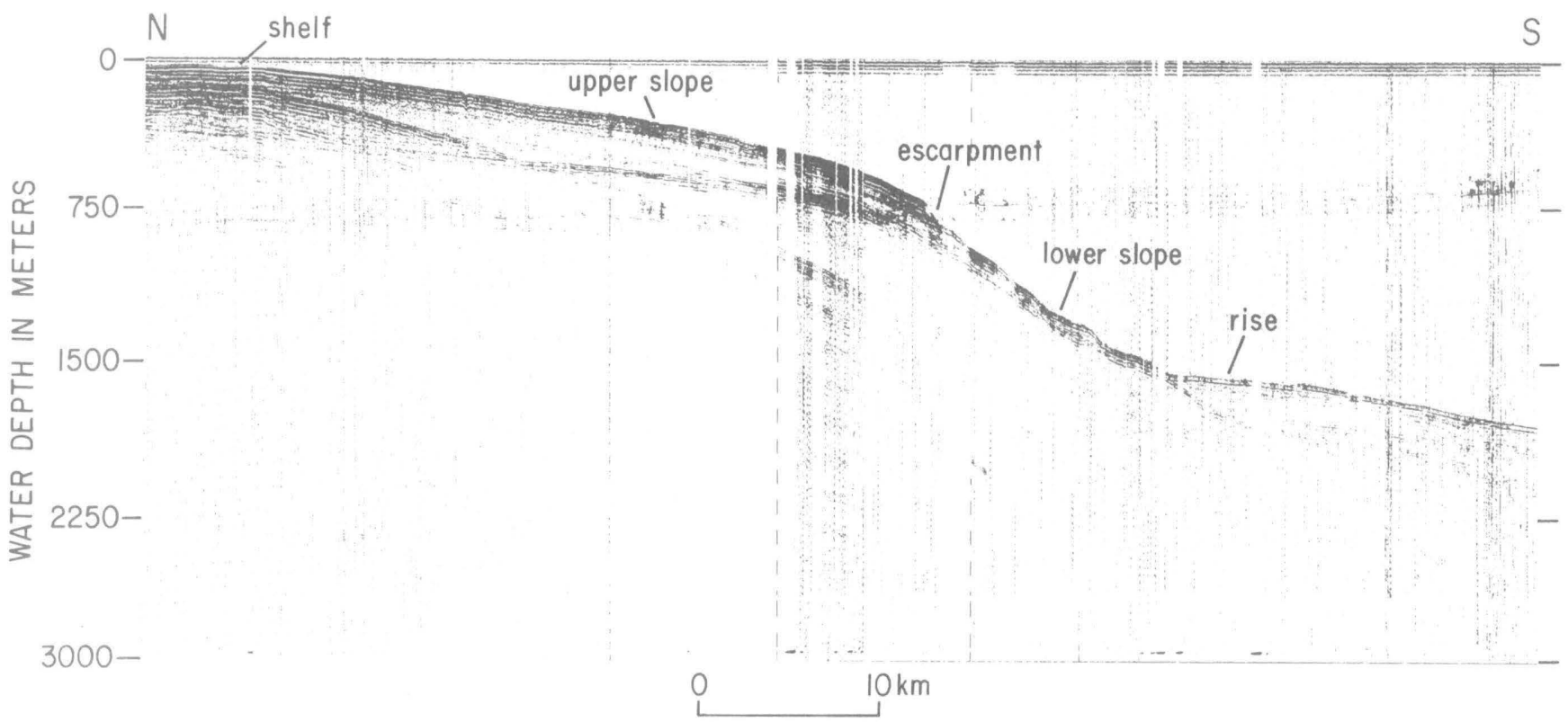

Figure 18. Seismic-reflection profile shows typical continental slope/rise profile in area of the southeast New England landslide complex. 
this report); it does not seem to be a result of local environmental factors, including rapid deposition at the shelf edge. Rather, the origin of the landslide complexes would seem to be found in the structural and tectonic characteristics of the passive margins themselves. The salient characteristics include generally uniform, deposition and lithification of fine-grained sediment upon a very slowly and gently subsiding surface, the stability of which is punctuated by sporadic, large earthquakes. Accordingly, a hypothesis of origin for the mass-movement complexes described above centers on a gradual weakening, due to creep, of key beds buried beneath the lower slope. Strainweakened beds would be susceptible to failure by earthquake shock; with structural support destroyed, the overlying section would thereupon fail and fragmentation of the detached mass would ensue during mass movement.

This simple hypothesis requires much more scrutiny in the light of more data. The actual mode of debris transport remains problematic, and the genetic relationships between slope failure and canyon erosion offer unexplored complexities. The period of active canyon erosion that preceded and postdated mass movement implies a different set of processes and conditions than existed for the large landslides, yet these conditions obviously intersected and jointly contributed to sedimentation on the New England continental rise for some significant period. Whether canyon activity reflects environmental phenomena related to the advance and retreat of Pleistocene ice sheets, and whether these climatic events contributed directly to submarine sliding on the New England slope remains to be seen. Despite present uncertainties, evidence indicates that large-scale submarine landsliding is an inherent part of both the depositional history and the tectonic processes that formed the Atlantic passive margin.

\section{REFERENCES CITED}

Bugge, Tom, Belderson, R.H., and Kenyon, N.H., 1988, The Storegga slide: Philosophical Transactions of the Royal Society of London (A), v. 325, p. 357-388.

Burk, C.A., and Drake, C.L., 1974, Continental margins in perspective, in Burk, C.A., and Drake, C.L., eds., The geology of continental margins: New York, Springer-Verlag, p. 1003-1009.

Danforth, W.W., and Schwab, W.C., 1990, High-resolution seismic stratigraphy of the upper continental rise seaward of
Georges Bank: U.S. Geological Survey Miscellaneous Field Studies Map MF-2111, 9 sheets and 10 p.

Embley, R.W., 1976, New evidence for occurrence of debris flow deposits in the deep sea: Geology, v. 4, p. 371-374.

1982, Anatomy of some Atlantic margin sediment slides and some comments on ages and mechanisms, in Saxov, Svend, and Nieuwenhuis, J.K., eds., Marine slides and other mass movements: New York, Plenum Press, p. 189-214.

Embley, R.W., and Jacobi, R.D., 1977, Distribution and morphology of large submarine sediment slides and slumps on Atlantic continental margins: Marine Geotechnology, v. 2, Marine Slope Stability, p. 205-228.

Gibson, T.G., 1965, Eocene and Miocene rocks off the northeastern coast of the United States: Deep-Sea Research, v. 12, p. 975-981.

Hecker, Barbara, 1982, Possible benthic fauna and slope instability relationships, in Saxov, Svend, and Nieuwenhuis, J.K., eds., Marine slides and other mass movements: New York, Plenum Press, p. 335-348.

Heezen, B.C., and Ewing, Maurice, 1952, Turbidity currents and submarine slumps and the 1929 Grand Banks earthquake: American Journal of Science, v. 250, p. 847-873.

Jacobi, R.D., 1976, Sediment slides on the northwestern continental margin of Africa: Marine Geology, v. 22, p. 157-173.

Kidd, R.B., Simm, R.W., and Searle, R.C., 1985, Sonar acoustic facies and sediment distribution on an area of the deep ocean floor: Marine and Petroleum Geology, v. 2, p. 210-221.

MacIlvaine, J.C., and Ross, D.A., 1979, Sedimentary processes on the continental slope of New England: Journal of Sedimentary Petrology, v. 49, no. 2, p. 563-574.

O'Leary, D.W., 1986, The Munson-Nygren slide: a major lowerslope slide off Georges Bank: Marine Geology, v. 72, p. 101-114

1988a, GLORIA reveals rise: Geotimes, v. 33, p. 22-24. 1988b, GLORIA shows late Cenozoic sediment distribution and erosion patterns of the New England continental rise: Abstracts with programs, Geological Society of America Annual Meeting, v. 20, no. 7, p. A131.

1988c, Shallow stratigraphy of the New England continental margin: U.S. Geological Survey Bulletin 1767, 40 p.

Saxov, Svend, and Nieuwenhuis, J.K., 1982, Marine slides and other mass movements: Series IV: Marine sciences, v. 6, New York, Plenum Press, 353 p.

Uchupi, Elazar, 1967, Slumping on the continental margin southeast of Long Island, New York: Deep-Sea Research, v. 14, p. 635-639.

Vassallo, Kevin, Jacobi, R.D., and Shor, A.N., 1984, Echo character, microphysiography, and geologic hazards, in Ewing, J.I., and Rabinowitz, P.D., eds., Eastern North American Continental Margin and Adjacent Ocean Floor, $34^{\circ}$ to $41^{\circ} \mathrm{N}$. and $68^{\circ}$ to $78^{\circ} \mathrm{W}$., Atlas 4 , Ocean Margin Drilling Program: Regional Atlas Series, Marine Science International: Woods Hole, Mass., p. 31.

Woodcock, N.H., 1979, Sizes of submarine slides and their significance: Journal of Structural Geology, v. 1, p. 137-142. 


\title{
The Cape Fear Landslide: Slope Failure Associated with Salt Diapirism and Gas Hydrate Decomposition
}

\author{
By Peter Popenoe, E.A. Schmuck, and W.P. Dillon
}

\section{INTRODUCTION}

The Cape Fear landslide is one of the largest and best documented of the U.S. Atlantic continental margin massmovement features. The landslide occurred on the continental slope and rise southeast of Cape Fear, N.C., with the main headwall scarp centered on the lower slope at 2,600 meter (m) water depth (fig. 1). The amphitheater-shaped headwall scarp, over 50 kilometers $(\mathrm{km})$ long and $120 \mathrm{~m}$ high, encircles two large salt diapirs that protrude above the sea floor within the failure area. (A diapir is a fold in which a mobile core has risen and broken through brittle overlying rock and sediment.) A complex of slumps extends more than $40 \mathrm{~km}$ upslope from the major headwall scarp (fig. 2), and mass-movement deposits can be traced for more than $400 \mathrm{~km}$ downslope to a water depth of over $5.4 \mathrm{~km}$ on the Hatteras Abyssal Plain.

The landslide is unique along the Atlantic continental margin, both because of its coincidence with the extruded salt diapirs, and because of its association with a gas hydrate in the shallow subsurface (fig. 1). Gas hydrate is an icelike material that forms, when a mixture of methane (or other gases) and water satisfy certain pressure and temperature conditions (see Kayen and Lee, this report). Both the intrusion of salt (Cashman and Popenoe, 1985) and decomposition of the gas hydrate caused by past global warming or sea-level lowering (Carpenter, 1981; Paull and others, 1989), have been proposed as possible causes of the slope failure. In this section, we document some of the features associated with the Cape Fear landslide and review evidence relating to the possible mechanisms and timing of the slope failure.

The Cape Fear landslide was discovered in the late 1970's, when mass-movement deposits on the continental rise below the area of slope failure were first identified from echo-sounder profiles and cores (Embley, 1980). The main headwall scarp created by the landslide was mapped by the U.S. Geological Survey (USGS) during geologic hazards investigations related to offshore petroleum lease activity in 1979 and 1980 (Popenoe and others, 1981, 1982; Carpenter, 1981; Cashmen and Popenoe, 1985). Most recently the lower headwall area of the landslide was surveyed by investigators (Paull and others, 1989) from the University of North Carolina (UNC). The USGS and UNC network of ship tracklines in this study area are shown on figure 2 .

\section{REGIONAL GEOLOGIC SETTING}

The continental slope and upper rise between Cape Hatteras and Blake Spur (fig. 1), overlie the eastern edge of the Carolina Trough. The Carolina Trough is a narrow sediment-filled basin that formed following the initial rifting (separation) of Africa and North America over 140 million years ago (Jurassic Period). In its early history, the Carolina Trough was the site of deposition of a thick layer of salt (Dillon and others, 1982; Hutchinson and others, 1982; Dillon and Popenoe, 1988, and references cited therein). Later, in Jurassic and Cretaceous time (140 to 65 million years ago), the landward part of the basin was covered by seaward-prograding sediment of the continental shelf and slope. This progradation across the basin loaded the salt layer and squeezed it seaward in front of the advancing wedge of sediment. When the displaced salt encountered a shallower rock basement that forms the eastern edge of the Carolina Trough, it flowed upward, forming a line of salt diapirs (fig. 1). Although there are several salt diapirs that extend above the sea floor on the continental rise, the two diapirs exposed in the scar of the Cape Fear landslide have the most relief and are the only diapirs that are associated with slope failure.

A well-developed gas-hydrate layer that in many areas has free gas trapped beneath it is present throughout the area of the crest of Blake Ridge and beneath the continental slope and upper rise off North Carolina (fig. 1), approximately coincident with the location of the Carolina Trough. Gas hydrate looks much like ice; in fact, its crystal structure consists of an ice lattice that incorporates gas molecules of the appropriate size into its structure. Commonly, this gas is methane or carbon dioxide. Temperature and pressure conditions of the deep ocean are conducive to the formation of gas hydrate within the upper several hundred meters of the sedimentary section (Kayen and Lee, this report) and, if adequate gas is available, gas hydrate will fill the pore spaces between sediment grains. As the sediment gets warmer with increasing depth (geothermal heating), eventually a temperature is reached in the subsurface below which the gas hydrate cannot exist. Thus, there is a distinct base to the gas-hydrate-cemented zone. This base reflects sound energy, so the base of the gas hydrate can be seen on seismic-reflection profiles as a reflector that tends to parallel the sea floor (bottom-simulating reflector or BSR). The BSR is easily seen to the south of the landslide area (fig. 3), where the continental slope is undisturbed by structures associated with the landslide. Also seen on seismic-reflection profiles are amplitude anomalies (bright spots) caused by free gas trapped beneath the gas hydrate. In comparison, the gas hydrate and 


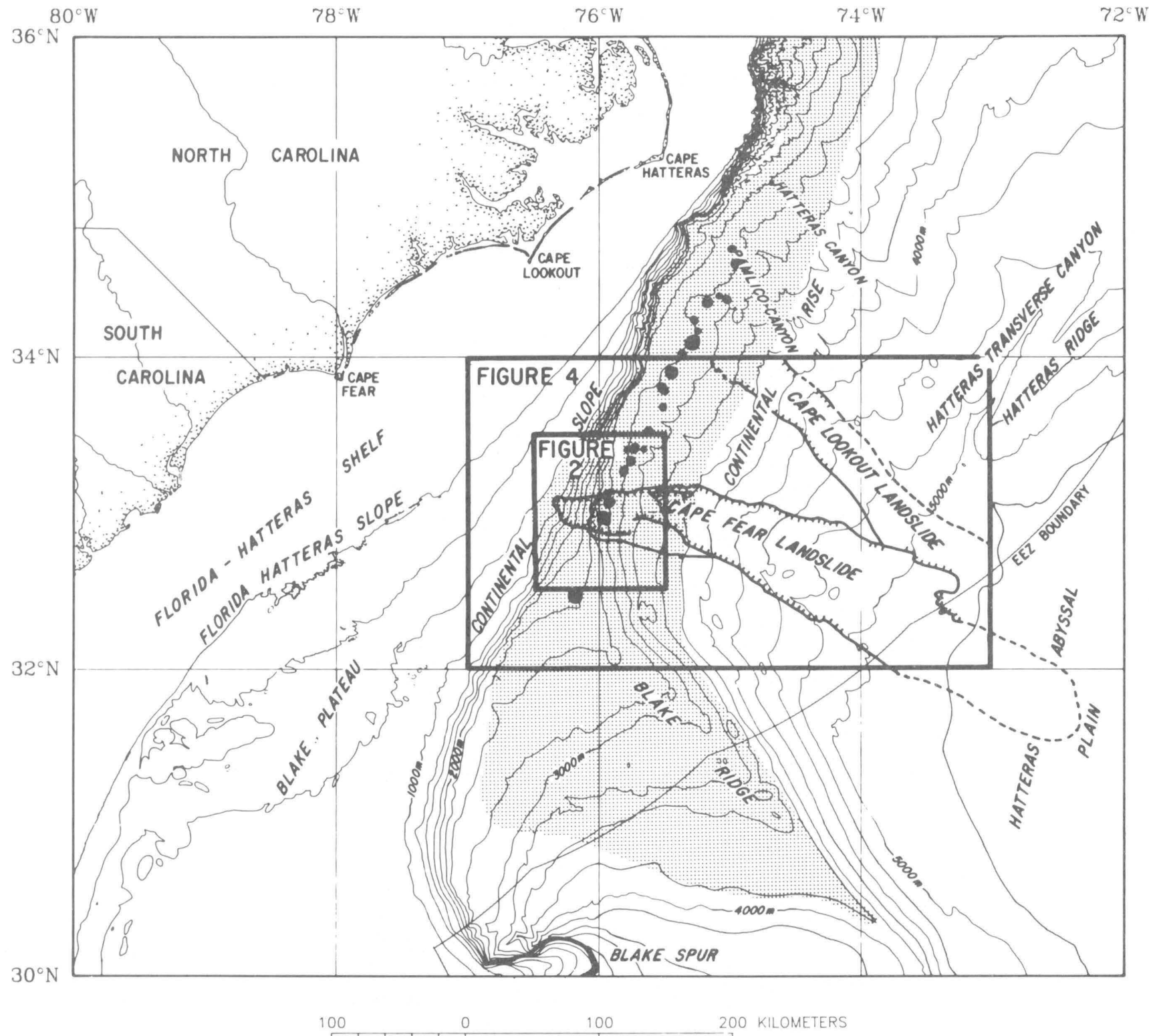

Figure 1. Regional setting of the Cape Fear landslide and the location of figures 2 and 4 . The delineation of the landslide beyond the EEZ boundary is from Embley (1980). Also shown are the locations (black dots) of salt diapirs

(from Dillon and others, 1982) and the known distribution (stippled) of the gas hydrate layer (Dillon and others, 1980; Popenoe, 1984).

underlying trapped gas are less obvious or are discontinuous in the area of the Cape Fear landslide. Perhaps structural complexities caused by slope failure have obscured the BSR, or the gas hydrate is actually discontinuous in this area.

\section{DESCRIPTION OF THE CAPE FEAR LANDSLIDE}

Figure 4 is a Geological LOng-Range Inclined Asdic (GLORIA) sidescan-sonar image of the continental slope and rise between $32^{\circ}$ and $34^{\circ} \mathrm{N}$ latitude (EEZ-SCAN 87 Scientific Staff, 1991). On this image, the path of the Cape
Fear landslide is easily traced across the continental rise by its light-toned (stronger) acoustic return that contrasts with the darker (weaker) return produced by surrounding undisturbed sedimentary deposits. The surface of the landslide is marked by longitudinal lines that represent both debris chutes between the salt diapirs at the head of the landslide area (A, fig. 4) and flow paths of debris further downslope (B, fig. 4). Near the head of the landslide there is an area of irregular, hummocky sea floor that has been crumpled and buckled by mass movement (C, fig. 4). The distal end of the Cape Fear landslide extends across an older mass movement, the Cape Lookout landslide (figs. 1 and 4). 


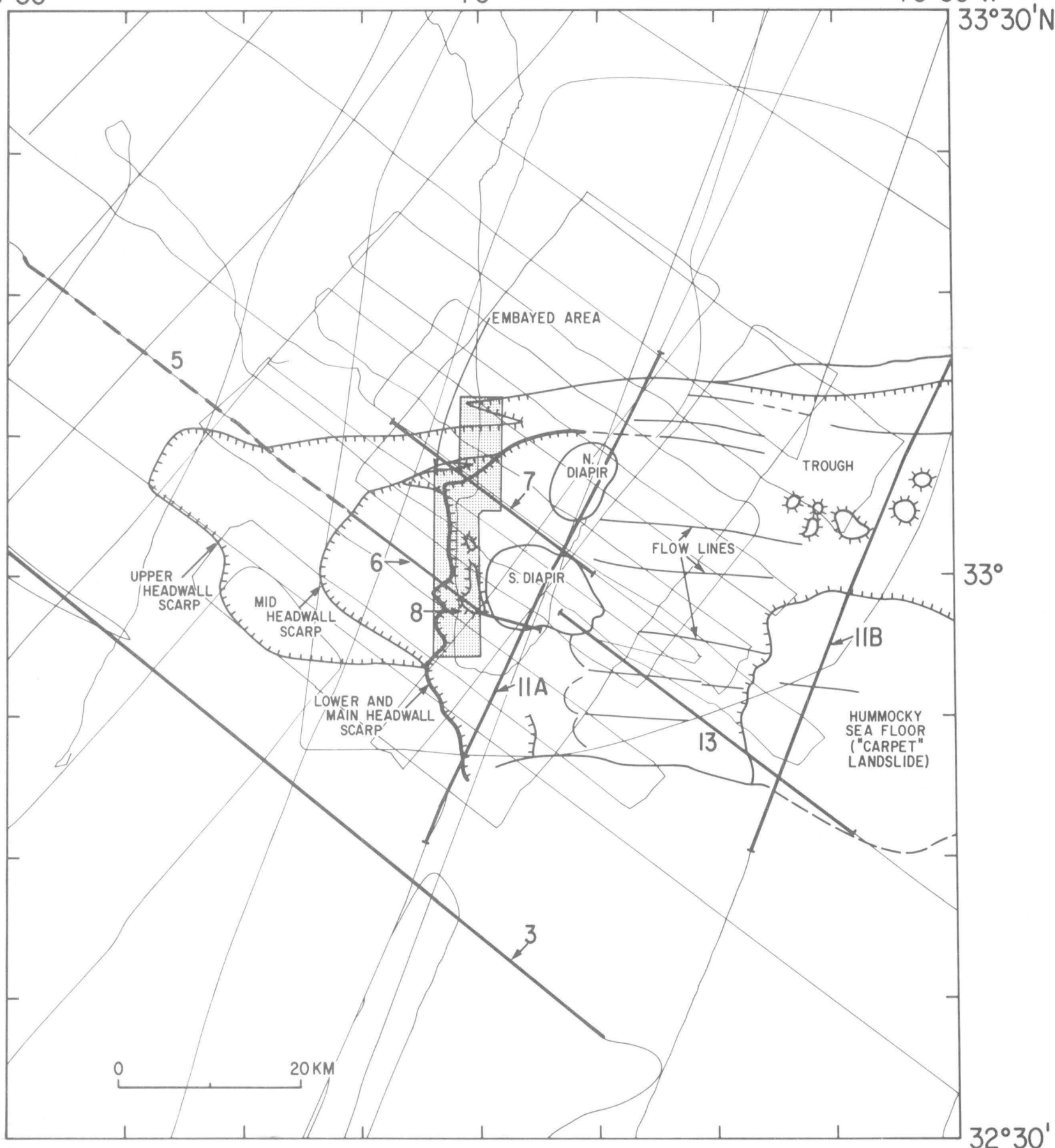

Figure 2. Headwall area of the Cape Fear landslide showing ship tracklines and major features. Also shown are the locations of seismic-reflection profiles (heavy lines) and sidescan-sonar images (shaded areas) referenced in text.

\section{The Headwall Area}

The main area of slope failure, expressed by a lower, main headwall scarp up to $120 \mathrm{~m}$ high, is located near the base of the continental slope just above two salt diapirs (lower, main headwall scarp, fig. 2). Above this lower, main scarp, higher on the slope, there are two arcuate scarps of lesser relief that encircle shallower landslide scars; one on the mid-slope expressed by a 20 - to 30 -m-high scarp (mid-headwall scarp, fig. 2), and one on the upper slope expressed by a 15- to 25-m-high scarp (upper headwall scarp, fig. 2). There is an additional small embayed area of 


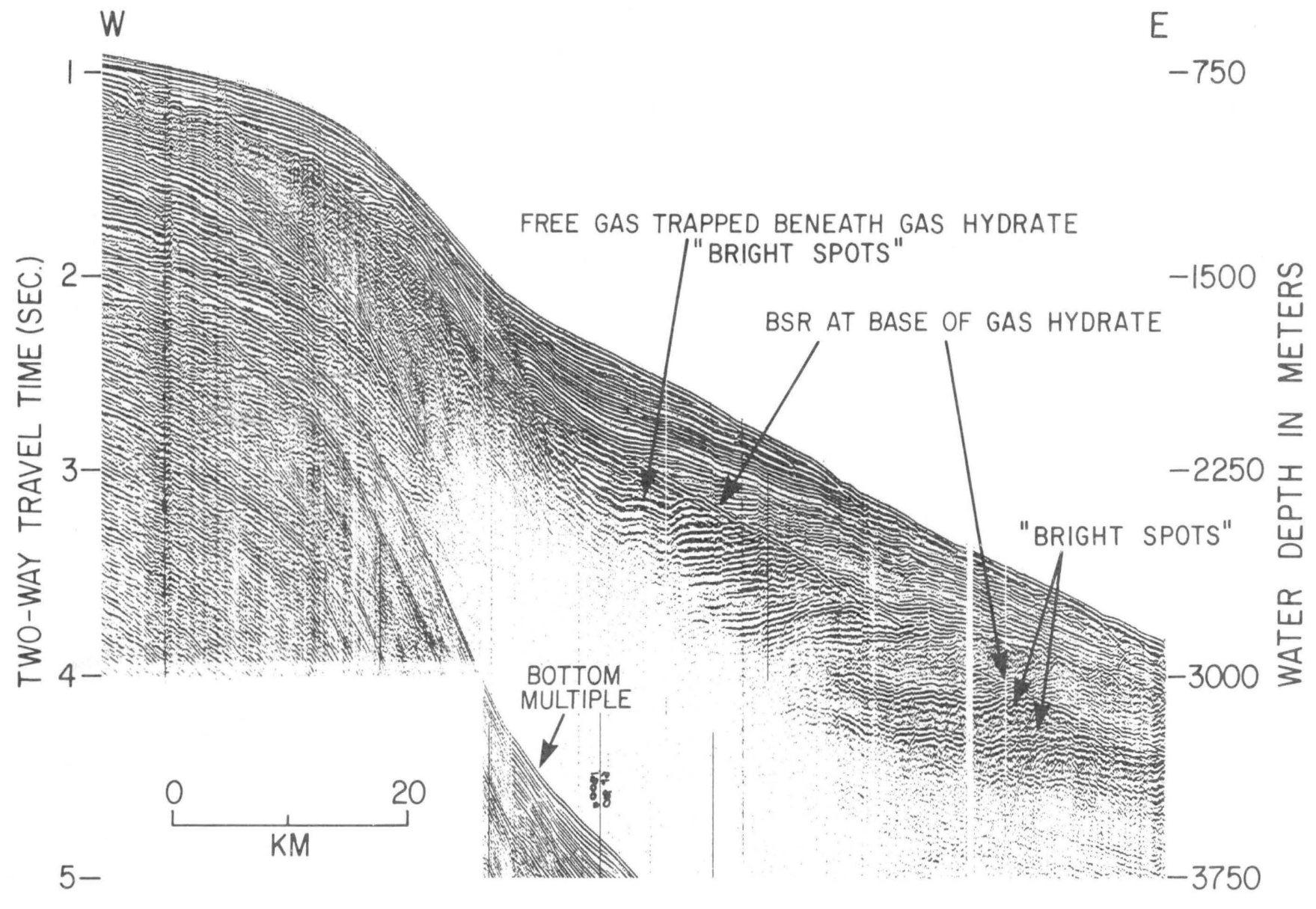

Figure 3. Airgun seismic-reflection profile across the slope south of the Cape Fear landslide showing a strong bottom simulating reflector (BSR) indicative of the base of the gas hydrate (see fig. 2 for location of this profile). The gas-

hydrate extends from the sea floor to the BSR and acts as a seal beneath which free gas is trapped, visible on this profile as high-amplitude reflections (bright spots) beneath the BSR.

slope failure that occurs just above the lower headwall scarp.

Figure 5 is a seismic-reflection profile which reveals the deeper geologic structure of the slope beneath and adjacent to the landslide complex. This profile shows that upslope of the lower headwall scarp there are a series of slip planes (listric faults) that flatten with depth and sole into a stratigraphic layer that is characterized by irregular bedding and thickening and thinning of strata; interpreted as a zone of relatively weak strata. This zone of weakness is coincident with the base of a discontinuous gas hydrate. The lithologic unit that the deformed zone of weakness follows is inferred to be the top of lower Miocene (about 20 million years old) strata (fig. 5; Popenoe, 1985).

Detail of the shallow subsurface and sea-floor character is shown by high-resolution seismic-reflection profiles (figs. 6 and 7) and Sea Mapping And Remote Characterization (SeaMARC) I sidescan-sonar images (figs. 8 to 10). The seismic-reflection profiles show a slope strewn with debris and rubble and marked by sea-floor depressions caused by downward rotation of blocks of strata along the underlying listric faults. These listric faults are actually slip planes of a large slump and the rotated blocks are slump blocks of undeformed sediment which have moved along discrete shear surfaces. The SeaMARC I images (figs. 8 to 10) along with the seismic-reflection profiles (figs. 6 and 7) show that indurated, well-bedded strata have been truncated along the lower headwall scarp. Promontories and recesses mark the scarp face (fig. 8) where large blocks of strata have broken free to cascade downslope. Below the headwall scarp (figs. 8 and 10) downslope-trending 5- to 15-m-deep tracks are furrowed into the sea floor. Some of these tracks can be followed downslope to large, unbroken displaced slide blocks that have come to rest against the upslope side of the protruding salt diapirs (fig. 6). The largest of the displaced slide blocks has an irregular edge that can be virtually "fitted back" into the headwall scarp from which it originated (fig. 8). In other places below the lower headwall scarp, both landslide tracks and rubble lobes caused by the downslope disintegration of slide blocks are evident. 


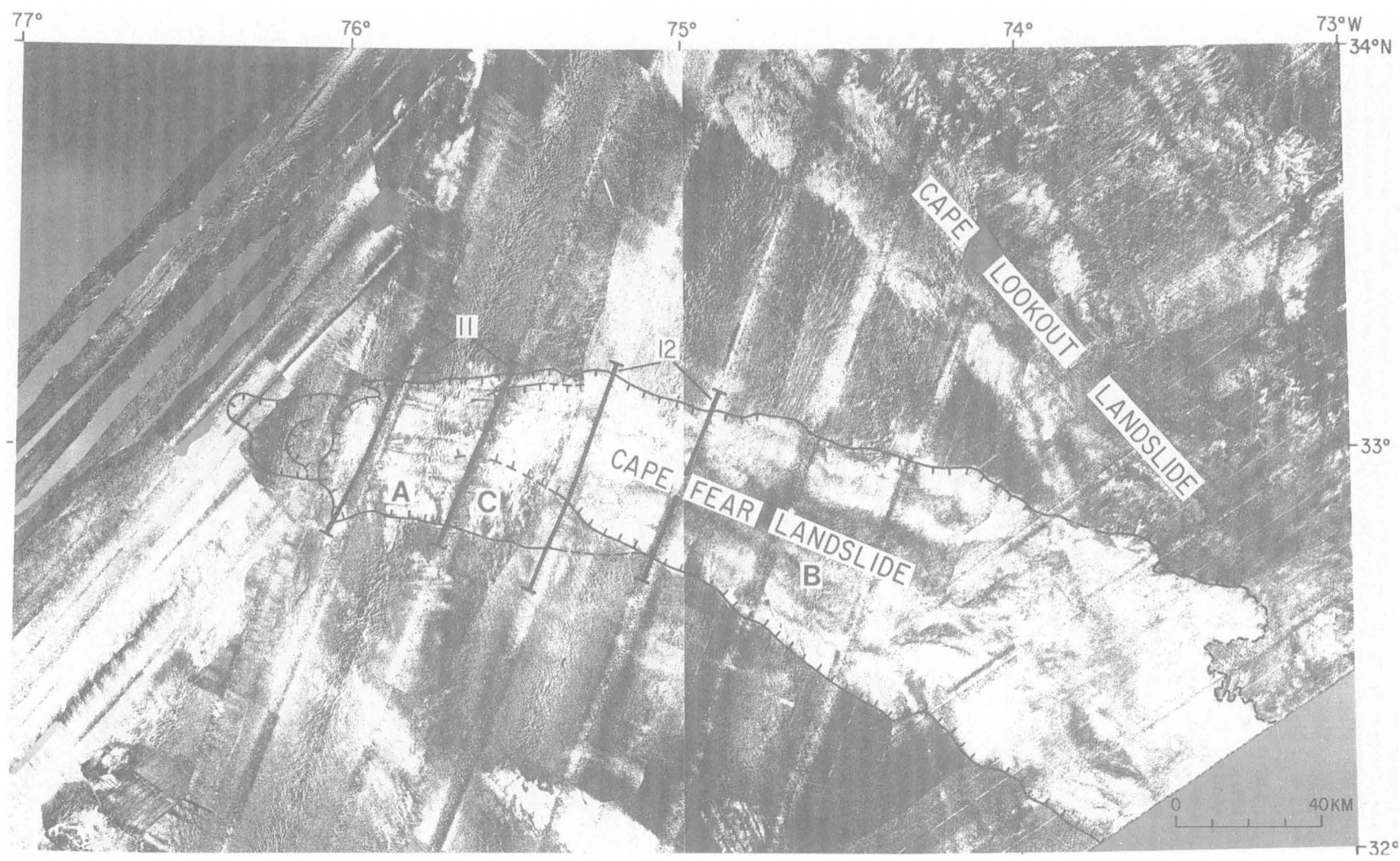

Figure 4. GLORIA sidescan-sonar image of the Cape Fear landslide (see fig. 1 for the location of this image). Scarps are outlined by hachures pointing downslope. Massmovement deposits produce the lighter acoustic return seen on the image. Undisturbed sedimentary deposits produce a dark return. Locations of seismic-reflection profiles shown in figures 11 and 12 are indicated. The

surface of the landslide is marked by longitudinal lines that represent both debris chutes between the salt diapirs at the head of the landslide area (A), and flow paths of debris further down slope (B). Near the head of the landslide there is an area of irregular, hummocky sea floor that has been crumpled and buckled by mass movement (C).

\section{The Mass Flow}

High-resolution seismic-reflection profiles (figs. 11 and 12) show four transverse crossings of the Cape Fear landslide track on the upper continental rise. In much of this area, only a thin layer of mass-movement debris overlies landslide-scoured bedrock, although near the north end of the profiles (figs. 11 and 12), mass-movement debris has been covered by younger well-layered sediment. Sidescansonar images (figs. 9 and 10) show that the bottom near the head of the mass flow is characterized by a rubble field containing large unbroken boulders and clasts that project above the bottom. Further downslope (fig. $11 B$ ), a flatbottomed trough over $25 \mathrm{~km}$ across and over $100 \mathrm{~m}$ deep has been cut across the rise (locations shown on figs. 2 and 4). Within the trough, the bottom is rough due to the presence of mass-movement debris and the seismicreflection profile shown on figure $11 B$ crosses a large displaced slide block about $20 \mathrm{~m}$ high. The southern end of the profile crosses the area of disturbed bottom that correlates with rough, hummocky bottom on the GLORIA image

(fig. 4) and with an irregular crumpled sea floor on figure 13. This area of sea floor was probably deformed due to downslope movement of a shallow layer of the sea floor, similar to a rumpled carpet, thus the term carpet slide. Slide tracks seen on GLORIA images upslope of the carpet slide (figs. 2 and 4) suggest downslope displacement of about 30 $\mathrm{km}$ for the head of this landslide mass.

Figure 12 shows echo-sounder profiles across the Cape Fear landslide 50- and 70-km-downslope from the headwall scarp. At $50 \mathrm{~km}$ (fig. 12A) the central trough is over $30 \mathrm{~km}$ wide and $150 \mathrm{~m}$ deep. The northern boundary of the trough is not as abrupt as farther upslope, and the southern boundary gradually slopes upward from the trough axis. Seventy $\mathrm{km}$ downslope from the headwall scarp (fig. $12 \mathrm{~B}$ ) the trough has widened to over $40 \mathrm{~km}$, and its relief has decreased to just over $100 \mathrm{~m}$, largely because the trough is partly filled with mass-movement deposits. The trough is not present toward the distal end of the landslide (east of $74^{\circ}$ longitude) where mass-movement debris forms an elevated, lenslike depositional high where it overlies older deposits (fig. 4). 


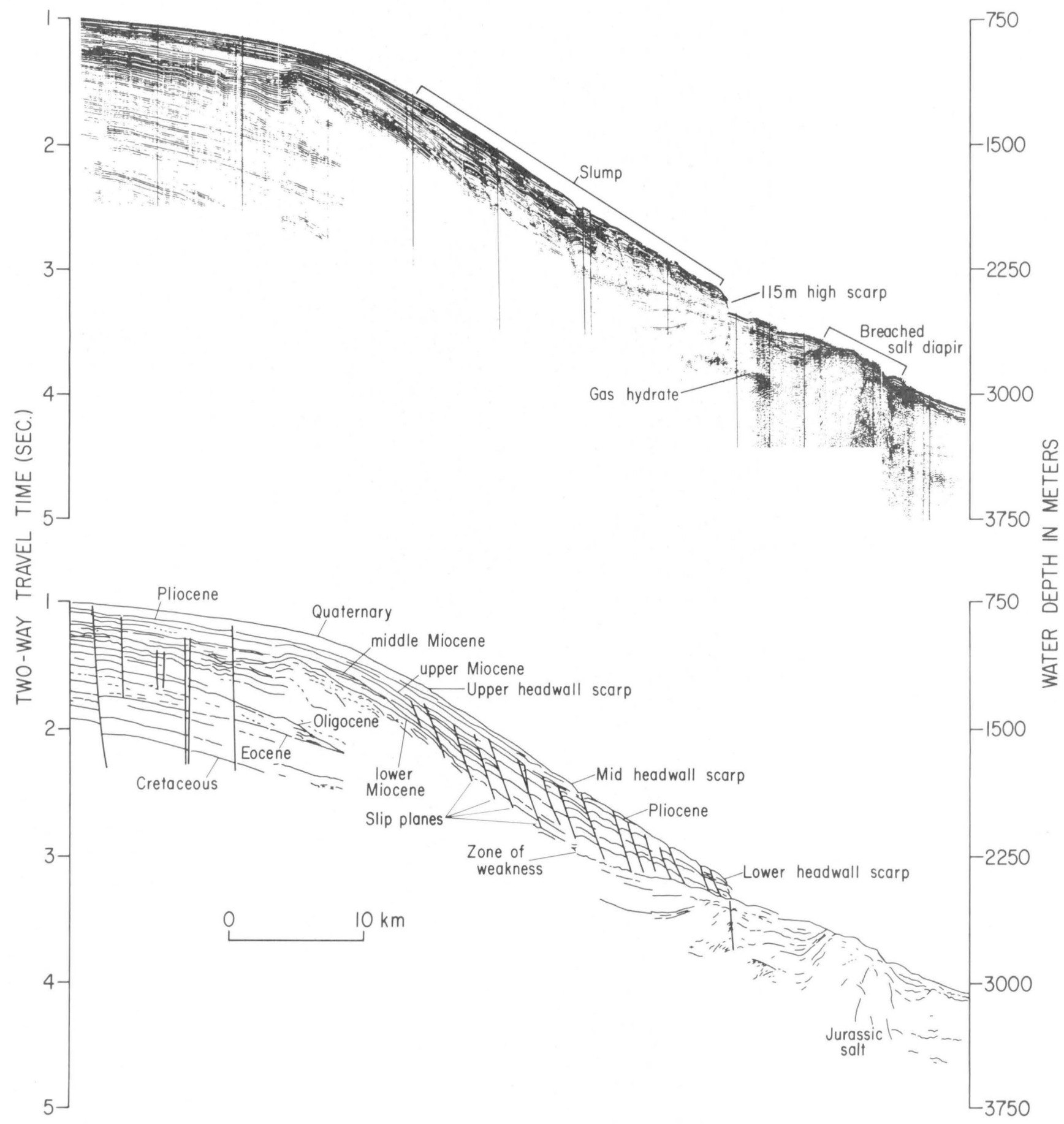

Figure 5. Airgun seismic-reflection profile that crosses the head of the Cape Fear landslide (see fig. 2 for the location of this profile). The middle slope is underlain by slumps whose slip planes (listric faults) terminate in a zone of weakness at about 400 meters below the sea floor. The zone is coincident with the top of lower Miocene strata and is nearly coincident with the base of the gas hydrate which is identifiable only beneath the base of the slope on this profile. The zone of weakness intersects the sea floor near the base of the slope, below the lower headwall scarp of the Cape Fear landslide. The profile also crosses a salt diapir enclosed by the headwall scarp. Ages of strata are from Popenoe (1985). 


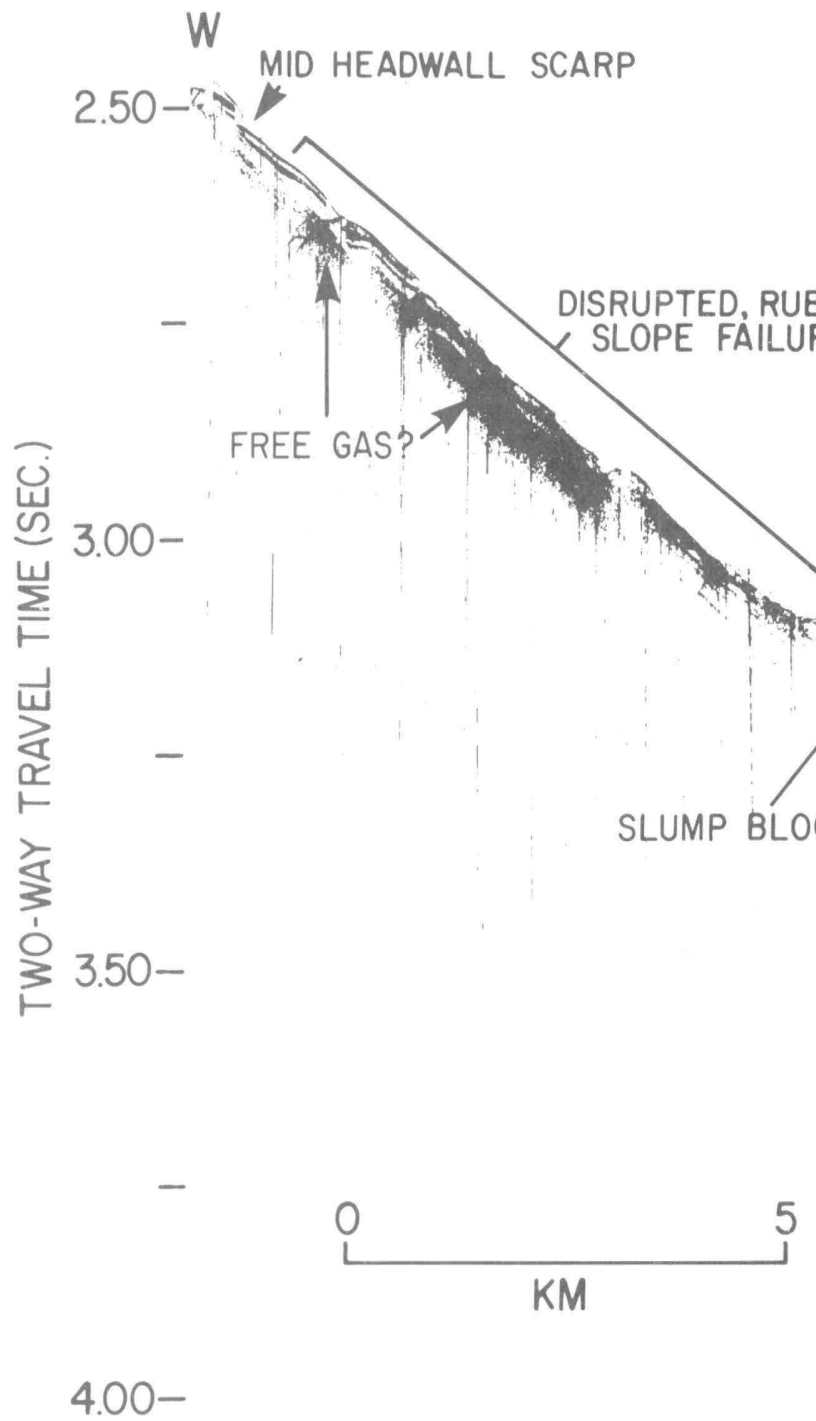

Figure 6. A 3.5-kilohertz frequency seismic-reflection profile that crossed the mid and lower headwall area of the Cape Fear landslide (see figs. 2 and 8 for the location of this profile). The part of the profile that correlates with the mid-range sidescan-sonar image shown in figure 8 is indicated. The slope above the lower headwall scarp is

Sediment cores taken in the lower part of the Cape Fear landslide area (Embley, 1980) contain a fabric representative of mass-movement deposits, such as inclined beds and small convolutions and clasts within a finer matrix, as well as a relatively large proportion of sand. In contrast, cores taken from the stratified continental rise adjacent to the landslide consisted primarily of homogeneous gray silty clay. All cores taken within the landslide area had a 1-m-thick capping surface layer of younger brown clay. Two radiocarbon datings at the base of this clay layer gave age dates of 20,830 and 12,125 years, indicating that there were possibly two landslide events, both of late Pleistocene age.

\section{FIGURE 8}

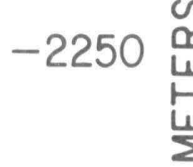

- 115 - M-HIGH LOWER HEADWALL SCARP

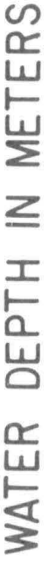
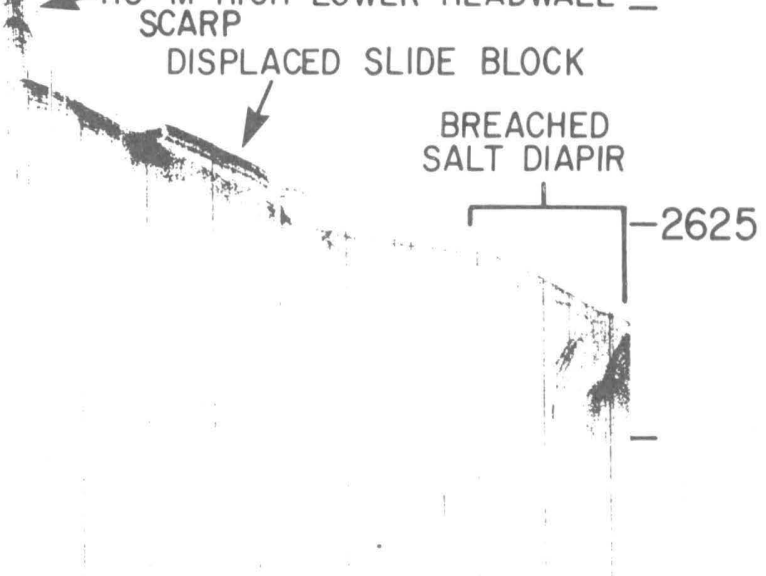

disrupted both by rubble and sea-floor depressions above slump blocks. A strong reflector in the subsurface is possibly caused by free gas. The lower part of the profile crosses a large displaced slide block, about 25 meters high and 5 kilometers across, that can be seen on the lower part of the SeaMARC I sidescan-sonar image (fig. 8).

\section{DISCUSSION}

Analysis of submarine slope stability requires making assessments of the strength of sediment and the magnitude of stresses acting downslope. Downslope stresses result from gravity, earthquakes, or storm waves (Lee, Schwab, and Booth, this report). An important behavioral aspect of sediment is that its strength decreases as the excess porewater pressure (in excess of hydrostatic pressure) increases. Excess pore pressures commonly exist in fine-grained sedimentary deposits that are accumulating rapidly and can also be caused by the occurrence of free gas (Kayen and Lee, this report) or by repeated loading from earthquakes or 


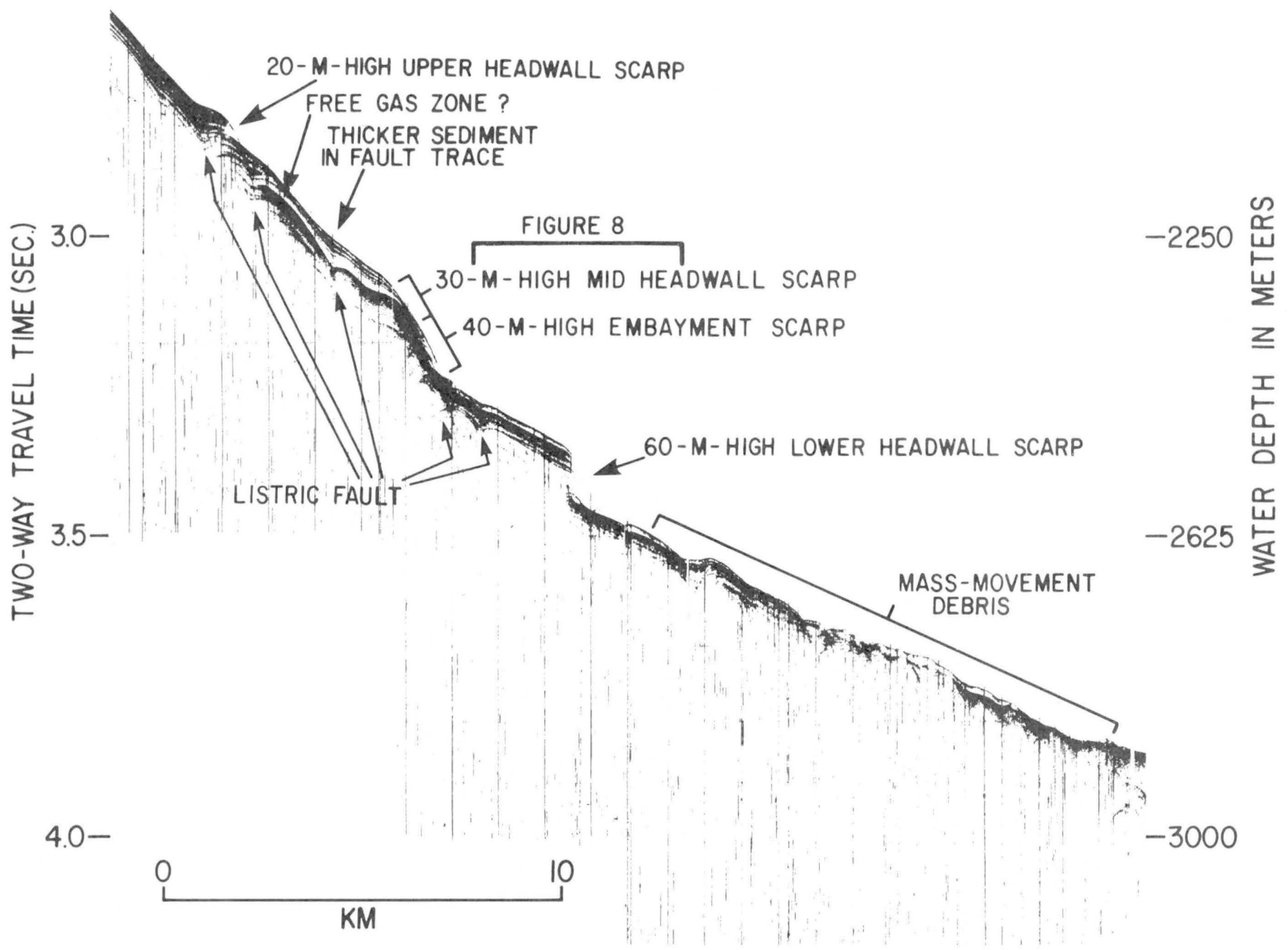

Figure 7. A 3.5-kilohertz frequency seismic-reflection profile shows the thicker sediment in sea-floor depressions above listric faults (see figs. 2 and 8 for the location of this profile). Note the lowermost two listric faults that indent the bottom about 2 kilometers above the lower headwall

storm waves (Schwab and Lee, this report). Slope destabilization due to storm waves probably can be ruled out as a triggering mechanism for the Cape Fear landslide because their effects would be minimal at the water depths encountered (from 900 to over 2,000 m).

High-amplitude reflections (bright spots) observed on seismic-reflection profiles (for example, figs. 3 and 5) point to abundant free gas beneath the gas-hydrate layer off Cape Fear and near and beneath the landslide area. These areas of high-amplitude reflections are zones of high pore-gas pressures and presumably low sediment strength. Bright spots also exist within the layer that we infer is cemented by gas hydrate, suggesting that the gas hydrate may be partially decomposed above the BSR. scarp. These active features suggest that a slide block 2 kilometers across, 80 meters high, and of unknown length, is slowly failing. The part of the profile corresponding to figure 8 is indicated.

During periods of global warming or lowered sea level, such as those that occurred during the Pleistocene, additional decomposition of gas hydrate could be initiated by lowering the base pressure and/or raising the temperature out of the hydrate stability field (Carpenter, 1981; Kvenvolden, 1988; Kayen and Lee, this report). This condition would release additional large volumes of free gas into the sediment column directly under the gas hydrate, leading to even lower sediment strength within this zone. The coincidence of the base of the gas hydrate with a major slope failure slip plane into which many of the listric faults off Cape Fear are rooted strongly suggests that free gas beneath the gas hydrate seal is a contributing mechanism to the slope instability. The presumed dates of slope failure, 12,125 and 

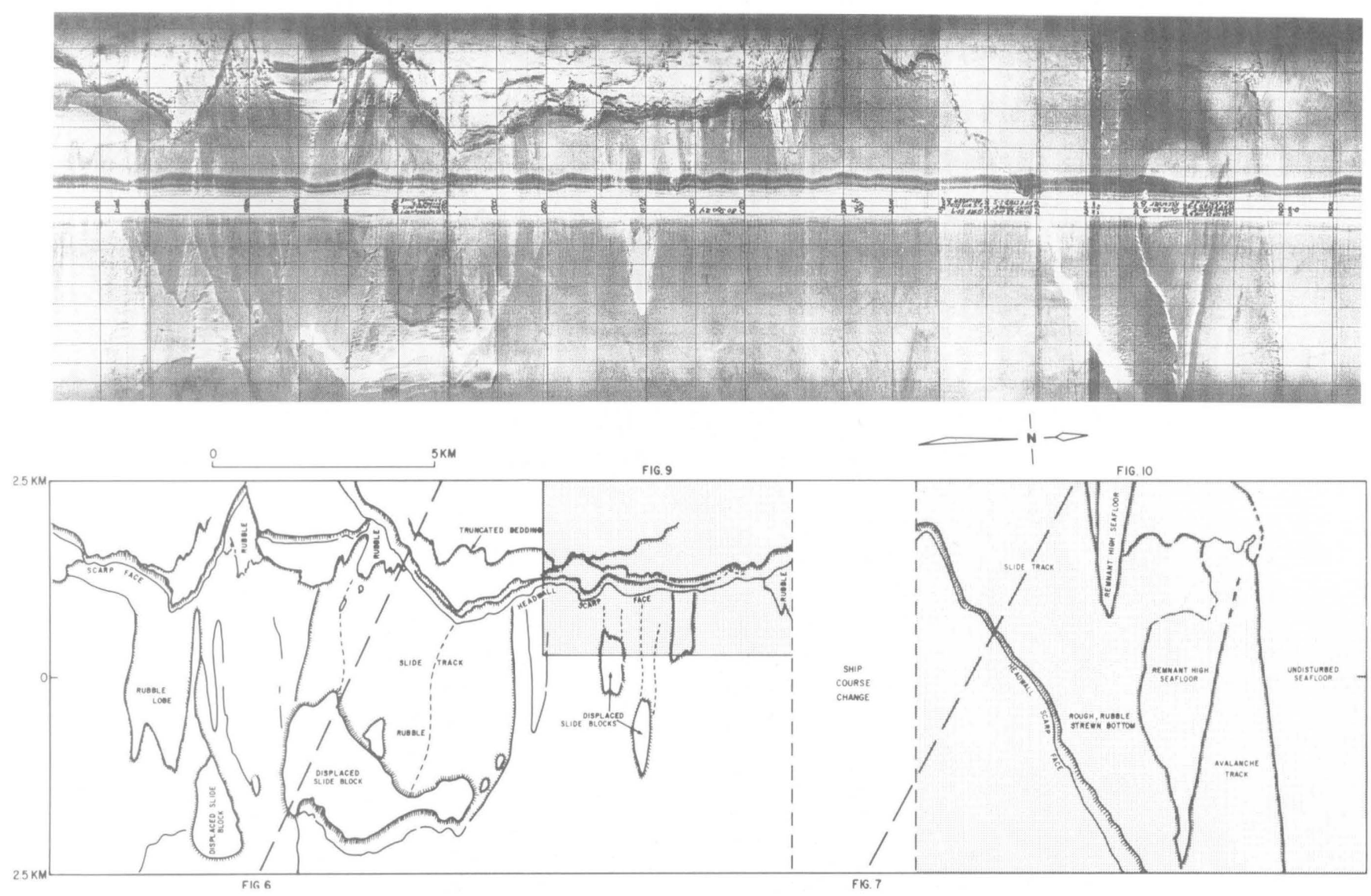

Figure 8. SeaMARC I sidescan-sonar image and interpretive drawing of the headwall area of the Cape Fear landslide (see fig. 2 for the location of this image). The upper part of this image shows the rugged lower headwall scarp, at places over 120 meters high, that truncates and exposes bedded sediments in the scarp face. The bottom below the scarp is furrowed by landslide tracks, cut 5 to 15

20,830 years before present (Embley, 1980), both fall within the late Wisconsinan Age when sea level was over 70 $\mathrm{m}$ below the present level (Dillon and Oldale, 1978). Thus, decomposition of the gas hydrate caused by lowered sea level probably contributed to the slope failure.

Earthquakes are an effective trigger mechanism for initiation of slope failure (Lee, Schwab, and Booth, this report). Because the Cape Fear landslide is near the site of the 1886 earthquake that did major damage to Charleston, S.C. (Bollinger, 1977), it is tempting to cite this historic earthquake as the possible triggering mechanism for the Cape Fear landslide (Embley, 1980; Carpenter, 1981). The evidence, however, indicates that the main slope failure predates the 1886 Charleston earthquake by thousands of years. The ubiquitous 1-m-thick layer of younger sediment that overlies the mass-movement deposits and age dates of 12,124 and 20,830 years before present taken at the base of this sediment layer (Embley, 1980) suggest that the last major slope failure occurred in late Pleistocene time. The meters deep, that extend downslope to large displaced slide blocks and to debris lobes. Shallower landslides have furrowed tracks into the bottom above the main scarp leaving remnant areas of high bottom. The location of two seismic-reflection profiles that cross this image area are indicated by the dashed lines.

thickened layers of sediment observed within the sea-floor depressions above listric fault traces (fig. 7) suggest a long history (thousands of years) of retrogressive slumping since the main failure event. Moreover, landslide tracks and slide blocks below the lower headwall scarp (fig. 8) indicate that episodic calving has occurred since the major failure. The evidence does not rule out a large, late Pleistocene earthquake as a cause of the main slope failure, or the 1886 event as a cause of minor calving.

The presence of the elevated salt diapirs centered within the scar of the major slope failure also suggests a cause-and-effect relationship. Although a number of salt diapirs underlie the continental rise (fig. 1), the two within the scar are the only diapirs that actually underlie the slope. Initial fracturing of the slope strata caused by intrusion of salt could have created an area of weakened slope above and near the salt diapirs. Oversteepening of the slope by upward movement of the salt diapirs to some critical angle could have initiated a failure of the lower slope. Once support was 


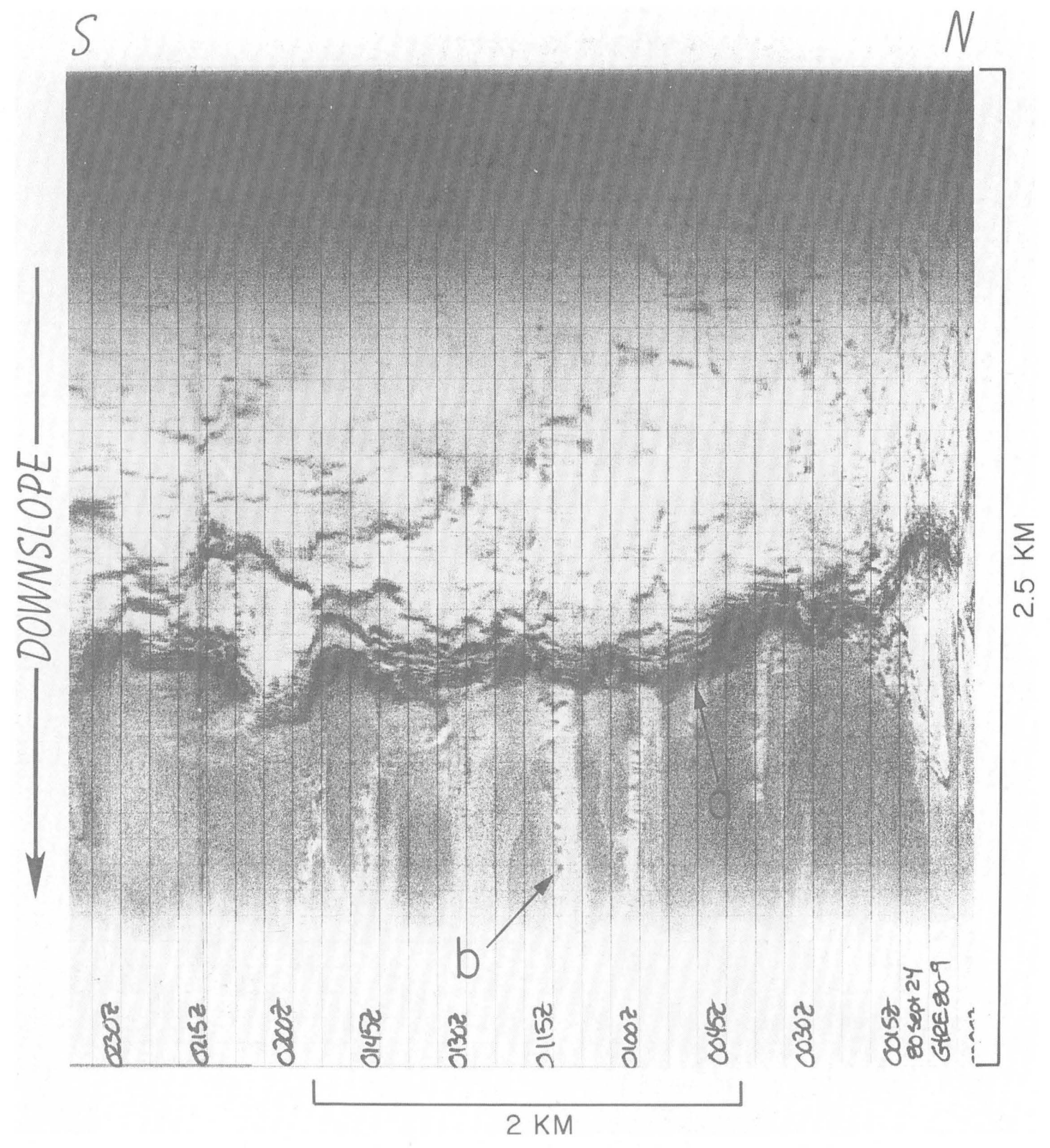

Figure 9. Detail of part of the SeaMARC I image presented in figure 8 showing outcropping bedding on the scarp face (a) and rubble along the edges of landslide tracks (b) below the scarp face. 


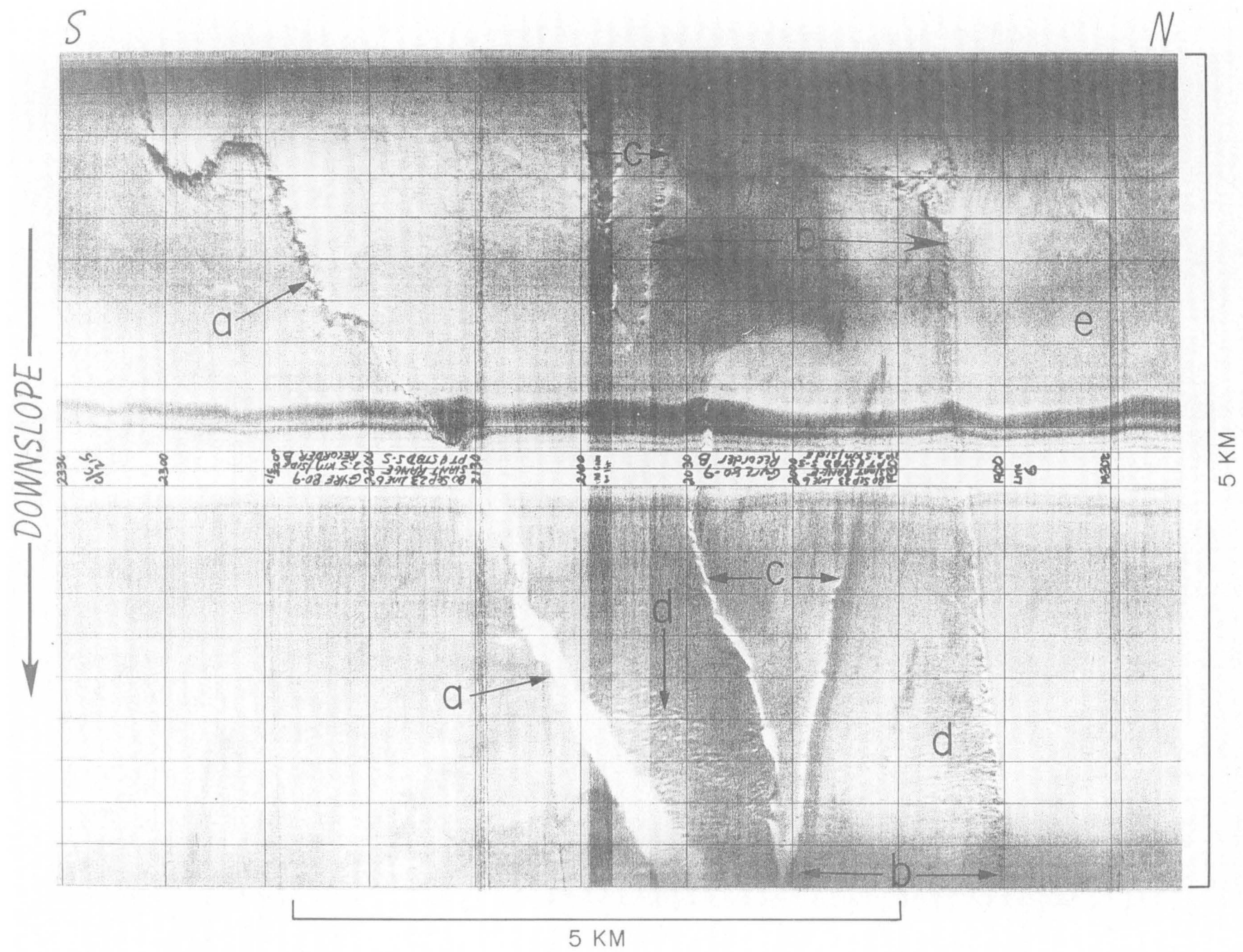

Figure 10. Detail of part of the SeaMARC I image presented in figure 8 . This image shows the northern part of the headwall scarp where the scarp (a) trends diagonally upslope. Slides and mass flows (b) have stripped bedding layers above the headwall and have furrowed the slope, leaving areas of remnant high bottom (c). Rough bottom within the slide tracks (d) probably represents rubble left by the descending landslide. The smooth featureless slope on the north side of the image (e) is typical of the undisturbed continental slope surrounding the Cape Fear landslide. 


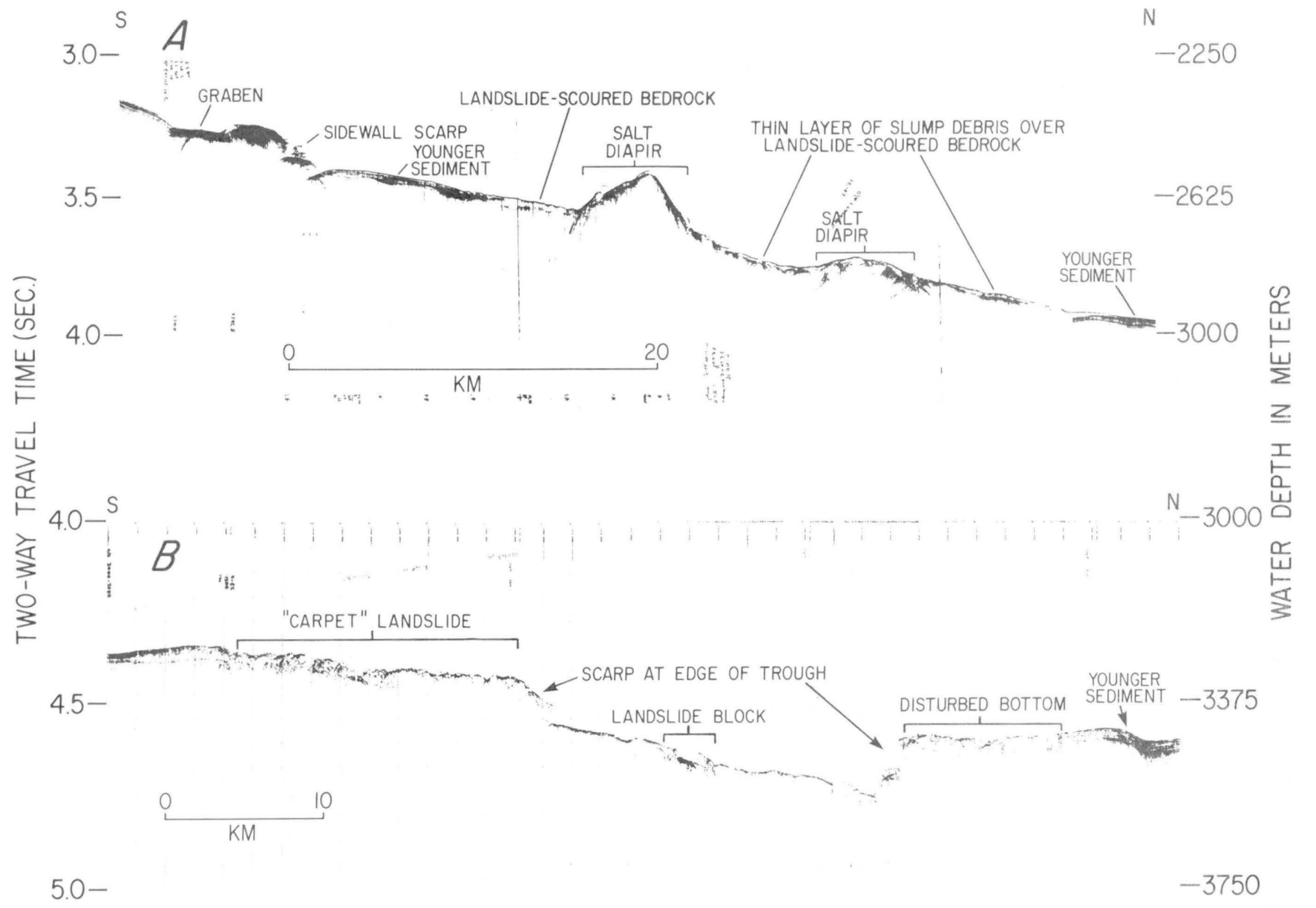

Figure 11. A. A 3.5-kilohertz seismic-reflection profile that crossed the Cape Fear landslide scar and the two salt diapirs just below the main headwall scarp. Within the central and northern part of the landslide scar only a thin cover of mass-movement debris overlies a bottom scoured to bedrock. In the southern part of the scar, younger sediment overlies the scoured bottom, suggesting that slope failure to the south predates the most recent slumping event in the northern part of the landslide scar. $B$. A 3.5-kilohertz seismic-reflection profile across the landslide-cut trough 30 kilometers below the headwall of the Cape Fear landslide. At this crossing, the north wall of the trough has about 150 meters of relief, whereas the south wall has about 90 meters of relief. The trough is filled with mass movement deposits including several slide blocks. The south end of the profile crosses an area of disturbed bottom that corresponds to an area of hummocky acoustic return on the GLORIA image. This irregular return is interpreted as having been caused by crumpled shallow strata (carpet slide) that have moved as a relatively intact body a distance of 30 kilometers downslope. See figure 2 for the locations of these profiles. removed from the base of the slope, retrogressive failure could have occurred on zones of weakness upslope, as suggested by Cashman and Popenoe (1985). In addition, arching of sediment above the rising salt diapirs may have contributed to the slope failure by creating a trap into which free gas could accumulate, causing elevated pore pressures immediately over and surrounding the diapirs. The elevation of the salt diapirs above the sea floor within the slump scar above the level of failed sediment, suggests that the diapirs uplifted the bottom prior to the failure, and then were excavated by the slide.

\section{CONCLUSIONS}

Although we cannot cite one particular mechanism as the cause of the initial slope failure, a number of classic conditions exist in the area of the Cape Fear landslide that probably contributed, in combination, to the slope failure. These include decomposition of a gas hydrate which caused high pore-fluid pressures to build, salt diapir intrusion that initially fractured and could have oversteepened the lower slope, and a location where earthquakes have occurred historically, and no doubt also occurred in the distant past. 


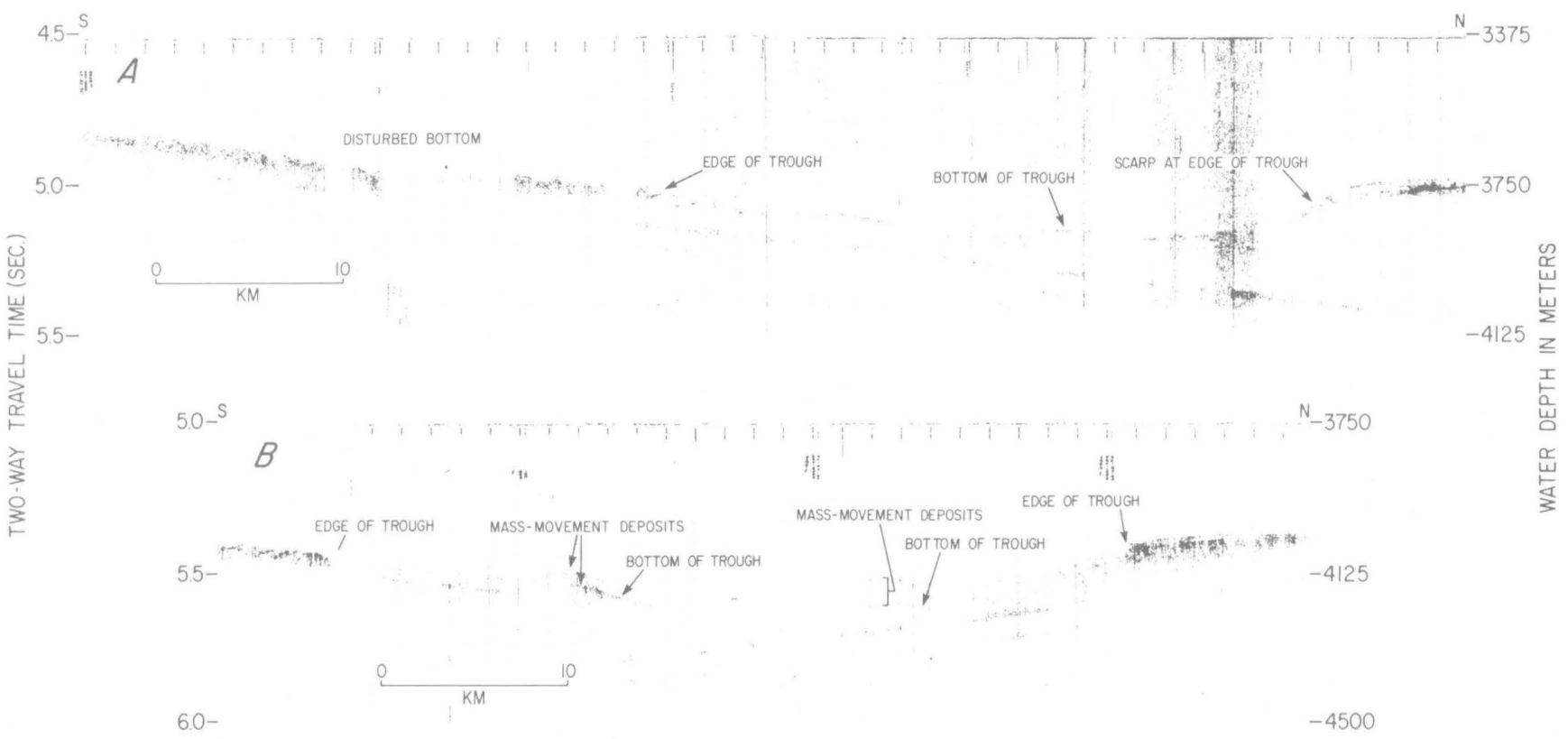

Figure 12. A 3.5-kilohertz seismic-reflection profiles across the Cape Fear landslide trough approximately 50 kilometers $(A)$ and 70 kilometers $(B)$ below the lower headwall area. On both profiles the trough is broader and

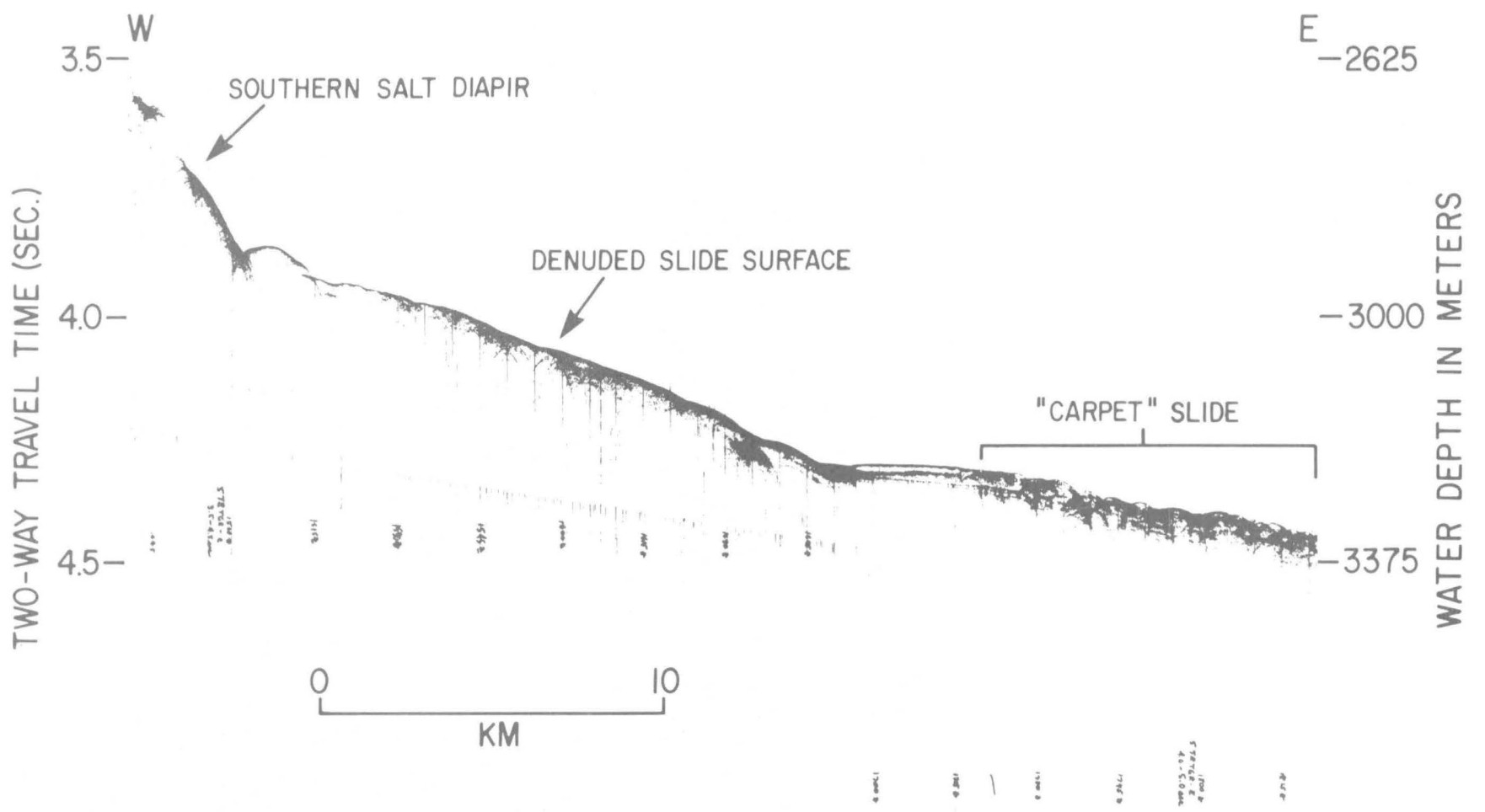

Figure 13. Echo-sounder profile across the carpet slide area below the Cape Fear landslide headwall scarp (see fig. 2 for the location of this profile).

Whatever the combination of initial mechanisms, once initial slope failure had removed support from the lower slope, retrogressive slope failure proceeded upslope to the shallower than farther upslope and is partly filled with a thick layer of mass movement debris. Locations of these profiles are shown on figure 4 . 


\section{REFERENCES CITED}

Bollinger, G.A., 1977, Reinterpretation of the intensity data for the 1986 Charleston, South Carolina Earthquake, in Rankin, D.W., ed., Studies related to the Charleston, South Carolina earthquake of $1886-$ A preliminary report: U.S. Geological Survey Professional Paper 1028, p. 17-32.

Carpenter, G.B., 1981, Coincident sediment slump/clathrate complexes on the U.S. Atlantic slope: Geo-Marine Letters, v. 1, p. $29-32$.

Cashman, K.V., and Popenoe, Peter, 1985, Slumping and shallow faulting related to the presence of salt on the continental slope and rise off North Carolina: Marine and Petroleum Geology, v. 2 , p. $260-270$.

Dillon, W.P., Grow, J.A., and Paull, C.K., 1980, Unconventional gas hydrate seals may trap gas off southeast United States: Oil and Gas Journal, v. 78, p. 124, 126, 129-130.

Dillon, W.P., and Oldale, R.N., 1978, Late Quaternary sea-level curve: reinterpretation based on glaciotectonic influence: Geology, v. 6, p. 56-60.

Dillon, W.P., and Popenoe, Peter, 1988, The Blake Plateau Basin and Carolina Trough, in Sheridan, R.E., and Grow, J.A., eds., The geology of North America, v. I-2, The Atlantic Continental Margin: U.S.: Geological Society of America DNAG Series, p. 291-328.

Dillon, W.P., Popenoe, Peter, Grow, J.A., Klitgord, K.D., Swift, B.A., Paull, C.K., and Cashman, K.V., 1982, Growth faulting and salt diapirism: their relationship and control in the Carolina Trough, eastern North America, in Watkins, J.S., and Drake, C.L., eds., Studies in continental margin geology: American Association of Petroleum Geologists Memoir 34, p. 21-46.

EEZ-SCAN 87 Scientific Staff, 1991, Atlas of the U.S. Exclusive Economic Zone, Atlantic continental margin, U. S. Geological Survey, Miscellaneous Investigations Series I-2054, 174 p.
Embley, R.M., 1980, The role of mass transport in the distribution and character of deep-ocean sediments with special reference to the North Atlantic: Marine Geology, v. 38, p. 25-50.

Hutchinson, D.R., Grow, J.A., Klitgord, K.D., and Swift, B.A., 1982, Deep structure and evolution of the Carolina Trough, in Watkins, J.S., and Drake, C.L., eds., Studies in continental margin geology: American Association of Petroleum Geologists Memoir 34, p. 129-152.

Kvenvolden, K.A., 1988, Methane hydrates and global climate: Global Biogeochemical Cycles, v. 2, p. 221-229.

Paull, C.K., Schmuck, E.A., Manheim, F.T., and Bralower, T.J., 1989, Carolina Trough diapirs: salt or shale?: EOS, Transactions, American Geophysical Union, v. 70, p. 370.

Popenoe, Peter, 1984, Summary geologic report for the South Atlantic Outer Continental Shelf (OCS) Planning Area: U.S. Geological Survey Open-File Report 84-476, 27 p., 10 maps, scale 1:1,000,000.

-1985 , Cenozoic depositional and structural history of the North Carolina margin from seismic stratigraphic analyses, in Poag, C.W., ed., Stratigraphy and depositional history of the U.S. Atlantic margin: Stroudsburg, Pa., Van Nostrand Reinhold Publishing, p. 125-187.

Popenoe, Peter, Cashman, K.V., Chayes, D., and Ryan, W.B.F., 1981, Mid-range sidescan sonar images covering parts of proposed tracts for OCS Lease Sale 56 and contiguous areas, Manteo, Cape Fear, and adjacent quadrangles off North Carolina: U.S. Geological Survey Open-File Report 81-554, $6 \mathrm{p}$.

Popenoe, Peter, Coward, E.L., and Cashman, K.V., 1982, A regional assessment of potential environmental hazards to and limitations on petroleum development of the United States Atlantic continental shelf, slope, and rise, offshore North Carolina: U.S. Geological Survey Open-File Report 82-136, $67 \mathrm{p}$. 


\title{
Ancient Crustal Fractures Control the Location and Size of Collapsed Blocks at the Blake Escarpment, East of Florida
}

\author{
By W.P. Dillon, J.S. Risch, K.M. Scanlon, P.C. Valentine, and Q.J. Huggett ${ }^{1}$
}

\section{INTRODUCTION}

The Blake Escarpment is a steep, high submarine cliff off the Southeastern United States that extends for about 500 kilometers $(\mathrm{km})$ from northern Florida to the Bahama Islands. Water depth at the base of the escarpment is about 5,000 meters $(\mathrm{m})$ and, at the top, somewhat more than $1,000 \mathrm{~m}$ (figs. 1 and 2 ). The cliff is far higher than the walls of the Grand Canyon (fig. 3). We have long been convinced that the present morphology of the Blake Escarpment is the result of erosion of the seaward side of a reef-fronted, limestone platform (Paull and Dillon, 1980; Dillon and others, 1985; Freeman-Lynde and Ryan, 1985), and this erosion is confirmed by Geological LOng-Range Inclined Asdic (GLORIA) sidescan-sonar images. The images disclose for the first time, however, that whereas most of the cliff-face is an erosional surface resulting from scour by ocean currents, the erosion of the southern segment of the escarpment took the form of slope failure of massive limestone blocks (fig. 4; EEZ-SCAN 87, 1991). How were these blocks formed, why did they fail, and why do they appear along only a short stretch of the escarpment? Indeed, off Eastern North America, this is the only place where they exist. The causes seem to involve the entire history of continental margin formation.

\section{GEOLOGIC SETTING-FORMATION OF THE CONTINENTAL MARGIN EAST OF FLORIDA}

The continental margin east of Florida is dominated by the broad, flat Blake Plateau, which is terminated to the east by the steep cliff of the Blake Escarpment (fig. 1). The plateau is underlain by one of the four main sedimentary basins of the Eastern U.S. continental margin. These basins are regions of basement rock subsidence that are now filled with sedimentary rocks. Basin locations were controlled by inherited weaknesses in the old continental crust that was rifted apart when Africa and North America separated. These crustal weaknesses also caused offsets in the rifting pattern, which are still evident as offsets in the present Mid-Atlantic Ridge, the present site of sea-floor spreading. The rocks of the Blake Plateau platform probably are mostly

\footnotetext{
${ }^{1}$ Institute of Oceanographic Sciences, Wormley, Surrey, U.K.
}

limestones that accumulated at sea level (at a water depth of only a few meters) in conditions similar to the present Bahama Banks. Although no samples of the earliest, now deeply buried, rocks are available, we infer that sediments began to accumulate in the Blake Plateau region not long after North America and Africa separated, about 170 million years ago (Dillon and Popenoe, 1988). Between then and now, the basin has subsided more than $14 \mathrm{~km}$ under the influence of cooling and loading. The initially hot continental margin rocks cooled, causing them to become more dense and to sink deeper into the soft layer below; the accumulating sediment weighted down this continental margin region as well. Accumulation of sediment kept up with this subsidence and maintained the surface of the plateau near sea level until about 100 million years ago. At that time, the growth rate of the carbonate platform slowed, the reefs died (perhaps due to stress from climate change), and the upbuilding of the platform surface no longer was able to keep up with subsidence. Since then, the region has sunk to become an intermediate depth plateau, now covered by about $1,000 \mathrm{~m}$ of water.

The seaward (eastern) side of the carbonate bank that formed the Blake Plateau probably was being eroded during most of its history, but two episodes of cutting-away of the slope are notable. One occurred during intense erosion of the sea floor of the Western North Atlantic Basin in Oligocene time (about 30 million years ago; Mountain and Tucholke, 1985), and another is going on now. Both apparently resulted from intensification of southwarddirected bottom currents that flowed along the western side of the North Atlantic basin. Such currents are formed by the chilling and resulting increase in density of water in the northernmost part of the basin. This dense water then sinks and flows southward, while being squeezed against the western side of the basin as a result of the rotation of the Earth (Coriolis effect). The earlier episode left an eroded bench that appears in seismic-reflection profiles that cross the escarpment (fig. 5). After that earlier period of erosion, the bench was covered with sediment and is now buried. A more recent pulse of erosion, which has continued to the present day, has cut into that sediment and eroded the escarpment back farther. A photograph of the surface of the Blake Escarpment (fig. 6) taken from the research submersible Alvin demonstrates the effects of the active erosion in the area of the profile shown in figure 4 . Here, truncated 


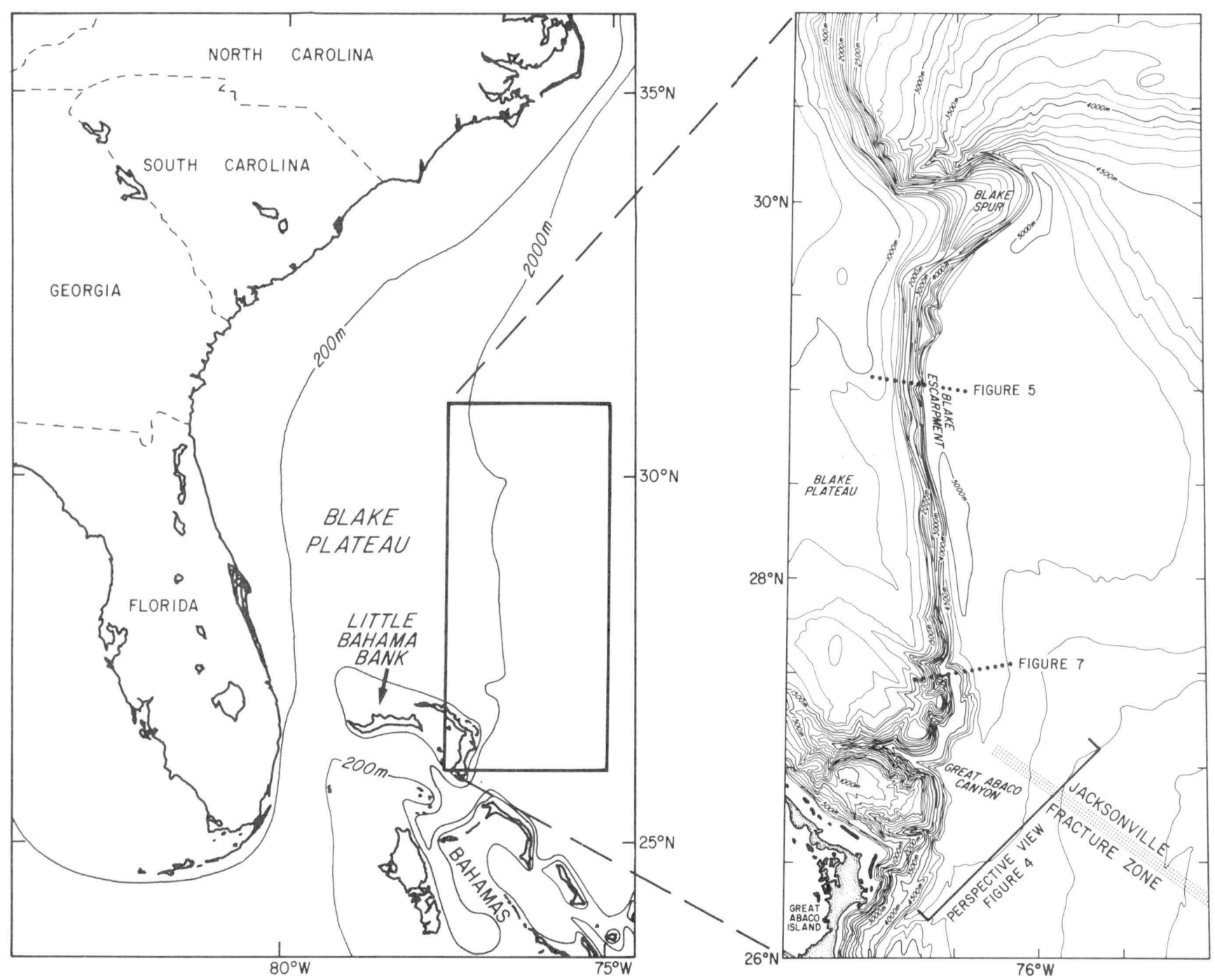

Figure 1. Blake Escarpment: location (left panel) and bathymetry (right panel). The locations of the seismic profiles shown in figures 5 and 7 and the extension of the Jacksonville fracture zone also are shown.

horizontal strata crop out on the straight cliff and small, broken fragments of strata (talus) accumulate on ledges, or at the bottom of the cliff, until they are eroded away.

\section{COLLAPSE OF THE SOUTHERN PART OF THE ESCARPMENT}

Along most of the Blake Escarpment's length, the scour by southward-flowing deep-sea currents (possibly aided by chemical dissolution of the carbonate rock) produces a cliff that is steep, straight, and smooth (figs. 1, 2, and 5), except for the small-scale, steplike irregularities that are caused by small differences in resistance of strata to erosion (fig. 6). The adjacent sea floor also is smoothly scoured by the current. Near the southern part of the escarpment, however, just north of Little Bahama Bank and Great Abaco Island (fig. 1), the deep sea floor is charac- terized by enormous agglomerations of blocks, commonly $10 \mathrm{~km}$ across, that appear to have fallen from the face of the cliff and that are shown both by seismic-reflection profiles (fig. 7) and by GLORIA sidescan-sonar imagery (fig. 4). The outer part of the Blake Plateau in the southern region also differs from the plateau farther north by being cut by submarine canyons that trend northwest, parallel to the northern side of Little Bahama Bank (figs. 1, 2, and 4). Several seismic profiles show faults in the rocks in the southern area; faults do not appear in the rest of the plateau.

\section{WHY IS THE SOUTHERN BLAKE PLATEAU FALLING APART?}

Because faults seem to exist in the southern region of the outer Blake Plateau and not to the north, we infer that the rock that slipped from the eroding escarpment probably 


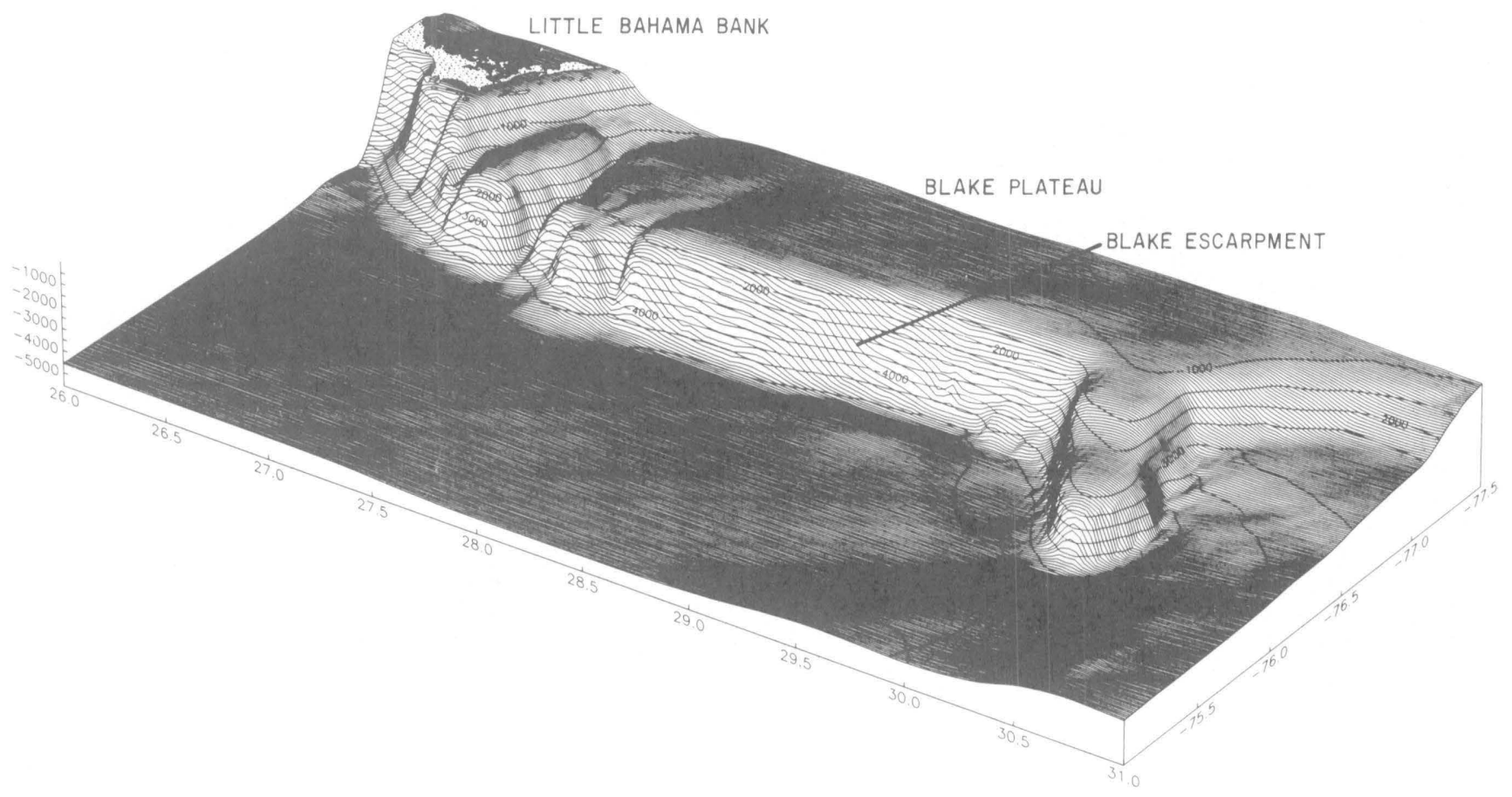

Figure 2. Perspective image of the Blake Escarpment for the area shown in the right panel of figure 1. View is to the southwest and vertical scale is in meters below sea level. Latitudes are indicated along the lower left side of the block and longitudes along the lower right. For most of its length, the escarpment is smooth and straight and the

consists of pre-existing blocks, bounded by faults. Although the bottom-current erosion (and possible dissolution) that is scouring the outer platform rocks and steepening the cliff shows no evidence of change from north to south, the response of the rocks to the steepening created by the erosion is different. In the south, being weakened by the pre-existing fractures, large blocks slide off when the cliff becomes very steep, whereas the massive, unfaulted limestones farther north are strong enough to maintain very steep slopes.

Why should such a set of faults exist in a region such as the Florida-Bahama Platform, that is far away from zones of active plate interactions and notable for its lack of earthquakes? The answer may be given by the orientation of faults that cut the rocks, an orientation that probably is indicated in figure 1 by the well-defined northwest trend of channels and canyons in the area (for example, Great Abaco Canyon) and the linear, northwest-oriented flank of Little Bahama Bank. This orientation is exactly the trend of the Jacksonville Fracture Zone (fig. 1; Klitgord and Schouten, 1986), a fracture zone that is identified in the oceanic crust to seaward. This fracture zone was generated at an offset in the initial rifting pattern when North America and Africa were ripped apart; the offset formed a boundary between different types of crust and, thus, controlled the location of
Blake Plateau behind it is smooth and flat. At its southern end, however, the face of the escarpment is more complex. There, it is incised by submarine canyons and valleys that trend northwest parallel to the northern flank of Little Bahama Bank, and displaced blocks of limestone litter the sea floor at the foot of the escarpment (see fig. 4).

the southern limit of the Blake Plateau Basin. Initially, subsidence was much greater and much faster on the basin side (north), where the crust was probably thinner and hotter. After the cessation of rapid sediment build-up on the Blake Plateau, the relative motion direction may have reversed. Since then, the sediment has built up faster to the south, where the Bahama Banks have succeeded in maintaining themselves at sea level by limestone deposition as

Figure 4. Perspective image of the southern Blake Escarpment, looking toward the northwest. The image was produced from the sea-floor reflections acquired by GLORIA sidescan-sonar system, which were "draped" on a computer image of the shape of the sea floor that was determined from echo sounder measurements of bathymetry along many ship tracks. The variations in tone result from variations in reflectivity of sound from the sea floor (see Lee, Schwab, and Booth, this report). Light areas, indicating strong acoustic reflections, occur where landslides (in landslide scars) or current erosion (in canyons) have stripped away loose sediment. Displaced blocks have slipped from the face of the Blake Escarpment as the escarpment was cut back and steepened by erosion. The blocks were defined by pre-existing fractures (and faults) that cut the limestone of the southern Blake Plateau, and thus predestine this response. 


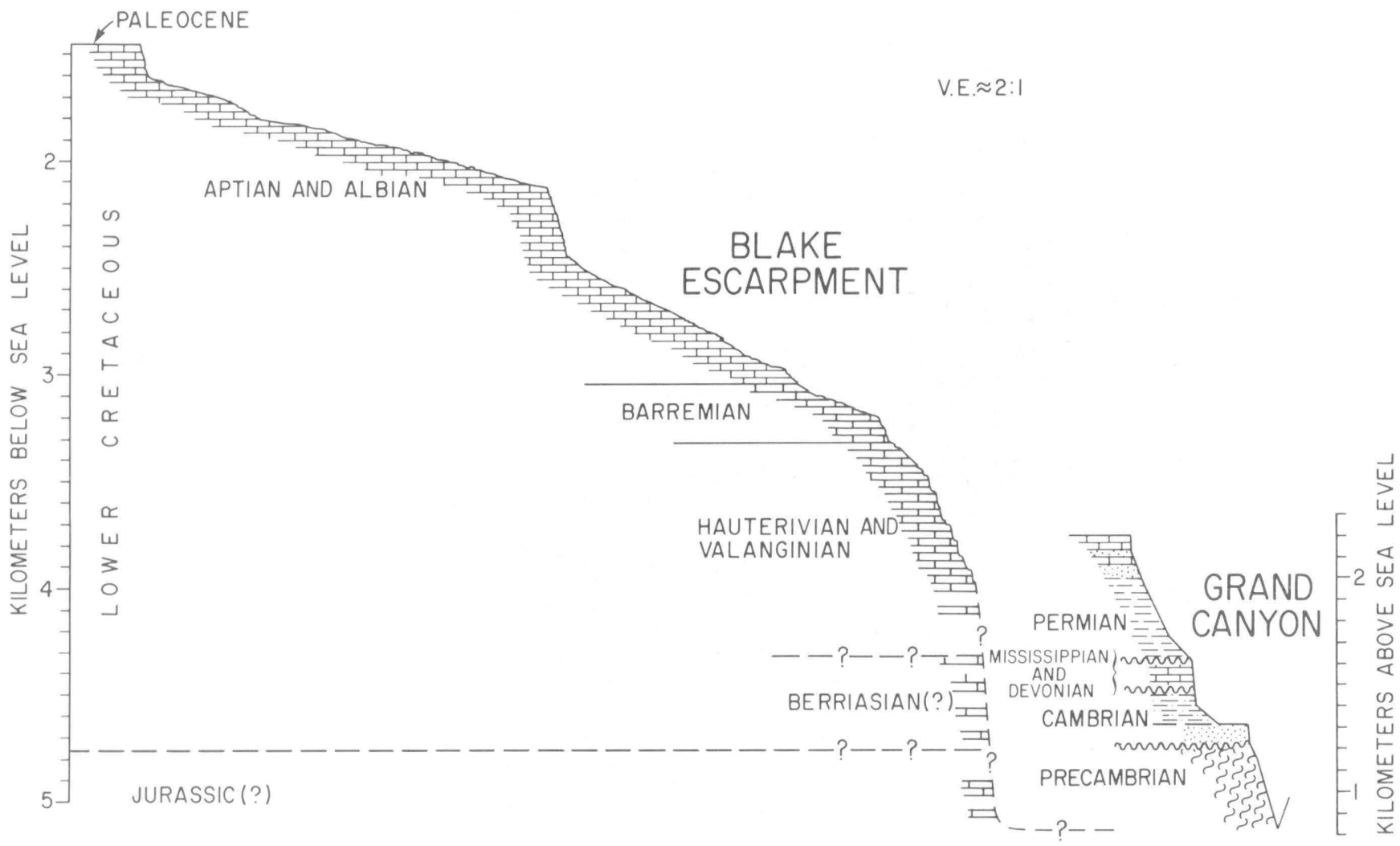

Figure 3. Comparison of cross-sections of the central Blake Escarpment and the south rim of the Grand Canyon. Vertical exaggeration is 2 to 1 , that is, vertical distances are stretched 2 times compared to horizontal distances. The rocks indicated for the Blake Escarpment may range from roughly 60 to 200 million years in age. Those in the Grand Canyon are older, perhaps from about 250 million to more than 600 million years in age.

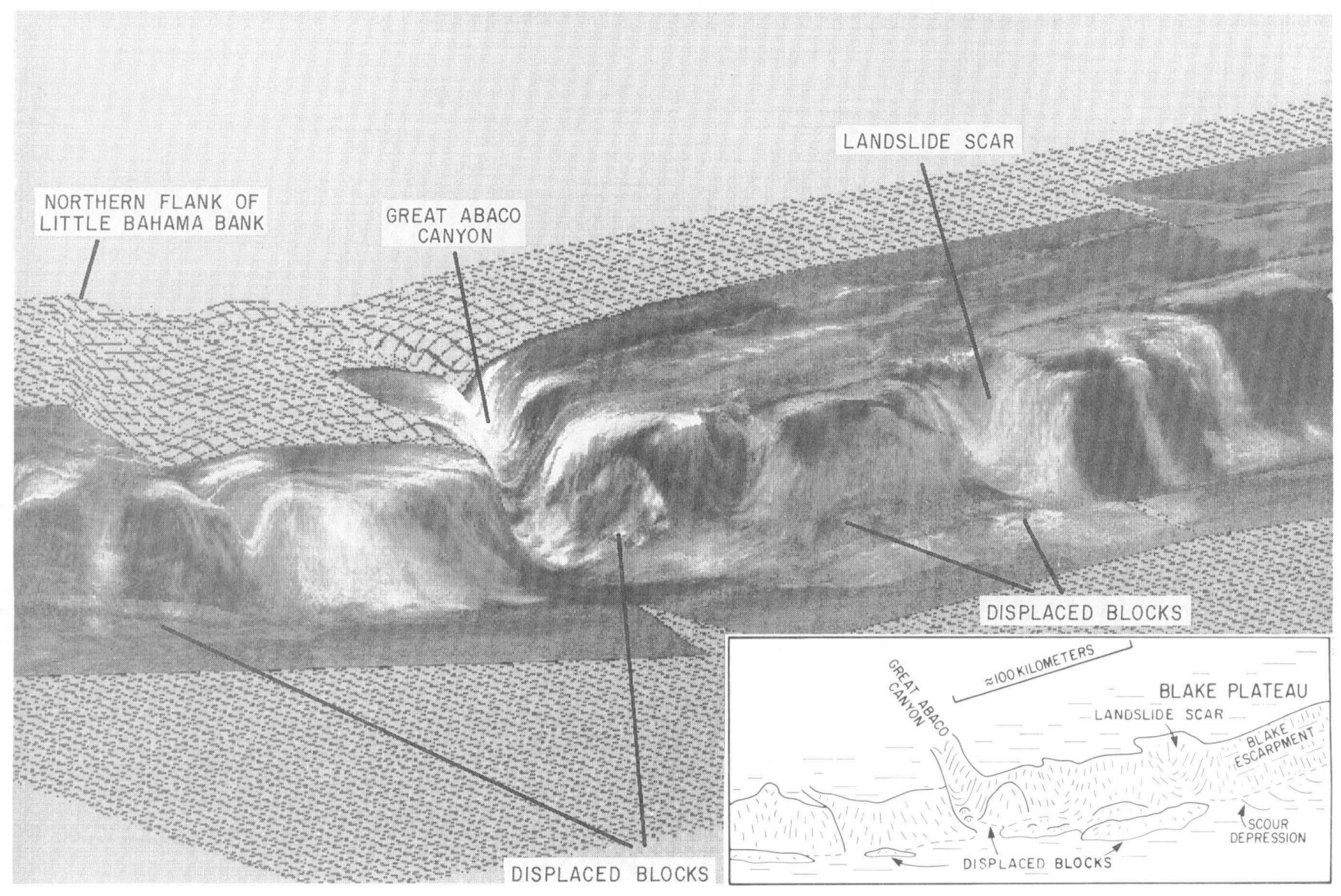



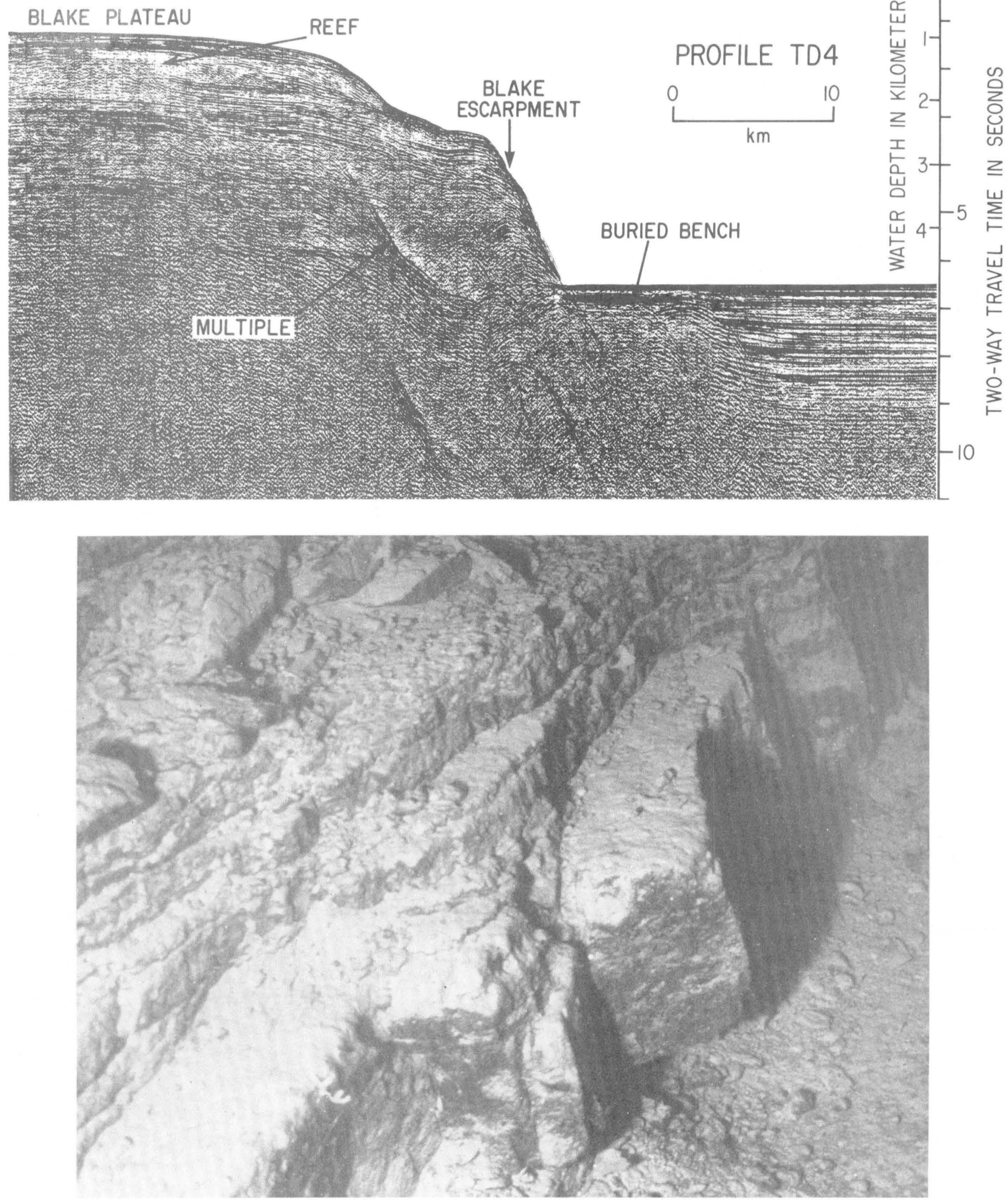

Figure 6. Surface of the Blake Escarpment at profile TD4 (fig. 5), at a water depth of 3,892 meters. The outcrop shown is about 2 meters high. The stepped pattern is created by the erosion of the essentially flat-lying limestone beds of the Blake Plateau. 
Figure 5. Multichannel seismic-reflection profile TD4 across the central Blake Escarpment. Location of this profile is shown in the right panel of figure 1. Seismicreflection profiles are cross-sectional images of the upper layers of the Earth (see Lee, Schwab, and Booth, this report). Because sound waves are used to make the images, the vertical scale is indicated in two-way travel time of sound, and actually, it is a variable scale in depth, as a result of the variable velocities of sound in the strata. Although the profiles are distorted by this effect, they are useful presentations of the subbottom structure. The buried bench at the base of the escarpment shows the extent of erosional retreat of this part of the escarpment. The strata of the plateau extend nearly horizontally to the escarpment, where they are truncated by erosion. The apparent downward curve of strata as they come close to the escarpment surface is an artifact of the seismic-reflection method, and should be disregarded. The multiple also should be disregarded; it does not represent a real subbottom structure. The profile is displayed with a vertical exaggeration of 4 to 1 for the sea floor.

the region subsided, and by doing so have placed a greater new load on the crust south of the fracture zone. These tendencies for differential vertical motions at the basin boundary may have continually reactivated faults there, and although the motions probably have been small in recent times, they have been enough to fracture the limestone continually.

Thus, active processes that form the present continental margin are influenced by a boundary that probably was inherited from a crustal weakness that predated the breakup of North America and Africa. Future block collapse prob- ably will occur at this same site, and, despite the steep slopes of the Blake Escarpment farther north, landslides probably are much less likely there.

\section{REFERENCES CITED}

Dillon, W.P., Paull, C.K., and Gilbert, L.E., 1985, History of the Atlantic Continental Margin off Florida; The Blake Plateau Basin, in Poag, C.W., ed., Geologic evolution of the United States Atlantic margin: New York, Van Nostrand Reinhold, p. 661-676.

Dillon, W.P., and Popenoe, Peter, 1988, The Blake Plateau Basin and Carolina Trough, in Sheridan, R.E., and Grow, J.A., eds., The Atlantic Continental Margin, U.S.: Geological Society of America, The Geology of North America, v. I-2, p. 291-328.

EEZ-SCAN 87 Scientific Staff, 1991, Atlas of the U.S. Exclusive Economic Zone, Atlantic continental margin, U.S. Geological Survey, Miscellaneous Investigations Series I-2054, 174 p.

Freeman-Lynde, R.P. and Ryan, W.B.F., 1985, Erosional modification of the Bahamas Escarpment, Geological Society of America Bulletin, v. 96, p. 481-494.

Klitgord, K.D., and Schouten, Hans, 1986, Plate kinematics of the central Atlantic, in Vogt, P.R., and Tucholke, B.E., eds., The Western North Atlantic region: Geological Society of America, The Geology of North America, v. M, p. 351-378.

Mountain, G.S., and Tucholke, B.E., 1985, Mesozoic and Cenozoic geology of the Atlantic continental slope and rise, in Poag, C.W., ed., Geologic evolution of the United States Atlantic margin: New York, Van Nostrand Reinhold, p. 293-341.

Paull, C.K., and Dillon, W.P., 1980, Erosional origin of the Blake Escarpment: An alternative hypothesis: Geology, v. 8, p. $538-542$.

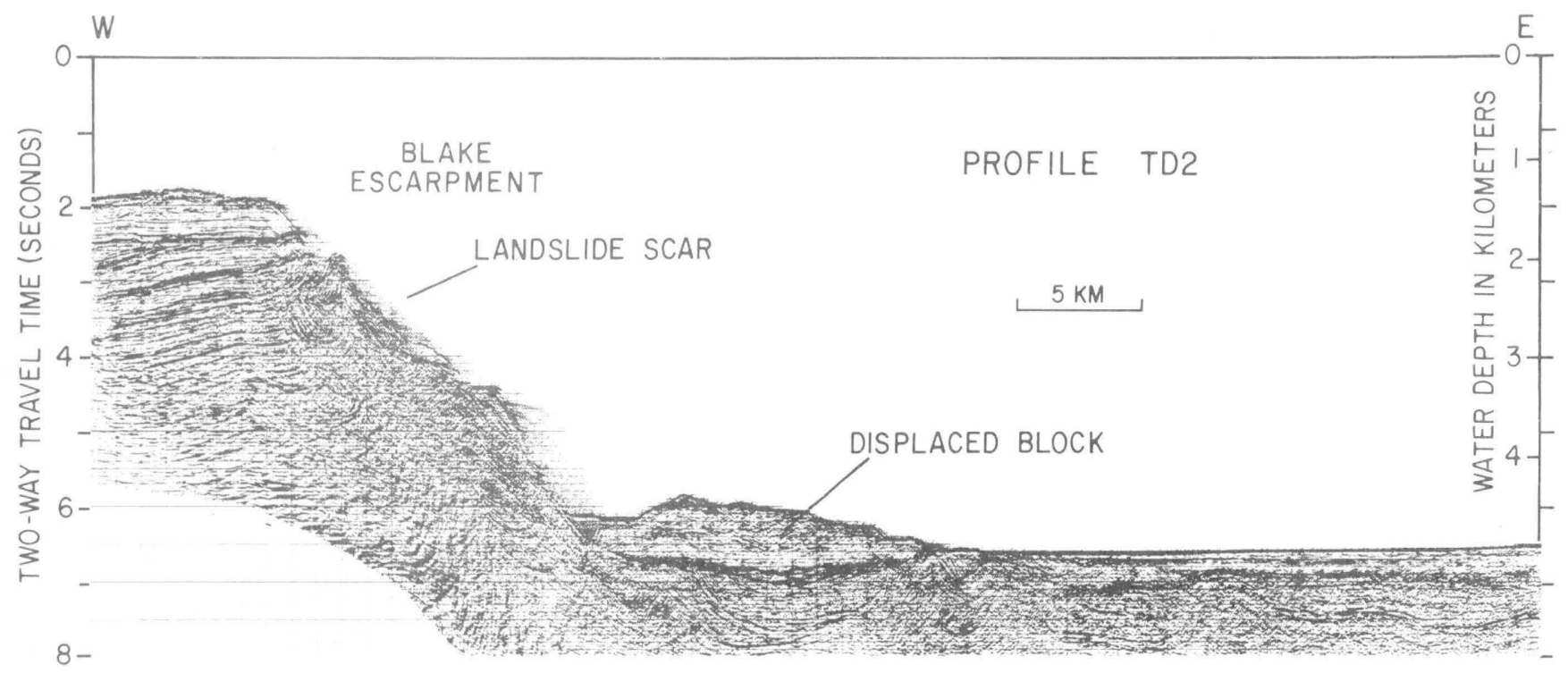

Figure 7. Seismic-reflection profile TD2 through the southern part of the Blake Escarpment, and extending through the image shown in figure 4. Location shown in figure 1 . The displaced block situated on the deep sea floor apparently slid from the escarpment, and may, in part, have come from the landslide scar indicated. Of course, the displaced block also may have moved across the plane of this section (into or out of the page). Vertical exaggeration is 4 to 1 . 


\title{
Tectonic and Stratigraphic Control on a Giant Submarine Slope Failure: Puerto Rico Insular Slope
}

\author{
By W.C. Schwab, W.W. Danforth, and K.M. Scanlon
}

\section{DESCRIPTION OF THE LANDSLIDE}

An amphitheater-shaped scarp, approximately 55 kilometers $(\mathrm{km})$ across on the insular slope north of Puerto Rico represents the removal of more than $1,500 \mathrm{~km}^{3}$ of rock and sediment. A review of the regional stratigraphy and tectonics (Schwab and others, 1991) suggests that the scarp formed as a result of slope failure of carbonate strata (limestone); a giant submarine landslide. The study area (fig. 1) lies along the plate boundary zone between the North American and Caribbean lithospheric plates (Sykes and others, 1982) (fig. 2). Strong earthquakes affect the entire region due to this tectonic setting (Mann and Burke, $1984)$ and were most likely responsible for triggering this slope failure.

During a 30-day cruise aboard the R/V Farnella in November and December 1985, the GLORIA (Geological LOng-Range Inclined Asdic) sidescan-sonar system was used to obtain a reconnaissance view of the sea floor surrounding Puerto Rico and the U.S. Virgin Islands (EEZ-SCAN 85 Scientific Staff, 1987). One spectacular feature revealed by the GLORIA imagery was a large amphitheater-shaped scarp north of Puerto Rico (figs. 3, 4, 5 , and 6). The amphitheater-shaped scarp has its crown (or rim) at a water depth of about 3,000 meters (m), and extends to a water depth of about $6,700 \mathrm{~m}$ (described on figs. 2 and 3 as "base of slope"). The average slope of the amphitheater-shaped scarp is $8.5^{\circ}$. A system of talus chutes has developed on the scarp and acts as a series of conduits for the seaward transport of sediment. Most of these talus chutes appear to have little relation to the submarine canyons that stripe the insular slope above the crown of the amphitheater-shaped scarp (figs. 3 and 4) and thus are related to the mass wasting (downslope movement of surface materials) of the amphitheater-shaped scarp itself (fig. 7).

\section{GEOLOGIC SETTING}

Puerto Rico has a central core of folded and faulted metamorphic, sedimentary, and volcanic rocks of Late Jurassic to Eocene age (150 to 45 million years old). Flanking these older rocks on the north and south are carbonate strata of Eocene to Pliocene age ( 45 to 4 million years old). The carbonate rocks on the north flank of the island form the Arecibo basin strata (Meyerhoff and others, 1983), which covers an area about $300 \mathrm{~km}$ long and 55 $\mathrm{km}$ wide, and have a maximum thickness of about $4,000 \mathrm{~m}$ (fig. 1). These Arecibo basin strata are exposed on the amphitheater-shaped scarp.

The offshore. stratigraphy in the area of the amphitheater-shaped scarp can be divided into three units based on seismic-reflection profiles (fig. 8; Meyerhoff and others, 1983). The lowest unit, unit 1, consists of basement rocks of Late Jurassic to middle Eocene age. Unit 1 is offset by several large normal faults. The middle unit, unit 2 , forms the lower part of the Arecibo basin strata. Unit 2 rocks are thought to be late middle Eocene to middle Oligocene (45 to 30 million years old) limestones that were originally deposited in shallow water. The uppermost part of the Arecibo basin strata, unit 3, consists of reef and other shallow-water limestones. Unit 3 rocks range in age from middle Oligocene to Pliocene ( 30 to 4 million years old).

The unit 3 strata, both onshore and offshore, have a northward dip of $3.5^{\circ}$ to $5^{\circ}$ (Meyerhoff and others, 1983). These strata extend offshore to a water depth of $3,300 \mathrm{~m}$, where the section is downfaulted (fig. 8). Because the faults cut the entire unit 3 section, they were active after deposition of the unit 3 strata; within the last 4 million years. Extrapolation of these faults along isobaths (bathymetric 'contour lines) eastward from the seismic-reflection profile (fig. 5) suggests that the location of the scarp is controlled by the faults themselves (Schwab and others, 1991). The slope failure that created the amphitheater-shaped scarp removed most, if not all, of the Arecibo basin strata.

The sea floor below the amphitheater-shaped scarp, between the base of slope (water depth 6,700 m) and the Puerto Rico Trench (water depth greater than $8,000 \mathrm{~m}$ ), exhibits several hundred meters of local relief while dis-

Figure 1. Study area showing the regional tectonic setting (modified from Schwab and others,...1991). The Earth's lithospheric plates interact in three ways; they diverge, converge, or they slide past each other. Arrows in the inset indicate relative motion of the North American and Caribbean plates. Although the relative motion between the North American and Caribbean plates is predominantly strike-slip (the two plates move parallel to each other in opposite directions), the presence of the Puerto Rico Trench suggests that a component of the motion between the two plates is convergent (Sykes and others, 1982; Mann and Burke, 1984). As a result of this convergence, the North American plate is being obliquely thrust under. the Caribbean plate (also see fig. 2). The ramifications of this oblique convergence is the northward tilting of the northern insular slope of Puerto Rico and the formation of a region of high seismic risk. 


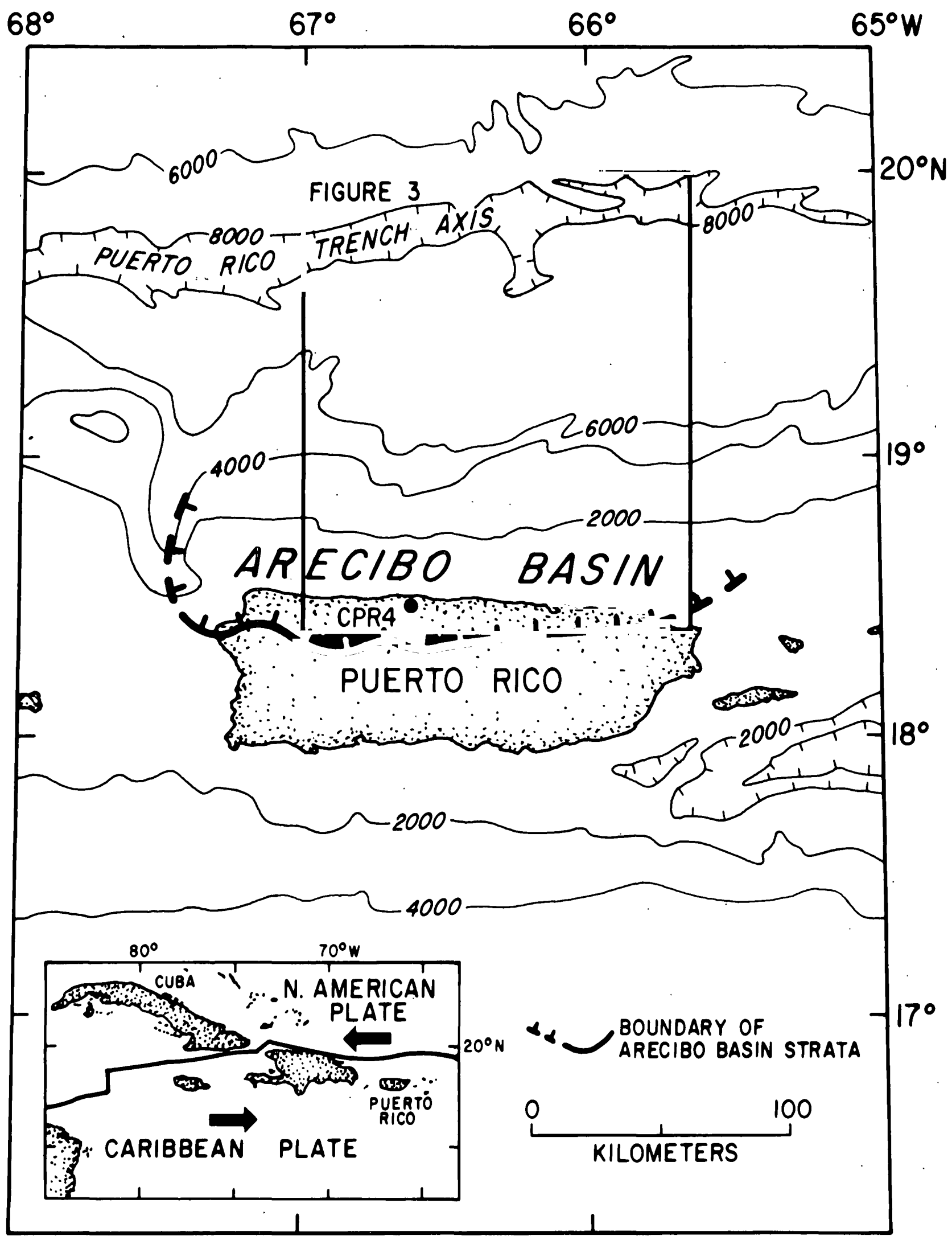




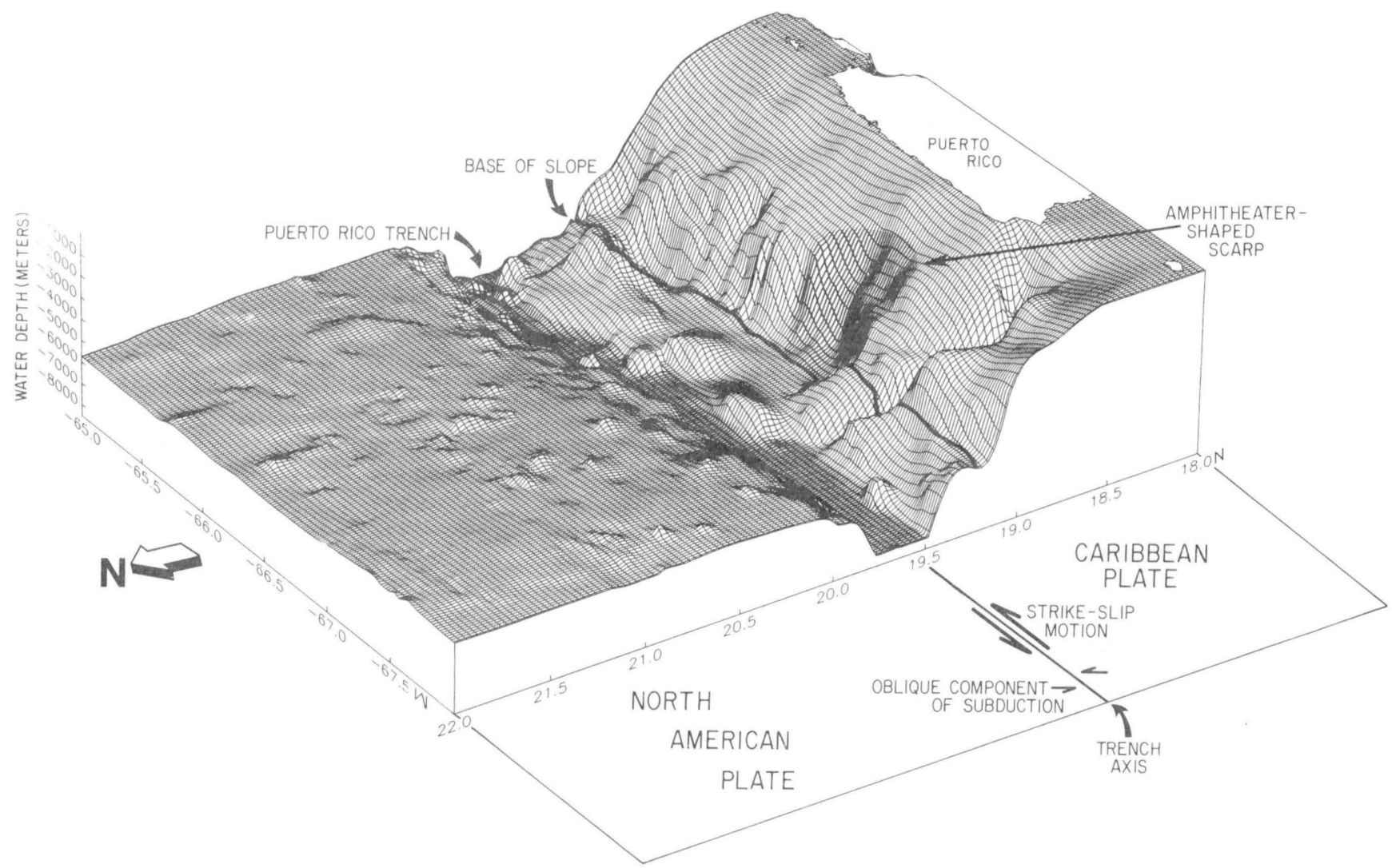

Figure 2. A three-dimensional depiction of the bathymetry of the sea floor north of Puerto Rico, a segment of the boundary between the North American and Caribbean lithospheric plates. Major physiographic features shown are the amphitheater-shaped scarp, the insular slope of Puerto Rico, and the axis of the Puerto Rico Trench.

playing a regional slope of only $1.7^{\circ}$ (fig. 2). GLORIA imagery of this $50-\mathrm{km}$-wide area of sea floor displays areas of high and low acoustic backscattering intensity (fig. 4). The areas of low backscatter have been interpreted from seismic-reflection profiles and sediment cores to be ponded turbidite basins (fig. 3). Some areas of high backscatter on the GLORIA imagery from the area of sea floor near the base of the slope have been identified based on dredged samples (Fox and Heezen, 1975; Perfit and others, 1980) as displaced carbonate debris (units 2 and 3) from further upslope, thus substantiating an inference that large volumes of rock from the insular slope have moved downslope.

\section{CAUSE OF THE LANDSLIDE}

A number of indicators suggest that slope failure of the Arecibo basin strata is principally responsible for the present morphology of the amphitheater-shaped scarp. These indicators include (1) the tectonic setting of the study area, a plate boundary and region of high seismicity; (2) the occurrence of shallow-water carbonate debris similar to the Arecibo basin strata that have been transported downslope and are now found in the area near the base of slope; and (3) the truncation of the strata by faults. Although thought to be the principal factor, it is unlikely that slope failure is the sole causative process. For example, the effects of erosion by abyssal currents or turbidity currents and/or bioerosion (the accumulated action of boring organisms over millions of years) are unknown.

In general, slope failure occurs when the environmental forces (stress) acting on the strata are greater than the resistance to deformation offered by the strata (strength). The two dominant driving forces of submarine slope failure applicable to the study area are downslope gravitational stress, due to the dip of the strata, and earthquake-induced shaking (Lee, Schwab, and Booth, this report).

Downslope gravitational stresses affecting the Arecibo basin strata have varied with time. The northern part of Puerto Rico slowly subsided due to crustal thinning and sediment loading (Birch, 1986) as unit 2 was being deposited. At this time, a strike-slip boundary existed between the Caribbean and North American lithospheric plates (Sykes and others, 1982) presumably in the vicinity of the present Puerto Rico Trench. During deposition of unit 3 in middle Oligocene to early Pliocene time (from 30 to 4 million years before present), the plate boundary seems to have been relatively stable. Seismic-reflection profiles 


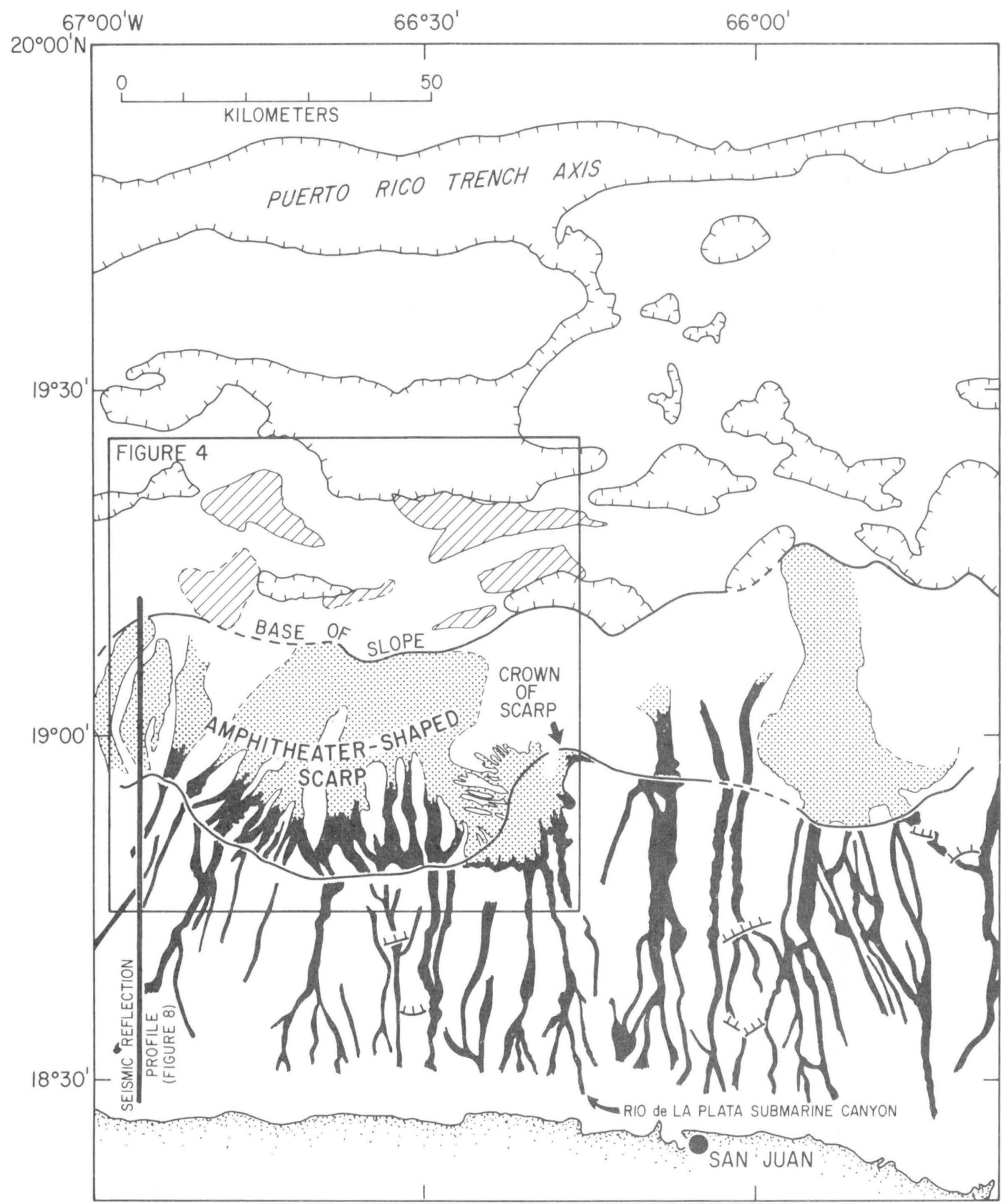

\section{EXPLANATION}

Submarine Canyons; Offshore
sediment/debris mass transpor conduits.

Mass-Movement Deposits; Composed of insular shelf sediment and debris from Arecibo Basin strata.
Ponded Turbidite Basins

Displaced Blocks of Arecibo

Basin strata (units 2 and 3 ) and /or outcrops of units I or 2 rocks.

Downslope-facing scarps on the insular slope.

Figure 3. Interpretive sketch (from Schwab and others, 1990) of the GLORIA imagery of the northern insular margin of Puerto Rico. The location of this interpretive sketch is shown on figure 1. 


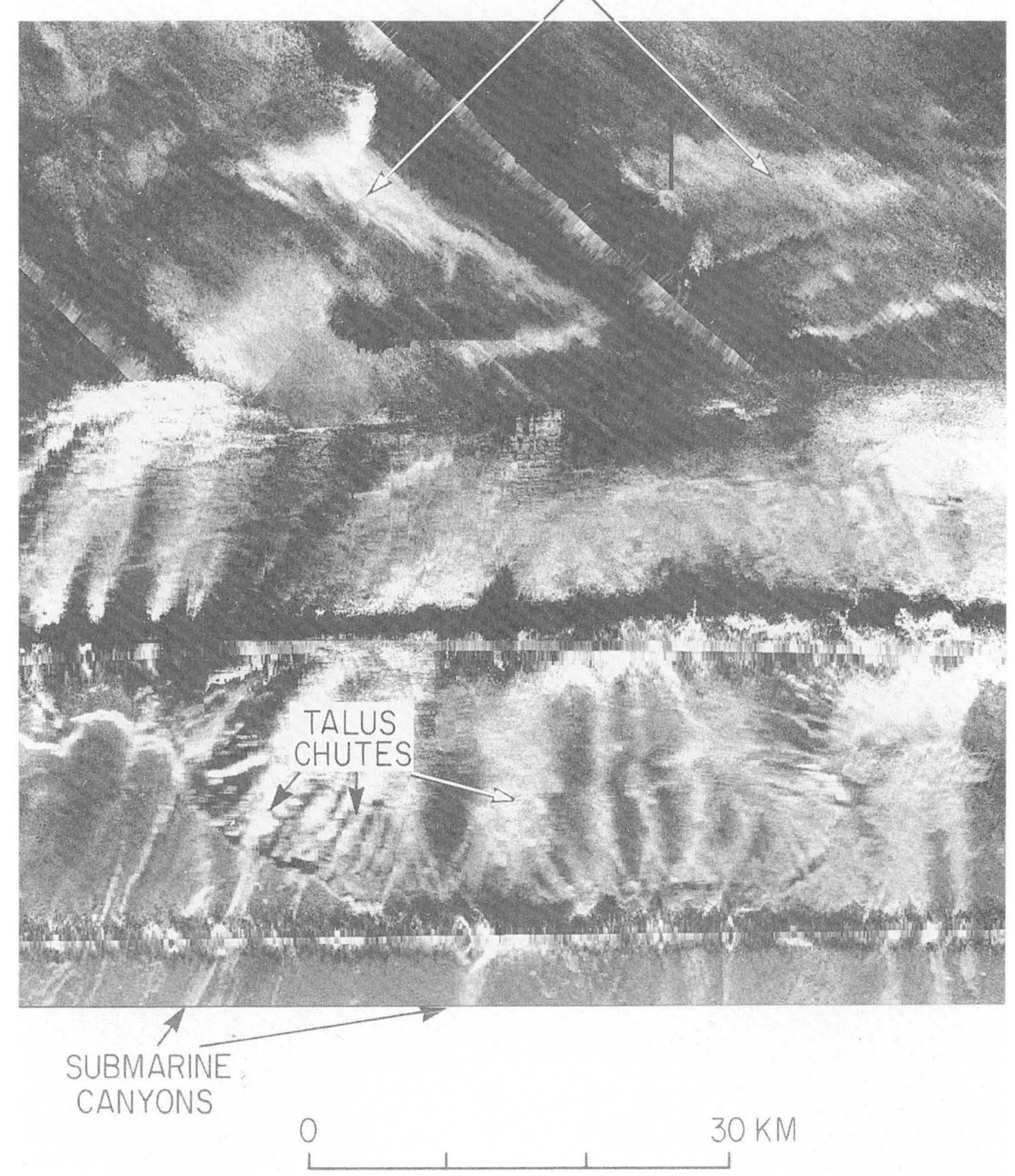

Figure 4. Digitally processed and enhanced GLORIA sidescan-sonar imagery of the amphitheater-shaped scarp north of Puerto Rico (following the computer processing routines outlined by Chavez, 1986; modified from EEZ-SCAN 85 Scientific Staff, 1987). The location of this figure is shown on figure 3. For a complete description of the GLORIA system, see Somers and others (1978). The principle of sidescan-sonar is described in Lee, Schwab, and Booth (this report). Areas of high acoustic backscatter on the GLORIA imagery are expressed as light tones while areas of low backscatter are dark. Geologic interpretation of this imagery is presented on figure 3.

showing unit 3 have continuous parallel reflections that are displaced by only a few faults (Meyerhoff and others, 1983). Therefore, approximately 4 million years ago, an extensive shallow-water carbonate platform existed north of the present coast of Puerto Rico.

Sometime since the early Pliocene (within the past 4 million years), slight convergence between the Caribbean and North American plates caused renewed subduction north of Puerto Rico. At least a small component of the relative motion between the two plates resulted in the thrusting of the North American plate beneath the Carib- bean Plate (Sykes and others, 1982). Tectonic erosion induced by this oblique subduction is suggested to have thinned the island basement from underneath (basement rocks of Puerto Rico where abraded by the downgoing North American plate and subducted beneath the Caribbean plate), causing the northern insular margin of Puerto Rico to tilt rapidly to the north (Birch, 1986). As a result, the southern part of unit 3 has been uplifted a few hundred meters, whereas the northern part has subsided more than $4,500 \mathrm{~m}$, thus generating a $4.5^{\circ}$ regional slope on the Arecibo basin strata. The present sea floor of the insular 


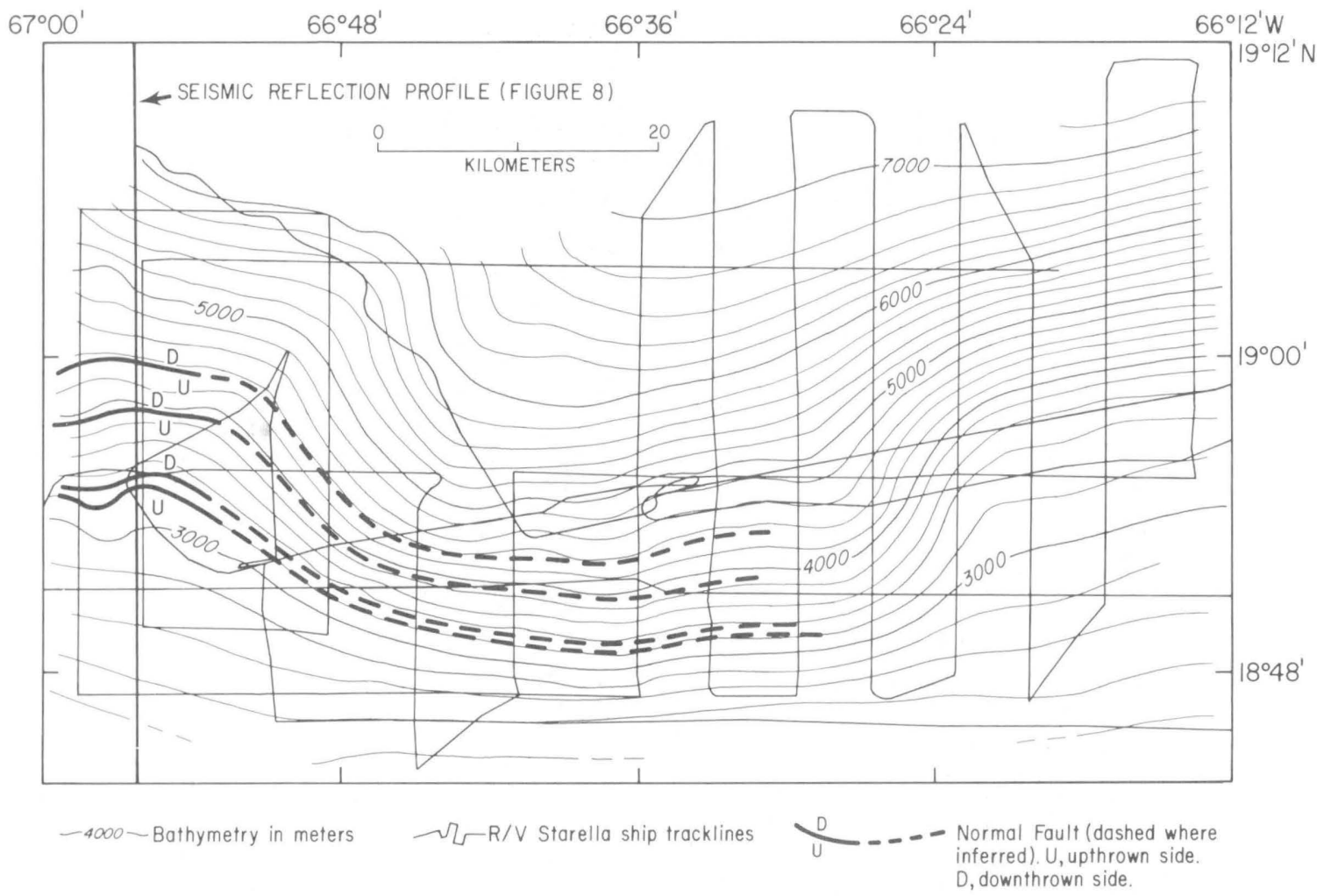

Figure 5. Bathymetry of the amphitheater-shaped scarp in meters (modified from Schwab and others, 1990). The location of the seismic-reflection profile (fig. 8) and faults that cut the sea-floor surface are from Meyerhoff and others (1983).

slope of Puerto Rico to a water depth of approximately $3,000 \mathrm{~m}$ is essentially the upper surface of unit 3 covered by a thin veneer of sediment. Therefore, the sea-floor slope, and thus the downslope gravitational stress affecting the Arecibo basin strata, has been steadily increasing due to the northward tilting of the northern insular margin during the past 4 million years.

Earthquake shaking has also affected the Arecibo basin strata. Earthquake-induced horizontal accelerations directly increase the downslope-directed stresses which act on strata. In addition, the cyclic ground motions increase pore-water pressure. An elevation of pore-water pressure directly decreases the strength of the strata and, therefore, reduces its ability to resist slope failure (Lee, Schwab, and Booth, this report). Furthermore, the strength of the Arecibo basin strata was probably significantly reduced by pre-existing faults that underlie the amphitheater-shaped headwall scarp (figs. 5 and 8).

The increase of the sea-floor slope with time, when coupled with earthquake shaking and associated possible strength reduction during major earthquakes, could be expected to exceed the strength of the Arecibo basin strata, particularly along the fault-induced pre-existing zones of weakness (Schwab and others, 1991). The result would be a slope failure, such that the northern section of the Arecibo basin strata would have broken off, disintegrated, and slid into the area between the base of slope and the Puerto Rico Trench. Mass wasting of the newly exposed failure plane (the amphitheater-shaped scarp) resulted in the formation of the talus chutes. Subsequent mass-flow activity transported debris from the talus chutes and from the insular slope above the amphitheater-shaped scarp and deposited this material north of the base of slope as turbidites (fig. 3). Thus, the mass-movement deposit associated with the slope failure that formed the amphitheater-shaped scarp has been partially buried by these younger turbidites and is not fully discernible on the GLORIA imagery (fig. 4).

\section{APPLICATION TO OTHER AREAS}

Amphitheater-shaped scarps have been identified and verified as the consequence of slope failure in various subaerial and submarine settings (for example, Brunsden and Prior, 1984; Mullins and others, 1986; Lee, 1989 and references therein). Although the amphitheater-shaped scarp north of Puerto Rico represents the removal of a huge amount of material (about $1,500 \mathrm{~km}^{3}$ of strata), submarine slope failures of this large scale may not be particularly unusual. Recent surveys using modern remote-sensing instruments show that the world's largest slope failures have occurred on submarine slopes. These include slope failures on the steep submerged volcanic slopes of the Hawaiian 


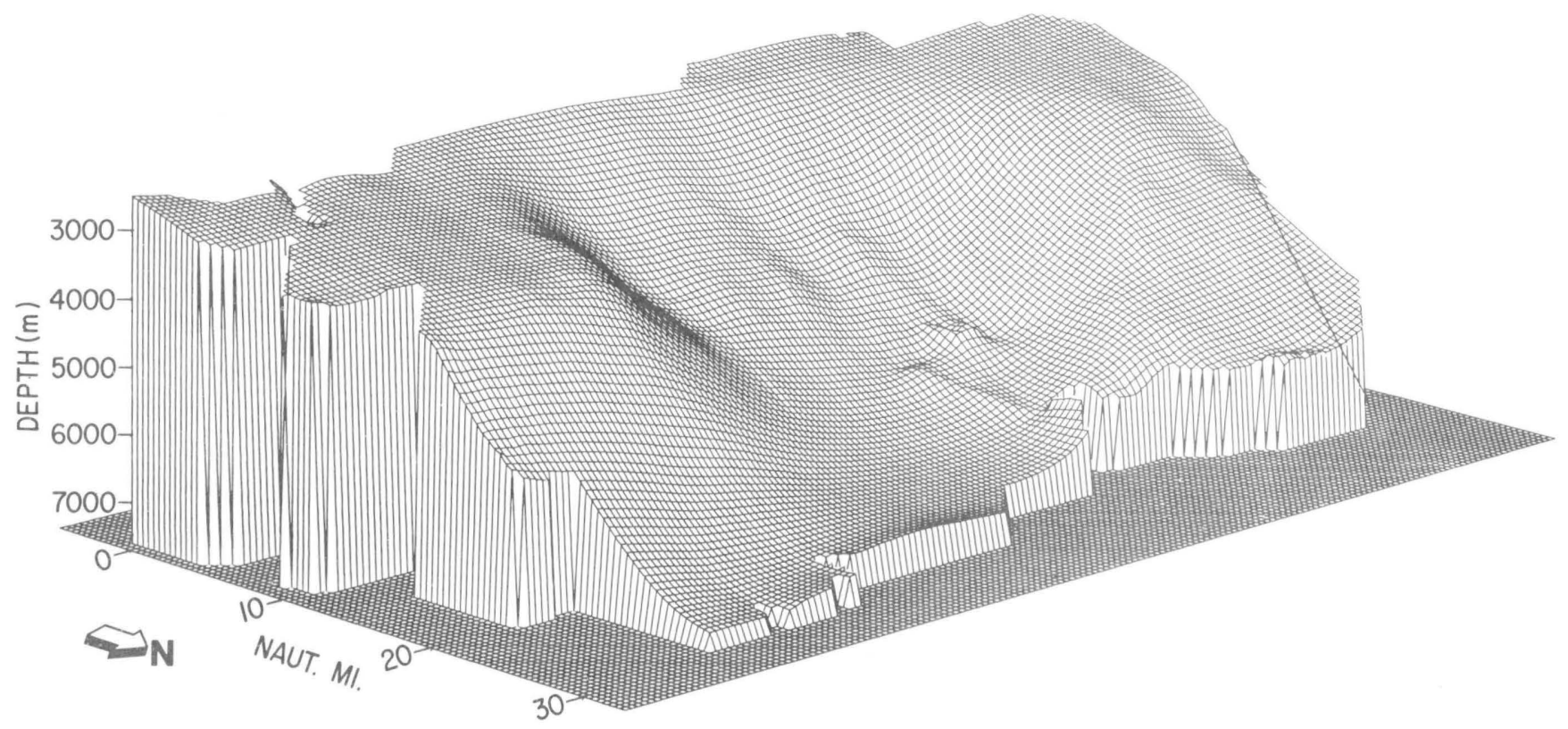

Figure 6. Three-dimensional perspective view of the bathymetry shown on figure 5 .

Islands (Moore and others, 1989; Normark and others, this report), the continental slope of Norway (Bugge and others, 1987) and along the middle and lower slopes of convergent margins (Lewis and others, 1988, von Huene and others, 1989).

It appears that the slope failure of the northern margin of the Arecibo basin strata resulted from oversteepening of the strata in a region of high seismicity. As this oversteepening continues, the relative stability of the insular slope decreases. Further east along the insular slope near longitude $66^{\circ} \mathrm{W}$. (fig. 3), a smaller area of high backscattering intensity on the GLORIA imagery has been interpreted to be another amphitheater-shaped scarp (EEZ-SCAN 85 Scientific Staff, 1987), suggesting that the entire northern edge of the Arecibo basin strata is failing under the present tectonic regime.

In addition to the amphitheater-shaped scarp and its possible smaller counterpart to the east, several other smaller scarps have been identified on the slope north of Puerto Rico in water depths less than 3,000 m (fig. 3). These smaller scarps may represent incipient slope failures and may indicate that the slope failure represented by the amphitheater-shaped scarp is retrogressive and will continue to be active.

\section{SEISMIC SEA WAVES FROM GIANT EARTHQUAKES}

The existence of large submarine landslides has significance for understanding of the generation of great sea waves. These giant waves are called seismic sea waves or tsunami (the Japanese word with the same form in both singular and plural). Tsunami have devastated oceanic islands and continental coastlines throughout history. Although tsunami can be caused by large earthquakes (for example, the 1964 Alaska earthquake (Plafker and others, 1969; von Huene and Cox, 1972) and the 1960 Chilean earthquake (Kajiura, 1979)), they also can be generated by other mechanisms, including submarine slope failure (McCulloch, 1985; von Huene and others, 1989; Hampton, Lemke, and Coulter, this report). We do not know if the slope failure that resulted in the amphitheater-shaped scarp off Puerto Rico was catastrophic (the entire mass disintegrating rapidly) or took place over a substantial period of time (block by block). If the amphitheater-shaped scarp was the result of a catastrophic slope failure, it was of sufficient size to have generated a large tsunami that must have had major impact on the nearby $(35 \mathrm{~km})$ coastal areas of Puerto Rico. Because the condition of slope instability that allowed an extremely large slope failure continues to develop north of Puerto Rico, and because the seismic risk remains the same as that when the studied slope failure took place, a repetition of the event is quite possible, with potential for generation of a catastrophic tsunami.

\section{ACKNOWLEDGMENTS}

The authors thank the captain and the crews of the R/V Farnella and R/V Starella for their cooperation at sea. Discussions with Kim Klitgord, William Dillon, Chris Polloni, and Douglas Masson were helpful during this research. All illustrations and photography were provided by Sarah Griscom, Patricia Forrestal, Dann Blackwood, and Jeff Zwinakis. Any use of trade names is for descriptive purposes only and does not imply endorsement by the U.S. Geological Survey. 

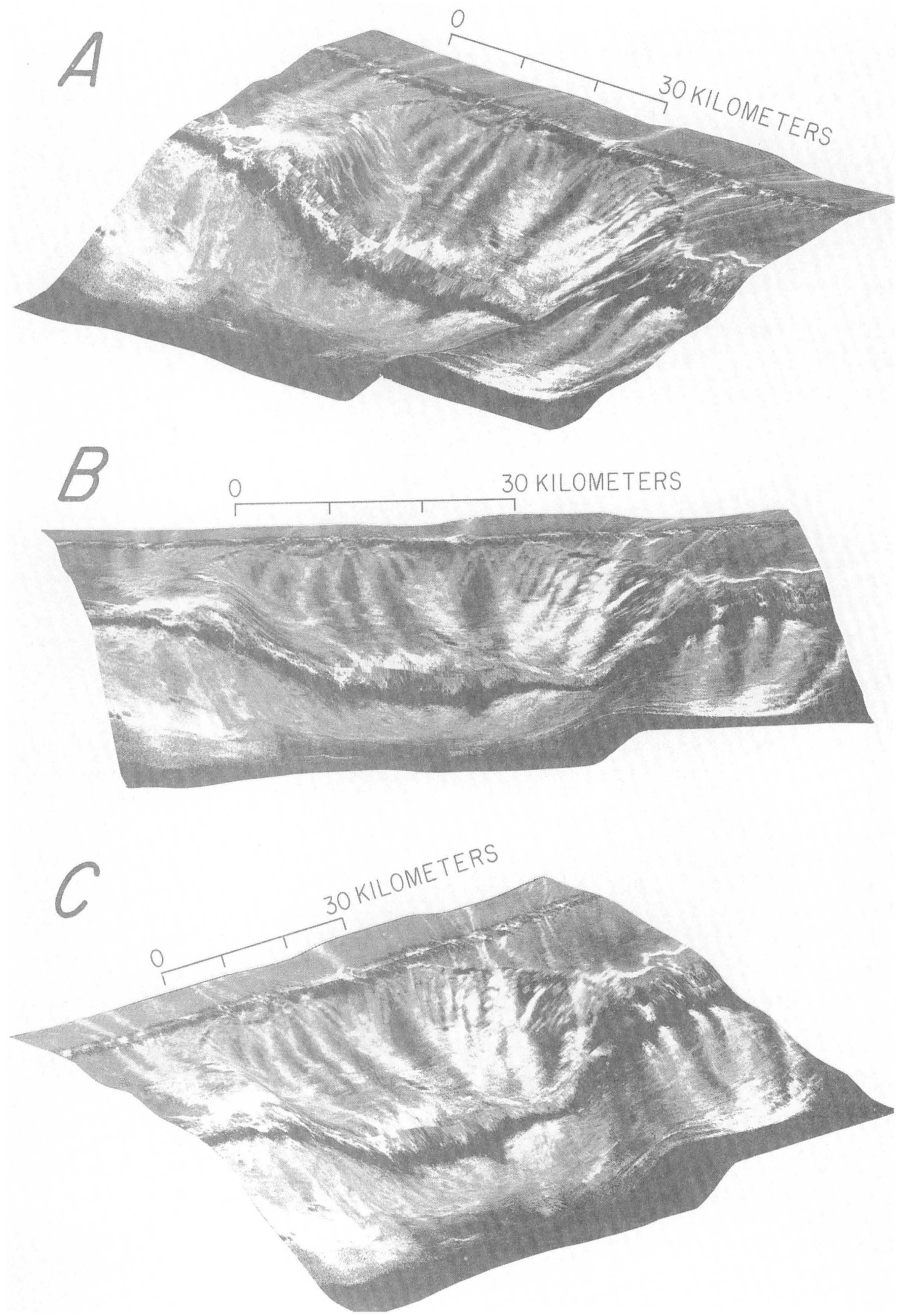

Figure 7. Three-dimensional perspective views of the amphitheater-shaped scarp using digitally merged GLORIA (from fig. 4) and bathymetric data (from fig. 6); $(A)$ viewed from the northwest. $(B)$ viewed from the north. (C) viewed from the northeast. See figures 3 and 4 for interpretation. 


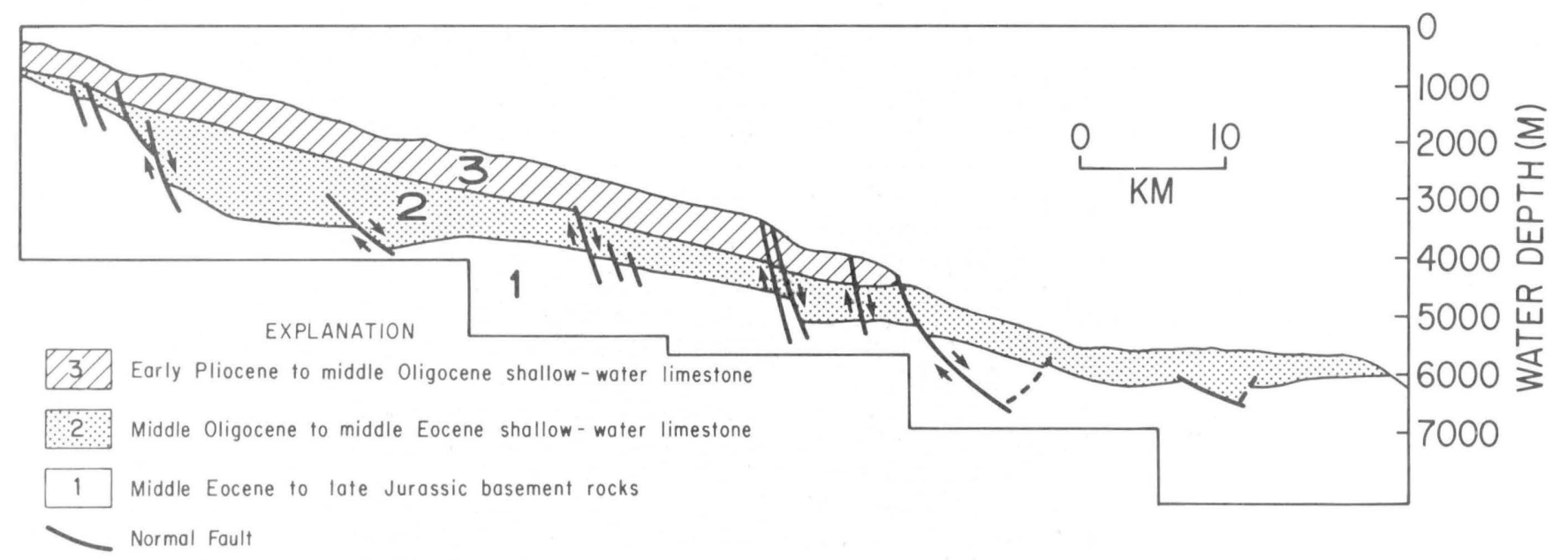

Figure 8. An interpretive sketch of a representative seismic-reflection profile collected over the Arecibo basin (modified from Meyerhoff and others, 1983). See figures 3 and 5 for the location of this profile.

\section{REFERENCES CITED}

Birch, F.S., 1986, Isostatic, thermal, and flexural models of the subsidence of the north Coast of Puerto Rico: Geology, v. 14, p. $427-429$.

Brunsden, Denys, and Prior, D.B., 1984, Slope instability: Wiley-Interscience Publication, $620 \mathrm{p}$.

Bugge, Tom, Befring, Stein, Belderson, R.H., Eidvin, Tor, Jansen, Eystein, Kenyon, N.H., Holtedahl, Hans, and Sejrup, H.P., 1987, A giant three-stage submarine slide off Norway: Geo-Marine Letters, v. 7, p. 191-198.

Chavez, P.S., Jr., 1986, Processing techniques for digital sonar images from GLORIA: Photogrammetric Engineering and Remote Sensing, v. 52, p. 1133-1145.

EEZ-SCAN 85 Scientific Staff, 1987, Atlas of the U.S. Exclusive Economic Zone, Eastern Caribbean: U.S. Geological Survey Miscellaneous Investigations Series I-1864 B, 59 p.

Fox, P.J., and Heezen, B.C., 1975, Geology of the Caribbean crust, in, Nairn, A.E.M., and Stehli, F.G., eds., The ocean basins and margins, Volume 3: New York, Plenum Press, $706 \mathrm{p}$.

Kajiura, K.T., 1979, Tsunami generation, in, Hwang, L.S., and Lee, Y.K., eds., Tsunami: Proceedings of the National Science Foundation Workshop, May 1979, p. 15-36.

Lee, H.J., 1989, Undersea landslides: extent and significance in the Pacific Ocean, in Brabb, E.E., ed., Landslides: extent and economic significance: Proceedings of the 28th International Geological Congress Symposium on Landslides, Balkema, Rotterdam, p. 361-374.

Lewis, S.D., Ladd, J.W., and Bruns, T.R., 1988, Structural development of an accretionary prism by thrust and strike-slip faulting: Shumagin region, Aleutian Trench: Geological Society of America Bulletin, v. 100, p. 767-782.

Mann, P.T., and Burke, K.W., 1984, Neotectonics of the Caribbean: Reviews of Geophysics and Space Physics, v. 22, p. 309-362.

McCulloch, D.S., 1985, Evaluating tsunami potential, in, Ziony, J.I., ed., Evaluating earthquake hazards in the Los Angeles Region: U.S. Geological Survey Professional Paper 1360, p. 325-382.
Meyerhoff, A.A., Krieg, E.A., Cloos, J.D., and Tanner, I.S., 1983, Petroleum potential of Puerto Rico: Oil and Gas Journal, v. 81, December, p. 113-120.

Moore, J.G., Clague, D.A., Holcomb, R.T., Lipman, P.W. Normark, W.R., and Torresan, M.E., 1989, Prodigious submarine slides on the Hawaiian Ridge: Journal of Geophysical Research, v. 94, p. 17,465-17,484.

Mullins, H.T., Gardulski, A.F., and Hine, A.C., 1986, Catastrophic collapse of the west Florida carbonate platform margin: Geology, v. 14, p. 167-170.

Perfit, M.R., Heezen, B.C., Rawson, M.P., and Donnelly, T.W., 1980 , Chemistry, origin and tectonic significance of metamorphic rocks from the Puerto Rico trench: Marine Geology, v. 34 , p. $125-166$.

Plafker, George, Kachadoorian, R.N., Eckel, E.B., and Mayo, L.R., 1969, Effects of the earthquake of March 27, 1964 on various communities: U.S. Geological Survey Professional Paper 542-G, 53 p.

Schwab, W.C., Danforth, W.W., Scanlon, K.M., and Masson, D.G., 1991, A giant submarine slope failure on the northern insular slope of Puerto Rico: Marine Geology, v. 96, p. 237-246.

Somers, M.L., Carson, R.M., Revie, J.A., Edge, R.H., Barrow, B.J., and Andrews, A.G., 1978, GLORIA II-An improved long-range sidescan sonar: Proceedings of the IEEE/IERE Subconference on Ocean Instruments and Communication, Oceanology International, London, BPS Publications, p. $16-24$.

Sykes, L.R., McCann, W.R., and Kafka, A.L., 1982, Motion of the Caribbean plate during the last 7 million years and implications for earlier Cenozoic movements: Journal of Geophysical Research, v. 87, p. 10,656-10,676.

von Huene, Roland, Bourgois, Jacques, Miller, John, and Pautot, Guy, 1989, A large tsunamogenic landslide and debris flow along the Peru Trench: Journal of Geophysical Research, v. 94, p. 1703-1714.

von Huene, Roland, and Cox, C.K., 1972, Locally generated tsunami and other local waves in the great Alaska earthquake of 1964, oceanography and coastal engineering: National Academy of Sciences, Washington, D.C., p. 211-222. 


\title{
Slope Failure of Carbonate Sediment on the West Florida Slope
}

\author{
By D.C. Twichell, P.C. Valentine, and L.M. Parson ${ }^{1}$
}

\section{INTRODUCTION}

Previous studies have shown that slope failure has been an important process in the development of the West Florida Slope in the eastern Gulf of Mexico throughout the last 65 million years of its history. Slope failures have left large headwall scarps preserved in the sedimentary record and, in places, still exposed on the sea floor (Mitchum, 1978; Holmes, 1985; Doyle and Holmes, 1985; Mullins and others, 1986; Mullins and others, 1988). Whether these headwall scarps are the result of a few large catastrophic mass-wasting events widely separated in age or whether they resulted from numerous smaller events were questions we were previously unable to answer and that have an important bearing on the origin of these features and on future economic use of this region. In this section, GLORIA (Geological LOng-Range Inclined Asdic) sidescan-sonar images and high-resolution seismic-reflection profiles (EEZ-SCAN 85 Scientific Staff, 1987) are used to document an area of sea-floor instability on the West Florida Slope in the eastern Gulf of Mexico (fig. 1). The new GLORIA imagery of the study area shows that these large headwall scarps, which extend for great distances along the slope, are composite features resulting from multiple smaller mass-wasting events (fig. 2). These data also show that the extent of mass wasting in this area is more vast than was previously thought. These failures lie within an area of potential offshore petroleum exploration, so their presence may prove a hazard to the development of this resource.

The study area is a 300-kilometer (km)-long section of the West Florida Slope in water depths of 500 to 2,000. meters (m) (fig. 1). The West Florida Slope is bounded on its shoreward side by the nearly flat West Florida Shelf and on its seaward side by the precipitous Florida Escarpment (fig. 3). The West Florida Slope itself is $30-50 \mathrm{~km}$ wide and has average gradients of less than $1^{\circ}$ to $5^{\circ}$. Surface sediment on the slope is calcium carbonate mud (Doyle and Sparks, 1980). Seismic-reflection profiles show that the mud forms a westward-thinning, wedge-shaped deposit (fig. 4) that is as much as $1,000 \mathrm{~m}$ thick (Mitchum, 1978). These Cenozoic-aged carbonate sediments are less than 65 million years old, and overlie limestone rocks exposed on the face of the Florida Escarpment that are older than the Middle Cretaceous (about 100 million years ago) (Freeman-Lynde, 1983; Paull and others, 1990).

\footnotetext{
' Institute of Oceanographic Sciences, Wormley, Surrey, U.K.
}

\section{METHODOLOGY}

GLORIA is a long-range sidescan-sonar system that provides an acoustic map view of the sea floor (Somers and others, 1978). The GLORIA data were collected in swaths along ship tracklines which were close enough together to provide complete coverage of the study area. These data were processed and combined by computer techniques (Chavez, 1984, 1986) to create a sidescan-sonar mosaic (fig. 2; EEZ-SCAN 85 Scientific Staff, 1987). On the GLORIA images, a strong acoustic return from the sea floor (referred to in the text as high-backscatter) is light and a weak return (low backscatter) is dark (fig. 2).

High-resolution seismic-reflection profiles were collected along the survey tracklines simultaneously with the GLORIA data. The seismic-reflection data show sea-floor topography and provide cross-sectional profiles of the shallow stratigraphy below the sea floor. The combination of the sidescan-sonar and seismic-reflection data provides a three-dimensional view of the geology of this area.

\section{A NEW VIEW OF WEST FLORIDA SLOPE MORPHOLOGY}

The GLORIA images and high-resolution seismic profiles reveal that the surface of the West Florida Slope is scarred by numerous slope failures. The seismic profiles show many scarps here (figs. 5, 6); on the GLORIA images (fig. 2) these scarps appear as light or dark stripes depending on whether the sonar is looking upslope at them (light) or downslope over them (dark). Discontinuous scarps can be traced along the eastern edge of the survey area (figs. 1, 2 ), and they have $50-$ to $150-\mathrm{m}$ relief where crossed by seismic profiles. (Doyle and Holmes, 1985; Holmes, 1985).

Downslope of the scarps, the northern and central parts of the West Florida Slope are heavily dissected by narrow, downslope-trending valleys (figs. 1, 3). These valleys are flat-floored and have steep sidewalls with as much as $100-\mathrm{m}$ relief (fig. 5). For the most part, the floors of these valleys show high-backscatter returns on the GLORIA images which are inferred to represent mass-flow deposits (fig. 2). The valleys of the central part of the study area are subparallel, and they commonly converge on the heads of large canyons that incise the Florida Escarpment (fig. 2,3). The whole set of valleys in the central area is bounded along its northwest and southeast sides by scarps having as much as $200-\mathrm{m}$ relief (figs. 1, 3, 5B, southern end). 


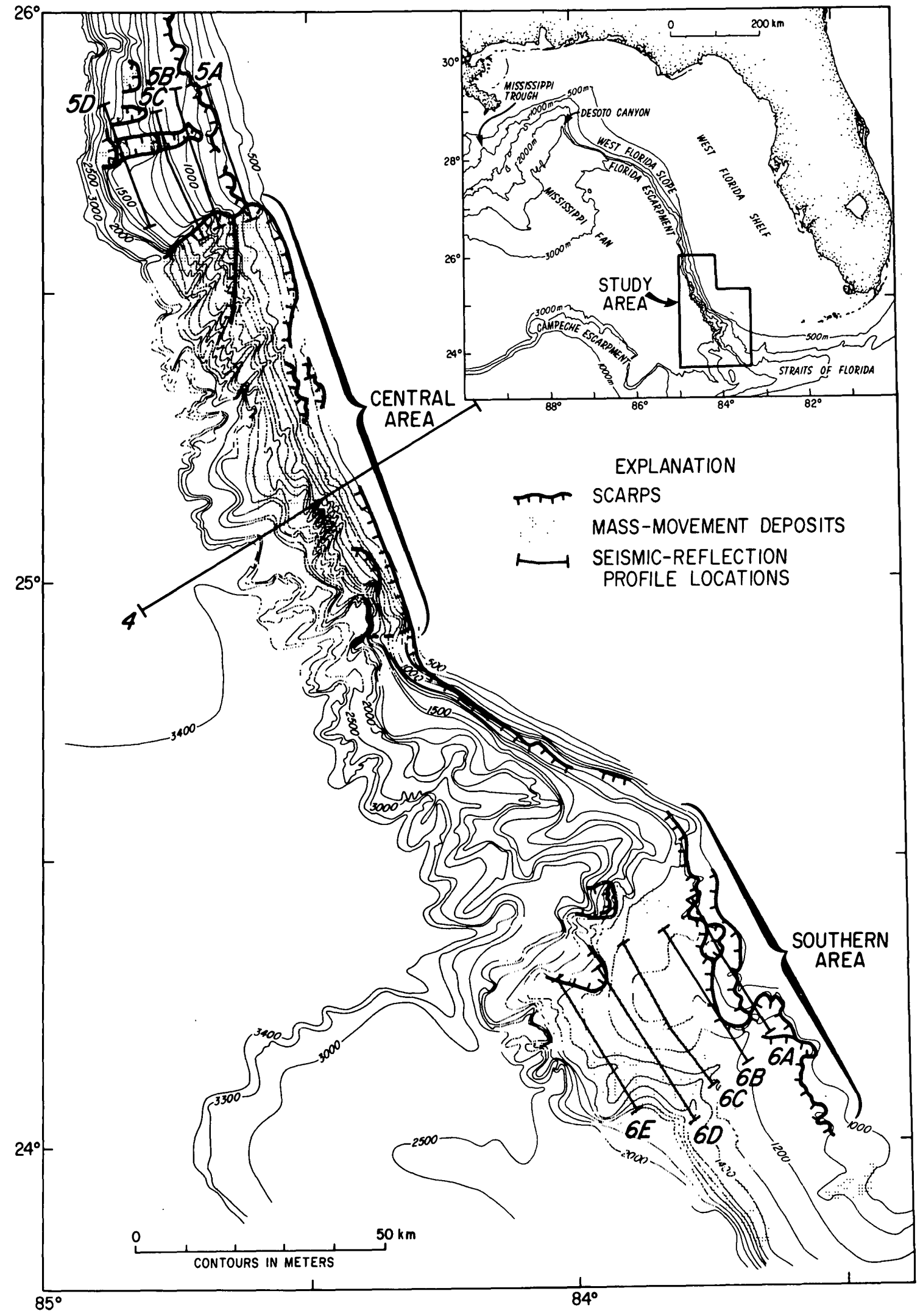


4 Figure 1. Bathymetric map showing the West Florida Slope in the southeastern Gulf of Mexico. Location of the study area is given in the inset map. Contours are in meters and have been created using the soundings collected during the EEZ-SCAN project in combination with the GLORIA images which were used as a guide to defining the shape of the sea floor between the track lines. Locations of scarps and mass-wasting deposits identified from the GLORIA images are shown as well as the locations of 3.5-kilohertz and multi-channel seismic profiles shown in figures 4,5 and 6.

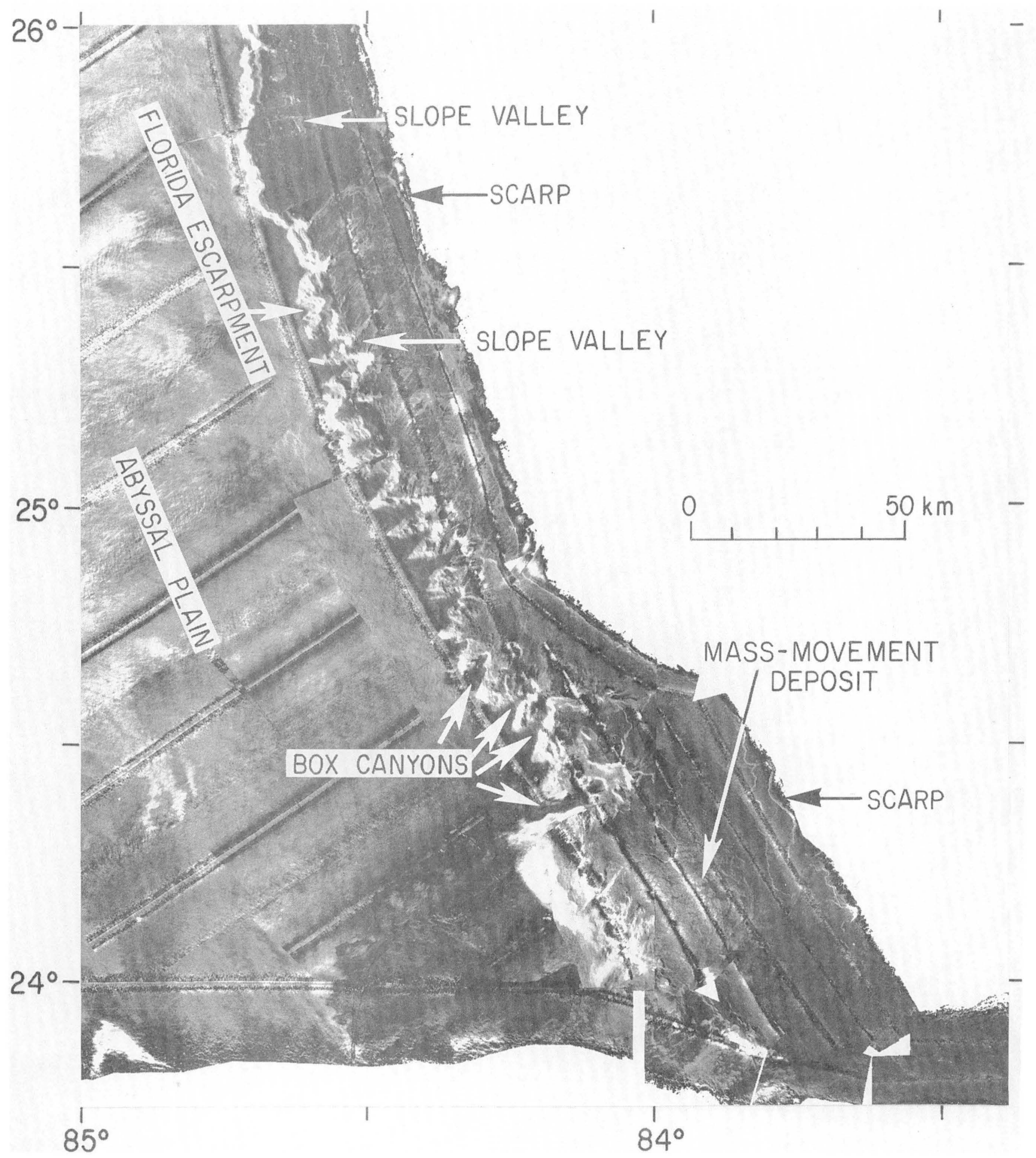

Figure 2. GLORIA sidescan-sonar mosaic showing the precipitous Florida Escarpment, failure scarps on the West Florida Slope, mass-flow valleys of the central part of the study area, and mass-flow deposits of the southern part of the study area. The area shown is the same as that given on figure 1. 

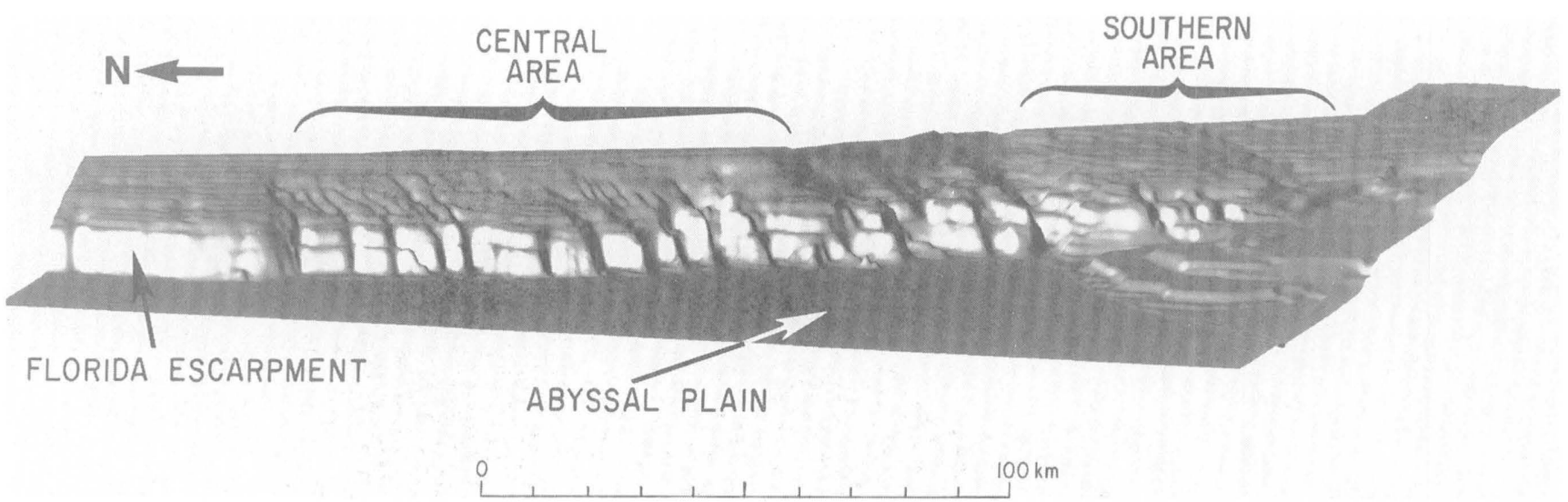

Figure 3. Computer-generated perspective view of the study area showing the high-relief Florida Escarpment, the flat abyssal Gulf of Mexico at the base of the escarpment, and the distribution of valleys on the West Florida Slope above the escarpment.

By contrast, the morphology of the slope failures in the southern part of the study area is different. A series of intersecting scarps, rather than a single one, is seen along the upslope edge of the zone of failed sediment (fig. 1). These scarps have as much as $100-\mathrm{m}$ relief (fig. 6A). Downslope of these scarps, the bathymetry shows few valleys (fig. 1), and the sonar images show irregular patches of high and low backscatter (fig. 2) rather than the linear valley floors seen in the central and northern areas. These irregular patches coincide with an area of rough sea floor on the seismic profiles (fig. $6 C, 6 D$, and $6 E$ ) and are interpreted to be mass- flow deposits derived from the scarps upslope.

Slope failures cover approximately 60 percent of the part of the West Florida Slope under study here. If the shape of the slope prior to failure resembled the sections that have not yet failed, then an average thickness of $150 \mathrm{~m}$ of material has been removed based on the heights of the scarps that bound the failed areas. The volume of sediment removed is in excess of $840 \mathrm{~km}^{3}$. We speculate that upon failure, the poorly cemented material disintegrated and that most of it was transported over the Florida Escarpment and now resides on the abyssal plain along the base of the escarpment. The small amount of mass-flow material that remains on the West Florida Slope forms a thin, rough veneer in the valley floors of the northern and central areas and rough, irregular patches in the southern area.

\section{COMPARISON OF SLOPE FAILURE REGIONS}

Although sediment type (Doyle and Sparks, 1980), shallow stratigraphy, and structure (Shaub, 1984; Doyle and Holmes, 1985) appear to be relatively uniform in the study area, the sidescan sonar results suggest that different parts of the West Florida Slope have been affected by the mass flows in different ways. The headwall scarps in the central area are in 500 to $700 \mathrm{~m}$ of water while the headwall scarps bounding the southern area are in 1,000 to $1,200 \mathrm{~m}$ of water (fig. 1). The regional sea-floor gradient in these two areas differs also. Gradients in the central area exceed $4^{\circ}$, whereas in the southern area, gradients are less than $1^{\circ}$. Box canyons cut the escarpment downslope of the central area, and many of the slope valleys feed into the heads of the box canyons (figs. 3,8 ). These box canyons are absent on the escarpment downslope of the southern area (fig. 1).

Downslope of the scarps in the northern and central areas, the sea floor is dissected by valleys. In the northern area, scarps cutting across the valley floors suggest that several episodes of slope failure were involved in forming the valleys. At the northern end of the central area, discontinuous scarps are dissected by some of the slope valleys. The cutting of these scarps by the slope valleys suggests that at least two stages of slope failure were involved in the development of the central area.

In the southern area, bathymetric, seismic, and sidescan-sonar data indicate that the sea floor downslope of the intersecting scarps is not cut by valleys (fig. 1), but rather it is covered by a layer of mass-flow deposits. The surface of the sea floor is rough, and one of the profiles crossed an individual block $50 \mathrm{~m}$ high and $1 \mathrm{~km}$ wide (fig. $6 C$ ). The cross-cutting relationship of the scarps in the southern area is another example of the multistaged development of the failures on the West Florida Slope (fig. 7). The shallowest scarp is interpreted to be the oldest (because it is truncated by scarps that extend into deeper water); younger failures occur in progressively deeper water. The youngest scarps (stage 4) cut into the mass-flow deposits derived from the older scarps farther upslope. Thus, although individual scarps have only 30 to $100 \mathrm{~m}$ of relief, the total relief of the scarps created by the failures of stages 1 to 3 is as much as $200 \mathrm{~m}$ (fig. 6A). There may have been additional episodes of slope failure, but evidence of these events has been masked by more recent failures. 


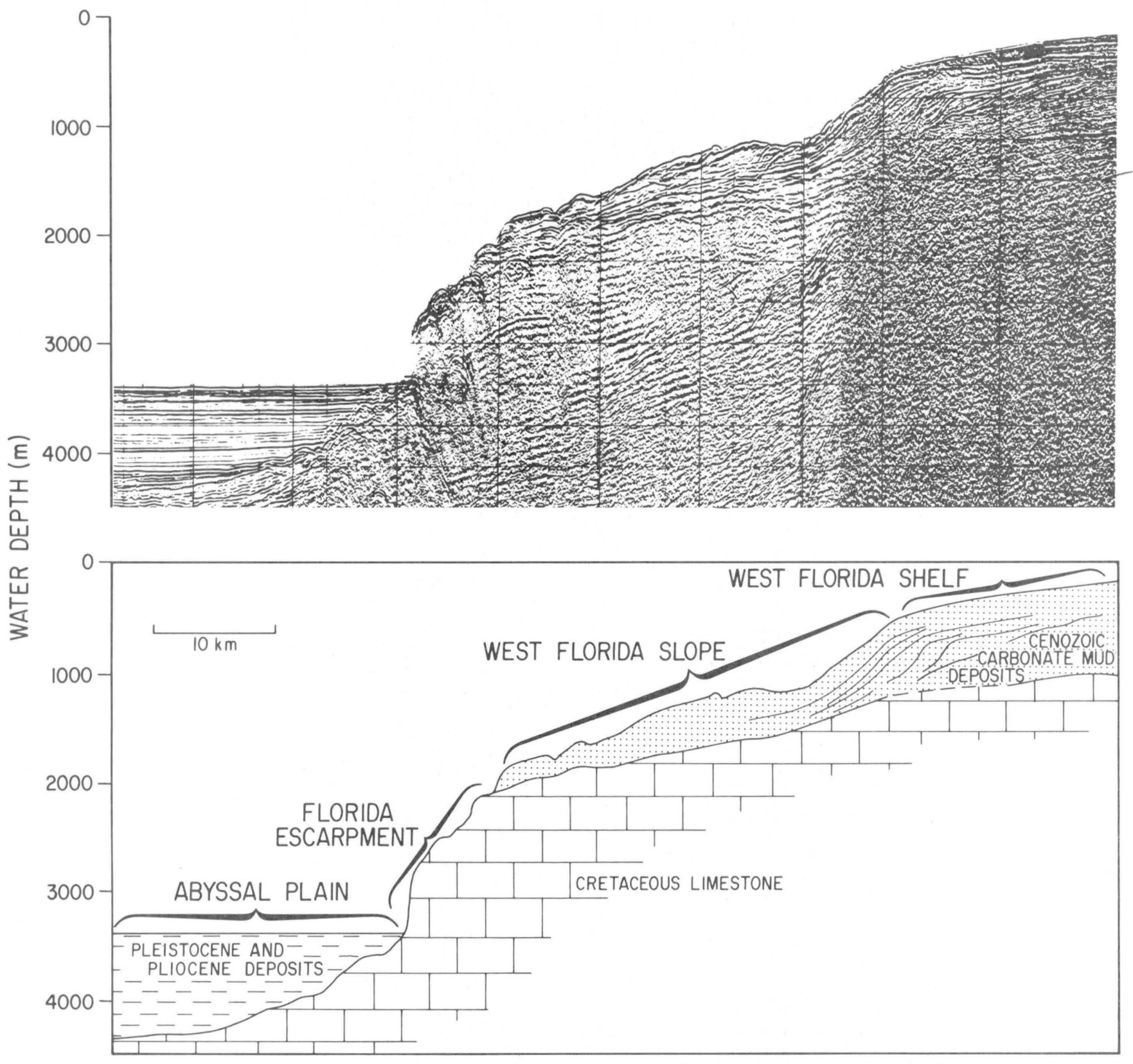

Figure 4. Multichannel seismic-reflection profile across the West Florida Slope and Escarpment (Institute of Geophysics of the University of Texas at Austin). Location of this profile is shown in figure 1 . Note the sequence of

prograding reflectors underlying the West Florida Slope (part of which has been removed by mass wasting) and the steep Florida Escarpment. Vertical exaggeration is about $10 \times$.

\section{POTENTIAL GEOLOGICAL HAZARDS}

Causes of the sediment failures on the West Florida Slope cannot be derived from these data, but some inferences about the triggering mechanisms can be made. Storm waves, a common triggering mechanism of slope failures in shallow water (Lee and Edwards, 1986; Lee, Schwab, and Booth, this report), probably did not contribute to the initiation of these failures because of the great water depths in which they occur. Even during periods of glaciation,

when sea level was as much as $200 \mathrm{~m}$ lower than now, these scarps would have been in at least $300 \mathrm{~m}$ of water, below the effect of storm waves. Earthquakes are an important triggering mechanism in tectonically active areas (Lee and Edwards, 1986), but in areas such as the Gulf of Mexico where the occurrence of earthquakes is infrequent, their importance has not been documented. If earthquakes were the triggering mechanism, the multistaged development of these failures suggests that several earthquakes rather than just one would have been needed. Another alternative is that 


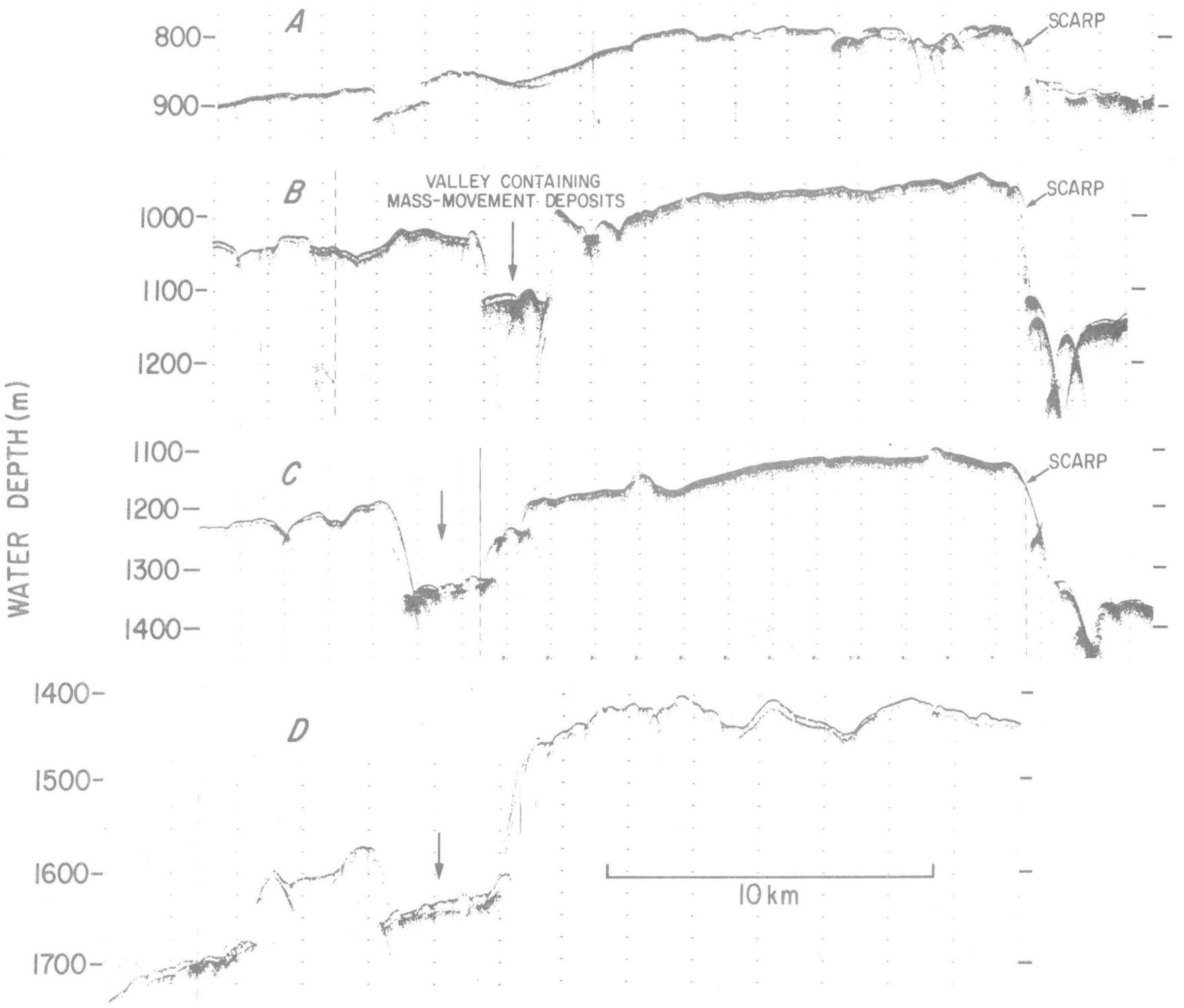

Figure 5. A series of 3.5-kilohertz seismic-reflection profiles from the northern part of the study area. Profile locations are shown in figure 1. In the left part of all four profiles is the flat-floored valley shown on the GLORIA image. The sidewalls of this valley have 50 to 150 meters of relief. The floor is covered by an acoustically transparent

local oversteepening resulted from physical erosion by the Loop Current which sweeps over this area or chemical dissolution of the carbonate rocks by acidic bottom waters or pore waters. Measurements of the strength of bottom currents and the chemistry of the bottom waters and pore waters do not exist for this area and will need to be measured before these alternatives can be considered.

The differences in the morphological expression of the slope failures in the southern and central areas may be a consequence of differences in the sea-floor gradient and layer that has a hummocky surface and is interpreted to be a mass flow deposit. The southern ends of profiles $A, B$, and $C$ cross the scarp that marks the northern limit of the central mass wasting area. Vertical exaggeration is about $25 \times$.

perhaps differences in sediment age and composition. Following slope failure, the sediment disintegrated and flowed. Although disintegrative failure occurred in both areas, the potential for flow mobilization was probably higher for the more steeply sloping northern and central areas than for the southern area. The mass flows would have more readily carved the sea floor and become more channelized. Alternatively, the scarps and slope valleys of the central area may represent two different styles and episodes of slope failure. The initial failures may have been like 

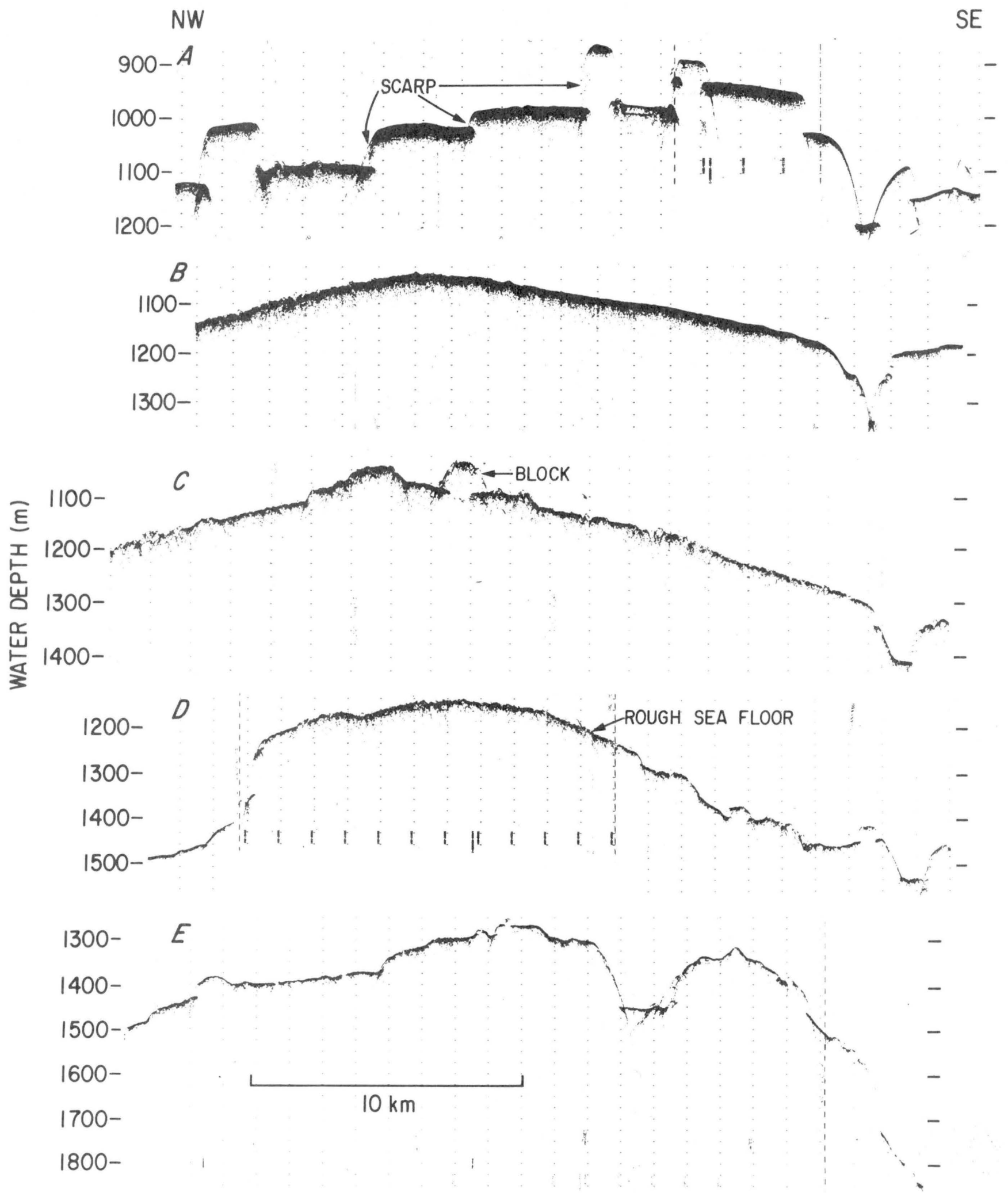

Figure 6. A series of 3.5-kilohertz seismic-reflection profiles across part of the southern mass-wasting area. Profile $A$ crosses the head-wall scarps of some of these slope failures. Profile locations are shown in figure 1. Profiles $B, C, D$, and $E$ show the hummocky surface of the mass-flow deposit downslope of the scarps. Most of the blocks in this deposit are too small to be individually resolved on these profiles or on the GLORIA image (fig. 2 ), but a large block ( $50 \mathrm{~m}$ high and $1 \mathrm{~km}$ wide) is shown on profile C. Vertical exaggeration is about $25 \times$. 

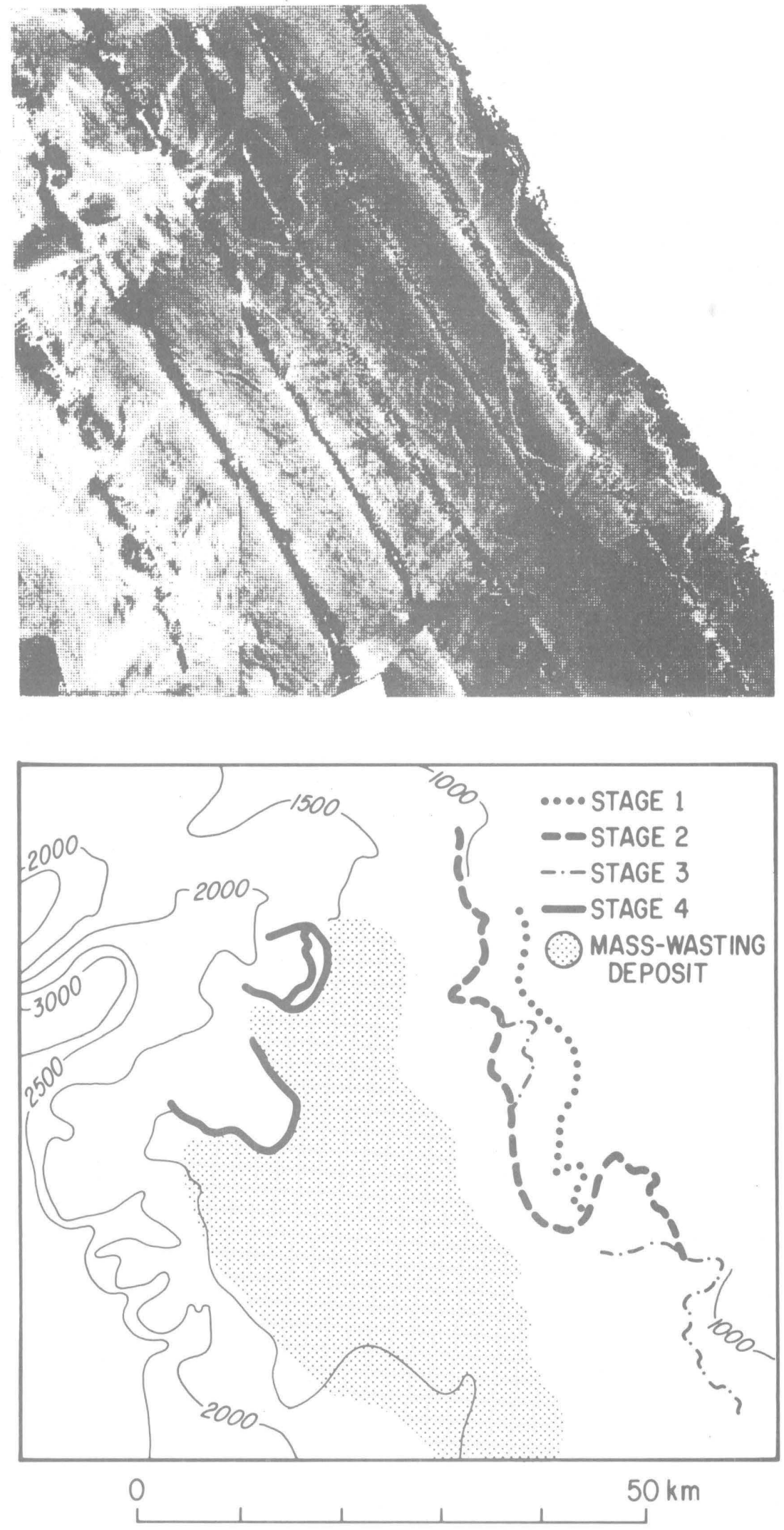

Figure 7. Summary interpretation of the multistaged evolution of the mass flows in the southern area based on the cross-cutting relationships of scarps revealed by the GLORIA images. The headwall of the oldest failure is farthest upslope, and younger scarps are progressively farther downslope. The youngest, stage 4, appears to cut the mass-flow deposits that originated further upslope. 


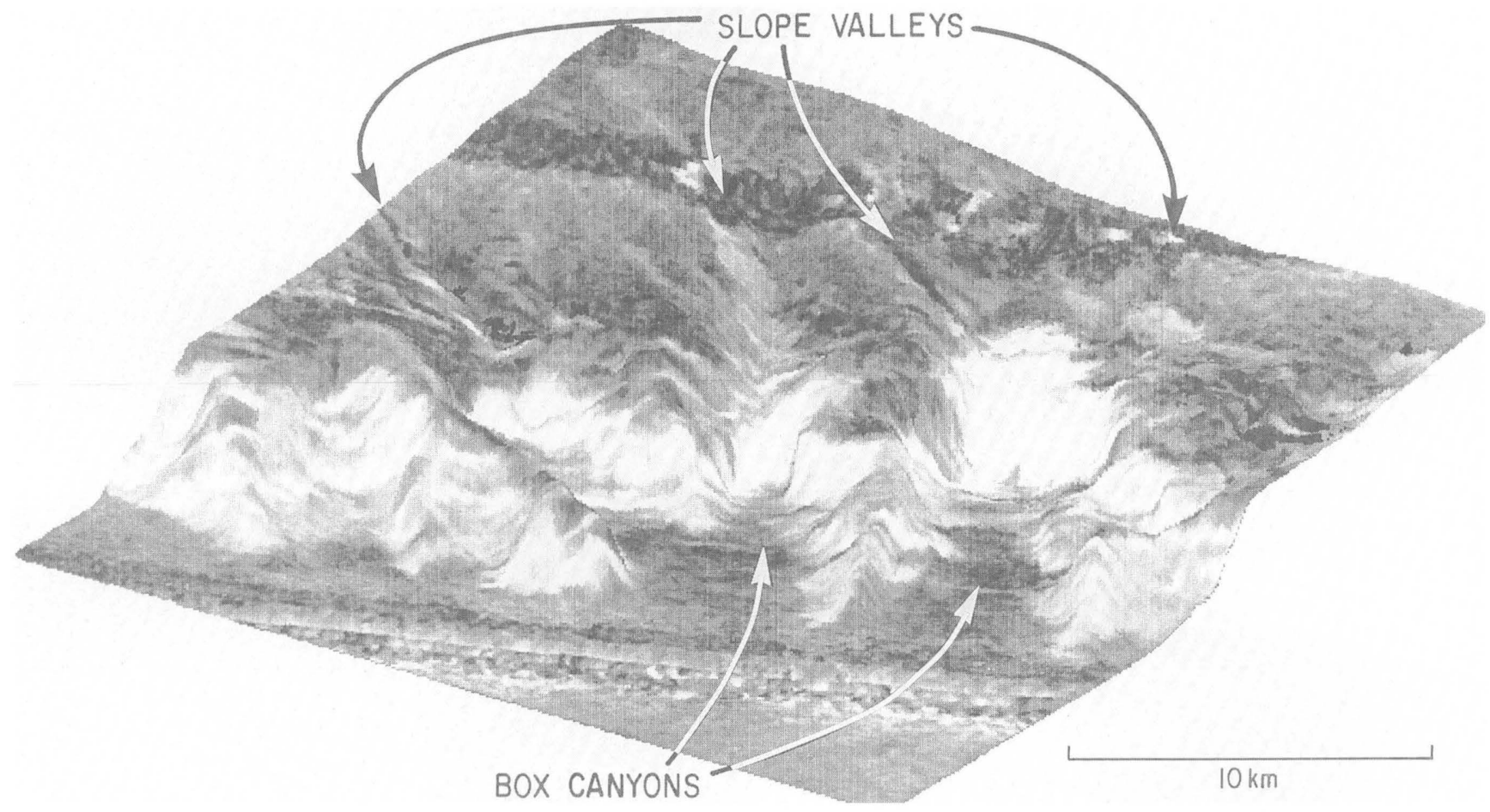

Figure 8. Perspective view of a part of the GLORIA mosaic showing the convergence of the mass-flow valleys of the central failure area on the heads of the box canyons that incise the Florida Escarpment. The convergence of these valleys on the heads of the box canyons may suggest that the valleys are the result of headward erosion that was initiated by erosion of the heads of the box canyons. those in the southern area and created the linear scarps along the eastern edge of the study area. Subsequently, these scarps could have been incised by slope valleys that formed by retrogressive failure.

The extent of the mass wasting on the West Florida Slope indicates that these carbonate sediments can become unstable on very gentle gradients in response to environmental conditions that have existed in the eastern Gulf of Mexico. From a practical point of view, if these slope failures continue to be active, they will be a hazard to petroleum exploration and related development of this area. Geologically, they are of interest because the morphology and failure mechanisms of carbonate sediments are poorly understood (Lee, 1985). This advance in our knowledge of carbonate sediment failure was made possible by our ability to depict large areas of the sea floor with sidescan-sonar imagery.

\section{ACKNOWLEDGMENTS}

Reviews by W.C. Schwab and K. Scanlon considerably improved an earlier version of this manuscript. Drafting and photography for the figures were done by $\mathrm{J}$. Zwinakis and D. Blackwood.

\section{REFERENCES CITED}

Chavez, P.S., 1984, U.S. Geological Survey mini image processing system (MIPS): U.S. Geological Survey Open-File Report 84-880, 12 p.

1986, Processing techniques for digital sonar images from GLORIA: Photogrammetric Engineering and Remote Sensing, v. 52, p. 1133-1145.

Doyle, L.J., and Holmes, C.W., 1985, Shallow structure, stratigraphy, and carbonate sedimentary processes of West Florida Upper Continental Slope: American Association of Petroleum Geologists Bulletin, v. 69, p. 1133-1144.

Doyle, L.J., and Sparks, T.N., 1980, Sediments of Mississippi, Alabama, and Florida (MAFLA) continental shelf: Journal of Sedimentary Petrology, v. 50, p. 905-916.

EEZ-SCAN 85 Scientific Staff, 1987, Atlas of the U.S. Exclusive Economic Zone, Gulf of Mexico: U.S. Geological Survey Miscellaneous Investigation Series I-1864-A, 104 p.

Freeman-Lynde, R.P., 1983, Cretaceous and Tertiary samples dredged from the Florida Escarpment, eastern Gulf of Mexico: Transactions-Gulf Coast Association of Geological Societies, v. 33, p. 91-99.

Holmes, C.W., 1985, Accretion of the South Florida Platform, Late Quaternary development: American Association of Petroleum Geologists Bulletin, v. 69, p. 149-160.

Lee, H.J., 1985, State of the art: Laboratory determination of the strength of marine soils, in Chaney, R.C., and Demars, 
K.R., eds., Strength Testing of Marine Sediment: Laboratory and In Situ Measurements, ASTM, STP 883: American Society for Testing and Materials, Philadelphia, p. 181-250.

Lee, H.J., and Edwards, B.D., 1986, Regional method to assess offshore slope stability: Journal of Geotechnical Engineering, American Society of Civil Engineers, v. 112, p. 489-509.

Mitchum, R.M., 1978, Seismic stratigraphic investigation of West Florida Slope, Gulf of Mexico, in Bouma, A.H., Moore, G.T., and Coleman, J.M., eds., Framework, Facies, and Oil-trapping characteristics of the upper Continental Margin: American Association of Petroleum Geologists Studies in Geology 7, p. 193-223.

Mullins, H.T., Gardulski, A.F., Hinchey, E.J., and Hine, A.C., 1988, The modern carbonate ramp slope of central West Florida: Journal of Sedimentary Petrology, v. 58, p. 273-290.
Mullins, H.T., Gardulski, A.F., and Hine, A.C., 1986, Catastrophic collapse of the west Florida carbonate platform margin: Geology, v. 14, p. 167-170.

Paull, C.K., Freeman-Lynde, R.P., Bralower, T.J., Gardemal, J.M., Neumann, A.C., D'Argenio, B.P., and Marsella, E.A., 1990, Geology of the strata exposed on the Florida Escarpment: Marine Geology, v. 91, p. 177-194.

Shaub, F.J., 1984, The internal framework of the southwestern Florida bank: Transactions-Gulf Coast Association of Geological Societies, v. 34, p. 237-245.

Somers, M.L., Carson, R.M., Revie, J.A., Edge, R.H., Barrow, B.J., and Andrews, A.G., 1978, GLORIA II-An improved long-range sidescan sonar, in' Proceedings, IEEE/IERE subconference on Offshore Instrumentation and Communications, Oceanology International, 1978, Technical Session J: London, BPS Publications, p. 16-24. 


\title{
Slope Failures in an Area of High Sedimentation Rate: Offshore Mississippi River Delta
}

\author{
By J.M. Coleman ${ }^{1}$, D.B. Prior ${ }^{2}$, L.E. Garrison ${ }^{3}$, and H.J. Lee
}

\section{INTRODUCTION}

Large sediment-laden rivers debouching onto the continental shelf rapidly build sedimentary bodies that can be highly susceptible to slope failure (submarine landsliding). Within the offshore waters of the United States, the deltaic sediment placed by the Mississippi River is the best example of such an unstable body. It has received extensive attention from both industry and the academic community because of the presence of major offshore oil resources and the massive scale area of submarine slope failure. The destruction of one offshore platform and the damaging of two others by submarine landslides during Hurricane Camille in 1969 (Sterling and Strohbeck, 1973; Bea and others, 1975) demonstrates the practical importance of understanding slope-failure mechanisms.

After Hurricane Camille, considerable research on the offshore part of the Mississippi Delta was initiated by the petroleum industry, consulting firms, governmental agencies, and universities, including a cooperative study involving the U.S. Geological Survey (USGS); the Coastal Studies Institute, Louisiana State University (LSU); and Texas A\&M University. The focus of this cooperative project was to (1) establish the regional geologic framework of the delta, (2) map the distribution and describe the variety of types of submarine slope instabilities, (3) characterize the sediment properties and their behavior under various stresses, and (4) determine the mechanisms responsible for the submarine slope failures. This section describes the results of part of this project. Specifically, it describes the extent and morphology of slope failures in the area, includes quantitative information on the rates and styles of movement, and explores the causes of the failures.

\section{MISSISSIPPI RIVER DELTA SETTING}

The Mississippi, the largest river system in North America, drains an area of 3.4 million square kilometers $\left(\mathrm{km}^{2}\right)$ or over 40 percent of the area of the coterminous United States. Average water discharge of the river at its delta is 15,400 cubic meters per second $\left(\mathrm{m}^{3} / \mathrm{sec}\right)$, and can be as high as $59,500 \mathrm{~m}^{3} / \mathrm{sec}$; the annual sediment discharge

\footnotetext{
' Louisiana State University, Baton Rouge, La.

${ }^{2}$ Geological Survey of Canada, Dartmouth, Nova Scotia, Canada. Tex.
}

is estimated at 210 to 680 million tons (Coleman and others, 1980; Milliman and Meade, 1983). The bedload consists of 90 percent fine sand, and the suspended load is characterized by 65 percent clay and 35 percent silt and very fine sand. Thus, the Mississippi River carries a substantial sediment load annually, a high percentage of which consists of fine-grained clay and silt transported as suspended load. The coarser material is deposited at or near the distributary mouths of the modern subaerial delta. The modern bird-foot delta is the youngest of the delta lobes of the Mississippi River; radiocarbon dates indicate that it formed within the past 600 to 800 years (Fisk and others, 1954). The average thickness of this delta lobe is 90 to 105 meters (m); seaward progradation rates of the distributary mouths vary from 50 to $100 \mathrm{~m}$ per year. The fine-grained sediment remains in suspension and spreads laterally; often as a visible plume, far beyond the immediate mouths of the distributaries. Sedimentation rates seaward of the distributaries are extremely high, averaging 0.6 to $1.2 \mathrm{~m}$ per year. In adjacent interdistributary bays, accumulation rates rarely exceed a few centimeters $(\mathrm{cm})$ per year, and in some places, the bay bottom is being eroded (Coleman and others, 1980).

Deposition of the fine-grained sediment builds a platform fronting the bird-foot delta that consists of rapidly deposited clay which has an extremely high water content and, because of abundant fine-grained organic matter, includes large concentrations of gases (primarily methane and carbon dioxide). Rapid deposition does not allow pore fluids to migrate through the low permeability clays and silts, and thus, the pore fluids remain trapped. As sediment accumulates, loading increases, and the pore fluids bear the weight of the overlying load; consequently, pore-fluid pressures increase to high levels. In-place measurements in shallowly buried delta sediment (less than $25 \mathrm{~m}$ beneath the sea floor) show pore-fluid pressures exceeding the pressure that would be produced by the weight of overlying water (hydrostatic pressure), and some pore pressures approach the pressure that would be produced by the weight of both overlying water and overlying sediment (geostatic pressure). Such a condition of elevated pore fluid pressures is termed underconsolidation.

Offshore of the Mississippi River Delta, the sea floor is nearly flat. Slopes of the delta-front rarely exceed $1.5^{\circ}$; and in the interdistributary bays, bottom slopes are generally less than $0.5^{\circ}$ and are rarely greater than $0.2^{\circ}$. At the shelf break, which generally is in water depths of 150 to 200 $\mathrm{m}$, the slopes increase slightly, averaging $1.7^{\circ}$ to $2.2^{\circ}$. In 
general, the bottom is characterized by many radial submarine gullies in water 10 to $75 \mathrm{~m}$ deep and by broad, flat terraces seaward to water depths as great as $180 \mathrm{~m}$. These submarine gullies were first described and illustrated from the Mississippi Delta by Shepard (1955). At the shelf edge and on the upper continental slope, abrupt scarps occur on the sea floor; some localized scarps are as high as $45 \mathrm{~m}$ with slopes that approach $2.5^{\circ}$ to $3.0^{\circ}$.

The major characteristics of the Mississippi River Delta and of its continental shelf influence the stability of marine sediment. These characteristics include (1) high rates of sedimentation, which result in excessive sedimentary loading; (2) deposition of dense sand and silt over weak clay, causing differential loading of the underlying sediment; (3):high water contents, generally low strengths, and underconsolidation of the deltaic deposits; (4) biochemical degradation of organic material in the deposits, which results in formation of large quantities of gases in the sediment; and (5) annual passage of winter storms or hurricanes, which result in cyclic wave-loading processes. Notably, the sea-floor slopes are very gentle.

\section{TYPES AND SOURCES OF DATA}

Maps depicting various aspects of the near-surface marine geology of a part of the delta region were prepared from high-resolution geophysical and sidescan-sonar surveys, which were supplemented by many bottom samples and sediment borings (location of study area in fig. 1; see Coleman and others, 1980, for a complete set of the maps). Most of the geophysical surveys used high-frequency (110 kilohertz (kHz)) acoustic sources for bathymetry, 3.5 to 12 $\mathrm{kHz}$ sources for near-surface (less than $60 \mathrm{~m}$ ) subbottom penetration, and lower frequency (50 to $100 \mathrm{kHz}$ ) sparkers or other acoustic sources for deeper-subsurface penetration (generally on the order of 150-250 m). Sidescan-sonar data were acquired with both standard analog systems and a digital system. Digital data were processed for corrections of ship speed and slant range; conventional sidescan-sonar data were distorted in both ship speed and slant range, and manual corrections were applied to these data.

\section{MEASURED CHANGES IN BATHYMETRY}

Sediment-accumulation rates are an important aspect of interpreting the frequency of sediment mass movements; and the delta region, because of the importance of navigation at the mouths of Southwest and South passes, has been the subject of many bathymetric surveys. Although many maps are available, only a few cover the entire region offshore of the Mississippi River Delta. Three accurate bathymetric charts have been prepared from data obtained in 1872 to 1874,1940 , and 1977 to 1979 (Coleman and others, 1980).
Data extracted from these maps can be used to draw regional cross sections that show the magnitude of mass movement that has taken place during a relatively short time. Figure 2 illustrates two such cross sections off South Pass, Mississippi River Delta. In profile $A-A^{\prime}$, large amounts of sediment can be seen to have accumulated between 1872 and 1979 in water depths of 90 to $180 \mathrm{~m}$. The accumulation of such large quantities of sediment in these water depths cannot be explained by settlement out of the water column and, thus, probably represents deposition by submarine mass movement. In profile $A-A^{\prime}$ off South Pass, some $30 \mathrm{~m}$ of sediment has accumulated in $120 \mathrm{~m}$ of water during the 100-year span. In addition, the shelf-edge break in slope has built seaward or prograded some $2.5 \mathrm{~km}$.

Profile $B-B^{\prime}$ (fig. 2), which is west of South Pass, shows still another type of phenomenon revealed by comparisons of the historic maps. Prior to 1874, a large mass of sediment, some $33 \mathrm{~m}$ thick, accumulated in water depths of 90 to $120 \mathrm{~m}$. During the period 1872 to 1940 , either current erosion or, more likely, slope failure resulted in removal of this sediment. If the removal was by slope failure, a large volume of sediment probably moved "en masse" well beyond the shelf-edge break before 1940. Deeper water surveys are not available to confirm this interpretation. Since 1940, sediment has again begun to accumulate in these water depths by mass-movement processes.

Even more specific information on accumulation rates can be obtained in those few areas that have been mapped more frequently. Figure 3 illustrates such examples in South Pass Block 30. On the earliest map (1875), points of reference were chosen, in a topographic gully and on an adjacent ridge. When these points are then transferred to each subsequent map, a profile can be drawn that shows how the water depths have changed with time: Two examples are shown (fig. 3). Water-depth changes on the ridges indicate nearly continuous shoaling or accumulation with time. The average rate is approximately $0.6 \mathrm{~m}$ per year. In the gullies, however, periods of rapid infilling were followed by periods of sediment loss. Accumulation rates were as much as $5 \mathrm{~m}$ per year. Usually the sediment loss takes place in less than a year's time. This episodic infilling and excavation of the gullies indicates the frequency of mass-movement processes. Comparison of many such sites around the delta indicates that gully evacuation takes place primarily after the gully totally infills and is nearly level with the adjacent ridge. Gully excavation (slope failure) usually follows major floods on the river. Sediment filling the gullies has accumulated extremely rapidly and, therefore, possesses high pore-water pressures and requires little additional stress to cause failure. Accordingly, once a landslide gully forms, it maintains episodic activity for long periods, whereas adjacent ridges maintain stability during the same time interval. 


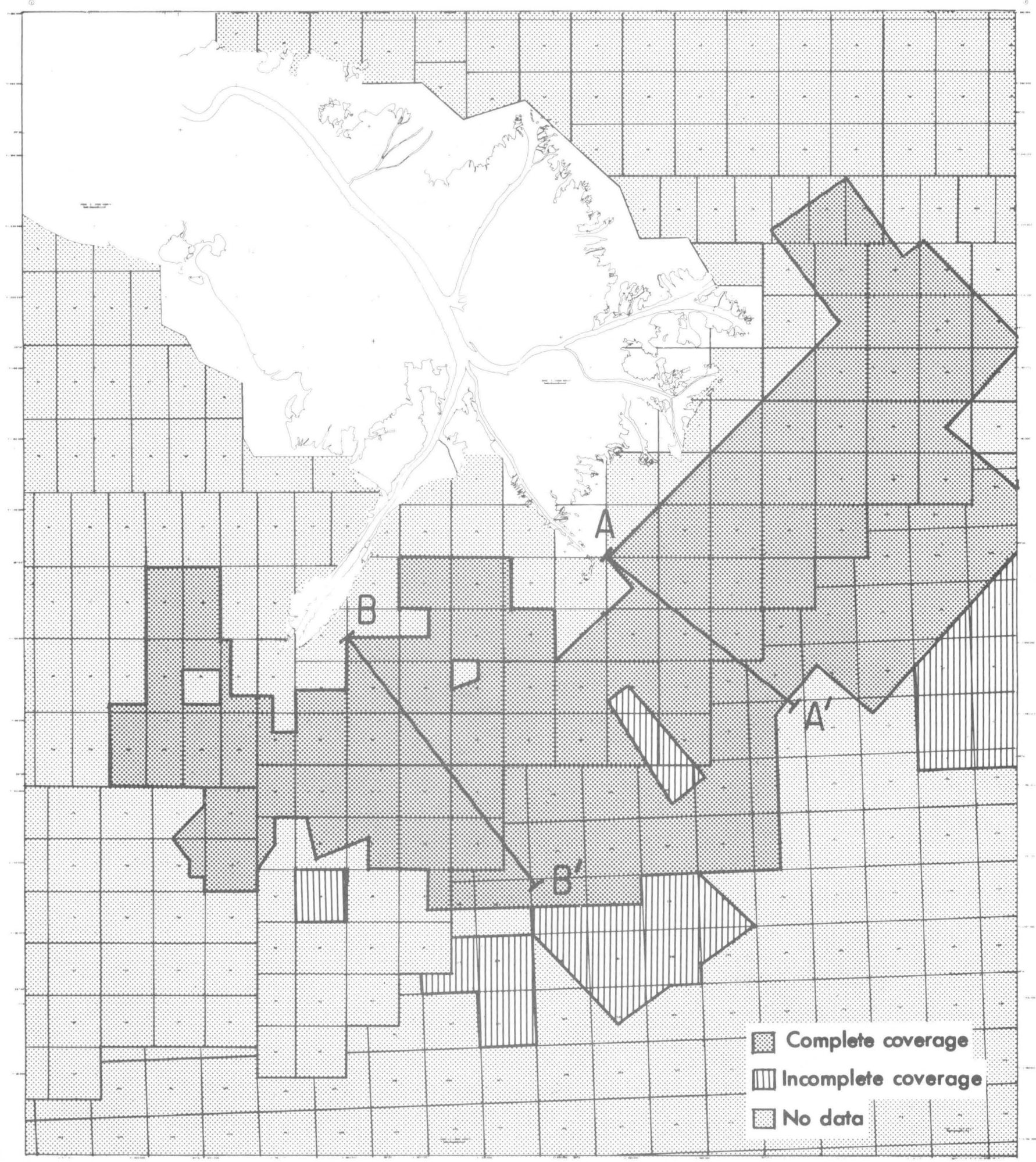

Figure 1. Modern "bird's foot" of the Mississippi River Delta and the extent of the survey area offshore of the delta. "Complete coverage" indicates total overlapping sidescan-sonar imagery areas; "Incomplete coverage" designates areas where survey lines were spaced more than 700 meters apart, requiring considerable interpretation; "No data" indicates those areas having no survey coverage or areas where survey grids were so widely spaced that spatial interpretation was impossible. Profiles $B-B^{\prime}$ and $A-A^{\prime}$ are given in figure 2 . 


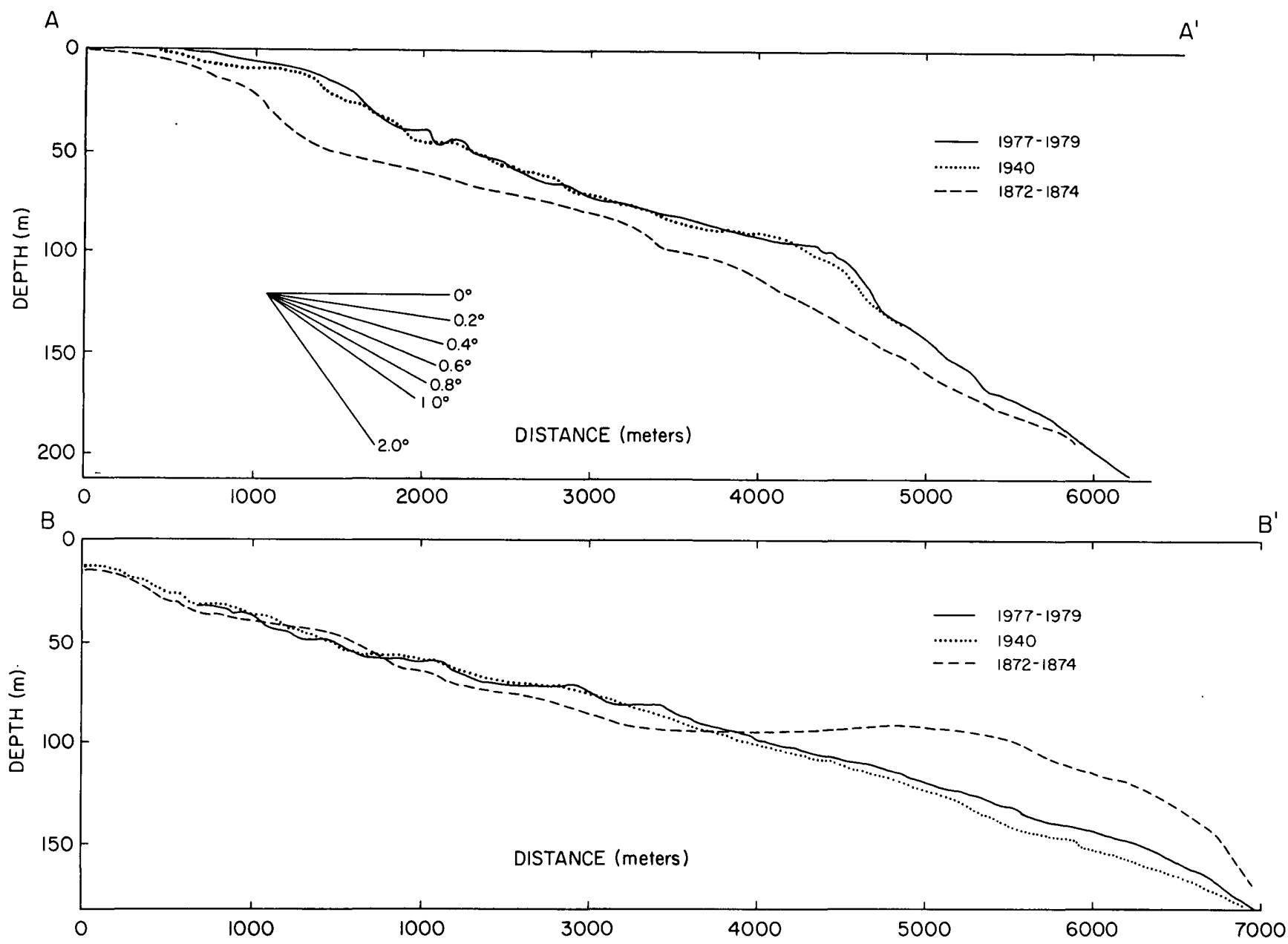

Figure 2. Cross sections showing bathymetric changes between 1872 and 1979. Profile locations shown in figure 1.

\section{SEA-FLOOR MORPHOLOGY}

Sidescan-sonar data obtained from late 1977 through early 1979 show a wide variety of submarine landslide features and other sea-floor irregularities (fig. 4). Because of the dynamic nature of the mass-movement processes, additional changes will undoubtedly take place.

The following principal features are found on sidescan-sonar mosaics:

1. Collapse depressions and bottleneck slides. Collapse depressions and bottleneck slides (a specific type of mudflow illustrated in fig. 5) are present primarily in the shallow-water areas of the interdistributary bays and slightly beyond the bays to water depths of 9 to $15 \mathrm{~m}$. They are most commonly associated with slopes ranging from less than $0.1^{\circ}$ to $0.4^{\circ}$ and show a spectrum from small rounded collapse features on lower slopes to more elongate bottleneck slides on the steeper slopes. In areas where they are most common, sedimentation rates are slower than rates elsewhere in the delta. Collapse depressions range in diameter from $35 \mathrm{~m}$ to more than
$150 \mathrm{~m}$ and have length-to-width ratios of 1.0 to 1.5 . Typically, the depressions are bounded by curved or near-circular scarps as much as $3 \mathrm{~m}$ high, within which the bottom is depressed and filled with irregular blocks or clasts of sediment (fig. 6).

Bottleneck slides (figs. $5 B$ and 6 ) occur on slightly steeper $\left(0.2^{\circ}\right.$ to $\left.0.4^{\circ}\right)$ slopes within the interdistributary regions and on the continental slope. These features are similar morphologically to collapse depressions, but the boundary scarps do not form a totally closed perimeter around the instability. Rather, they have narrow openings at the downslope margin, through which flowing sediment is discharged over surrounding intact sea floor.

2. Peripheral slumps. Downslope movement of large sediment masses commonly begins near the distributary mouths of the river, where bottom slopes range from $0.2^{\circ}$ to $1.0^{\circ}$. In many places, major scarps having distinctive curved or curvilinear plan views scar the sea floor. The scarps range in height from 3 to $6 \mathrm{~m}$ and have local slopes of $1^{\circ}$ to $4^{\circ}$. In many areas, these scarps give the sea floor a stairstepped appearance in profile view 


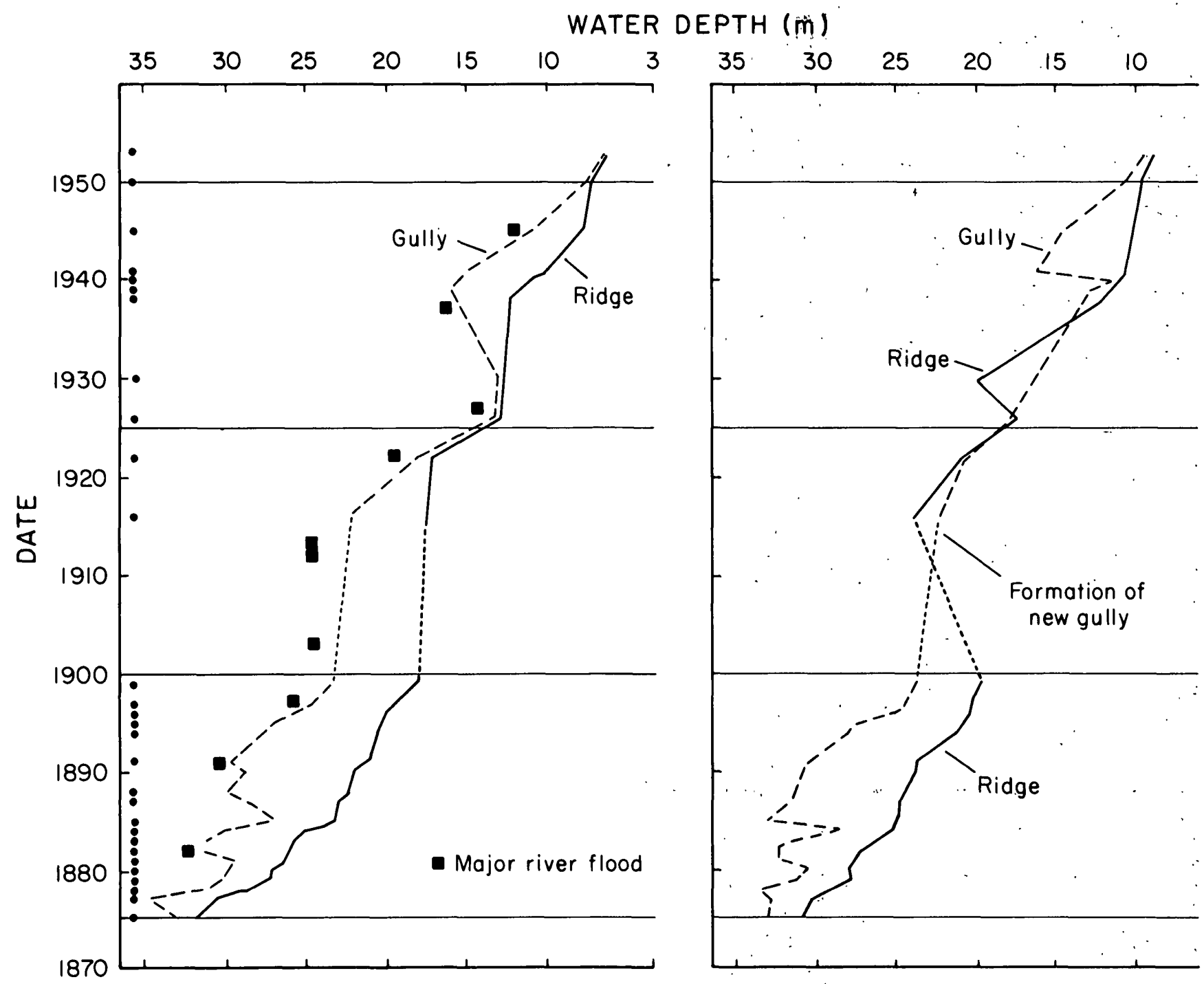

Figure 3. Sediment accumulation in mudflow gullies and adjacent ridges in South Pass Block 30 during the period from 1874 to 1953. A dot at the left-hand margin denotes that a map is available for that period. Squares represent times of major flood.

(figs. $5 C$ and 7). Although movement rates are difficult to document, repeated surveys suggest that blocks can move downslope more than $1.5 \mathrm{~km}$ in a 1-year period.

3. Mudflow gullies. Extending radially seaward from each of the distributaries, in water depths of 6 to $90 \mathrm{~m}$, are major elongate systems of sediment instabilities referred to as mudflow gullies (fig. 5D). Sidescan-sonar records (fig. 8) from an extremely disturbed area of slumped topography high on the submarine delta. Each gully has a clearly recognizable area of rotational instability or slumping at its upslope margin. Mudflow gullies are the most common type of sediment instability fronting the Mississippi River Delta.

Each mudflow gully possesses a long, sinuous, narrow chute or channel that links a depressed, hummocky source area on the upslope margin to composite overlapping depositional mudflow lobes on the seaward end (fig. $5 D$ ). The slopes along the sides of the gullies range from less than $1^{\circ}$ to as high as $19^{\circ}$. Most of the gullies extend downslope approximately at right angles to the depth contours and may be more than $75 \mathrm{~km}$ long. The widths of the individual gullies range from $20 \mathrm{~m}$ to $550 \mathrm{~m}$.

Elongate chutes of this type are similar morphologically to subaerial debris flows and some types of subaerial mudflows. The chutes or channels generally emanate from upslope slump zones and constitute transport conduits for flowing sediment, together with displaced blocks of various sizes.

4. Mudflow lobes..At the seaward or downslope ends of the mudflow gullies, extensive areas of irregular bottom. topography are composed of blocky disturbed sediment. 


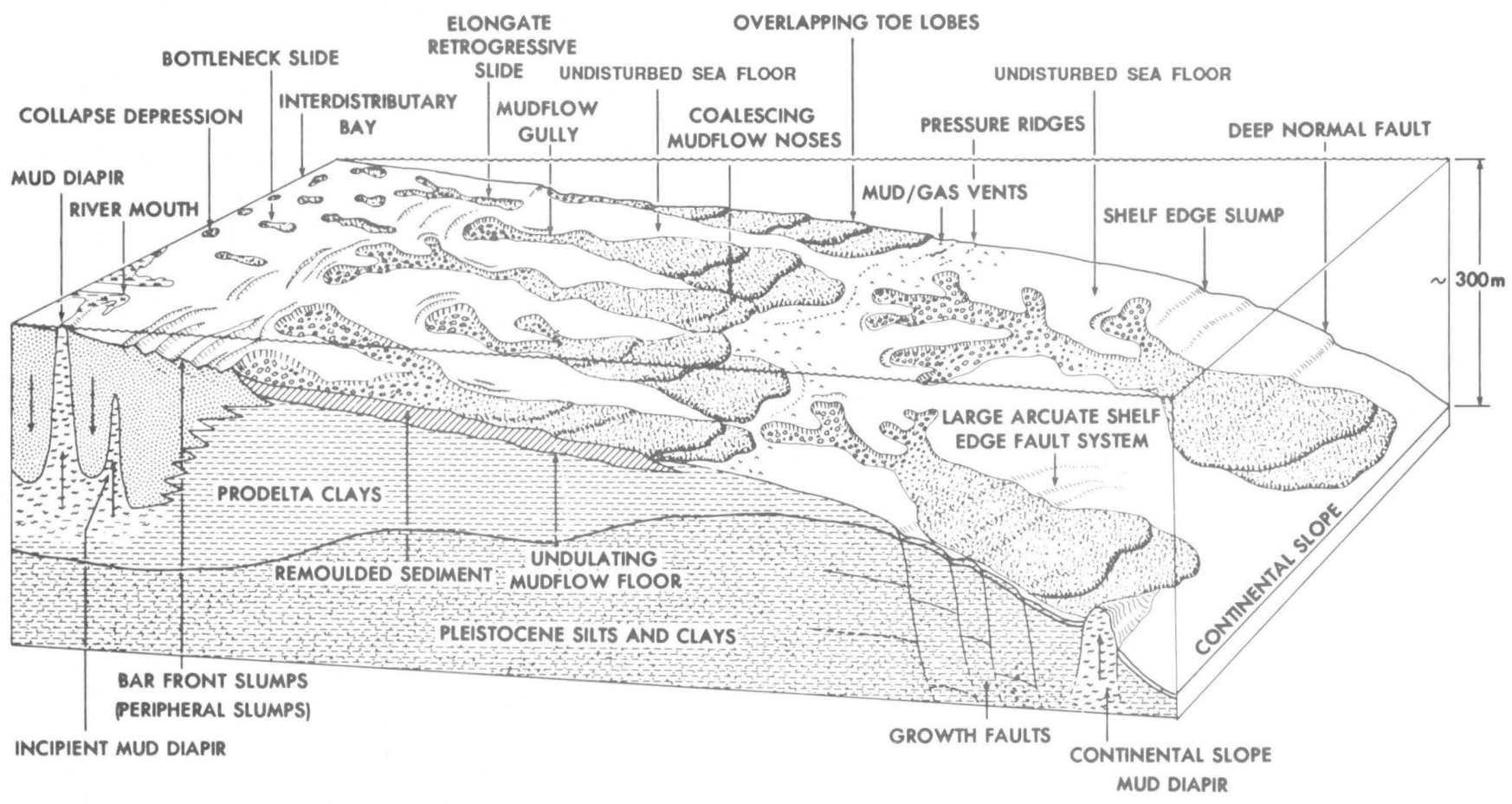

Figure 4. Schematic block diagram showing the relationship of the various types of submarine sediment instabilities.

In plan view, this discharged sediment is arranged into widespread overlapping lobes or fans (fig. 9). Each lobe is composed of two major morphological features: an almost flat or gently inclined surface (less than $0.5^{\circ}$ ) and an abrupt distal slope representing the downslope toe (or seaward limit) of the displaced sediment. The toes range in height from only a few meters to more than $20 \mathrm{~m}$ and have slopes as great as $7^{\circ}$ to $10^{\circ}$. In plan view, the toes are generally curved, and adjacent lobes are separated from one another by reentrants. Because of the large number of gullies that front the present delta of the Mississippi River, the displaced sediment from adjacent gullies may coalesce, providing an almost continuous sinuous frontal toe 25 to $30 \mathrm{~km}$ seaward of the delta. The mudflow lobes advance downslope at varying rates and probably move rapidly but episodically. Although no actual instantaneous rates have been measured, repeated surveys have shown as much as $5 \mathrm{~km}$ per year seaward advance of some mudflows.

\section{CAUSES OF SLOPE FAILURE}

One of the best documented examples of the occurrence of sediment instability in the Mississippi Delta was the failure of bottom-supported structures in South Pass Block 70 associated with the passage of Hurricane Camille in 1969 (Bea, 1971; Sterling and Strohbeck, 1973; Bea and others, 1983). Three of the eight platforms in the area failed; platform "B," in $100 \mathrm{~m}$ of water, fell to the west and moved downslope about $30 \mathrm{~m}$. Investigations included a comparison of bathymetric surveys obtained before and after the hurricane, a detailed sidescan sonar, diving, and underwater TV inspection of the fallen platform "B," and an above-water inspection of several adjacent platforms. The studies showed that waves with heights of 21 to $23 \mathrm{~m}$ occurred near the area accompanied by bottom relief changes of up to $12 \mathrm{~m}$. At the site of platform "B," the sea floor dropped over $1.5 \mathrm{~m}$ (Bea and others, 1983). Major reductions in sediment strength occurred to depths in the sediment of $24 \mathrm{~m}$ (Sterling and Strohbeck, 1973). Consideration of these factors, along with the observation that piles failed in bending, rather than by pullout, led investigators to believe that sediment mass movements were a primary cause of the toppling of platform "B" and major damage to two nearby platforms.

The suggested trigger for these movements is cyclic loading of the sea floor by passing waves (Henkel, 1970). As large waves pass, the crests produce elevated pressure on the sea floor, while the troughs produce lowered pressure. The passage of many waves loads the sea floor cyclically and gradually lowers the strength of the seabed sediment. Ultimately, a combination of intense wave loading, pre-existing low strength owing to underconsolidation and gas charging, and further strength reduction caused by cyclic loading causes the sediment to fail. On these gentle slopes there is a small component of gravitational stress that is directed downslope. A combination of this gravitational stress and the wave-induced stresses causes a part of the sea floor to move downslope. 
A
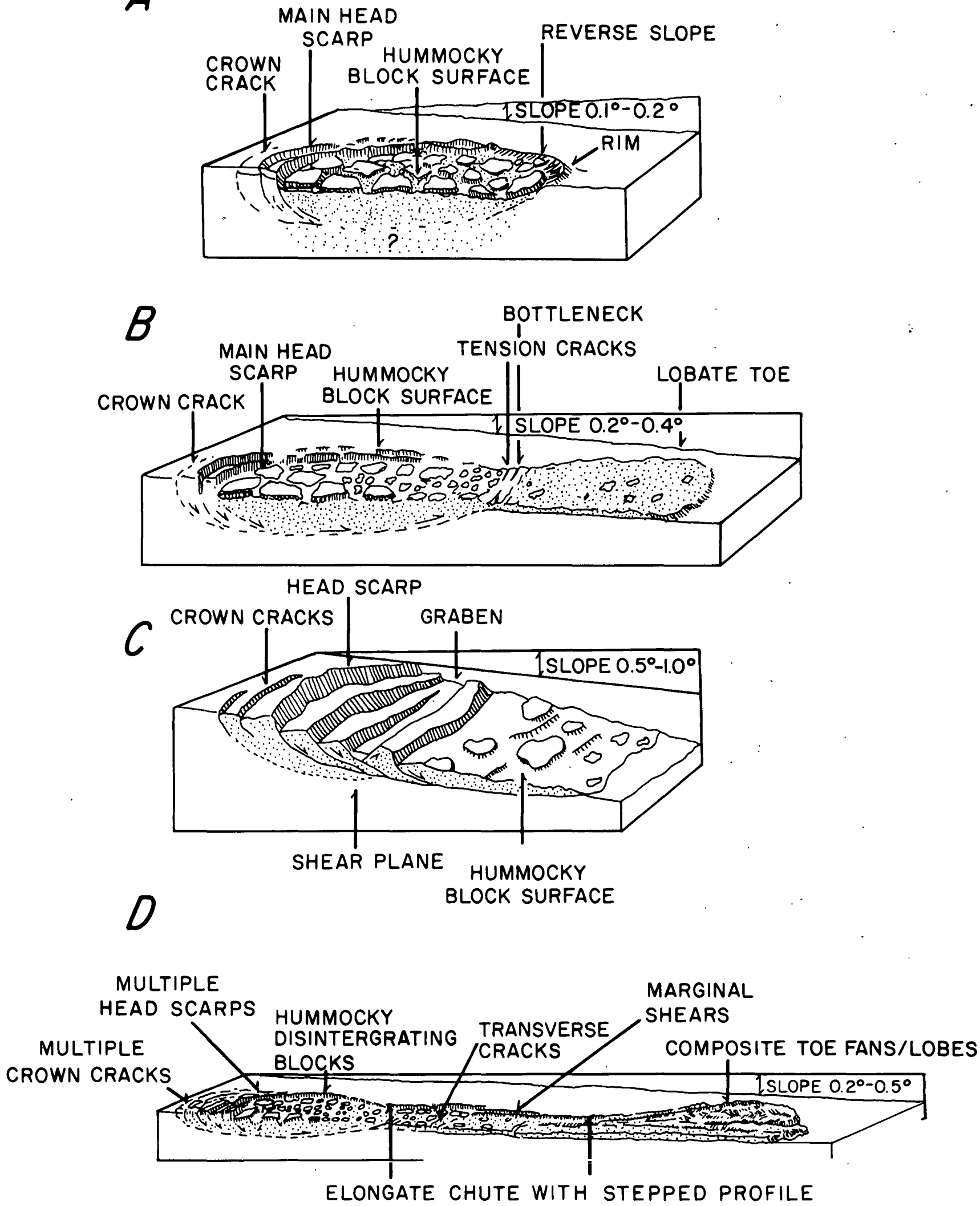

Figure 5. Schematic diagrams illustrating the morphology of $(A)$ collapse depressions, $(B)$ bottleneck slides, $(C)$ peripheral slumps, and $(D)$ mudflow gullies and depositional mudflow lobes. 


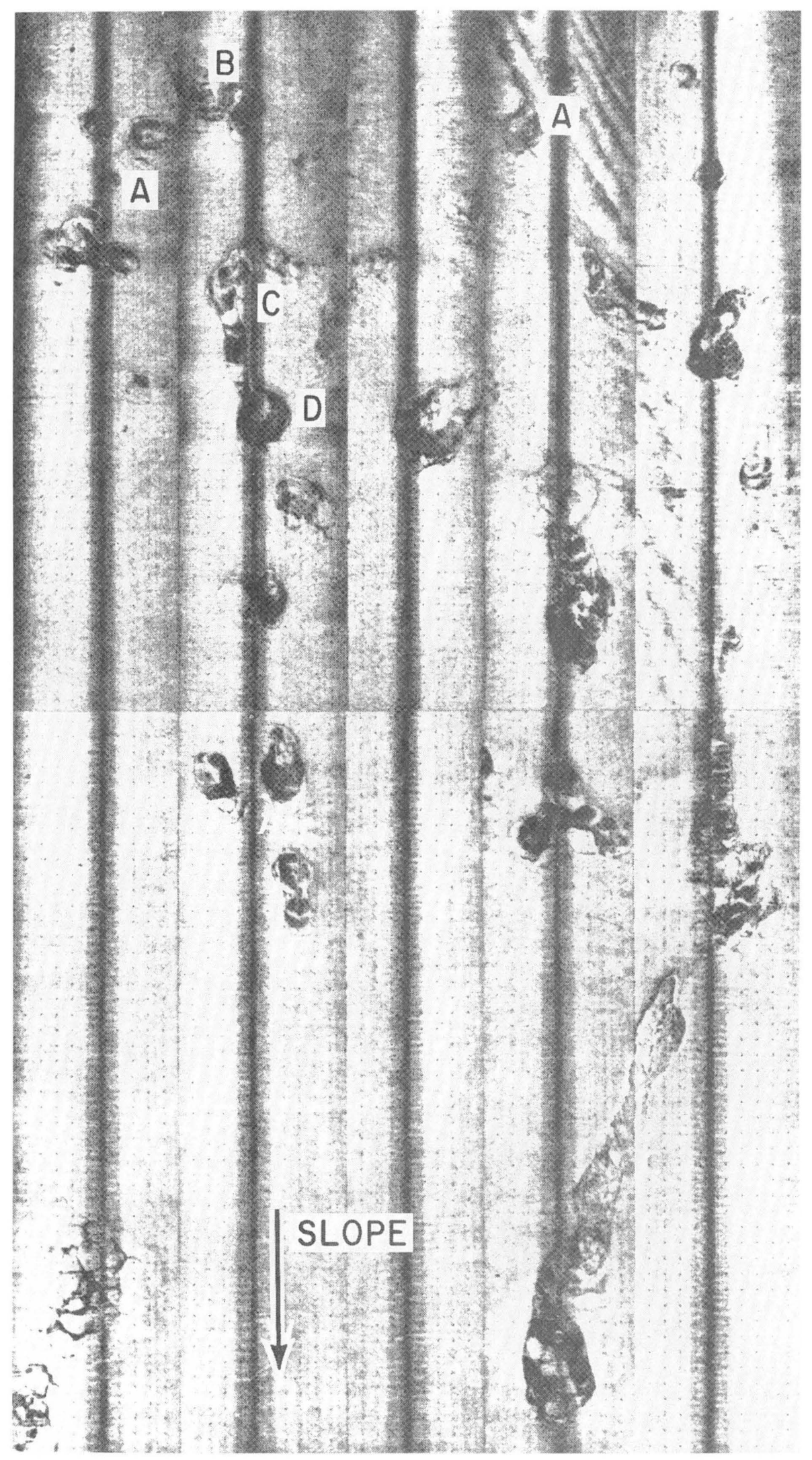

Figure 6. Sidescan-sonar mosaic, illustrating several collapse depressions and a bottleneck slide. The grids are 25 meters apart and the mosaic covers a region of $1.3 \times 2.2$ kilometers. (A) collapse depressions; (B) crown cracks; (C) bottleneck slide; (D) depositional lobe of bottleneck slide. 


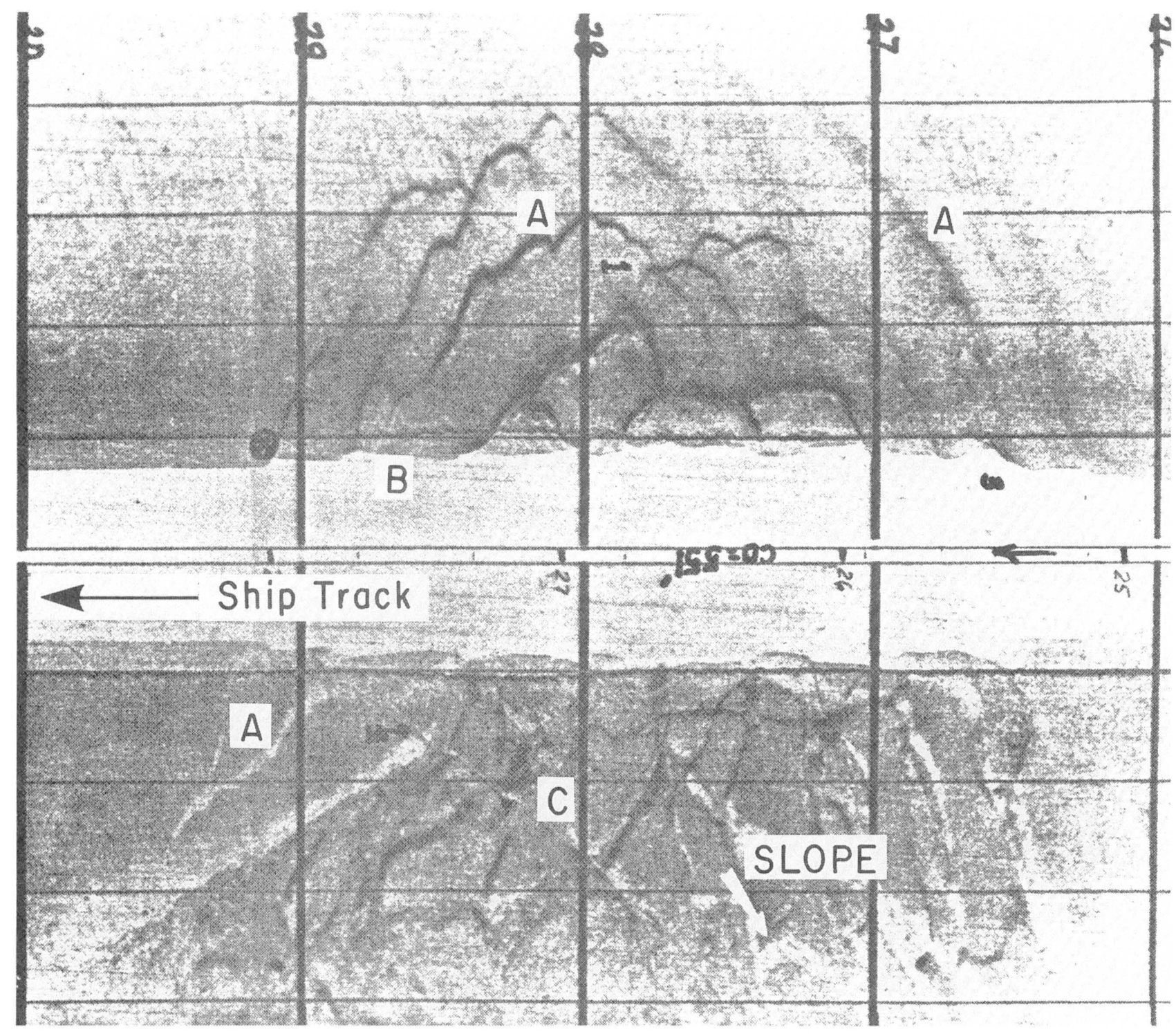

Figure 7. Conventional sidescan-sonar record, showing several slumps. Navigational fixes are 152 meters apart, and lateral timing lines are 25 meters apart. (A) shear planes showing up as scarps on the sea floor; (B) rotated block; (C) shrimp trawler's drag mark.

There is also evidence that collapse depressions, bottleneck slides, and mudflow gullies have been active when there were no hurricanes (Prior and others, 1979). In particular, the creation of new mudflow gullies frequently accompanies major flood and sediment discharges from the Mississippi River. In the South Pass area, 15 new chutes followed the 1922 flood, 7 in 1927, and 10 were observed after the 1945 flood. Recent annual surveys have also shown large mudflow lobe advances; in the period 1975 to 1976 , the toe of one lobe advanced a distance of $1.9 \mathrm{~km}$ (Prior and Coleman, 1978). Repeated annual sidescan-sonar mapping since 1974 of particular chute areas has also shown bottom sediment changes associated with instability. Feature enlargement, offset of anchor scars and trawler drag marks on the bottom, as well as comparisons of identifiable blocks of sediment, indicate rates of movement up to $100 \mathrm{~m}$ per year (Coleman and Garrison, 1977).

\section{SUMMARY}

Owing to high sedimentation rates, fine grain-size, and abundance of organic matter and gas, sediment deposited on the sea floor offshore of the Mississippi River Delta is extremely underconsolidated. Although the bottom slopes are very gentle, ranging from less than $0.5^{\circ}$ to somewhat over $2^{\circ}$ beyond the shelf-edge break, the occurrence of sediment instability features is widespread. In some sec- 


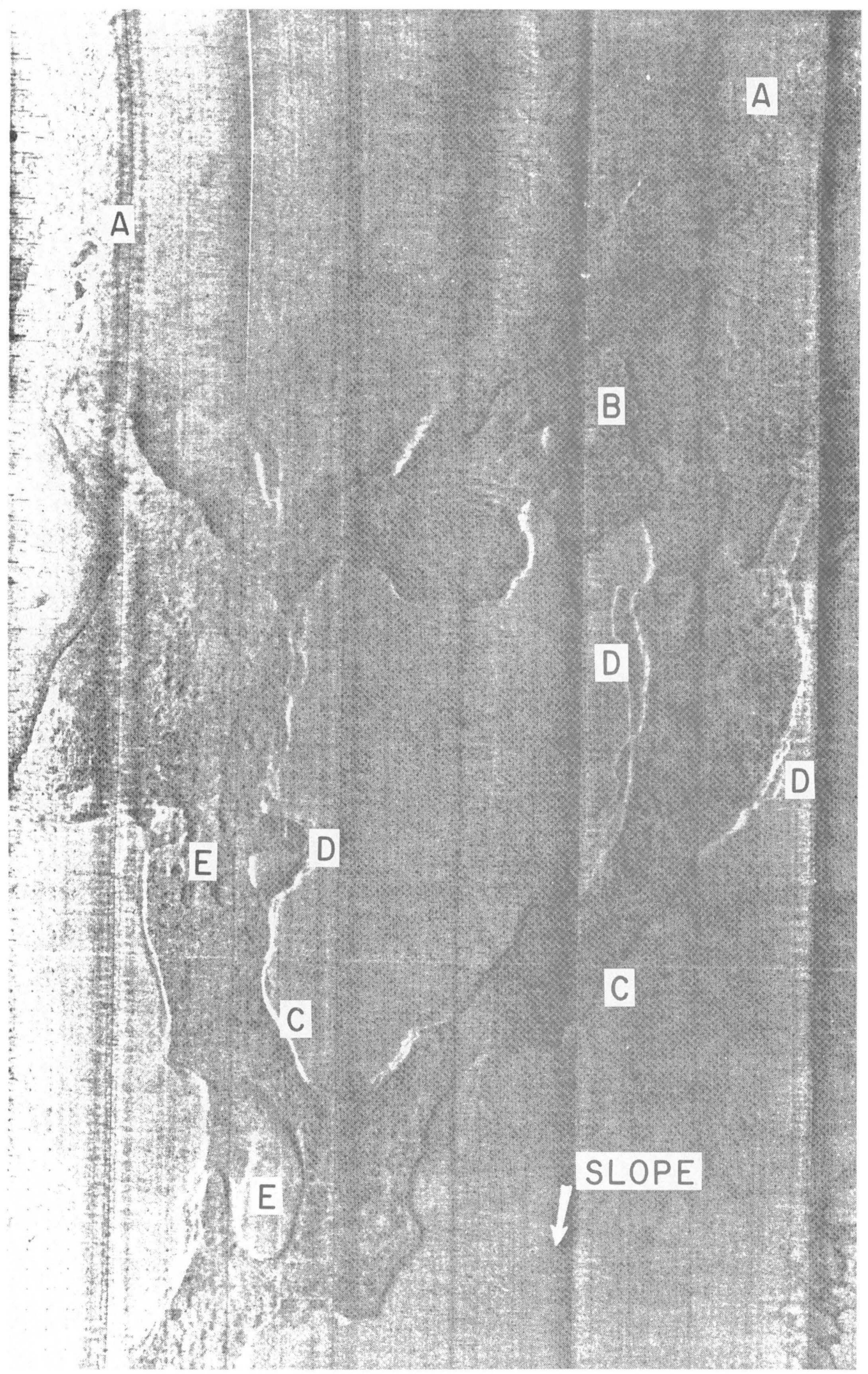

Figure 8. Sidescan-sonar mosaic showing several landslide gullies. Grid is $25 \times 25$ meters, and the mosaic is $1.1 \times 1.8$ kilometers. Water depths are approximately 20 meters at the top of the figure and 35 meters at the lower end. (A) source areas; (B) mudflow gully; (C) narrow incised gully; (D) sidewall-instability slides; (E) large erratic blocks in gully floor. 


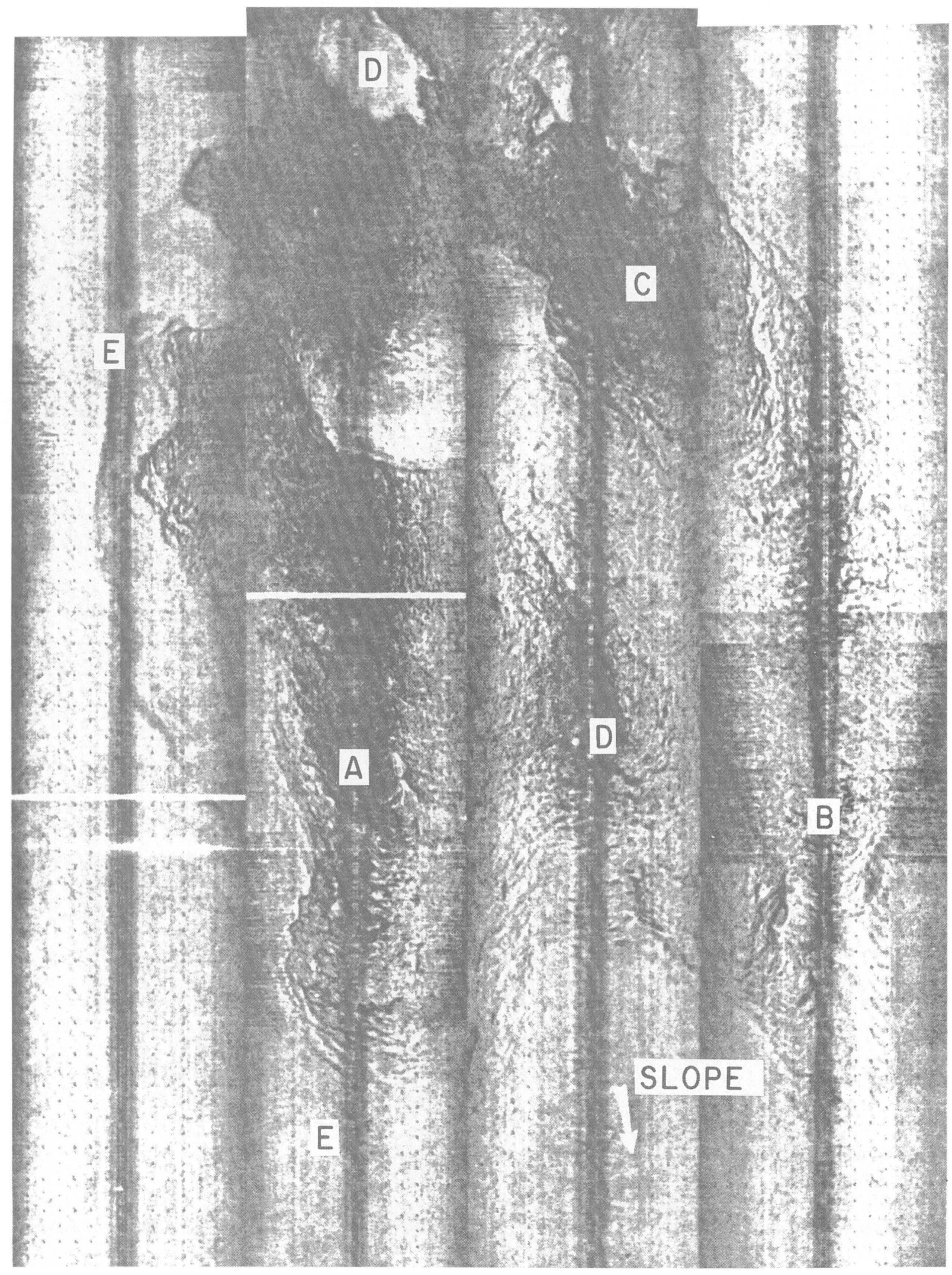

Figure 9. Sidescan-sonar mosaic showing multiple overlapping mudflow depositional lobes. Grid tick marks are 25 meters apart. (A, B, and C) mudflow lobes; (D) erratic blocks; (E) pressure ridges. 


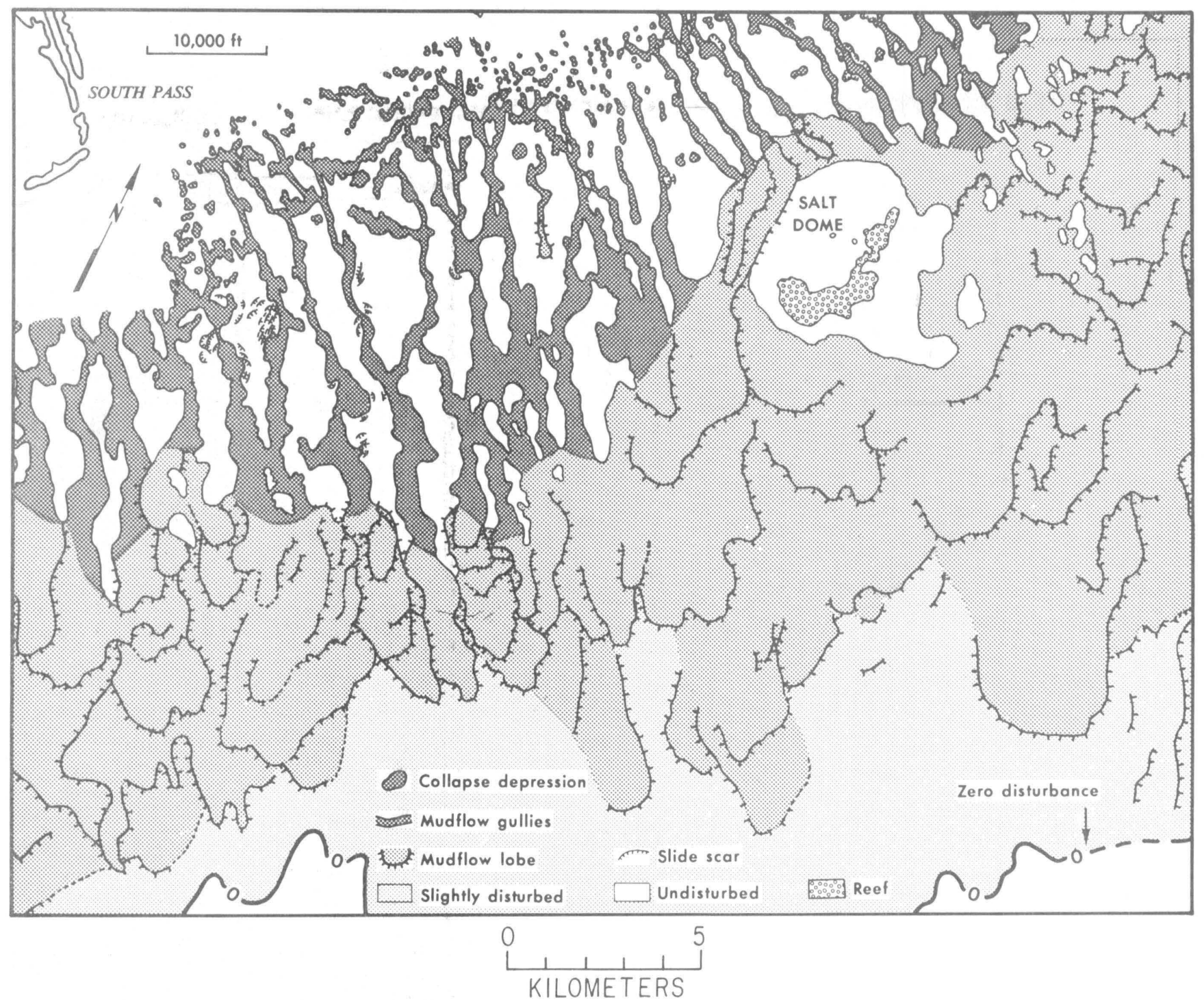

Figure 10. Map illustrating the distribution of slope-failure features on the delta-front of the Mississippi River Delta (from Coleman, 1988).

tions, most of the sea floor is covered by these features (fig. 10). The slope failures have varying morphologies. Collapse depressions and bottleneck slides occur in water depths shallower than $15 \mathrm{~m}$ on slopes less than $0.5^{\circ}$. On steeper slopes near the distributary mouths of the river are peripheral slumps, which give these locations a stairstepped appearance. Farther seaward are major elongate systems of mudflow gullies that carry sediment downslope into mudflow lobes. These gully-lobe systems are the most common type of sediment instability in the Mississippi River Delta.

The mass-movement features of the Mississippi River Delta are very dynamic and have shown considerable change over the last century. The gullies infill slowly and then evacuate rapidly, often during or after major floods (fig. 3). Hurricanes can also cause sea-floor slope failures, as shown dramatically during Hurricane Camille in 1969.
Documented major changes to the sea floor occurred and caused considerable damage and destruction to offshore drilling structures.

\section{ACKNOWLEDGMENTS}

This section is a direct product of the Mississippi Delta Project, a joint research program between LSU and the USGS, but is also, in a broader sense, a result of the cooperation of government agencies, academic institutions, and the offshore petroleum industry. We extend our thanks to members of the Minerals Management Service in Metairie, La., (formerly part of the USGS) who supplied the major part of the data for this study, especially to Dick Scrivener and Bill Sweet of that office, who assisted greatly 
in the project, and to U.S. Bureau of Land Management personnel in New Orleans, where Jack Rebman and Doug Elvers were most helpful. Special thanks go to the many oil company geologists, engineers, and consulting firms who, through the contribution of data and interpretations, helped to fill in some of the blank areas in our coverage. The authors thank Monty Hampton and James Booth for helpful reviews of this section.

\section{REFERENCES CITED}

Bea, R.G., 1971, How sea floor slides affect offshore structures: Oil and Gas Journal, v. 69, p. 88-92.

Bea, R.G., Bernard, H.A., Arnold, Peter, and Doyle, E.H., 1975, Soil movements and forces developed by waveinduced slides in the Mississippi Delta: Journal Petroleum Technology, v. 28, p. 500-514.

Bea, R.G., Wright, S.G., Sircar, Partha, and Niedoroda, A.W., 1983, Wave-induced slides in South Pass Block 70, Mississippi Delta: Journal of Geotechnical Engineering, v. 109, p. 619-644.

Coleman, J.M., 1988, Dynamic changes and processes in the Mississippi River delta: Geological Society of America Bulletin, v. 100, p. 999-1015.
Coleman, J.M., and Garrison, L.E., 1977, Geological aspects of marine slope stability, northwestern Gulf of Mexico: Marine Geotechnology, v. 2, p. 9-44.

Coleman, J.M., Prior, D.B., and Garrison, L.E., 1980, Subaqueous sediment instabilities in the offshore Mississippi River delta: Bureau of Land Management, Open-File Report $80-01,60 \mathrm{p}$.

Fisk, H.N., McFarlan, E.H., Jr., Kolb, C.R., and Wilbert, L.J., Jr., 1954, Sedimentary framework of the modern Mississippi Delta: Journal of Sedimentary Petrology, v. 24, p. 76-99.

Henkel, D.J., 1970, The role of waves in causing submarine landslides: Geotechnique, v. 20, p. 75-80.

Milliman, J.D. and Meade, R.H., 1983, World-wide delivery of river sediment to the oceans: Journal of Geology, v. 91, p. $1-21$.

Prior, D.B., and Coleman, J.M., 1978, Disintegrating, retrogressive landslides on very low angle subaqueous slopes, Mississippi Delta: Marine Geotechnology, v. 3, p. 37-60.

Prior, D.B., Coleman, J.M., Suhayda, J.N., and Garrison, L.E., 1979, Subaqueous landslides as they affect bottom structures: Proceedings, Conference on Port and Ocean Engineering under Arctic Conditions, Trondheim, Norway, v. 2, p. 921-933.

Shepard, F.P., 1955, Delta front valleys bordering the Mississippi distributarie: Geological Society of America Bulletin, v. 66, p. 1489-1498.

Sterling, G.H., and Strohbeck, E.E., 1973, The failure of the South Pass 70 "B" platform in Hurricane Camille: Proceedings, 6th Offshore Technology Conference, Paper No. 1898, p. 719-730. 


\title{
Salt Tectonics and Slope Failure in an Area of Salt Domes in the Northwestern Gulf of Mexico
}

\author{
By B.A. McGregor ${ }^{1}$, R.G. Rothwell ${ }^{2}$, N.H. Kenyon ${ }^{2}$, and D.C. Twichell
}

\section{INTRODUCTION AND REGIONAL GEOLOGIC SETTING}

The northwestern part of the Gulf of Mexico (fig. 1) is an area where an enormous amount of sediment has been deposited during the last 63 million years (the Cenozoic Era). The sedimentary deposits consist of a series of deltas on the continental shelf with associated submarine fans in the deep Gulf of Mexico basin. The centers of sediment deposition in this area migrated eastward through the Cenozoic from the Rio Grande River area of southern Texas to the presently active Mississippi River in the north central Gulf of Mexico (Humphris, 1984).

The sediment of the outer continental shelf and continental slope in the northwestern Gulf of Mexico has been subject to a unique form of deformation due to a thick layer of salt that is buried by this Cenozoic sediment. The thick layer of salt was deposited during the Jurassic period (205 to 138 million years ago) when the Gulf of Mexico ocean basin was forming (Martin, 1978). The loading of the Cenozoic sediment on the salt caused the salt to deform and to flow plastically. As the salt flows under the load of the overlying sediment, numerous fingers of salt (diapirs) move upward through the sediments. When these salt fingers reach the sea floor, they create mounds known as salt domes. The morphology of the continental slope in the northwestern Gulf of Mexico is extremely complex as a consequence of the numerous salt domes that have deformed the sea floor (fig. 2).

Mass wasting is often associated with areas of rapid sedimentation (Lee, Schwab, and Booth, this report; Coleman and others, this report; Schwab and Lee, this report) and with areas subject to active salt deformation (Popenoe, Schmuck, and Dillon, this report). A major landslide, the East Breaks submarine landslide, has been identified on the continental slope in the northwestern Gulf of Mexico using seismic-reflection profiles (Lerner, 1969), but these seismic data do not define the extent of this landslide deposit nor the relative importance of rapid sedimentation and salt deformation in the formation of this landslide. More control on the sea-floor morphology and sea-floor geology was needed to address this question. A detailed understanding of the surficial geology of this morphologically complex area became available with the collection of GLORIA (Geolog-

\footnotetext{
${ }^{1}$ U.S. Geological Survey, Reston, Va.

${ }^{2}$ Institute of Oceanographic Sciences, Godalming, Surrey, U.K.
}

ical LOng-Range Inclined Asdic) sidescan-sonar data by the U.S. Geological Survey (USGS) (EEZ-SCAN 85 Scientific Staff, 1987). The GLORIA data in concert with bathymetric measurements collected along closely spaced ship tracklines provide a clearer view of the surface expression of this landslide deposit and its association with the sea-floor morphology.

The continental slope in the northwestern Gulf of Mexico is thought to contain significant amounts of oil and gas resources and is a major deep-water exploration frontier. Slope failures are known to destroy or damage oil rigs and pipelines placed on the sea floor with a potential for an accompanying loss of human life (Lee, Schwab, and Booth, this report). The ability to identify and predict slope failure is an important aspect in locating and designing sea-floor structures. As interest in exploring the deeper water areas of the Gulf of Mexico increases, a corresponding need to understand the geologic hazards of the area must be addressed. The GLORIA sidescan-sonar images are proving useful as a means to target potentially dangerous areas for more detailed study and to predict how geohazards such as landslides and salt deformation might affect man's activities on the sea floor.

\section{EAST BREAKS SUBMARINE LANDSLIDE}

A bathymetric map was compiled using the GLORIA sidescan-sonar images.in concert with bathymetric information collected along the survey tracklines. A perspective view of the bathymetry of the study area is shown in figure 2 . The sea floor has a regional gradient of $1^{\circ}$ to $3^{\circ}$ on the upper continental slope (water depths of 200 to 1,000 meters $(\mathrm{m})$ ) that decreases to about $0.5^{\circ}$ on the middle slope (water depths of 1,000 to about $1,500 \mathrm{~m}$ ). The gradient again becomes steeper on the lower continental. slope between 2,000- and 3,000-m depths where the Sigsbee Escarpment is crossed (fig. 1). The Sigsbee Escarpment represents the seaward limit of the salt deformation.

Salt domes are numerous on the upper and middle sections of the continental slope, have as much as $150-\mathrm{m}$ relief, and disrupt the regional sea-floor gradient (fig. 2). Locally, on the flanks of salt domes the sea-floor gradient exceeds $10^{\circ}$. The salt domes do not have a systematic distribution and give the continental slope a mottled appearance of domes and depressions. (fig. 2). Submarine canyons, which are common on most continental slopes such as off the Eastern or Western United States (for example, 


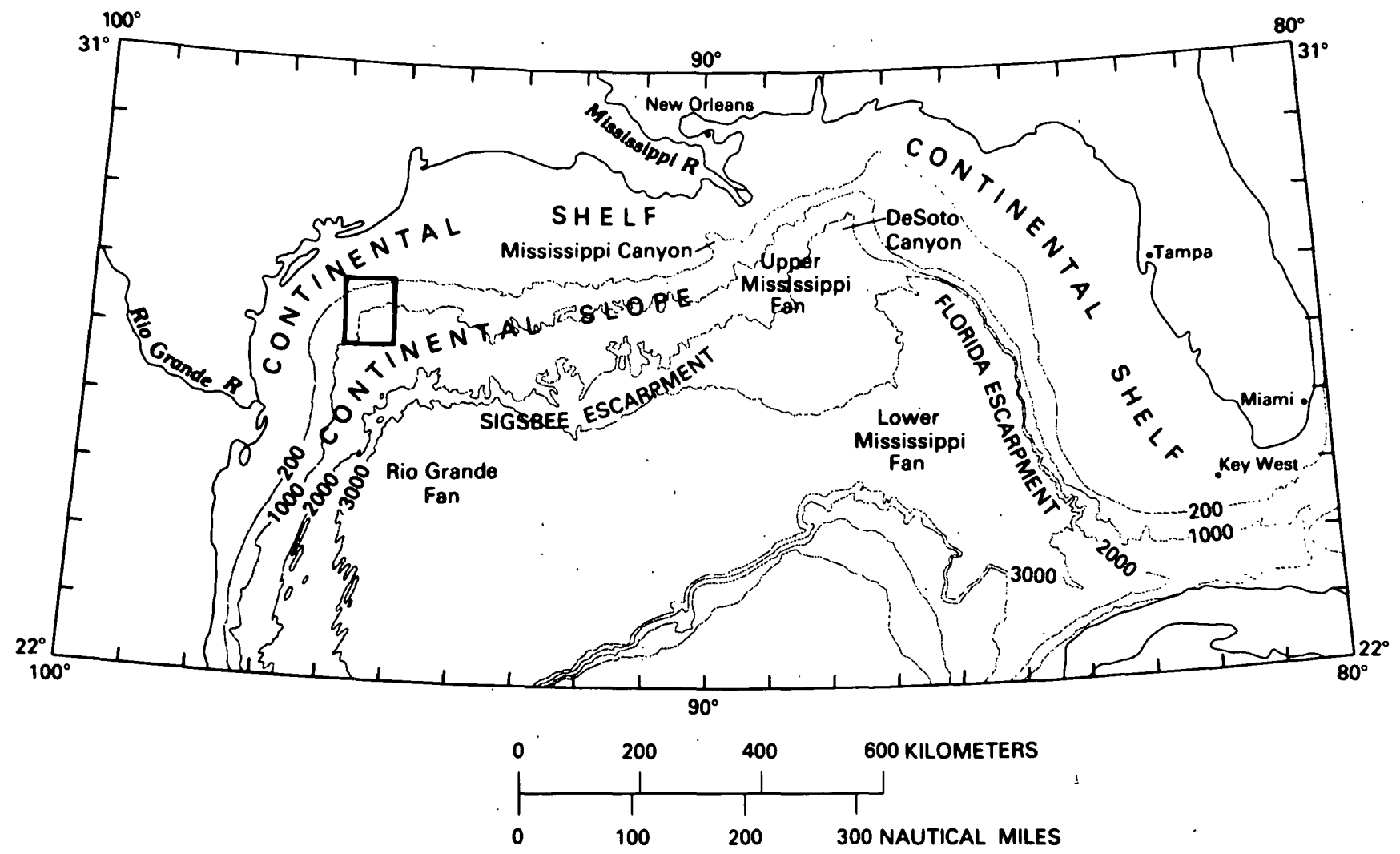

Figure 1. Index map of the Gulf of Mexico. Contours are in meters. The box outlines the study area.

Booth and others, this report; O'Leary, this report; Carlson and others, this report), are absent or so completely disrupted by the salt deformation as to be unrecognized in this area.

Combining the GLORIA data with the bathymetric data shows the relationship between the acoustic backscatter of the sea floor and the sea-floor relief (fig. 3). A particularly notable feature on the GLORIA image is a region of high backscatter (bright area) that correlates with the East Breaks submarine landslide that was initially identified by Lerner (1969) based on seismic-reflection profiles. The high-backscatter area corresponds with an area of hyperbolic echoes on seismic-reflection profiles (fig. 4). These hyperbolae indicate a rough, blocky sea floor. GLORIA images show that the landslide covers an area of 2,250 square kilometers $\left(\mathrm{km}^{2}\right)$ on the upper and middle continental slope (fig. 3). The head of the landslide is located in approximately $200 \mathrm{~m}$ of water near the shelf edge. The body of the landslide can be divided into two lobes. The eastern lobe extends $70 \mathrm{~km}$ downslope to a water depth of $1,350 \mathrm{~m}$ and covers an area of $650 \mathrm{~km}^{2}$. It is separated from the western lobe by a topographic high - a salt dome. The western lobe covers $1,600 \mathrm{~km}^{2}$ and extends $110 \mathrm{~km}$ downslope to a water depth of approximately $1,300 \mathrm{~m}$ where it is channeled between two salt domes. Downslope of these salt domes, the landslide continues as fingerlike projections to a maximum water depth of $1,600 \mathrm{~m}$ (fig. 3).
The thickness of the landslide deposit, based on seismicreflection studies varies from an estimated $20 \mathrm{~m}$ for the eastern lobe to over $100 \mathrm{~m}$ for the western lobe (Lerner, 1969; Woodbury, 1977; EEZ-SCAN 85 Scientific Staff, 1987). A maximum thickness of $180 \mathrm{~m}$ occurs on the mid slope where the salt diapirs have constricted movement of the slide and caused ponding.

The East Breaks landslide fills in bathymetric lows around the salt domes. The deposit does not have bathymetric expression that can be resolved by available bathymetric data (fig. 2). Thus, it is only by combining the bathymetry and GLORIA image (fig. 3) that the extent of this deposit can be clearly defined. The high backscatter that corresponds to the area of the landslide debris is believed to be caused by fine-scale surface irregularities as shown by the hyperbolae on the seismic-reflection profiles (fig. 4). This surface roughness presumably was formed by deformation during the downslope movement. Sediment cores in the landslide show contorted beds of sand and mud (Woodbury and others, 1978). Sand and mud layers are typical of deltaic sediments, and imply an original shallowwater source for these sediments.

\section{AGE OF SLOPE FAILURE}

The East Breaks landslide is classified as a mass flow because of the degree of disintegration shown by the 


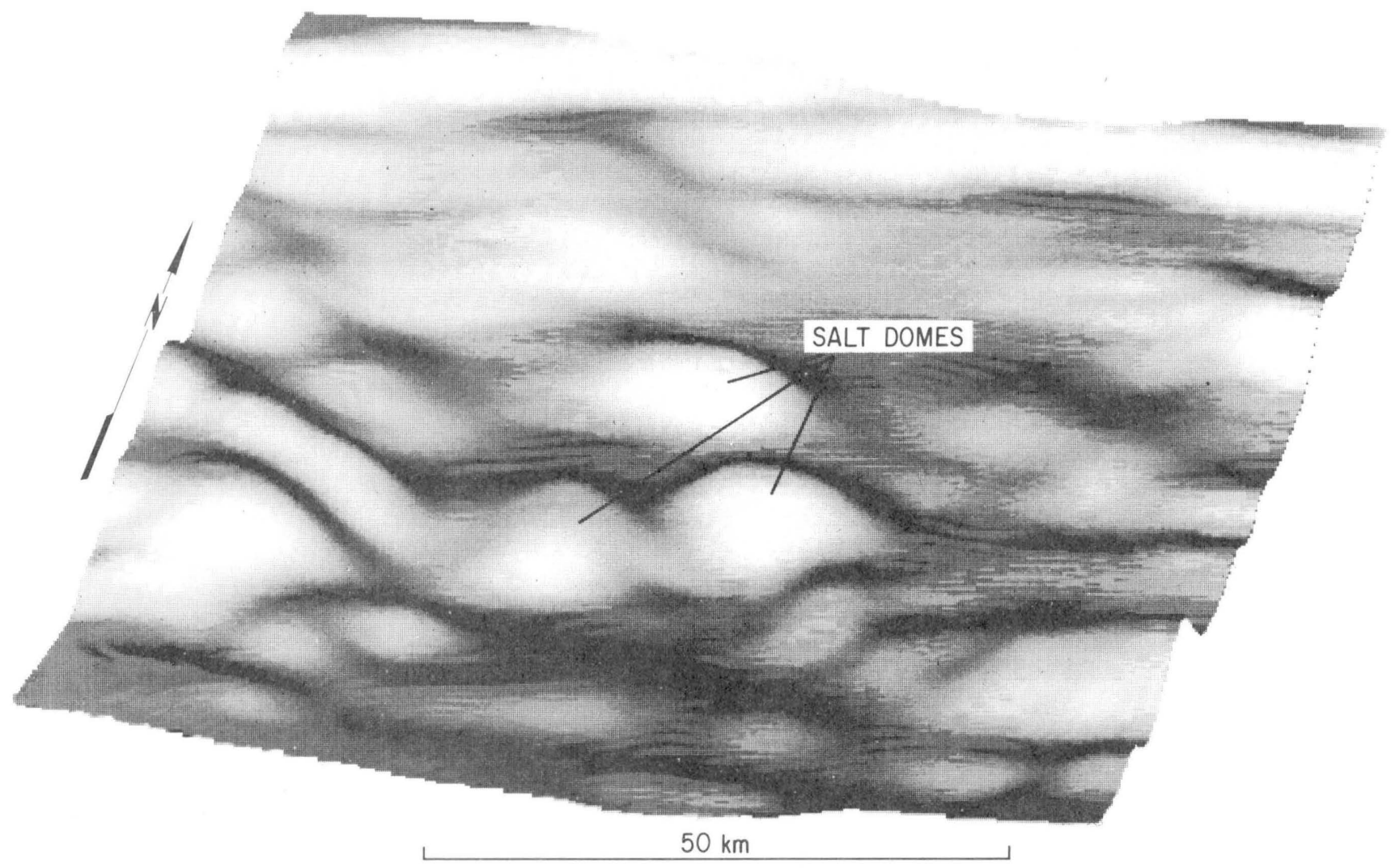

Figure 2. Perspective view of the bathymetry of the study area on the continental slope in the northwestern Gulf of Mexico (see fig. 1 for location). The bathymetry was compiled using the GLORIA sidescan-sonar images in concert with bathymetric information collected along the survey tracklines.

deposits. Based on examination of core samples, the mass movement can be further classified as a sandy debris flow. Interpretation of seismic-reflection profile data from the East Breaks landslide shows that slope failure has occurred repeatedly in the area (Lerner, 1969). During geologic periods when sea level was lower and the shelf was subaerially exposed, large deltas built the shelf edge seaward and sediment was deposited on the upper continental slope. The source area for the East Breaks landslide is the seaward edge of a delta that was constructed at the shelf edge during the last low stand of sea level 15,000 to 20,000 years ago (fig. 5; Suter and Berryhill, 1985). Cores from the East Breaks landslide recover sediment that is interpreted to be deltaic in origin (Woodbury and others, 1978) and indicate that the landslide is younger than 15,000 to 20,000 years. We speculate that this landslide occurred 15,000 to 20,000 years ago when sea level was lower. The delta likely would have contained underconsolidated sediment subjected to cyclic loading by storm waves. Cyclic loading by storm waves on modern deltas is an important triggering mechanism for slope failures (Lee, Schwab, and Booth, this report; Coleman and others, this report; Schwab and Lee, this report). This slope failure probably is not younger than the last period of low sea level because similar types of sediment on the steep flanks of salt domes do not show any evidence of mass movement.

\section{IMPLICATIONS}

The combination of the GLORIA and bathymetric data reveals that the salt domes do not appear to have played a major role in the formation of this landslide. Scarps on the sides of the salt domes and landslide deposits originating from the salt domes generally cannot be resolved by the GLORIA images and are presumed to be either small or nonexistent. Accordingly, we suggest that the salt domes have not been a significant source of failed sediment. Instead, the salt domes appear to have contributed only to shaping the pathway of the landslide.

The flanks of salt domes have proven to be effective petroleum traps because the sedimentary layers are bent up and truncated as the salt penetrates the overlying sediment. Landslides do transport coarse-grained sediment to the continental slope, and these coarse-grained deposits could prove to be effective reservoirs for petroleum. Thus, understanding the distribution of these deposits, in addition to showing the geologic hazards of the area, may also prove to 


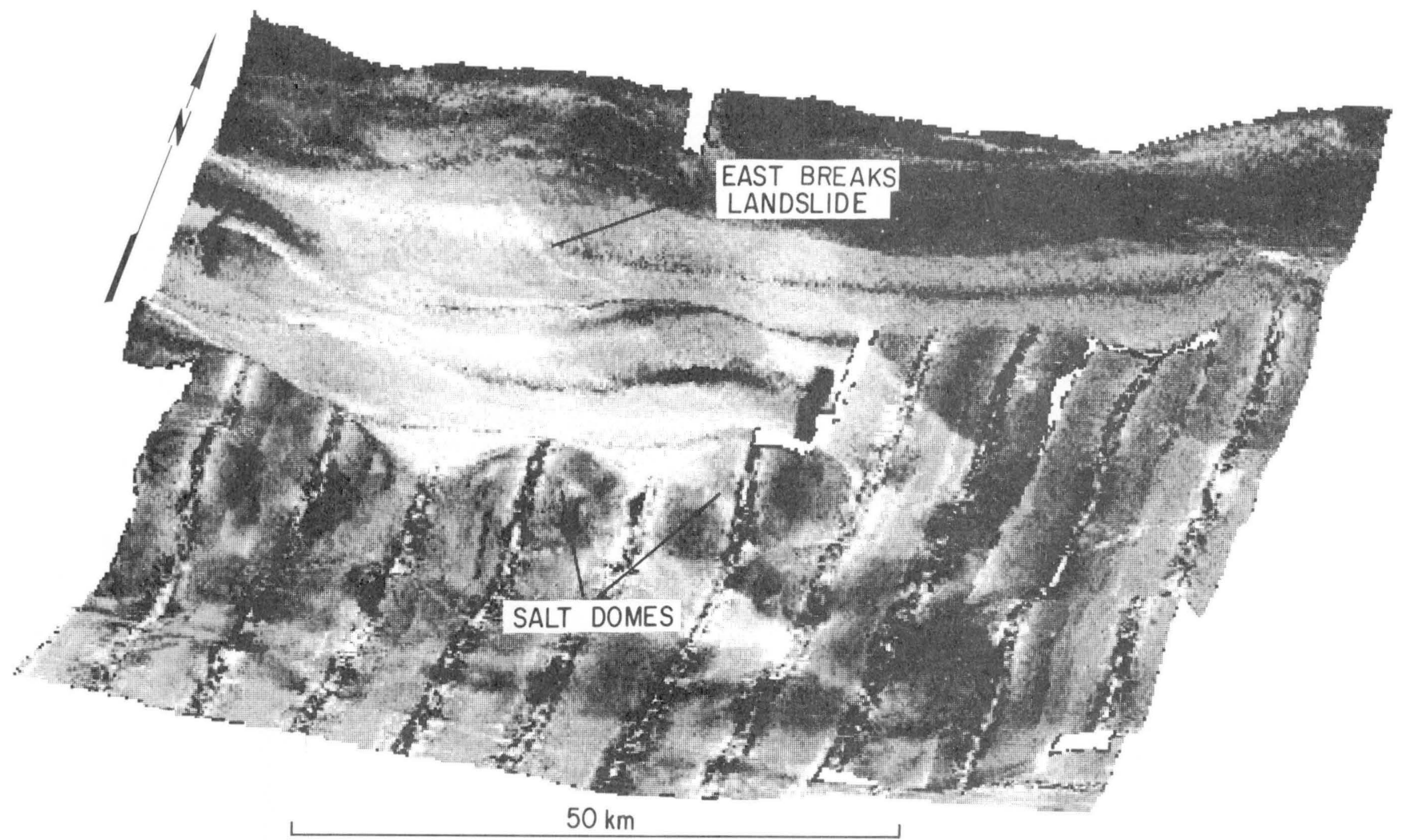

Figure 3. GLORIA sidescan-sonar data are draped over the bathymetry data (fig. 2). Areas of high backscatter (light areas) are the surface of the East Breaks submarine landslide.

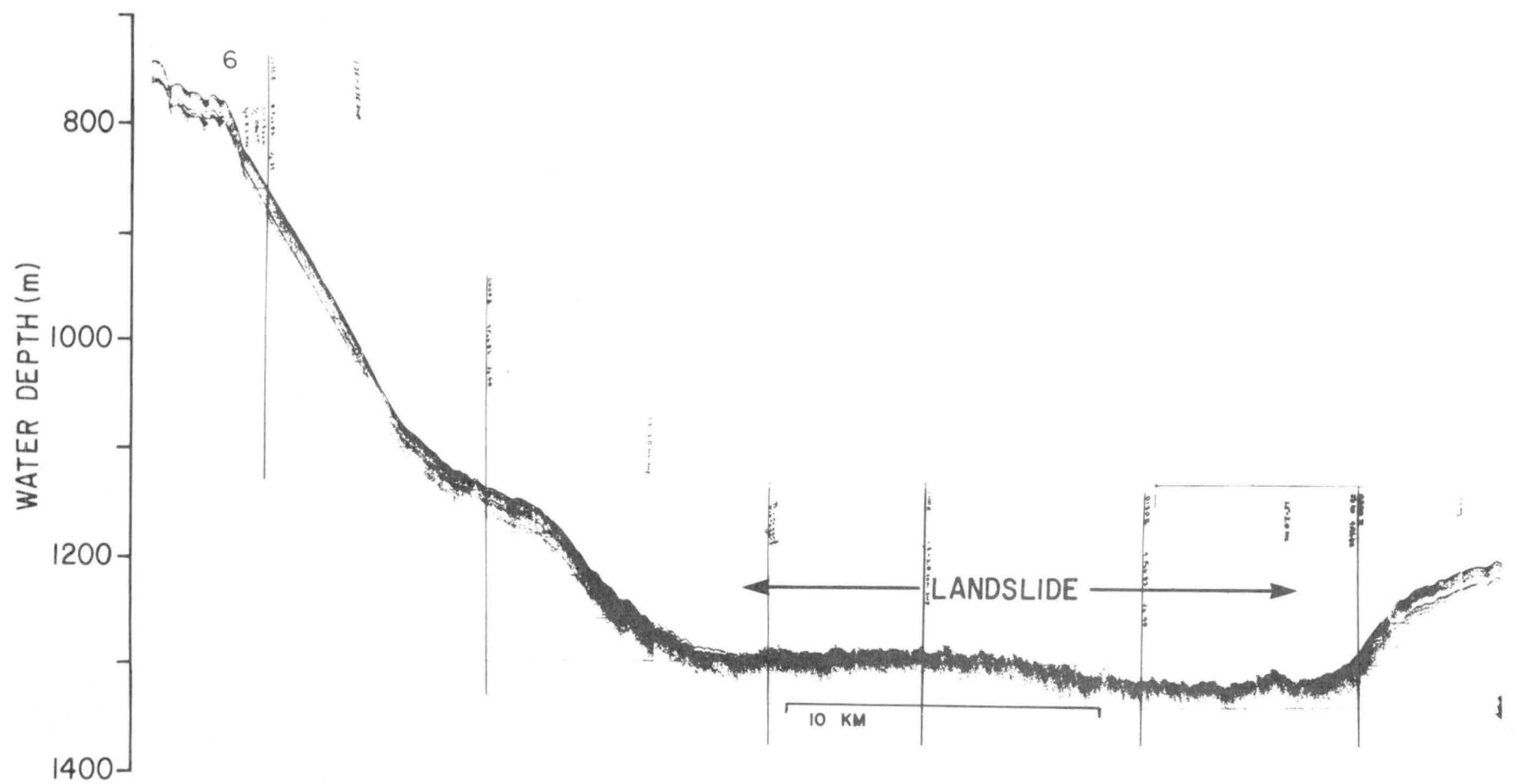

Figure 4. A high-resolution subbottom profile (10-kilohertz frequency) showing surface irregularity (hyperbolic echoes) on the western lobe of East Breaks landslide. The topographic high on right side of profile is the flank of a salt dome (see fig. 5 for location of the profile). 


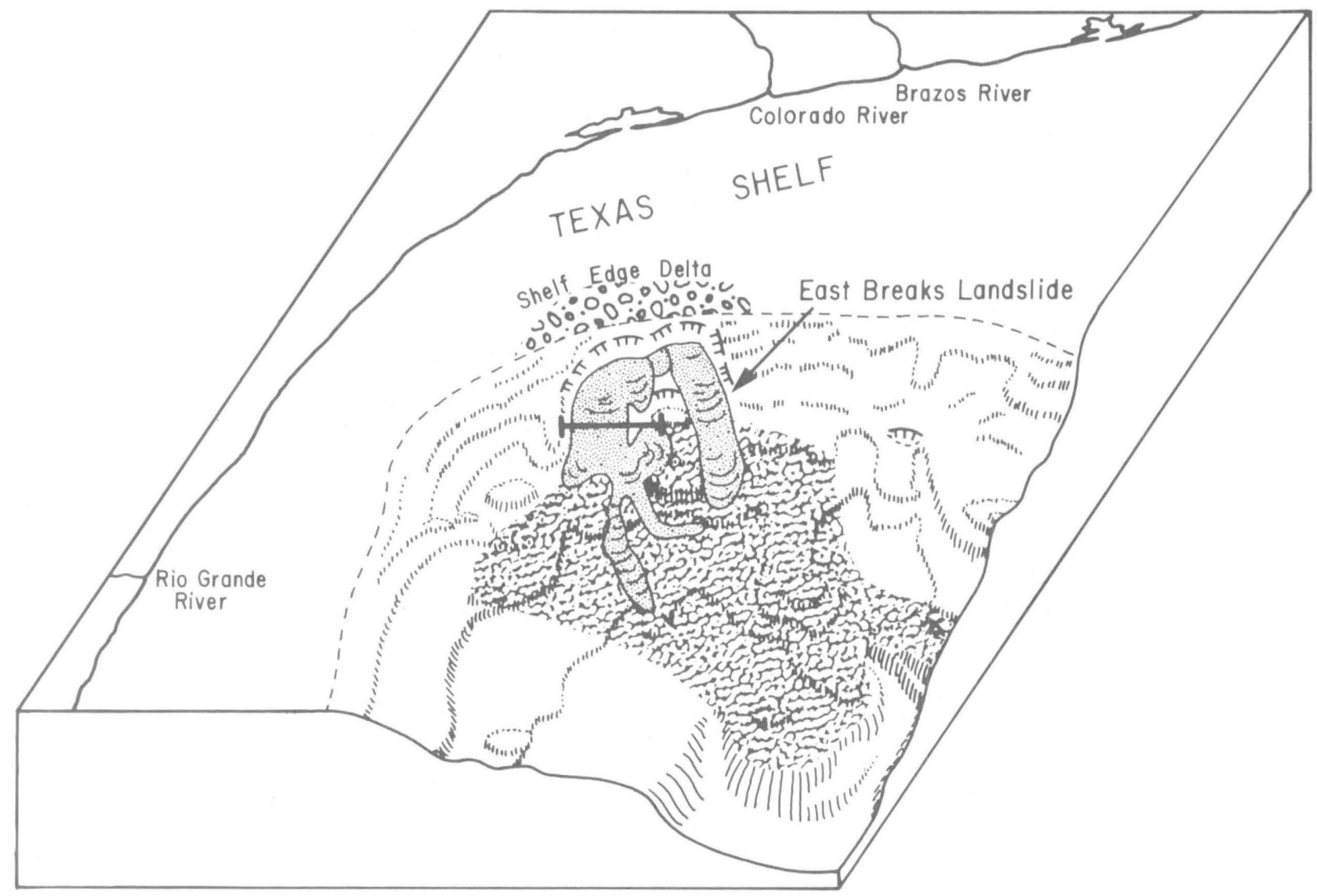

Submarine mass-flow deposits (probably sandy debris flows)

Blanket mud deposits (mud tubidites + hemipelagic mud)

तT Scarps

$\mapsto$ Location of profile shown in Figure 4

Figure 5. Sketch of the major geologic features in the northwestern Gulf of Mexico.

be a useful depositional model in the exploration for petroleum in this large salt-dome province.

\section{REFERENCES CITED}

EEZ-SCAN 85 Scientific Staff, 1987, Atlas of the U.S. Exclusive Economic Zone, Gulf of Mexico, U.S. Geological Survey Miscellaneous Investigations Series I-1864-A, 104 p.

Humphris, C.C., Jr., 1984, Interrelations of Tertiary deposition, growth faulting, and salt movement, northern Gulf of Mexico, in Characteristics of gulf basin deep-water sediments and their exploration potential: Fifth Annual Research Conference Gulf Coast Section of Society of Paleontologists and Mineralogists, p. 50-51.

Lerner, Peter, 1969, Salt tectonics and Pleistocene stratigraphy on continental slope of northern Gulf of Mexico: American Association of Petroleum Geologists Bulletin, v. 53, p. 2431-2479.
Martin, R.G., 1978, Northern and eastern Gulf of Mexico continental margin: stratigraphic and structural framework, in Bouma A.H., Moore G.T., and Coleman, J.M., eds., Framework, facies, and oil-trapping characteristics of the upper continental margin: American Association of Petroleum Geologists, Studies in Geology No. 7, p. 21-42.

Suter, J.R., and Berryhill, H.L., 1985, Late Quaternary shelfmargin deltas, northwestern Gulf of Mexico: American Association of Petroleum Geologists Bulletin, v. 69, p. 77-91.

Woodbury, H.O., 1977, Movement of sediment on the Gulf of Mexico continental slope and upper continental shelf: Marine Geotechnology, v. 2, p. 263-273.

Woodbury, H.O., Spotts, J.H., and Akers, W.H., 1978, Gulf of Mexico continental-slope sediments and sedimentation, in Bouma A.H., Moore G.T., and Coleman, J.M., eds., Framework, facies, and oil-trapping characteristics of the upper continental margin: American Association of Petroleum Geologists, Studies in Geology No. 7, p. 117-137. 


\title{
Slope Stability in Regions of Sea-Floor Gas Hydrate: Beaufort Sea Continental Slope
}

\author{
By R.E. Kayen and H.J. Lee
}

\section{INTRODUCTION}

The continental slope of the Alaskan Beaufort Sea is disrupted by an apparently continuous area of submarine landslides (Grantz and Dinter, 1980). The zone of slope instability extends from water depths of 200 to 400 meters (m) at the shoreward edge, to depths in excess of 2,000 m (fig. 1). The thickness of displaced sediment typically is 100 to $400 \mathrm{~m}$. The area of slope failure largely lies in a region underlain by marine gas hydrate (sediment bonded by a solid mixture of water and methane). Gas hydrate has been interpreted from seismic-reflection profiles (Grantz and Greenberg, 1981; Grantz and others, 1981), and extends down from near the sea floor to at least $700 \mathrm{~m}$ beneath the sea floor between the 400- and 2,800-m water depths (fig. 2). For many of the landslides, the basal shear surface corresponds approximately with the base of the gas hydrate. For example, the mass-movement deposit in figure 3 , profiled in the eastern Alaskan Beaufort Sea, is bounded upslope by a scarp and appears to share its basal shear surface with a strong gas-hydrate reflector. Many of the

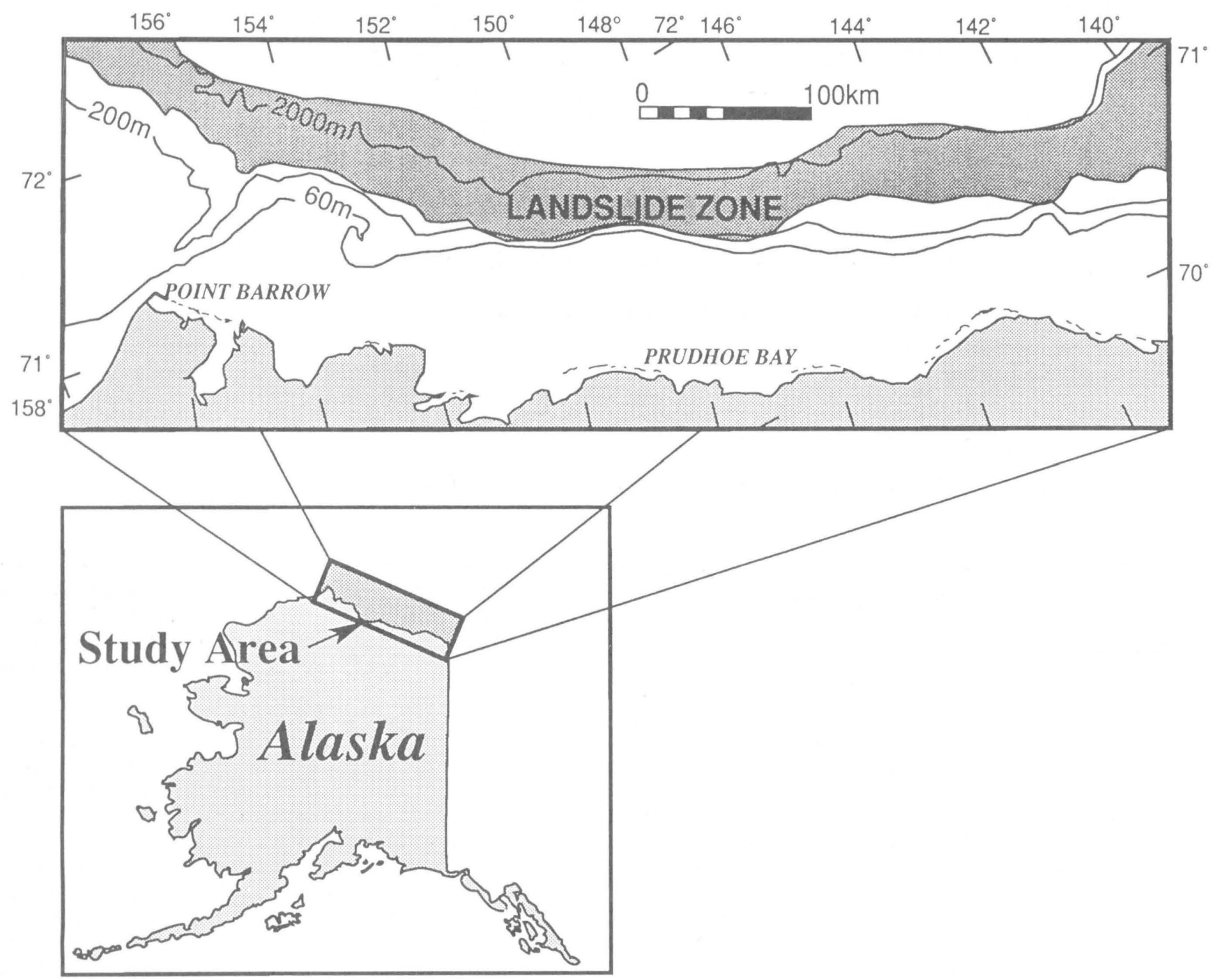

Figure 1. The zone of large landslides on the continental margin of the Beaufort Sea, interpreted from seismic-reflection profiles (from Grantz and Dinter, 1980). 


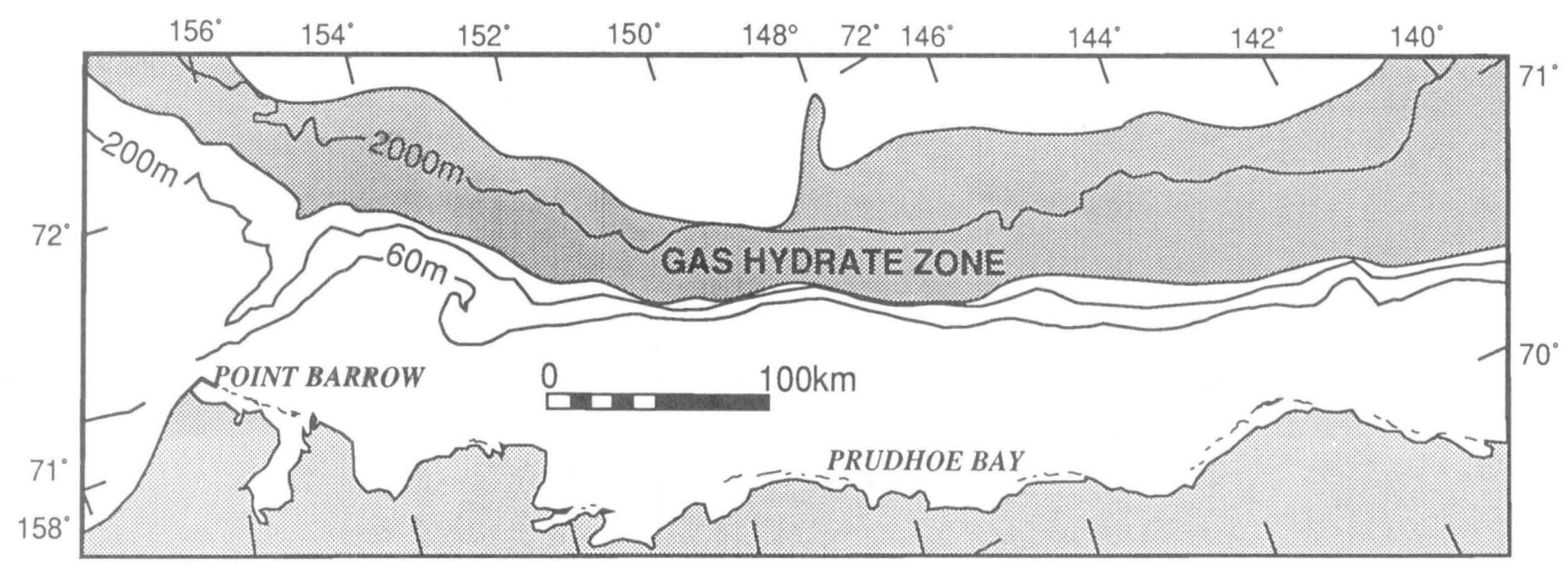

Figure 2. The region of sea-floor gas hydrate on the continental slope extends from approximately 400 meters water depth near shore to over 2,000 meters. The presence of gas hydrate within sea-floor sediment is interpreted from a strong bottom-simulating reflector in seismic-reflection profiles (from Grantz and Dinter, 1980).

observed slope failures probably were triggered during Pleistocene sea-level fall in response to partial disassociation of the gas hydrate.

\section{THE FORMATION OF GAS HYDRATE}

Solid-solution gas hydrate forms beneath the sea floor from natural gas and water within a stability field determined by temperature and pressure (fig. 4). Formation can occur in both polar and nonpolar regions due to the normally cold bottom-water conditions (typically $2^{\circ}$ to $5^{\circ} \mathrm{C}$ ) found on continental slopes throughout the world. Hence, most slopes found in water deeper than 400 to $500 \mathrm{~m}$ have a sea-floor pressure and temperature environment within the stable phase for gas-hydrate formation. To produce a marine gas hydrate, water molecules bond to form a cubic lattice structure within which individual gas molecules, primarily methane, are caged (Kvenvolden and McMenamin, 1980). The resulting structure densely packs natural gas molecules in a configuration that is far tighter than would exist in free gas at the same pressure and temperature. For example, at standard temperature and pressure approximately 170 volumetric units of free methane gas are compressed and stored in a single volumetric unit of gas hydrate.

Conditions conducive to formation of gas hydrate lie below a phase boundary (left side of fig. 4). The actual depth and temperature conditions at a representative location on the Beaufort Sea slope (profile $A-A^{\prime}$ ) intersect the phase boundary diagram and show where gas hydrate is stable beneath the sea floor. Because temperature increases relatively rapidly with depth in the sediment due to the geothermal gradient, gas hydrate can form only within the upper section beneath the sea floor. The depth beneath the sea floor at which the pressure and temperature conditions reach the phase boundary determines the location of the base of the gas-hydrate zone, which can be seen readily in seismic-reflection profiles (fig. 3, also see Carpenter, 1981). The reflection from the base of the gas hydrate approximately mimics the bottom bathymetry and commonly is termed a bottom-simulating reflector or BSR (fig. 3).

\section{EFFECT OF SEA-LEVEL FLUCTUATIONS ON GAS HYDRATE}

During ice ages, a worldwide drop in sea level that occurs in response to the formation of massive glaciers on land causes reduced total pressure within sediment beneath the sea floor. Normally, pore pressures within the hydratefree sediment dissipate very rapidly during a drop in sea level to maintain essentially hydrostatic conditions (fig. $5 A)$. In regions of gas hydrate, however, the lowering of sea level reduces pressure along the gas-hydrate base, initiating disassociation (melting) and consequently releasing large volumes of bubble-phase gas into the sediment directly beneath the hydrate base. The dense concentration and large quantity of natural gas within a gas hydrate is such that disassociation of only a small part of the base elevates pressures back into equilibrium phase-boundary conditions. That is, as sea level drops, gas-augmented pore-water pressures near the phase boundary remain almost as great as they were when sea level was high.

Therefore, as sea level falls, the gas-hydrate base tends to disassociate and retreat upward in the sediment column to a new position of lower equilibrium pressure and temperature (Field and Kvenvolden, 1985; 1986), but elevated pore-water pressures at the base, trapped beneath 


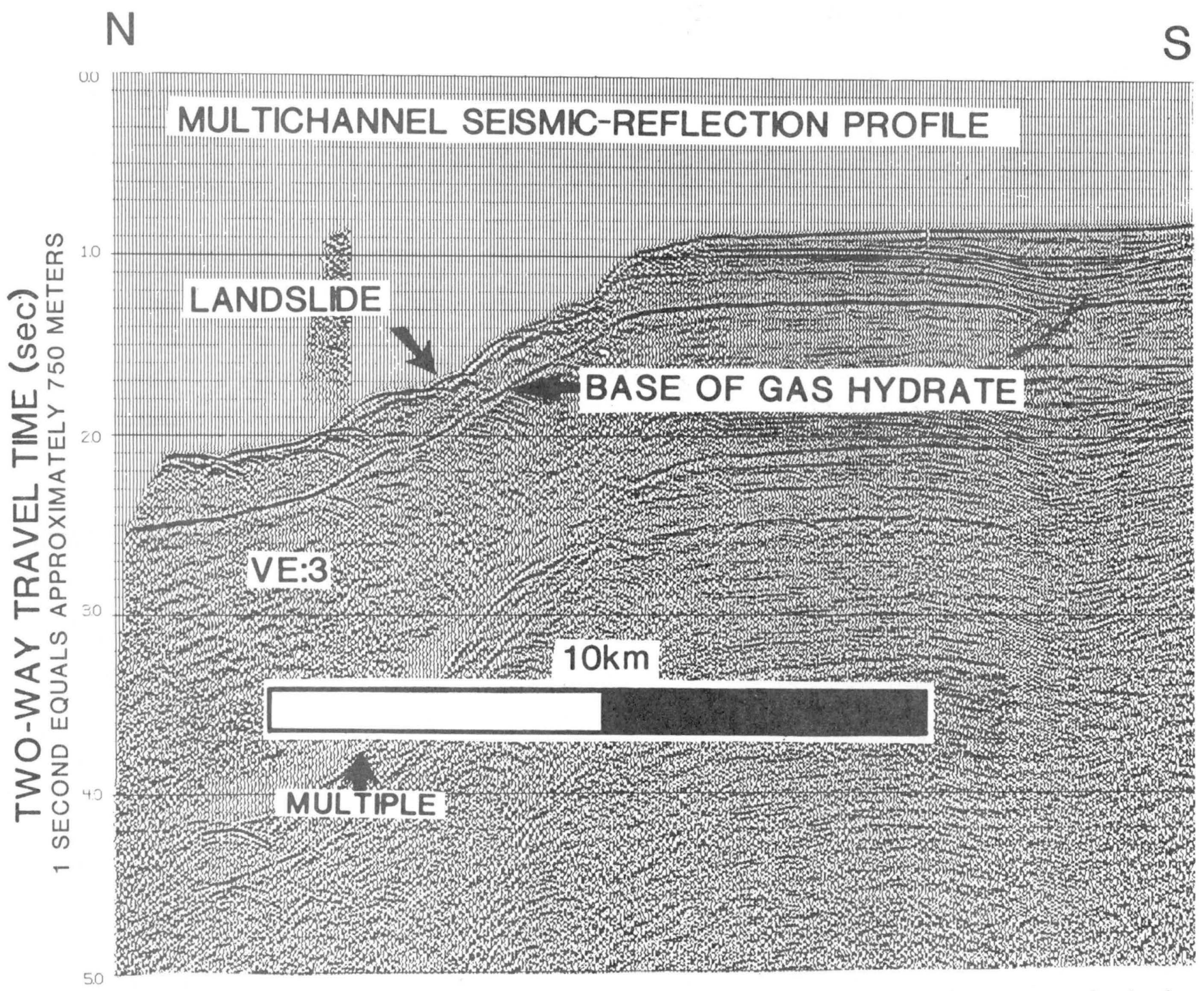

Figure 3. The landslide revealed on this seismic-reflection profile in the eastern Beaufort Sea displays a 100-meterhigh headwall scarp at the shelf-edge break that defines the landward edge of the slope failure (data from Grantz and Greenberg, 1981). Seaward, the hummocky irregular topography, characteristic of the disrupted surface of a

the largely impermeable gas hydrate above, oppose further disassociation. As a result, excess pressures preserve a base that is deeper in the sediment column than the base would be if these pressures did not exist.

A predicted pore-water pressure profile through the sediment column at the completion of a large drop in sea level is presented in figure $5 B$. Because of disassociation, hydrodynamic pressures are elevated at the gas-hydrate base with respect to the hydrostatic profile developed in unhydrated sediment as seen in figure $5 \mathrm{~A}$. These excess pressures compromise the stability of the slope by reducing the normal stress between individual sediment grains and, mass-movement deposit, extends to a water depth of at least 1,900 meters. The basal shear surface of the slide appears to closely follow the strong bottom-simulating reflector that marks the base of the gas hydrate. Note: Vertical exaggeration (VE) is 3 times.

consequently, the sediment's resistance (sediment strength) to shear stresses that tend to move the sediment downslope. Because the shear stresses acting downslope in this region are primarily caused by gravity acting on a sea-floor slope, the excess pore-water pressure may cause the slope under static conditions to become unstable (Kayen, 1988).

\section{SLOPE STABILITY DURING GAS-HYDRATE DISASSOCIATION}

Evaluating the effect of gas-hydrate disassociation on slope stability requires quantifying the process of excess 


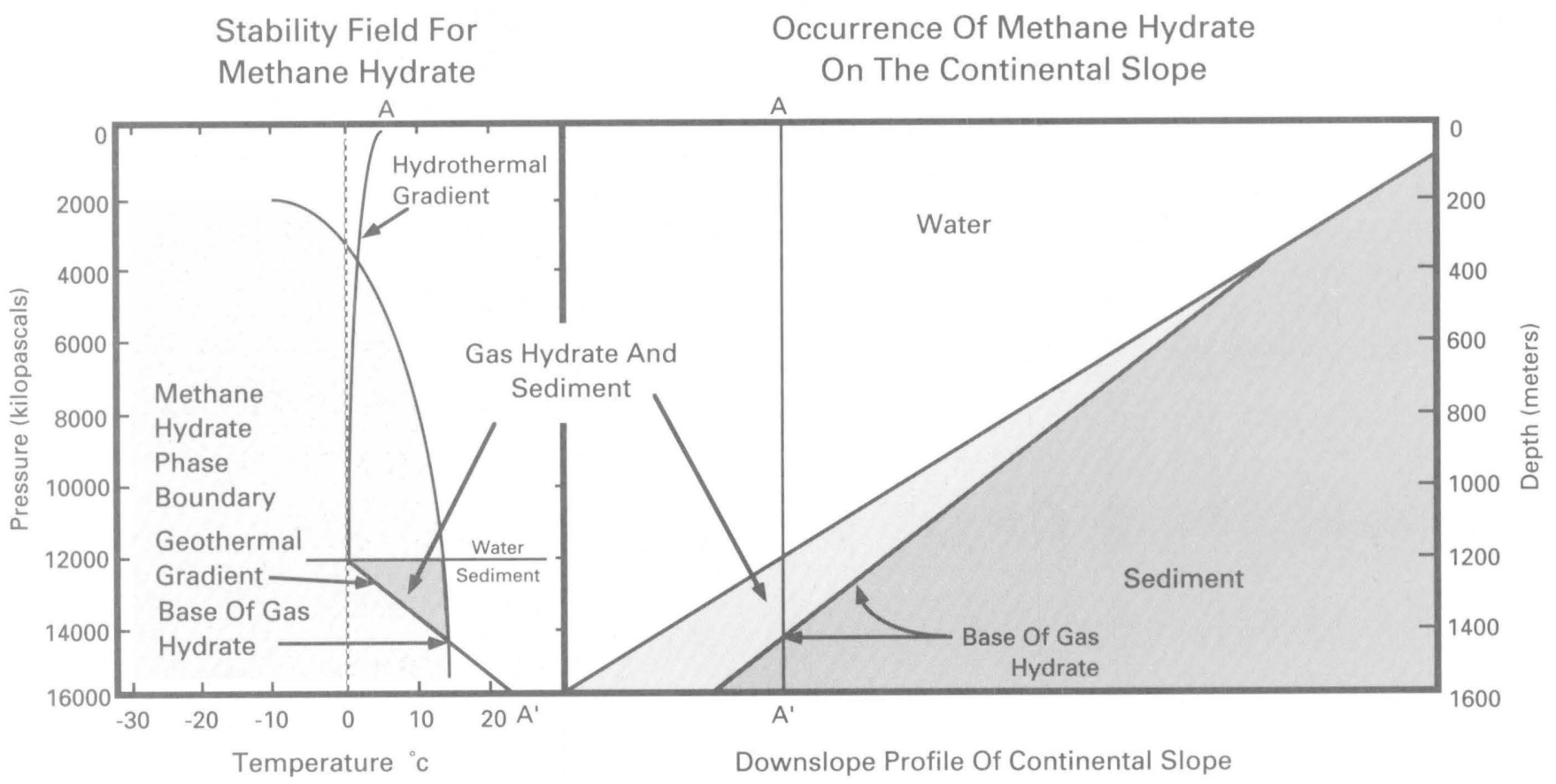

Figure 4. On the left is a gas hydrate pressure-temperature stability field (phase diagram) and on the right a schematic diagram of the continental slope. Formation of gas hydrate can occur only below the methane-hydrate phase boundary. Pressure (in kilopascals) and temperature (in degrees Celsius) conditions of profile $\mathrm{A}-\mathrm{A}^{\prime}$ through the sediment

slope on the right are drawn on the phase diagram. Environmental conditions are well within the stability field at the sea-floor surface but intersect the phase boundary with burial, which determines the thickness of the hydrate zone in sediment.

pore-pressure generation and dissipation. Numerical solutions were obtained by Kayen (1988) for the temporal and spatial distribution of excess pore-water pressures developed during gas-hydrate disassociation for a variety of possible sediment types, from coarse sand to fine-grained deposits of clay, beneath a gas-hydrate base. The numerical approach, a finite-difference model, was formulated around an averaged and linearized sea-level fall of $100 \mathrm{~m}$, occurring over 9,100 years ago, representative of the last Pleistocene lowering of sea level as based on the work of Matthews (1973), Steinem and others (1973), Bloom and others (1974), and Chappell (1974). The model for predicting excess pore-water pressures beneath the base of the hydrate was constrained by previously determined gas hydrate thermodynamic data (Kvenvolden and others, 1984; Makogon, 1981; and Sloan, 1990).

The model shows that a continuous fall of sea level causes a slow degradation of the gas-hydrate base. The level of excess pore-water pressure that develops near the base depends largely on the ability of the sub-base sediment to dissipate excess pressures. For example, clayey deposits have a low pore-fluid dissipation capability: excess pressures do not dissipate and, therefore, suppress further disassociation (fig. 6). Accordingly, at the completion of a sea-level fall, a large excess pressure is present. If little disassociation occurs, the excess pressure at the end of the drop in sea level will be nearly equal to the total hydrostatic pressure change, from high stand of sea level to low stand. In contrast, sand deposits can readily dissipate excess pressures, so the rate of disassociation along the base is relatively high and largely controlled by heat flow into the base. At the end of a large drop in sea level, a marked upward retreat of the base and relatively low excess pressure are expected. The numerical solution for a sandy sediment supports this prediction (fig. 7). The two sediment types, sandy and clayey, can be considered end-members with regard to pore-fluid dissipation. Thus, a sub-base clayey sediment will tend to develop greater excess porewater pressure than sandy sediment during gas-hydrate disassociation and would be more prone to slope failure.

\section{SLOPE STABILITY OF THE BEAUFORT SLOPE: CONCLUSIONS}

Studies of sediment sampled from the zone of slope failure of the Beaufort Sea continental slope indicate that the diffusion and physical properties are more like clayey sediment than sandy sediment (Kayen, 1988). Given the geometry and sediment physical properties of the contine- 


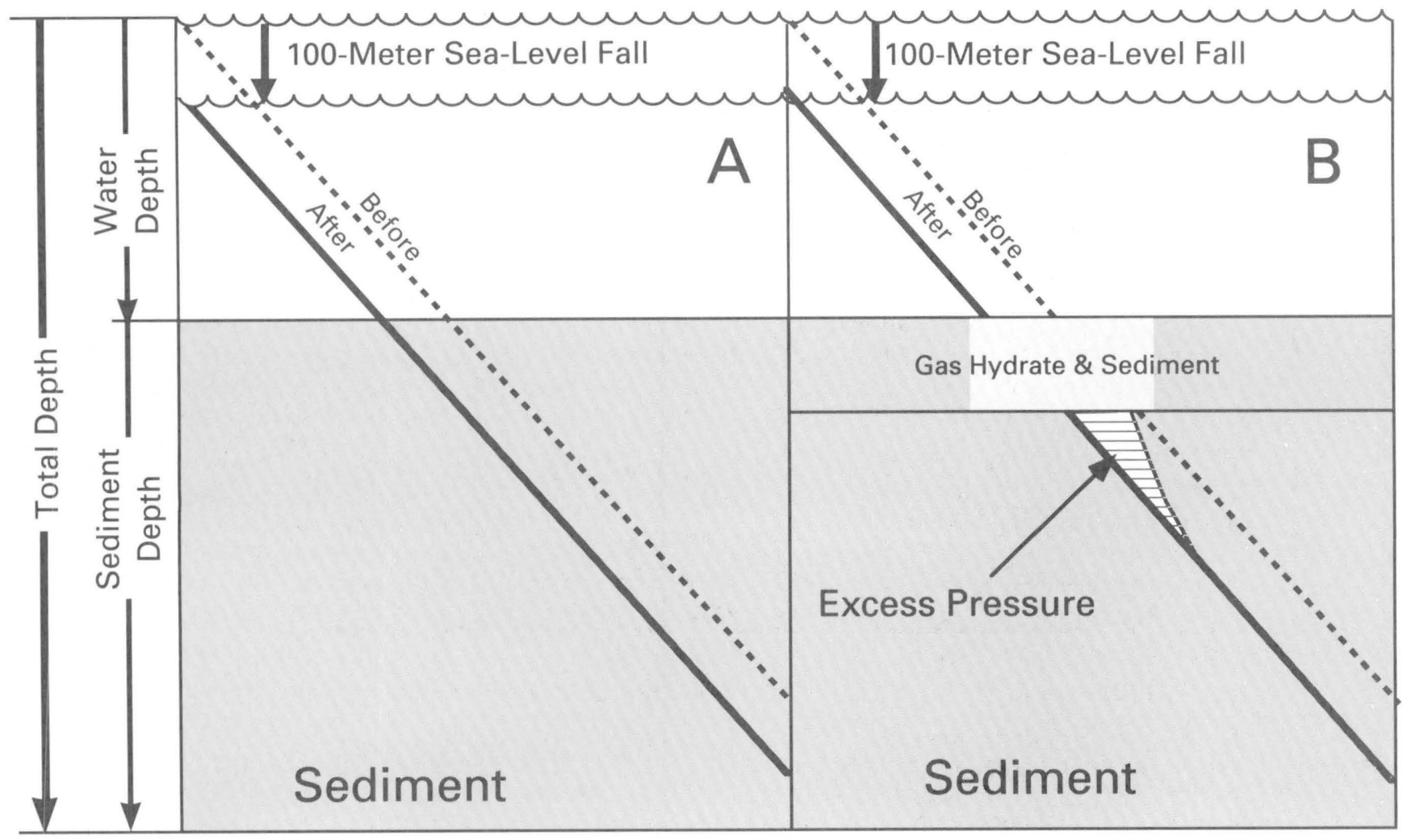

Pore-Water Pressure

Pore-Water Pressure

\section{A) Without Gas Hydrate}

B) With Gas Hydrate

Figure 5. Pressure profiles before and after a 100- meter sea-level fall caused by a glaciation cycle are displayed for $(A)$ normal sea floor without gas hydrate and $(B)$ sea floor bearing gas hydrate. The dashed line marks the hydrostatic pressure profile before sea-level fall. The solid line marks the pressure profile at the completion of the sea-level fall. Without gas hydrate, sea-floor sediment can fully adjust to the lowering of sea level, and a hydrostatic pore-water pressure profile can be maintained. The presence of gas hydrate prevents the normal reduction of pressures with sea-level fall because the lowering of pressure initiates disassociation along the base. This excess pressure reduces slope stability if the sea floor is inclined. tal slope, the amount of excess pore-water pressure that will cause slope failure can be calculated using basic soil mechanics principles (Kayen, 1988). The range of pressures likely to trigger slope failure of a 100- and 200-m-thick sedimentary deposit on a $5^{\circ}$ sea-floor slope, typical of the Beaufort margin, is presented in figure 8. Superimposed on this critical range of pore pressures are the pressures likely to be generated at a gas-hydrate base during disassociation induced by sea-level fall.

For finer-grained sediment, dissipation of excess pressures through sediment pore space is probably sufficiently slow to cause slope failure on the continental slope of the Beaufort Sea. Stability is maintained only if excess pressures are rapidly vented away from a disassociating base, perhaps along fault planes. Stability may also be maintained if gas hydrate forms in the pore space of strongly cemented sediment or in the joint space (cracks) of a consolidated rock mass. In both cases, the materials have high inherent cohesive strengths. For many of the unlithified sedimentary deposits on the Beaufort Slope, however, excess pressure generation at the base of the gas-hydrate zone during Pleistocene drops in sea level was sufficient to initiate sea-floor landsliding (Kayen, 1988). This mechanism for triggering mass movement probably also applies to the numerous other regions of the world where gas hydrate is present within sea-floor sediment (Lee, Schwab, and Booth, this report; Popenoe, Schmuck, and Dillon, this report). Accordingly, times of lowered sea level during ice ages also are times of widespread instability of continental slopes that are underlain by gas hydrates. 


\section{Clayey Sediment}

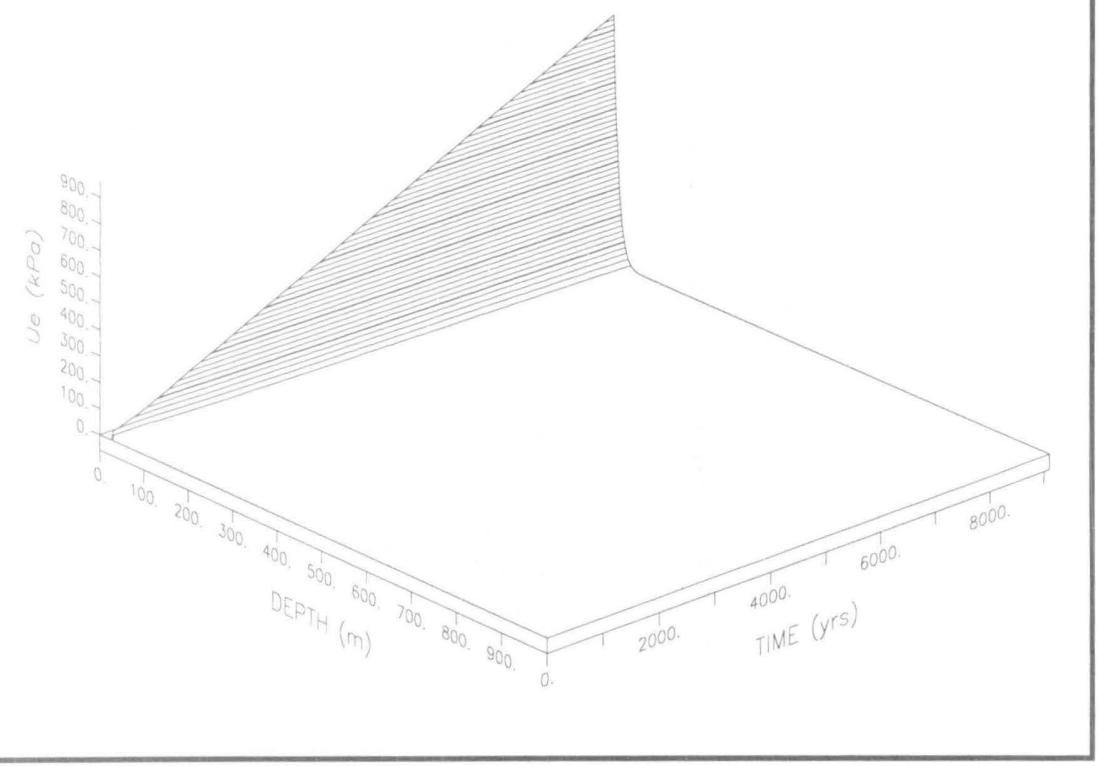

Figure 6. This three-dimensional block diagram demonstrates the excess porewater pressures (in kilopascals) in clayey sediment beneath a gas hydrate base during a sea-level drop predicted by a finite-difference model. The lower left axis is the depth below the hydrate base; the lower right axis is time during which sea level falls steadily by 100 meters. The upper left-hand (vertical) axis shows the predicted pore-water pressures, $\mathrm{u}_{\mathrm{e}}$, in excess of hydrostatic. Because clayey sediment has low fluiddissipation properties, pressures cannot readily diffuse away from the disassociating base. The excess pressures generated at the base are maintained, as seen by the tightly grouped isobars. Consequently, disassociation of the base is severely limited and a condition of high excess pressure exists. Such a condition can lead to slope instability.
Figure 7. In contrast to figure 6, excess pore-water pressures (in kilopascals) generated beneath the base of a decomposing gas hydrate within sandy sediment can more readily dissipate away from the gas-hydrate base as seen by the broad fan of isobars. As a result, disassociation of the base occurs more rapidly than clayey sediment, and the base retreats upward in the sediment column where equilibrium pressures are lower. Consequently, relative to slopes of clayey sediment, there are lower excess pressures within a sandy slope at any given time during a sea-level fall. The sandy slope would probably be less likely to fail.

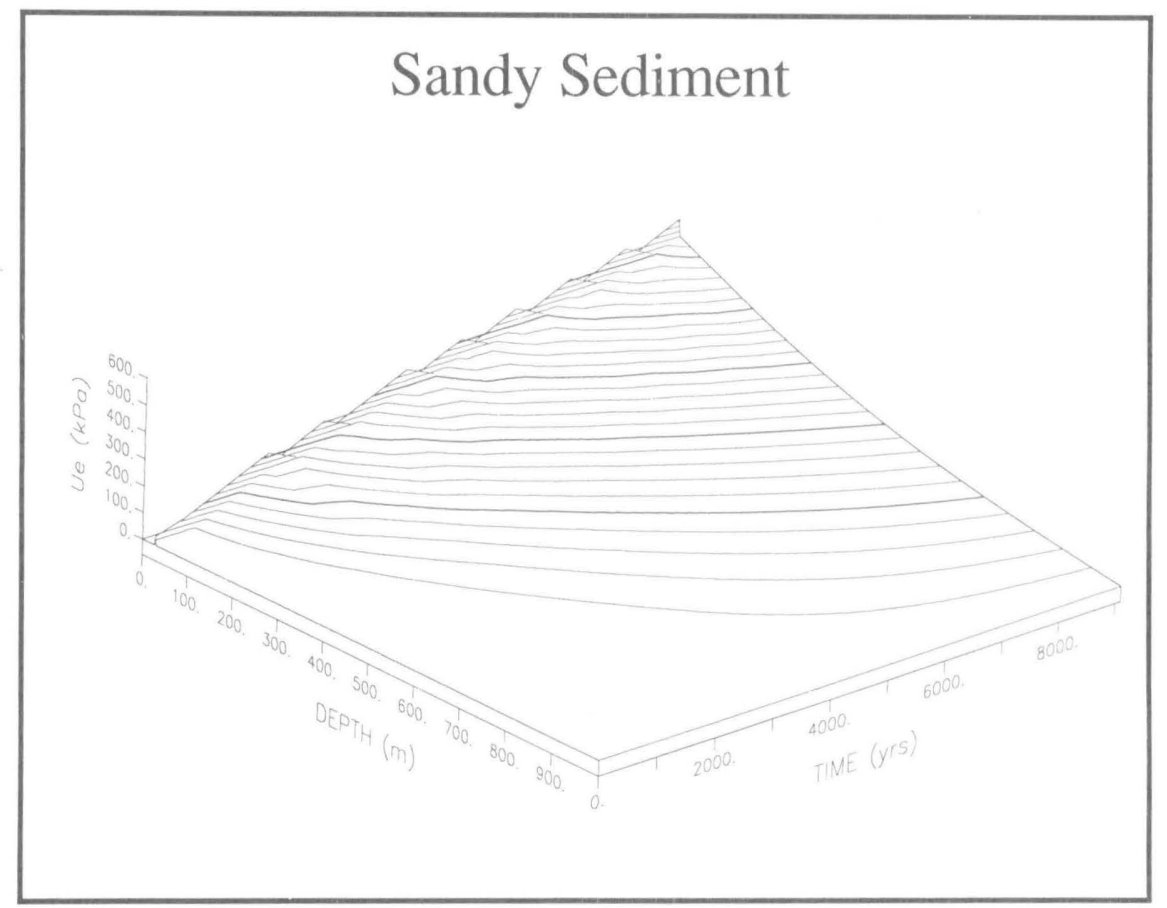




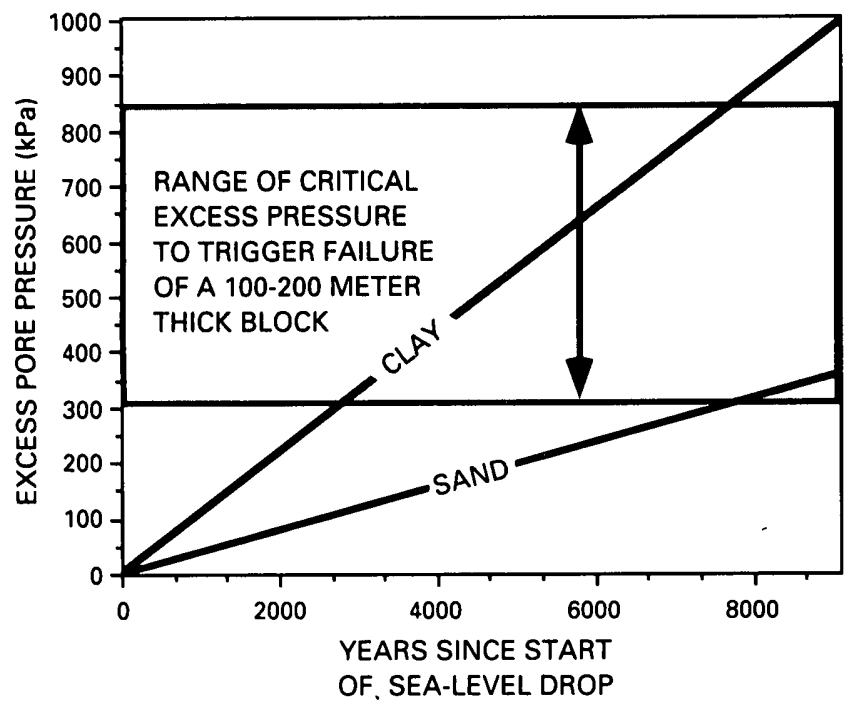

Figure 8. Predicted excess pore-water pressures (in kilopascals) generated at the base of a disassociating gas hydrate (diagonal lines) during a 100-meter sea-level fall are presented against, and exceed, a range of likely excess pressures required to initiate slope failure (horizontal lines). For sandy to clayey sediment, slope failure is predicted unless excess pore pressures can be rapidly vented to the sea floor through alternate conduits.

\section{REFERENCES CITED}

Bloom, A.L., Broecker, W.S., Chappell, J.M.A., Matthews, R.K., and Mesolella, K.J., 1974, Quaternary sea level fluctuations on a tectonic coast: New ${ }^{230} \mathrm{Th} /{ }^{234} \mathrm{U}$ dates from the Huon Peninsular, New Guinea: Quaternary Research, v. 4, p. 185-205.

Carpenter, G., 1981, Coincident sediment slump/gas hydrate complexes on the U.S. Atlantic continental slope: GeoMarine Letters, v. 1, p. 29-32.
Chappell, J.M.A., 1974, Geology of coral terraces, Huon Peninsula, New Guinea: a study of Quaternary tectonic movements and sea level changes: Geological Society of America Bulletin, v. 89 , p. 356 .

Field, M.E., and Kvenvolden, K.A., 1985, Gas hydrates on the northern California continental margin: Geology, v. 13, p. 517-520.

1986, Reply on "Gas hydrates on the northern California continental margin": Geology, v. 14, p. 537-538.

Grantz, Arthur, and Dinter, D.A., 1980, Constraints of geologic processes on western Beaufort oil developments: Oil and Gas Journal, v. 78, p. 304-319.

Grantz, Arthur, Eittreim, S.L., and Whitney, O.J., 1981, Geology and physiography of the continental margin north of Alaska and implications for the origin of the Canada Basin, in Nairn, A.S., Chamber, M.T., and Stehli, F.A., eds., The ocean basins and margins: Plenum Publishing Corp., p. 439-492.

Grantz, Arthur, and Greenberg, A.L., 1981, High-resolution uniboom seismic reflection profiles from the Beaufort Sea, 1977: U.S. Geological Survey Open-File Report 81-34.

Kayen, R.E., 1988, Arctic Ocean landslides and sea-level fall induced gas hydrate decomposition: M.S. Thesis, California State University, Hayward, 227 p.

Kvenvolden, K.A., Claypool, G.E., Threlkeld, C.N., and Sloan, E.D., Jr., 1984, Geochemistry of a naturally occurring massive marine gas hydrate: Organic Geochemistry, v. 6, p. 703-713.

Kvenvolden, K.A., and McMenamin, M.A., 1980, Hydrates of natural gas: a review of their geological occurrence: U.S. Geological Survey Circular 825, $11 \mathrm{p}$.

Makogon, Y.F., 1981, Hydrates of natural gas (translation of: Gidraty prirodnykh gazov): PenWell Publishing Company, Tulsa, Oklahoma, p. 237.

Matthews, R.K., 1973, Relative elevation of late Pleistocene high sea level stands: Barbados uplift rates and their implications: Quaternary Research, v. 3, p. 147-153.

Sloan, E.D., Jr., 1990, Clathrate hydrates of natural gases: New York, Marcel Dekker.

Steinem, R.P., Harrison, R.S., and Matthews, R.K., 1973, Eustatic low stand of sea level between 125,000 and 105,000 B.P.: Evidence from the sub-surface of Barbados, West Indies: Geological Society of America Bulletin, v. 84, p. $63-70$. 


\title{
Mass Movement Related to Large Submarine Canyons Along the Beringian Margin, Alaska
}

\author{
By P.R. Carlson, H.A. Karl, B.D. Edwards, J.V. Gardner, and R. Hall
}

\section{INTRODUCTION}

The 1,400-kilometer-long Beringian continental slope extends between the Aleutian Islands and the Soviet Far East and divides the Bering Sea into the wide, shallow Bering Sea shelf and the deep Aleutian Basin (fig. 1). The continental slope and outer shelf of the U.S. part of the
Beringian margin is dissected by seven large submarine canyons, several of which are among the world's largest (Carlson and Karl, 1988). Recently collected GLORIA sidescan-sonar imagery has documented the importance of mass movement in shaping the entire Beringian continental margin.

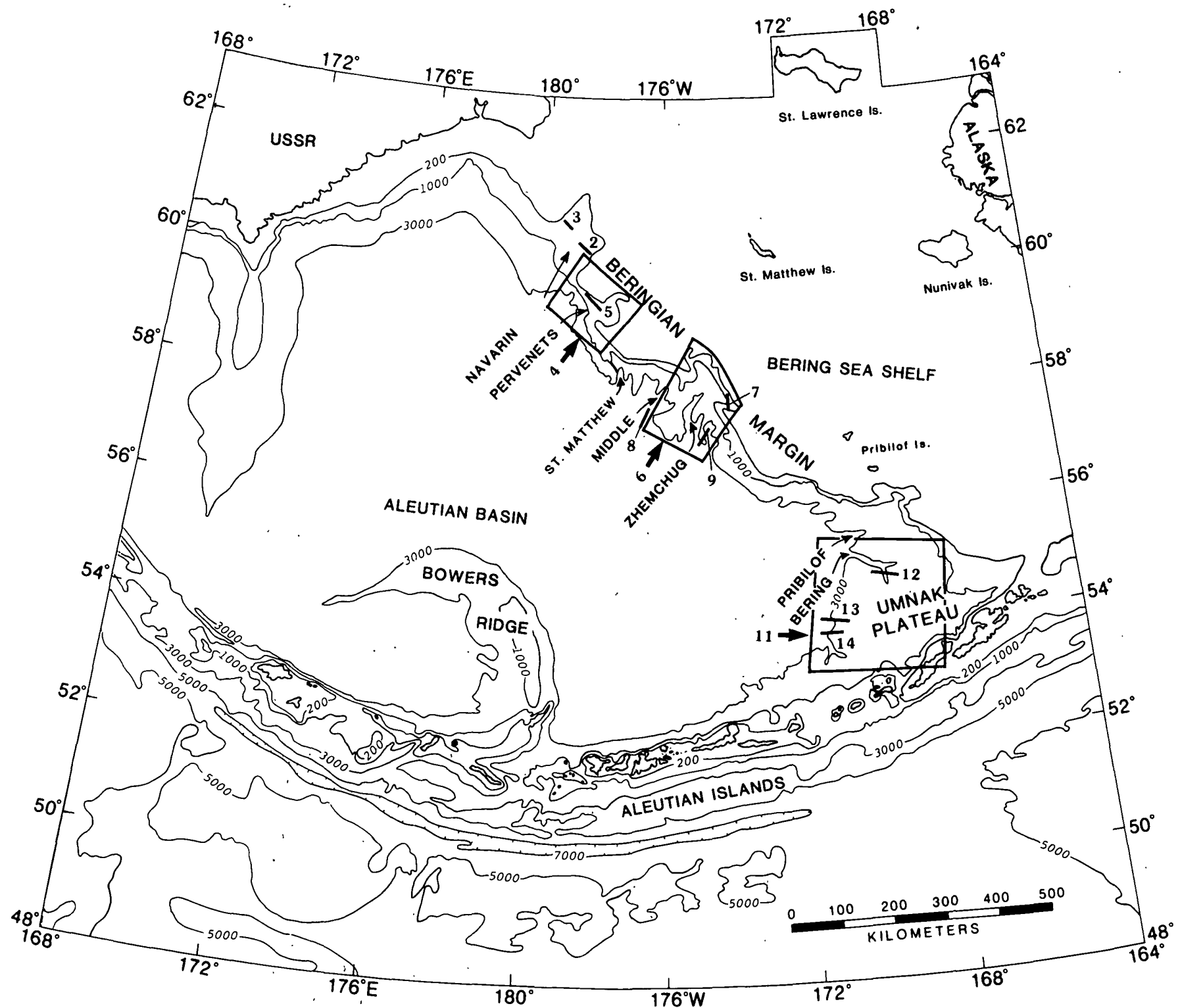

Figure 1. The Beringian margin, incised by several large canyons, lies between the Bering Sea shelf and the Aleutian basin. The seismic-reflection profiles and GLORIA images shown in figures 2 to 14 are'indicated by numbered lines and outlined areas. 


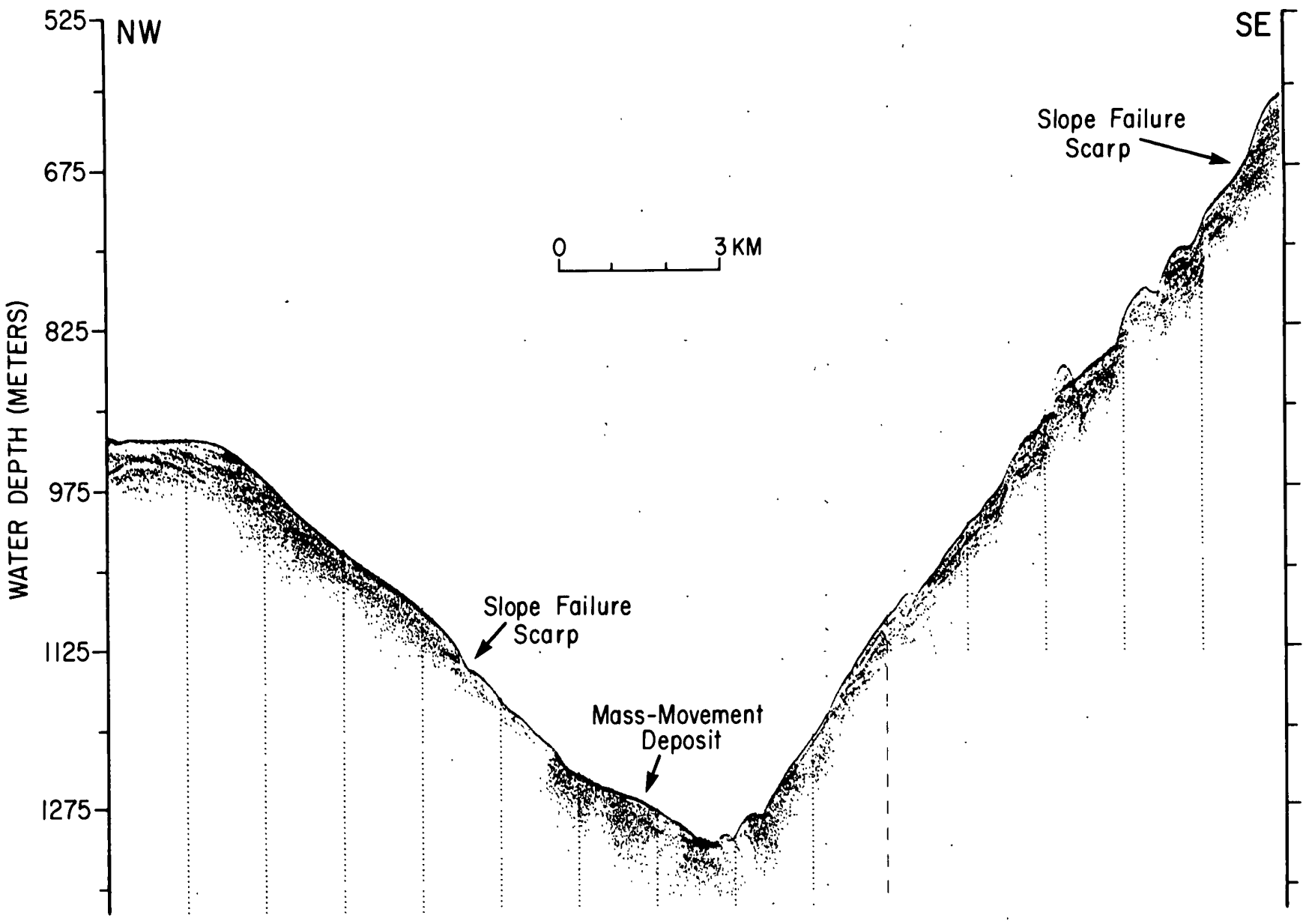

Figure 2. Seismic-reflection profile (3.5 kilohertz) across southeast branch of Navarin Canyon showing slope failure scarps, about 15 meters high, on both walls and mass-movement deposits several tens of meters thick on the canyon floor.

Soviet scientists were some of the first to study the Beringian margin and discovered several of the canyons (Kotenev, 1965). U.S. scientists began to study the area in the late 1960's (Scholl and others, 1968), and petroleum lease sales efforts in the 1970's and early 1980's intensified scientific interest. In 1986, the U.S. Geological Survey conducted three GLORIA (Geological LOng-Range Inclined Asdic) sidescan-sonar surveys that covered the entire Beringian slope and provided a reconnaissance image of this frontier region.

This report illustrates the large canyons that are incised in the margin and demonstrates that these canyons have been shaped by several styles of mass movement, including mudflows, debris flows, slumps, and massive slides. The illustrations show bathymetric, GLORIA sidescan-sonar, and seismic-reflection data. We discuss selected mass-movement features of the Beringian margin in three segments, beginning in the north with Navarin Canyon, which straddles the U.S.-U.S.S.R. 1867 convention line, then shifting to the central part of the margin, which is dominated by Zhemchug Canyon, and ending with the southern margin, which includes two large canyons and an oceanic plateau (fig. 1).

\section{NORTHERN MARGIN}

Navarin Canyon, the most northerly (fig. 1) and the second largest of the Beringian canyons, is 258 kilometers $(\mathrm{km})$ long from its head to the base of the slope and has a width and relief, where it cuts the shelf edge, of $100 \mathrm{~km}$ and 1,150 meters (m), respectively (Carlson and Karl, 1988). Many of the seismic-reflection profiles across Navarin Canyon show slope-failure scarps on both walls and massmovement deposits on the canyon floor (fig. 2). Massmovement features were identified along $830 \mathrm{~km}$ of a total of $2,570 \mathrm{~km}$ of seismic-reflection profiles ( 32 percent) collected across the northern Beringian margin (Carlson and Karl, 1984/85). An example of a relatively thick landslide mass on the floor of Navarin Canyon is presented in figure 3 . Figure $3 A$ shows a seismic-reflection profile collected in 1980 that crosses the axis of Navarin Canyon transversely 


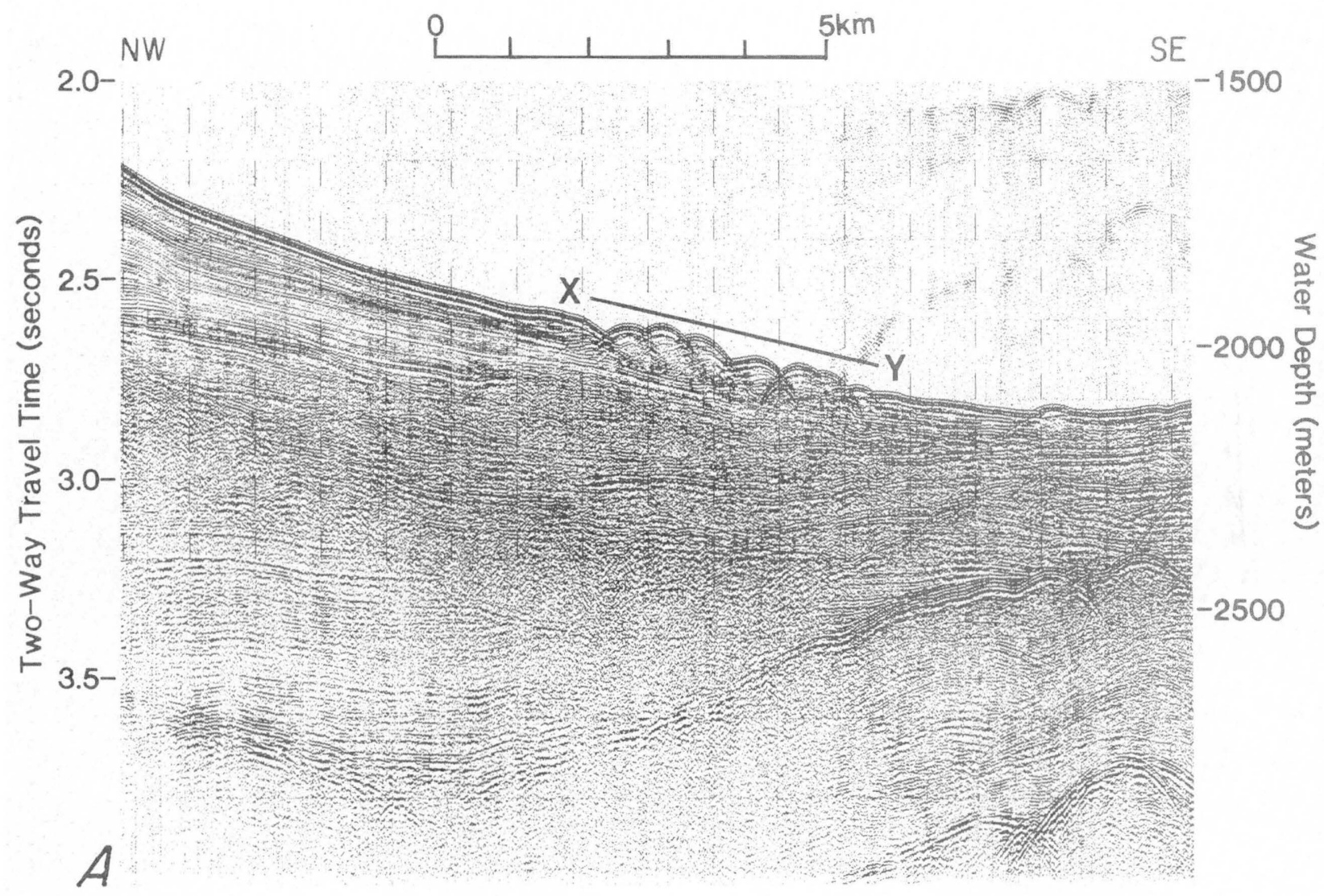

NW
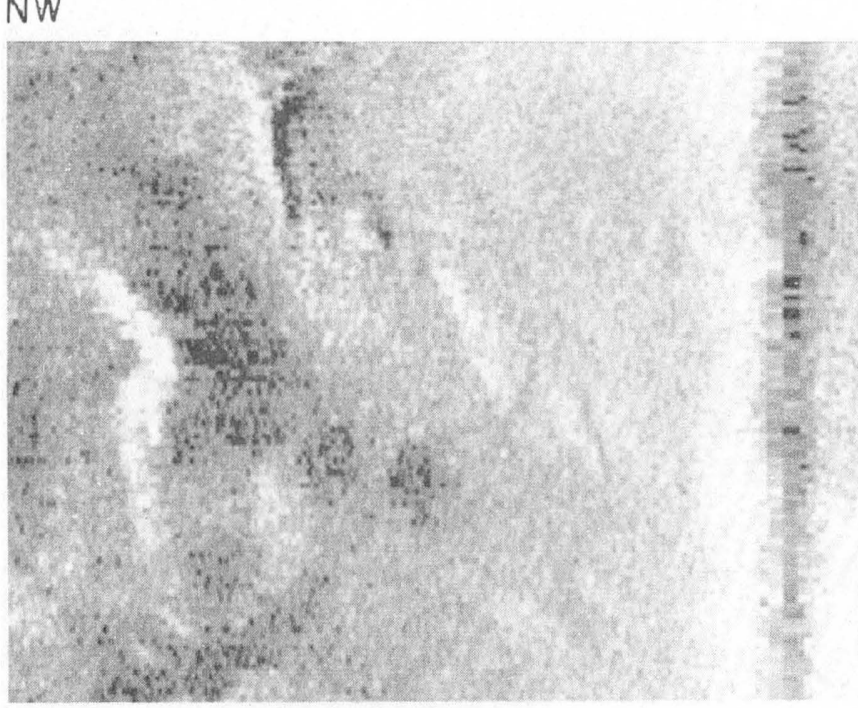

\section{$B$}

0

$10 \mathrm{KM}$

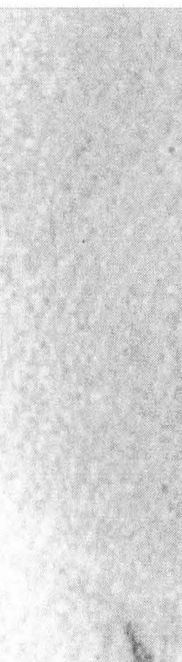

SE

Figure 3. Two views of a mass-movement deposit on the floor of Navarin Canyon, (A) seismic-reflection profile showing hummocky, crumpled sediment constituting the toe of a mass-movement deposit. The ship track was run transverse to the axis of the canyon (vertical exaggeration is $10 \times)$. (B) GLORIA sidescan-sonar image showing same hummocky toe $(X-Y)$. The width of this deposit is about 10 kilometers. The trackline of the GLORIA image is located on the canyon wall about 5 kilometers to the left (northwest) of the seismic-reflection profile. 


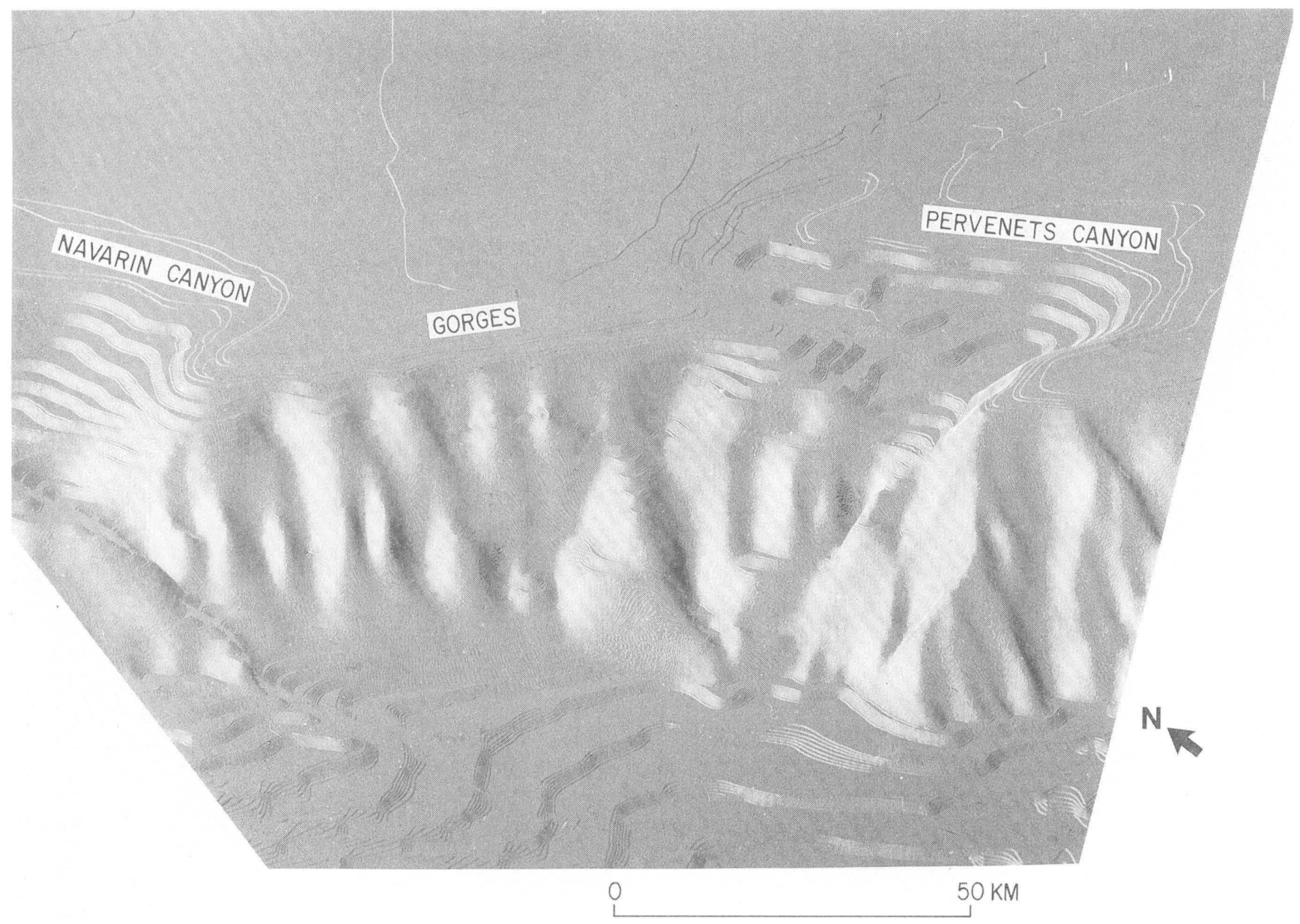

Figure 4. Three-dimensional shaded-relief image of bathymetry showing relatively small canyons (gorges) incised in the slope between Navarin and Pervenets canyons. This computer-processed image uses a look-angle of $45^{\circ}$ above the horizon and has a vertical exaggeration of $5 \times$.

and shows the hummocky nature of the 100-m-thick toe of a landslide (X-Y). In 1986, our GLORIA survey of this area imaged this same landslide deposit (fig. 3B). The seismic-reflection profile shows that the landslide deposit is about $100 \mathrm{~m}$ thick. By combining the map view provided by the GLORIA image and the sediment thickness provided by the seismic profile, we can calculate the volume of sediment disturbed to be at least $5 \mathrm{~km}^{3}$.

Several relatively small canyons, 5 to $10 \mathrm{~km}$ wide, are incised into the $100-\mathrm{km}$-long upper slope between Navarin and Pervenets canyons (fig. 4). GLORIA imagery of the upper slope near the heads of these small canyons, suggests that these incisions may have been initiated by sliding of large sedimentary blocks (fig. 5). These blocks are as large as several kilometers across, thus, nearly the width of the small canyons.

\section{CENTRAL MARGIN}

The central part of the Beringian margin is dominated by the massive Zhemchug Canyon (fig. 6). The submarine canyon, with a volume at $5,800 \mathrm{~km}^{3}$ is the world's largest. It is $168 \mathrm{~km}$ long from its head to the base of the slope, and at the shelf edge, its incision has a relief of $2.6 \mathrm{~km}$ and a width of $100 \mathrm{~km}$ (Carlson and Karl, 1988). Most seismicreflection profiles across the Zhemchug Canyon system show evidence of mass movement. Some mass-movement deposits are composites of multiple events that accumulated on the floor of the canyon and severely constricted the axis of the canyon (fig. 7). Such constrictions along the axis of the canyon inhibit water circulation as well as mass flows down the canyon. In the development of submarine canyons, as well as subaerial canyons, however, such constric tions or dammings are geologically short lived, as long 

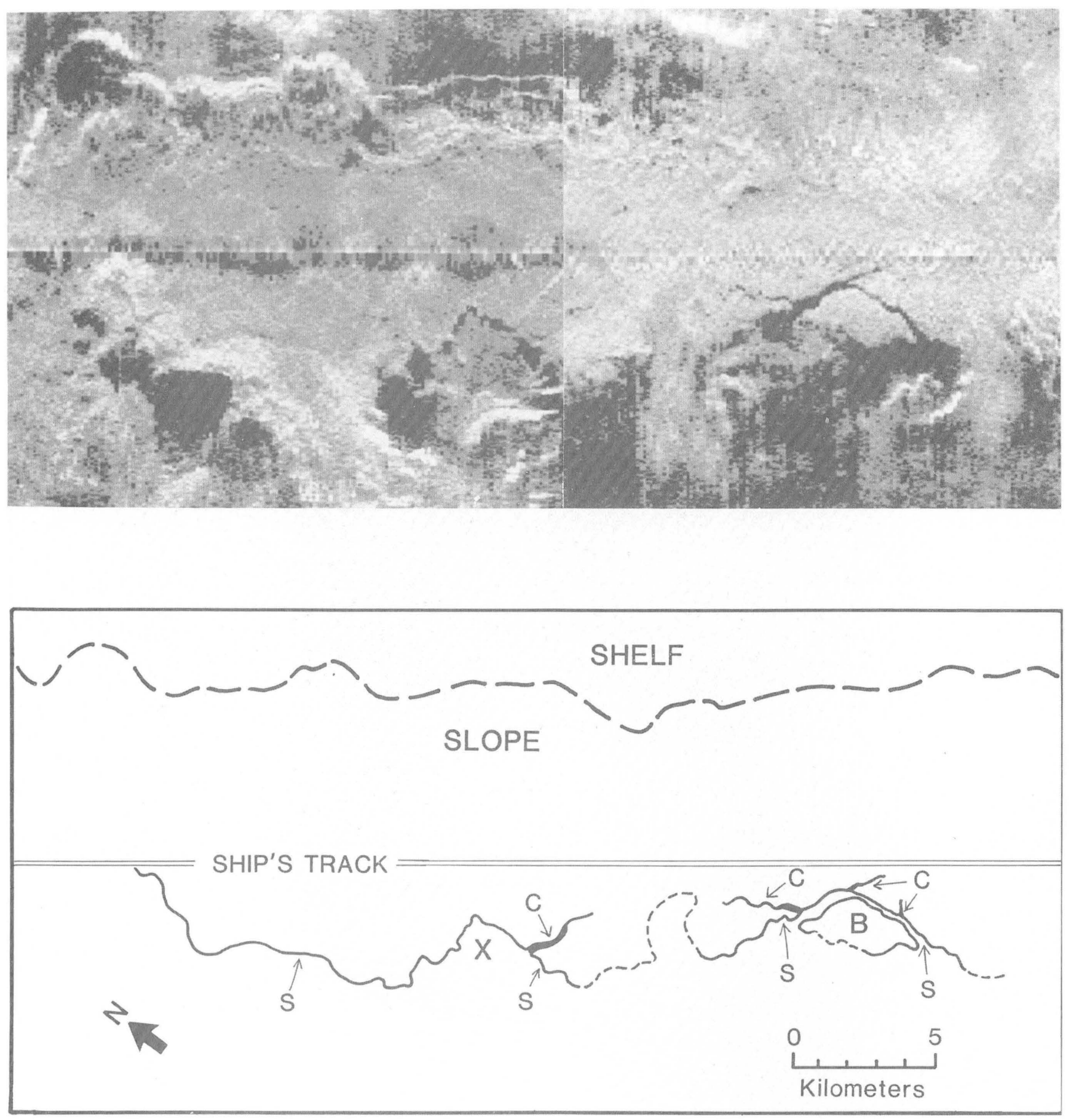

Figure 5. GLORIA sidescan-sonar image and interpretive sketch of upper slope area between Navarin and Pervenets canyons showing a 4-kilometer long, 2-kilometer wide block (B) that has slipped away from long irregular scarps (S). One scarp can be traced for 26 kilometers along the slope. Cracks (C) have developed at several locations along the scarp. A large block has slipped down at left of center of image from evacuated area (X). as the canyon-forming processes are active. Cores collected on the basin floor at the mouth of the canyon contain graded sand and silt layers and shallow-water organisms, evidence of the transporting power of mass flows that in some instances originated at the shelf edge (Carlson and Karl, 1988). 


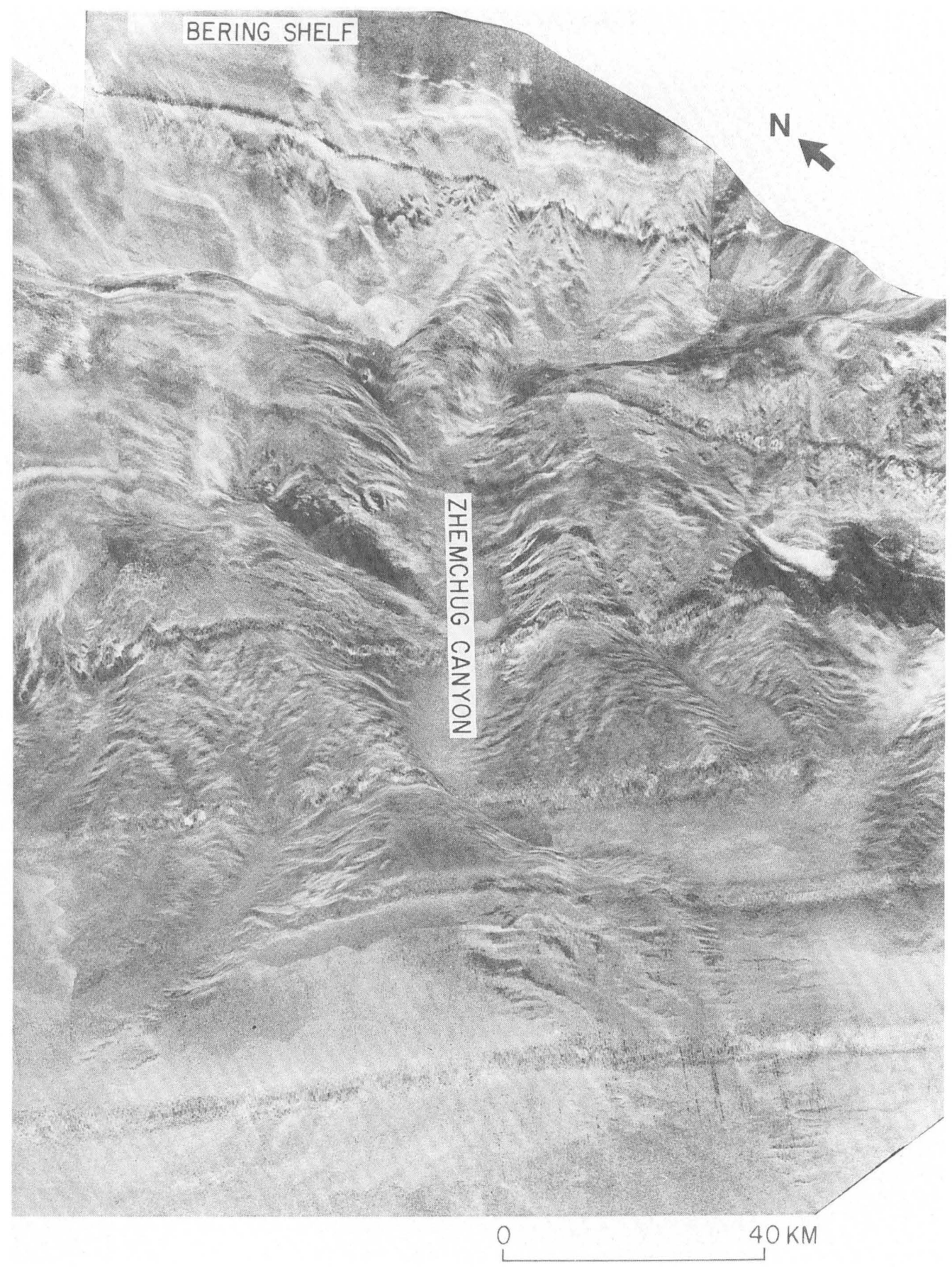

Figure 6. GLORIA sidescan-sonar imagery merged with bathymetry of the central Beringian slope including Zhemchug Canyon. The look angle is $45^{\circ}$ and vertical exaggeration is $5 \times$. The canyon walls and lower continental slope are intensively gullied. Some of the large mounds near the base of the slope are enormous slide masses whose edges are also highly gullied. 


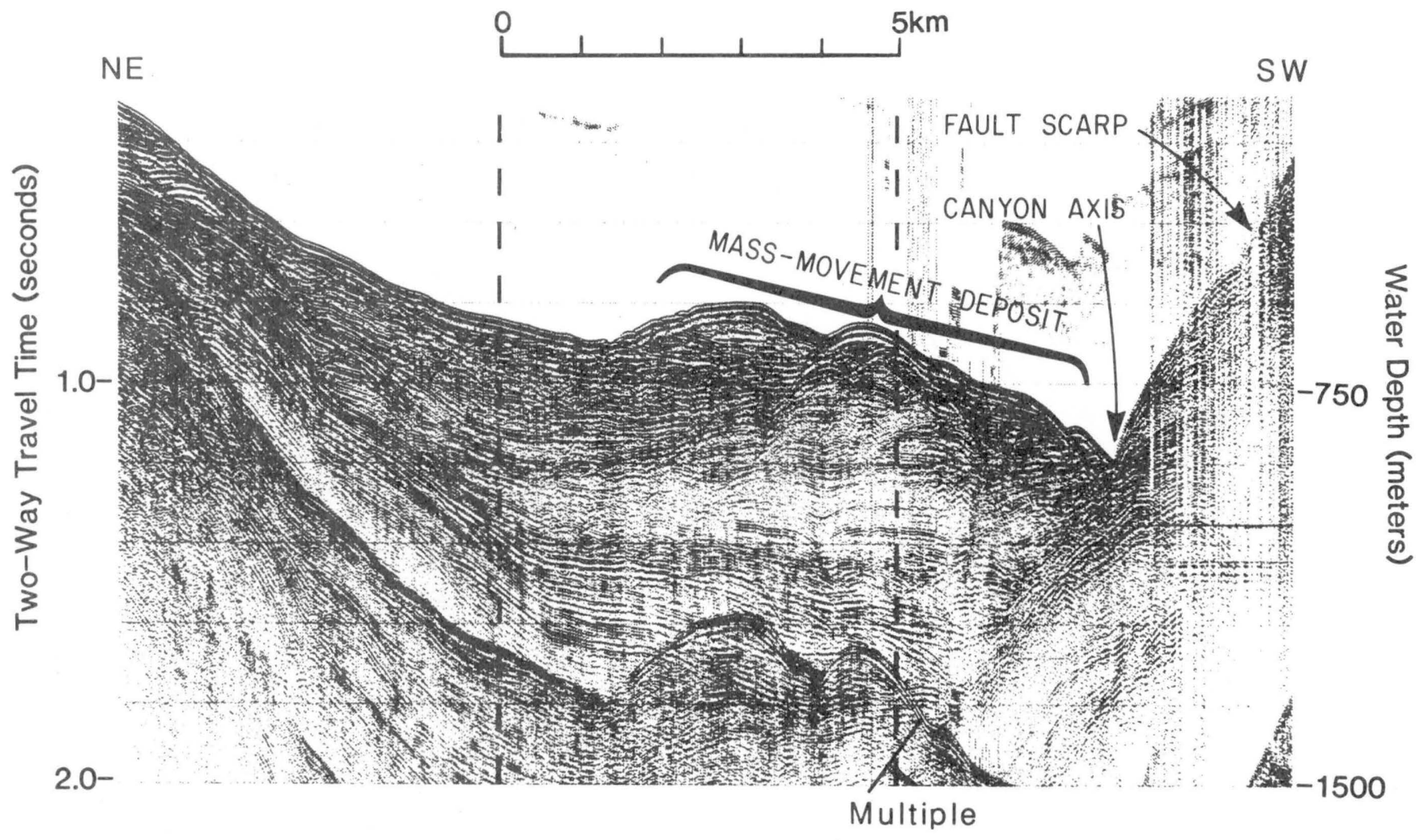

Figure 7. Seismic-reflection profile across upper Zhemchug Canyon showing the complex mass-movement deposit that has accumulated on the floor of the canyon, constricting the down-canyon axial flow. A fault scarp

forms the southwest wall of the canyon. The southeast branch of the canyon was eroded along this scarp after the shelf edge was breached by the headward erosion of the canyon. 


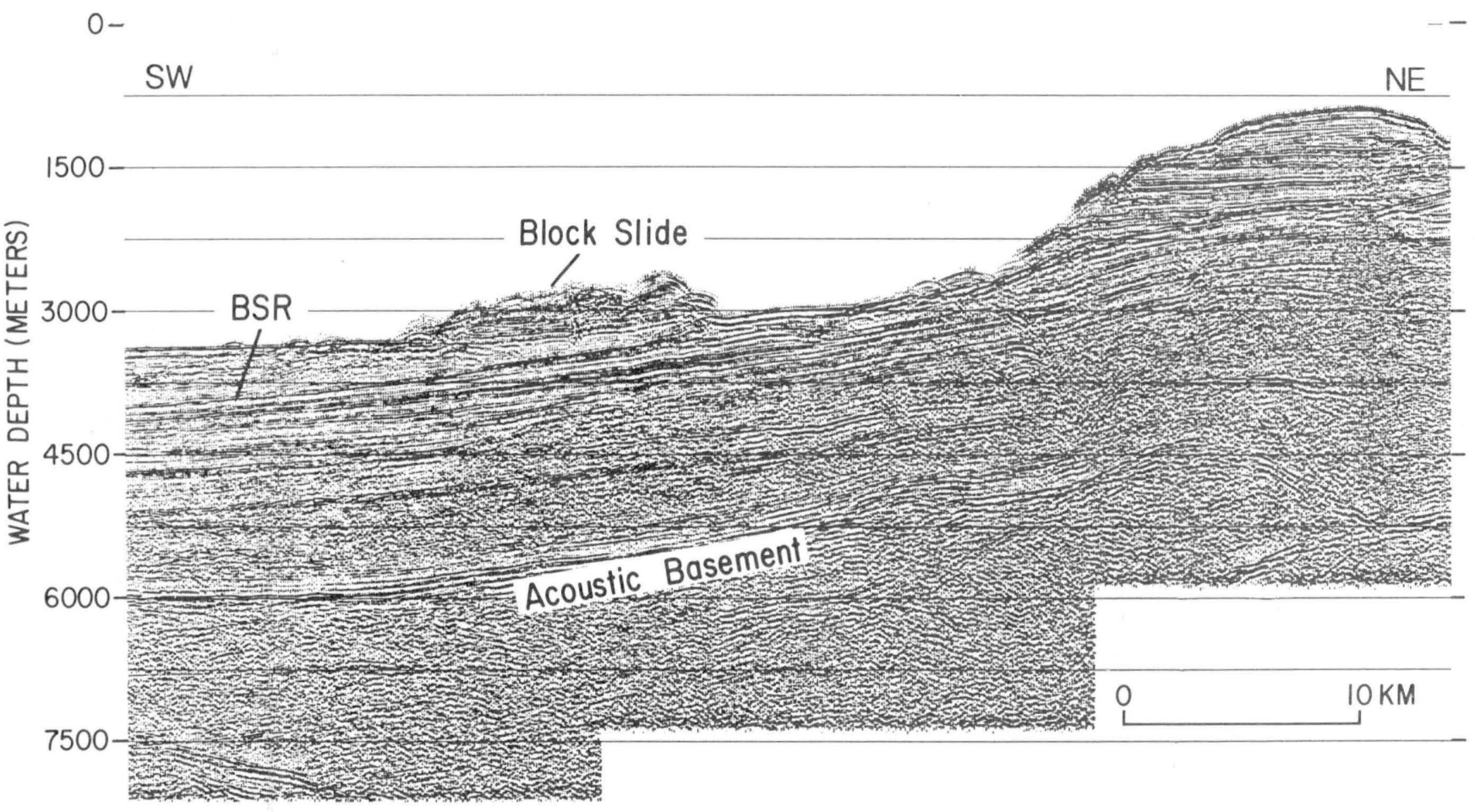

Figure 8. Seismic-reflection profile at base of slope seaward of Middle Canyon showing a large slide block (greater than 10 kilometers long and 500 to 800 meters thick). The bottom-simulating reflector (BSR), which has been speculated to be a silica diagenetic boundary (Cooper and others, 1987), may have been the slip surface for the large block.

Other slope failures along the central margin have generated large block slides (fig. 8) that have been found at the base of the slope near the mouths of several canyons (Carlson and Karl, 1984/85; Cooper and others, 1987; Karl and others, 1987). Some seismic-reflection profiles collected over this large slope failure show an internal reflector that cuts across layered reflectors (indicative of rock/sediment layers) and mimics the sea-floor slope (bottomsimulating reflector, BSR). In one example, a BSR coincides with the base of the slope-failure zone (fig. 8) and may be the glide plane along which the failed sediment mass moved. Similarly, a large sediment mass at the base of the slope near Zhemchug Canyon, also associated with a BSR (fig. 9), may have been one of the large blocks that was dislodged from the margin and slid downslope as Zhemchug Canyon was formed.

We hypothesize that Zhemchug Canyon was formed by headward erosion, principally by large block slides (fig. $10 A, B)$, until finally the shelf edge was breached and the canyon reached a series of outer-shelf parallel faults (fig. $10 \mathrm{C}$ ). Erosion then proceeded along the fault scarps nearly parallel to the shelf edge (fig. 10D). Subsequently, further mass movement has produced the intensively gullied walls evident on the GLORIA imagery (fig. 6).

\section{SOUTHERN MARGIN}

The southern part of the Beringian slope includes Pribilof and Bering canyons, but the dominant morphologic feature is the large, Umnak Plateau (fig. 1), whose flat summit is at a water depth of about 2,000 m (fig. 11). Bering Canyon, whose 400-km-long path is structurally controlled by the Aleutian Island arc and Umnak Plateau, and Pribilof Canyon, whose morphology and probably its genesis mimic that of Zhemchug Canyon, are both areas of extensive slope failures similar to those in other Beringian canyons (Scholl and others, 1970; Cooper and others, 1986; Stevenson and others, 1988). At the northeastern margin of Umnak Plateau, GLORIA imagery (fig. 12) shows slope failure, apparently resulting in mass flows that have moved down Bering Canyon and undercut the base of the slope.

An even larger slope failure, at the western edge of the plateau, can be observed on the GLORIA imagery (fig. 13). This slope failure is about $55 \mathrm{~km}$ long and $35 \mathrm{~km}$ wide. Nearby imagery (fig. 14) shows a small slope failure. Both of these slope failures are apparently associated with emergent diapirs (Cooper and others, 1986); a diapir is a fold in which a mobile core has risen and broken through brittle overlying rock and sediment (McGregor and others, this 


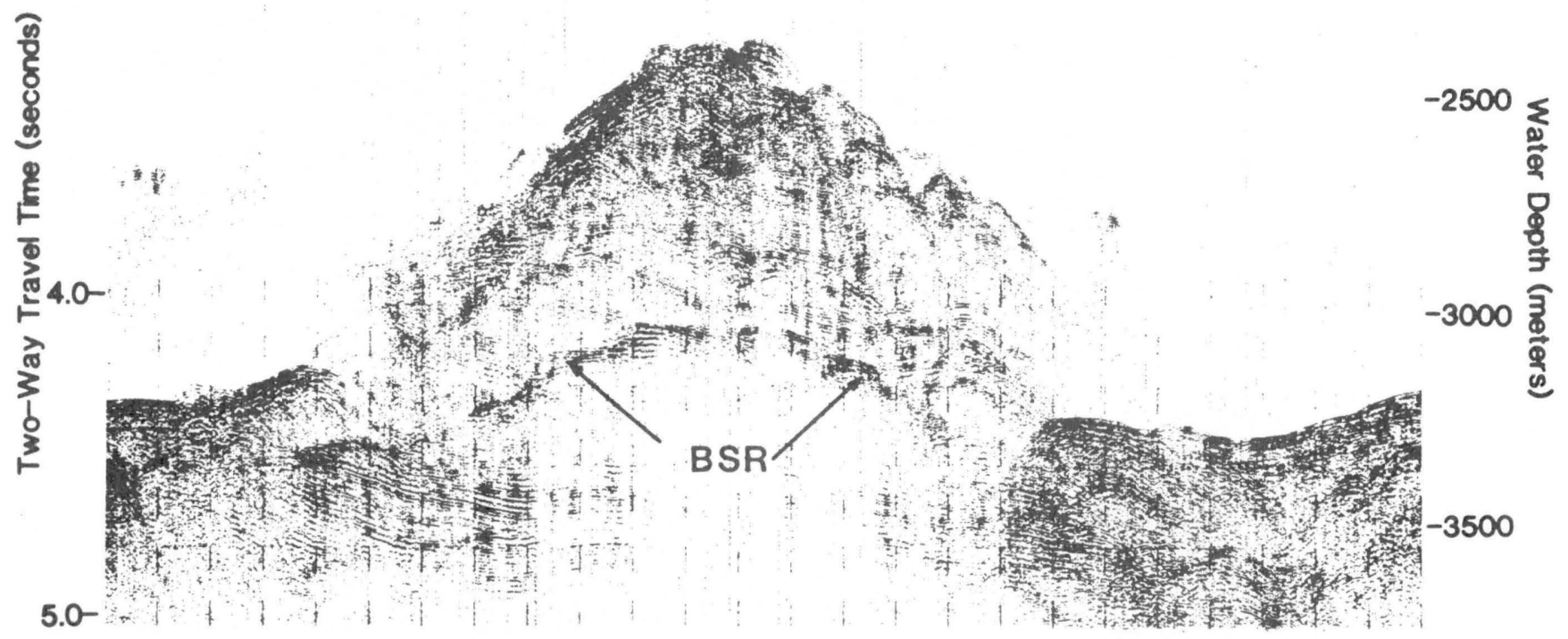

Figure 9. Seismic-reflection profile across large slide block near the mouth of Zhemchug Canyon. The bottom-simulating reflector (BSR) is probably a silica diagenetic boundary.
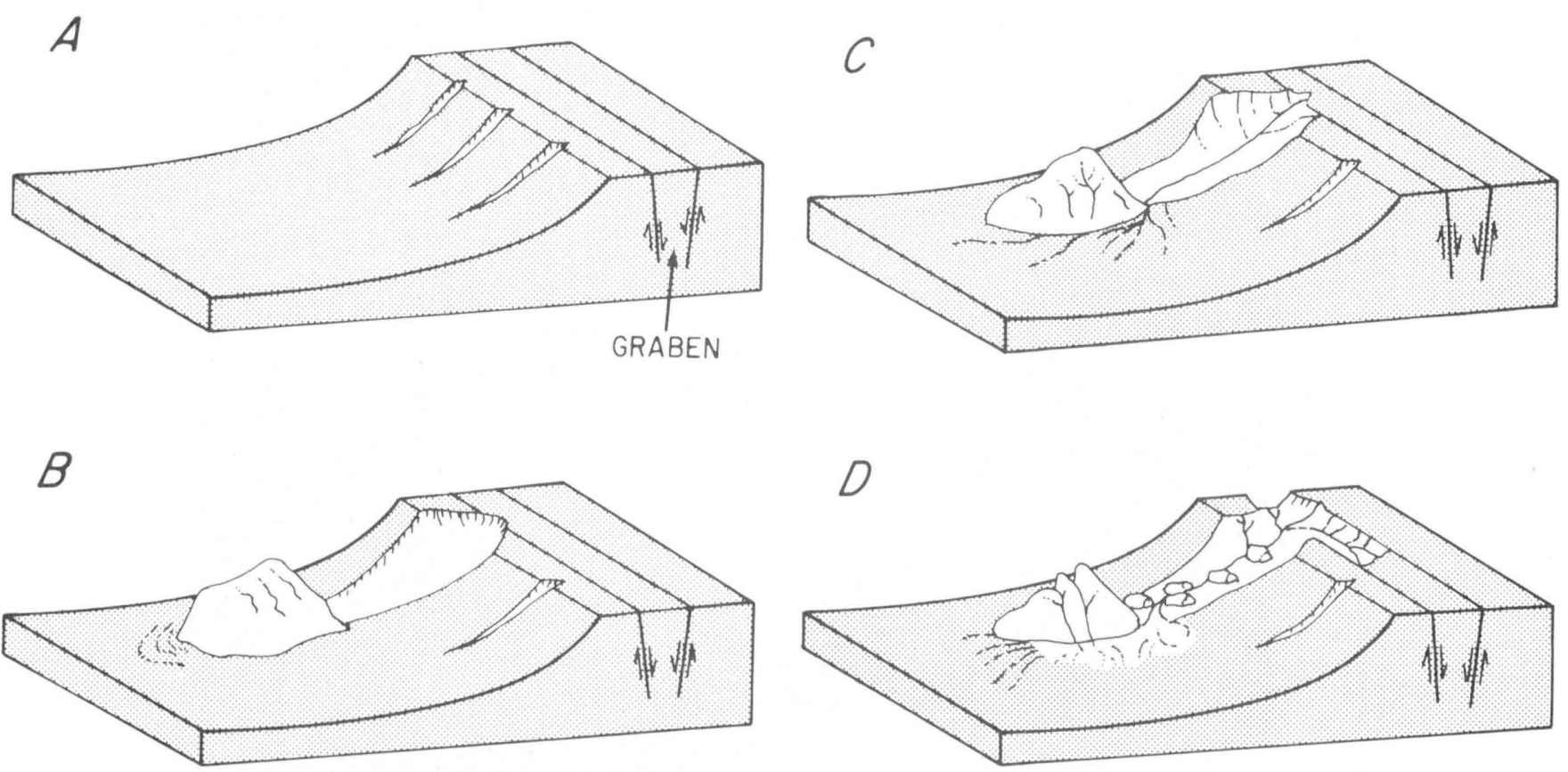

Figure 10. Hypothetical model of evolutionary development of Zhemchug Canyon. (A) Gullies begin eroding into upper slope. Outer shelf is cut by normal faults that are parallel to the shelf edge and a slight graben is formed. (B) Large blocks tear loose from upper slope initiating the breeching of the shelf-slope break. (C) Continuing mass

movement results in headward and lateral canyon excavation of the continental margin. Here, the headward growth of the canyon reaches the shelf-edge faults. (D) Excavation of canyon progresses laterally along the fault scarps and canyon develops its modern morphology. 


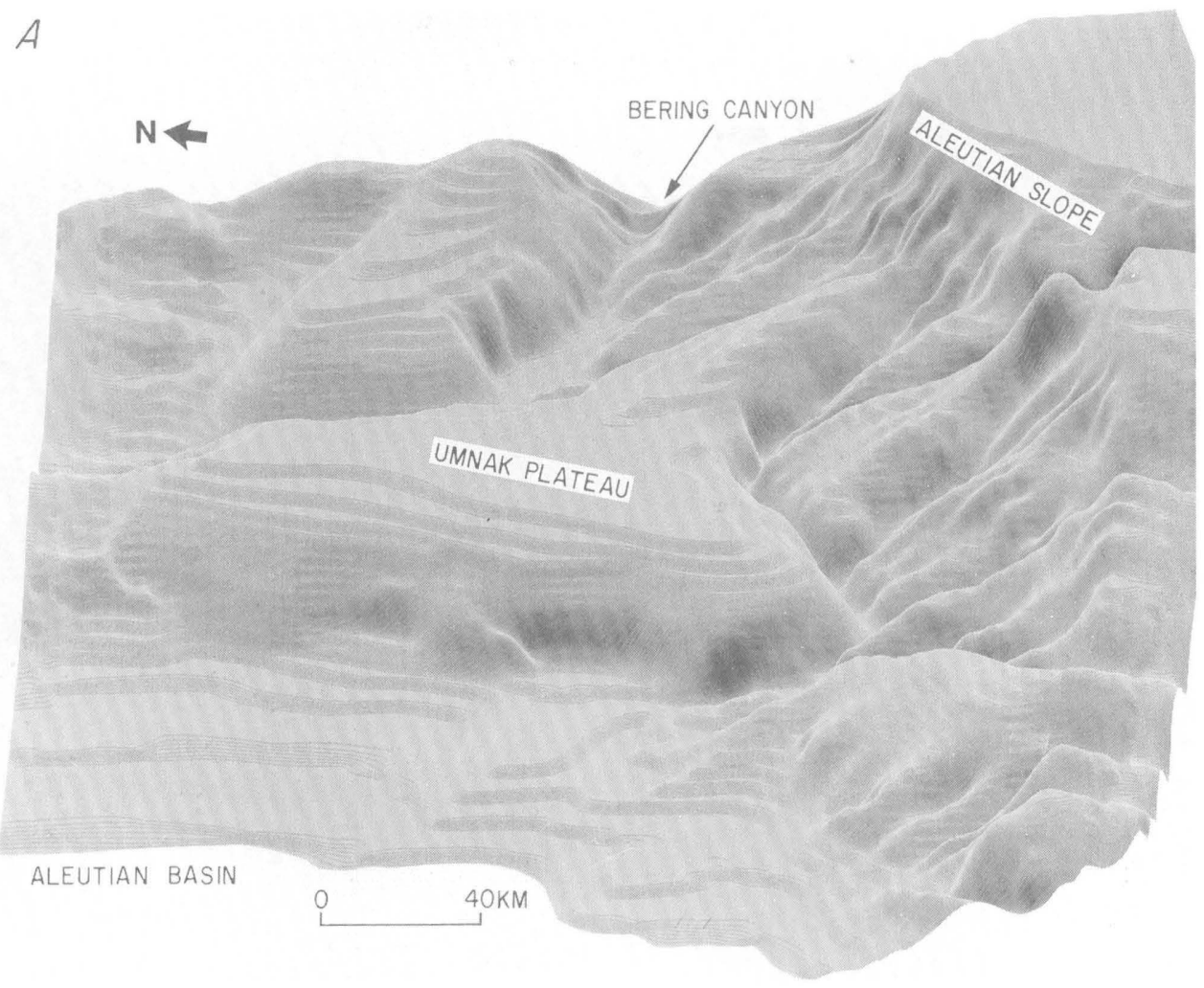

Figure 11. (A) Three-dimensional shaded relief image of Umnak Plateau and adjacent continental slope with a look angle of $20^{\circ}$ from the horizontal and a vertical exaggeration of $10 \times$.

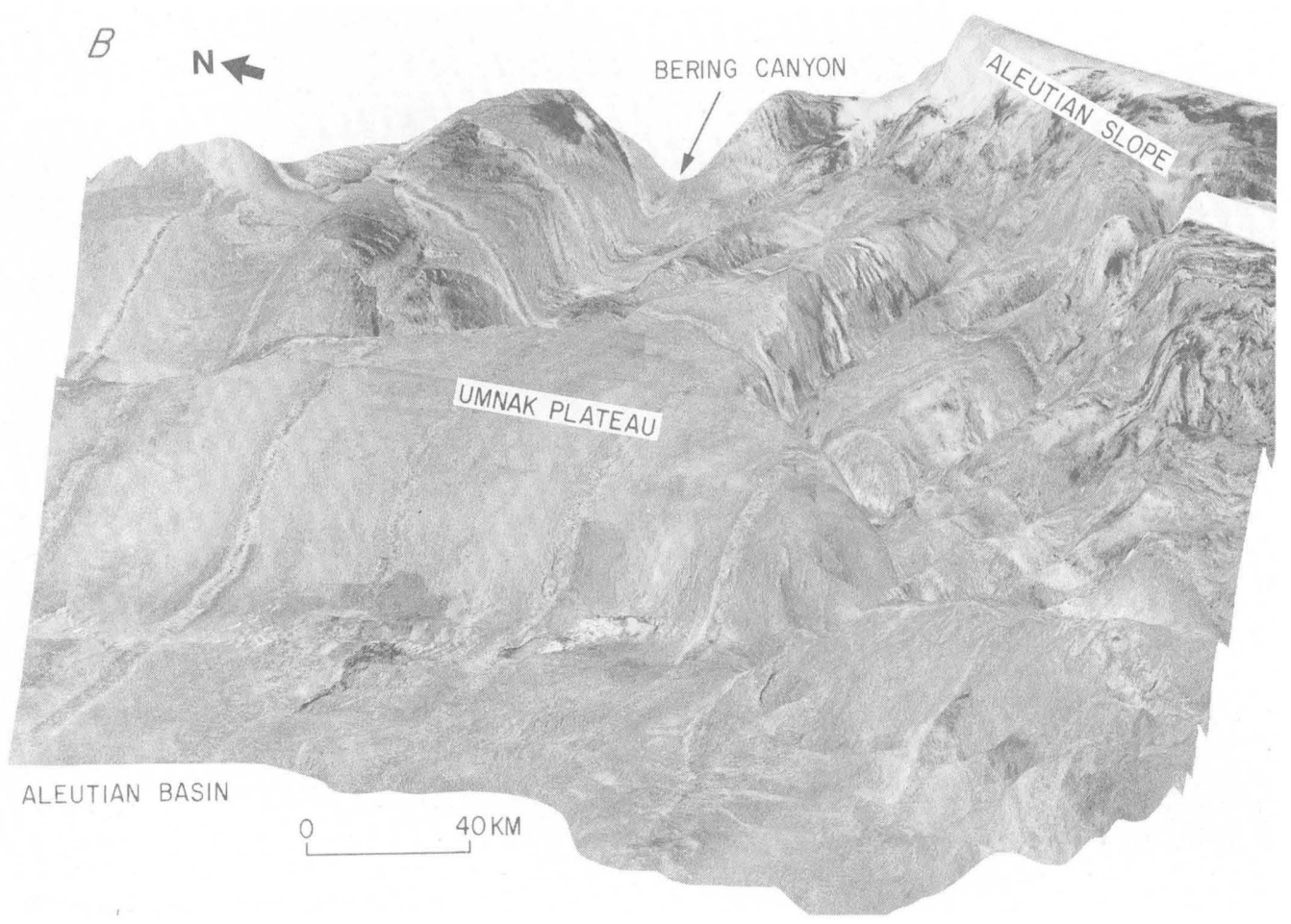

Figure 11. (B) GLORIA image of same area merged with bathymetry. 


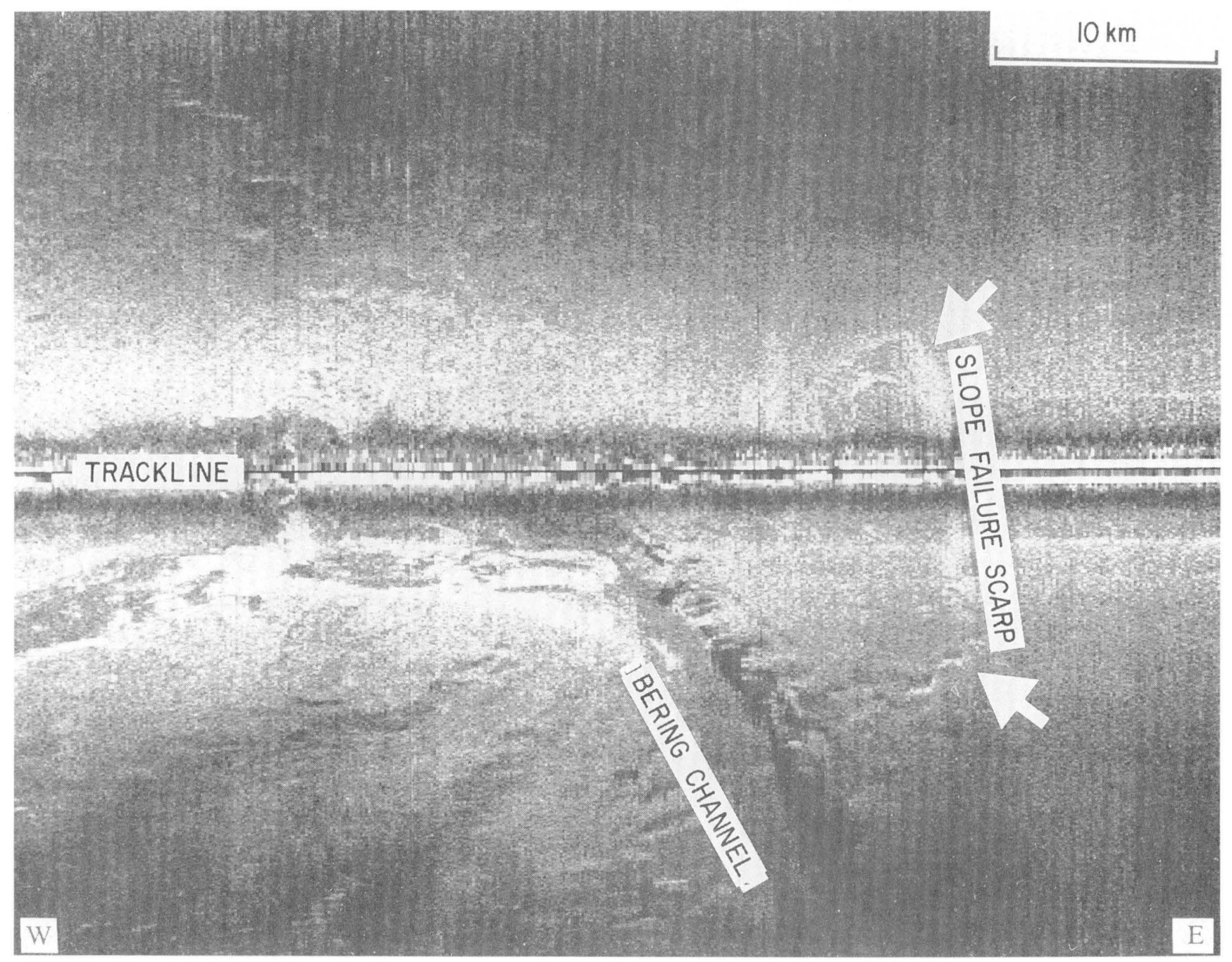

Figure 12. GLORIA sidescan-sonar image of a slope failure on eastern edge of Umnak Plateau, adjacent to Bering Canyon. Note that much of the debris from the slope failure has been removed from the channel. Based on the size of the slopefailure scarp, more than 18 cubic kilometers of sediment appears to have been incorporated in this mass movement. 


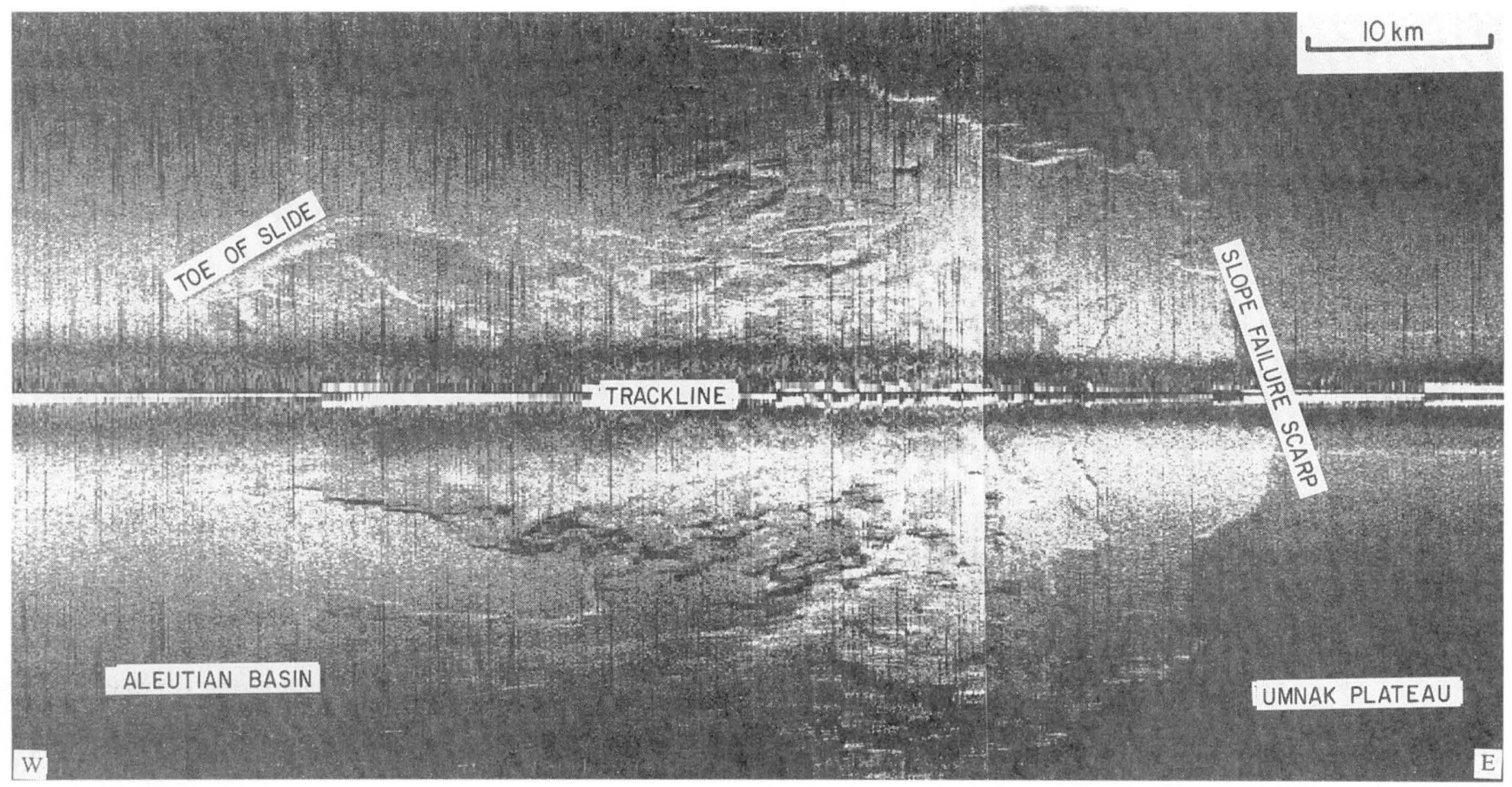

Figure 13. GLORIA sidescan-sonar image of a large slope failure on the western edge of Umnak Plateau. This 60 cubickilometer mass-movement deposit averages 150 meters in thickness and covers an area of 400 square kilometers.

report). This association suggests that the emplacement of these diapirs contributed to these failures.

\section{SUMMARY}

We have seen from seismic-reflection profiles and sidescan-sonar imagery that mass movement is a dominant and apparently on-going process that is sculpting the Beringian margin. The large canyons appear to have been excavated principally by mass-movement processes. The canyons grow headward by a combination of processes, but sliding of large blocks is volumetrically the most important. Slumps, block slides, and mass flows also provide the principal mechanisms for lateral and vertical excavation. In the case of Zhemchug Canyon, submarine erosion resulted in an incision $2.6 \mathrm{~km}$ deep and $100 \mathrm{~km}$ wide at the edge of the shelf along the central Beringian margin.

\section{REFERENCES CITED}

Carlson, P.R., and Karl, H.A., 1984/85, Mass movement of fine-grained sediment to the basin floor, Bering Sea, Alaska: Geo-Marine Letters, v. 4, p. 221-225.
1988, Development of large submarine canyons in the Bering Sea, indicated by morphologic, seismic, and sedimentologic characteristics: Geological Society of America Bulletin, v. 100 , p. 1594-1615.

Cooper, A.K., Scholl, D.W., and Marlow, M.S., 1987, Structural framework, sedimentary sequences, and hydrocarbon potential of the Aleutian and Bowers Basins, Bering Sea, in Scholl, D.W., Grantz, Arthur, and Vedder, J.G., eds., Geology and resource potential of the continental margin of western North America and adjacent ocean basins - Beaufort Sea to Baja, California: Circum-Pacific Council for Energy and Mineral Resources Earth Science Series, v. 6, p. 473-502.

Cooper, A.K., Stevenson, A.J., Kenyon, Neil, and Bishop, Derek, 1986, GLORIA study of the Exclusive Economic Zone off Alaska-southern Bering Sea: Initial report for cruise F4-86-BS: U.S. Geological Survey Open-File Report 86-596, 19 p.

Karl, H.A., Gardner, J.V., and Huggett, Quentin, 1987, GLORIA images of Zhemchug Canyon and Bering Channel-Fan system, Bering Sea, in Hamilton, T.D., and Galloway, J.P., eds., Geologic studies in Alaska by the U.S. Geological Survey during 1986: U.S. Geological Survey Circular 998, p. 147-151.

Kotenev, B.N., 1965, Submarine valleys in the zone of the continental slope in the Bering Sea: All-Union Research Institute Marine Fishery Oceanography Transactions, U.S. 


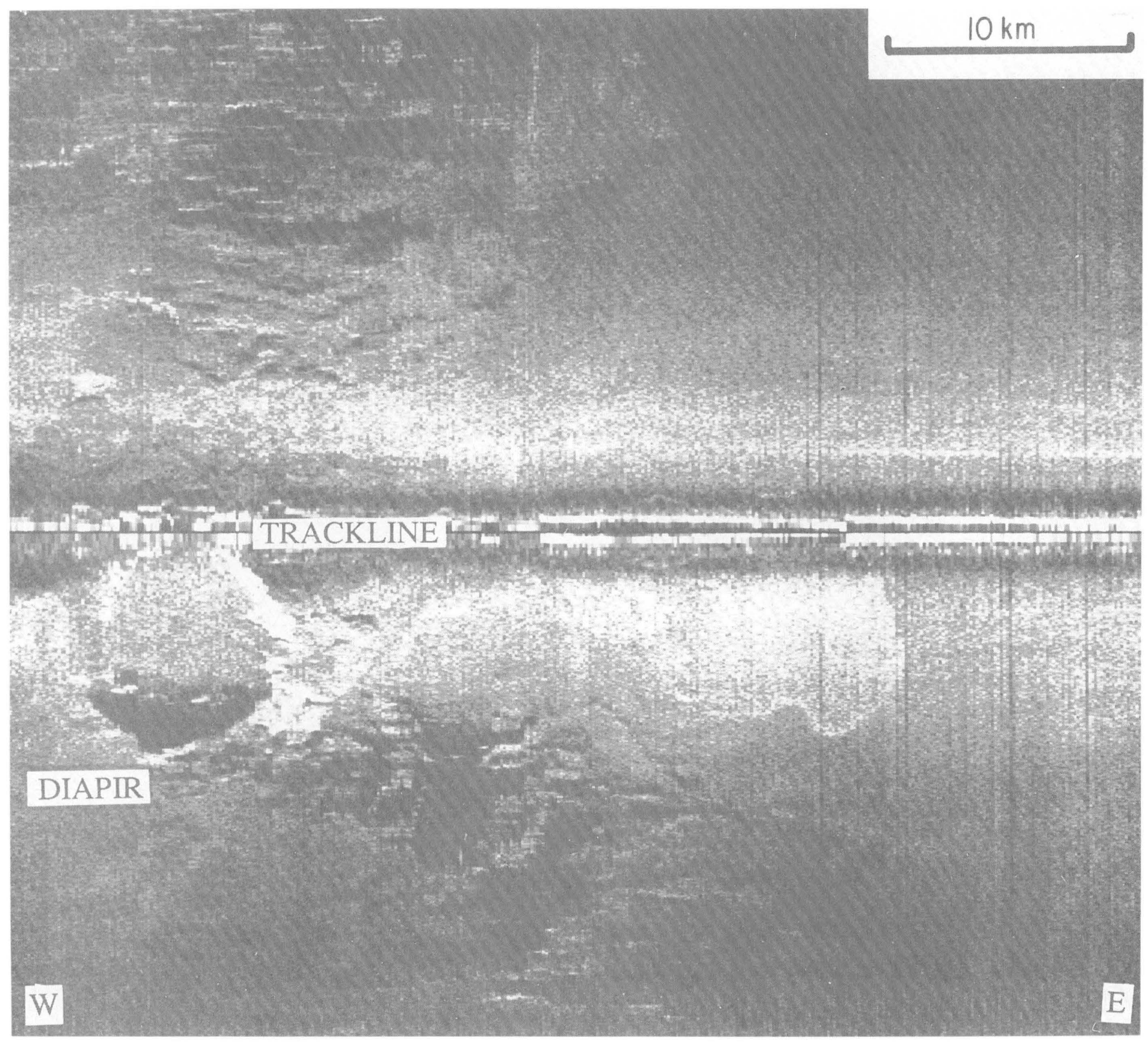

Figure 14. GLORIA sidescan-sonar image of an exposed diapir and associated small slope failures along the western edge of Umnak Plateau.

Naval Electronics Laboratory, San Diego, California, NEL Translations 112 , v. 58 , p. $35-44$.

Scholl, D.W., Buffington, E.C., and Hopkins, D.M., 1968, Geologic history of the continental margin of North America in the Bering Sea: Marine Geology, v. 6, p. 297-330.

Scholl, D.W., Buffington, E.C., Hopkins, D.M., and Alpha, T.R., 1970, The structure and origin of the large submarine canyons of the Bering Sea: Marine Geology, v. 8, p. 187-210.

Stevenson, A.J., Karl, H.A., Gardner, J.V., Cooper, A.K., Carlson, P.R., and Edwards, B.D., 1988, Slope failure and sediment mass movement on the margins of the Aleutian Basin, styles and causes: Geological Society of America, Abstracts with Program, v. 20, no. 7, p. A129. 


\title{
Comparison of Tectonic and Stratigraphic Control of Submarine Landslides on the Kodiak Upper Continental Slope, Alaska
}

\author{
By M.A. Hampton
}

\section{DESCRIPTION}

The upper continental slope southeast of the Kodiak Island group, Alaska, contains two distinct types of submarine landslides (slope failures) whose locations apparently are controlled by different geologic factors (Hampton and Bouma, 1977). The first type, large slumps, appears in seismic-reflection profiles from two areas, one off southernmiddle Albatross Bank and the other off Portlock Bank (fig. 1), where the geologic structure indicates that the sea floor is being deformed in response to tectonic forces. In contrast, the large slumps are absent in seismic-reflection profiles from the intervening area off northern Albatross Bank where the structure indicates relatively little deformation, and the sea floor is less steep. The second type, shallow slides, appears in seismic-reflection profiles from all areas of the upper continental slope. Their location probably is related to local stratigraphy; that is, the presence of a buried weak sediment layer or an abrupt sedimentstrength increase at some depth below the sea floor. Strong earthquakes occasionally affect the entire region and may be responsible for actually triggering the slides. Slides are virtually absent from the adjacent continental shelf, probably because the inclined areas of the sea floor are underlain by coarse-grained sediment that is strong enough to withstand the forces that cause the slope failures on the continental slope.

The best examples of large slumps show a steep headwall scarp upslope from a slide mass that is displaced a relatively short distance along a curved slide surface, or slip plane (figs. 2 and 3). The height of the headwall scarp and the thickness of the slide mass range up to a few hundred meters. The best examples of shallow slides show a headwall scarp and several displaced blocks above a distinct, undeformed acoustic reflector no deeper than about 50 meters $(\mathrm{m})$ beneath the sea floor (fig. 4).

The appearance of both types of slides varies widely on the seismic-reflection profiles, from a clear display of the distinctive features described above to equivocal indications such as hummocky sea floor that might indicate the presence of erosional submarine canyons rather than landslide-disrupted sea floor (for example, compare figs. 2 to 4 with figs. 5 and 6).

\section{CAUSES}

The Kodiak continental margin is located at the edge of the North American lithospheric plate where it is being underthrust from the south by the oceanic crust of the Pacific plate. The junction of the two plates occurs at the Aleutian Trench. A collisional setting such as this creates strong tectonic forces that deform the margin. The deformation is spatially nonuniform; in particular, it is strongest where the large slumps occur. For example, the seismicreflection profile in figure 2 shows a large, fault-bounded, downdropped block (graben) on the continental shelf, and the profiles in figures 5 and 6 show a relatively steep-limbed anticlinal fold near the edge of the shelf and a similar, but smaller, fold seaward. Growth of the faults and folds might have occurred recently, as judged by their deformation of the sea floor. Indications of slumps on the continental slope appear in seismic-reflection profiles in each of the deformed areas. In contrast, the shelf-edge. anticline is subdued and major faults are absent along the seaward edge of northern Albatross Bank (fig. 7; von Huene and others, 1980). Here, the sea floor of the upper continental slope is more gently inclined, and there is no indication of large slumps. Therefore, this regional overview indicates that large slumps occur only in areas where the sea floor has been tectonically deformed in the recent past.

On the other hand, the shallow slides occur throughout the region, regardless of the degree of deformation. The displaced blocks disrupt acoustic reflectors on seismicreflection profiles (indicative of sedimentary bedding) only down to a certain, shallow subbottom depth (fig. 4). Beneath the displaced blocks is a continuous acoustic reflector that defines the deepest extent of the slide. By analogy with studied examples on land (Varnes, 1978), the surface along which the slide initiated probably lies at or just above this reflector. That is, slope failure might have initiated along a relatively thin, weak sediment layer that could not resist the downslope forces acting upon it. Alternatively, slope failure might have occurred just above a surface of abrupt strength increase, such as at an erosional unconformity, where forces of sufficient magnitude would tend to make an overlying, relatively homogeneous unit fail (Lee and Edwards, 1986). Movement would be transla- 


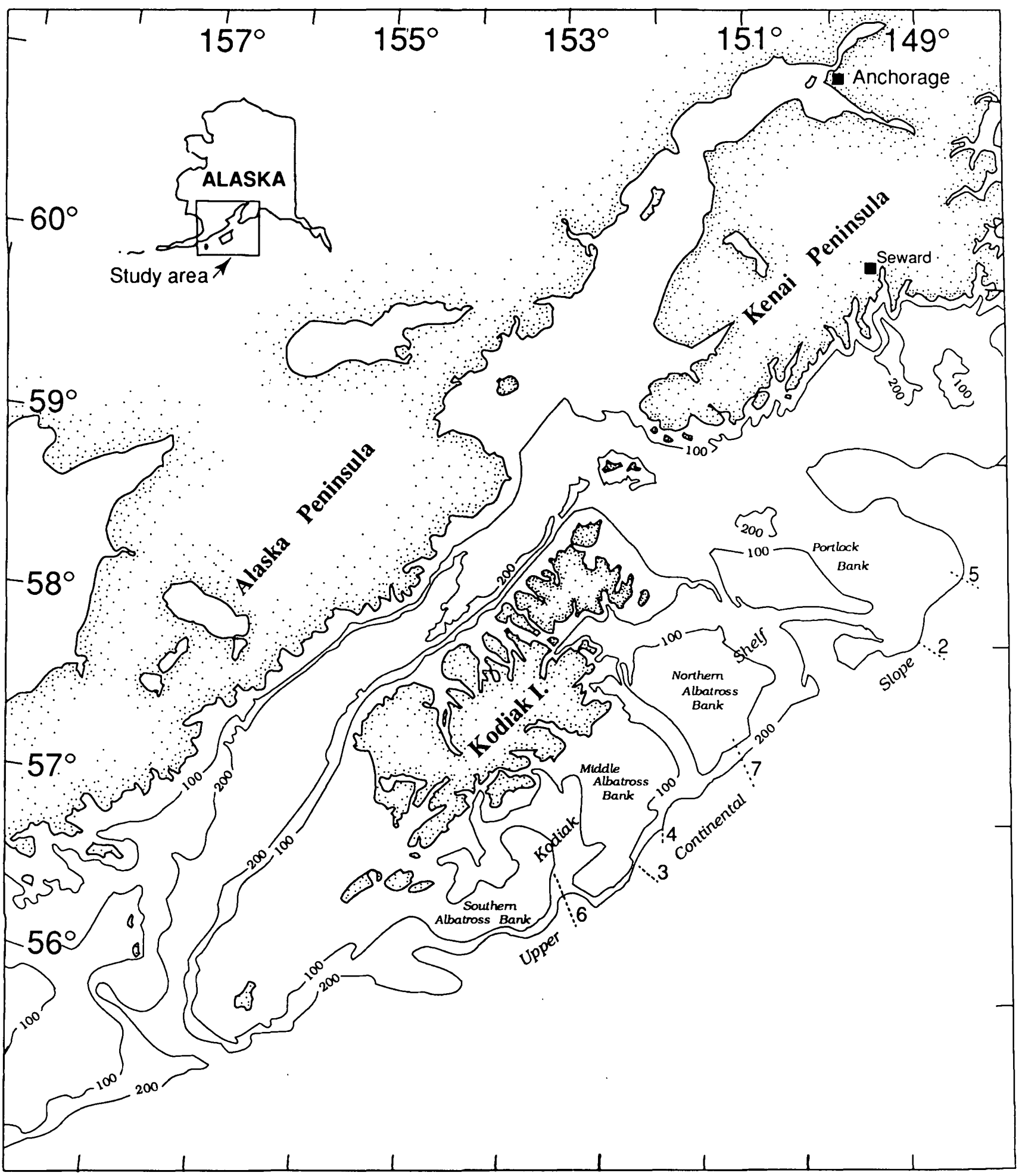

Figure 1. Location of the Kodiak upper continental slope seaward of the Kodiak shelf. Numbered dashed lines indicate location of the seismic-reflection profiles in figures 2 to 7. 


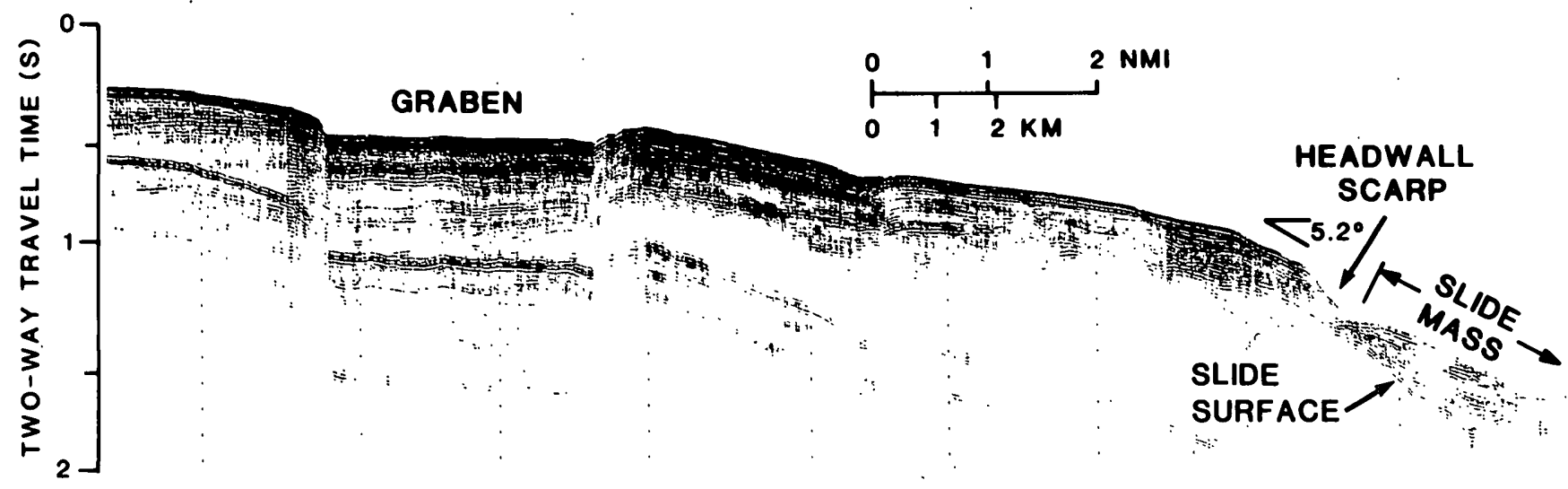

Figure 2. Seismic-reflection profile across the outer continental shelf and upper continental slope of Portlock Bank that displays the features of a large slump: Headwall scarp at the top of the slump is the main separation of the failed and unfailed slope sediment. The vertical relief of the scarp is about 150 meters. Slide mass is the displaced, failed body of sediment; that is, the slide proper. The slide mass is about 120 meters thick. Slide surface is the curved continuation of the headwall scarp beneath the slide mass. Slope failure occurred along the headwall scarp and the slide surface. The slump occurred on an initial seafloor slope of about $5.2^{\circ}$. Notice the large downdropped graben that offsets the sea floor. The tectonic forces that caused this structural feature also may be responsible for the slump, by steepening the sea floor and by causing large earthquakes. (One second of two-way travel time indicates a water depth of approximately 750 meters.)

1964 triggered many landslides, some of which were initiated offshore (Coulter and Migliaccio, 1966; Lemke, 1967; Kachadoorian, 1969; Hampton, Lemke, and Coulter, this report). Earthquakes can trigger slope failures in several ways (Lee, Schwab, and Booth, this report). The earthquake accelerations create a direct force that can augment on Earth (Jacob, 1986). The great Alaska earthquake of

tional along such a surface, and the presence of several distinct slide blocks may indicate episodes of retrogressive slope failure (in the upslope direction) after the initial event.

Strong earthquakes occur frequently throughout the Kodiak region; it is one of the most seismically active areas

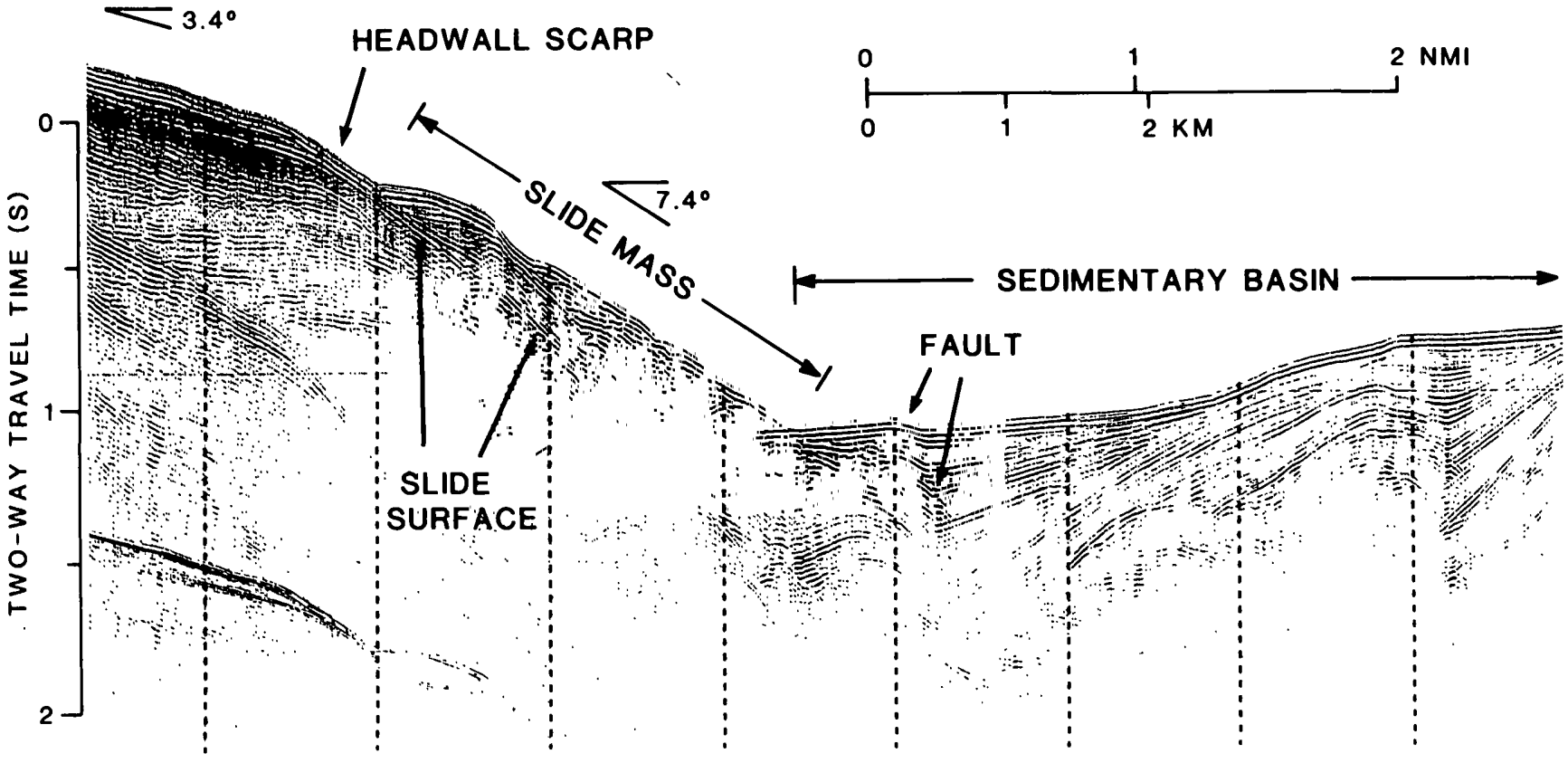

Figure 3. Slump with the same clearly displayed features as shown in figure 2 . The slump occurs adjacent to a sediment-filled basin that is disrupted by a fault. Slumping probably is controlled by movement of the fault, which removes support from the base of the slope and also causes earthquake shaking. (One second of two-way travel time indicates a water depth of approximately 750 meters.) 

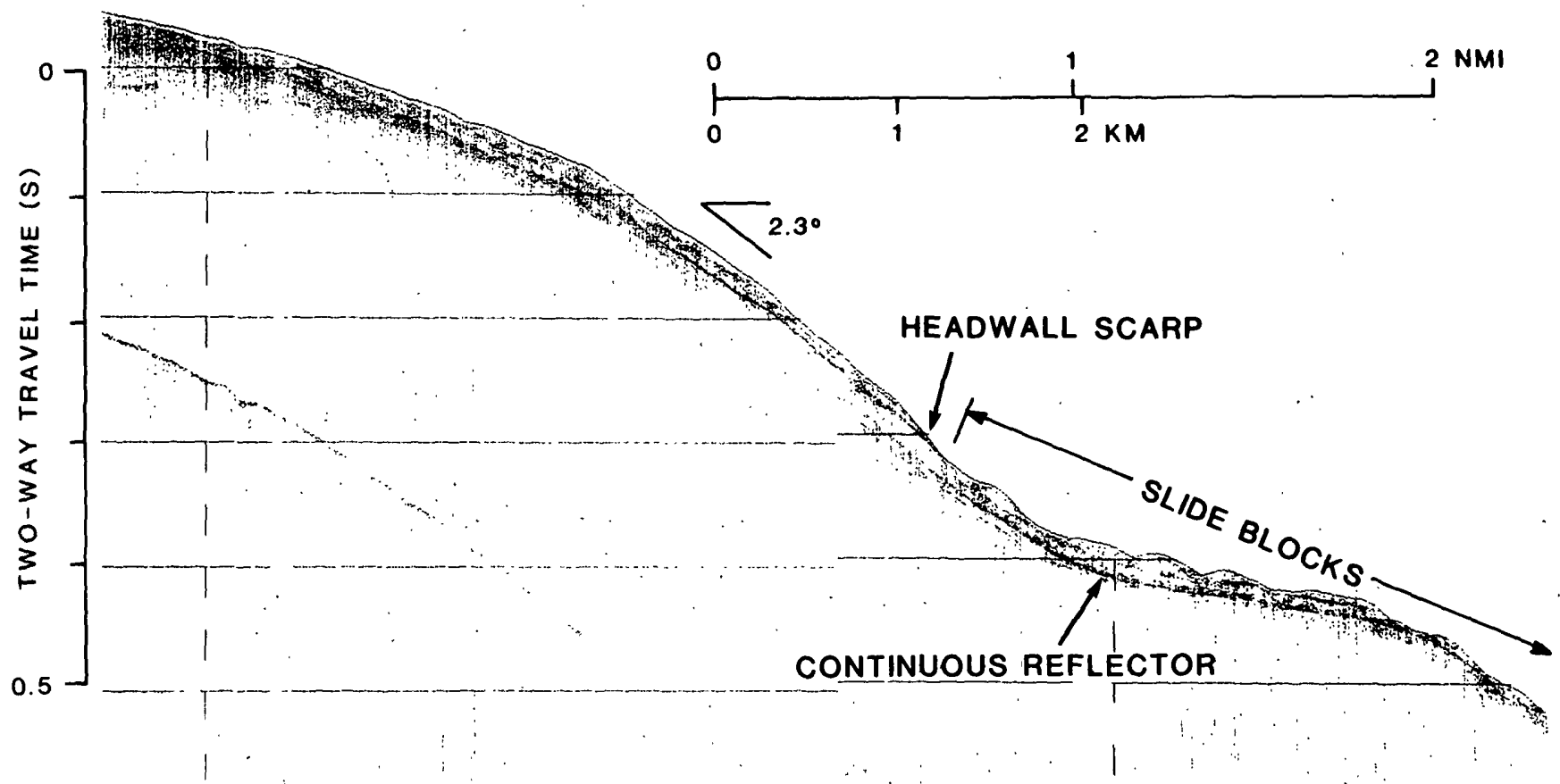

Figure 4. Shallow slide consisting of several slide blocks, less than 20 meters thick, that extend down to a continuous acoustic reflector. The features of this slide suggest that initial failure occurred either within a relatively thin, weak sediment layer at or slightly above the continuous reflector or at the base of a relatively homogeneous deposit in contact at the reflector with an underlying stronger unit. Earthquakes may trigger this kind of shallow slide, but tectonic deformation of the sea floor (slope steepening and/or faulting) does not appear to be important because this type of slide occurs off northern Albatross Bank, where the tectonic deformation is relatively minor. (One second of two-way travel time indicates a water depth of approximately 750 meters.) the force of gravity and cause failure of an otherwise stable slope (Morgenstern, 1967; Lee and Edwards, 1986). In addition, the repeated jostling of grains within a deposit can cause buildup of internal pore-water pressure that weakens the sediment, sometimes to the point of failure (Poulos and others, 1985). Stability analysis based on a few measurements of geotechnical (civil engineering) properties of sediment from the Kodiak upper continental slope indicate

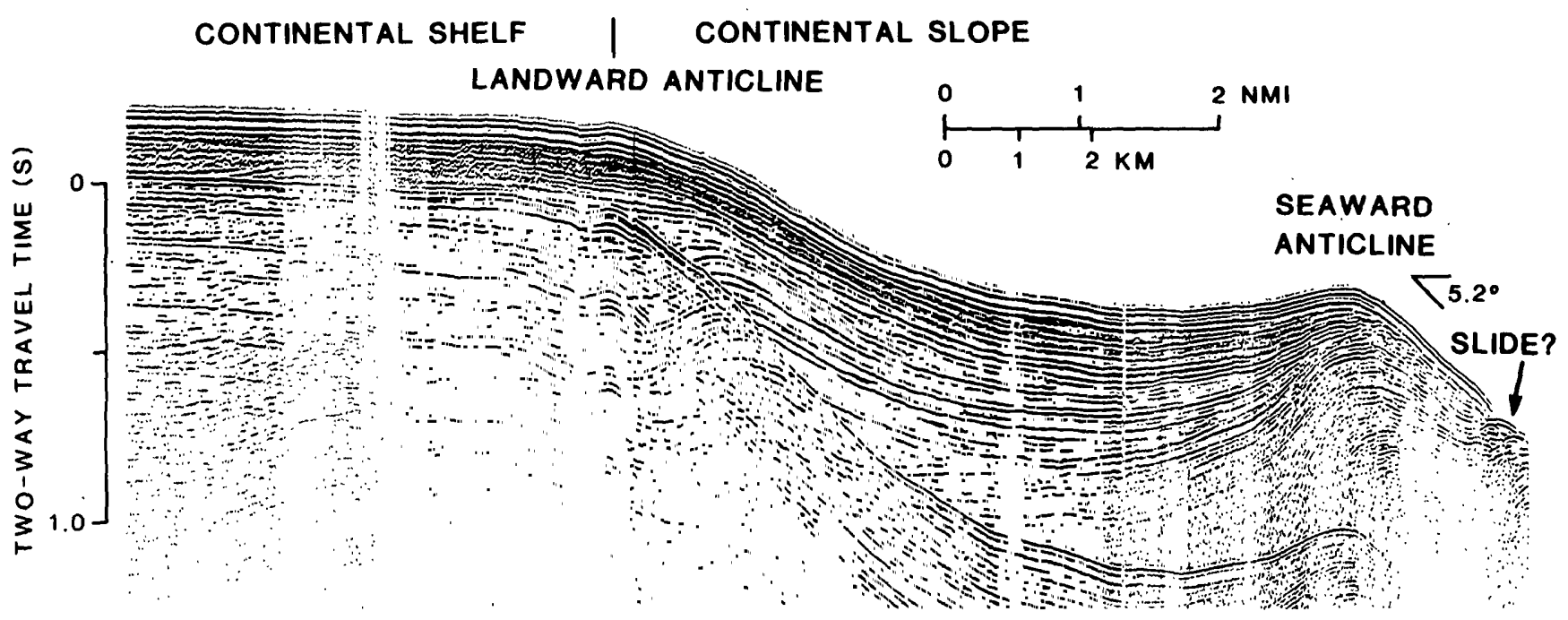

Figure 5. A large anticlinal fold (an arch of strata in which the sediment beds bend downward in opposite directions) is succeeded seaward by a smaller and probably younger anticline whose recent growth may have contributed to slumping on the steepening seaward limb. (One second of two-way travel time indicates a water depth of approximately 750 meters.) 


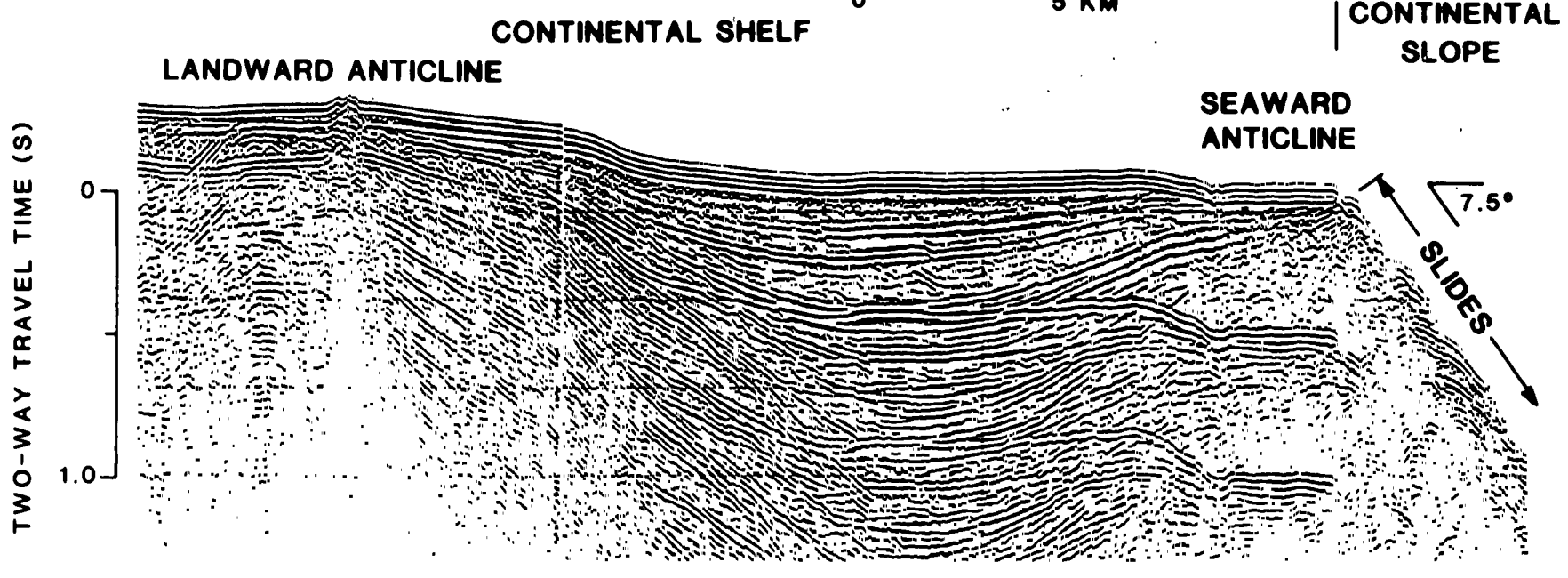

Figure 6. A more mature example of the multiple anticlinal folds shown in figure 5, where the seaward anticline has grown sufficiently to extend the shelf seaward and define a new shelf-slope break. (One second of two-way travel time indicates a water depth of approximately 750 meters.)

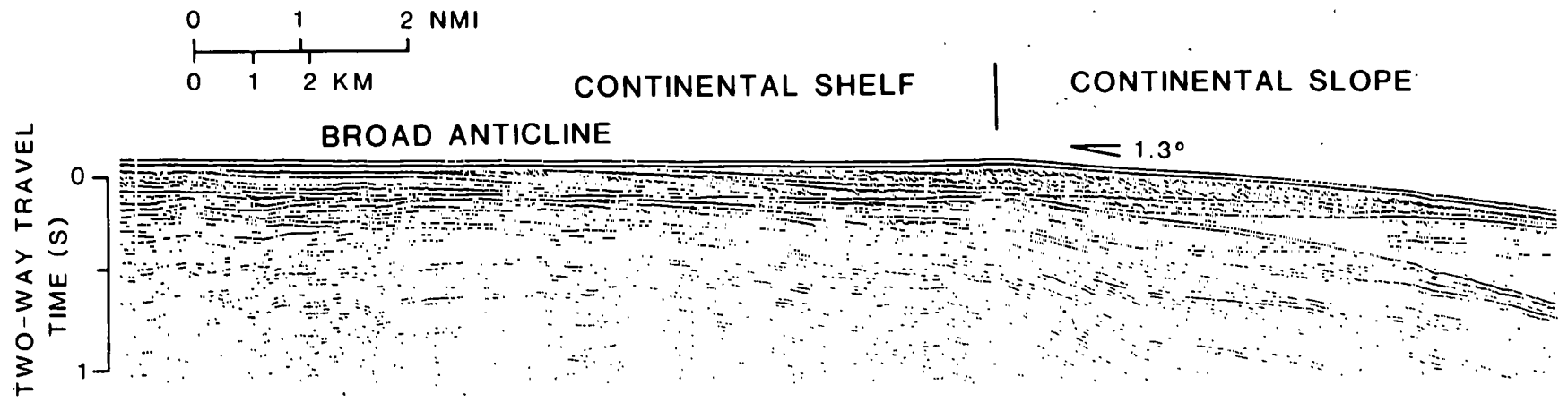

Figure 7. Relatively mildly deformed outer shelf and upper slope on northern Albatross Bank. The subsurface strata are broadly folded, the inclination of the upper continental slope sea floor is gentle, and no large slumps occur, at least to the seaward extent of the seismic profile. (One second of two-way travel time indicates a water depth of approximately 750 meters.)

that all but the steepest areas are stable under static, gravitational loading (downslope- directed forces of gravity acting on the sedimentary deposit due to the sea-floor slope angle), but that earthquake loading can cause slope failure (Hampton and others, 1978; Hampton, 1989). Earthquakes probably triggered many of the slides on the Kodiak upper continental slope.

Another factor associated with tectonism is removal of the buttressing support of slopes by earthquakeassociated faulting. Such an example is shown on the seismic-reflection profile in figure 3. The slump occurs on the landward slope of a basin that is filled by a thick sequence of well-stratified sediment. Offset of the sea floor within the basin, just seaward of the toe of the slide mass, and discontinuity of acoustic reflectors beneath the offset suggest the presence of a recently active fault. Hampton and others (1978) proposed that repeated movement of the fault removes support from the toe of the slide mass and, thereby, promotes sliding.

\section{SUMMARY}

Geologic analysis of seismic-reflection profiles indicates that large slumps on the Kodiak upper continental slope occur only where tectonic deformation has occurred recently, with the implication that sea-floor steepening and removal of support by faulting control the location of the slumps. Smaller, shallow slides occur in all areas of the upper continental slope, implying that their location is independent of sea-floor deformation. By analogy with similar slides studied on land, their location probably is 
determined by the local presence of a buried weak sedimentary layer or an abrupt strength increase at the depth of failure. Limited geotechnical data support the contention that earthquakes actually trigger slides in the region.

\section{REFERENCES CITED}

Coulter, H.W., and Migliaccio, R.P., 1966, Effects of the earthquake of March 27, 1964, at Valdez, Alaska: U.S. Geological Survey Professional Paper 542 C, p. C1-C36.

Hampton, M.A., 1989, Geotechnical properties of unconsolidated sediment on the Kodiak continental shelf and upper slope, Gulf of Alaska: Marine Geotechnology, v. 8, p. 159-180.

Hampton, M.A., and Bouma, A.H., 1977, Slope instability near the shelf break, western Gulf of Alaska: Marine Geotechnology, v. 2, p. 309-331.

Hampton, M.A., Bouma, A.H., Carlson, P.R., Molnia, B.F., Clukey, E.C., and Sangrey, D.A., 1978, Quantitative study of slope instability in the Gulf of Alaska: Proceedings of the 10th Offshore Technology Conference, p. 2307-2318.

Jacob, K.H., 1986, Seismicity, tectonics, and geohazards of the Gulf of Alaska regions, in Hood, D.W., and Zimmerman, S.T., eds., The Gulf of Alaska-Physical environment and biological resources: U.S. Department of the Interior, Mineral Management Service, Washington, D.C., p. 145-186.
Kachadoorian, Reuben, 1969, Effects of the earthquake of March 27, 1964, at Whittier, Alaska: U.S. Geological Survey Professional Paper 542 B, p. B1-B21.

Lee, H.J., and Edwards, B.D., 1986, Regional method to assess offshore slope stability: Journal of Geotechnical Engineering, American Association of Civil Engineers, v. 112, p. 489-509.

Lemke, R.W., 1967, Effects of the earthquake of March 27, 1964, at Seward, Alaska: U.S. Geological Survey Professional Paper 542 E, p. E1-E43.

Morgenstern, N.R., 1967, Submarine slumping and the initiation of turbidity currents, in Richards, A.F., ed., Marine Geotechnique, University of Illinois Press, Urbana, Ill., p. 189-210.

Poulos, S.J., Castro, Gonzalo, and France, J.W., 1985, Liquefaction evaluation procedure: Journal of Geotechnical Engineering, American Association of Civil Engineers, v. 111, p. $722-791$.

Varnes, D.J., 1978, Slope movement types and processes, in Schuster, R.L., and Krizek, R.J., eds., LandslidesAnalysis and control: Washington, D.C., National Academy of Sciences, p. 12-33.

von Huene, R., Hampton, M.A., Fisher, M.A., Varchol, D.J., and Cochrane, G.R., 1980, Map showing near-surface geologic structures of Kodiak shelf, Alaska: U.S. Geological Survey Miscellaneous Field Studies Map MF-1200, 1:500,000 Scale. 


\section{Subrnarine Landslides That Had a Significant Impact on Man and His Activities: Seward and Valdez, Alaska}

By M.A. Hampton, R.W. Lemke ${ }^{1}$, and H.W. Coulter ${ }^{2}$

\section{INTRODUCTION}

On the evening of March 27, 1964, the largest earthquake: to occur in North America during this century struck southern Alaska. The epicenter of the magnitude (Mw) 9.2 shock "was at the head of Prince William Sound near the foot of the Chugach Mountains (fig. 1). The duration of strong ground motion lasted an incredibly long 3 to 4 minutes, with tectonically induced elevation changes

' Consulting Engineering Geologist, Lakewood, Colo.

${ }^{2}$ Retined, Washington, D.C. occurring over a land and sea-floor area exceeding 180,000 square kilometers $\left(\mathrm{km}^{2}\right)$. Of the several destructive earthquake-related effects, slope failure (landslides) probably caused the most property damage, and large sea waves (tsunami), most of which were generated by submarine landslides, took the most lives (Hansen and Eckel, 1966). These two phenomena were particularly devastating to the communities of Seward and Valdez (Lemke, 1967; Coulter and Migliaccio, 1966). Large landslides originated below sea level and retrogressed landward to destroy the waterfront of both towns, sinking the dock and harbor facilities that were their economic lifeblood. Sea waves generated by

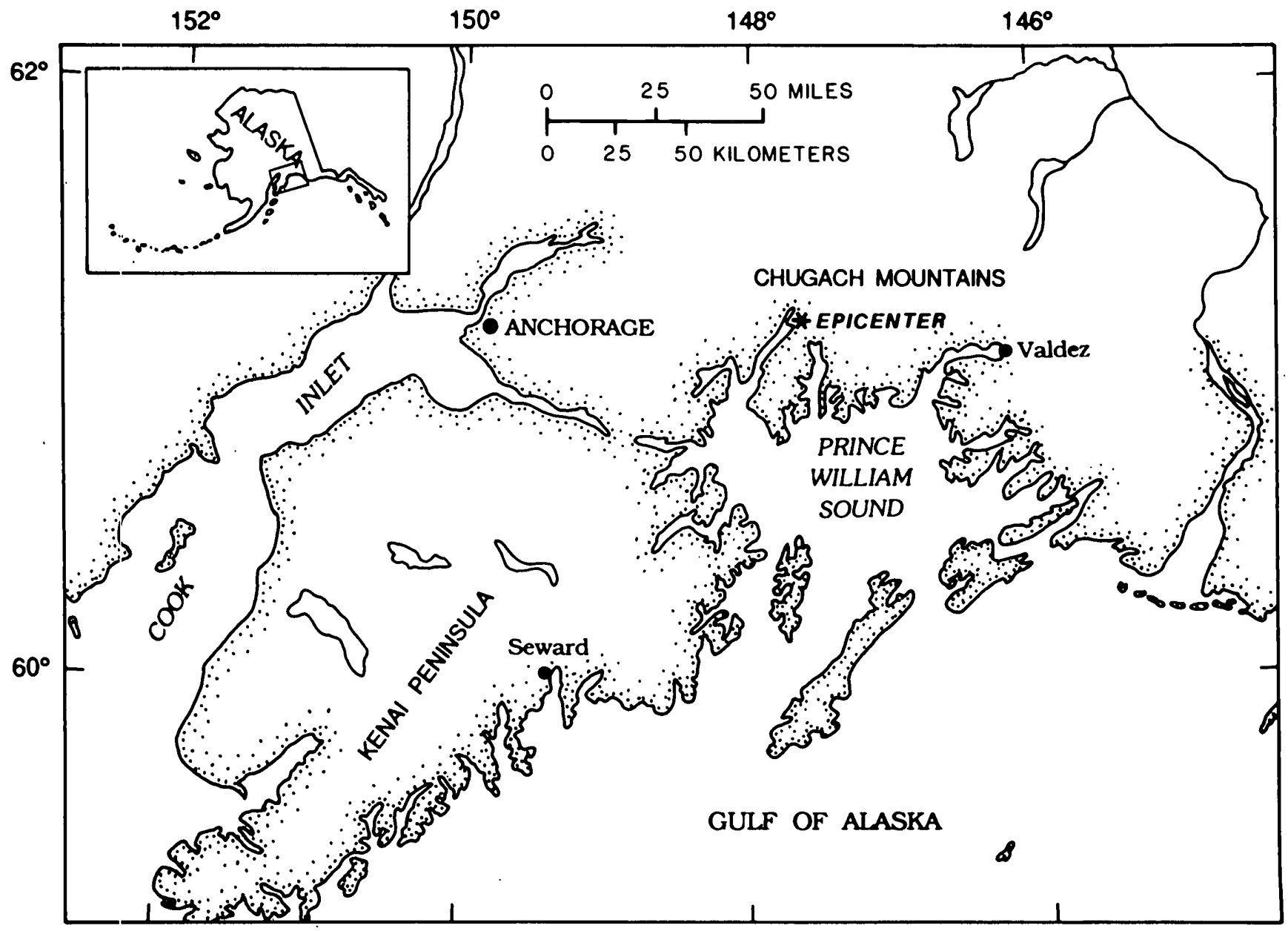

Figure 1. L.ocation of the epicenter of the Alaskan earthquake of 1964 and the towns of Seward and Valdez. 


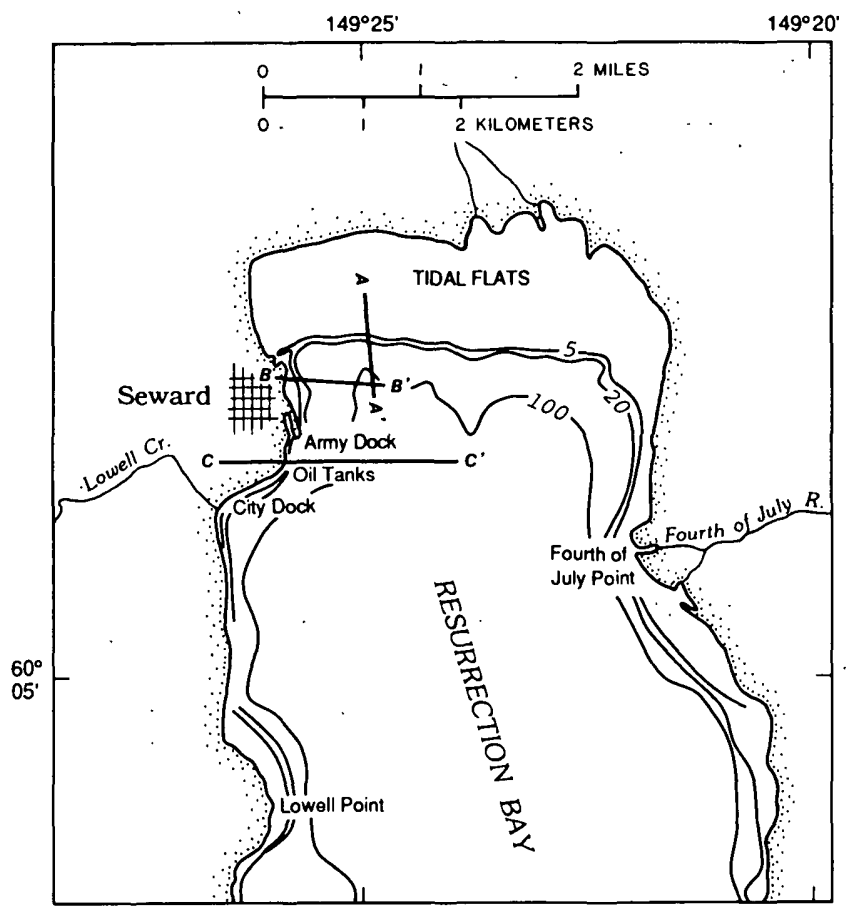

Figure 2. Northern part of Resurrection Bay showing Seward, Alaska, and vicinity. (Contours are in feet.)

the landslides caused further destruction, both by flooding and by spreading burning oil from local storage depots.

The geologic settings of Seward and Valdez are similar, a fact that explains the similarity of earthquake effects. Seward is located near the head of Resurrection Bay and Valdez at the head of Port Valdez, both steep-sided fjords (figs. 2 and 3). The landslide-affected areas are on deltas constructed of stream-transported sediment that derives from a nearby steep, glaciated mountain front. This type of sediment, especially when composed of sand- and silt-size grains, is particularly susceptible to liquefaction during earthquakes (Committee on Earthquake Engineering, 1985; Lee, Schwab, and Booth, this report; Schwab and Lee, this report). Landslide displacement of water in the restricted bays creates an ideal situation for the generation of destructive waves that reflect back and forth across the narrow fjords and repeatedly inundate the coast.

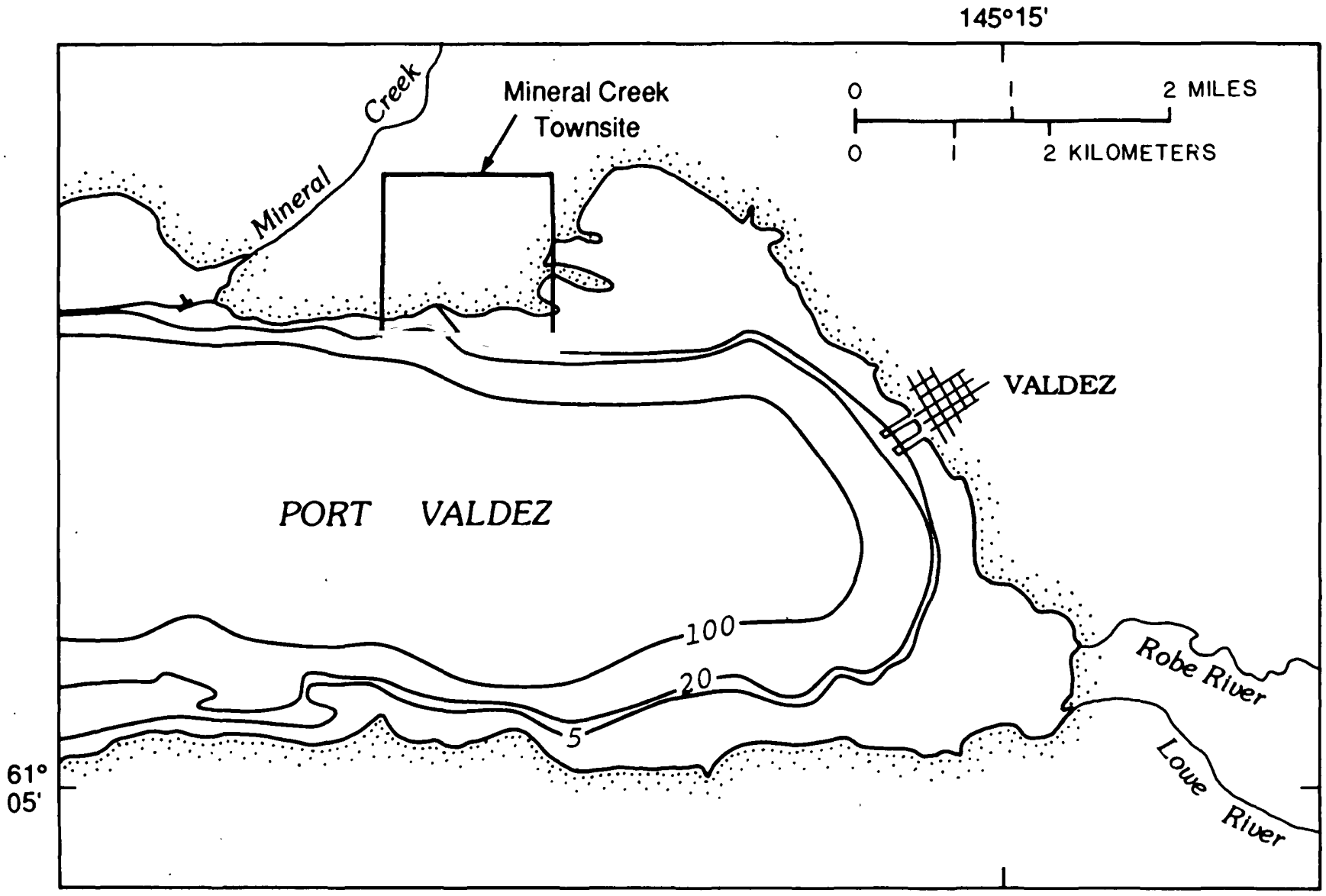

Figure 3. Eastern part of Port Valdez showing the town of Valdez, Alaska, and vicinity. Note the Mineral Creek townsite, a safer location where the town of Valdez was moved after the earthquake. (Contours are in feet.) 


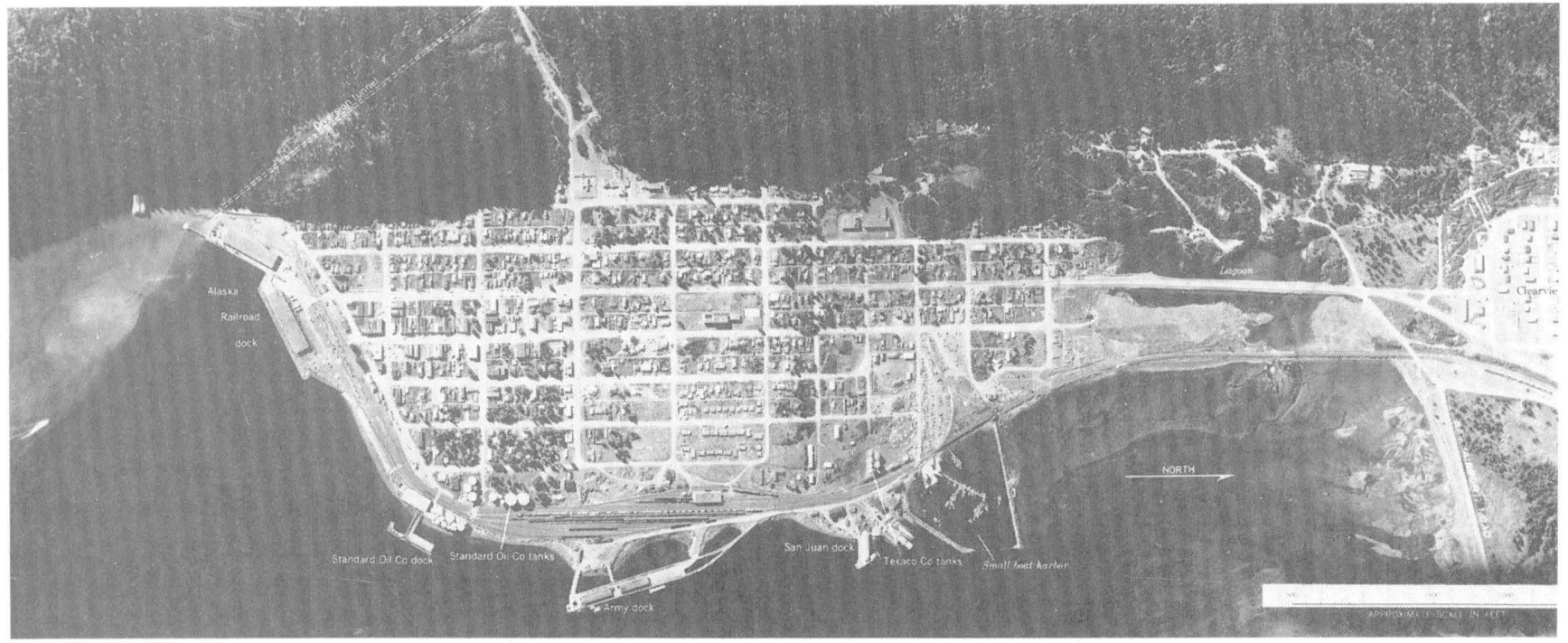

Figure 4. Seward before the earthquake (from Lemke, 1967). (Scale is in feet.)

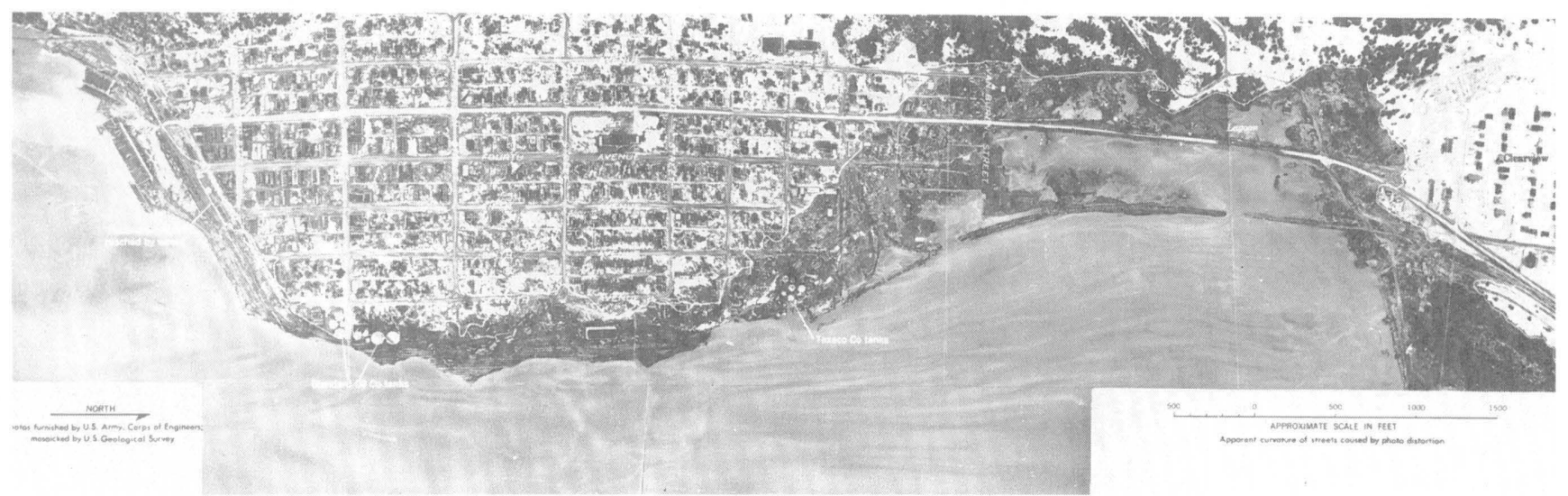

Figure 5. Seward 1 day after the earthquake (from Lemke, 1967). Note the white line that indicates the landward limit of wave runup. The most obvious indication of the landslide effects at the scale of the photograph is the missing docks and other coastal facilities (see fig. 4).

\section{THE EARTHQUAKE DAMAGE AT SEWARD}

Seward is located principally on the Seward delta of Lowell Creek (fig. 2), about $150 \mathrm{~km}$ south southwest of the earthquake's epicenter (fig. 1). After about 35 to 40 seconds of earthquake shaking on March 27, 1964, a strip of waterfront 1,200 meters (m) long and 15 to $150 \mathrm{~m}$ wide started to subside slice by slice and eventually disappeared into the bay (figs. 4 and 5). This was a consequence of landward retrogression of a slope failure that initiated on the steep $\left(20^{\circ}\right.$ to $35^{\circ}$ to a water depth of $\left.50 \mathrm{~m}\right)$ submerged delta-front. By the time shaking stopped, a zone of incipient slope failure marked by cracked ground had formed for a distance up to $250 \mathrm{~m}$ behind the landslide (figs. 6-8). Nearshore water depths increased more than $30 \mathrm{~m}$ in some places (fig. 9). Delta sediment in the northwest corner of the bay, deposited from the Resurrection River, also failed, and the sea surface deformed, presumably in response to the sudden underwater sediment movement. Within 30 seconds after the slope failure began, the first of three landslidegenerated sea waves attacked the shoreline, continuing for about 15 minutes and surging to elevations of approximately $10 \mathrm{~m}$ above sea level. Wave runup resumed when another train of waves, generated by tectonic displacement of the sea floor outside Resurrection Bay, rather than by the landslides, hit the coast about 30 minutes after the earthquake.

The land that slid into Resurrection Bay took docks, railroad equipment, and oil storage tanks with it (fig. 10). Fire erupted when storage tanks overturned and pipes 


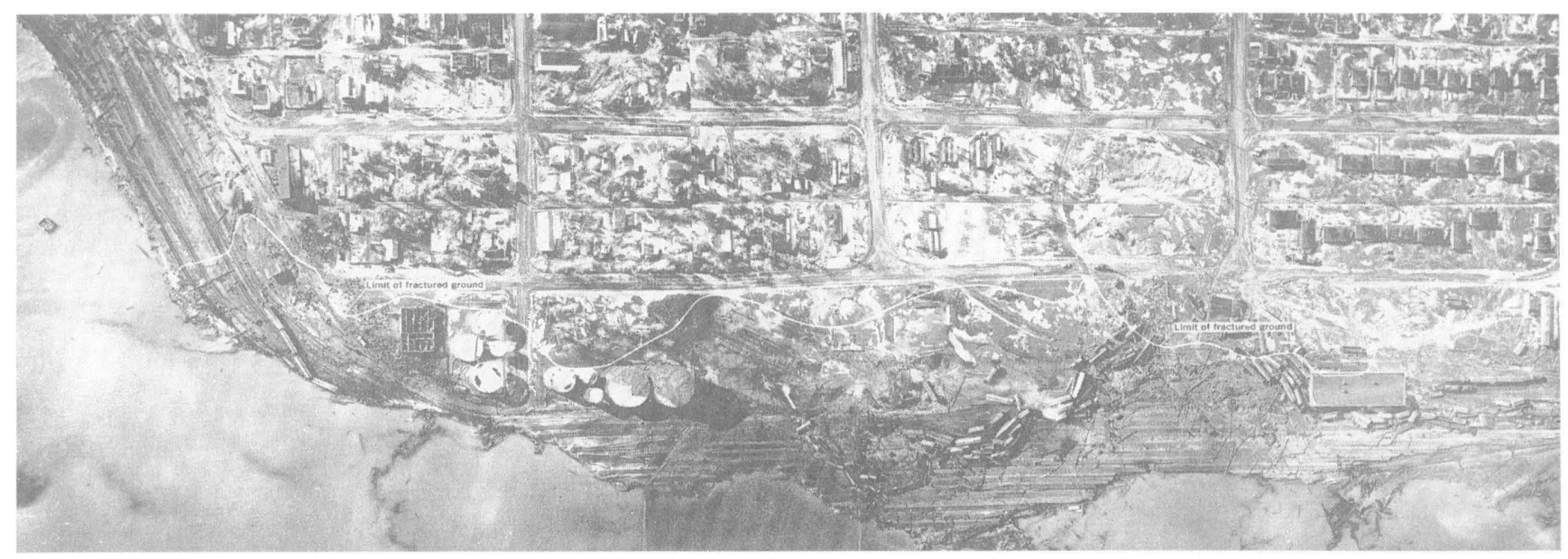

Figure 6. Southern part of the Seward waterfront showing the limit of fractured ground associated with landslides (from Lemke, 1967).
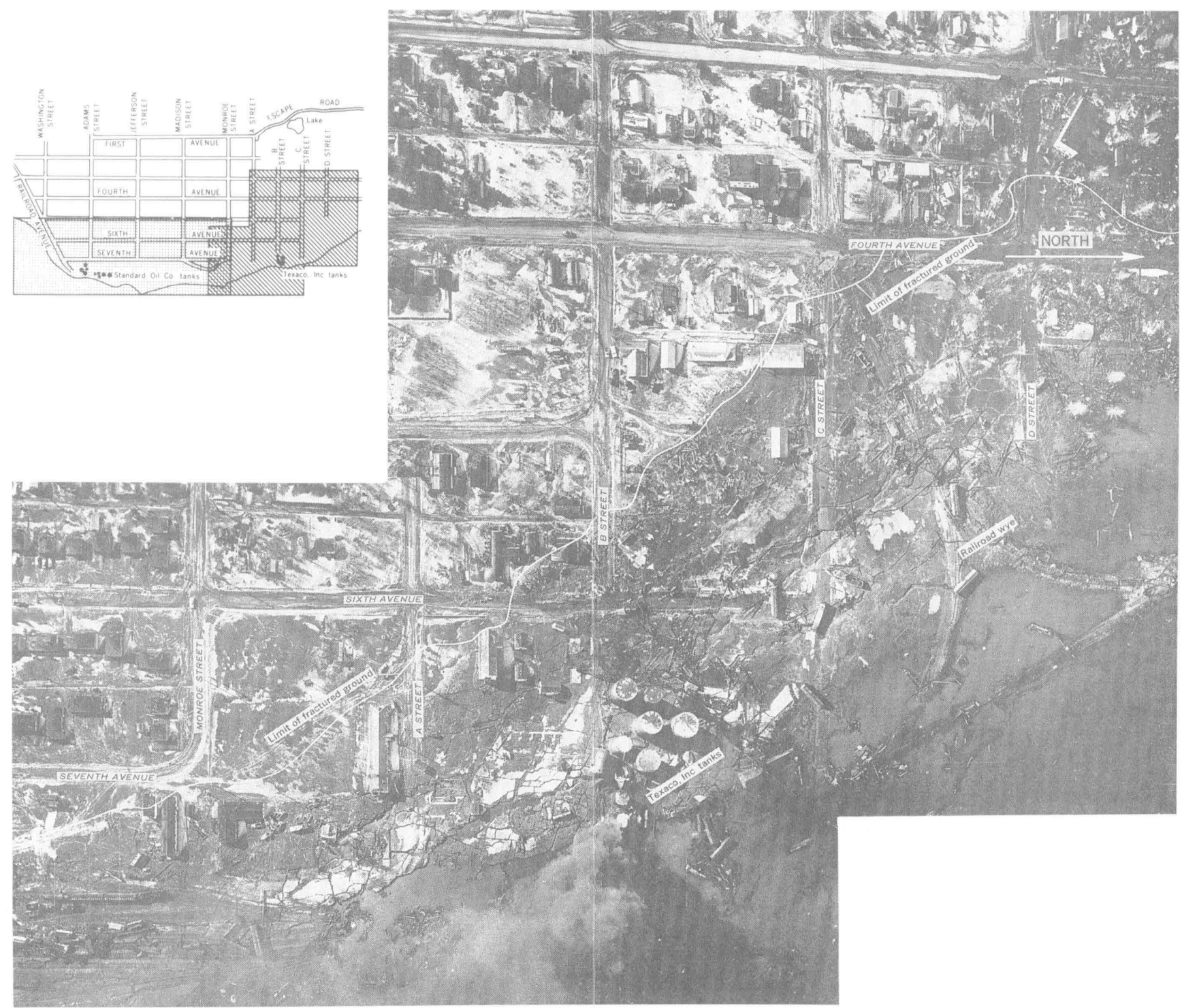

Figure 7. Northern part of the Seward waterfront showing the limit of fractured ground associated with landslides (from Lemke, 1967). Index map shows relation between figures 5 and 6. 


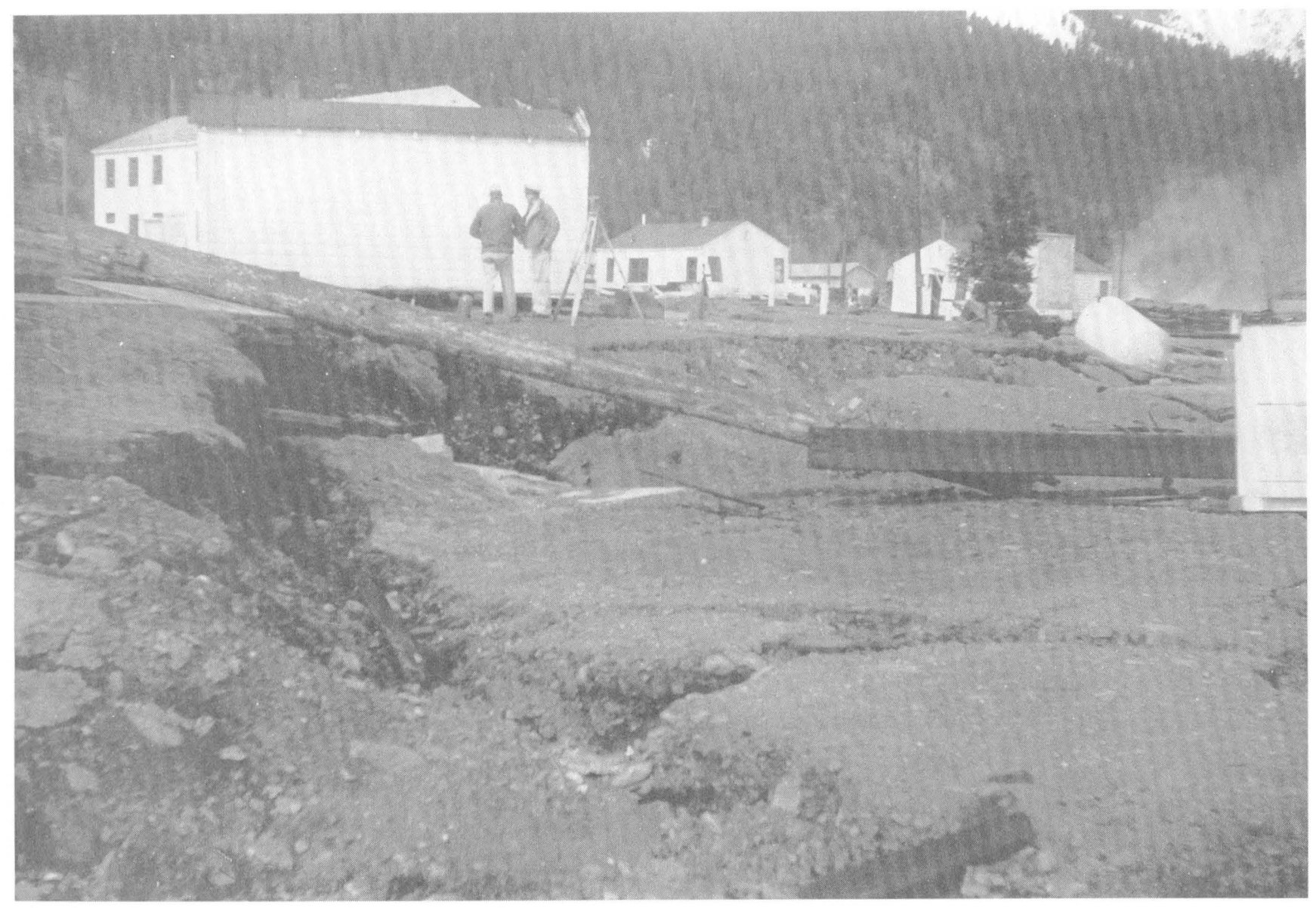

Figure 8. An example of ground displacement (approximately 1.5 meters) and fractures associated with landslides, 30 meters from the shoreline (from Lemke, 1967).
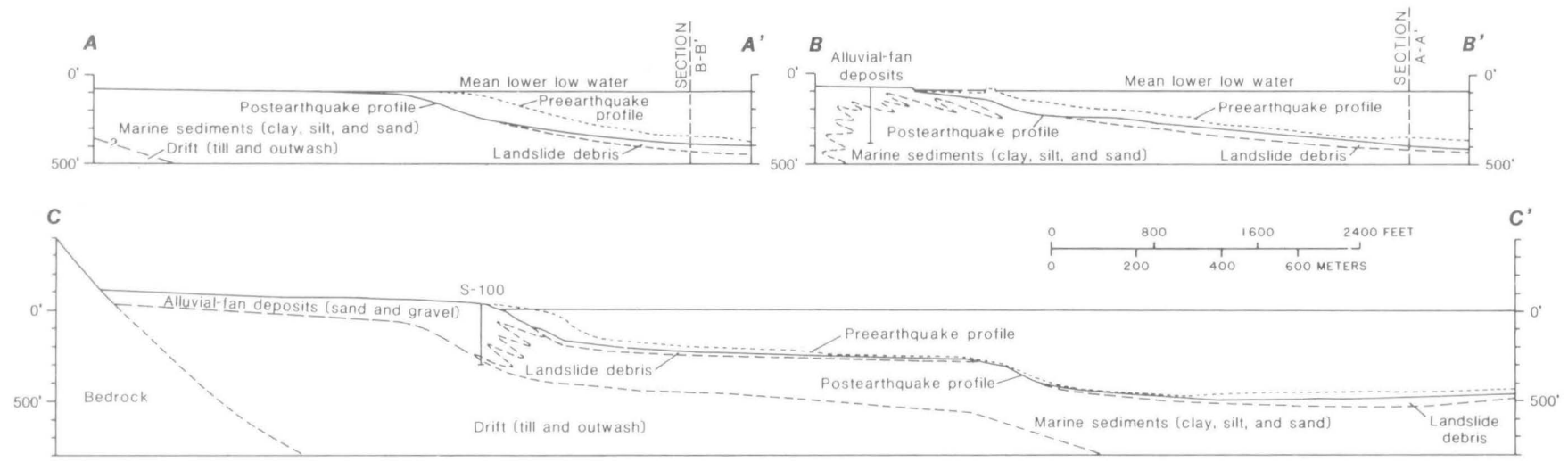

Figure 9. Cross sections showing pre- and postearthquake profiles of the land surface in Resurrection Bay (from Lemke, 1967). Note that the sea floor has been lowered up to 30 meters by the displacement of sediment by the landslides. The locations of these cross sections are shown on figure 2 .

ruptured. Water that receded from the shore as a result of the initial landslide displacement carried the fire offshore, then sea waves returned it with each subsequent runup. The waves lifted railroad cars off the tracks, smashed earthmoving equipment, lifted boats over a breakwater, displaced houses from their foundation, and dumped a cargo 


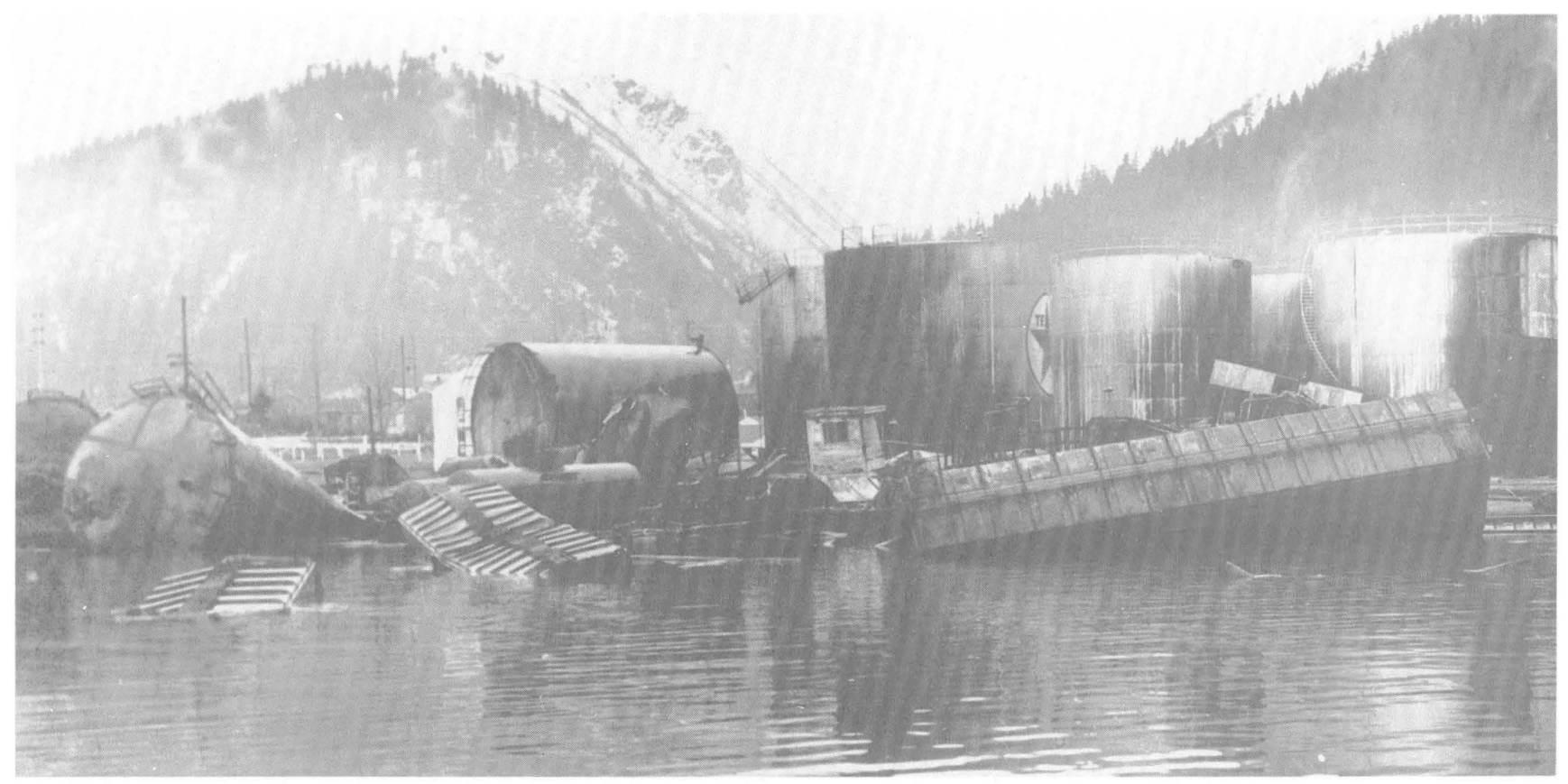

Figure 10. Landslide destruction of railroad and petroleum-storage facilities on the Seward waterfront (from Lemke, 1967).

dock into the bay (fig. 11). The death toll at Seward was 13 people, mostly as a result of wave runup. Damage to property was estimated at $\$ 22,363,349$.

Geologic and engineering studies conducted after the earthquake identified several factors that contributed to the landslides at Seward (Shannon and Wilson, Inc., 1964a; Lemke, 1967). Onshore and offshore subsurface borings were made to identify sediment types, and physical properties were measured on sediment core samples. Offshore seismic-reflection profiling provided acoustic data for description of sea-floor morphology and subbottom stratigraphy. Obviously, the slope failures were related to the earthquake. Strong ground motion initiated the slope failures, and the long duration of the earthquake led to the great extent of mass movement. Some of the deltaic sediment in Resurrection Bay, such as rapidly deposited, interbedded fine- and coarse-grained layers, is known to build up pore-water pressures and liquefy under repeated, earthquake-type loading, even if the packing of the sediment grains is medium to high density (Committee of Earthquake Engineering, 1985). A large component of gravitational force acted downslope because of the steep delta fronts, and the weakness along sedimentary bedding planes that dip up to $30^{\circ}$ seaward probably lessened the applied force necessary for failure.

The less obvious factors concern static pore-water pressure conditions within the sedimentary deposit (see Lee, Schwab, and Booth, this report). In particular, sediment borings revealed the presence of high artesian pressure in some confined, buried sedimentary beds, which decreased the stabilizing frictional stress ("effective stress") that acts between grains, thereby weakening the sediment irrespective of earthquake loading. Moreover, the low tidal level at the time of the earthquake, along with the rapid drawdown of water in the bay that accompanied the initial slope failure, also decreased the stability because the pore water could not drain from the sediment quickly enough to maintain hydrostatic conditions during the removal of external water pressure. Submarine landslides on fjord deltas elsewhere have occurred in conjunction with tidal drawdown, without earthquake loading (Terzaghi, 1956; Prior and others, 1981; Prior and others, 1982).

Man-induced loading in the form of artificial fill, dock facilities, oil storage tanks, and railroad cars aided the slope failure, as did the added surcharge due to wave runup. The magnitude of these man-induced effects relative to others is uncertain, however.

Seismic-reflection profiles point out that postearthquake sea-floor slopes are as steep as those before. A stability analysis based on measured solid properties implies that pre- and postearthquake slopes are stable under static conditions but could readily fail under earthquake accelerations of $0.15 \mathrm{~g}$ (Shannon and Wilson, Inc., 1964a). Contrary to normal expectations, the overall stability of the offshore sediment was not improved because of the slope failure.

A scientific and engineering task force was formed to study the earthquake effects and, thereby, aid the reconstruction effort. On July 24, 1964, the task force made recommendations to Seward city officials regarding the 


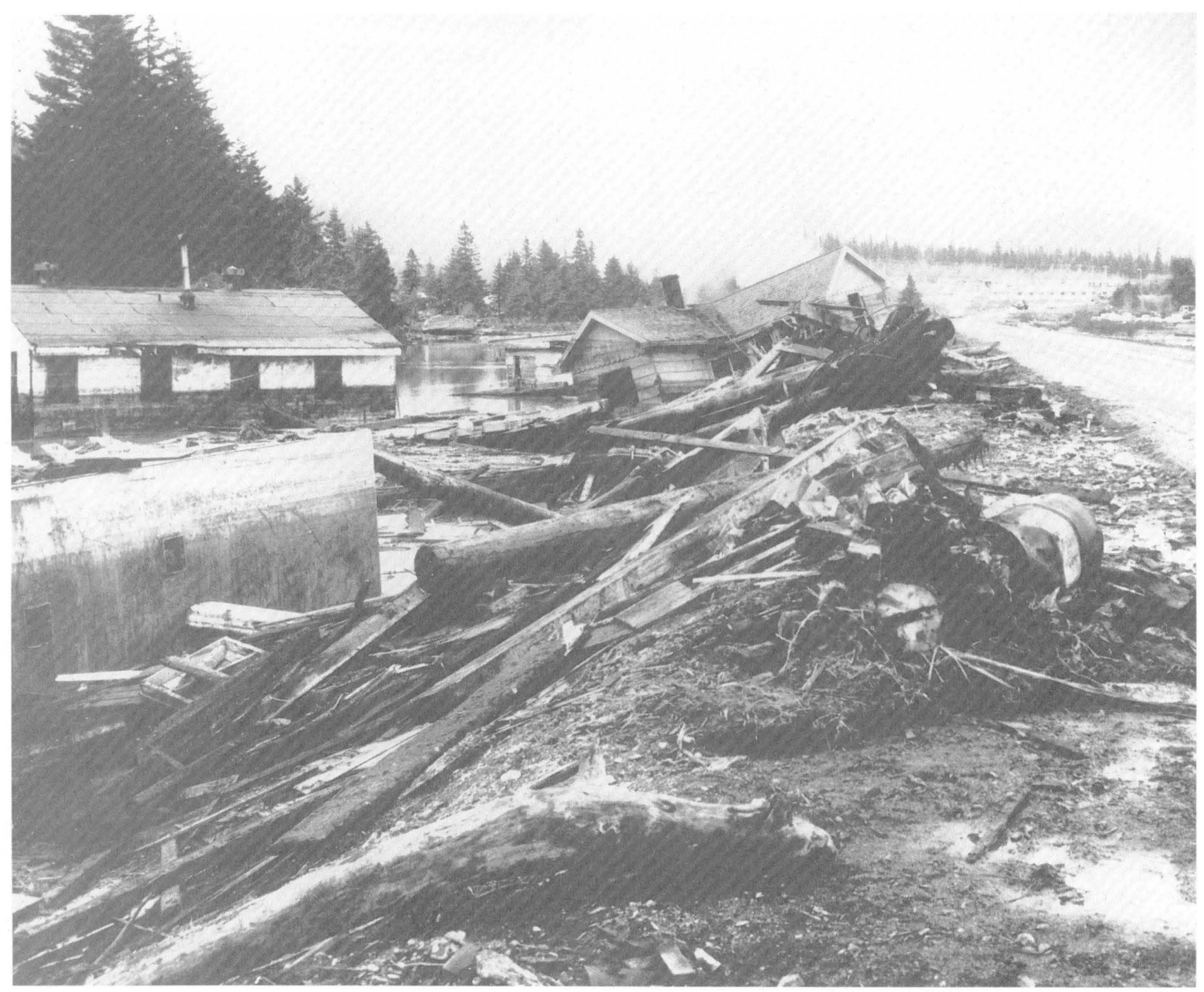

Figure 11. Houses and other debris carried by earthquake-related waves into the lagoon at the north end of Seward (from Lemke, 1967).

stability of the Seward delta. The recommendations were based on the geologic studies of Lemke (1967), the geotechnical engineering studies of Shannon and Wilson, Inc. (1964a), and visits by the task force to Seward (Hansen and others, 1966). The delta area was divided into two categories: (1) nominal risk and (2) high risk (fig. 12). The high-risk category included much of the waterfront area and was essentially coincident with the area of fractured ground shown in figures 6 and 7. On the basis of these recommendations, the city officials restricted the high-risk area, formerly used for railroad marshalling and by the oil tank farms, to parkland use. There was little doubt that under resumed dynamic conditions of severe earthquake shaking, the area of fractured ground would again fail and begin sliding into Resurrection Bay.

\section{THE EARTHQUAKE DAMAGE AT VALDEZ}

At Valdez, located about $70 \mathrm{~km}$ east of the earthquake's epicenter (figs. 1 and 3), the greatest damage was associated with a delta-front landslide involving an estimated 75 million cubic meters of sediment. The landslide was first observed indirectly when, shortly after shaking began, a cargo ship unloading at the town dock began to toss violently, with vertical motion in excess of $10 \mathrm{~m}$ and rolls of $50^{\circ}$. The motion was caused by landslide-generated sea waves. Shoreward retrogression of the landslide soon reached the docks, causing them to vanish instantly into the turbulent water. The entire waterfront was lost, along with warehouses, a cannery, heavy equipment, and 30 people (figs. 13-15). The initial 10-m-high wave inundated the 


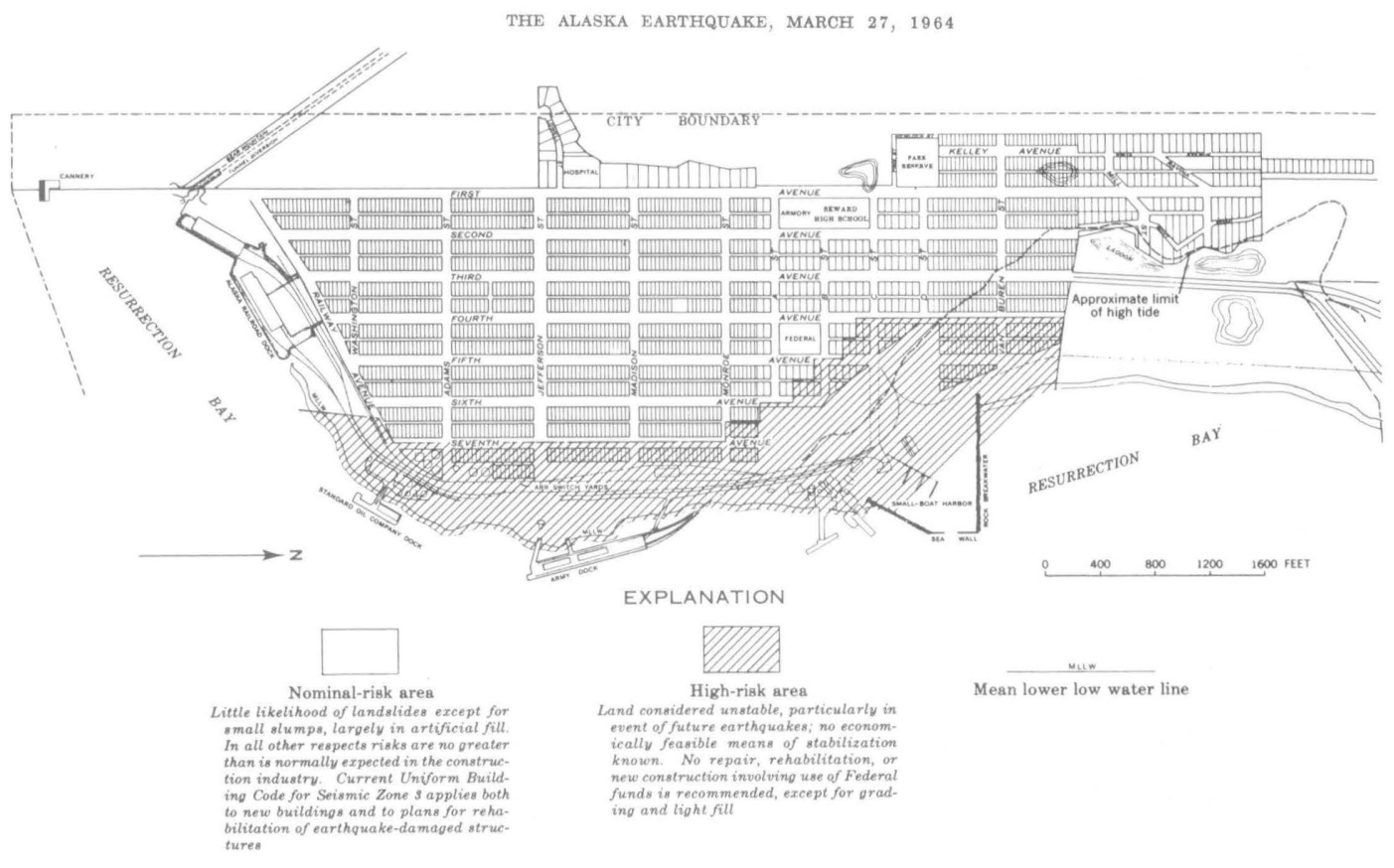

Figure 12. High- and nominal-risk areas of a part of Seward, as concluded by the scientific and engineering task force (from Hansen and Eckel, 1966).

waterfront and propagated westward down the bay where it surged to $50 \mathrm{~m}$ above sea level. A wave of similar size, probably reflected from the far end of the bay, struck Valdez about 10 minutes after the earthquake. Later that night, at 11:45 p.m. and 1:45 a.m., tidally augmented seiche waves (an oscillation of the surface of the bay) again advanced into the town. Waves surged a distance exceeding $500 \mathrm{~m}$ inland at Valdez. Parts of the shore area subsided because support was removed from the face of the delta. Subsidence continued for several months after the earthquake.

The sediment along the waterfront consists of a surficial 7- to 10 -m-thick layer of sandy gravel fill that is underlain by an unknown thickness of gravelly sand outwash with interbedded layers of silt. Both sedimentary units have loose to medium density. Scientists and engineers who studied the slope failure at Valdez speculated that the delta-front liquefied in response to the earthquake and the drop in water level, then the landslide material transformed into a mobile, low-density turbidity current that spread much of the sediment as a thin deposit away from the delta.

At least five previous seismic events in Valdez, between 1899 and 1925, were accompanied by submarine landslides, as evidenced by the occurrence of phenomena such as communication cable breaks and sudden waterdepth increases (Coulter and Migliaccio, 1966). There are reports of three small submarine landslides (in the early and late 1920's and in the early 1940's) that damaged parts of the dock facilities but were not associated with earthquakes.
Instead, they probably were due to loading by the docks themselves or by localized sedimentation consequent to river-control projects.

As at Seward, the stability of the delta at Valdez did not seem to be increased by the landslide, and similar large slope failures are expected in future earthquakes. This threat prompted the decision to move the entire town of Valdez to a more stable site $5.5 \mathrm{~km}$ to the west on the Mineral Creek fan (fig. 3). An engineering and geological study of the fan pointed out the comparative desirability of this site (Shannon and Wilson, Inc. 1964b). The area is underlain by complexly bedded, medium to very dense sand and gravel that is buttressed by bedrock ridges and apparently was stable during the earthquake. The nearshore sea-floor slope is relatively gentle to a distance of 100 to $300 \mathrm{~m}$ offshore, where it steepens to about $25^{\circ}$. Offshore sediment in part of the area is a loose, fine sand of the type that is prone to slope failure when shaken, and comparison of pre- and postearthquake water depths indicates that a small mass of this sediment about $100 \mathrm{~m}$ offshore failed during the earthquake. The overall stability of the Mineral Creek fan during the earthquake indicates that it is a safer location for the town of Valdez, however.

\section{CONCLUSION}

The destruction at Seward and Valdez clearly demonstrated the devastating effects that offshore landslides can have on man and his activities. Most submarine slope 


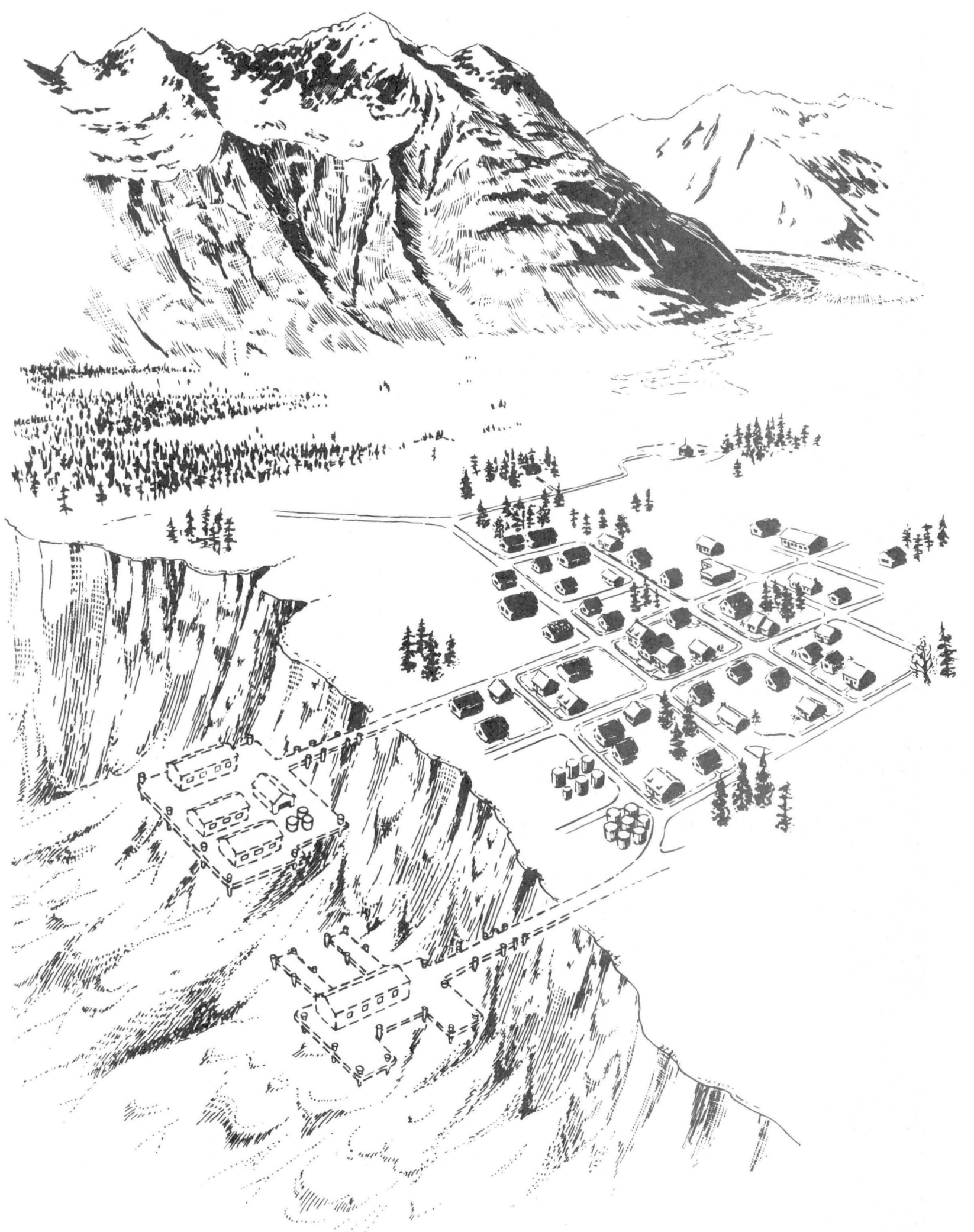

Figure 13. Submarine landslide area at Valdez (from Coulter and Miliaccio, 1966). The dashed lines indicate the dock area destroyed by the landslide. 


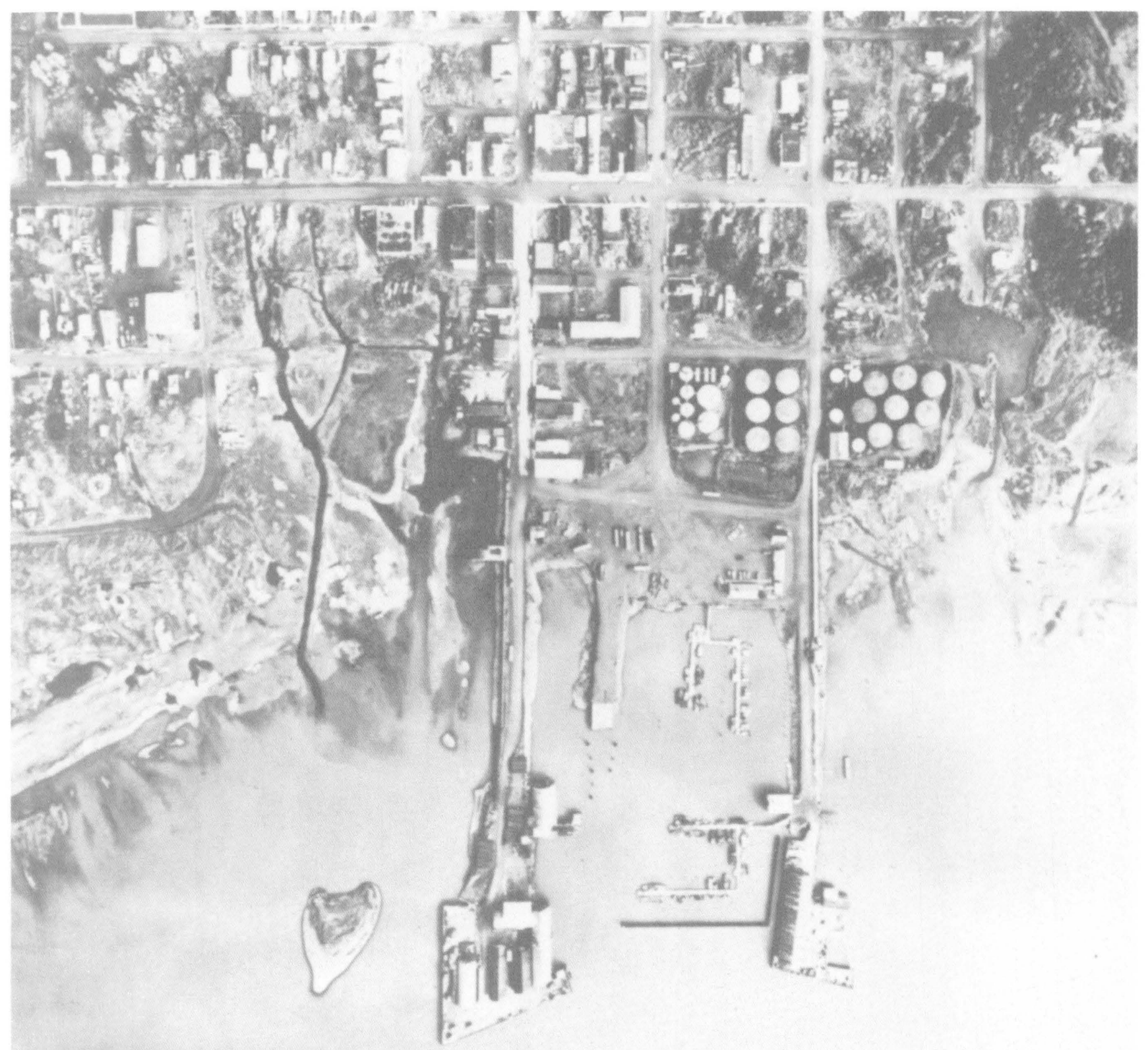

Figure 14. Valdez before the earthquake. Note the intact dock facilities extending out into Port Valdez (from Coulter and Migliaccio, 1966).

failures are benign in this regard; they occur far offshore and the range of their influence does not extend to the coastline. Moreover, the geologic conditions (coarse sediment, gentle sea-floor slope) in most nearshore areas do not permit slope failure even during the strongest seismic events; however, in those places where sandy and silty sediment is deposited rapidly on a steep sea-floor gradient, especially if earthquakes occur or if the tidal range is high, offshore landslides must be regarded as a potential hazard. This situation exists in nearly all Alaskan fjords. 


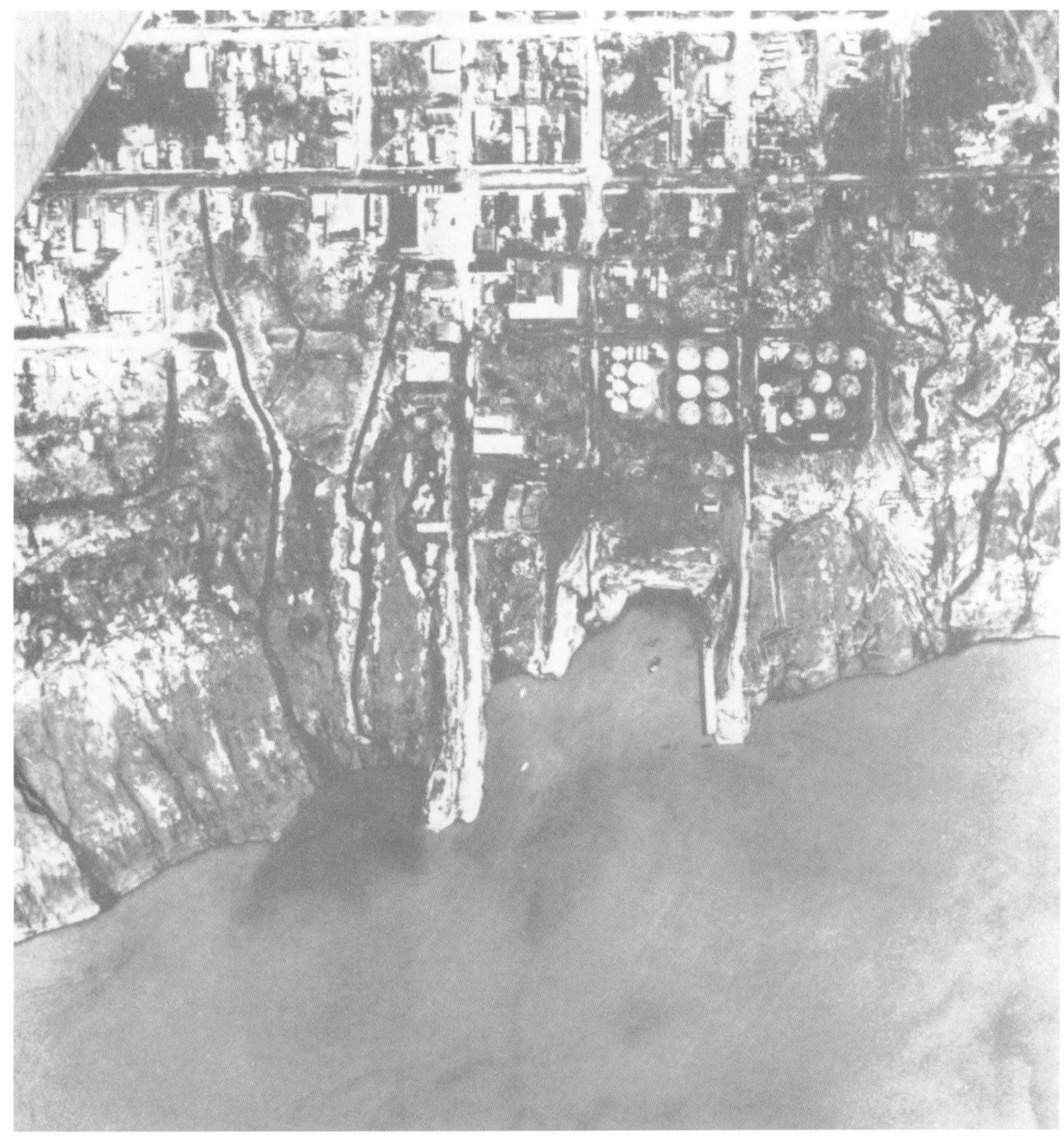

Figure 15. Valdez about 3 months after the earthquake (from Coulter and Migliaccio, 1966). Note the disappearance of the dock facilities and the devastation along the waterfront.

\section{REFERENCES CITED}

Committee on Earthquake Engineering, 1985, Liquefaction of soils during earthquakes: Washington, D.C., National Research Council, National Academy Press, 240 p.
Coulter, H.W., and Migliaccio, R.P., 1966, Effects of the earthquake of March 27, 1964, at Valdez, Alaska: U.S. Geological Survey Professional Paper 542-C, p. C1-C36. Hansen, W.R., and Eckel, E.B., 1966, A summary description of the Alaska earthquake-Its setting and effects, in Hansen, 
W.R., Eckel, E.B., Schaem, W.E., Lyle, R.E., George, W., and Chance, Genie., eds., U.S. Geological Survey Professional Paper 541, p. 1-37.

Hansen, W.R., Eckel, E.B., Schaem, W.E., Lyle, R.E., George, Warren, and Chance, Genie, 1966, The Alaska earthquake of March 27, 1964: field investigations and reconstruction effort: U.S. Geological Survey Professional Paper 541, $111 \mathrm{p}$.

Lemke, R.W., 1967, Effects of the earthquake of March 27, 1964, at Seward, Alaska: U.S. Geological Survey Professional Paper 542-E, p. E1-E43.

Prior, D.B., Coleman, J.M., and Bornhold, B.D., 1982, Results of a known seafloor instability event: Geo-Marine Letters, v. 2, p. $117-122$.
Prior, D.B., Wiseman, W.J., and Gilbert, R.A., 1981, Submarine slope processes on a fan delta, Howe Sound British Columbia: Geo-Marine Letters, v. 1, p. 85-90.

Shannon and Wilson, Inc., 1964a, Report on subsurface investigation for city of Seward, Alaska and vicinity: Seattle, Wash., Shannon and Wilson, Inc., 26 p.

-1964b, Report on subsurface investigation for Mineral Creek townsite, city of Valdez, Alaska: Seattle, Wash., Shannon and Wilson, Inc., 12 p.

Terzaghi, Karl, 1956, Varieties of submarine slope failures: Proceedings of the 8th Texas Conference on Soil Mechanics and Foundation Engineering, p. 1-41. 


\title{
Processes Controlling the Style of Mass Movement in Glaciomarine Sediment: Northeastern Gulf of
} Alaska

\author{
By W.C. Schwab and H.J. Lee
}

\section{INTRODUCTION}

The type of mass movement that occurs following slope failure can range from rigid block motion to fluidlike flow. As use of sea-floor resources and development of the sea floor continues to expand, it becomes increasingly desirable to develop methods that allow the ocean engineer to predict not only the relative stability of a slope but also the amount of sea-floor deformation that follows slope failure. We investigated several large areas of slope instability on the continental shelf of the northeastern Gulf of Alaska in an attempt to explain the different types of slope failure encountered (Schwab and Lee, 1983, 1988; Lee and Edwards, 1986; Schwab and others, 1987). Results of these studies are applicable to the development of a methodology that can predict the consequences of slope failure (also see Edwards, Lee, and Field, this report).
Glaciation is the dominant process contributing sediment to the northeastern Gulf of Alaska continental shelf (Molnia, 1983). Just as in the case of streams of water, glaciers perform erosion, transportation, and deposition of mineral matter. Blocks of rock being carried within the glacial ice are scraped and dragged along the rock floor, gouging and grooving the bedrock and chipping out fragments of rock. Much of the rock is ground by the glacier into extremely fine particles of silt- and clay-sized sediment; termed rock flour. Glaciers in the Chugach-St. Elias Mountains discharge their sediment into lakes, streams, and bays, and in turn, much of this material is transported by currents into the open-marine environment. This Holocene (deposited since the last ice age) glaciomarine sediment blankets most of the inner continental shelf (fig. 1), reaching a thickness of 200 meters (m) seaward of Icy Bay and Yakutat Bay (Carlson and Molnia, 1975) and $260 \mathrm{~m}$

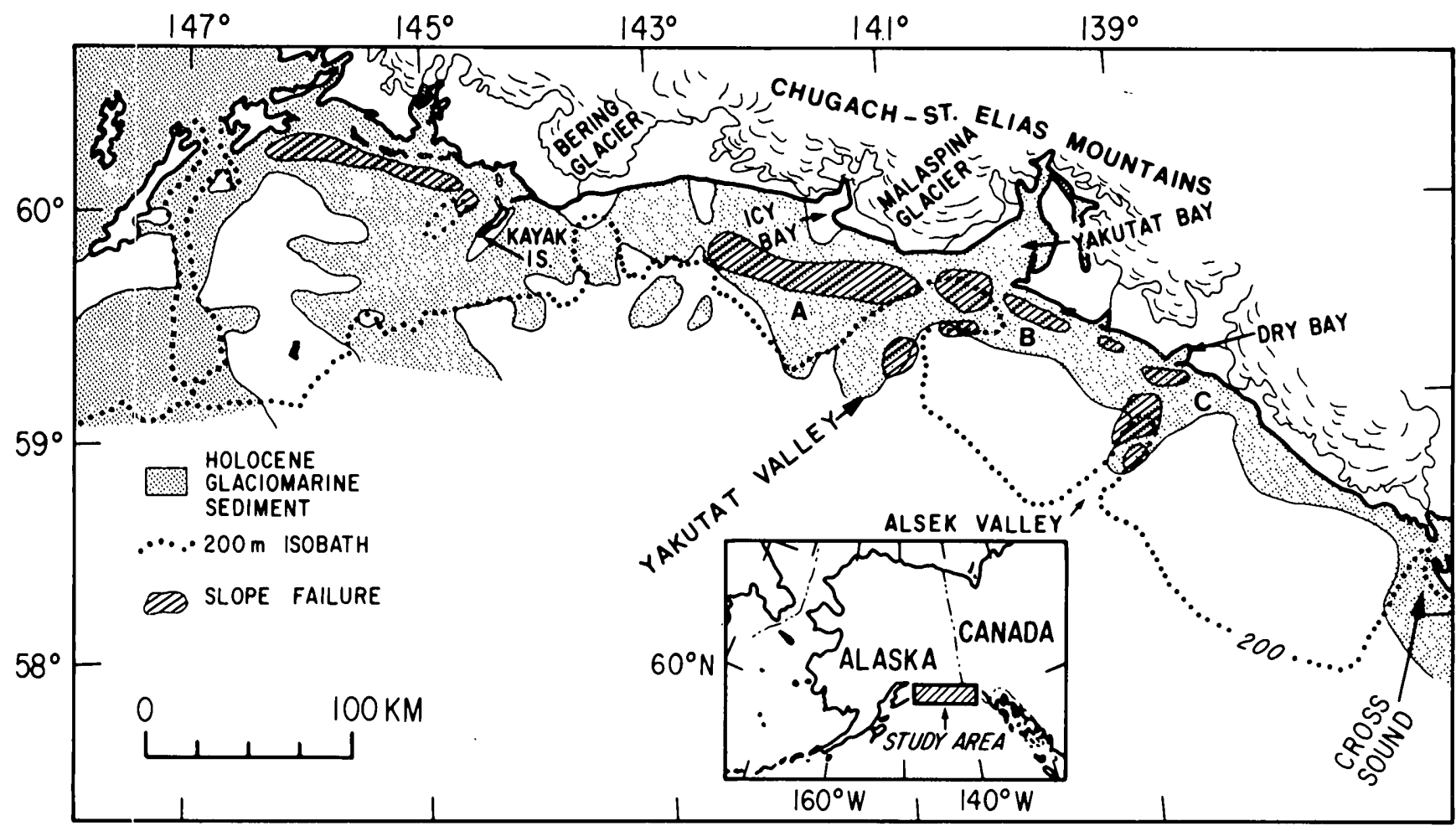

Figure 1. Northeastern Gulf of Alaska depicting the Holocene (deposited since the last ice age) glaciomarine sedimentary deposit and the location of areas of slope failure on the continental shelf, including (A) the Icy Bay-Malaspina slump, (B) the Yakutat slump, and (C) the Alsek prodelta slope instability area (from Schwab and Lee, 1988). 

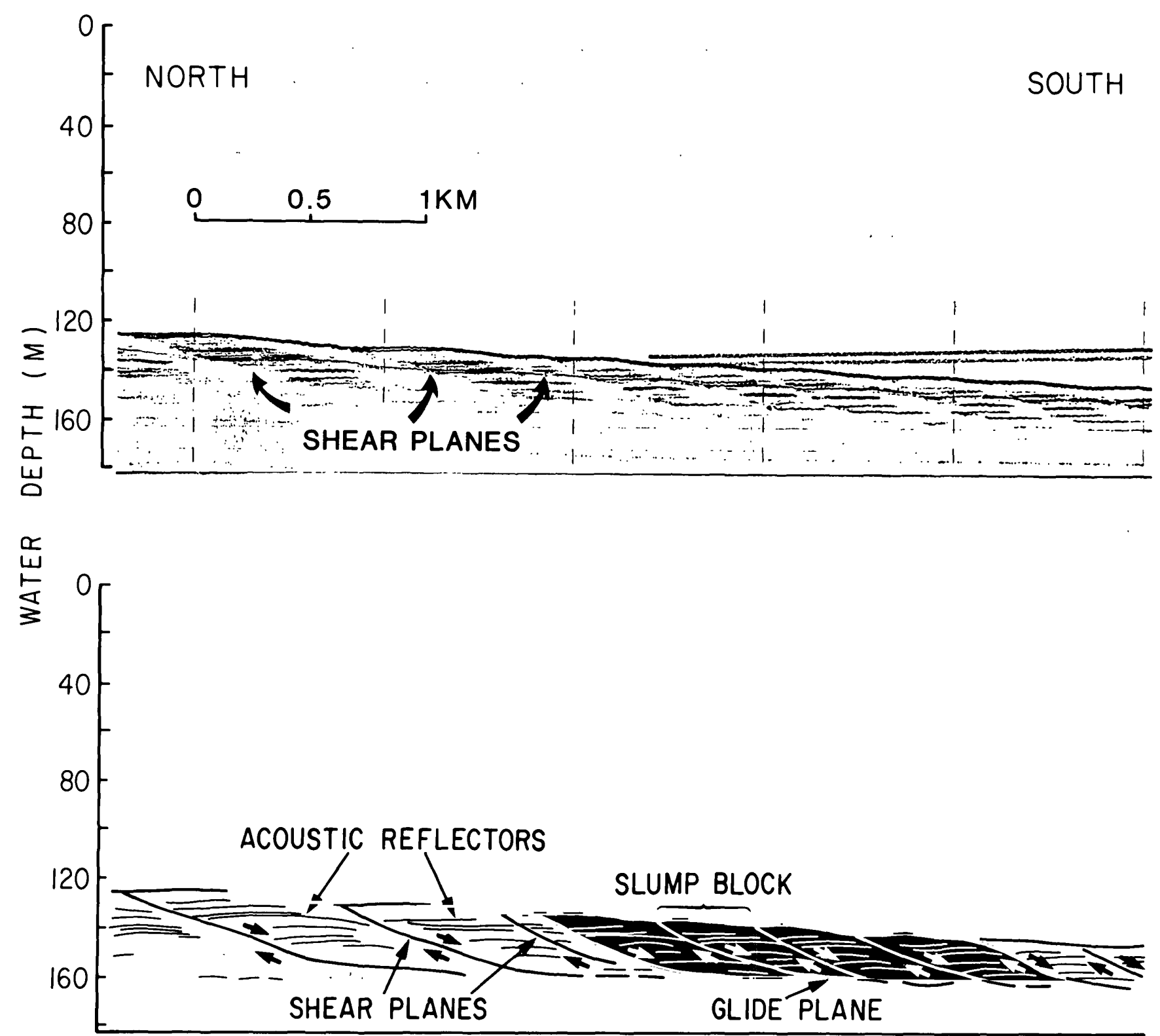

Figure 2. A 3.5-kilohertz seismic-reflection profile and interpretive sketch collected over part of the Icy Bay-Malaspina slump (modified from Lee and Edwards, 1986).

seaward of Dry Bay (Schwab and Lee, 1983). Slope failures on the continental shelf of the northeastern Gulf of Alaska occur entirely within this Holocene glaciomarine sedimentary deposit.

\section{CASE STUDIES}

The Icy Bay-Malaspina slump, the Yakutat slump, and mass flows on the Alsek prodelta (fig. 1) typify the two types of slope failures found on the continental shelf of the northeastern Gulf of Alaska. The region offshore from Icy
Bay and the Malaspina Glacier is an area where the glaciomarine clayey silt has failed over an area of about 1,080 square kilometers $\left(\mathrm{km}^{2}\right)$ in water depths of 70 to 150 $\mathrm{m}$ on a sea-floor slope less than $0.5^{\circ}$ (Carlson, 1978). Seismic-reflection profiles (for example, fig. 2) collected over the area of slope failure show broken acoustic reflectors in the subsurface (reflectors are indicative of sedimentary bedding) and scarplike surficial forms, suggesting that discrete slump blocks have undergone a slight backward tilting while moving approximately $18 \mathrm{~m}$ downslope. These slump blocks extend over the entire failure area and are about $0.5 \mathrm{~km}$ long and offset the sea floor from 2 to $5 \mathrm{~m}$. 


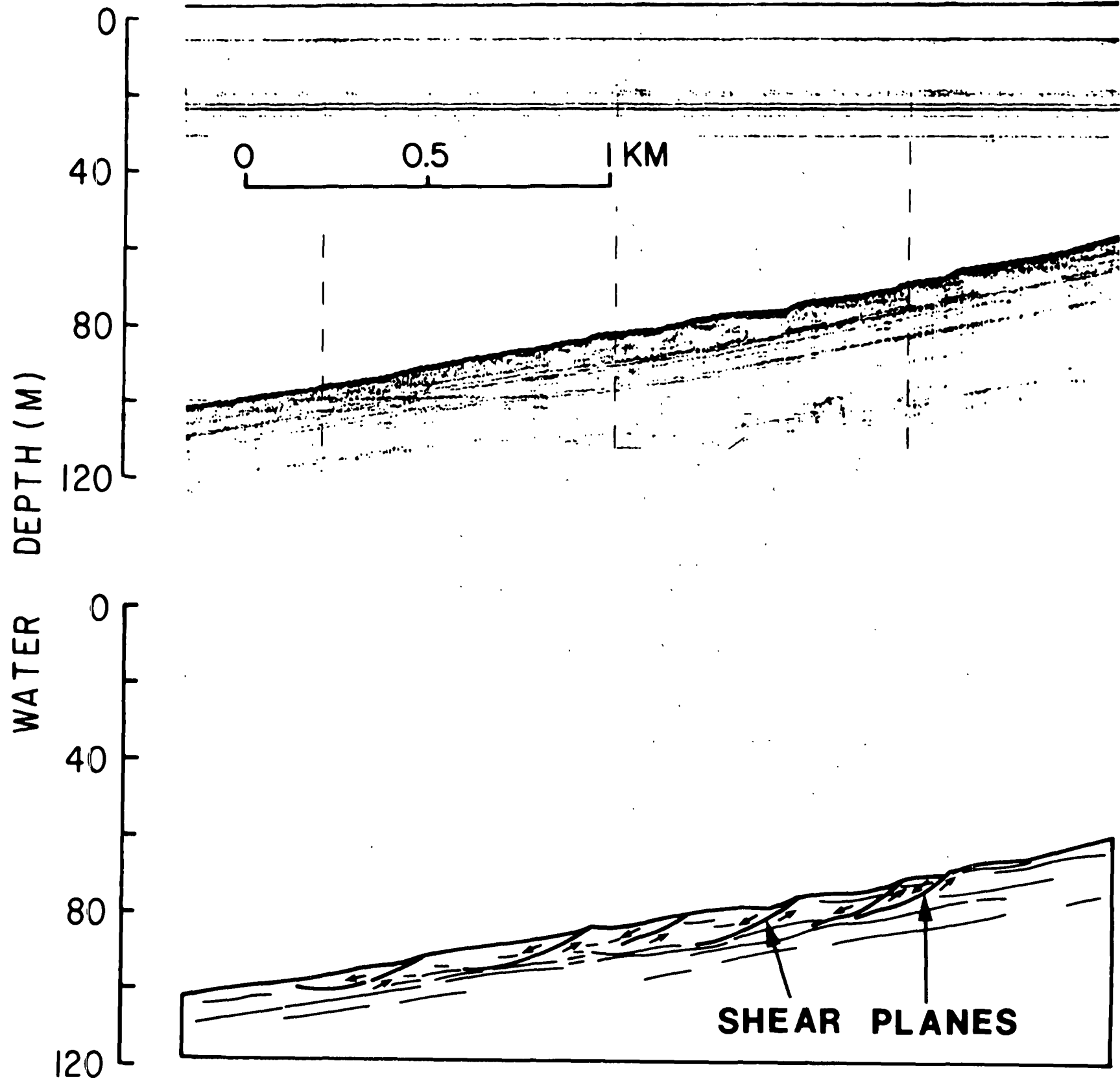
Figure 3. A 3.5-kilohertz seismic-reflection profile and interpretive sketch collected over the Yakutat slump (Schwab and
Lee, 1988).

The individual failure planes (shear planes) extend down below the sea floor to a depth of 15 to $40 \mathrm{~m}$, where they form a well-defined glide plane parallel to the sea floor.

The: Yakutat slump is characterized by backwardtilted blocks of glaciomarine clayey silt that have undergone about $13 \mathrm{~m}$ of downslope movement in water depths of 65 to $90 \mathrm{~m}$ (Carlson and others, 1980). Seismic-reflection profiles show that the slump blocks, although not as well developed as in the Icy Bay-Malaspina slump, extend over an area of about $260 \mathrm{~km}^{2}$ and are about $100 \mathrm{~m}$ long and have sea-floor relief of 3 to $4 \mathrm{~m}$ (fig. 3). The failure planes extend $10 \mathrm{~m}$ below the sea floor. The nearshore part of the Yakutat slump has a slope angle of about $1^{\circ}$. The sea-floor slope decreases to about $0.5^{\circ}$ at the seaward edge of the failure area.

Slope failures (fig. 4) cover an area of at least 150 $\mathrm{km}^{2}$ on the Alsek prodelta (Molnia, 1982). These slope failures originate in a water depth of about $35 \mathrm{~m}$ on a 


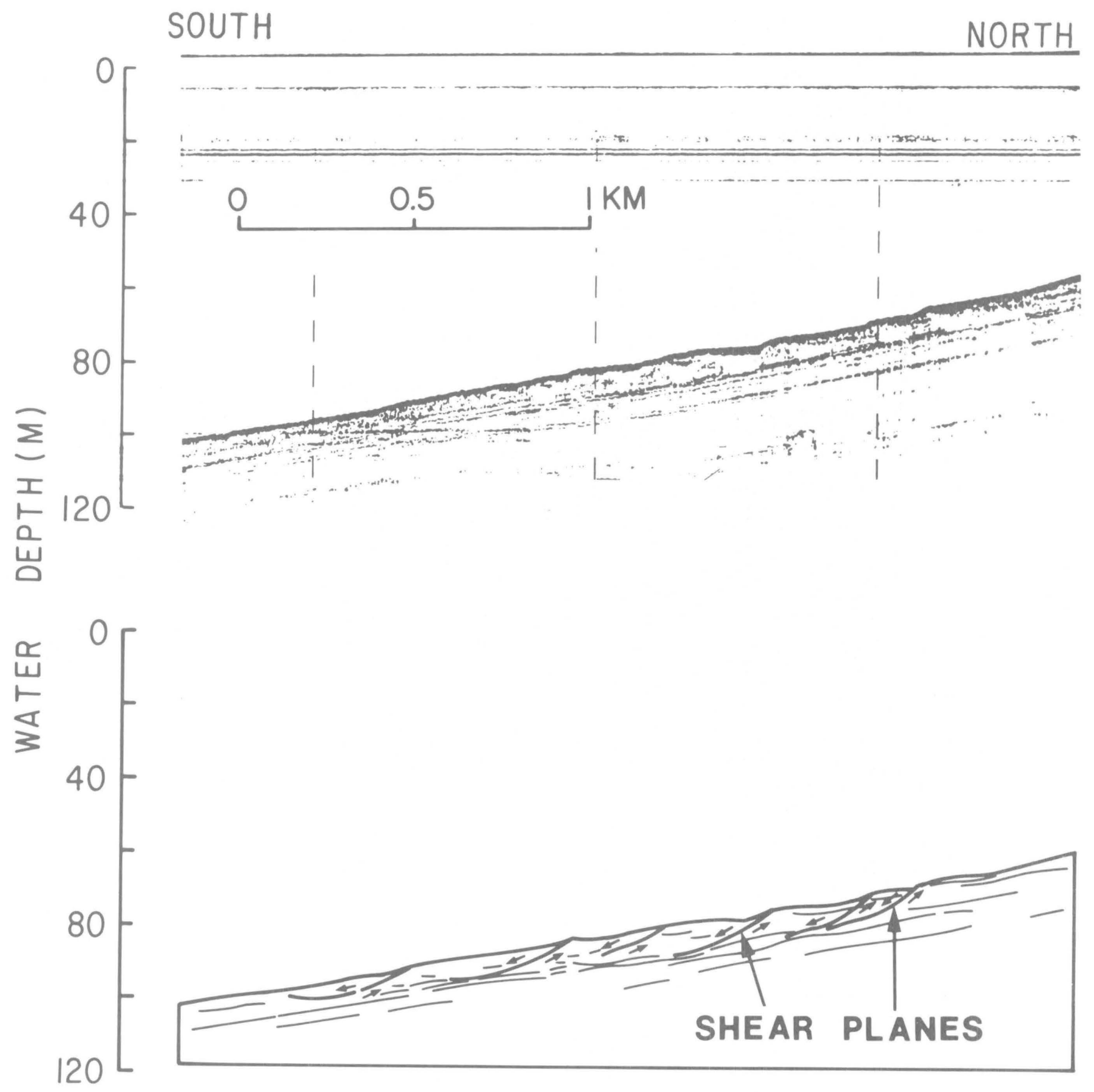

Figure 3. A 3.5-kilohertz seismic-reflection profile and interpretive sketch collected over the Yakutat slump (Schwab and Lee, 1988).

The individual failure planes (shear planes) extend down below the sea floor to a depth of 15 to $40 \mathrm{~m}$, where they form a well-defined glide plane parallel to the sea floor.

The Yakutat slump is characterized by backwardtilted blocks of glaciomarine clayey silt that have undergone about $13 \mathrm{~m}$ of downslope movement in water depths of 65 to $90 \mathrm{~m}$ (Carlson and others, 1980). Seismic-reflection profiles show that the slump blocks, although not as well developed as in the Icy Bay-Malaspina slump, extend over an area of about $260 \mathrm{~km}^{2}$ and are about $100 \mathrm{~m}$ long and have sea-floor relief of 3 to $4 \mathrm{~m}$ (fig. 3). The failure planes extend $10 \mathrm{~m}$ below the sea floor. The nearshore part of the Yakutat slump has a slope angle of about $1^{\circ}$. The sea-floor slope decreases to about $0.5^{\circ}$ at the seaward edge of the failure area.

Slope failures (fig. 4) cover an area of at least 150 $\mathrm{km}^{2}$ on the Alsek prodelta (Molnia, 1982). These slope failures originate in a water depth of about $35 \mathrm{~m}$ on a 
precludes determination of the maximum depth below the sea floor that is affected by slope failure; however, it is estimated to be less than $20 \mathrm{~m}$ (Carlson and others, 1980).

Using engineering analyses of the strength characteristics of the glaciomarine sediment and the environmental stresses affecting this sedimentary deposit, Schwab and Lee (1983) determined that earthquake-shaking and the passage of storm waves are the two triggering forces that caused the slopes to fail. Downslope stress resulting from gravitational forces (that is, sea-floor slope angle) are a less important factor, although they determine the ultimate direction of movement. Some uniformity in the style of mass movement following slope failure on the continental shelf of the northeastern Gulf of Alaska might be expected because the sediment in the failure areas is all of the same type, glaciomarine clayey silt. However, variation in the morphology of the mass movement deposits implies that there are major differences in the styles of mass movement.

\section{ANALYSIS}

To determine what caused the sediment found on the northeastern Gulf of Alaska continental shelf to deform in two different ways, we compared the environmental factors affecting the slumps and mass flows (Schwab and Lee, 1988). Our three study areas are suited for this type of comparison because the seismic and storm-wave environments, as well as the sediment, are similar in each. For example:

1. Due to its tectonic setting (Bruns, 1985), the northeastern Gulf of Alaska is the most seismically active region in the United States, apart from the Aleutian Islands. All three study areas are located in a region suggested as having a uniform ground-shaking intensity; that is, each study area will, over a period of time be subjected to earthquake movements having about the same maximum intensity (Stephens and Page, 1982).

2. All three areas are influenced by the same storm-wave climate. Large storm waves, which commonly have a wave height of at least $15 \mathrm{~m}$, roll across the continental shelf throughout the winter (Royer, 1975). The probable maximum height of winter storm waves in the area is 37 m (Quayle and Fulbright, 1975; Bea, 1976).

Table 1. Sediment textural data for the three slope failure study areas

\begin{tabular}{lccc}
\hline & $\begin{array}{c}\text { Sand } \\
(>0.063 \mathrm{~mm}) \\
(\%)\end{array}$ & $\begin{array}{c}\text { Silt } \\
(\%)\end{array}$ & $\begin{array}{c}\text { Clay } \\
(<0.004 \mathrm{~mm}) \\
(\%)\end{array}$ \\
\hline $\begin{array}{l}\text { Icy-Bay-Malaspina } \\
\text { slump }\end{array}$ & $1.23 \pm 1.94$ & $66.15 \pm 9.94$ & $32.60 \pm 10.11$ \\
Yakutat slump & $7.74 \pm 6.09$ & $54.32 \pm 6.59$ & $37.93 \pm 6.20$ \\
Alsek prodelta & $1.70 \pm 2.41$ & $59.26 \pm 7.33$ & $39.16 \pm 6.83$ \\
\hline
\end{tabular}

3. The grain-size distribution of samples collected in the three study areas varies locally but similarly in each area (table 1). The glaciomarine sediment on the continental shelf of the northeastern Gulf of Alaska is dominantly clayey silt.

4. The mineralogy of the sediment from the three study areas is similar (Molnia and Hein, 1982; Schwab and Lee, 1988).

5. Sediment cores in the three study areas that contain a higher proportion of sediment with water content in the range of 35 to 45 percent of the dry sediment weight correlate with the locations of submarine slope failure (Schwab and Lee, 1983). The water content of this sediment is a simple index property that correlates with more advanced engineering properties and also more basic sediment properties such as grain-size distribution.

6. Sediment pore-water pressures in the three study areas do not appear to be in excess of hydrostatic pressure, an important condition that relates to slope stability (Schwab and Lee, 1983; Lee, Schwab, and Booth, this report).

Our slope-stability analysis (Schwab and Lee, 1983) described the influence of storm waves and earthquake forces that lead to slope failure of the glaciomarine sediment. These forces were defined by laboratory testing in which only a relatively small amount of sediment deformation was found to occur. This level of deformation, although small, is sufficient to be seen in high-resolution seismic-reflection profiles collected over the Icy BayMalaspina and Yakutat slumps (fig. 2). The slope failures on the Alsek prodelta (fig. 4), however, include elements of flow that extend well beyond the level of deformation that typically is observed in a laboratory-test-based slope stability analysis. Therefore, although our initial slope-stability analysis most likely predicts the initiation of slope failure, it provides little information regarding its consequences.

Two end-member consequences of slope failure have been described: disintegration and nondisintegration (Whitman, 1985; Schwab and others, 1987). Disintegrative failure is a condition in which a sediment mass is so weak following slope failure that it deforms continuously under downslope gravitational stresses even after the stress causing the slope failure has been removed (for example, following an earthquake). This deformation ceases only after large displacement has occurred or the slope gradient is reduced. Nondisintegrative failure involves permanent displacement during slope failure, but the sedimentary deposit stops deforming after the triggering stress is removed. The Icy Bay-Malaspina slump and the Yakutat slump are nondisintegrative failures whereas the mass flows in the Alsek prodelta are disintegrative failures.

To achieve a disintegrative failure, the sediment must lose a good deal of its strength during a transient loading event (earthquake or major storm). In the case of the continental shelf in the northeastern Gulf of Alaska, the 
sediment strength must be reduced to the point that continued downslope sediment movement can occur on slopes that are less than $1^{\circ}$. Our laboratory testing of sediment samples from the area of the slope failures show that the strength of the sediment cannot be reduced sufficiently, as long as the natural water content of the sediment remains constant. That is, the sediment in place has a water content that is too low to allow the development of a mass flow. If the water content were increased during a transient loading event, however, the sediment's strength could be lowered enough to allow a mass flow to develop (Schwab and others, 1987; Schwab and Lee, 1988).

How can sediment water content be increased during an earthquake or major storm? One mechanism proposed by Whitman (1985) involves local pore-water movement within the sediment column; that is, pore water is redistributed within the sediment but does not flow out of the overall sediment system. A unique characteristic of the response of fine-grained sediment to cyclic stresses (the stresses induced by storm waves or earthquakes) is the tendency to develop sediment pore-water pressures that equal lithospheric stress (the stress induced by the overlying sediment which, in turn, increases with increasing depth in the deposit). If the level of cyclic stress is high enough, pore-water pressures that are equal to the lithospheric stress develop over a substantial thickness of the sedimentary deposit. The resulting pore-pressure gradient leads to an upward flow of pore water; from the area of high pressure to the area of relatively lower pressure (fig. 5). The base of the part of the sediment column affected by the cyclic stresses becomes more dense while the upper sections loosen, resulting in a continually decreasing strength of the upper sedimentary section. Once the sediment strength falls below a critical level, a disintegrative failure occurs.

Another mechanism for converting a nondisintegrative failure into a disintegrative failure was described by Hampton (1972). He suggested that water is incorporated from the overlying sea water into a submarine slump by the jostling and agitation it received as it begins to move. Sediment deformation during a transient loading event can become large. Some of the sea water may be incorporated into the sediment simply as a result of these rapid movements and agitations, thus significantly reducing the strength of the sediment.

On the continental shelf in the northeastern Gulf of Alaska, we suggest that these two mechanisms are most effective during storm-wave loading and that storms are the principal cause of mass flows in this glaciomarine sediment. Sediment framework expansion (and strength reduction) during a major storm event, enhanced relative to what would occur in an earthquake, can be justified in three ways.

First, a long series of loading cycles causes the sediment strength to fall to a low level. Our experimental results on the behavior of Gulf of Alaska glaciomarine clayey silt suggest that the strength of sediment samples is about 73 percent lower after 1,000 stress cycles are applied than after 10 (Schwab and Lee, 1983, 1988). Major earthquakes produce from 10 to 25 representative loading cycles (Seed and Peacock, 1971), whereas a major storm would likely produce 1,000 cycles or more. With such large reductions of sediment strength during major storms, the level of deformation experienced during each cycle of storm-wave loading should be greatly enhanced. The mechanism proposed by Hampton (1972) could then come into play; the increased level of jostling would cause increased amounts of sea water to be incorporated into the sediment.

Second, the long duration of stress application during a major storm allows increased pore-water redistribution. Thus, by Whitman's (1985) mechanism, water begins to flow from deeper strata into shallower strata (fig. 5). If the duration of cyclic stress application is short, the process is limited, and pore-water pressure drops in the deeper strata, thus, halting the upward flow. With a long period of cyclic stress application, however, the pore-water pressures in the deeper strata are renewed continually. A steady pumping action, drawing water from deeper sediment toward steadily expanding sediment near the sea floor occurs.

Third, storm waves generate stresses that propagate from the sea floor down, whereas earthquakes generate stresses that propagate from the bedrock up. Because weakening and failure of sediment occurs after application of a number of cycles of stress, the ability of the failed sediment to transmit stresses is degraded. In the case of an earthquake, the slump blocks, once they have formed, become partially isolated from the source of the stress application below. Significant stresses cannot propagate upward across the failure plane (Lee, 1976). On the other hand, with storm-wave-induced failures, it is the zone under the failure blocks that become partly isolated from the source of stress. The blocks themselves are still openly exposed to wave-induced stresses propagating down from the sea floor. The processes leading to framework expansion are free to proceed, unhindered by the development of a barrier to stress propagation.

The suggestion that storm waves are more likely to cause mass flows than are earthquakes in this environment is also supported by field and laboratory evidence. We determined the water depths in which major earthquakes are most likely to cause a slope failure and those in which peak storm waves are the most critical factor (Schwab and Lee, 1983). We found that earthquake shaking dominates in water depths greater than $76 \mathrm{~m}$ and storm-wave loading dominates in water depths less than $35 \mathrm{~m}$. Sediment in depths between 35 and $76 \mathrm{~m}$ have an equal chance of failure by either mechanism. Using these criteria, we suggested that the Icy Bay-Malaspina slump, in water depths between 70 and $150 \mathrm{~m}$, was caused by earthquake shaking. The Yakutat slump, with water depths between 65 and $90 \mathrm{~m}$, was also probably seismically induced. However, the Alsek 


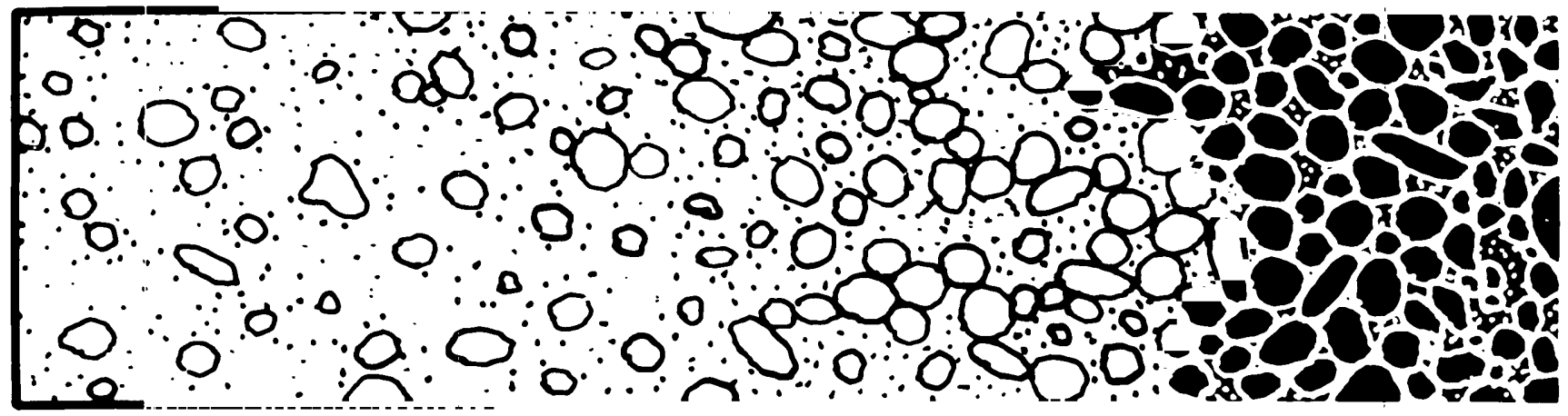

C

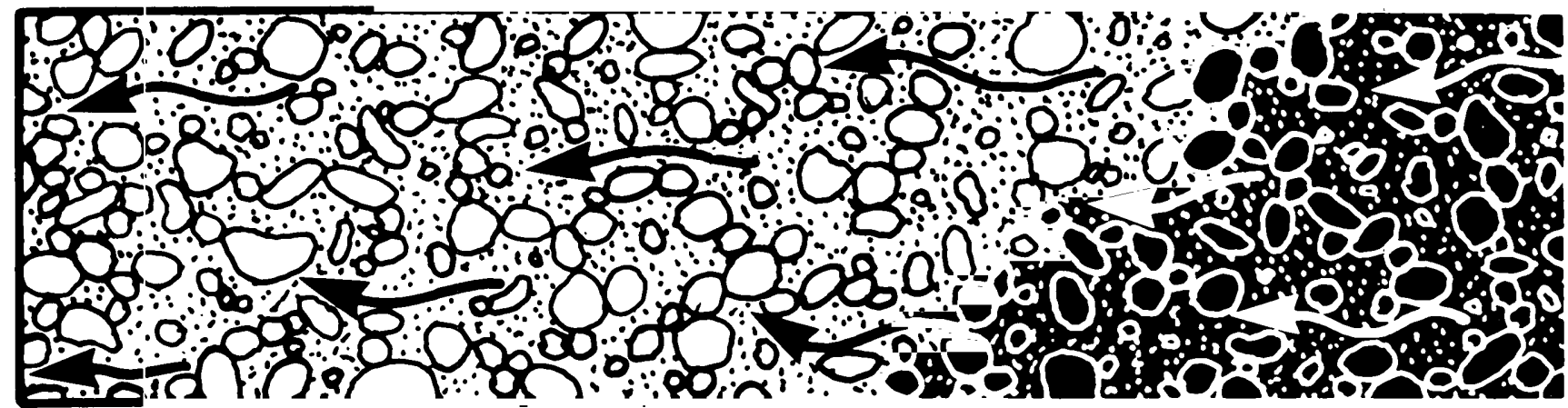

$B$

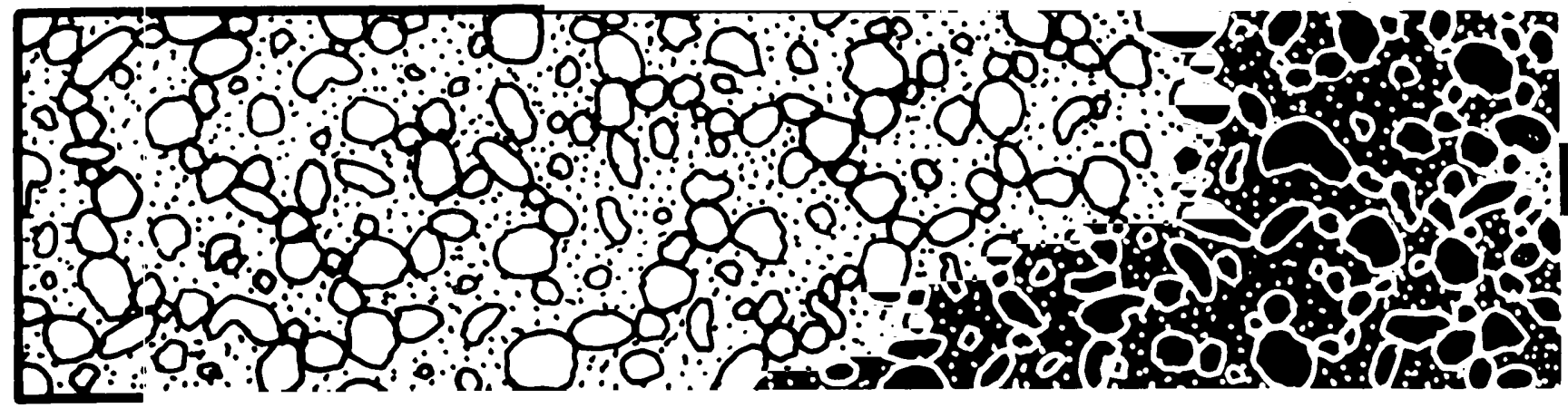

A

Figure 5. Illustration of the possible redistribution of pore water during the application of cyclic stresses: $(A)$ the sediment column at rest, $(B)$ pore water flowing upward due to the pore-water pressure gradient induced by the

prodelta failures, in water depths of 35 to $80 \mathrm{~m}$, occurred in a depth range where storm waves could cause slope failure as readily as earthquakes.

Disintegrative failures on the Alsek prodelta are found within an environment in which either winter storm waves or earthquakes can cause failure. On the other hand, nondisintegrative failures in the Icy Bay-Malaspina slump and Yakutat slump are associated with environments in which storm waves are probably insufficient to cause application of cyclic stresses, and $(C)$ the base of the sediment column affected by the cyclic stresses contracts due to the redistribution of pore water while the upper section expands. 


\section{CONCLUSIONS}

Three differences-(1) enhanced jostling, (2) enhanced redistribution of pore water, and (3) the absence of a partial barrier to stress propagation-separate the application of cyclic stresses related to storm waves from those related to earthquakes. These factors are sufficient to allow disintegrative failures to form during storms. On the other hand, only nondisintegrative failures are likely to occur during earthquakes on the northeastern Gulf of Alaska continental shelf. These differences explain the varied types of slope failure found in the region.

These findings regarding the cause of mass flows are not universally applicable to other sedimentary deposits. That is, we cannot state that slumps are caused by earthquakes and disintegrative failures by pore-water redistribution during major storms. For example, earthquake-induced mass flows may be common wherever relatively loose (low-density) sedimentary deposits are found. Recent extensive liquefaction on a $0.25^{\circ}$ slope following an earthquake off northern California (Field, this report) illustrates such a situation. A mudflow on a $4^{\circ}$ slope in Santa Barbara Basin, Calif., is another illustration (Edwards, Lee, and Field, this report). Likewise, disintegrative failures in fine-grained deltaic deposits can probably occur without a significant redistribution of pore water during major stormwave-loading events. Disintegrative failures on very gentle slopes $\left(0.01^{\circ}\right.$ to $\left.0.45^{\circ}\right)$ of the Mississippi Delta (Coleman and others, this report) illustrate the behavior of sediment that flowed without needing to expand. In each new situation, therefore, a full evaluation of the factors relating to slope failure is needed. For the case of the northeastern Gulf of Alaska however, we have shown that the unique loading environment, sediment type, and sediment conditions lead to limited possibilities in terms of resulting failure types.

\section{ACKNOWLEDGMENTS}

Initial phases of this study were supported by the U.S. Geological Survey and the U.S. Bureau of Land Management (BLM). Support from BLM was through an interagency agreement with the National Oceanic and Atmospheric Administration, under which a multi-year program responding to needs of petroleum development of the Alaskan continental shelf, was managed by the Outer Continental Shelf Environmental Assessment Program Office. Reviews of the manuscript by W.W. Danforth and D.C. Twichell were extremely helpful.

\section{REFERENCES CITED}

Bea, R.G., 1976, Earthquake criteria for platforms in the Gulf of Alaska: Proceedings of the 8th Offshore Technology Conference, Houston, Texas, v. 2, p. 657-679.

Bruns, T.R., 1985, Tectonics of the Yakutat block, an allochthonous terrane in the northern Gulf of Alaska: U.S. Geological Survey Open-File Report 85-13, 112 p.
Carlson, P.R., 1978, Holocene slump on the continental margin off the Malaspina Glacier, Gulf of Alaska: American Association of Petroleum Geologists Bulletin, v. 62, p. 2412-2426.

Carlson, P.R., and Molnia, B.F., 1975, Preliminary isopach map of Holocene sediments, northern Gulf of Alaska: U.S. Geological Survey Open-File Report 75-507, 1 sheet, scale 1:500,000.

Carlson, P.R., Molnia, B.F., and Wheeler, M.C., 1980, Seafloor geologic hazards in OCS lease sale area 55, eastern Gulf of Alaska: Proceedings of the 12th Annual Offshore Technology Conference, Houston, Texas, v. 1, p. 563-603.

Hampton, M.A., 1972, The role of subaqueous debris flow in generating turbidity currents: Journal of Sedimentary Petrology, v. 42, p. 775-793.

Lee, H.J., and Edwards, B.D., 1986, Regional method to assess offshore slope stability: Journal of Geotechnical Engineering, American Association of Civil Engineers, v. 112, p. 489-509.

Lee, K.L., 1976, Predicted and measured pore pressure in the Ekofisk tank foundation: Proceedings of the first International Conference, Behavior of Offshore Structures: BOSS 76, Trondheim, Norway, Norwegian Institute of Technology, p. 355-424.

Molnia, B.F., 1982, Geology of the Alsek sediment instability study area: U.S. Department of Commerce, NOAA, OCSEAP Final Report 47, v. 1, p. 40-55.

1983, Subarctic glacial-marine sedimentation, in Molnia, B.F., ed., Glacial-Marine Sedimentation: New York, N.Y., Plenum Press, p. 95-144.

Molnia, B.F., and Hein, J.R., 1982, Clay mineralogy of a glacially dominated, subarctic continental shelf: northeastern Gulf of Alaska: Journal of Sedimentary Petrology, v. 52, p. 515-527.

Quayle, R.G., and Fulbright, D.C., 1975, Extreme wind and wave return periods for the U.S. coast: Mariners' Weather Log, NOAA, U.S. Department of Commerce Publication, v. 19 , p. $67-70$.

Royer, T.C., 1975, Seasonal variations of waters in the northern Gulf of Alaska: Deep Sea Research, v. 22, p. 403-416.

Schwab, W.C., and Lee, H.J., 1983, Geotechnical Analyses of submarine landslides in glacial marine sediment, northeastern Gulf of Alaska, in Molnia, B.F., ed., Glacial-Marine Sedimentation: New York, N.Y., Plenum Press, p. 145-183.

1988, Causes of two slope-failure types in continentalshelf sediment, northeastern Gulf of Alaska: Journal of Sedimentary Petrology, v. 58, p. 1-11.

Schwab, W.C., Lee, H.J., and Molnia, B.F., 1987, Causes of varied sediment gravity flow types on the Alsek prodelta, northeast Gulf of Alaska: Marine Geotechnology, v. 7, p. 317-342.

Seed, H.B., and Peacock, W.H., 1971, Procedures for measuring soil liquefaction characteristics: Journal of Soil Mechanics and Foundations, American Society of Civil Engineers, v. 97, SM8, p. 1099-1119.

Stephens, C.D., and Page, R.A., 1982, Seismic activity in the northern Gulf of Alaska since 1974, in Bruns, T.R., ed., Hydrocarbon resource report for proposed OCS lease sale 88: southeastern Alaska, northern Gulf of Alaska, Cook Inlet, and Shelikoff Strait, Alaska: U.S. Geological Survey OpenFile Report 82-928, p. 115-121.

Whitman, R.V., 1985, On liquefaction: Proceedings of the 11th International Conference on Soil Mechanics and Foundation Engineering, San Francisco, v. 4, p. 1923-1926. 


\title{
Liquefaction of Continental Shelf Sediment: The Northern California Earthquake of 1980
}

\author{
By M.E. Field
}

\section{INTRODUCTION}

Earthquakes have long been recognized as a major cause of submarine landslides. Much of this recognition has been based on (1) the assumption that earthquakes alone possess the force required to cause abrupt slope failures and, to a degree, on (2) comparisons with onshore observations of mass movement during earthquakes. Our understanding of exactly how an earthquake affects the sea floor has been hampered by a lack of observations. Because sea-floor landslide deposits often consist of multiple events, it is difficult and often impossible to determine exactly what happened during a particular earthquake.

In 1980, following a large (Richter magnitude $\mathrm{M}=7.0$ ) earthquake off northern California, a unique opportunity existed to survey a landslide caused by earthquake-induced liquefaction of sediment on the continental shelf (for a definition of liquefaction see Lee, Schwab, and Booth, this report). Many aspects of the earthquake and the landslide were well documented - an unusual circumstance for marine scientists unraveling geologic events for which most evidence is thousands to millions of years old. The timing, size, magnitude, and location of the earthquake were accurately known, and, because the sea floor had been surveyed 1 year prior to the earthquake, all changes to the sea floor could be linked directly to this particular earthquake. Within a month of the earthquake, marine surveys were initiated to map the sea floor in an area where local fishermen had reported the sudden presence of scarps and ridges. What follows is a synthesis of those surveys, emphasizing the landslide patterns and processes observed and identifying the implications this study has for development activities (for example, mining, disposal, pipelines) on the continental shelf. This paper draws heavily on previously published results (Field and others, 1982; Field and Hall, 1982; Field, 1984) as well as on research that is still in progress.

\section{The November 8, 1980 Earthquake}

High levels of seismic activity are commonplace in northern California due to overthrusting of the Gorda lithospheric plate by the North American plate and rightlateral slip along the Gorda Escarpment (fig. 1; Couch, 1980). Since 1920, for example, an average of one earthquake of $M \geq 6.0$ per decade has occurred (Couch and others, 1974). Before the 1980 earthquake, two other events of $\mathrm{M} \geq 7.0$ were known to have occurred in the area in the past century (Real and others, 1978).

At 2:27 a.m. (Pacific Standard Time), on November 8, 1980, a large-magnitude earthquake occurred 60 kilometers $(\mathrm{km})$ west of Trinidad, Calif., on the continental margin. The earthquake had an estimated magnitude of $\mathrm{M}=7.0$. Some damage occurred onshore, but for the most part, the effects were relatively minor in comparison with onshore earthquakes of comparable size (such as the Loma Prieta California earthquake of October 17, 1989). Rockfalls and sand boils (caused by the liquefaction of sand below the ground) were reported along the coast, and, south of Eureka, an overpass on U.S. Highway 101 collapsed (Lajoie and Keefer, 1981). No other immediate reports of damage were received.

Several days after the earthquake, Crescent City commercial fishermen, who frequently travel the coastal waters, reported the presence of one or more northwest-

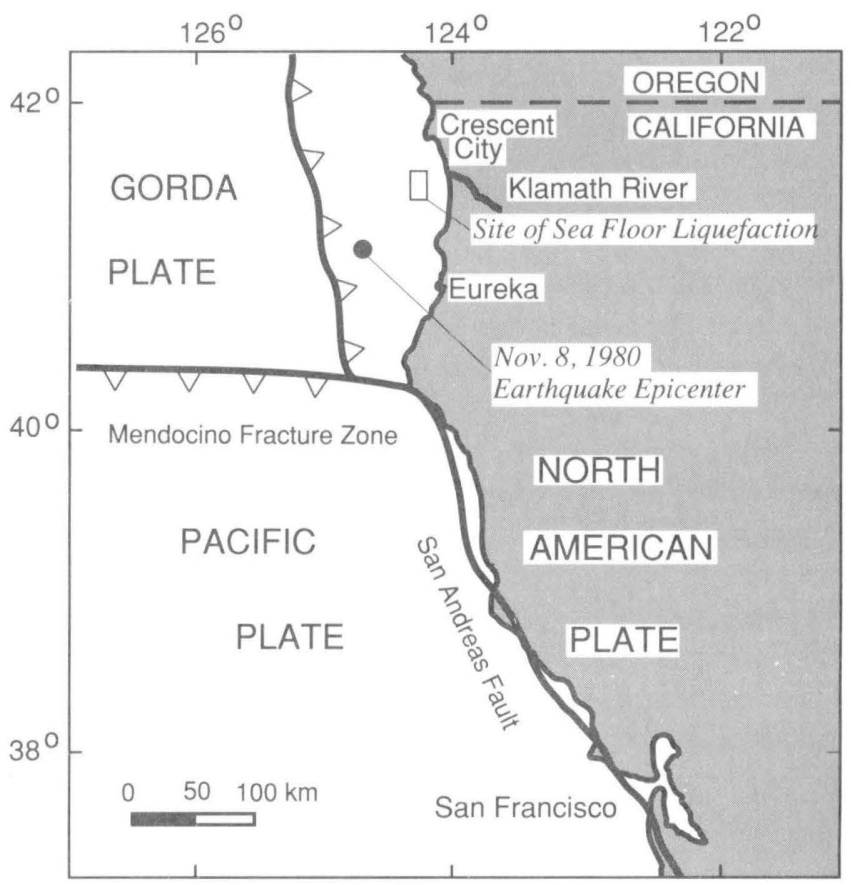

Figure 1. This map shows the complex interaction of tectonic plates near the coast of northern California. These interactions result in a high number of earthquakes in the region. On November 8, 1980, an earthquake of magnitude 7.0 (similar to the Loma Prieta earthquake of October 17, 1989) occurred offshore, and the seismic motion caused liquefaction and ground failure onshore and offshore along the coast. 
trending scarps offshore of the Klamath River. This area is a smooth, featureless depositional environment, and the sudden appearance of scarps suggested a causal relation to the earthquake. A survey of the area was conducted in mid-December 1980 aboard the research vessel S.P. Lee, using high-resolution seismic-reflection equipment. As a part of the expedition, several tracklines that had been surveyed 1 year before the earthquake were resurveyed. The entire area was surveyed again in May and October 1981, using high-resolution seismic-reflection equipment, sidescan sonar, and bottom cameras.

\section{Setting of the Northern California Continental Shelf}

The northern California continental shelf exhibits both active tectonism and relatively high rates of sedimentation. Off the Klamath River, the shelf is composed of a complex sequence of folded and faulted rocks that were deposited prior to several hundred thousand years ago. These strata are underlain by older rocks of the Franciscan Complex, and they are overlain by undeformed seawarddipping sediment deposited during the past 20,000 years. Offshore of the Klamath River, these young deposits lie on an erosional surface and attain a thickness of 20 to 50 meters $(\mathrm{m})$ in water depths of 30 to $70 \mathrm{~m}$ (figs. 2 and 3 ; Field and others, 1980). This lobe-shaped sediment body presumably is derived largely from sediment delivered to the coast by the Klamath River, a major contributor of sediment to the northwestern U.S. continental shelf. Two main types of surficial sediment occur on the shelf in this area: muddy sand inshore of the $60-\mathrm{m}$ isobath, and sandyclayey silt from the $60-\mathrm{m}$ isobath seaward (Field and others, 1980; Welday and Williams, 1975).

\section{NATURE OF THE LANDSLIDE}

\section{Geometry of the Landslide Deposit}

The submarine landslide is highly complex in shape, and this complexity indicates that several different processes occurred during or shortly after the earthquake. The part of the shelf that failed forms a 1- to 4-km-wide horizontal terrace (termed failure terrace) lying in $60 \mathrm{~m}$ of water. The seaward edge of this mass-movement deposit is defined by a 1 - to $2-\mathrm{m}$-high toe ridge that is nearly continuous for a distance of 10 to $15 \mathrm{~km}$ along the shelf (fig. 3 ). Comparison of high-resolution seismic-reflection profiles obtained immediately after the earthquake with profiles collected a year before illustrates the sudden and distinct changes that occurred as a direct result of the earthquake. The slope of the sea floor in the landslide area is approximately $0.25^{\circ}$. Although the subsurface depth of failure is not precisely known, seismic-reflection data indicate that it is at least $5 \mathrm{~m}$ and no more than about $15 \mathrm{~m}$.
In map view, the landslide zone is irregular, measures about $2 \mathrm{~km}$ by $20 \mathrm{~km}$, and extends northwestward along the shelf, parallel to the coastline and shelf bathymetric contours (fig. 2). The landward side of the zone is marked in some places by a subtle scarp or a change in slope angle. Some of the features within and seaward of the landslide provide clues as to the mechanisms and processes involved in slope failure (figs. 4 and 5). Specific features include: toe ridges, pressure ridges, sand boils, collapse depressions, sediment mass flows, and gas seeps. A prominent toe ridge is evident along the seaward edge of much of the landslide, particularly in the southern part (figs. 4 and $5 C$ ). Seaward of the mass flow and toe ridge is a zone of compressional ridges up to $100 \mathrm{~m}$ wide and lying parallel or subparallel to the orientation of the toe ridge (figs. 4, 5C, and 6). Sidescan-sonar images collected in May 1981 (6 months after the earthquake) show evidence of the eruption of sand boils onto the failure terrace (see sketch in fig. 6). Discrete rings of sand, some superimposed on one another, measure from a few meters to as much as $25 \mathrm{~m}$ in diameter (Field and others, 1982). Sand boils are commonly observed on land after large earthquakes and show a similar range in size (Herd and others, 1981). In many areas, the failure terrace has a mottled appearance that likely results from modification of the sand boils and other features by waves and currents.

Depressions of the sea floor on the failure terrace, indicative of settling within the sediment and collapse of evacuated voids, occurred throughout the area at a broad range of scales (fig. 6). Individual pockets of settled sediment coalesced to form a cluster of depression features, often bounded by small scarps generally less than $0.5 \mathrm{~m}$ high. Some collapse depressions measure less than several meters across; others are approximately $25 \mathrm{~m}$ across and roughly circular to elliptical in shape. Sidescan sonographs and bottom photographs from the north half of the landslide zone show evidence of deposits that formed by the flow of liquefied sediment for short lateral distances into overlapping lobes measuring as much as several hundred meters across. As many as five successive overlapping lobes were identified at one locality. Most of these deposits are interpreted to result from lateral spreading of sediment, are generally of low relief (less than $0.5 \mathrm{~m}$ ), show only subtle variations in sediment texture, and do not show evidence of having moved more than $100 \mathrm{~m}$ (fig. $5 D$ ).

In the general vicinity of the landslide zone, there is also evidence of seepage of hydrocarbon gases. Gas is evident from the presence of bubbles dispersed in the water column, small vents, and several large active seeps. These indications appear on high-resolution seismic-reflection profiles and on sonographs obtained at intervals of 1,6 , and 11 months after the earthquake. The origin of the gas emanating from the seeps is surmised to be thermogenic (Field and Jennings, 1987). 


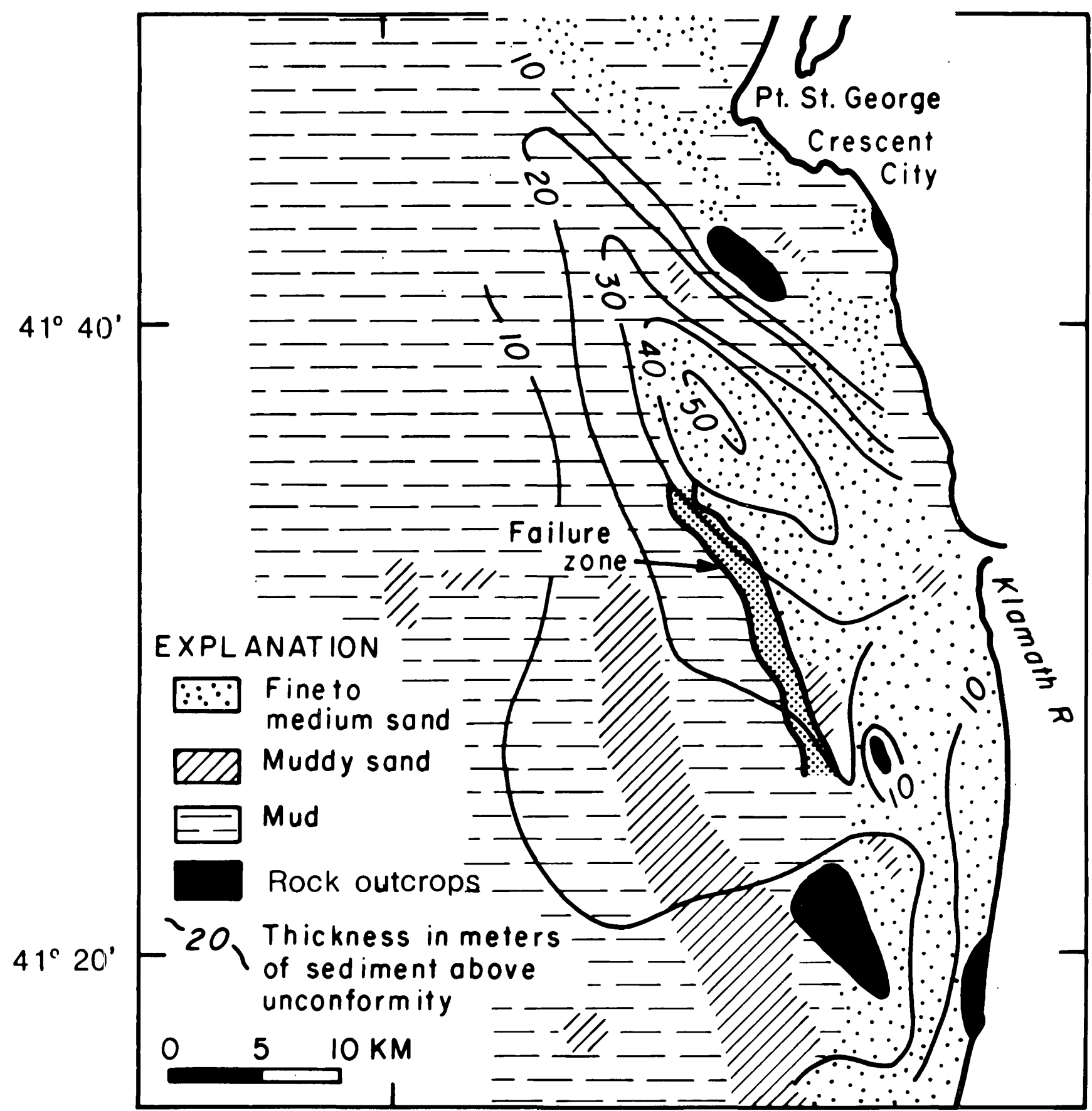

Figure 2. Northern California continental shelf showing the general location of the landslide zone in relation to the nature and thickness of surface sediment. The landslide occurred in sandy deposits derived from the Klamath River and did not spread into the mud deposits that characterize the mid-shelf; thus, it appears that grain size was an important control on slope failure (the sediment distribution is from Welday and Williams, 1975). The thickness contours show that where the landslide occurred, the deltaic deposits were only 20 to 30 meters thick and that failure did not occur in the thickest sediment deposits. 

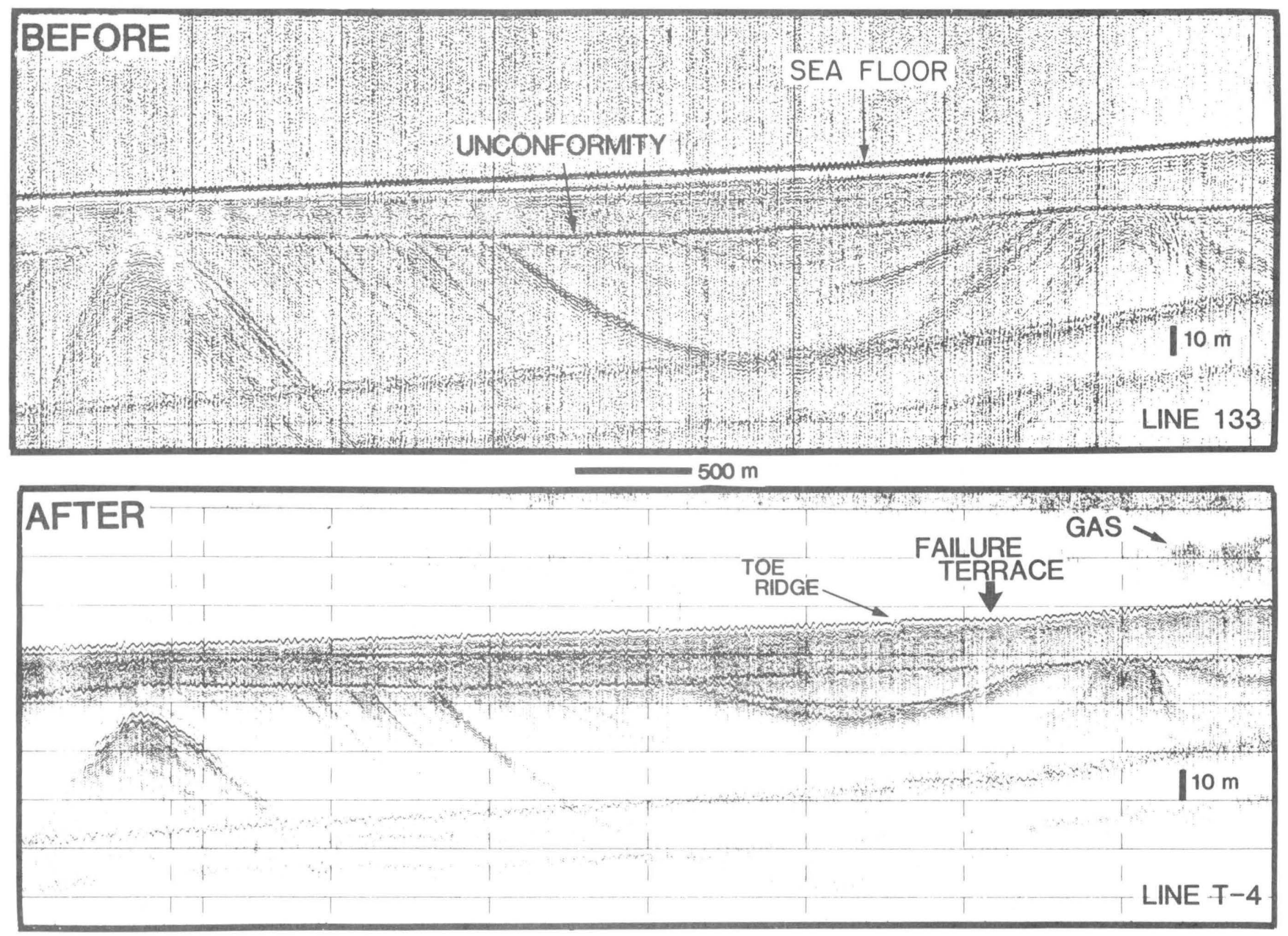

Figure 3. Two seismic-reflection profiles collected along the same line, one before the earthquake, and one after (note that the folded strata below the sea floor are the same in each profile). In the "before" profile, the sea floor is smooth and gently inclined; in the "after" profile, the sea floor has changed dramatically. The unconformity is a surface of erosion separating two sediment sequences. These profiles are best viewed from the side at a low angle. The vertical scale is based on the speed of sound in water.

\section{Styles of Mass Movement}

The complex and varied features in the landslide zone indicate that the progression of failure was complicated and included several modes of mass movement (fig. 6). Lateral spreading is inferred from the presence of a nearly continuous toe ridge that bounds the seaward edge of the flat-lying failure terrace, and the presence of a zone of compression (pressure ridges) lying seaward of the zone of mass movement. Liquefaction, the primary mode of slope failure, resulted in lateral spreading of approximately 800 million cubic meters of sediment and ejection of sand onto the sea floor (Field, 1984). A map of surface sediment types, with the landslide zone superimposed, shows that failure occurred in predominantly sandy deposits (fig. 2). The presence of overlapping sediment lobes indicates that the sediment liquefied and flowed as part of the failure process. As Lee, Schwab, and Booth (this report) point out, liquefaction occurs when a loosely packed sediment collapses under a force. Here, the grains temporarily lose contact with one another, and the particle weight is temporarily transferred to the pore fluid. The liquefied sediment may flow downslope or spread laterally. A summary of the processes involved in the Klamath landslide is given in figures 6 and 7. Subsurface liquefaction is inferred at shallow depths as a result of excess pore-fluid pressures generated in sand by the earthquake and, possibly, enhanced by the presence of gas. Following liquefaction, or as a part of the process, reorganization of the subsurface sand into a somewhat 

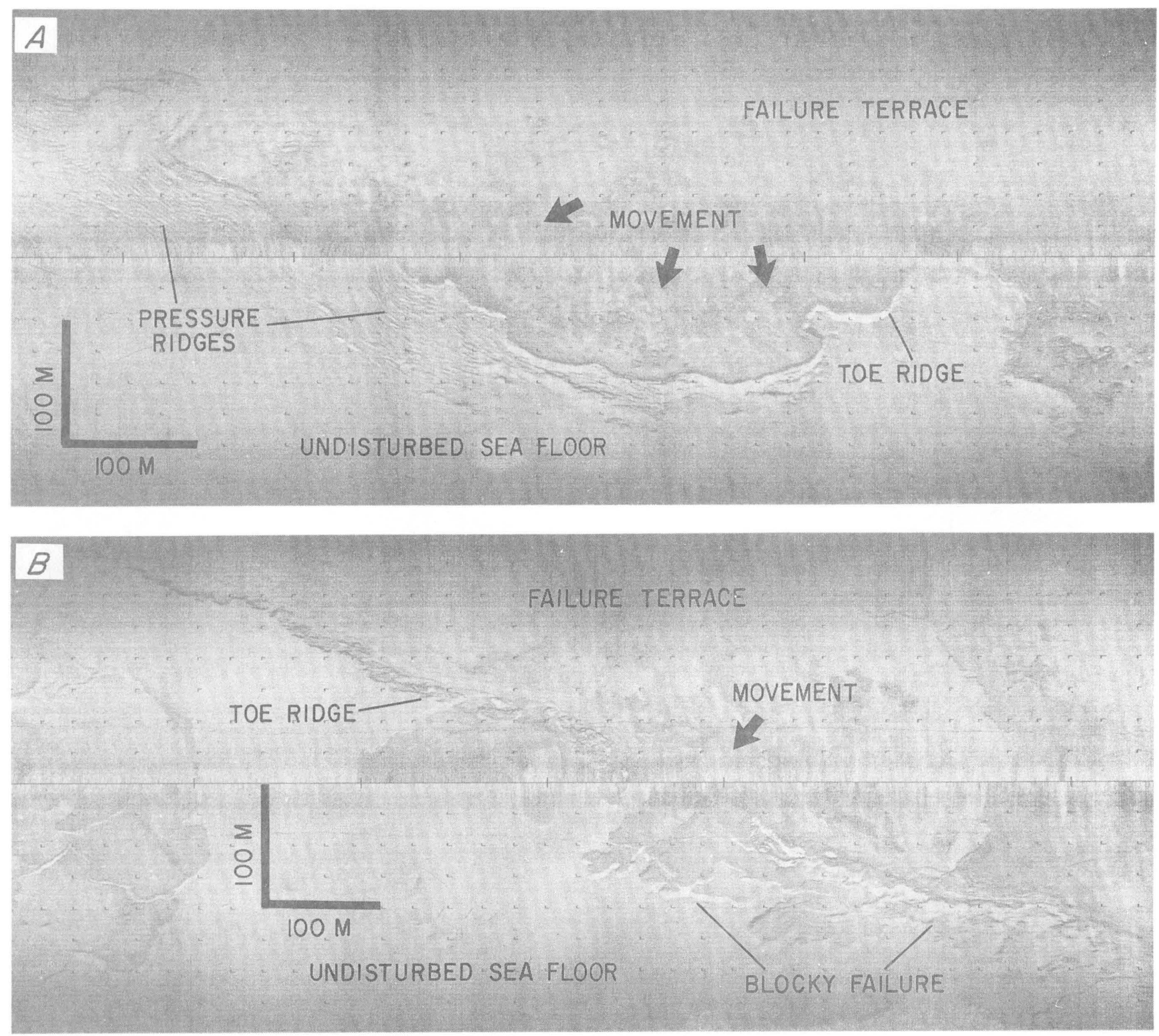

Figure 4. Sidescan-sonar images of the sea floor showing the complexity of the landslide. (A) The failure terrace has a mottled appearance distinctly different than that of the unfailed area of the sea floor. Note the well-defined toe ridge that marks the seaward edge of the landslide and the parallel pressure ridges formed by movement from upper

denser packing arrangement and expulsion of pore fluids and gases occurred and led to collapse and flow of surface sediment.

\section{Importance of the 1980 Earthquake-Induced Landslide}

Because none of the factors, including sediment thickness, earthquake magnitude, and sediment type, right of the sonograph toward the lower left. (B) Similar to $A$ but shows more complexity near the terminus. The boundary between the landslide zone and the undisturbed sea floor is marked by a series of discrete blocks measuring 10 to 50 meters on each side.

involved in the 1980 liquefaction of sediment off the Klamath River were extraordinary, the landslide is important for appreciating the potential for greater effects here and on other shelves. Some of the aspects that are of particular importance are

1. Mass movement occurred off the Klamath River on a nearly flat $\left(0.25^{\circ}\right.$ slope $)$ area of the sea floor. Much of the continental margin has greater slopes $\left(1.0^{\circ}\right.$ to $\left.4.0^{\circ}\right)$ and, thus, may be more susceptible to liquefaction by earthquake shocks. 

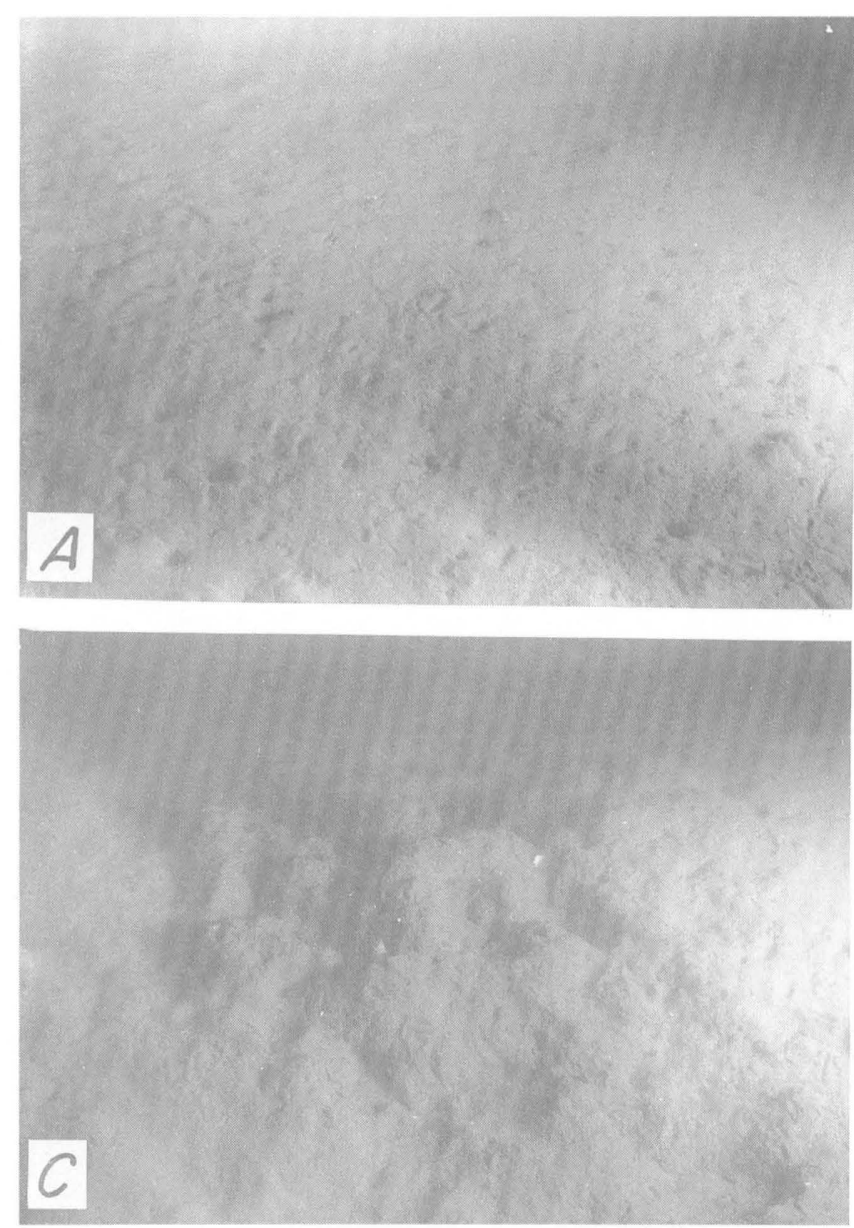

Figure 5. Photographs of the sea floor made by towing an underwater camera sled. (A) Photograph of a 70-meterdeep area of the sea floor that was not disturbed by the earthquake. Note the large number of burrows and tracks formed by biologic activity. $(B)$ Highly disturbed sediment

2. The earthquake had a magnitude of about 7.0 and occurred $60 \mathrm{~km}$ from the submarine landslide. Earthquakes of greater than 30 times that energy and much closer to the California shelf have occurred in the past and will occur in the future; thus, the probability of similar or greater landslides due to liquefaction is high.

3. Upper Quaternary sediment (deposited during the past 20,000 years) is only 20 to $30 \mathrm{~m}$ thick at the landslide site; thus, thick accumulations of modern sediment are not requisite for slope failure. This thickness of upper Quaternary sediment is equaled or exceeded in many areas of the California shelf and slope, so many areas are sites of potential landsliding.

4. The landslide occurred in Holocene terrigenous sediment on the prodelta of a medium-size river. Many other such prodeltas exist in seismically active areas of the U.S. Pacific coast, and these are probable sites of submarine landslides or liquefaction.
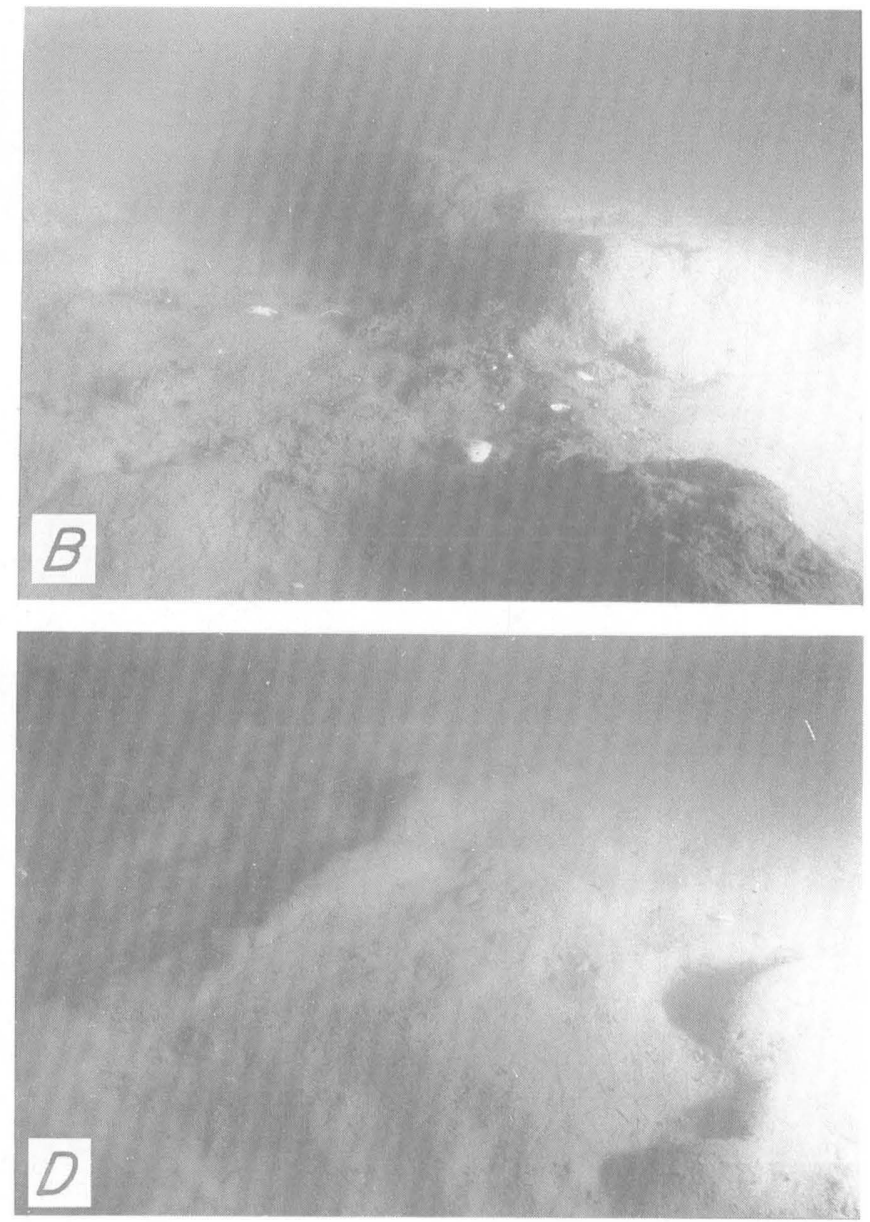

near the toe ridge showing complete disruption of the sea floor. (C) Example of a small pressure ridge formed seaward of the landslide zone. $(D)$ Residual mass-flow deposits, with sediment appearing remolded as a result of liquefaction and flow.

5. The surface manifestations of the landslide deposit are small (maximum relief of $2 \mathrm{~m}$ ) and are difficult to detect with conventional geophysical techniques. Furthermore, the landslide occurred in relatively shallow water $(60 \mathrm{~m})$ that is subject to smoothing and obliteration of diagnostic features by waves and currents and by subsequent deposition of sediment. Therefore, absence of surficial expression does not necessarily indicate that mass movement has not taken place in the past; it merely indicates that it has not occurred or been observed within the past several years or decades.

\section{ACKNOWLEDGMENTS}

Brian Edwards, James Gardner, Robert Hall, and Ann Jennings were all valuable contributors to earlier reports used in this summary. Paul Carlson and Robert Kayen provided careful and thoughtful reviews of the manuscript. 


\section{PROGRESSION OF FAILURE}
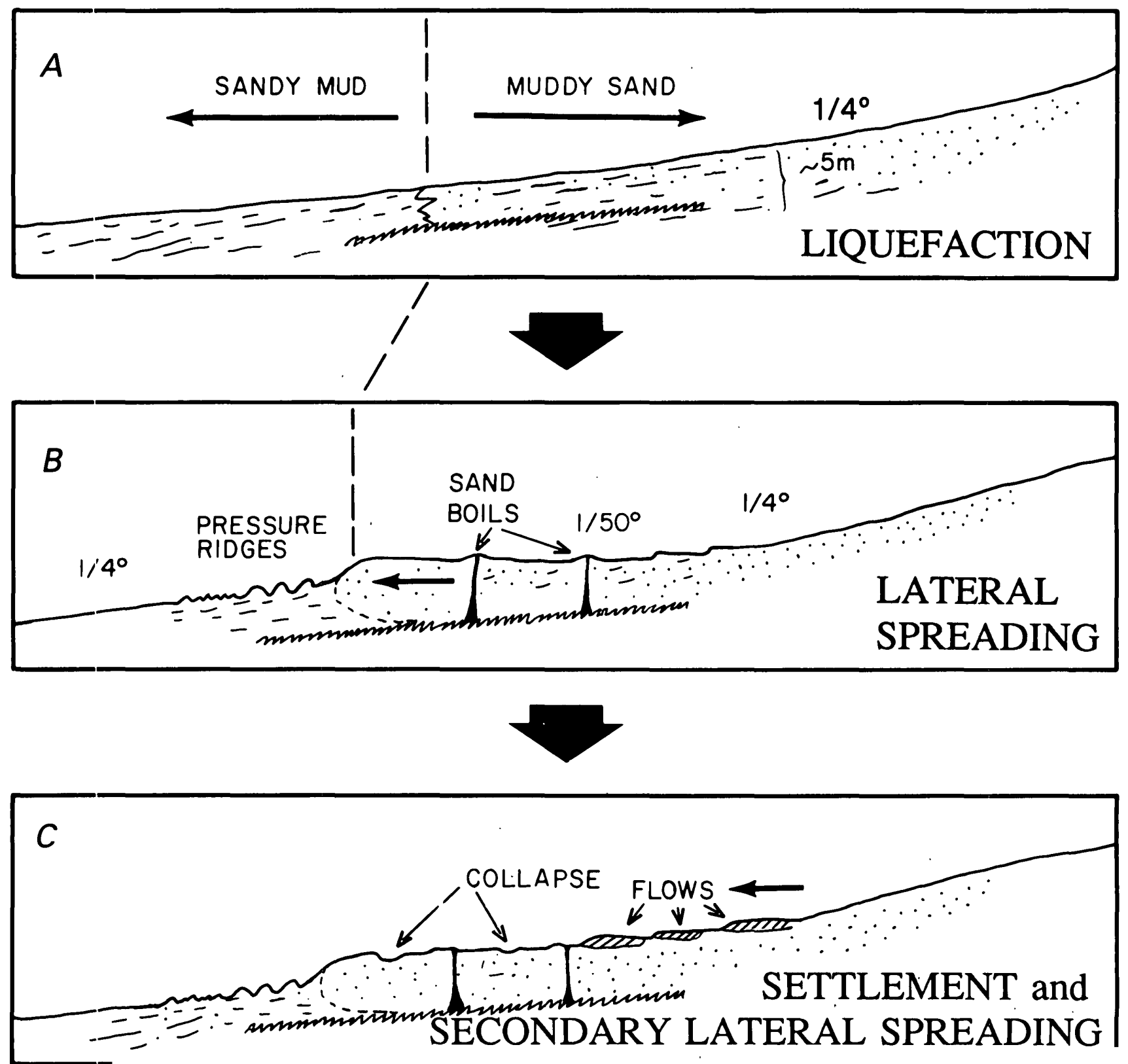

Figure 6. This series of diagrams shows the supposed progression of landsliding, based on the observations of features in the failure zone. $(A)$ Initiation of slope failure started with earthquake-induced liquefaction of sandy sediment, probably as deep as 5 meters below the sea floor. (B) As the near-surface deposits liquefied, they spread laterally and erupted vertically onto the sea floor. (C) In the final stage, loose sediment flowed across the terrace and surface deposits collapsed and settled. 


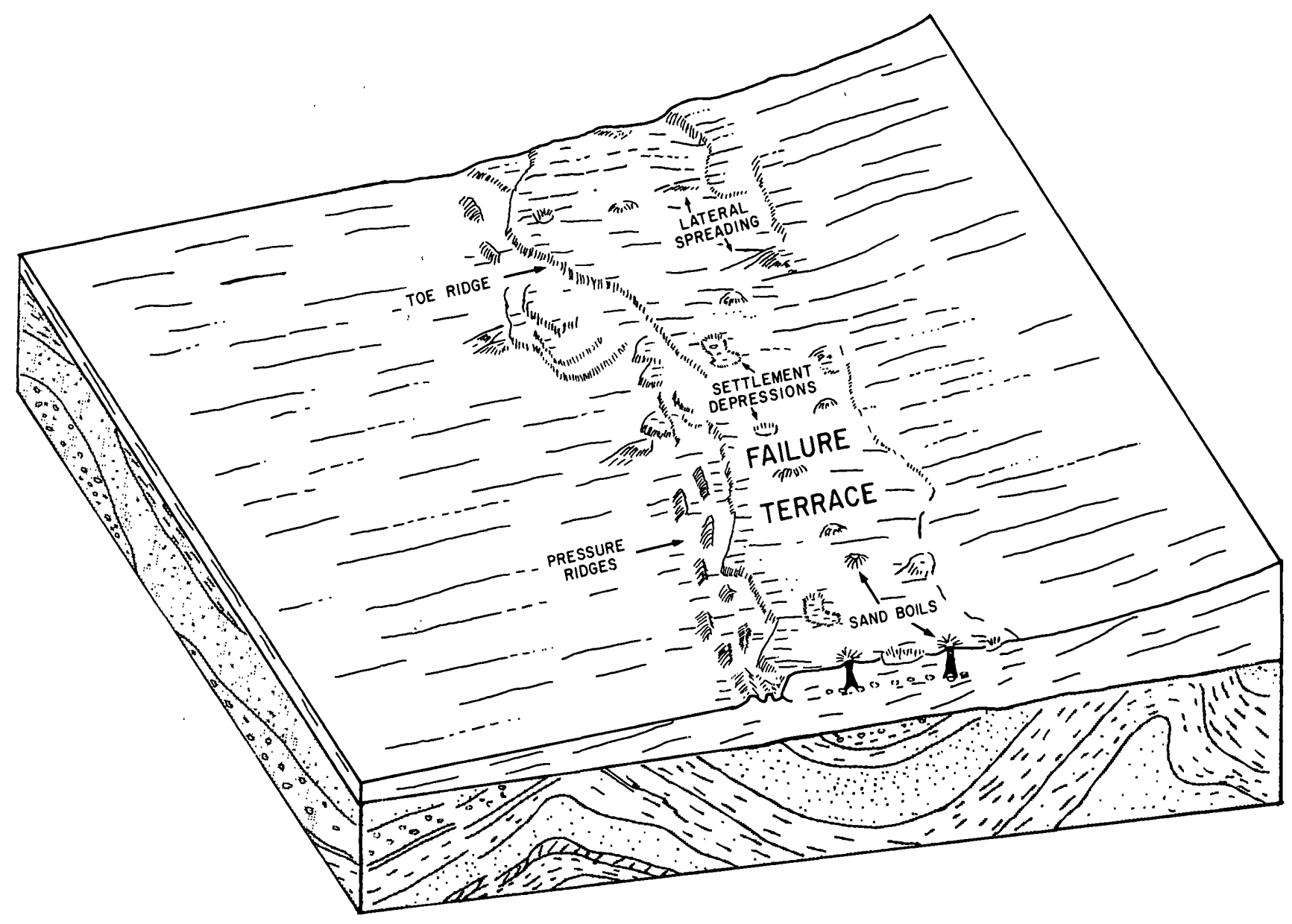

Figure 7. This three-dimensional diagram shows the subsurface geology and the overall nature of the landslide zone on the shelf. Note the irregular nature of the toe ridge along the length of the slope failure. This diagram is an accurate portrayal of the features and geometry of the landslide zone that were observed using sidescan sonar, underwater cameras, and acoustic profilers.

\section{REFERENCES CITED}

Couch, R.W., 1980, Seismicity and crustal structures near the north end of San Andreas fault system, in Streitz, Robert, and Sherburne, Roger W., eds., Studies of the San Andreas Fault Zone in Northern California: California Division of Mines and Geology Special Report 140, p. 139-151.

Couch, R.W., Victor, L.P., and Keeling, K.M., 1974, Coastal and offshore earthquakes of the Pacific Northwest between $39^{\circ}$ and $49^{\circ} \mathrm{N}$ latitude and $123^{\circ}$ and $131^{\circ} \mathrm{W}$ longitude: Corvallis, Oreg., Oregon State University Press, School of Oceanography, $67 \mathrm{p}$.

Field, M.E., 1984, The submarine landslide of 1980 off northern California, in Clarke, S.H., Jr., ed., Highlights in Marine Research of the U.S. Geological Survey: U.S. Geological Survey Circular 938, p. 65-72.

Field, M.E., Clarke, S.H., Jr., and White, M.E., 1980, Geology and geologic hazards of offshore Eel River Basin, northern California continental margin: U.S. Geological Survey OpenFile Report 80-1080, 80 p.

Field, M.E., Gardner, J.V., Jennings, A.E., and Edwards, B.D., 1982, Earthquake-induced sediment failures on a $0.25^{\circ}$ slope, Klamath River delta, California: Geology, v. 10, p. 542-546.
Field, M.E., and Hall, R.K., 1982, Sonographs of submarine sediment failure caused by the 1980 earthquake off northern California: Geo-Marine Letters, v. 2, p. 135-142.

Field, M.E., and Jennings, A.E., 1987, Seafloor gas seeps triggered by a northern California earthquake: Marine Geology, v. 77, p. 39-51.

Herd, D.G., Youd, T.L., Meyer, Hansjürgen, Arango, J.L., Person, W.J., and Mendoza, Carlos, 1981, The great Tumaco, Colombia, earthquake of 12 December 1979: Science, v. 211, p. 441-445.

Lajoie, K.R., and Keefer, D.K., 1981, Investigations of the November 1980 earthquake in Humboldt County, California: U.S. Geological Survey Open-File Report 81-397, 30 p.

Real, C.R., Toppozada, T.R., and Parke, D.L., 1978, Preliminary earthquake epicenter map of California, showing events from 1900-1974 equal to or greater than magnitude 4.0 or intensity V: California Department of Conservation, California Resources Agency, Sacramento, Open-File Report 78-4 SAC, scale 1:1,000,000.

Welday, E.E., and Williams, J.W., compilers, 1975, Offshore surficial geology of California: California Division of Mines and Geology Map Sheet 2, scale 1:500,000. 


\title{
A Submarine Landslide Associated with Shallow Sea- Floor Gas and Gas Hydrates off Northern California
}

\author{
By M.E. Field and J.H. Barber, Jr.
}

\section{INTRODUUCTION}

\section{Submarine Landslides and Their Causes}

Submarine mass movements of sedimentary material occur in a remarkable variety of geologic settings around the world (Lee, Schwab, and Booth, this report). They range in size from a few meters to hundreds of kilometers along a side and involve materials that range from thin layers of weak, recently deposited sediment to great thicknesses of sediment or lithified strata. The factors that cause sediment slope failure to occur, however, have not been as thoroughly studied as the shape and character of the failures themselves. Discussions by Prior and Coleman (1982), Field (1937); and Lee (1989) point out that setting and sediment mass are important characteristics to evaluate. Scientists now recognize that earthquakes, storm waves, and locally high rates of sedimentation are associated with sediment slope failure. Specific reasons why one area undergoes slope failure while an adjacent area does not, however, are elusive. Most likely, these reasons are related to both the heterogeneous nature of the sediment mass and the variations in the local environmental setting (Schwab and Lee, this report; Edwards, Lee, and Field, this report). The natural variations in grain size, mineralogy, porosity, and bedding surfaces which occur in sedimentary deposits produce variations in sediment strength; those variations may produce planes of weakness along which slope failure can occur. Locally, variations in the slope geometry, deposition rate, current activity, earthquake ground-motion responses, and the presence of excess pore-water pressures (in excess of hydrostatic pressure) and gaseous hydrocarbons charige the environmental stress acting on a sediment mass and affect the strength of the sediment (Lee, Schwab, and Booth, this report).

\section{Gassy Sediment and Submarine Landslides}

Gaseous hydrocarbons occur naturally in marine sediment. They are commonly classified as either biogenic gas (chiefly methane), which forms by biologic decay of organic material near the sea floor, or thermogenic gas, which forms by exposure of organic material to high temperatures from deep burial and includes many complex hydrocartions. Gaseous hydrocarbons also occur in the shallow subsurface in a solid, icelike structure called a gas hydrate. Changes in temperature, pore pressure, or depth of burial can cause the hydrate to become unstable (melt) and release gas into the sediment (Popenoe, Schmuck, and Dillon, this report; Kayen and Lee, this report).

Gas concentrated in seeps and disseminated in sediment is not unusual in areas of sediment slope failures, for example, the organic-rich fluvial deposits that form the Mississippi Delta (Sieck, 1973; Whelan and others, 1977). Dissolved gas is relevant to considerations of sediment slope stability because it can abruptly change phase out of solution to a gas in response to rapid decreases in pressure (for example, from storm waves in shallow water, extreme tidal fluctuations, or earthquake accelerations). Although its exact role in slope failure is unclear, the presence of bubble-phase gas in pore spaces is thought by some workers to decrease sediment strength by generating excess porefluid pressures and reducing effective confining stresses, thereby increasing the likelihood of failure (Sangrey, 1977; Whelan and others, 1977). Those authors point out, however, that the presence of bubble-phase gas may absorb pressure changes from an external source and, thereby, strengthen the deposit. More clear is the role of exsolution of dissolved gas in muddy sediment, where it almost certainly disturbs the sediment fabric and leads to a reduced sediment strength. Thus, when bubble-phase gas is present, regardless of its source, a reduction of sediment strength is possible due to an increase in excess pore pressures.

Although our study focuses on the northern California continental margin, there are at least two other locations where subsurface gas thought to be derived from degrading gas hydrates has been suggested as the principal cause of slope failure. Off the Southeastern United States, Carpenter (1981) and Popenoe, Schmuck, and Dillon (this report) suggest that the decay of gas hydrates and subsequent release of gas into the sea floor led to failure of sediment. On the north slope of Alaska, recent studies by Kayen (1988) and Kayen and Lee (this report) document the relationship of large sediment slides to the release of gas from degradation of gas hydrate beneath the sea floor.

\section{THE NORTHERN CALIFORNIA CONTINENTAL MARGIN: ABUNDANT SLOPE FAILURES AND GASSY SEDIMENT}

The continental slope off Eureka, northern California, lies within the Eel River Basin, an active forearc basin that contains over 4,000 meters $(\mathrm{m})$ of Pliocene- and 


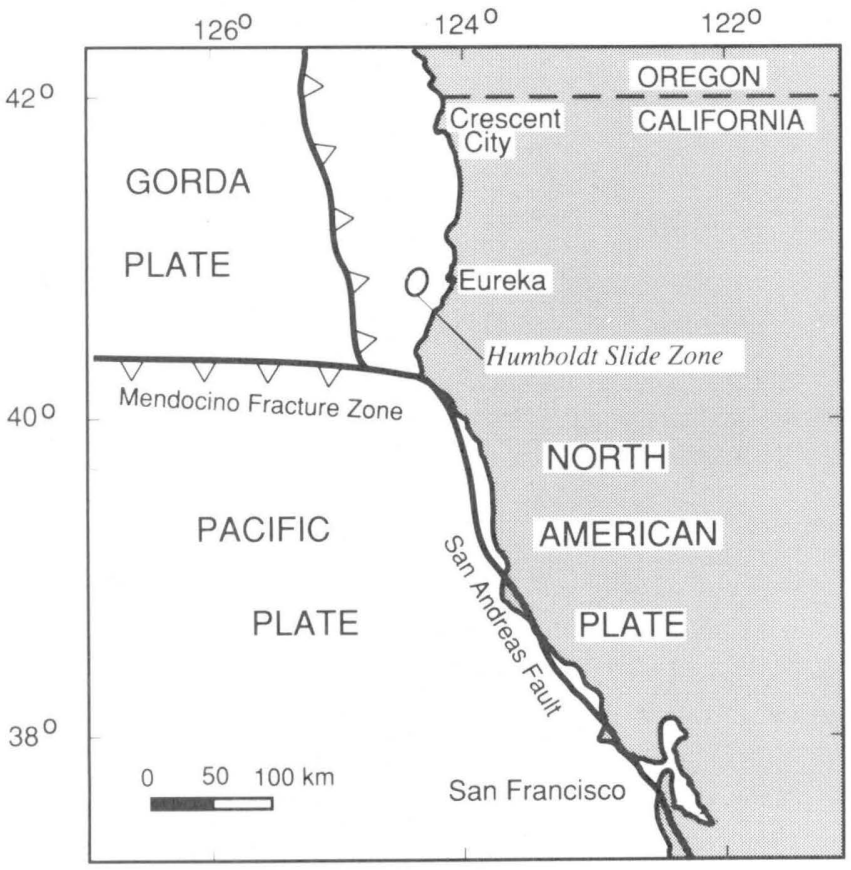

Figure 1. Northern California continental margin. The study area is on the continental slope west of Eureka, just north of where the Pacific, Gorda, and North American crustal plates meet.

Quaternary-age sediment (deposited throughout the past 5 million years) (Field and others, 1980; Bachman and Crouch, 1986). The study area lies just north of the Mendocino triple junction, the intersection of the Gorda, Pacific, and North American crustal plates (fig. 1). Active tectonic forces have generated numerous large-magnitude earthquakes in the region (fig. 2; Couch, 1980), and these no doubt have been influential in causing substantial slope failure. Another result of the regional tectonic activity has been uplift of onshore regions, which has in turn led to substantial erosion and sediment transport to the continental shelf and slope. Local rivers deliver more than 20 million metric tons of organic-rich sediment to the coast annually (Field and others, 1980). Biogenic gas derived from these deposits, combined with the upward migration of thermogenic gas from sources deeper in the basin deposits, provides an abundance of gas in the near-surface deposits. All of these factors make the northern California continental margin between Eureka and Crescent City (fig. 1) an ideal location to examine the relationship between sediment mass movement and sea-floor gas.

Through repeated research cruises to the area, much information about sediment character and processes has been acquired. The entire slope region is dominated by the presence of areas of mass movement, and one of these, the Humboldt Slide Zone, has been studied in detail. Other studies in the area (for example, Field and Kvenvolden,
1987) have mapped subsurface acoustic patterns (on seismic-reflection profiles) indicative of shallow sea-floor gas and of gas hydrates; follow-up sampling cruises recovered sediment enriched in both. This pool of information, along with published studies from other regions, provides a solid background for examining the inferred role of gas in decreasing sediment strength and increasing the possibility of slope instability.

\section{Humboldt Slide Zone}

The continental margin off California north of Cape Mendocino contains more landslides than any other comparable region along the west coast of the United States. One of the more prominent areas of slope instability is the Humboldt Slide Zone, which lies west of Eureka on a $4^{\circ}$ slope at water depths of 250 to $500 \mathrm{~m}$. The Humboldt Slide Zone consists of large slump blocks that failed in a retrogressive (failure retrogrades upslope) manner (fig. 3). In cross section, individual slump blocks are up to $500 \mathrm{~m}$ wide and extend $50 \mathrm{~m}$ below the sea floor. The Humboldt Slide Zone is young, because it creates surface relief and is unburied, even though local sediment deposition rates are high relative to most continental margins (Lee and others, 1981; EEZ-SCAN 84 Scientific Staff, 1986; Field and others, 1987).

Studies of the physical properties and stratigraphic relationships within the upper several meters of the Humboldt Slide Zone, which consist of late Pleistocene age (deposited in the last 100,000 years) thin-bedded turbidites and silt interbeds, indicate that the sediment apparently failed due to earthquake-generated accelerations (Lee and others, 1981). Adjacent areas also have high earthquake incidence and a rapid sedimentation rate but have not failed. Therefore, some additional factor or factors must predispose certain areas, such as the Humboldt Slide Zone, to slope instability. Our work shows that gas is abundant in the shallow subsurface and may be important in reducing the strength of the sediment and allowing failure to occur.

\section{Evidence of Shallow Gas and Gas Hydrates}

The evidence for shallow gas beneath the northern California slope and outer shelf is abundant. Seismic reflections from below the sea floor are affected by the presence of gas both by masking (blanking out) and by enhancement (brightening) of reflectors from bedded deposits. Both of these effects are common throughout the study area, particularly in the slide zone (fig. 3; Field and others, 1980; Richmond and Burdick, 1981). Hundreds of pockmarks (craters formed by seeping gas) have been mapped along two sidescan-sonar images that were collected parallel to the slope through the slide zone (pockmarks are shown 


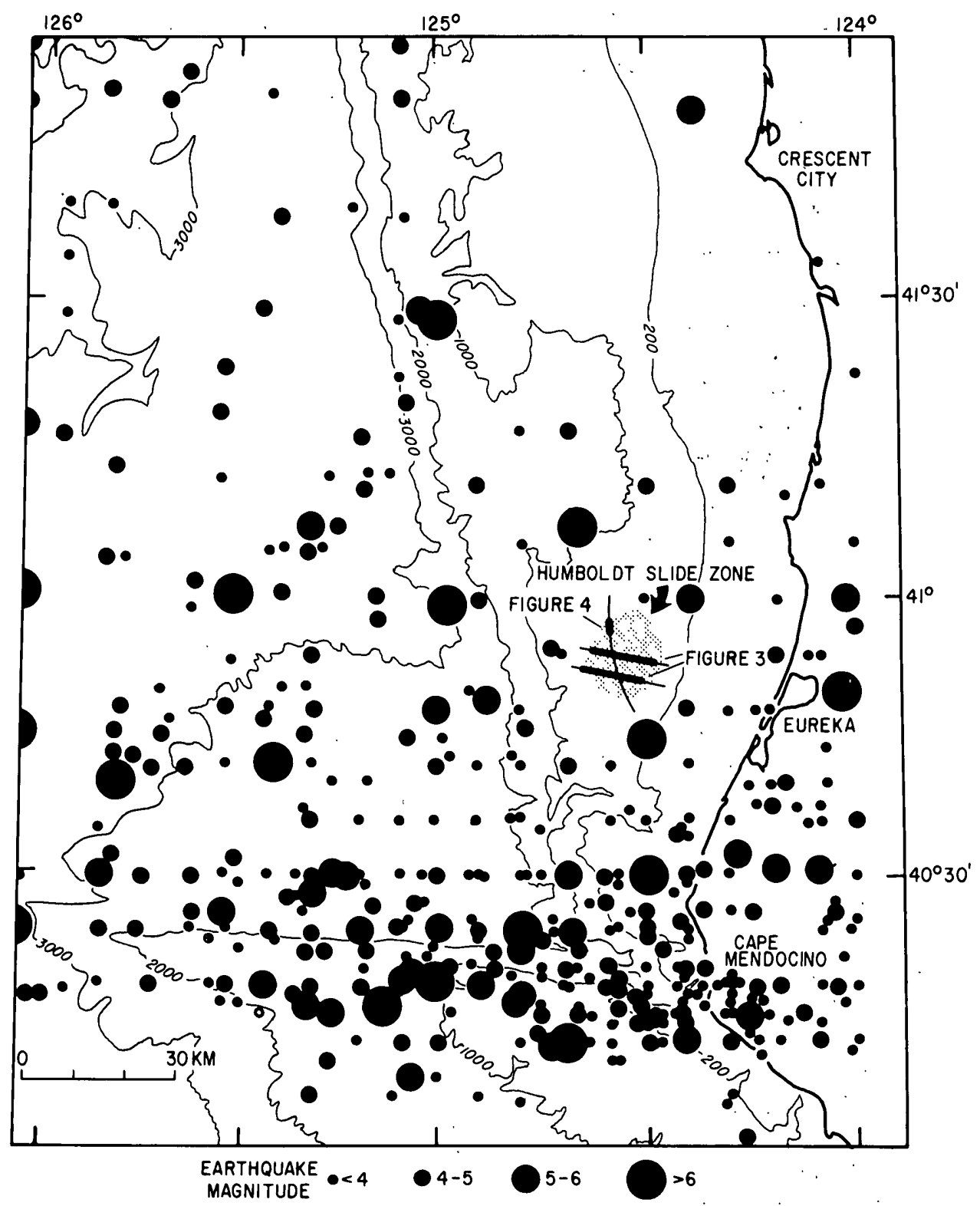

Figure 2. Study area showing the location of the Humboldt Slide Zone and the many historical earthquakes that have occurred in the area. The epicenters represent historical observations and instrument measurements from 1860 to 1980 compiled mainly by Couch (1980). Also shown are the locations of the seismic profiles in figures 3 and 4 . The bathymetric contours are in meters.

in fig. 4 and their location in fig. 5). The pockmarks average about $4 \mathrm{~m}$ in diameter and range up to a maximum of $25 \mathrm{~m}$. Studies from a host of continental margin settings around the world have shown that such pockmarks are diagnostic of seepage of gas or fluid from the sea floor (Curzi and Veggiani, 1985; Hovland and Judd, 1988).

Cores collected from the northern California margin were routinely analyzed for dissolved gas content. In one area just upslope from the Humboldt Slide Zone, these analyses indicate elevated levels $(>10,000$ microliters per liter $(\mu \mathrm{L} / \mathrm{L}))$ of methane gas in the upper $2 \mathrm{~m}$ of sediment (fig. 5; Field and Kvenvolden, 1987). Normal background levels of dissolved methane in this area are less than 1000 $\mu \mathrm{L} / \mathrm{L}$. The high-methane samples were recovered from the area of gas-charged sediment that includes the slide zone.

The presence of gas hydrates in the study area is well documented. Gas hydrates were initially inferred to be present off northern California on the basis of a BottomSimulating Reflector (BSR) that underlies the continental margin at a subsurface depth of about $250 \mathrm{~m}$ (Field and Kvenvolden, 1985). A BSR is a subbottom reflector that mimics the sea floor and appears to cut across other 
PROFILE $\| 4$
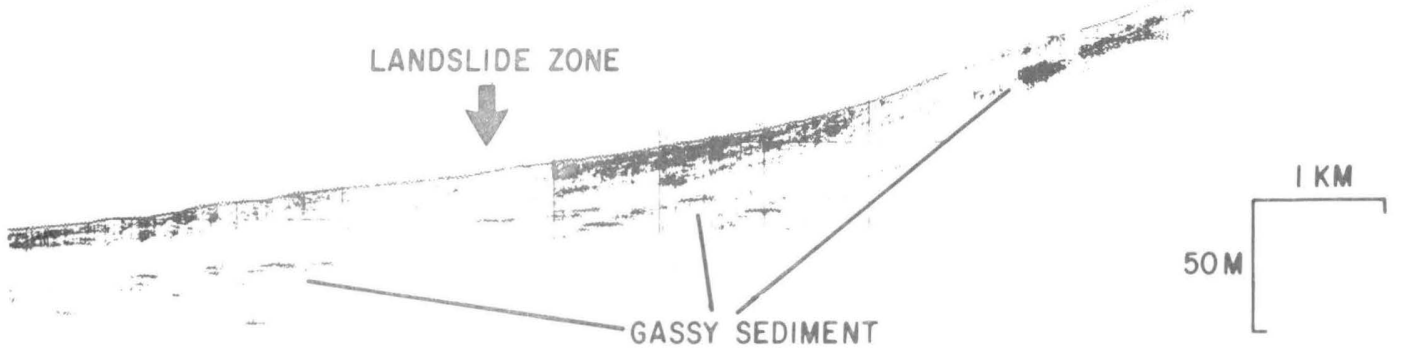

PROFILE $\| 15$

LANDSLIDE ZONE

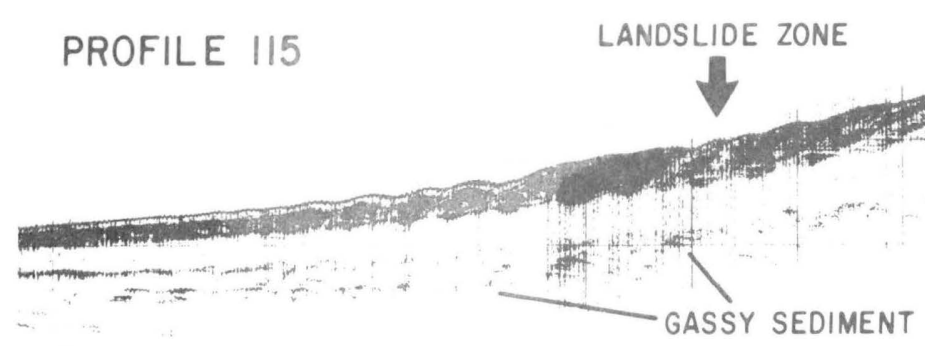

Figure 3. High-resolution acoustic profiles crossing the Humboldt Slide Zone (see fig. 2 for locations). Note the hummocky surface of the sea floor in the slide zone (best seen on profile 115). Also evident in these profiles are numerous individual shear planes and slump blocks of sediment. Beneath the slide zone, acoustic reflectors are locally enhanced or "brightened," and are indicators of subsurface gas. The arrows show the location of the sidescan-sonar image shown in figure 4. Vertical scale bar is based on speed of sound in water.

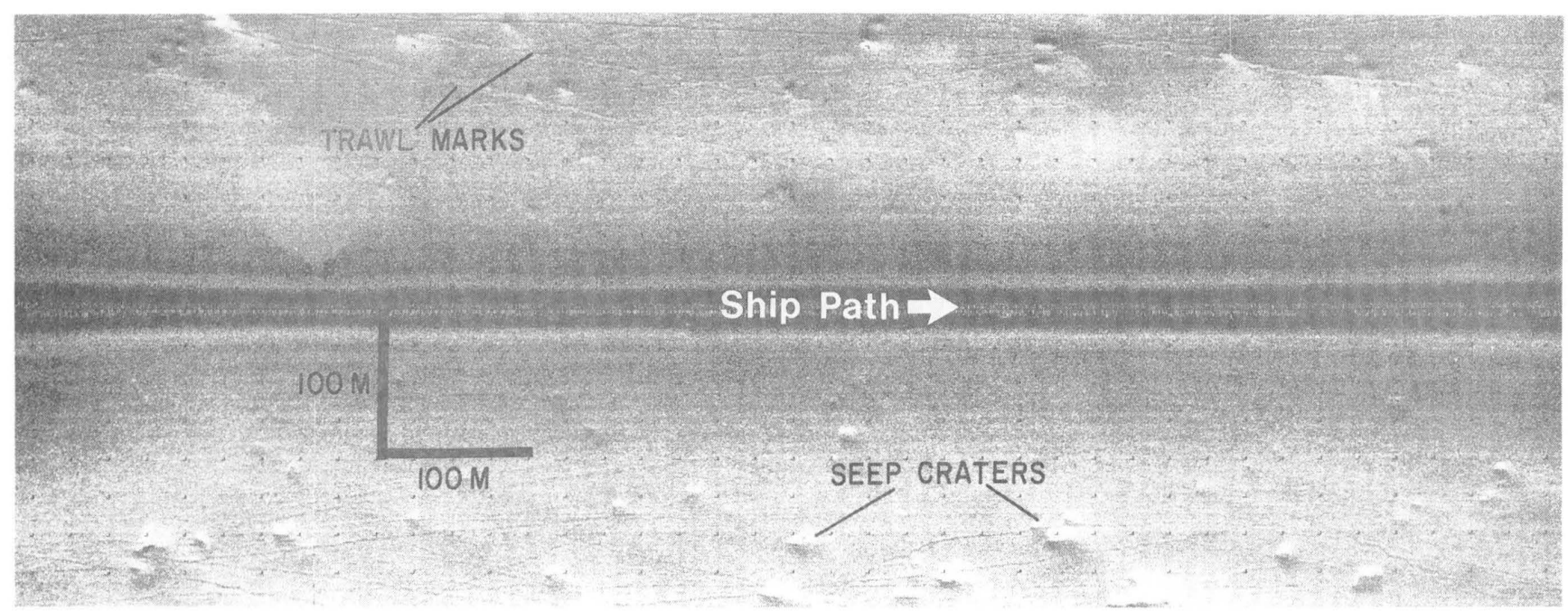

Figure 4. Sidescan-sonar image of the sea floor along the slope (see figs. 2 and 3 for location). The sonar vehicle was towed from left to right along the center of the image. Dark patterns are areas of high-energy return (strong backscatter); light patterns are areas of low backscatter of energy, or shadows. Thus, the circular features viewed in this image, shadows succeeded by strong returns, are depressions on the sea floor. 


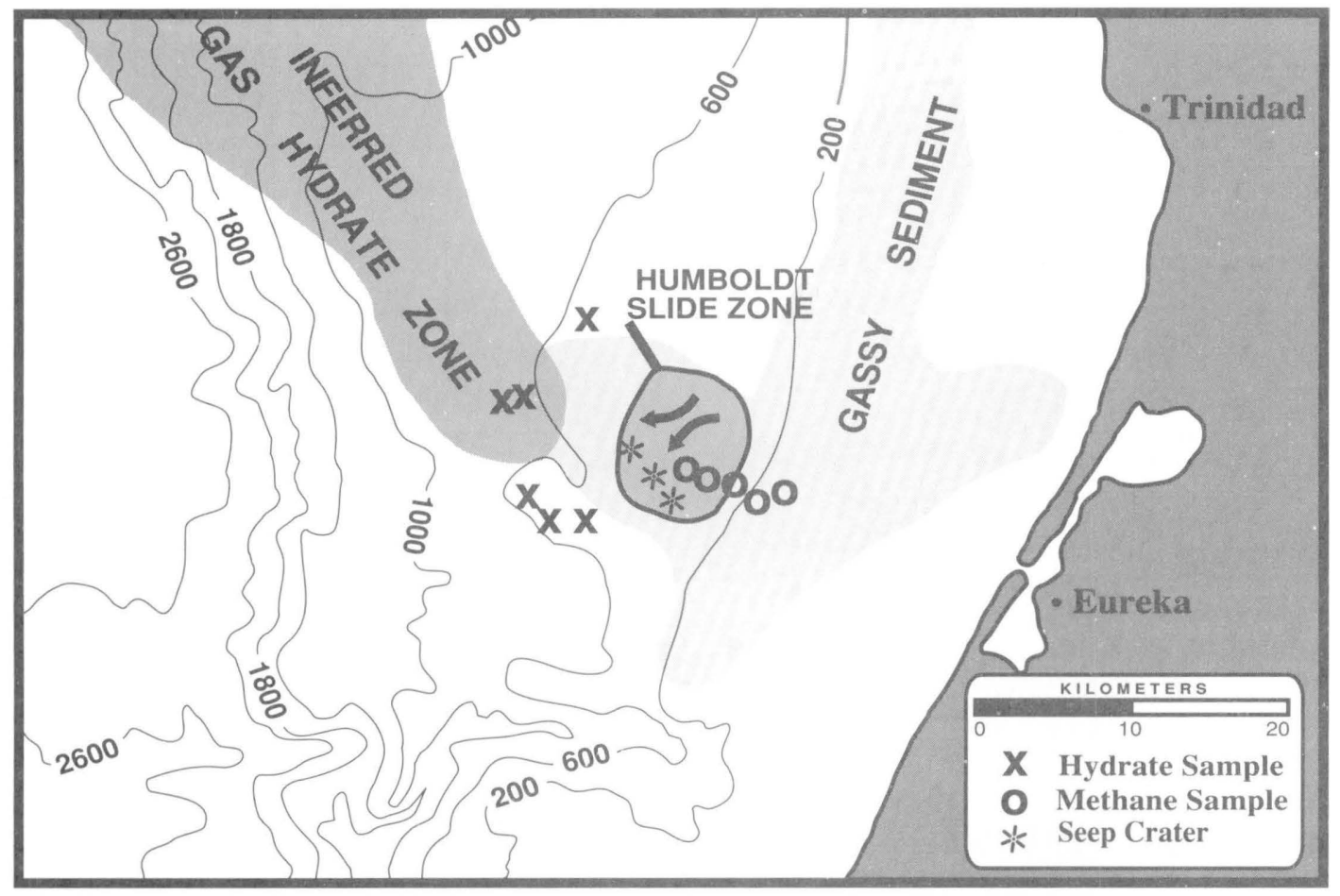

Figure 5. Study area showing the relationship between the location of the Humboldt Slide Zone and observations of shallow gas and gas hydrates. The arrows indicate the direction of mass movement. Note that (1) gas hydrates were observed (acoustically on seismic-reflection profiles) and sampled in surface sediment just downslope from the slide zone, (2) acoustic anomalies on seismic-reflection profiles indicative of shallow gas have been observed throughout the area, and (3) cores containing high con-

reflectors, thus indicating that it is not a sedimentary layer. BSR's apparently follow the gas-hydrate phase boundary (the pressure-temperature boundary that separates the gaseous phase below from the solid-hydrate phase above); thus, they mark the base of an extensive zone of gas hydrate (Kvenvolden, 1988). The landward extent of gas hydrate off northern California (fig. 5) is not accurately known owing to the difficulty in recognizing the BSR in flat-lying strata. The presence of gas hydrate off northern California was recently confirmed with samples obtained from the upper $1 \mathrm{~m}$ of the sea floor (Brooks and others, 1991). The hydrate samples occur as solid layers, lumps, and crystals separated by normal unhydrated terrigenous mud. The gas hydrates begin to sublimate (degrade) as soon as the core samples are withdrawn from the sea floor. As they decay, they yield gas volumes (at sea level) that are many times larger than their volume in the hydrated state. Thus, the hydrates, which cover an estimated area of 3,000 square kilometers $\left(\mathrm{km}^{2}\right)$ (Field and Kvenvolden, 1985), represent a potentially enormous source of sea-floor gas. The volume of gas released in the sea floor, where it is still under pressure and at low temperature, is significantly less. centrations of dissolved methane-rich gas were collected from within and upslope of the slide zone. Sources of information are as follows: gas hydrate zone (Field and Kvenvolden, 1985); gas hydrate samples (Brooks and others, 1991); gas anomalies (Field and others, 1980; Field and Kvenvolden, unpublished data); gas measurements (Field and Kvenvolden, 1987); and Humboldt Slide Zone (Field, Clarke, and White, 1980; Field, Gardner, and others, 1987; Lee and others, 1981).

Nonetheless, if the hydrate is in a state of disequilibrium, perhaps due to changing geothermal gradients, then bubblephase gas may be released into the sediment.

\section{THE ROLE OF GAS IN CAUSING SLOPE FAILURE IN THE HUMBOLDT SIIDE ZONE}

Factors contributing to the abundance of landslides along this region of the Pacific continental margin are high levels of seismicity (historically, one event of magnitude 6 or greater per decade), ongoing tectonic uplift and deformation, and the large quantities of sediment delivered to the margin each year from rivers. More recently, interstitial gas (derived from biogenic, thermogenic, and possibly from degraded gas hydrate sources) has been recognized as a potentially important factor contributing to the landslides. Gas in bubble phase can markedly increase the pore-water pressure and decrease the effective strength of the sediment, thereby reducing stability.

A strong correlation exists between the location of the gas hydrate, gas-charged sediment, and the Humboldt Slide 


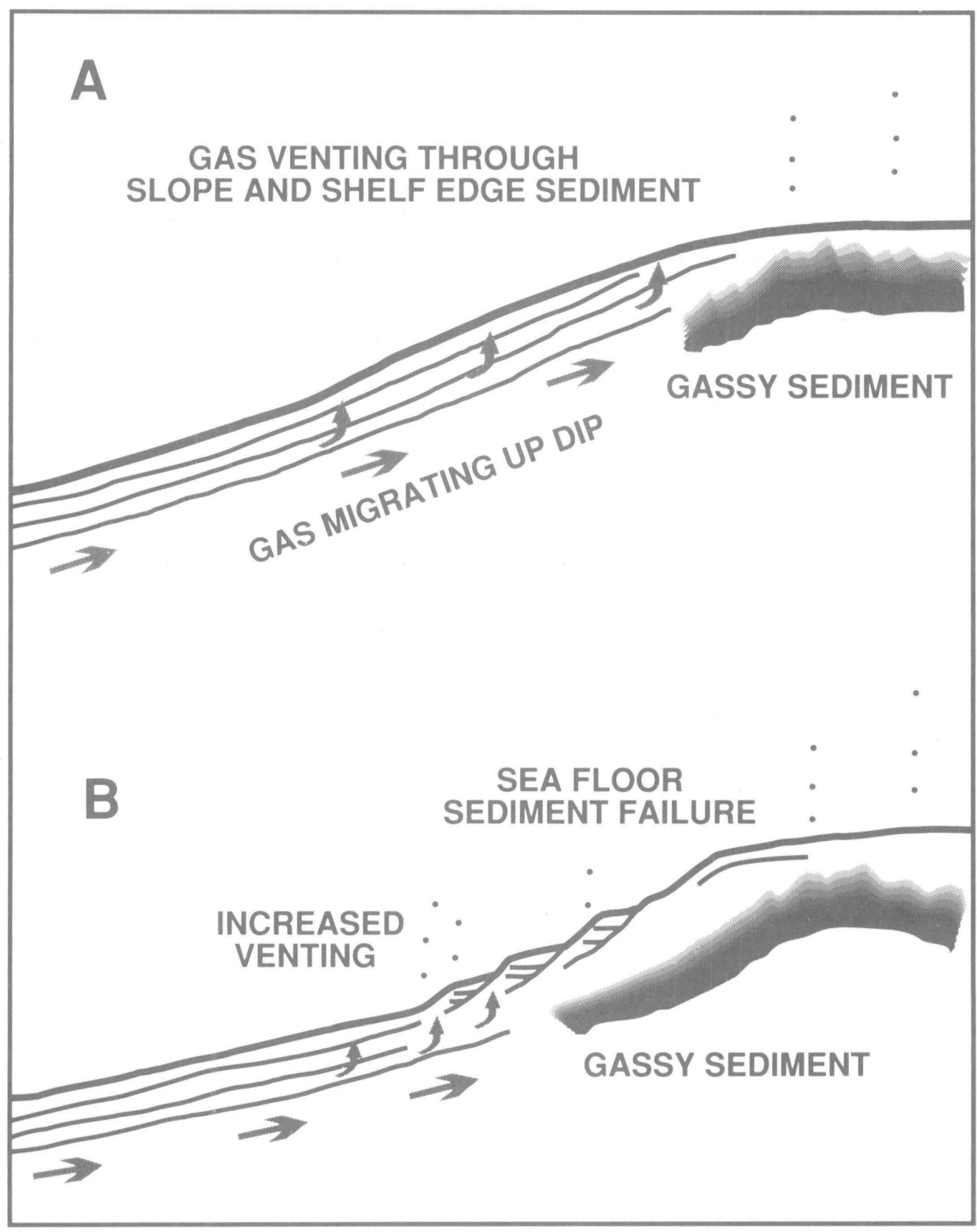

Figure 6. Schematic diagram showing the process by which subsurface gas, perhaps derived from a decaying gas hydrate, might exacerbate slope instability. In the top diagram $(A)$, shallow gas seeps up in the sediment column and migrates updip beneath a partially impervious sediment layer. Due to the migrating gas, acoustic anomalies are present beneath the slope and outer shelf. The elevated gas content of pore waters decreases the strength of the sediment and increases the potential for slope failure, as shown in $(B)$. Slope failure of the weakened sediment likely occurs in response to accelerations experienced from nearby earthquakes. 
Zone. Gas hydrates contain enormous quantities of gas, and their presence, along with abundant free gas in the slide zone, indicates a possible link between the gas hydrates and the slope failure. Gas migrating updip beneath the slope seeps through slope and outer shelf sedimentary deposits (fig. 6A). The resulting increase in bubble-phase gas content, in turn., leads to an overall reduction in strength and an increased tendency toward slope failure (fig. $6 B$ ). On some continental margins, this increased weakness may not result in slope failure without an external driving force. In Eel River Basin, however, the frequency of large-magnitude earthquakes (fig. 2) is probably more than sufficient to induce failure of the weakened slope deposits.

\section{REFERENICES CITED}

Bachman, S.B., and Crouch, J.K., 1986, Geology and Cenozoic history of the northern California margin: Point Arena to Eel River, in Ingersoll, R.V., ed., Cenozoic Basin Development of Coastal California: Englewood Cliffs, N.J., Prentice Hall, p. 124-145.

Brooks, J.M., Field, M.E., and Kenicutt, M.C., II, 1991, Observations of gas hydrates offshore northern California: Marine Geology, v. 96, p. 103-109.

Carpenter, George, 1981, Coincident sediment slump-clathrate complexes on the U.S. Atlantic continental slope: GeoMarine Letters, v. 1, p. 29-32.

Couch, R.W., 1980, Seismicity and crustal structure near the north end of the San Andreas fault system, in Streitz, Robert, and Sherburne, Roger, eds., Studies of the San Andreas Fault Zone in Northern California: California Division of Mines and Geology Special Report 140, 187 p.

Curzi, P.V., and Veggiani, A., 1985, I pockmarks nel mare Adriatico centrale: Acta Naturalia de l'Ateneo Parmense, v. 21, p. $79-90$.

EEZ-SCAN 84 Scientific Staff, 1986, Atlas of the Exclusive Econornic Zone, Western Conterminous United States: U.S. Geological Survey Miscellaneous Investigations Series 1-1792, 152 p., scale 1:500,000.

Field, M.E., 1987, Sediment mass-transport in basins: controls and patterns, in Gorsline, D.S., ed., Depositional Systems in Active Margin Basins: SEPM Pacific Section, v. 54, p. 1-23.

Field, M.E., Clarke, S.H., Jr., and White, M.E., 1980, Geology and geologic hazards of offshore Eel River Basin, northern California continental margin: U.S. Geological Survey OpenFile Re:port 80-1080, 80 p.
Field, M.E., Gardner, J.V., Drake, D.A., and Cacchione, D.A., 1987, Tectonic morphology of offshore Eel River Basin, California, in Schymiczek, Herman, and Suchsland, Reinhard, eds., Tectonics, sedimentation, and evolution of the Eel River and other coastal basins of Northern California: San Joaquin Geological Society Miscellaneous Publication 37, p. 41-48.

Field, M.E., and Kvenvolden, K.A., 1985, Gas hydrates on the northern California continental margin: Geology, v. 13, p. 517-520.

1987, Preliminary report on gaseous hydrocarbons in sediment and seeps, offshore Eel River Basin, California, in Schymiczek, Herman, and Suchsland, Reinhard, eds., Tectonics, sedimentation, and evolution of the Eel River and other coastal basins of Northern California: San Joaquin Geological Society Miscellaneous Publication 37, p. 55-60.

Hovland, Martin, and Judd, A.G., 1988, Seabed pockmarks and seepages: Graham and Totman, London, 293 p.

Kayen, R.E., 1988, The mobilization of Arctic Ocean landslides by sea level fall-induced gas hydrate decomposition: Unpublished M.S. Thesis, California State University, Hayward, 227 p.

Kvenvolden, K.A., 1988, Methane hydrates and global climate: Global Biogeochemical Cycles, v. 2, p. 221-229.

Lee, H.J., 1989, Undersea landslides: extent and significance in the Pacific Ocean, in Brabb, E.E., and Harrod, B.L., eds., Landslides: Extent and Economic Significance: Balkema, Rotterdam, p. 367-379.

Lee, H.J., Edwards, B.D., and Field, M.E., 1981, Geotechnical analysis of a submarine slump, Eureka, California: Proceedings of the Offshore Technology Conference, Houston, Tex., OTC 4121 , p. 53-59.

Prior, D.B., and Coleman, J.M., 1982, Active slides and flows in underconsolidated marine sediments on the slopes of the Mississippi delta, in Saxov, Svend, and Nieuwenhuis, J.K., eds., Marine Slides and Other Mass Movements: Plenum, New York, p. 21-49.

Richmond, W.C., and Burdick, D.J., 1981, Geologic hazards and constraints of offshore northern and central California: Proceedings of the Offshore Technology Conference, Houston, Tex., OTC 4117, p. 9-12.

Sangrey, D.A., 1977, Marine geotechnology - state of the art: Marine Geotechnology, v. 2, p. 45-80.

Sieck, H.C., 1973, Gas-charged sediment cores pose possible hazard to offshore drilling: Oil and Gas Journal, v. 71, p. 148-163.

Whelan, Thomas, III, Coleman, J.M., Suhayda, J.N., and Roberts, H.H., 1977, Acoustical penetration and shear strength in gas-charged sediment: Marine Geotechnology, v. 2, p. $147-159$. 


\title{
Sur Submarine Landslide, a Deep-Water Sediment Slope Failure
}

\author{
By C.E. Gutmacher and W.R. Normark
}

\section{INTRODUCTION}

Sur submarine landslide originated on the continental slope west of Point Sur, central California (fig. 1). The failed material moved downslope onto the surface of the adjacent Monterey Fan (Hess and others, 1979) and came to rest between 3,200 and 3,750 meters (m) water depth (fig. 2 ). The resulting mass movement deposit is 70 kilometers $(\mathrm{km})$ long, 5 to $25 \mathrm{~km}$ wide, and covers an area slightly less than 1,000 square kilometers $\left(\mathrm{km}^{2}\right)$. It ranges in thickness from a thin veneer (centimeters) to approximately $75 \mathrm{~m}$ and has an estimated volume of 35 cubic kilometers $\left(\mathrm{km}^{3}\right)$. Our study of Sur landslide is unusual because we have used many methods of remote-sensing, plus physical cores of the mass-movement debris, on a deep-water deposit. Many similar studies have been done in shallow water on smaller deposits where it is much easier and faster to gather data. Our work helps bridge a gap in the understanding of underwater slope failures, because Sur landslide is intermediate in size between the landslides studied in shallow water and the commonly much larger deep-water sediment slope failures. A full presentation of the data and comparisons with modern smaller-scale fjord and delta slope failures is given by Normark and Gutmacher (1988).

Mass-movement debris, a product of the Sur submarine landslide, is one of the most recent depositional units on the Monterey Fan, a large turbidite system on the central California continental margin (fig. 1). Monterey Fan is fed by two major submarine canyon systems, the Monterey and the Ascension. Coarse-grained terrigenous sediment commonly reached the heads of these canyons during periods of lowered sea-level, but during sea-level high-stands (interglacial times such as today), only the Monterey canyon was an active pathway for sediment en route to the deep-ocean floor (Normark, 1970; Normark and others, 1985).

The Sur landslide deposit was initially recognized and mapped during a cruise aboard the research vessel S.P. Lee in 1977. Subsequent cruises aboard the research vessel Sea Sounder in 1978 and 1979 completed our data base of 3.5-kilohertz $(\mathrm{kHz})$ bathymetric profiles, high-resolution seismic-reflection profiles, and sediment cores. We compiled the bathymetric map of figure 2 using depth measurements along our survey tracklines together with limited multibeam sounding data (Eittreim and others, 1983). The limit of the landslide deposit shown in figure 2 was interpreted from our 3.5-kHz profiles. GLORIA (Geological LOng-Range Inclined Asdic) sidescan-sonar imagery collected in 1984 provides a map of the near-surface part of the deposit and more detailed definition of the margins (fig. 3; EEZ-SCAN 84 Scientific Staff, 1986).

\section{MORPHOLOGY}

The Sur landslide deposit extends southwest approximately $70 \mathrm{~km}$ from the base of the continental slope, crossing the main Monterey Fan valley at about $35^{\circ} 45^{\prime} \mathrm{N}$ latitude (figs. 2 and 3). The landslide deposit is elongate with irregular margins. It occupies, and locally spreads laterally from, a roughly rectilinear, sloping depression that is 8 to $15 \mathrm{~km}$ wide. The shape of the deposit is influenced by the continental slope to the east, local topographic highs near the southern distal margins, and by the levee of the Monterey Fan valley. The northwest side of the deposit onlaps the eastern levee of Monterey East Fan valley (MEFV in fig. 1). Except where the landslide deposit abuts a steeply dipping surface, the surfaces of Monterey Fan can be followed under the edge of the landslide deposit (fig. 4). The present surface of the landslide deposit has a relatively uniform slope in the direction of movement, averaging $0.46^{\circ}$.

The Sur landslide may have originated in $2,100 \mathrm{~m}$ water depth where a scarp can be seen on seismic-reflection profiles and the GLORIA imagery (fig. 3). Above the scarp, seismic-reflection profiles show gently folded sedimentary units of the lower continental slope mantled by a layer of unlithified sediment with slope-parallel internal structure. This sediment layer is missing downslope from the scarp and presumably now forms much of the landslide deposit. The mobilized sediment apparently moved onto the fan near " $X$ " in figure 2. Part of the landslide material moved to the northwest, where it ponded between the continental slope and the fan-valley levee, but most of the material moved to the southwest where it crossed the Monterey Fan valley (see arrows in fig. 2). The GLORIA imagery (fig. 3) confirms that the landslide debris extends past the Monterey Fan valley. It also shows the landslide deposit area to be generally wider than can be recognized on $3.5-\mathrm{kHz}$ profiles alone, especially along the northwestern margin.

\section{SUR LANDSLIDE STRUCTURE AND DEPOSITS}

The Sur landslide deposit exhibits several major topographic and structural features, best seen in the $3.5-\mathrm{kHz}$ 


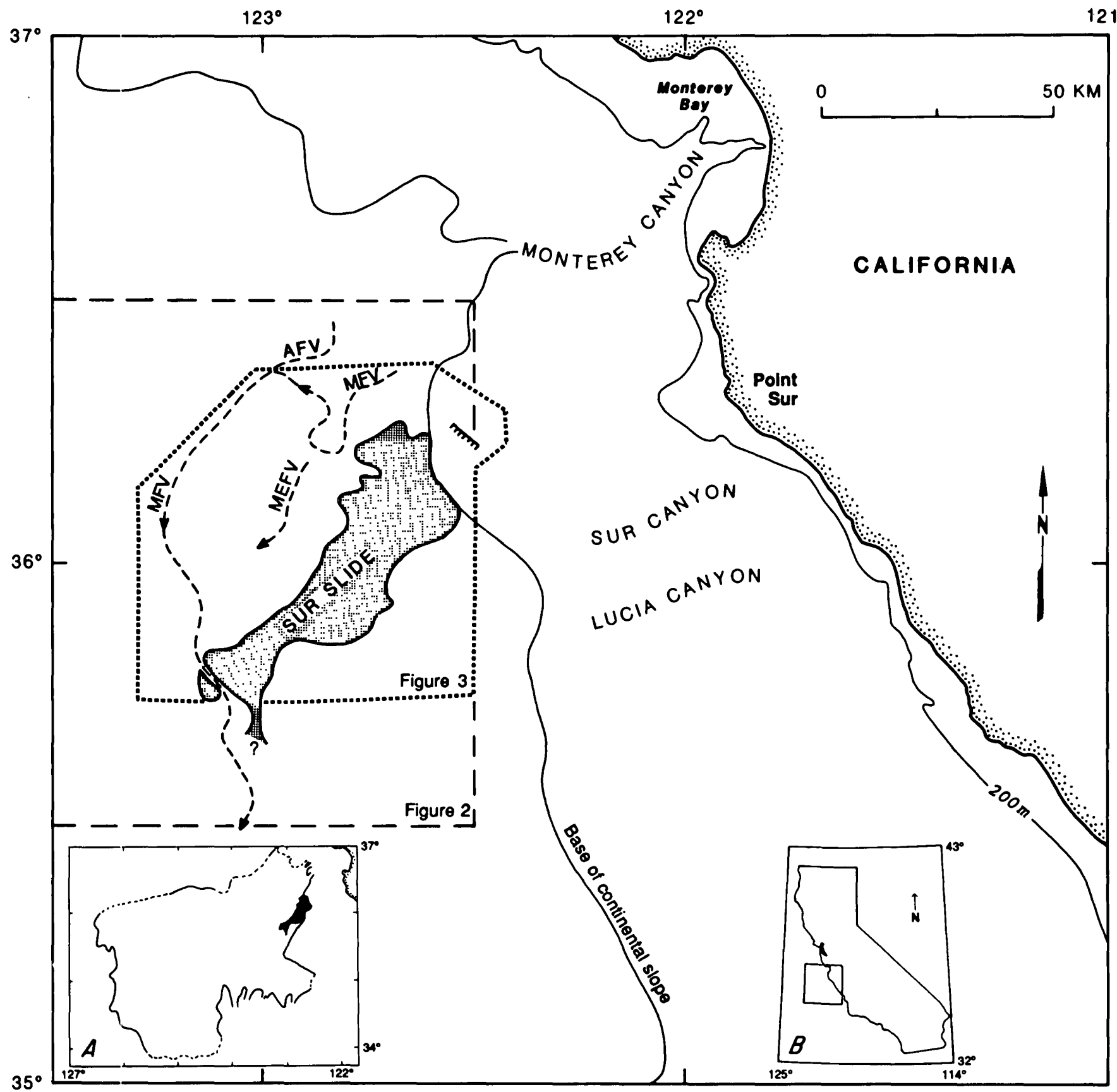

Figure 1. Location of Sur landslide deposit in relation to the outline of Monterey Fan (Inset $A$; modified from Normark and others, 1985); inset $B$ shows location of figure 1 in relation to the State of California. The heavy dashed lines show major fan valleys as follows: Monterey fan valley (MFV), conduit of sediment from Monterey Canyon and, thus, from the rivers that empty into Monterey Bay; Ascension fan valley (AFV), a hanging tributary to Monterey fan valley that receives sediment that moves along the outer continental shelf; Monterey East fan valley (MEFV), a hanging distributary from Monterey fan valley. "Hanging" means that the Monterey fan valley floor is lower than the floors of AFV and MEFV at their junctions with MFV. The dashed line encloses area shown in figure 2. The dotted outline shows the area covered by the GLORIA image of figure 3. Figure modified from Normark and Gutmacher (1988). profiles, that distinguish it from the turbidite sediment of the Monterey Fan. The presence of landslide material is further supported by the chaotic nature of sediment in cores recovered from the deposit, as opposed to the orderly layers of turbidite sediment seen in cores from the immediately adjacent fan and continental slope. 


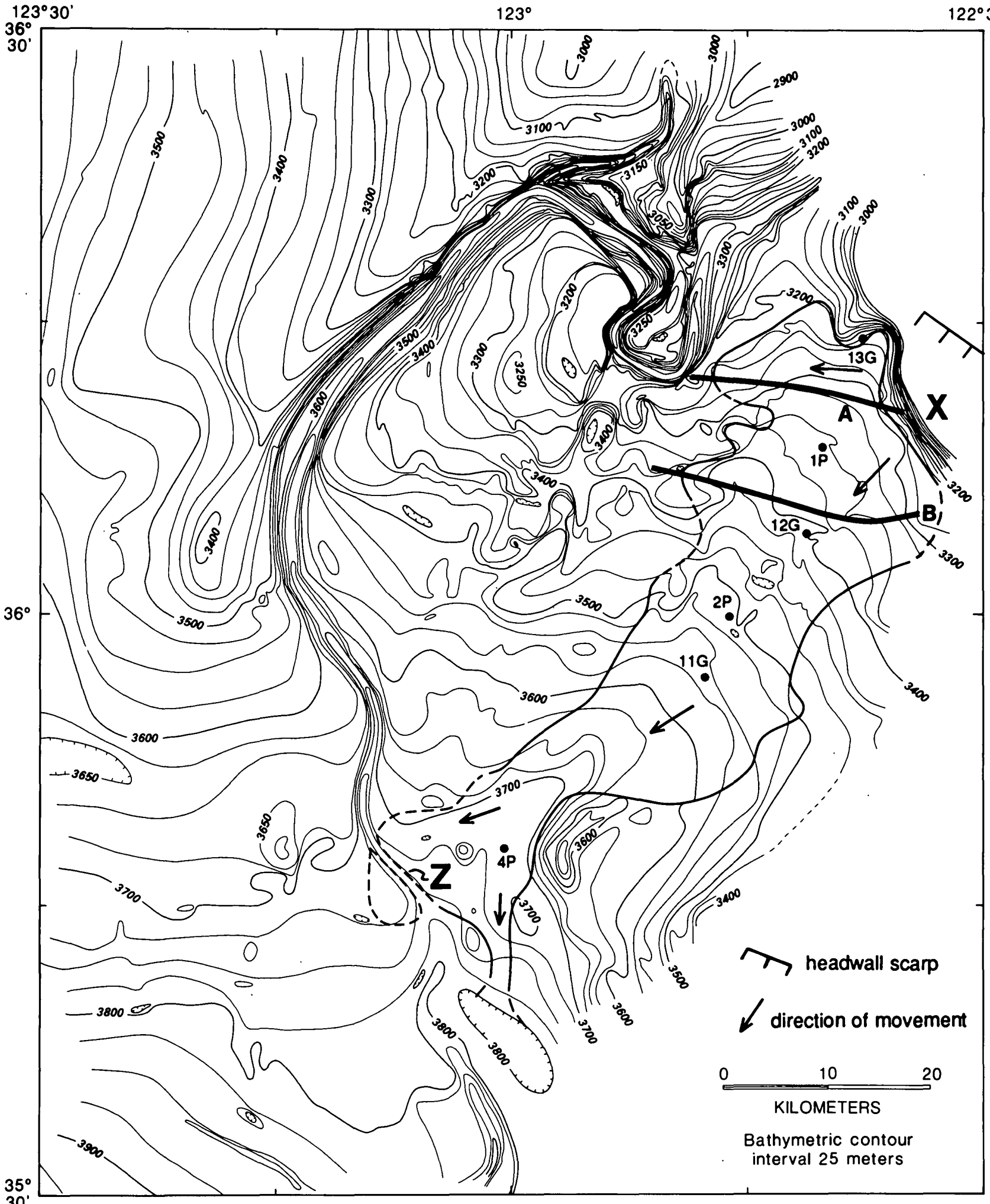

Figure 2. Detailed bathymetry (topography of the ocean floor) of Sur slide and nearby fan valleys (see location in fig. 1). The outline of the Sur landslide deposit is derived from interpretation of 3.5-kilohertz records, and dashed where the edge of the landslide deposit is poorly known. Depths, taken from acoustic soundings (measurements of travel time of reflected sound energy), are corrected for variation of the speed of sound in water using correction tables by Carter (1980). The location of seismic- reflection profiles and cores shown in figures 4 and 5 , respectively, are labeled. $X$ marks the location where landslide material moved onto Monterey Fan. Z marks where the landslide debris crossed the MFV. The portion of headwall scarp that falls within this map boundary is shown to help orient the reader when comparing figures 2 and 3 . Figure modified from Normark and Gutmacher (1988). 


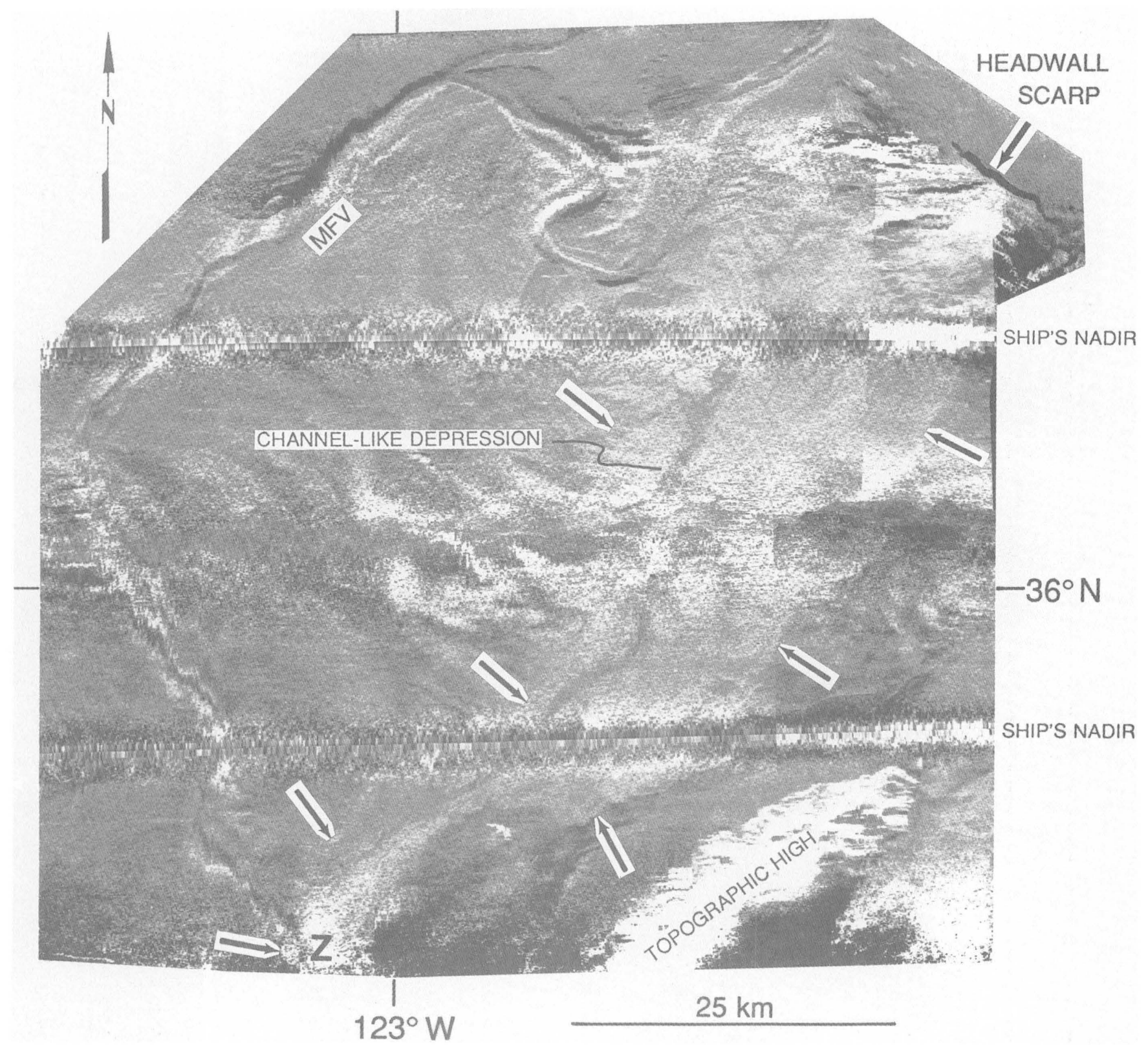

Figure 3. GLORIA sidescan-sonar imagery of the Sur landslide area (EEZ-SCAN 84 Scientific Staff, 1986). See Lee, Schwab, and Booth (this report) for a description of sidescan-sonar techniques. The arrow in the northeast corner points to the headwall scarp (breakaway area) of Sur landslide; this scarp appears as a black shadow perpendicular to the tip of the arrow. The other arrows point to the irregular boundary of the landslide deposit, which is slightly lighter (grayer) on these GLORIA images. The boundary is distinct in some places but is difficult to recognize in areas of local relief on the fan (for example, northwest side of the landslide north of latitude $36^{\circ}$ ). Monterey Fan valley (MFV) can be discerned easily along the north and west sides of the image. As in figure 2, Z marks where the landslide debris crossed the MFV. Figure modified from Normark and Gutmacher (1988).

\section{Acoustic Characteristics of the Sur Landslide Deposit}

The acoustic characteristics of the Sur landslide deposit are generally similar to those seen on echo-sounding and seismic-reflection records from larger deep-water landslide deposits on passive margins, for example, Embley
(1976) and Damuth and Embley (1981). The deep water, however, often prevents sufficient resolution of detail needed for interpretation of the processes involved. Therefore, to make better use of detailed data from our modestsized Sur landslide deposit, we have also looked to studies of shallow-water $(<500 \mathrm{~m})$ landslide deposits to help interpret the acoustic character in conjunction with the core 


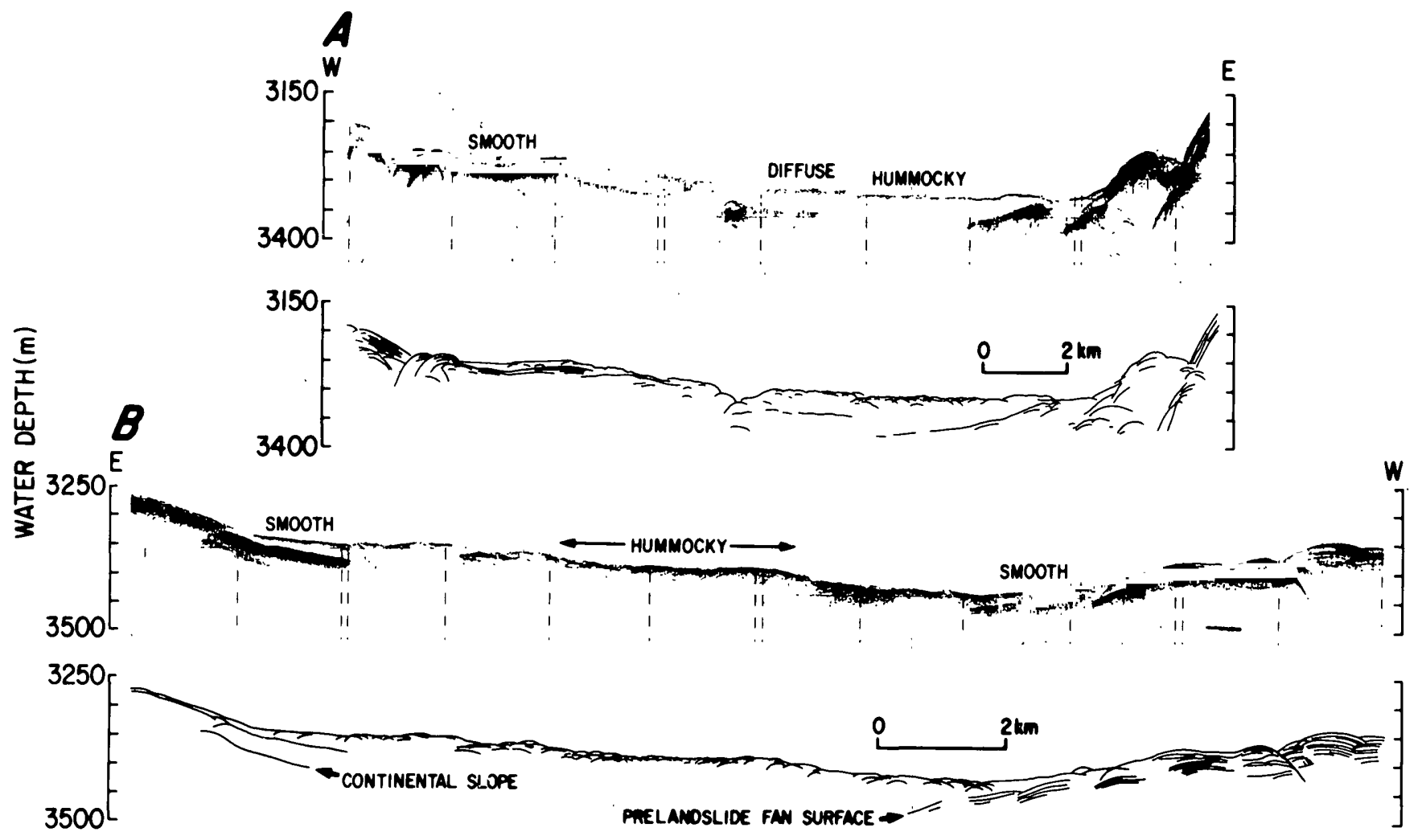

Figure 4. Selected 3.5-kilohertz acoustic-reflection profiles across the Sur landslide deposit. Line drawings show interpretation of reflecting surfaces to indicate structure. See figure 2 for locations. $W$ and $E$ indicate west and east orientations, respectively, for the individual profiles. Vertical exaggeration of the profiles is between 9 and 14 times. This means that the slope of the sea floor and of any subbottom reflecting surfaces will appear grossly exaggerated (up to 14 times actual slope). Areas of different acoustic character are indicated as follows: (1) hummocky

data presented later. Only detailed studies of shallow-water deposits have led to definitive correlation of type of sea-floor bottom relief with given acoustic character, for example, Prior, Bornhold, Coleman, and Bryant (1982), Prior, Bornhold, and Johns (1984), and Coleman and others (this report).

Hummocky-surfaced deposits occur over large areas of the northern half of the Sur landslide deposit. Where observed with a wide-beam profiling system (that is, 3.5 $\mathrm{kHz}$ ) from a sea-surface source, edges of depressions and the summits of individual blocks or ridges of sediment within the landslide mass act as point reflectors. Such point reflectors produce hyperbolic echoes on the $3.5-\mathrm{kHz}$ profiles, resulting in a generally hummocky appearance. Profiles from the northern part of the Sur landslide deposit show numerous hyperbolic echoes (fig. 4), with a few individual sea-floor reflection sources standing more than 10 to 20 meters above adjacent hummock apices. The hyperbolic echoes are too numerous to allow an estimate of returns, (hyperbolic echoes) thought to be from blocks of landslide debris, (2) smooth sea-floor reflection overlying acoustically transparent sediment, thought to be debrisflow deposits resulting from Sur landslide, and (3) diffuse returns, thought to be from surface roughness on the order of tens of centimeters to a few meters high. Under the acoustically transparent layers in the smooth areas, the pre-existing surfaces of Monterey Fan and the lower continental slope can be observed to a depth of more than 50 meters.

the size or height of individual blocks. We interpret the hyperbolic echoes to be from areas of blocky debris flow. The original sea floor is observed to dip beneath the margins of the landslide mass but is not observed beneath the strongly reflective hummocky terrane (fig. 4).

Smooth-surfaced deposits without internal reflectors occur as ponded sediment units both within the main landslide deposit and perched on its margins (fig. 4, profile A); this type of deposit also abuts most hummocky areas (fig. 4, profile B). We interpret the strongly reflective, smooth sea floor overlying the acoustically transparent sediment to be areas of debris-flow deposits following the interpretations by Damuth and Embley (1981). On Sur landslide, the smooth-surfaced debris-flow deposits are mostly around the margins of the northern hummocky area and near the distal margin adjacent to Monterey Fan valley.

Zones of small-scale hummocky sea-floor relief and areas of smooth sea floor both exhibit a weak (diffuse) sea-floor acoustic return that tends to obscure subsurface 
acoustic character. These zones are distinct from both the areas of strong hummocky and smooth reflectors described above but are not always distinct from each other. Zones of diffuse, weak surface reflectivity (fig. 4, line A) on Sur landslide appear to be an intermediate stage between blocky (hummocky) debris flow and smooth-surfaced debris flow, and are common in the southern half of the mass movement deposit. We interpret the zones of diffuse reflectivity to result from fine-scale relief on the surface of the massmovement deposit. Embley (1976) suggested small-scale folding or other relief causes the prolonged echo character in his deep-water study areas (we use the term diffuse to describe the same echo character).

There is a fringing zone where the mass-movement deposits are too thin $(<3 \mathrm{~m})$ to be resolved on $3.5-\mathrm{kHz}$ profiles but where the character of the sea-floor reflector is nevertheless distinct from that of the adjacent fan or continental-slope sediment surface. The acoustic backscatter pattern on GLORIA imagery shows this fringing zone locally has a greater extent than can be detected on our $3.5-\mathrm{kHz}$ profiles (compare the landslide outlines in figs. 2 and 3 ).

Fan sediment, characteristic of overbank deposition (parallel-bedded, locally showing the "dune" shape of sediment waves), derived from the MEFV is buried by the mass-movement deposit without apparent disruption (see west end of profile fig. $4 B$ ). Most margins of the landslide deposit show this onlapping onto prelandslide sediment.

Small, isolated, topographic highs and lows (fig. 2) lie along a band of darker gray backscatter within the lighter gray landslide area seen on the GLORIA image (fig. 3). This darker band might mark a continuous channellike depression which might have partly channelized the flow or been created by it.

We know that Sur landslide is relatively young, because no layer of sediment thick enough to be resolved on the $3.5-\mathrm{kiHz}$ profiles is observed to bury the landslide deposit on any of the profiles.

\section{Cores From the Sur Landslide Deposit}

It is important to remember that the thickness of the landslide mass (up to $75 \mathrm{~m}$ ) is far greater than the length of any available core. The cores show us the composition of only the top of the deposit and the thin postlandslide deposits that the $3.5-\mathrm{kHz}$ system cannot resolve. The six cores we obtained from the study area are illustrated in figure 5; their locations are shown in figure 2. Core $13 \mathrm{G}$ is immediately adjacent to the landslide deposit, and contains undisturbed turbidites of the Monterey Fan.

Cores IP and 12G are from the area of hummocky acoustic character and contain a muddy matrix with mud clasts (mud balls, mud chips, and large rounded to subangular fragments) that range in size from a centimeter across to some that are wider than the core barrel. Indeed, some of the thicker "layers" in the cores may be fully penetrated large clasts (for example, see "clast" in $1 \mathrm{P}$, fig. 5). The mud-clast rich intervals include both matrix- and clastsupported intervals (see 1P). In both cores, the mud-clast units are overlain by a sand and muddy turbidite unit. We think the mud-clast layers and overlying turbidite units pond in the low areas between the large slide blocks of the hummocky areas. As the blocks move and break apart, various sized clasts would be continuously generated.

Color can be used to distinguish turbidite mud from hemipelagic mud (sediment derived mainly from particles sinking through the water column) on Monterey Fan (Brunner and Normark, 1985; Brunner and Ledbetter, 1987). Mud in cores $12 \mathrm{G}$ and $1 \mathrm{P}$, however, includes mixtures of both of these distinctive sediment types indicating a postdepositional mixing of sediment such as by involvement in the Sur landslide event. There is also a variety of other mud types not seen in cores from the Monterey Fan, indicating the sediment probably is from a nonfan source area. Further support for a nonfan source is the fact that the benthic foraminifers taken from both the clasts and matrix in these cores indicate the original site of deposition was on the continental slope (oral comm., J.C. Ingle, Jr., 1979).

Cores $2 \mathrm{P}$ and $4 \mathrm{P}$ from areas of diffuse sea-floor reflectivity (interpreted from acoustic character to be debris flows) consist mainly of intensely deformed turbidites, overlain by thicker units of undisturbed turbidite mud and sand. A layer of mud with some upper-slope component separates the deformed turbidites below from the undisturbed turbidite at the surface of both cores. Much of core $2 \mathrm{P}$ has vertical or steeply inclined sections of contorted and sheared turbidite sediment (fig. 5). Other indications of disturbance within these two cores are overturned folds or refolded tabular rip-up clasts (see F, fig. 5), mud-clast debris-flow units, mudballs with the appearance of sandy armor (see middle of E, fig. 5), and irregularly shaped sand blebs in mud matrix (see lower $F$ and mid-lower G, fig. 5). These cores (especially 2P) may have penetrated a zone of small blocks of deformed sediment or fold ridges similar to those observed in a fjord and described by Prior and others (1984). The deformed turbidites in cores $2 \mathrm{P}$ and $4 \mathrm{P}$ suggest either incorporation of Monterey Fan sediment into the debris flow or deformation of the fan surface by its passage. These details have been adequately described only from the fjord (shallow water) studies. Their sedimentologic characters are consistent with an area of fine-scale topographic relief on the order of tens of centimeters to a few meters high. This fine-scale relief would contribute to a diffusely reflective acoustic character as observed in our profiles of the area.

Core 11G (fig. 5) is from the middle of the landslide area, where the mass-movement deposits, as interpreted from acoustic character, are locally thin or nonexistent (similar to the fringe zone). The core contains sections of 

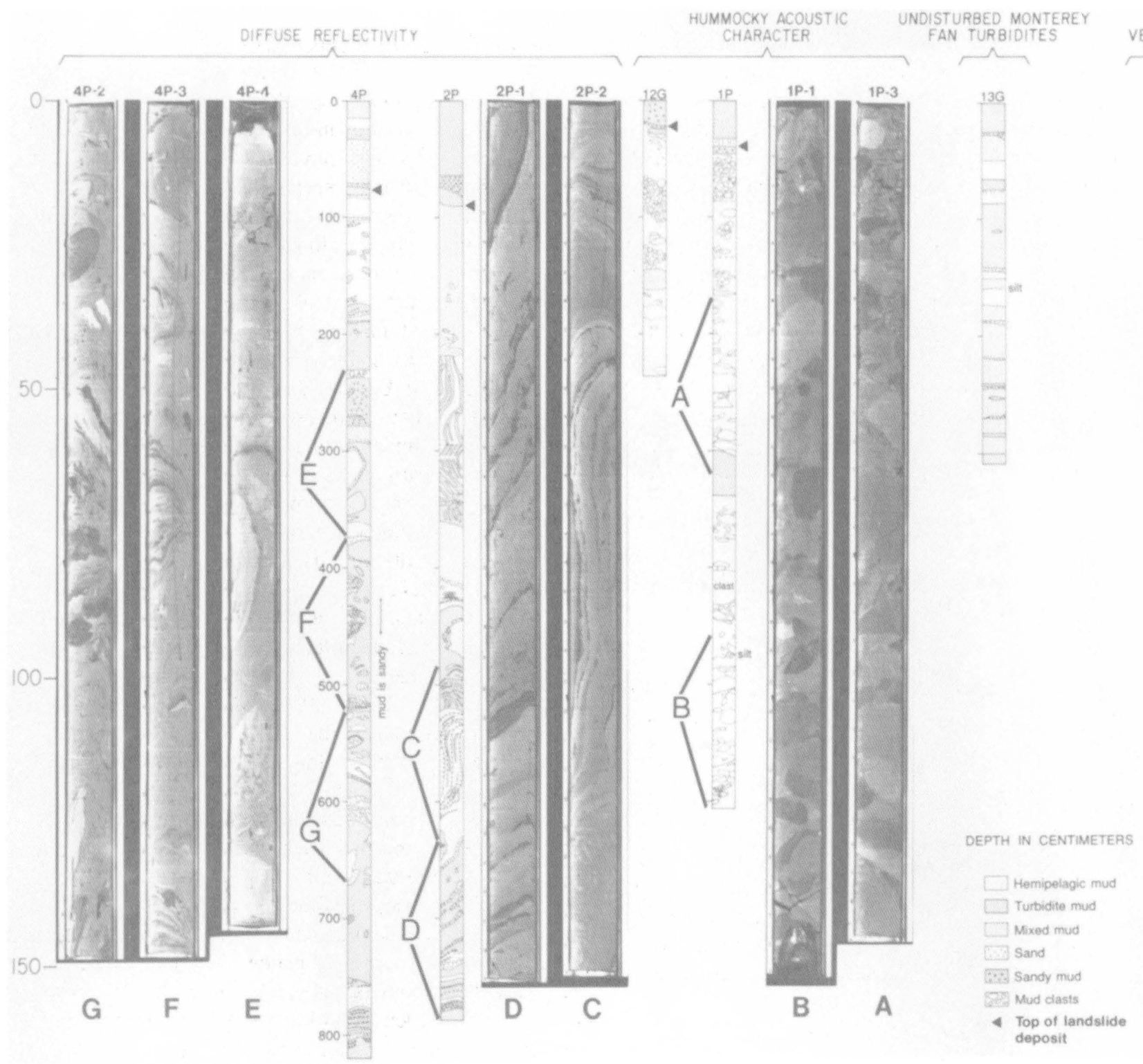

Figure 5. Schematic logs (drawings) of sediment cores from Sur landslide deposit, with selected associated photographs. All scales are in centimeters: 100-centimeter interval for the drawings and 50-centimeter interval for photographic sections. Lines and letters A through $G$ next to the core logs indicate section of core shown in photographs $\mathrm{A}$ through $\mathrm{G}$. The core logs are horizontally exag-

gerated (2 times) to make it easier to show important features; a side effect of this exaggeration is a noticeable difference in the shape of some features between the log and the photograph (for example, the armored mudball (half-circle with dotted rim) in section E appears rounder in the drawing). Core locations are given in figure 2 . Figure modified from Normark and Gutmacher (1988).

mixed-source mud, but the undisturbed appearance of the sandy turbidite units makes it look like a typical fan core. The corer seems to have penetrated through a thin veneer of debris-flow mud (represented by a sandy mixed-source mud from 0 to 12 centimeters $(\mathrm{cm}))$ and recovered underlying preslide fan turbidites.

We have no cores from any area of strong, smooth reflectors. More complete core descriptions are given by Normark and Gutmacher (1988).

\section{VOLUME}

When considering an underwater landslide deposit that covers an area roughly equal to that of the entire Monterey Bay, it is interesting to look also at the volume of material that moved. Hess and others (1979) calculated the volume of the landslide deposit to be $35 \mathrm{~km}^{3}$ based on the thickness of disturbed sediment shown by the $3.5-\mathrm{kHz}$ profiles and assuming a maximum thickness of $75 \mathrm{~m}$ for the 
axis of the deposit, where the base of the landslide could not be resolved by the profiles. This is the greatest thickness observed in any $3.5-\mathrm{kHz}$ profile from the landslide deposit and is a reasonable estimate considering that the thickness of the deposit cannot be resolved on many of the available single-channel seismic-reflection profiles that cross it and that can generally be used to map layers 50 to $60 \mathrm{~m}$ or thicker. A crude estimate of the missing lower-slope section described above (see fig. 5 in Normark and Gutmacher, 1988), however, is only about $10.5 \mathrm{~km}^{3}$ (derived from an observed average slab thickness of $100 \mathrm{~m}$ and a "denuded" area of $105 \mathrm{~km}^{2}$ based on an approximation from the GLORIA image). These two volumes are a factor of three apart, suggesting either that much of the landslide debris came from other areas of the slope or that a large component of fan sediment has been incorporated into the landslide.

\section{AGE OF MOVEMENT}

The timing of submarine mass movement is commonly difficult to establish. In rare cases, the age of a landslide is known, as when it moves manmade objects from their known locations (Hampton, Lemke, and Coulter, this report; Normark, Moore, and Torresan; this report) or when pre- and postlandslide data are available in a given area (Field, this report). In most cases, we measure the thickness of undisturbed, overlying sediment and estimate its rate of deposition. The age of the Sur landslide is difficult to determine from the overlying sediment cover, but the following lines of reasoning suggest a geologically recent event:

1. The four cores from the landslide deposit (12G, 1P, 2P, and $4 F^{\prime}$ ) have between 23 and $87 \mathrm{~cm}$ of apparently undisturbed hemipelagic and turbiditic sediment at the top. The closest data we have are from a paleoenvironmental study of a levee core taken on Monterey Fan 50 $\mathrm{km}$ northwest of the landslide (Brunner and Normark, 1985; McGann, 1986), showing the Holocene hemipelagic sedimentation rate is about $15 \mathrm{~cm} / 1,000$ years. If all the hemipelagic sediment veneer were deposited at this rate, the Sur landslide's age is 1,500 to 6,000 years.

2. Sand and mud turbidites occur in the top parts of the same four cores (fig. 5). Because turbidites are deposited almost instantaneously relative to hemipelagic mud, we use only the hemipelagic intervals to calculate a time of landslide movement of about 1,500 years before present. If, however, the surficial turbidite layers were generated at the time of a landslide event, the youngest phase of the Sur landslide may be just several decades old, and the failure must have occurred in more than one event. Until accurate dates are obtained from the deposit, however, the age estimates are speculative.

\section{SUR LANDSLIDE SCENARIO}

The source area for the Sur landslide is on a sedimentologically inactive section of lower continental slope. It is bypassed by Monterey Canyon and its large load of terrigenous sediment. It may receive small amounts of sediment from downslope transport, but we believe the primary sediment input to be the slow rain of hemipelagic material. The source area is deep enough (about 2,200 m), to be beyond the deepest effect of storm waves. Its slope of $5^{\circ}$ and slow gradual loading by hemipelagic sedimentation point to a statically stable environment. In their study of a mud flow in Santa Barbara Basin, Edwards, Lee, and Field (this report) analyze a somewhat more gentle slope with a source area of similar although smaller features, and conclude that an earthquake was needed to trigger such a landslide. Likewise, one or more earthquakes likely caused the Sur landslide. Such an earthquake could occur along one of the many faults in this seismically active region of northern California. As an example of the importance of earthquakes in causing landslides in this area, researchers suspect that new slope failures took place along this part of the California margin as a result of the Loma Prieta Earthquake of October 17, 1989 (Greene and others, 1991).

We envision that the Sur landslide deposit formed from breakup and downslope transport of large slabs of slope sediment that were destabilized by one or more earthquakes. It is not possible with the available data to discern whether this landslide was the result of a single event or is a multistage slope failure. In either case, some intact sections of slope sediment as large as office buildings ( $\leq 25 \mathrm{~m}$ high) moved $5 \mathrm{~km}$ down the continental slope and as much as $20 \mathrm{~km}$ across the gentle $0.5^{\circ}$ incline of Monterey Fan. Smaller, house-sized ( $\leq 10 \mathrm{~m}$ high) blocks were transported as much as $30 \mathrm{~km}$ farther. Movement of these blocks incorporated prelandslide fan sediment within the main mass-movement deposit. Breakup of the partially consolidated sediment blocks and incorporation of water gave rise to debris flow(s) and turbidity current(s). Deposits from the latter events both formed the cap or "icing" on the Sur landslide blocks and also travelled another $15 \mathrm{~km}$ to cross the 50-m deep. Monterey Fan valley before finally coming to rest.

\section{ACKNOWLEDGMENTS}

We thank G.R. Hess for his assistance during the initial phase of this study. C.A. Brunner helped us prepare detailed core descriptions, and T.E. Chase provided continuous-strip 3.5-kHz profiles and color photographs of the core sections shown in figures 4 and 5 . We thank J.V. Gardner, for providing the GLORIA data for figure 3. The manuscript was improved through reviews by Mike Field and Monty Hampton. 


\section{REFERENCES CITED}

Brunner, C.A., and Ledbetter, M.T., 1987, Sedimentological and micropaleontological detection of turbidite muds in hemipelagic sequences: an example from the late Pleistocene levee of Monterey Fan, central California continental margin: Marine Micropaleontology, v. 12, p. 223-239.

Brunner, C.A., and Normark, W.R., 1985, Biostratigraphic implications for turbidite depositional processes on the Monterey deep-sea fan, central California: Journal of Sedimentary Petrology, v. 55, p. 495-505.

Carter, D.J.T., 1980, Echo-sounding correction tables: Hydrographic Department, Ministry of Defence, Taunton, United Kingdom, 150 p.

Damuth, J.E., and Embley, R.W., 1981, Mass-transport processes on Amazon Cone: western equatorial Atlantic: Bulletin American Association of Petroleum Geologists, v. 65, p. 629-643.

EEZ-SCAN 84 Scientific Staff, 1986, Atlas of the Exclusive Economic Zone, western conterminous United States: U. S. Geological Survey Miscellaneous Investigations Series, I-1792, 152 p., scale 1:500,000.

Eittreim, S.L., Embley, R.W., and Normark, W.R., 1983, Monterey sea-valley meander revisited: EOS, Transactions American Geophysical Union, v. 64, p. 730.

Embley, R.W., 1976, New evidence for occurrence of debris-flow deposits in the deep sea: Geology, v. 4, p. 371-374.
Greene, H.G., Gardner-Taggart, Joan, Ledbetter, M.T., Barminski, Robert, Chase, T.E., Hicks, K.R., and Baxter, Charles, 1991, Offshore and onshore liquefaction at Moss Landing spit, central California-Result of the October 17, 1989, Loma Prieta earthquake: Geology, v. 19, p. 945-949.

Hess, G.R., Normark, W.R., and Gutmacher, C.E., 1979, Sur submarine slide, Monterey Fan, central California: Geological Society of America Abstracts with Programs, v. 11, p. 83-84.

McGann, M.L., 1986, Paleoenvironmental analysis of latest Quaternary levee deposits of Monterey Fan, Central California continental margin: foraminifers and pollen: Unpublished M.S. thesis, University of California, Berkeley, $155 \mathrm{p}$.

Normark, W.R., 1970, Channel piracy on Monterey deep-sea fan: Deep-Sea Research, v. 17, p. 837-846.

Normark, W.R., and Gutmacher, C.E., 1988, Sur submarine slide, Monterey Fan, central California: Sedimentology, v. 35 , p. 629-647.

Normark, W.R., Gutmacher, C.E., Chase, T.E., and Wilde, Pat, 1985, Monterey Fan, Pacific Ocean, in Bouma, A.H. Barnes, N.E., and Normark, W.R., eds., Submarine Fans and Related Turbidite Systems: Springer-Verlag, New York, p. $79-86$.

Prior, D.B., Bornhold, B.D., Coleman, J.M., and Bryant, W.R., 1982, Morphology of a submarine slide, Kitimat Arm, British Columbia: Geology, v. 10, p. 588-592.

Prior, D.B., Bornhold, B.D., and Johns, M.W., 1984, Depositional characteristics of a submarine debris-flow: Journal of Geology, v. 92, p. 707-727. 


\title{
Seismically Induced Mudflow in Santa Barbara Basin, California
}

\author{
By B.D. Edwards, H.J. Lee, and M.E. Field
}

\section{INTRODUCTION}

The California Continental Borderland is a seismically active region of complex topography located offshore of southern California. This submerged margin is characterized by slope failures and mass-movement deposits of many scales, ranging from features covering less than 100 square meters $\left(\mathrm{m}^{2}\right)$ to those covering more than 100 square kilometers $\left(\mathrm{km}^{2}\right)$ (Thornton, 1986; Field and Edwards, this report). This section summarizes a detailed study of one of these features, a 6- to 15-m-thick mass flow covering nearly $4 \mathrm{~km}^{2}$ of the sea floor in Santa Barbara Basin (fig. 1). This study allows us to evaluate a number of driving mechanisms that might have initiated the slope failure as well as to provide an understanding of why the failure developed into a mud flow.

Mass flows involve some amount of continuous deformation throughout the failed sediment mass, in contrast to slumps which exhibit discontinuous deformational behavior (distinct shear surfaces) along the failure plane and within the failed mass (Lee, Schwab, and Booth, this report). A mudflow is a special type of mass flow that involves predominantly muddy sediment. Most mudflows that have been studied in the marine environment are located at active delta-fronts (Coleman and Garrison, 1977; Roberts, 1980; Prior and others, 1984; Coleman and others, this report; Schwab and Lee, this report). The deposit we describe here lies on a smooth section of the continental slope removed from major river sediment sources.

The muddy sediment blanketing the floor and flanks of Santa Barbara Basin is derived from the Ventura and Santa Clara River systems which carry detritus eroded from coastal mountains into the eastern end of the basin (fig. 1). At present, no delta system exists at the river mouths; river-derived sediment is transported southeastward along the coast by longshore currents where most of the sand component is shunted into the adjacent Santa Monica Basin

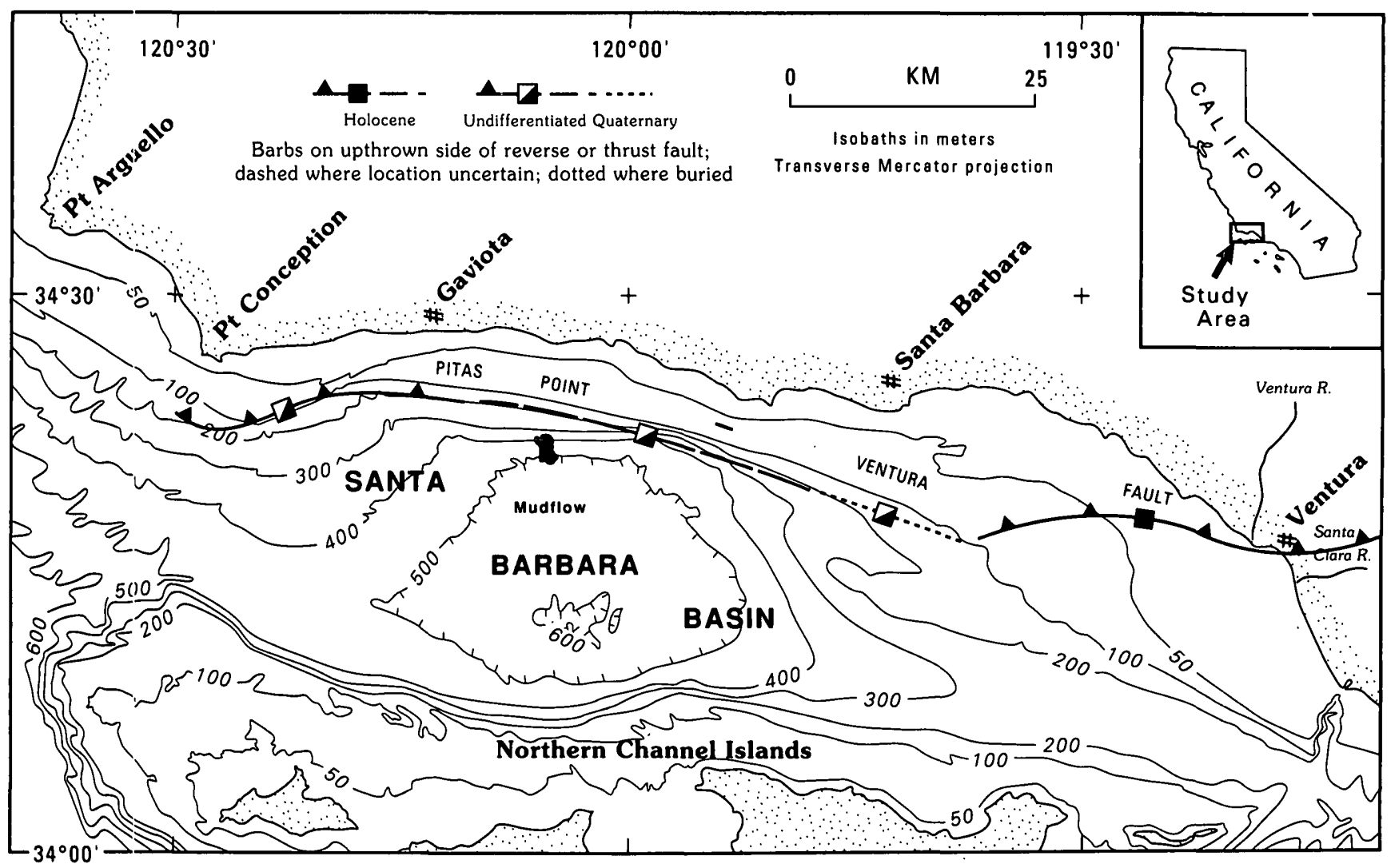

Figure 1. Santa Barbara Basin showing the location of the slope failure. The location of the Pitas Point-Ventura fault is from Yerkes (1985). Bathymetry is in meters. 


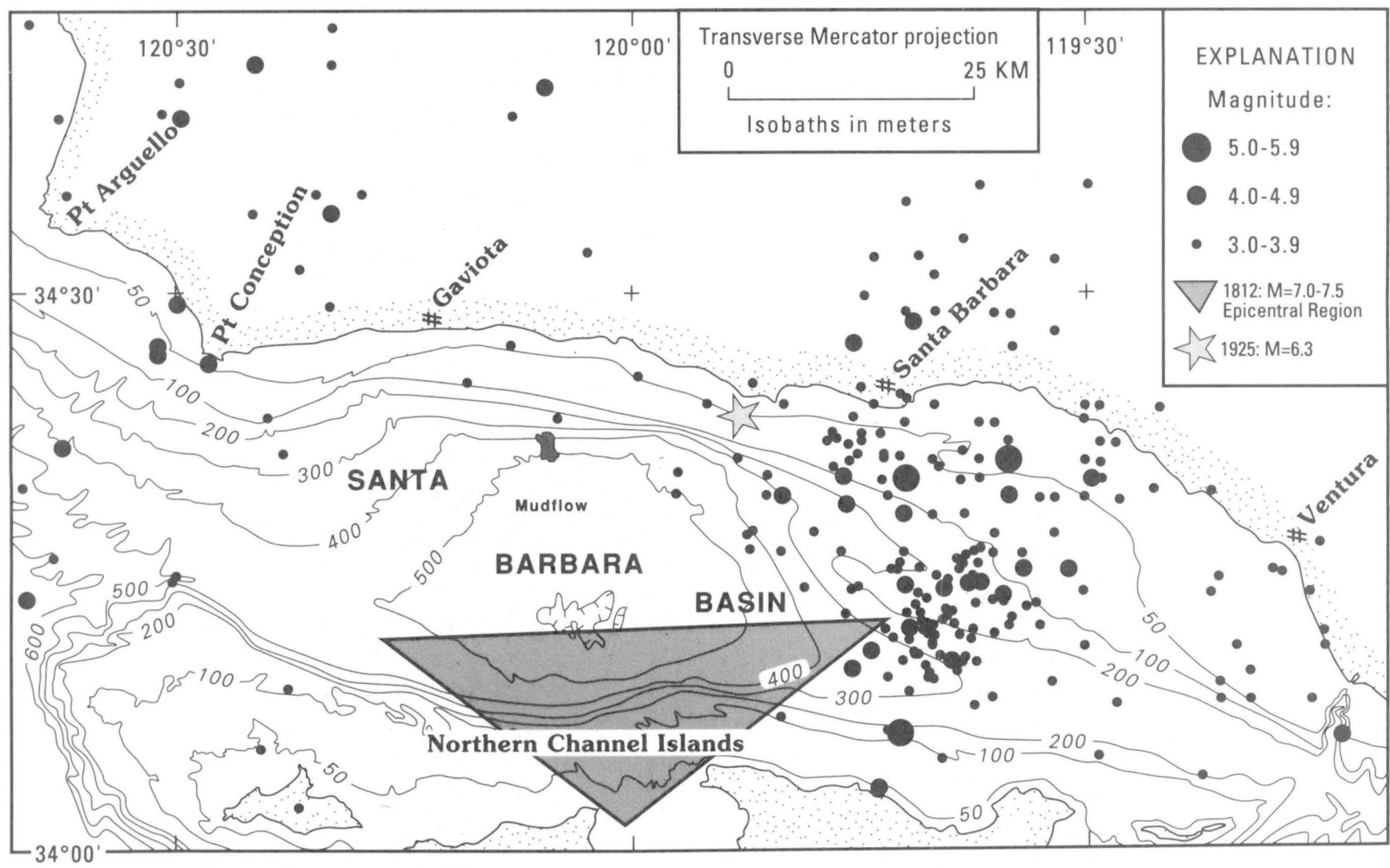

Figure 2. Seismicity of the Santa Barbara Basin region for the period 1932 to 1981. Also shown are the estimated locations for selected events: 1925 magnitude $=6.3$ and 1812 magnitude $=7.0$ to 7.5 (Yerkes and others, 1981). The zone shown for the 1812 event indicates the uncertainty in interpreting historic records.

through submarine canyon systems (Malouta and others, 1981). In contrast, the fine-grained suspended sediment load is transported westward into Santa Barbara Basin by the Anacapa Current entering the basin from the east (Thornton, 1984).

\section{TECTONIC SETTING}

Santa Barbara Basin began forming about 15 million years ago by lateral shear at the boundary between the North American and Pacific plates (Crowell, 1974; Howell, 1976). This coastal region is cut by a large number of faults, many of them active in Pleistocene and Holocene time (2 million years ago to present; Yerkes, 1985). Most of the faults trend parallel or sub-parallel to the coastline and regional bathymetry. One of the major faults, the Pitas Point-Ventura fault, cuts near-surface sediment just upslope from the area of slope failure (fig. 1). Continuing tectonic disturbance is indicated by strong seismic activity recorded throughout historic time (fig. 2). Notably, the Richter magnitude 6.3 Santa Barbara earthquake of 1925 was centered roughly $20 \mathrm{~km}$ from the site of slope failure. The even stronger 1812 earthquake, which did considerable damage to Spanish missions located in the area, had an estimated magnitude of 7.0 to 7.5 ; estimates of the epicenter location range between 25 to $40 \mathrm{~km}$ from the site of the slope failure (fig. 2; Yerkes and others, 1981). A magnitude 7.5 event is thought to be the largest credible earthquake for the Santa Barbara Basin area (Greensfelder, 1974).

\section{MORPHOLOGY OF THE MUDFLOW}

More than 100 trackline-km of high- and intermediate-resolution seismic-reflection profiles document a well-bedded, prograding sequence of marine sediment that has developed on the mainland flank of Santa Barbara Basin since the late Pleistocene $(700,000$ years ago; Vedder and others, 1969). Deformed sediment and faults that cut this prograded sequence at depth attest to tectonic disturbance of the sediment throughout this period. Only the uppermost part of this sedimentary section, however, has been disrupted by the shallow-seated (6- to 15-m-thick) mudflow described here (fig. 3).

Major characteristics of the zone of slope failure (as shown in figs. 4,5 , and 6 ) include the following:

1. A main scarp at the head of the slope failure that marks the point of detachment from the upslope, undisturbed, 


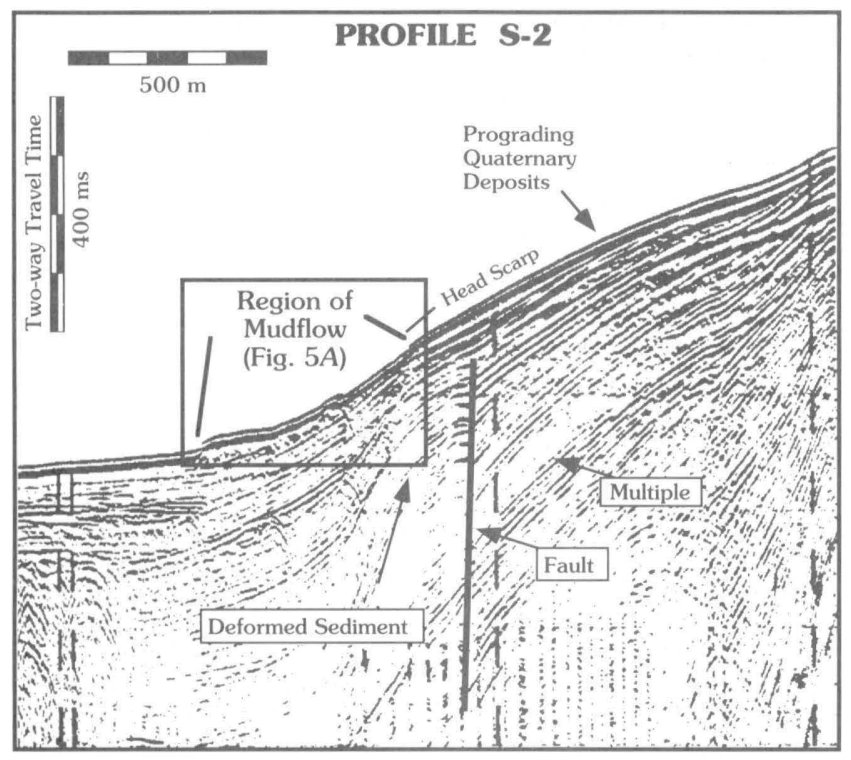

Figure 3. Seismic-reflection profile (40-cubic inch airgun source) of the Santa Barbara Basin mainland slope. The record shows a prograding sequence of Pleistocene and Holocene sediment. Note the deformed sediment and shallow-seated fault just upslope from the head scarp of the failure. Trackline location is shown in figure $7 D$. One millisecond (ms) of two-way travel time is approximately equal to 0.75 meter water depth. intact sediment on the basin flank. This scarp, termed the head scarp, extends from water depths of 374 to 400 $\mathrm{m}$.

2. An arcuate, amphitheater-shaped region, termed the evacuation zone, is exposed downslope of the head scarp. Sediment that originally filled this zone was dislodged and removed from the area during slope failure and now constitutes the main body of the mudflow deposit located farther downslope. The head scarp continues laterally around the upper part of the evacuation zone to become side scarps.

3. In the western part of the slope failure, the evacuation zone has not been covered by sediment as viewed on high-resolution seismic-reflection profiles (figs. $5 \mathrm{~A}$ and 7). Here the slope-failure surface remains exposed or only thinly mantled $(<1 \mathrm{~m})$ and is termed the scar.

4. The eastern part of the slope failure has been enlarged by the degradation of the head scarp, a process referred to as retrogressive failure (figs. $5 B$ and 7 ). The resulting coherent blocks of sediment and secondary mudflow deposits are found in the evacuation zone below the head scarp. In places, secondary and tertiary mudflow deposits rest on top of older deposits located farther downslope (figs. 4, 5B, and 7).

5. The main body of the mudflow is tongue-shaped and has roughly parallel flanks. The main body is about $1 \mathrm{~km}$ long, has up to $12 \mathrm{~m}$ of relief relative to the adjacent

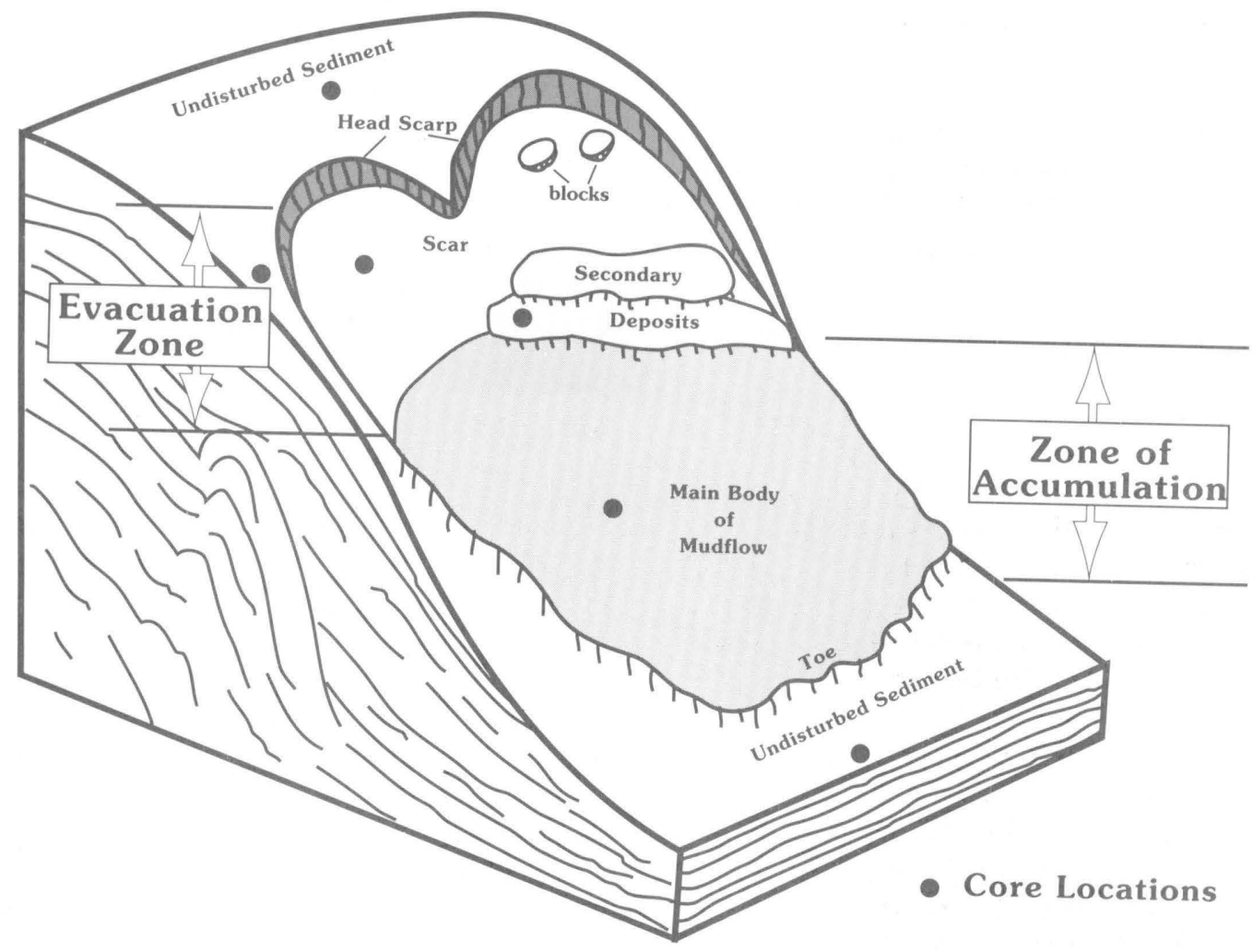

Figure 4. Interpretive block diagram showing important morphologic features of the mudflow site and sampling locations. 

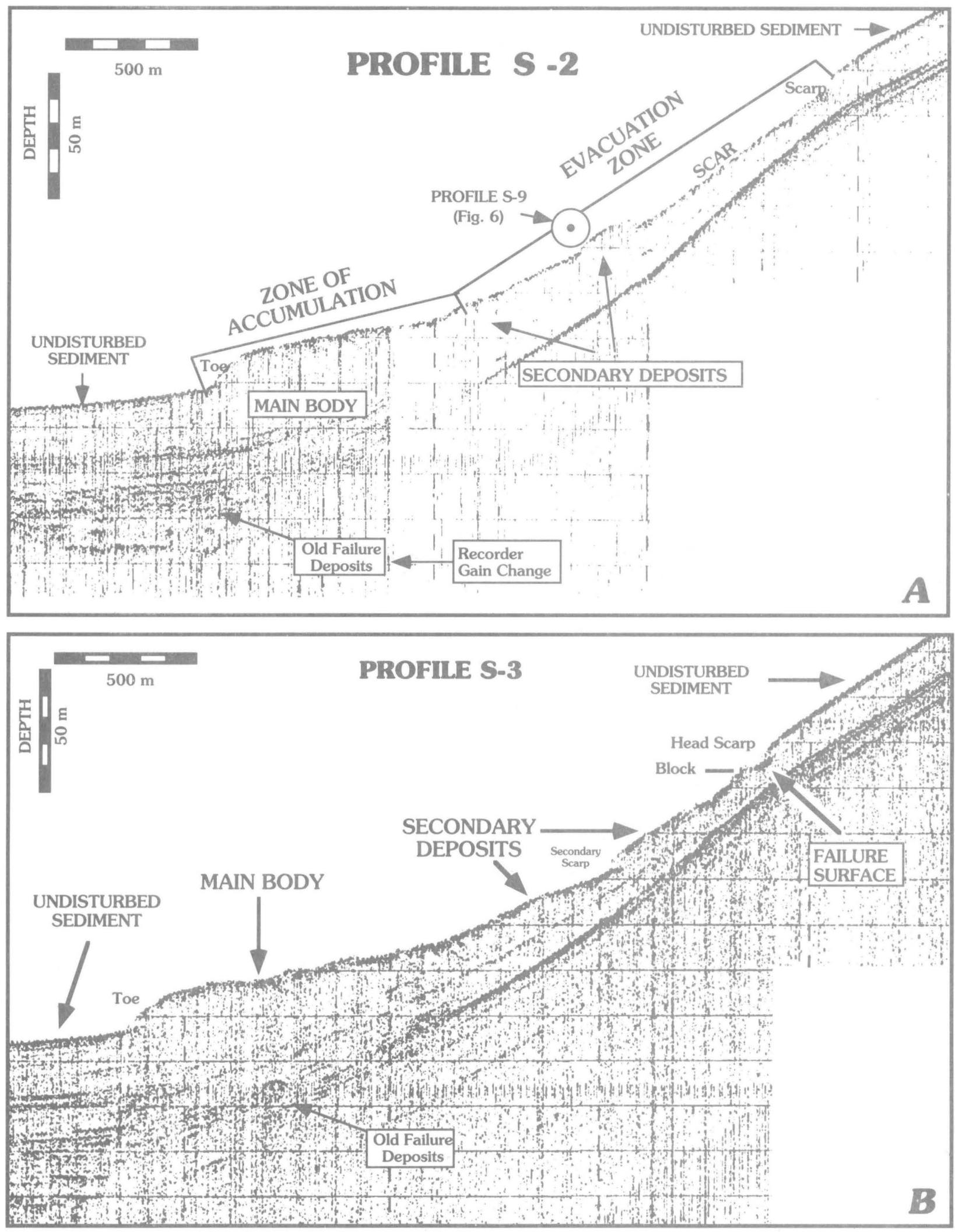

Figure 5. (A) High-resolution 3.5-kilohertz seismicreflection profile of part of the record shown in figure 3 showing the general morphology of the slope failure zone. Note the broad expanse of the exposed scar surface, the secondary flow deposits onlapping the main mudflow body, and evidence of older massmovement deposits deeper in the section. The location of the seismic profile of figure 6 is shown as a circled dot. Trackline locations are shown in figure $7 D$. (B) High-resolution 3.5-kilohertz frequency seismicreflection profile of the eastern part of the slope failure zone. Note the coherent blocks and secondary mass-movement deposits resting on the scar surface near the head scarp. Also note evidence of older mass movement deposits deeper in the section. Trackline locations are shown in figure $7 D$. 

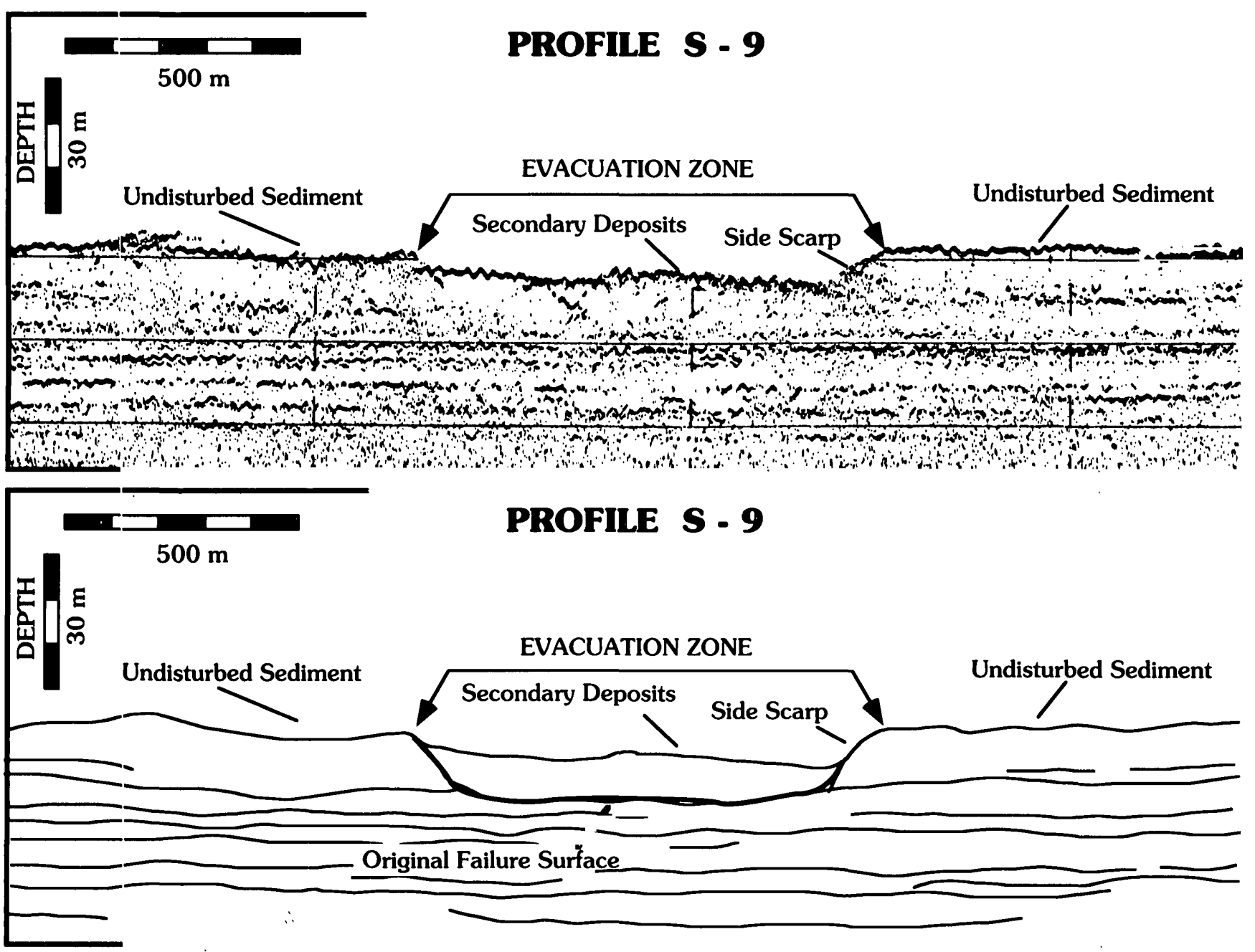

Figure 6. Slope-parallel high-resolution 3.5-kilohertz frequency seismic-reflection profile and interpretive line drawing across the evacuation zone. Note the infilling of the initial failure surface by secondary deposition.

undisturbed sea floor, and represents the deposit derived from the head scarp. The main body terminates as a bulging toe at a water depth of about $510 \mathrm{~m}$ where the regional. slope angle decreases from $4^{\circ}$ to less than $1^{\circ}$.

Slope failure occurred in several stages. Initially, muddy sediment failed along a 6- to 10-m-high scarp and disintegrated into a mudflow which transported material to the base of the slope (stage 1, fig. $7 A$ ). Next, retrogressive failure along the eastern part of the head scarp resulted in deposition both on the exposed, initial scar surface and on the initial mudflow deposit (stage 2, fig. $7 B$ ). Subsequent retrogressive failure resulted in emplacement of coherent blocks and additional mudflow deposits (stage 3, fig. 7C). This entire sequence of slope failures may have occurred rapidly or the individual stages of failure may have been separated in time by days, weeks, or years; we cannot resolve the time scale with our data.

\section{SEDIMENT CHARACTERISTICS}

A series of gravity cores was collected from sites within and near the slope failure in order to characterize the near-surface sediment and to analyze the cause of the slope failure (fig. 4). From our analyses of the cores, sediment physical properties vary with increasing distance from shore. For example, sediment mean grain size, which is relatively constant downcore except in the cores from the scar, decreases from about 12 microns to less than 8 microns with increasing distance from shore. Sediment water content correlates with mean grain size and increases offshore as the sediment becomes finer grained. There are no visual differences between the cores within and outside the mudflow, but geotechnical (engineering) measurements indicate that distinct differences do exist. For example, cores recovered from the scar have unusually high strength 

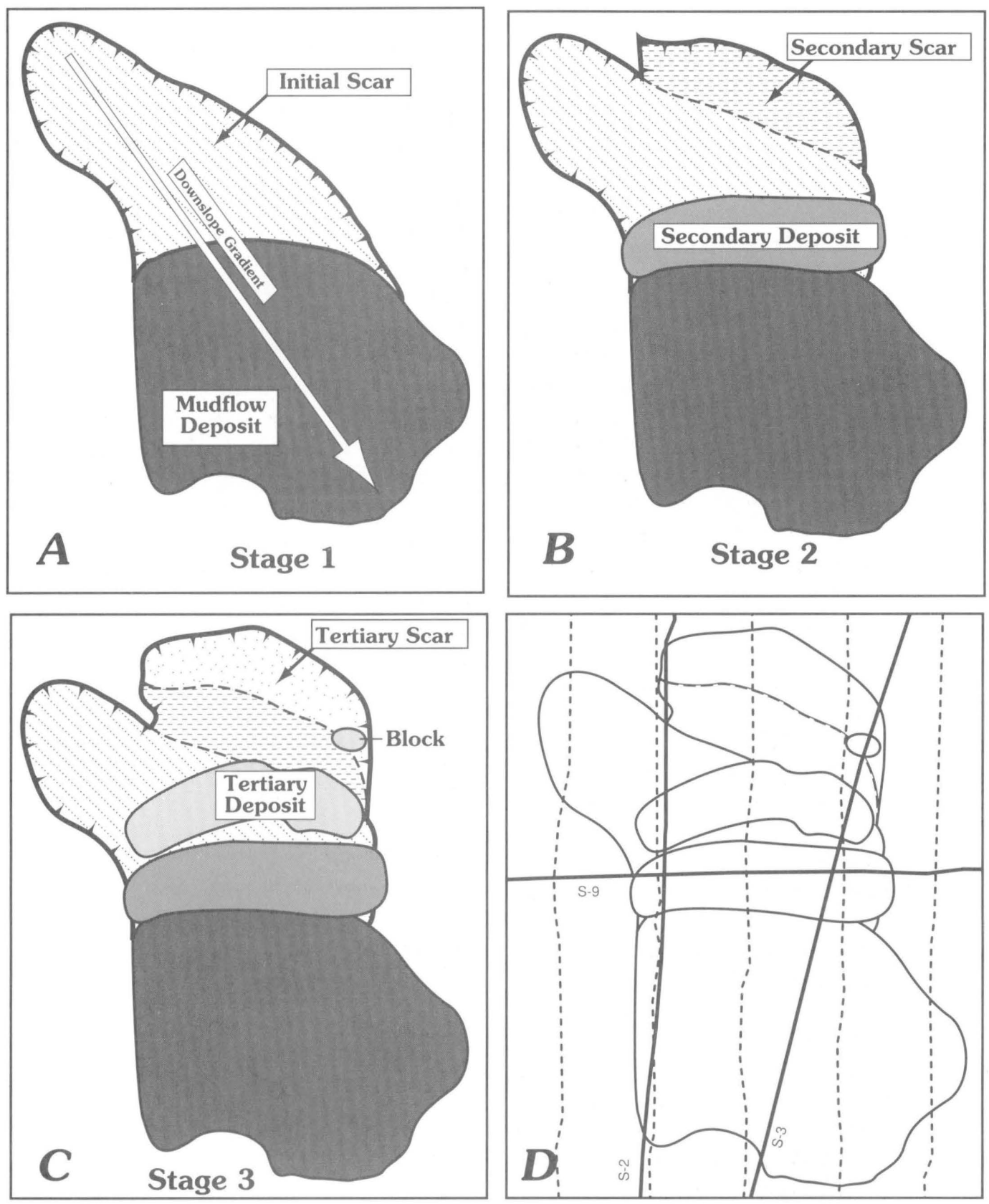

Figure 7. Interpretive model showing developmental stages of the slope failure zone $(A-C)$. $D$ shows trackline coverage (bold lines show the locations of the seismic-reflection profiles presented in figs. 3,5 , and 6).

below about $0.50 \mathrm{~m}$, the same level at which the core becomes significantly finer grained. These variations document the location of the failure surface and the amount of sedimentation that has occurred since the slope failure.

Reported sedimentation rates for this area range from $0.8 \mathrm{~m} / 1,000$ yrs (Marks and others, 1980) to $1.4 \mathrm{~m} / 1,000$ yrs (Duncan and others, 1971). Duncan and others (1971) recovered only $0.15 \mathrm{~m}$ of postfailure sediment atop the scar and report that slope failure occurred about 100 years ago. Applying these rates to the $0.50 \mathrm{~m}$ of sediment we recovered overlying the scar indicates that failure occurred between 350 and 625 years ago. Thus, slope failure likely occurred between 100 and 625 years ago and may be younger if a significant part of the sediment overlying the scar is associated with retrogressive failure deposits and not uniform accumulation of sediment. 


\section{GEOTECHNICAL ANALYSIS}

Slope failure occurs when the driving stresses exceed the capacity of the sediment to resist the stress (Lee, Schwab, and Booth, this report). Three agents commonly produce the downslope driving stress that can trigger slope failure: gravity, ocean waves, and earthquakes. Gravity acts continuously and has a downslope component that increases with the steepness of the slope. Waves produce cyclically varying shear stresses. As a result of the oscillatory loads, internal pore-water pressure is developed which reduces sediment resistive strength. The magnitude of such waveinduced stresses varies with wave length, wave height, water depth, sediment properties, and location in the affected sediment column. Earthquakes also generate cyclically varying stresses within the sediment. These stresses vary with e:arthquake magnitude, distance from the zone of rupture (earthquake epicenter), slope geometry, position within the sediment column, total thickness of the sediment body, and the properties of the affected sediment and rock mass.

The capacity of the sediment to resist driving stresses (that is, the sediment strength) is a complicated quantity that typically varies with depth in the sediment column, sediment grain characteristics (for example, mineralogy, grain size, and plasticity), sediment history, intensity and rate of loading, type of loading (cyclic or static), duration of loading, and the overall configuration of the slope and its stratigraphy (Lee, 1985; Lee and Edwards, 1986; Kayen and Lee, this report; Lee, Schwab, and Booth, this report; Schwab and Lee, this report). For example, the strength developed in sediment to resist earthquake shaking is a function of the sediment static and cyclic stress history and sediment physical characteristics. As a consequence of earthquake loading, shear stresses acting on a slope are typically increased while the resistive strength of the sediment is reduced due to the generation of excess pore pressures (l-ee, Schwab, and Booth, this report).

We performed a geotechnical engineering analysis on selected cores to evaluate each of the driving stresses mentioned above and to determine how the slope failure was initiated. Additional analyses were performed to determine how the slope failure developed into a mudflow and to evaluate why retrogressive failure occurred. Analysis showed that the slope is stable under conditions of static gravitational loading and that storm waves generate negligible stresses at these water depths. The analysis showed, however, that a strong earthquake can easily generate stresses great enough to fail the slope.

We used the procedures of Lee and Edwards (1986) to reconstruct and estimate, theoretically, the strength properties of the sediment that likely existed above the present scar prior to failure. These procedures assume that deposition.in the area has been fairly steady and uniform and that sediment at depth is comparable (except for shear strength and consolidation properties) to the sediment that was removed during the slope failure. We compared the strength of this theoretically reconstructed sediment with driving stresses (Seed and Idriss, 1971; Joyner and Boore, 1981) that would likely be produced by a magnitude 7.5 earthquake occurring $25 \mathrm{~km}$ away (probably comparable to the 1812 event). Slope failure can occur when the driving stresses exceed the sediment resistive strength, that is when the ratio of sediment strength to driving stress is less than 1 . In the study area, this condition was met for a subbottom depth range of about $5 \mathrm{~m}$ to greater than $20 \mathrm{~m}$ with the lowest value (about 0.75 ) occurring at a subbottom depth of $10 \mathrm{~m}$ (fig. 8). Based on the degree of compaction of sediment in the present scar, we believe that slope failure occurred to a depth of about $8 \mathrm{~m}$ in the sediment column.

Thus, earthquake loading is the only one of the three primary agents capable of producing downslope driving stresses large enough to trigger the slope failure. This slope failure almost certainly was caused by seismic shaking and the depth of failure was constrained by the physical properties of the local sediment column. Sediment from other locations near the site of the slope failure also shows ratios of sediment strength to driving stress that are less than 1 , but none are as low as that for the sediment that existed above the present scar (fig. 8). Our conclusion is that much of this basin slope is marginally stable to unstable during strong earthquake motion. The occurrence of the slope failure at this exact site was likely controlled by local ground motion and sediment behavior effects not considered in this analysis.

To determine why the failed sediment mobilized into a mudflow, we estimated the sediment strength that would remain after the initial failure caused by seismic loading (see Schwab and Lee, this report). We found that this residual or "steady-state" strength (Poulos and others, 1985) was less than the gravitational shear stress on the $4^{\circ}$ basin slope but greater than the gravitational shear stress available near the edge of the basin floor (about a $1^{\circ}$ slope). Accordingly, following the earthquake, the weakened sediment was able to flow down the $4^{\circ}$ slope under the influence of gravity alone. The mudflow left behind a steep scarp at the head of the evacuation zone and stopped at the base of the slope because gravitational stresses on the basin floor were not great enough to cause further movement.

Why was the failure retrogressive? Either additional seismic shaking or high static stress concentrations within the head scarp after the earthquake led to further slope failure and movement of sediment away from the scarp. Failure propagated upslope until the static sediment strength was great enough to prevent further disintegration of the head scarp. The head scarp that exists today likely has a low resistance against static gravitational failure and probably will fail again during strong earthquakes in the future. 


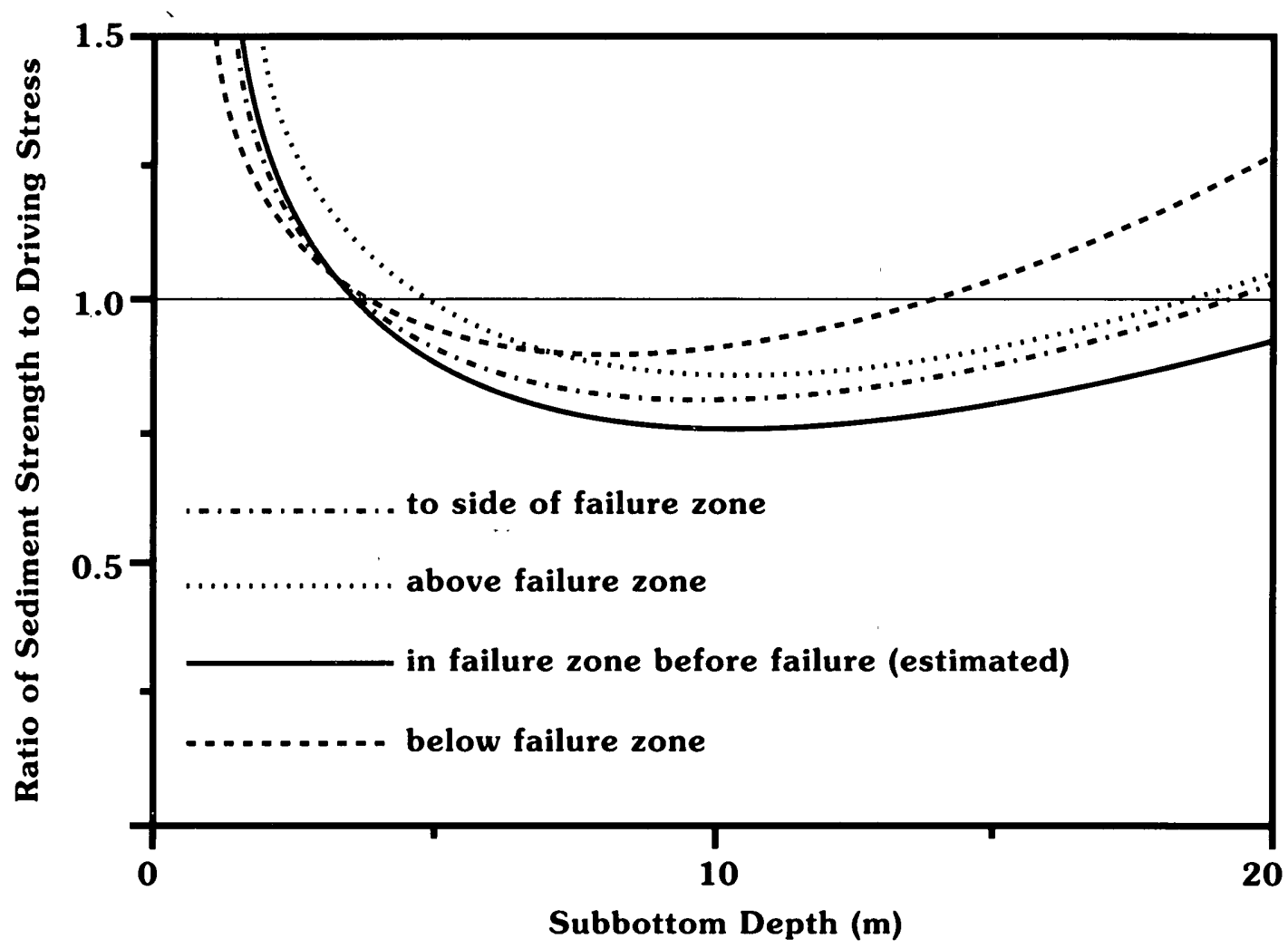

Figure 8. Plot of the ratio of sediment strength to driving stress versus subbottom depth for selected sediment sites in and near the failure zone. Sediment strength is the estimated cyclic shear strength; driving stress is the estimated average peak downslope shear stress developed during a magnitude 7.5 earthquake located 25 kilometers from the slope failure. Slope failure is likely when this ratio has a value that is less than 1 . Also shown is the estimated ratio for a theoretically reconstructed, intact sediment profile located at the site of the scar at a time prior to slope failure. Note that this presumed condition (bold line) has the lowest ratio of all the surrounding cores and documents why failure occurred at that site.

\section{SUMMARY}

The slope failure likely occurred in response to shaking from a large magnitude (Richter magnitude of about 7.5) earthquake occurring within Santa Barbara Basin within the last 1,000 years and possibly within the last few hundred years. A mudflow developed in the western part of the study area involving approximately 0.01 to $0.02 \mathrm{~km}^{3}$ of slope sediment. Because the residual strength of the sediment mass was low relative to downslope gravitational stress, slope failure developed into a mudflow leaving a steep 6- to 10-m-high scarp at the head of the evacuated area. Either continued earthquake shaking or high residual static shear stresses within the head wall caused subsequent slope failure and upslope erosion of the headwall scarp with deposition of secondary mudflow deposits on the exposed scar region.

\section{REFERENCES CITED}

Coleman, J.M., and Garrison, L.E., 1977, Geological aspects of marine slope stability, northwestern Gulf of Mexico: Marine Geotechnology, v. 2, p. 9-41.
Crowell, J.C., 1974, Origin of late Cenozoic basins in southern California, in Dickinson, W.R., ed., Tectonics and Sedimentation: Society of Economic Paleontologists and Mineralogists Special Publication 22, p. 190-204.

Duncan, J.R., Hoover, R.A., Pflum, C.E., Widmier, J.M., and Daetwyler, C.C., 1971, Near surface geology of Santa Ynez Unit, Santa Barbara Channel, California: Esso Production Research Company, EPR.49ES.71, 40 p.

Greensfelder, R.W., 1974, Maximum credible rock acceleration from earthquakes in California: California Division of Mines and Geology Map Sheet 23, scale 1:2,500,000, 12 p.

Howell, D.G., ed., 1976, Aspects of the Geologic History of the California Continental Borderland: American Association of Petroleum Geologists Miscellaneous Publication 24, 561 p.

Joyner, W.B., and Boore, D.M., 1981, Peak horizontal acceleration and velocity from strong-motion records including records from the 1979 Imperial Valley, California, earthquake: Bulletin of the Seismological Society of America, v. 71, p. 2011-2038.

Lee, H.J., 1985, State of the art: Laboratory determination of the strength of marine soils, in Chaney, R.C., and Demars, K.R., eds., Strength testing of marine sediment: laboratory and in situ measurements, ASTM STP883: American Society for Testing and Materials, Philadelphia, Pa., p. 181-250. 
Lee, H.J., and Edwards, B.D., 1986, Regional method to assess offshore slope stability: Journal of Geotechnical Engineering, American Society of Civil Engineers, v. 112, p. 489-509.

Malouta, D.N., Gorsline, D.S., and Thornton, S.E., 1981, Processes and rates of Recent (Holocene) basin filling in an active transform margin: Santa Monica Basin, California Continental Borderland: Journal of Sedimentary Petrology, v. 51, p. 1077-1096.

Marks, J.G., Marianos, A.W., Gonzaga, F.R., and Pflum, C.E., 1980, Foraminiferal correlation of Quaternary sediments in the Santa Barbara Channel, California: Cushman Foundation Special Publication No. 19, Memorial to Orville L. Bandy, p. 127-133.

Poulos, S.I., Castro, Gonzalo, and France, J.W., 1985, Liquefaction evaluation procedure: Journal of Geotechnical Engineering, American Society of Civil Engineers, v. 111, p. 722-791.

Prior, D.B., Bornhold, B.D., and Johns, M.W., 1984, Depositional characteristics of a submarine debris flow: Journal of Geology, v. 92, p. 707-727.

Roberts, H.H., 1980, Sediment characteristics of Mississippi River delta-front mudflow deposits: Gulf Coast Association of Geological Societies Transactions, v. 30, p. 485-496.

Seed, H.B., and Idriss, I.M., 1971, Simplified procedure for evaluating soil liquefaction potential: Journal of Soil Mechan- ics and Foundation Engineering Division, American Society of Civil Engineers, v. 97, p. 1249-1273.

Thornton, S.E., 1984, Basin model for hemipelagic sedimentation in a tectonically active continental margin: Santa Barbara Basin, California Continental Borderland, in Stow, D.A.V., and Piper, D.J.W., eds., Fine-Grained Sediments: Deep Water Processes and Facies, Blackwell Scientific Publications, Oxford, p. 377-394.

1986, Origin of mass flow sedimentary structures in hemipelagic basin deposits: Santa Barbara Basin, California borderland: Geo-Marine Letters, v. 6, p. 15-19.

Vedder, J.G., Wagner, H.C., and Schoellhamer, J.E., 1969, Geologic framework of the Santa Barbara Channel Region, in Geology, Petroleum Development, and Seismicity of the Santa Barbara Channel Region, California: U.S. Geological Survey Professional Paper 679, p. 1-11.

Yerkes, R.F., 1985, Geologic and seismologic setting, in Ziony, J.I., ed., Evaluating earthquake hazards in the Los Angeles Region-An earth-science perspective: U.S. Geological Survey Professional Paper 1360, p. 25-41.

Yerkes, R.F., Greene, H.G., Tinsley, J.C., and Lajoie, D.R., 1981, Seismotectonic setting of the Santa Barbara Channel Area, southern California: U.S. Geological Survey Miscellaneous Field Studies Map MF-1169, 1 sheet, 25 p. 


\title{
Submarine Landslides in a Basin and Ridge Setting, Southern California
}

\author{
By M.E. Field and B.D. Edwards
}

\section{INTRODUCTION}

One of the hallmarks of the California continental borderland is the extraordinary topographic and geologic complexity of this type of continental margin. Unlike the continental shelf-slope-rise sequence that characterizes most continental margins of the world, the continental borderland of southern California is a repeating pattern of extremes. The relatively narrow mainland shelf (average width of 8 kilometers $(\mathrm{km})$ ) gives way to steep slopes that lead, in turn, to flat-floored basins and troughs; nearshore basins are bounded on the west by slopes that rise to island platforms, bank tops, and ridge crests. This pattern continues for over $200 \mathrm{~km}$ to the west (fig. 1). Between Point Conception and the latitude of the U.S.-Mexican border, there are 11 major basins; numerous smaller basins and sediment ponds are present throughout the area (Emery, 1960).

A simplified contour map of the southern California borderland (fig. 1) shows the distinctive general pattern of a predominantly sloping terrane containing isolated shelves, banks and basins. Emery (1960) estimated that 63 percent of the borderland area is composed of slopes and deep irregular areas, 20 percent is shelves and bank tops, and 17 percent is basins and trough floors. Neither these data nor the generalized map of figure 1 , however, can fully convey the regional extremes and local complexities in slope geometry that characterize the borderland.

The borderland was formed by tectonic forces active throughout the past 30 million years, and its morphology reflects this influence. Many present-day slopes are controlled by the dip of large-scale flexures of sedimentary strata, some are shaped by variations in resistance of interbedded sedimentary and volcanic rocks, and others are formed by large faults that have offset the sea floor. For example, seismic-reflection profiles from the east slope of the Santa Rosa-Cortes Ridge (fig. 2) illustrate that the dip of folded subsurface strata defines the dip of that slope. Additionally, minor flexures and faults create local changes in slope morphology.

Although the overall configuration of borderland slopes is controlled by these large-scale geologic structures, secondary modifications to slope geometry result from sedimentary processes. These processes include erosioninduced formation of canyons and scarps, removal and deposition of sediment by slope failure and mass movement, and local sediment buildup from surface and deep currents.

\section{SIZES OF LANDSLIDES ON BORDERLAND SLOPES}

Numerous geologic studies conducted in the borderland show that landslide deposits vary widely in size from a few meters to tens of kilometers on a side. Because of this large variation in size, the ability to identify and describe accurately the morphology of a particular landslide deposit depends on the technique of observation. The tools employed in our studies include (1) high-resolution seismicreflection systems; (2) sediment cores; (3) bottom cameras; (4) near-bottom towed geophysical systems; and (5) observations from a manned submersible. Each tool has a unique resolution capability and, hence, is limited in the size of feature that it can identify. Our observations on different scales of mass movement reflect this constraint.

\section{Large-Scale Landslides}

Large-scale landslides measuring hundreds of meters to kilometers along a side are commonly recognized on borderland slopes, and they appear to be more common than smaller ones. This apparent greater abundance of large slope failures may be due to the large number of seismicreflection profiles available, the limited resolution of seismic-reflection systems operated from the sea surface, and the limited number of camera and submersible observations that would be more suitable for identifying small failures. Of these large landslides, most do not exceed 5 $\mathrm{km}$, and few exceed $10 \mathrm{~km}$, on a side. They are commonly found at a significant break in slope gradient or at the base of slopes (fig. 2). In contrast, those landslide deposits found resting on the mid-slope are generally less than $5 \mathrm{~km}$ on a side. Many of the larger landslides $(>5 \mathrm{~km})$ have a chaotic, hummocky appearance, and in many places show evidence of a complex failure history (figs. 2 and 3 ).

\section{Small-Scale Landslides}

Smaller-scale landslides, those measuring meters to hundreds of meters on a side, are also common on slopes of the borderland. In ancient slope sequences that are now subaerially exposed, small slope failures measuring a few meters to a few tens of meters are common and are more easily delineated in outcrop than are large-scale failures. For example, studies by Cook (1979) identified numerous small-scale deposits of slides and mass flows in slope rocks 


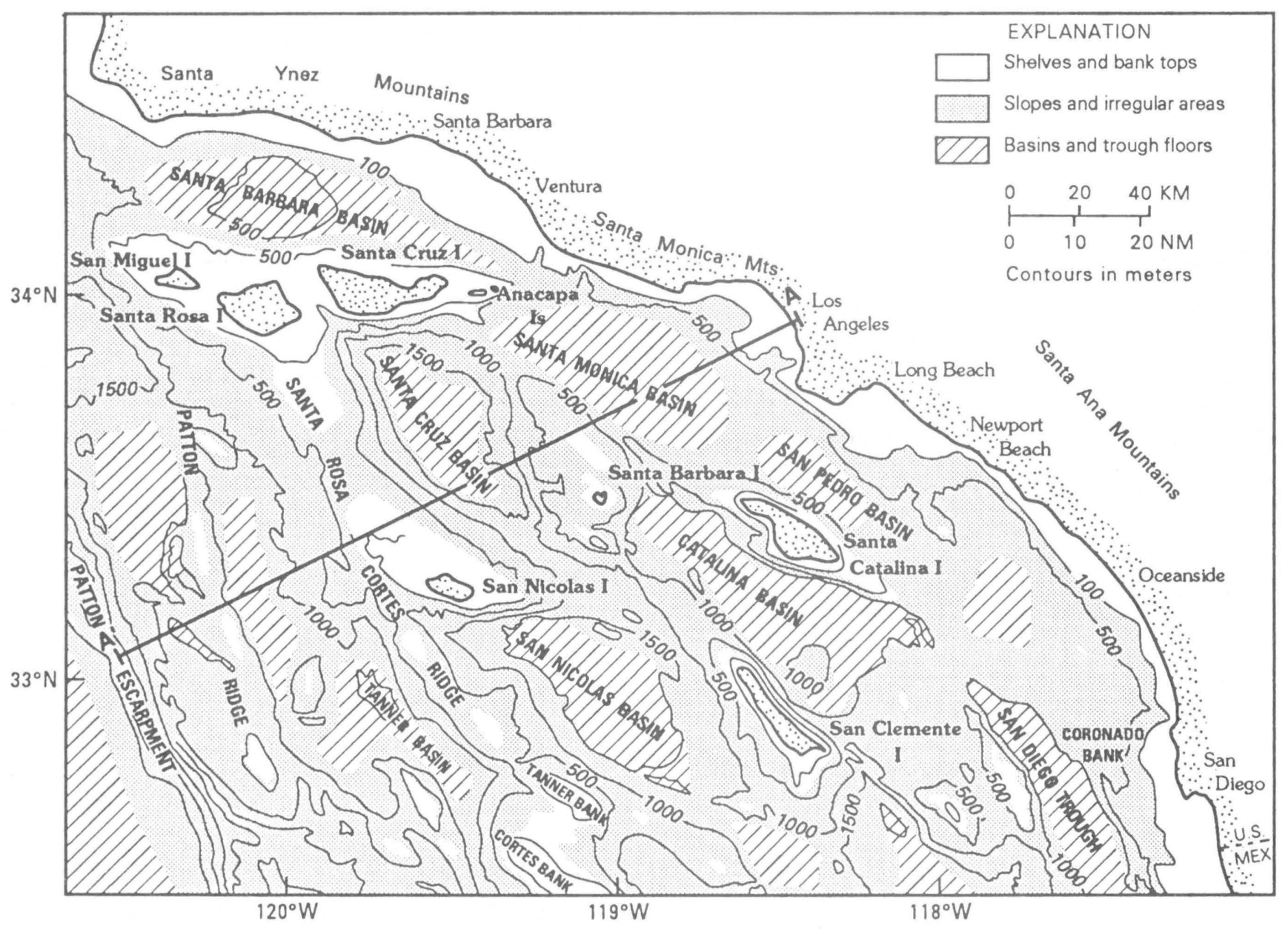

$A^{\prime}$

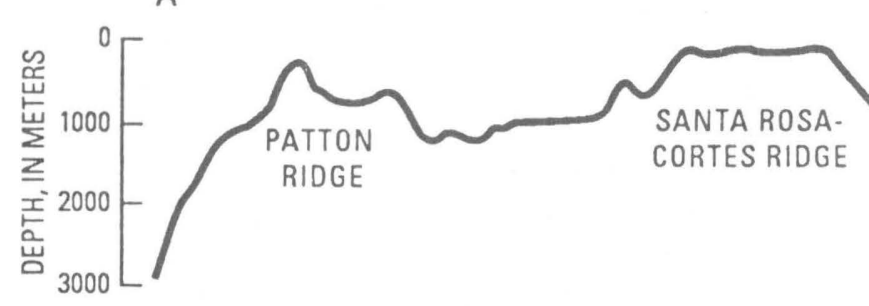

Figure 1. Generalized bathymetric map of the offshore region of southern California, known as the California continental borderland. Depths are shown at 500-meter increments; along the mainland coast the 100-meter contour is also shown. The three patterns divide the offshore region into three types of terrain: (1) shelves and bank tops, which are relatively shallow and flat; (2) slopes and irregular areas that are generally steep and lead from

shelves to deeper water; and (3) basins and trough floors, which are the deepest areas but relatively flat. Note the abundance of steep slope areas throughout the borderland. The cross section $A-A^{\prime}$ shows the irregular nature of sea-floor topography off southern California and the repeating nature of the shelf-slope-basin sequence across the entire borderland.

of Cambrian age (570 to 500 million years old). On most modern continental slopes and deep-sea basins, however, slides and mass flows of this scale have received scant attention relative to the larger slope failures because they are too small to delineate with conventional, surface-

operated acoustic systems. Instruments capable of resolving landslides of this scale do exist, however. Field and Clarke (1979) were able to identify the presence of small-scale landslide features on the slope off San Nicolas Island by using a deep-towed geophysical package containing up-, 


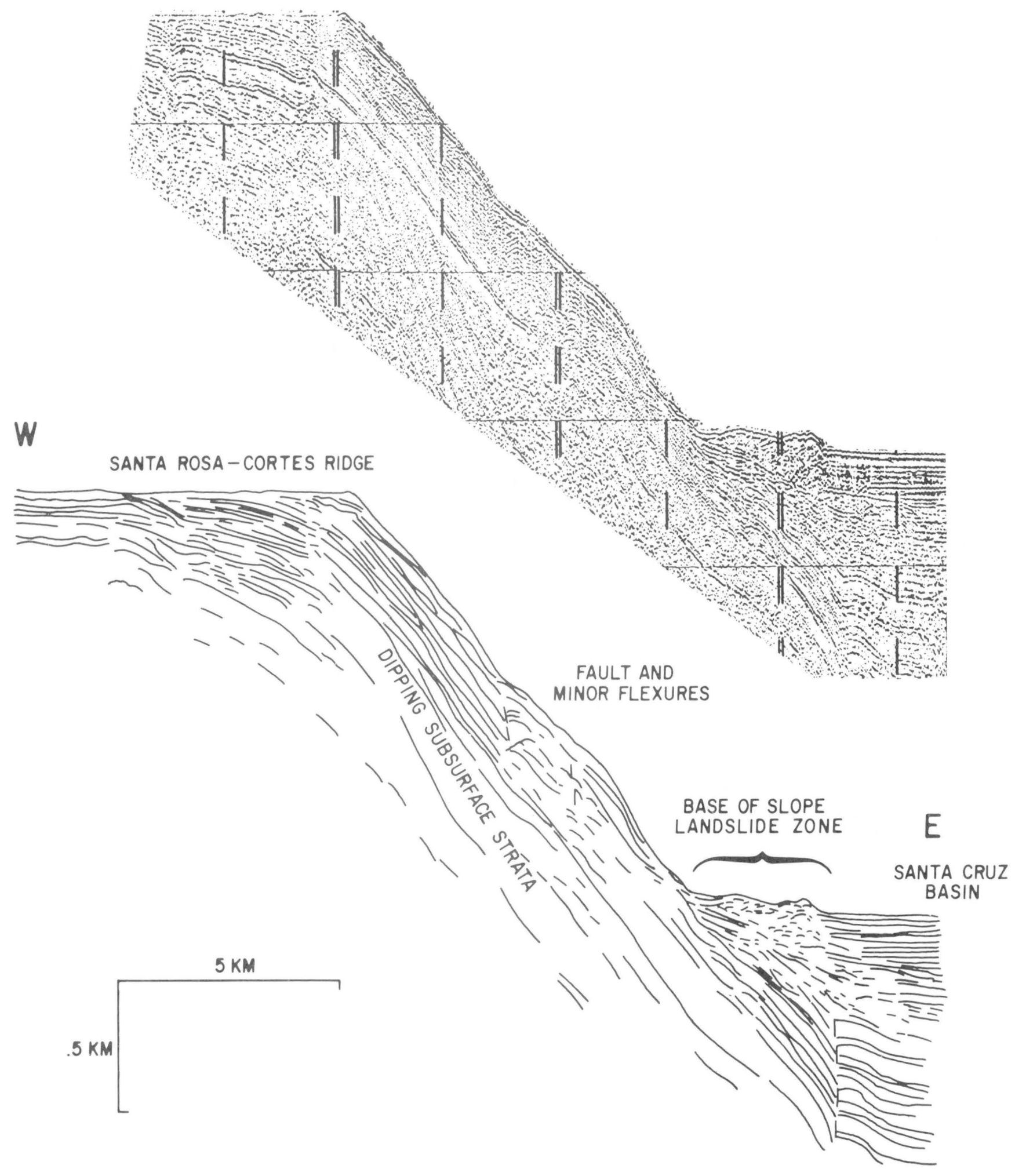

Figure 2. Geophysical profile ("sparker" record) and a line-drawing interpretation of a large landslide zone in western Santa Cruz Basin at the base of the slope of the Santa Rosa-Cortes Ridge. Mapped in the mid-1970's (Nardin and others, 1979; Field and Richmond, 1980), this is one of the largest landslides known off southern California and probably resulted from a series of slope failures rather than a single event. The slope is relatively steep compared to other continental-margin or borderland slopes and locally exceeds $10^{\circ}$, a factor which may have contributed to slope-sediment failure. The flat, eroded surface of the ridge top results from migration of the coastline back and forth across the ridge top during glacial epochs (as sea level falls and rises); this produces an abundance of loose sediment at the ridge edge, perhaps another contributing factor to the slope failures. The vertical bar scale is based on the speed of sound in water. 


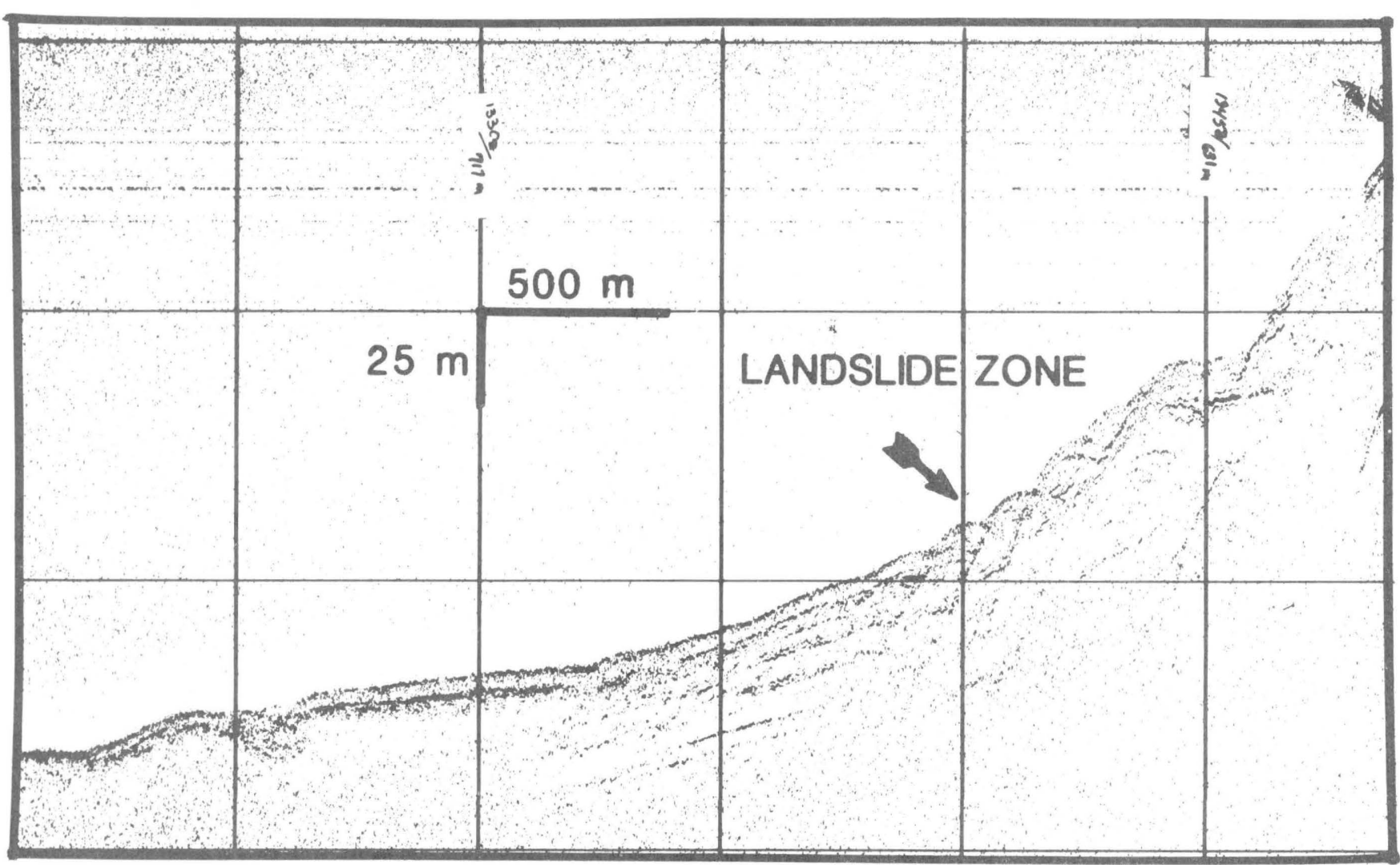

Figure 3. A high-resolution seismic-reflection profile ("uniboom") showing a typical large-scale sediment landslide lying on the mainland slope (Edwards and others, 1980).

down-, forward-, and side-looking sonars, bottom cameras, and a 4-kilohertz $(\mathrm{kHz})$ frequency seismic-reflection system. Within a small $\left(\sim 150 \mathrm{~km}^{2}\right)$ intercanyon slope region, they identified six landslides that vary in size, geometry, age, and probable mechanism of failure. One of the landslides is shown by the seismic-reflection profile and interpreted line drawing in figure 4 . This slump deposit is less than 400 meters (m) long and about 15 to $20 \mathrm{~m}$ thick. The lateral extension is unknown, for although a scarp can be traced more than $150 \mathrm{~m}$ laterally from the line of the profile, it appears to be discontinuous. Because of its small size, the slump was not evident on the shipboard seismicreflection profiler and would not have been recorded by most surface-towed instruments.

Even though many small-scale landslides have been located in modern environments, the identification of their character and origin is difficult because of the resolving power of most surface-towed acoustic systems. The smaller landslides of the borderland tend to be simple in shape compared to large-scale landslides, which may be a reflection of the inability of marine techniques to resolve the fine details of the sea floor. The small landslides commonly are characterized by a smooth upper surface and either an acoustically transparent interior or rotated internal reflec- tors. The chaotic internal fabric and hummocky or chaotic upper surfaces that are common to larger landslide deposits are rare. Bottom photography has been an aid in identification of small landslide deposits, but often the field of view is too limited to allow coverage of the entire deposit. Photographs from Field and Clarke (1979) show some of the characteristics of sediment in a small landslide zore. Clasts are as large as $1 \mathrm{~m}$ and some of them show evidence (sag fractures and rounded noses) of downslope transport. Photographs in figure 5 show a comparison of the smooth and burrowed nature of the sea floor in an undisturbed area (fig. $5 A$ ) with the eroded and slablike character of the sea floor in a recent landslide area (fig. $5 B$ ).

Small-scale landslides on slopes of the California borderland are recognized but poorly understood. They have been found only in those regions where detailed work has been conducted and then only through careful study using special instruments. Direct observations from manned submersibles, such as Sea Cliff, in addition to bottom photography and deeply towed instrument packages, are typically the only means of identification of small landslides simply because the scales of high-resolution geophysics and wide-swath sidescan sonar are not ideally suited for their size. 

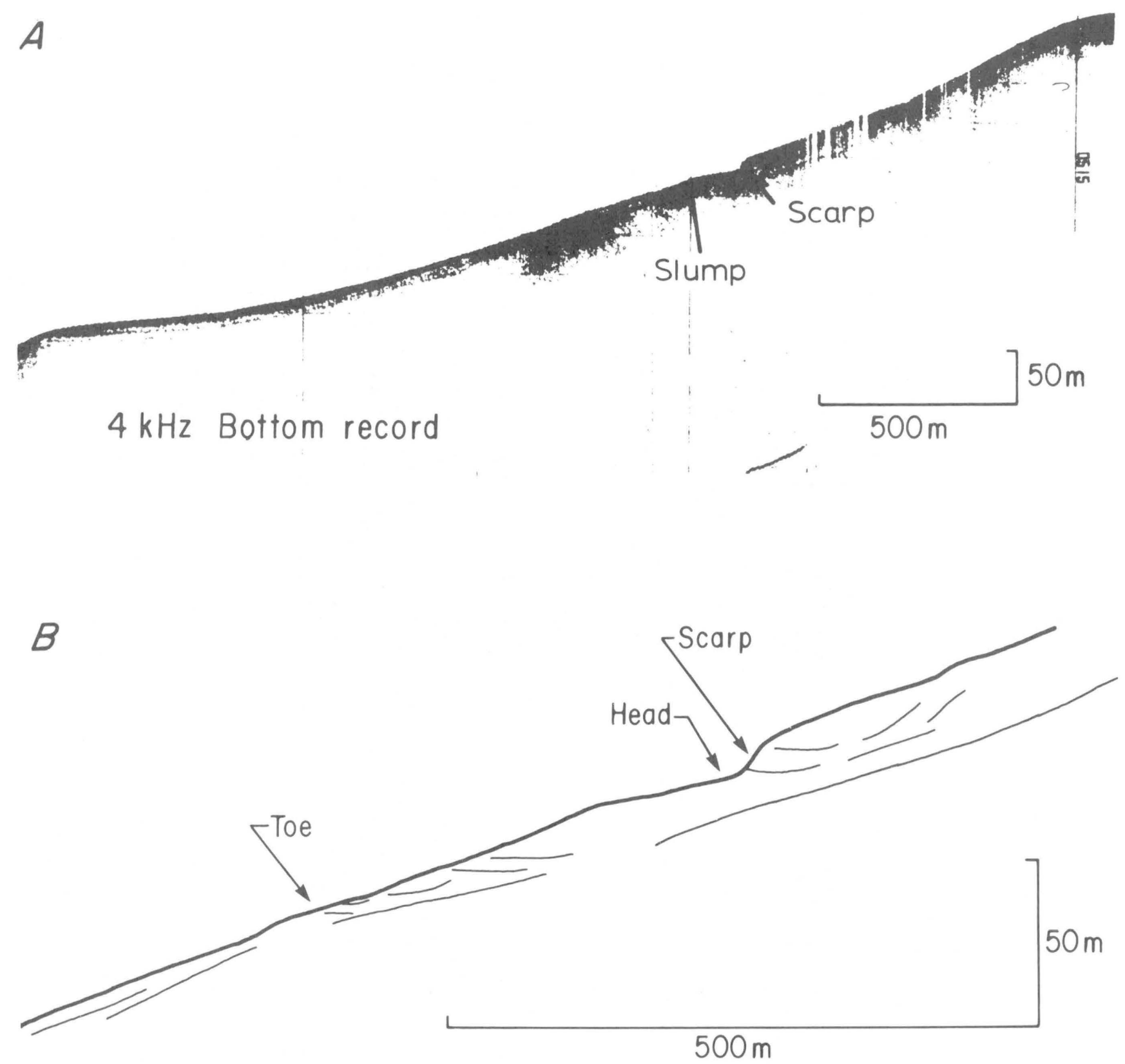

Figure 4. Seismic-reflection profile (4-kilohertz frequency) obtained with a bottom-towed system and line-drawing interpretation of a small-scale landslide. This feature, which lies on the slope east of San Nicolas Island (figs. 1 and 6) could not be identified using most surface-towed acoustic systems (from Field and Clarke, 1979).

\section{Very Small-Scale Landslides}

Some deposits derived from sediment landslides, and more commonly from sediment mass flows, have little lateral extent and can be identified and measured only in terms of their thickness. The deposits are centimeters to meters thick and frequently are observed only in individual cores. Edwards (1979) and Nardin and others (1979) presented examples of thin zones of deformation observable on radiographs of box and piston cores collected from the west slope of Santa Cruz Basin. These types of deposits are commonly characterized by an abrupt or erosional lower contact, rotated or chaotic internal beds, and occasional rip-up clasts.

Basinward transport of sediment by mass flows also produces anomalies in sediment particle sizes, mineral content, and animal trails in surface or near-surface sediment. The anomalies may or may not be associated with slope failures that can be defined acoustically. Photographs of the sea floor near an acoustically recognized landslide area off San Nicolas Island revealed that the activity of benthic fauna was markedly different inside and outside of 


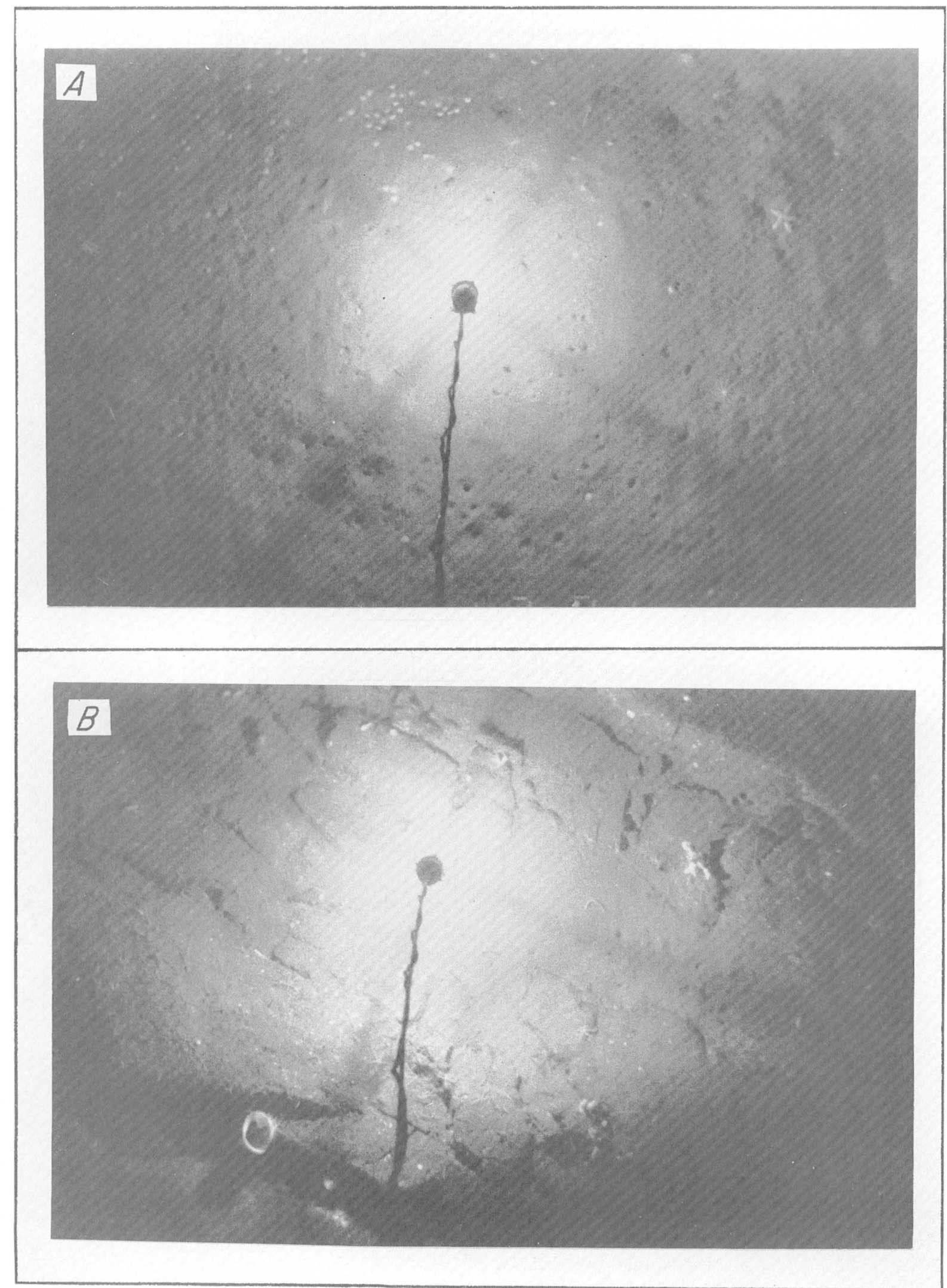

Figure 5. (A) Sea floor east of San Nicolas Island at a water depth of about 800 meters. The photograph is typical of these depths and shows soft, fine-grained sediment shaped by animals into burrows, trails, and mounds; the white spots are sea-urchin shells.

There is no sign of disturbance by slope failure. $(B)$ Sea floor east of San Nicolas Island in the vicinity of the photograph in $5 A$ above. The sea floor here shows the effects of slope failure; the surface is blocky and cracked, and no burrows are evident. 


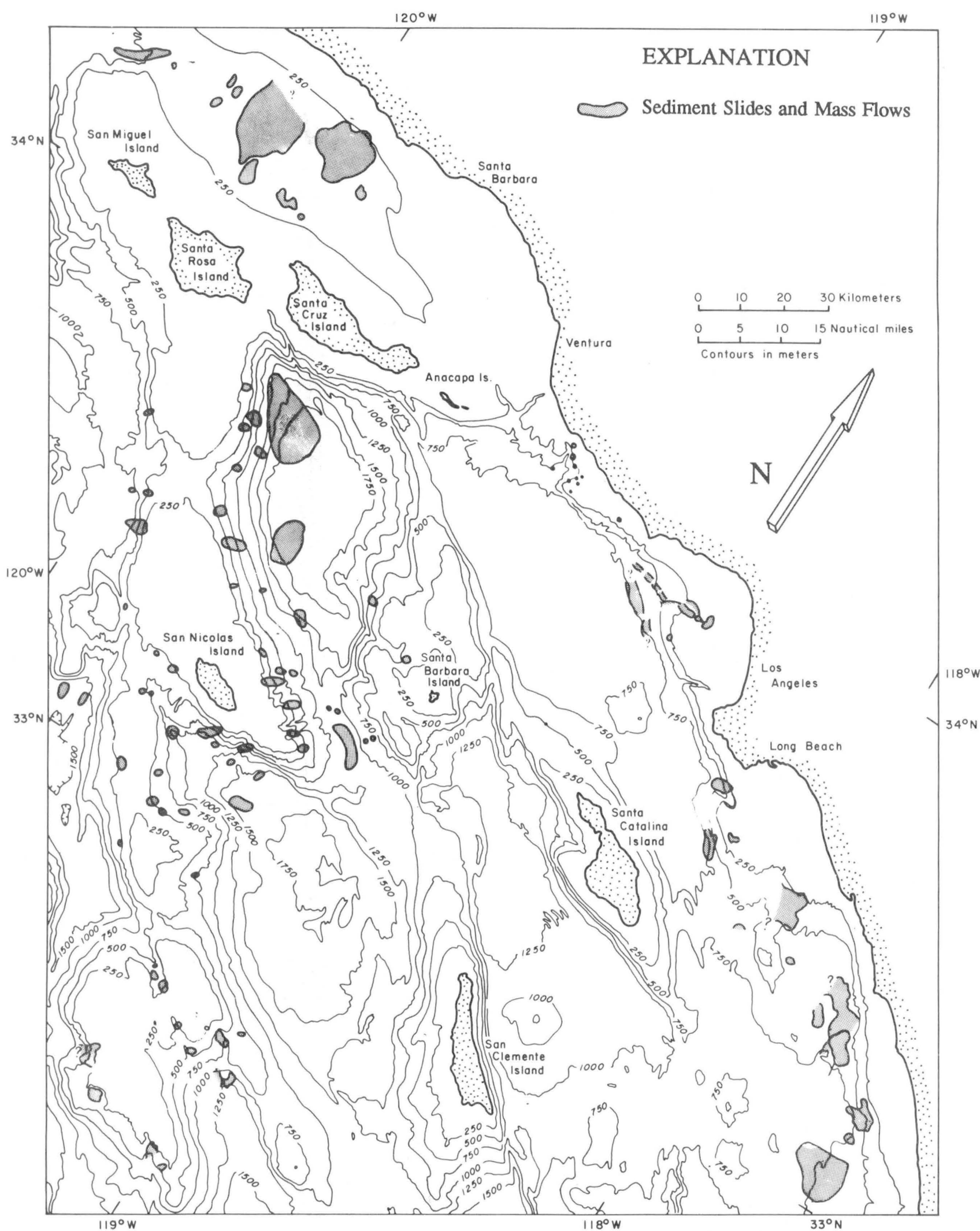

Figure 6. Southern California borderland showing the location of sediment slides and mass flows (modified from Field and Edwards, 1980). Sediment landslides are common on the slopes of the borderland, and they occur at various scales. Slides and mass flows on the offshore slope from south of San Nicolas Island to Santa Rosa Island and on the mainland slope from San Diego and west of Santa Barbara are relatively abundant, and this may simply reflect the large effort invested in identifying slope failures in those two areas. With only two exceptions, the slope-sediment failures in the mainland slope are larger than those on the offshore slope. Most failures mapped on borderland slopes are seen only in a single crossing; some of the larger ones were identified on multiple crossings. Our understanding of the distribution and the sizes of mass-transport deposits seems to depend largely on the density and kinds of available geophysical data. Landslides shown on the map are from Greene and others (1975), Haner and Gorsline (1978), Nardin and others (1979), Field and Edwards (1980), and Richmond and others (1981). 
the landslide zone (fig. 5). Within the landslide zone, tracks and trails of surface grazing organisms (holothurians and echinoids) predominated, whereas out of the landslide zone the bottom was heavily burrowed and traces of surface feeding organisms were not common. Presumably this difference resulted from the repopulation of the recently disturbed landslide zone by mobile fauna which ingest surface sediment, whereas the undisturbed regions were heavily populated by infaunal deposit feeders.

\section{DISTRIBUTION OF LANDSLIDES ON BORDERLAND SLOPES}

Detailed studies of 'selected areas by a host of investigators have contributed measurably to our knowledge of slope-sediment failures on slopes of the southern California borderland. By collating information from our studies and those of our colleagues onto a map of the borderland, we can examine the distribution of sediment landslides throughout the entire region. The map is not complete, because many areas have not been explored or have been studied only in a reconnaissance mode; the map, however, is representative of the slopes of the mainland and the Santa Rosa-Cortes Ridge (fig. 1). The density of mapped landslides shown in figure 6 is strongly biased by the amount and kinds of data collected. For example, few slope failures are mapped on the slopes of the Catalina Ridge or off San Clemente Island, probably because of the paucity of data from those areas, not necessarily because of a scarcity of slope failures. In areas where high-resolution seismic-reflection data were collected specifically to identify the scale and geometry of slides and mass flows, many such failures are identified (for example, off San Nicolas Island and the central Santa Rosa-Cortes Ridge).

Because of the imbalance in areal data collection, it is not possible to infer causes of slope failure based on their apparent distribution. Nevertheless, several general trends and relations can be identified:

1. Slope failure has occurred on practically every type of slope, regardless of steepness, orientation, or smoothness.

2. Slope failures of all sizes have been mapped but most of those that have been identified measure on the order of a few hundreds to thousands of meters on a side.

3. Very large zones of slope failure, measuring tens of kilometers on a side, occur in selected localities and perhaps result from a series of slope failures rather than from a single event.

4. The presence of active submarine canyons does not inhibit slope failures. Indeed, some canyons derive part of their transport load from failures on the canyon walls or adjacent slopes.
5. The large number of slope failures along the mainland slope of the borderland correlates with relatively high sedimentation rates on this slope that result from fluvial transport from upland regions.

6. A source of sediment, either active or formerly active at a time of lower sea level, is usually evident for slopes having numerous failures.

7. Slopes having no apparent source of material except hemipelagic deposition have few large landslides, and most slides and mass flows are relatively thin.

\section{REFERENCES CITED}

Cook, H.E., 1979, Ancient continental slope sequences and their value in understanding modern slope development: Society of Economic Paleontologists and Mineralogists, Special Publication 27, p. 287-305.

Edwards, B.D., 1979, Animal-sediment relationships in dysaerobic bathyal environments, California continental borderland: Unpublished Ph.D. Dissertation, University of Southern California, Los Angeles, Calif., 291 p.

Edwards, B.D., Field, M.E., and Clukey, E.C., 1980, Geological and geotechnical analysis of a submarine slump, California borderlands: Proceedings, 12th Annual Offshore Technology Conference, Houston, Tex., v. 1, OTC 3726.

Emery, K.O., 1960, The sea off southern California, a modern habitat for oil: New York, N.Y., John Wiley and Sons, $366 \mathrm{p}$.

Field, M.E., and Clarke, S.H., Jr., 1979, Small-scale slumps and slides and their significance for basin slope processes, southern California Borderland: Society of Economic Paleontologists and Mineralogists, Special Publication 27, p. 223-230.

Field, M.E., and Edwards, B.D., 1980, Slopes of the southern California borderland: a regime of mass transport, in Field, M.E., Bouma, A.H., Colbourn, I.P., Douglas, R.G., and Ingle, J.C., eds., Pacific Section SEPM, Pacific Coast Paleogeography Symposium No. 4, Los Angeles, Calif., p. 169-184.

Field, M.E., and Richmond, W.A., 1980, Sedimentary and structural patterns on the northern Santa Rosa-Cortes Ridge, southern California: Marine Geology, v. 34, p. 79-98.

Greene, H.G., Clarke, S.H., Jr., Field. M.E., Linker, F.I., and Wagner, H.C., 1975, Preliminary report on the environmental geology of selected areas of the southern California continental borderland: U.S. Geological Survey Open-File Report 75-596, 69 p.

Haner, B.E., and Gorsline, D.S., 1978, Processes and morphology of continental slope between Santa Monica and Dume submarine canyons, southern California: Marine Geology, v. 28 ,

p. $77-87$.

Nardin, T.R., Edwards, B.D., and Gorsline, D.Scott, 1979, Santa , Cruz basin, California borderland: dominance of slope processes in basin sedimentation: Society of Economic Paleontologists and Mineralogists, Special Publication 27, p. 209-221.

Richmond, W.C., Cummings, L.J., Hamlin, S., and Nagaty, M.E., 1981, Geologic hazards and constraints in the area of proposed OCS oil and gas lease sale 48, southern California: U.S. Geological Survey Open-File Report 81-307, 37 p. 


\title{
Giant Volcano-Related Landslides and the Development of the Hawaiian Islands
}

\author{
By W.R. Normark, J.G. Moore, and M.E. Torresan
}

\section{INTRODUCTION}

Using the sidescan-sonar system GLORIA (Geological LOng-Range Inclined Asdic), recent investigations of the U.S. Exclusive Economic Zone (EEZ) that surrounds Hawaii have defined 37 major landslides (figs. 1 and 2; table 1). The astonishingly large size of the area covered by such massive submarine masș-movement deposits was not anticipated before these GLORIA surveys. This section reviews the characteristic features of some of these landslides and attempts to relate them to the processes that built, and modified, the volcanic systems of the Hawaiian Ridge.

The role of major landsliding in shaping Hawaiian volcanoes has long been a subject of debate. The subaerial parts of the volcanoes are fairly well known, but the submarine parts, which constitute the great bulk of these volcanoes, are poorly understood because only limited submarine mapping existed until recently. An early controversy concerned the relative importance of faulting versus marine erosion in producing high cliffs along the coasts of some of the islands. The high cliffs of northeast Oahu (Nuuanu Pali), east Niihau, the Na Pali coast of Kauai, and northern Molokai were interpreted by Dana (1890) as resulting from "profound fracturing of the mountain dome" and "downdrop" of the seaward part beneath the sea. Dana's faulting model was rejected by Hitchcock (1900), who believed that erosion alone was sufficient to form the cliffs without the additional complexity of faulting. Wentworth (1927), comparing estimates of marine and fluvial erosion rates, concluded that marine erosion alone was insufficient to produce some of the larger cliffs (for example, those of north Molokai), and that they were probably produced by faulting.

The idea of faulting of the flanks of the volcano led to the concept that the faults bound the headwalls of giant landslides. Stearns and Clark (1930) and Stearns and Macdonald (1946) suggested that the 50-kilometer $(\mathrm{km})$ long Hilina fault system on the south flank of Kilauea volcano, located on the island of Hawaii, owes its origin to, and is at the head of, a major landslide. Macdonald (1956) later discounted landsliding, suggesting that large-volume intrusion beneath the volcano center forcibly uplifted the summit causing faulting on the volcano flank. Moore and Krivoy (1964) revived the landslide concept for Kilauea's south flank and suggested that not only, is the Hilina fault system related to landsliding, but also that the east rift zone of the volcano forms the upper margin of a large slump. Lipman and others (1985) assessed the deformation associ- ated with a magnitude 7.2 earthquake, which occurred in 1975 on Kilauea's south flank, and concluded that a deep-seated slump, partly related to forcible intrusion of magma into the rift zone at its head, could explain the geologic and geophysical observations. They suggested that the base of the mass movement was the pre-Hawaiian sea floor and, hence, that the landslide was as much as $10 \mathrm{~km}$ thick.

Irregular blocky ridges extending downslope from giant amphitheaters on the submarine north flanks of Molokai and Oahu were interpreted as representing giant landslides by Moore (1964). Macdonald and Abbott (1970), however, questioned the immense size of these features and proposed that blocky edifices located seaward of these giant amphitheaters are in-place volcanoes. Irregular bathymetry suggesting submarine landslides on the west flank of Mauna Loa on the island of Hawaii was investigated by the U.S. Geological Survey in 1976 and 1978. This work showed that a large region (including the south Kona slump and Alika debris avalanche complex; fig. 2) between the previously enigmatic, subaerially exposed Kealakekua and Kahuku faults was involved in landsliding that reached 80 $\mathrm{km}$ offshore (Normark and others, 1979). Analysis of bathymetry and newly acquired SeaMARC II sidescansonar images of small areas (Fornari and Campbell, 1987) further emphasizes the importance of mass movement on the flanks of the Hawaiian Ridge. The ubiquitous nature of large landslides from the volcanoes of the Hawaiian Ridge was not fully realized, however, until the systematic EEZ GLORIA surveys began in 1986.

\section{METHODS}

Regional mapping of the U.S. EEZ around Hawaii was conducted aboard the research vessel Farnella beginning in 1986 by the U.S. Geological Survey and the U.K. Institute of Oceanographic Sciences using the GLORIA sidescan-sonar system. The GLORIA images, which extend as much as $22.5 \mathrm{~km}$ to each side of the ship track, can resolve features as small as a few hundred meters (Somers and others, 1978). The systematic and uniform coverage by the GLORIA surveys is well suited to compare the more than 30 large landslide deposits (for further discussion of methods used to recognize and map submarine landslides see Lee, Schwab, and Booth, this report). The surficial parameters (relief and shape) of the slide deposits and other acoustically sensed characteristics can be used to help 


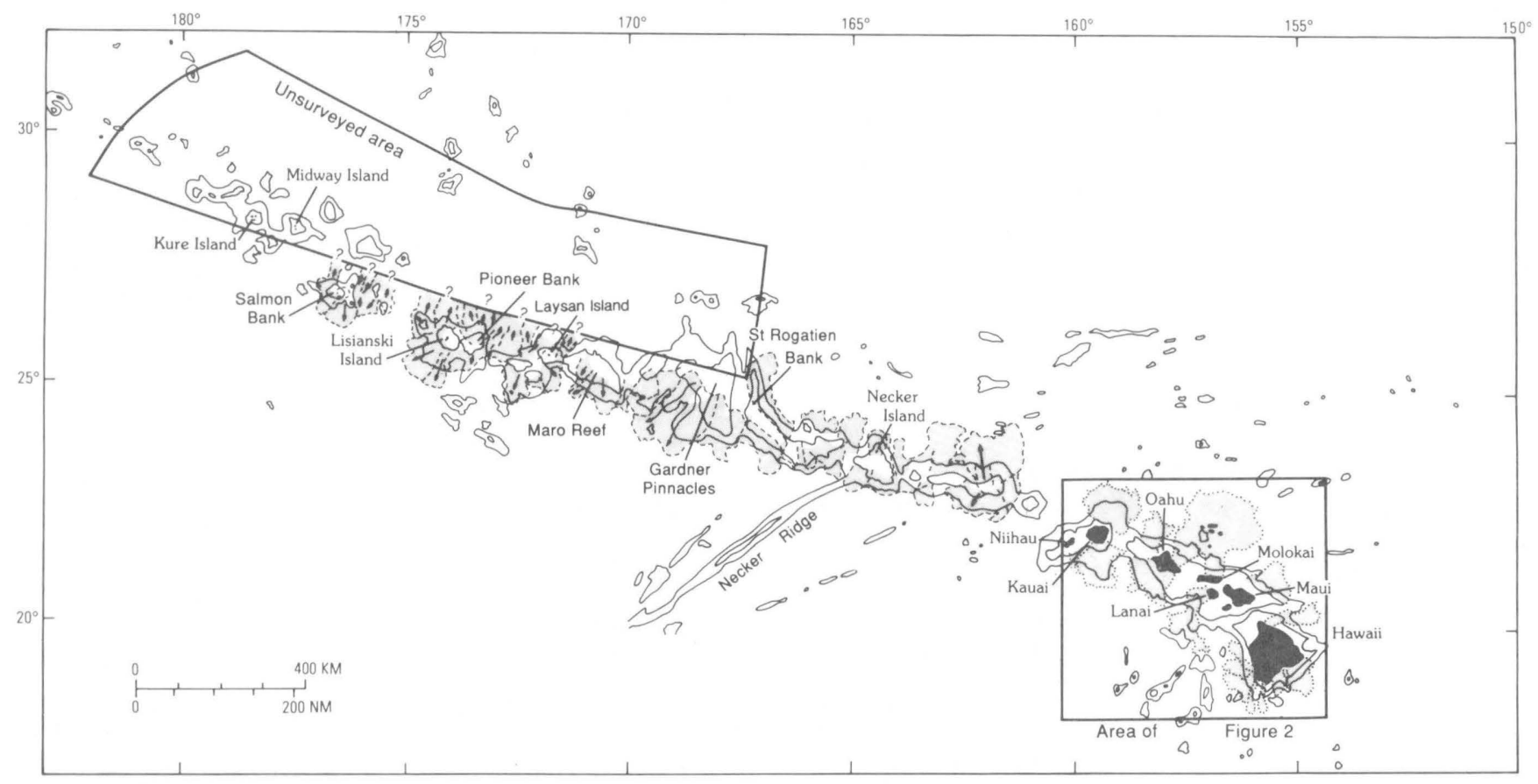

Figure 1. Hawaiian Ridge showing major landslides mapped as of the spring of 1990 by the GLORIA sidescan sonar system. The main islands are shown in black and the landslides around them are shown with dotted lines; see figure 2 for details. Landslides to the northwest are shown with dashed lines because the position is approximate and

distinguish between different parts of the same landslide or to compare widely separated slides of different age that have a common mode of origin.

\section{LANDSLIDE TYPE}

Along the $1,400-\mathrm{km}$ reach of the Hawaiian Ridge from Hawaii to Gardner Pinnacles, well-exposed massmovement deposits involve roughly one-half of the flanks of the Ridge (figs. 1 and 2). Most of these mass movements have been known only since the recent GLORIA surveys, and until more detailed studies are carried out, our understanding of the processes of landslide formation will be limited by the small scale of available sonar images. Finer blocky facies and related turbidite deposits, both of which are generally unresolvable with GLORIA data, doubtless extend beyond the presently identified landslide margins (fig. 2). The general characteristics and distribution of the giant landslides, with a detailed review of three of the larger and younger debris avalanches, are the focus of this report.

The large Hawaiian slope failures are divided into two types based on the classification system of Varnes (1978) that has been adapted for use in submarine landslides (Lee, Schwab, and Booth, this report). We distinguish slumps (for example, Hilina slump, fig. 2) and debris based on unprocessed data. Mapping of the north side of the Hawaiian Ridge west of $167^{\circ} \mathrm{W}$. Iongitude is incomplete, and the distribution of slide deposits is poorly known. Contours are the 2,000- and 4,000-meter isobaths and are adapted from U.S. Naval Oceanographic Office (1973).

avalanches (for example, Nuuanu debris avalanche, figs. 2 and 3) while the term landslide is retained as a general term for all mass movements. A slump is a movement of essentially rigid, internally undeformed masses along discrete slip planes in which the blocks of failed material rotate along curved slip surfaces. Giant landslides that involve the failure of thousands of cubic kilometers of rock and sediment that have disintegrated into relatively smaller pieces (compared to the large slump blocks but commonly include blocks of many cubic kilometers) and have clearly moved rapidly are referred to as debris avalanches. Each debris avalanche is thought to represent a single episode of catastrophic slope failure.

The slumps on the Hawaiian Ridge are particularly steep and thick (up to $10 \mathrm{~km}$ ) and are wide at their heads relative to their lengths. The overall sea-floor gradient in the area of slumping is generally greater than $3^{\circ}$, and the width/length ratio exceeds one. The slumps maintain physical continuity, that is, the bulk of the failed material is still on the flank of the volcano and only a relatively limited volume of debris has moved far from the source. Several slumps lack well-defined amphitheaters at their heads, probably because the morphology was continually modified by volcanic material throughout the episodic development of the slumps. The surfaces of the slump deposits are commonly marked by transverse ridges and scarps that are 


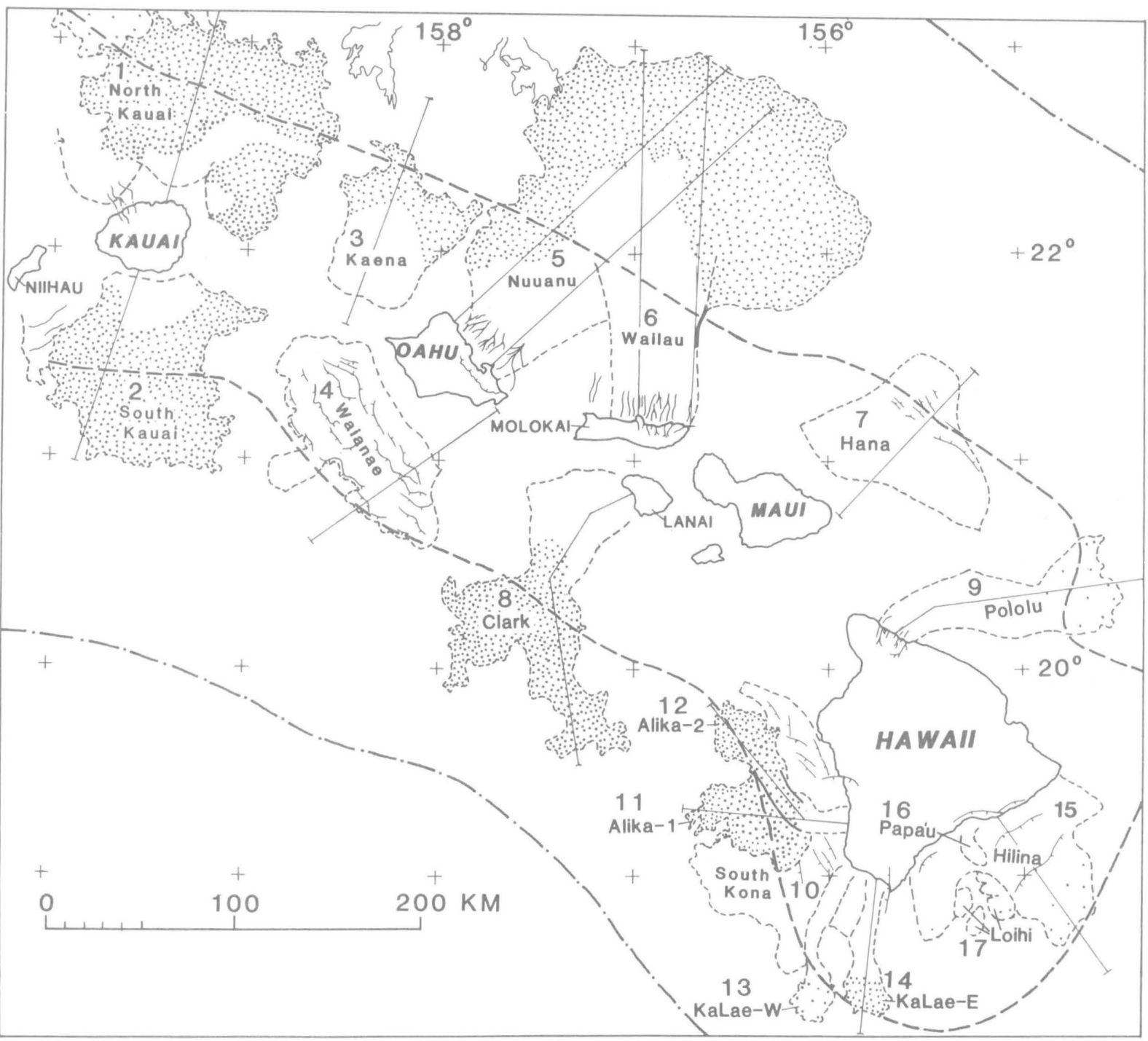

Figure 2. Southeastern Hawaiian Ridge from the island Kauai to the island of Hawaii showing the outline of major landslides (dashed lines) identified by name and number (see table 1 for landslide characteristics). Dotted pattern indicates hummocky deposits observed on seismic-reflection profiles and GLORIA images; more widely spaced dot pattern indicates subdued relief. Hachured lines indicate

generally bounded by faults but perhaps in some places represent bulges or folds (Borgia and others, 1990). The toes of the slumps commonly form a distinct scarp where they meet the pre-slide sea floor.

Using the Hilina slump on the flank of Kilauea volcano (fig. 2 and table 1) as a model, scientists have determined that these slumps apparently develop during the active stage of shield-building. A shield volcano is built from lava erupted quietly from a central vent or from two or more rift zones that meet at the central vent. The subaerial slopes of shield volcanoes seldom exceed $5^{\circ}$, but submarine slopes may exceed $10^{\circ}$. When rift zones are well estab- major fault scarps. Thin, downslope-directed, irregular lines indicate submarine canyons and their subaerial extensions. Heavy dashed line is the axis of the Hawaiian Trough, and the dash-dotted line is the crest of the Hawaiian Arch. Alika- 1 and Alika-2 are separate depositional deposits described as phase- 1 and phase-2 Alika failures in text and table 1.

lished, mass movement may result from the gravitational instability of the growing and widening volcanic shield, the stresses caused by injection of magma into the rift zones (Lipman and others, 1985), and the reduction in strength as magma is injected along possible failure planes. The slumps along the Hawaiian Ridge probably moved intermittently at a rate that was controlled by the accumulation of lava flows on their upper reaches, as well as by magma intrusion in the rift zones. Earthquakes probably have contributed to the development of these slope failures and also are likely a result of their movement. Earthquake focal depths for the 1975 7.2-magnitude Kilauea earthquake and its aftershocks 
Table 1. Hawaiian submarine landslides

[Landslides are located in figure 2]

\begin{tabular}{|c|c|c|c|c|c|c|c|}
\hline No. & Name & Type $^{1}$ & Location & $\begin{array}{l}\text { Area } \\
\left(\mathrm{km}^{2}\right)\end{array}$ & $\begin{array}{l}\text { Length }{ }^{2} \\
(\mathrm{~km})\end{array}$ & $\begin{array}{l}\text { Width } \\
(\mathrm{km})\end{array}$ & $\begin{array}{l}\text { Estimated } \mathrm{Age}^{4} \\
\text { (thousand yrs.) }\end{array}$ \\
\hline $1 \ldots \ldots \ldots \ldots \ldots \ldots \ldots \ldots$ & N Kauai & A & N Kauai & 14,000 & 140 & 100 & $<5,000 \mathrm{~V}$ \\
\hline $2 \ldots \ldots \ldots \ldots \ldots \ldots \ldots \ldots$ & S Kauai & A & S Kauai & 6,800 & 100 & 50 & $<5,000 \mathrm{~V}$ \\
\hline $4 \ldots \ldots \ldots \ldots \ldots \ldots \ldots$ & Waianae & $\mathrm{S}$ & SW Oahu & 6,100 & 50 & 80 & $<3,700 \mathrm{~V}$ \\
\hline $5 \ldots \ldots \ldots \ldots \ldots \ldots \ldots$ & Nuuanu & A & NE Oahu & 23,000 & 235 & 35 & $2,600-1,400 \mathrm{~V}$ \\
\hline $6 \ldots \ldots \ldots \ldots \ldots \ldots$ & Wailau & A & N Molokai & $>13,000$ & $<195$ & 40 & $1,400 \mathrm{~V}, \mathrm{~S}$ \\
\hline $9 \ldots \ldots \ldots \ldots \ldots \ldots$ & Pololu & A & N Hawaii & 3,500 & 130 & 20 & $370 \mathrm{R}, \mathrm{S}$ \\
\hline $10 \ldots \ldots \ldots \ldots \ldots \ldots \ldots$ & S Kona & $S$ & W Hawaii & 4,600 & 80 & 80 & $300-105 \mathrm{~V}, \mathrm{~T}$ \\
\hline $11 \ldots \ldots \ldots \ldots \ldots \ldots$ & Alika-1 & A & W Hawaii & 2,300 & 88 & 15 & $300-105 \mathrm{~V}, \mathrm{~T}$ \\
\hline $12 \ldots \ldots \ldots \ldots \ldots \ldots \ldots$ & Alika-2 & A & W Hawaii & 1,700 & 95 & 15 & $105 \mathrm{~T}$ \\
\hline $13 \ldots \ldots \ldots \ldots \ldots \ldots \ldots$ & W Ka Lae & A & S Hawaii & 850 & 85 & 10 & $<105 \mathrm{~T}^{5}$ \\
\hline $14 \ldots \ldots \ldots \ldots \ldots \ldots \ldots$ & E Ka Lae & A & S Hawaii & 950 & 75 & 10 & $<105 \mathrm{~T}^{5}$ \\
\hline
\end{tabular}

I Type of slide is: A, debris avalanche; S, slump; or U, undifferentiated.

${ }^{2}$ Length of the Waianae and South Kona slumps omits indistinct irregular topography beyond the steep toe.

${ }^{3}$ Width at the head of the landslide.

${ }^{4}$ Age constraints: V, age of host volcano lavas; $R$, coral reef date; $S$, inferred from terrace depth and assumed rate of submergence of the Hawaiian Ridge; $T$, age of tsunami deposit tentatively correlated with the landslide; $A$, intermittently active.

${ }^{5}$ Base:d on a qualitative estimate comparing the degree of acoustic backscattering observed on the GLORIA images between these landslides and the Alika phase-2 event.

indicate that the base of the Hilina slump is close to the 10-km-deep, pre-Hawaiian sea-floor surface (Lipman and others, 1985). Geodetic measurements show that the flank of Kilaue:a volcano near sea level subsided as much as 3.5 meters $(\mathrm{m})$ and locally moved seaward more than $8 \mathrm{~m}$ during the: earthquake.

The debris avalanches typically are longer and not as thick as the slumps (fig. 2 and table 1). The amphitheaters at their heads mark the source areas from which the avalanche material was derived. The debris avalanches commonly include a long middle and distal train of hummocky debris (figs. 3, 4, and 5). Blocks up to tens of kilometer: in horizontal dimension (for example, Tuscaloosa Seamount; fig. 3) may be present immediately below the amphitheater, and blocks $1 \mathrm{~km}$ across are common in the distal parts of the deposits. The deposits are of variable thickness along their course, but the greatest thickness in the blocky and hummocky sectors is probably 0.4 to $2 \mathrm{~km}$, and the average thickness may be as little as 50 $\mathrm{m}$ in the smaller avalanches. Debris blocks are relatively scarce immediately below the amphitheaters; the debris layer in the distal part is thin and probably includes deposits that are transitional with, and include, turbidite units. Some of the debris avalanches may develop by partial or complete failure of a volcano slope already oversteepened by a slump. Urilike the slumps, most debris avalanches probably move at a high velocity in a single episode, as shown by the uniform mound size and spacing in the distal hummocky facies, and the fact that some debris avalanches have moved upslope several hundred meters in their distal reaches (Moore and others, 1989).

\section{RELATIVE AGES OF LANDSLIDES}

Proceeding northwest along the Hawaiian Ridge, the volcanoes become progressively older. Kure Island, which is $2,600 \mathrm{~km}$ northwest from the active volcanoes on the island of Hawaii, was built by volcanoes about 30 million years ago (Clague and Dalrymple, 1987). Along this span, GLORIA images and seismic-reflection profiles show a progression from youthful- to older-appearing slope-failure features (Torresan and others, 1990). The Hilina slump and Alika debris avalanches are some of the youngest examples on the slopes of Hawaii's active volcanoes (Moore and others, 1989), and they are covered by less than $1 \mathrm{~m}$ of sediment. GLORIA images, SeaBeam bathymetric data, and seismic-reflection profiles of the Alika debris avalanches depict rugged, hummocky topography (figs. 4 and 5; Normark, Lipman, and Moore, 1979).

In contrast, the older slumps and debris avalanches along the Hawaiian Ridge west of Niihau are covered by as much as $30 \mathrm{~m}$ of sediment that drapes, subdues, and locally masks many of the features commonly observed on the younger landslides. The hummocky topography of older debris avalanches is more gently undulating because of the thicker sediment cover. Back-rotated blocks of older 


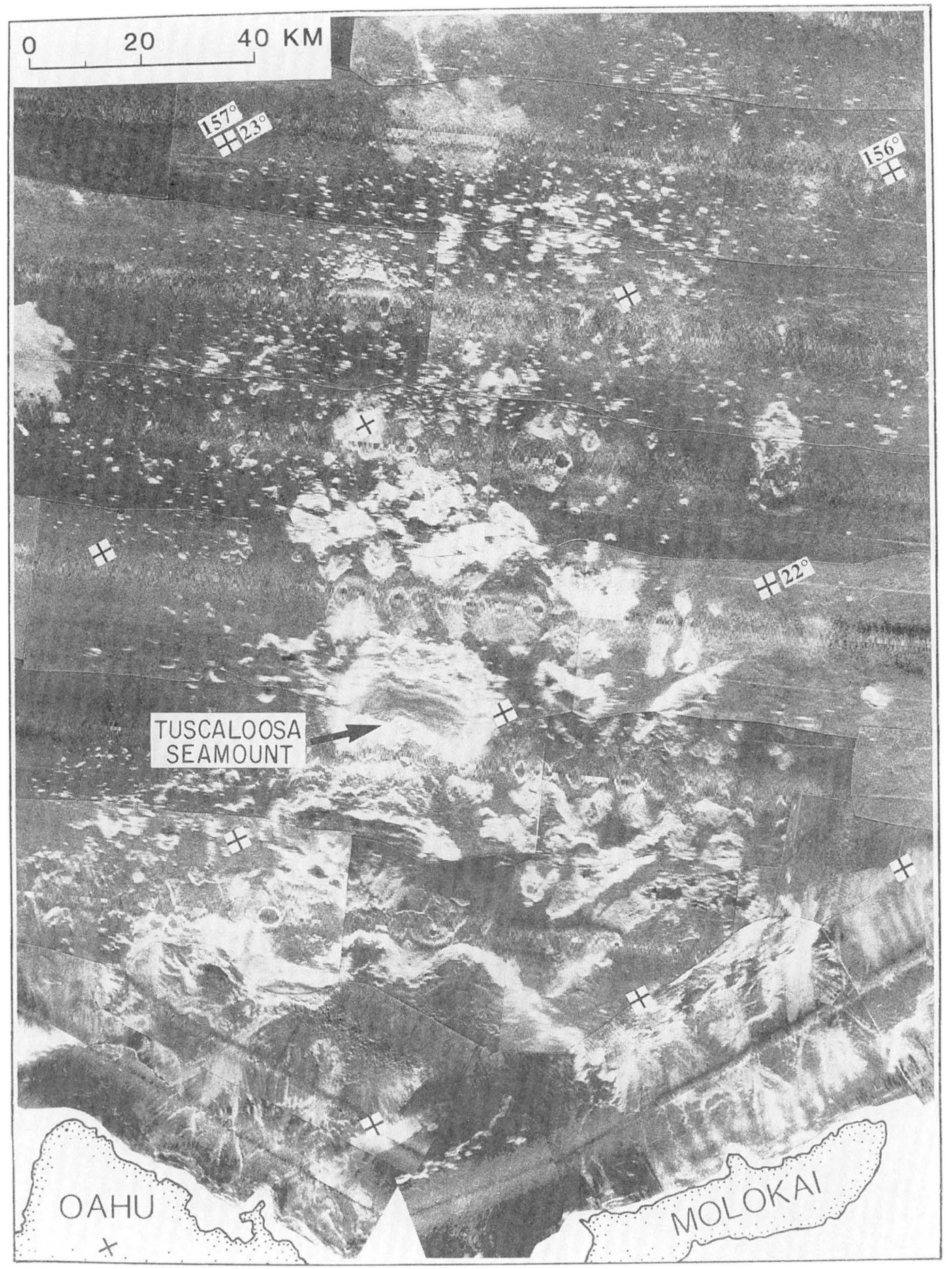

Figure 3. Mosaic of GLORIA sonographs showing the Nuuanu and Wailau debris avalanches; see figure 2 for location and outline of deposits. Lighter shades designate regions of greater acoustic backscatter either because of more reflective bottom material or because of a steep slope facing the incoming sonar signal; this type of acoustic return characterizes the blocky terrain of debris-avalanche deposits. The debris blocks range in size from Tuscaloosa Seamount, the large (greater than $20 \mathrm{~km}$ across) tabular block extending north-

west from $22^{\circ} \mathrm{N}$, $157^{\circ} \mathrm{W}$, down to talus below the resolution of the GLORIA images (about 100 meters). The apparent elongation of hummocks parallel to ship tracks (observable on the sonar images as straight line swaths of poor data quality) is an artifact caused by horizontal beam spreading and yaw of the towed GLORIA vehicle. The relatively thin, irregular, downslope trending light returns immediately offshore of the islands are from the numerous submerged canyons. 


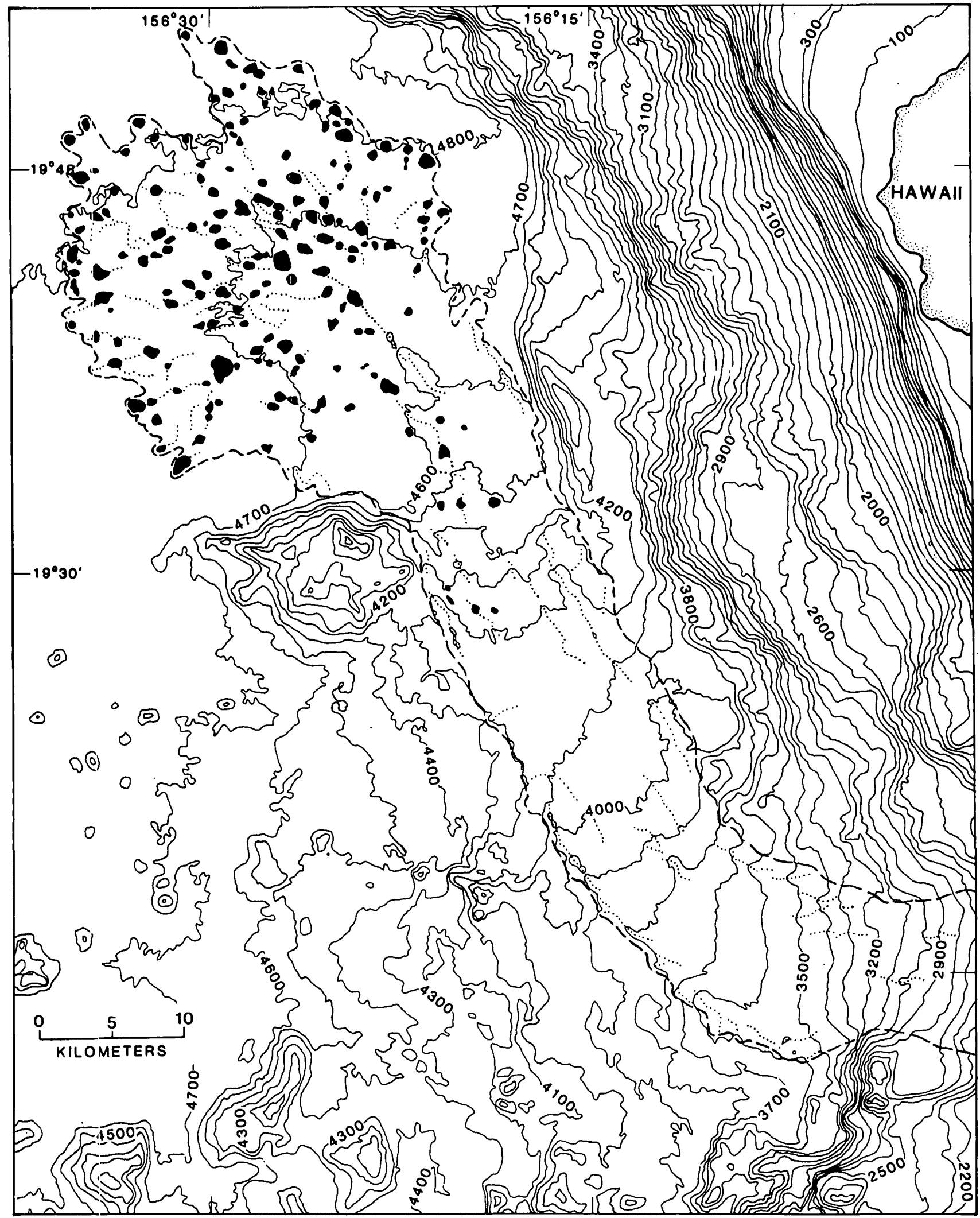

Figure 4. Alika phase-2 debris avalanche along the west side of the island of Hawaii outlined by the heavy dashed line. Ridge!s and levees are shown by dotted lines, and discrete hummocks, or large debris blocks are shown in black and are identified as those features on the SeaBeam bathymetry data that are more than $35 \mathrm{~m}$ high and $250 \mathrm{~m}$ wide. Contour interval is $100 \mathrm{~m}$. Bathymetry from NOAA SeaBeam charts. 


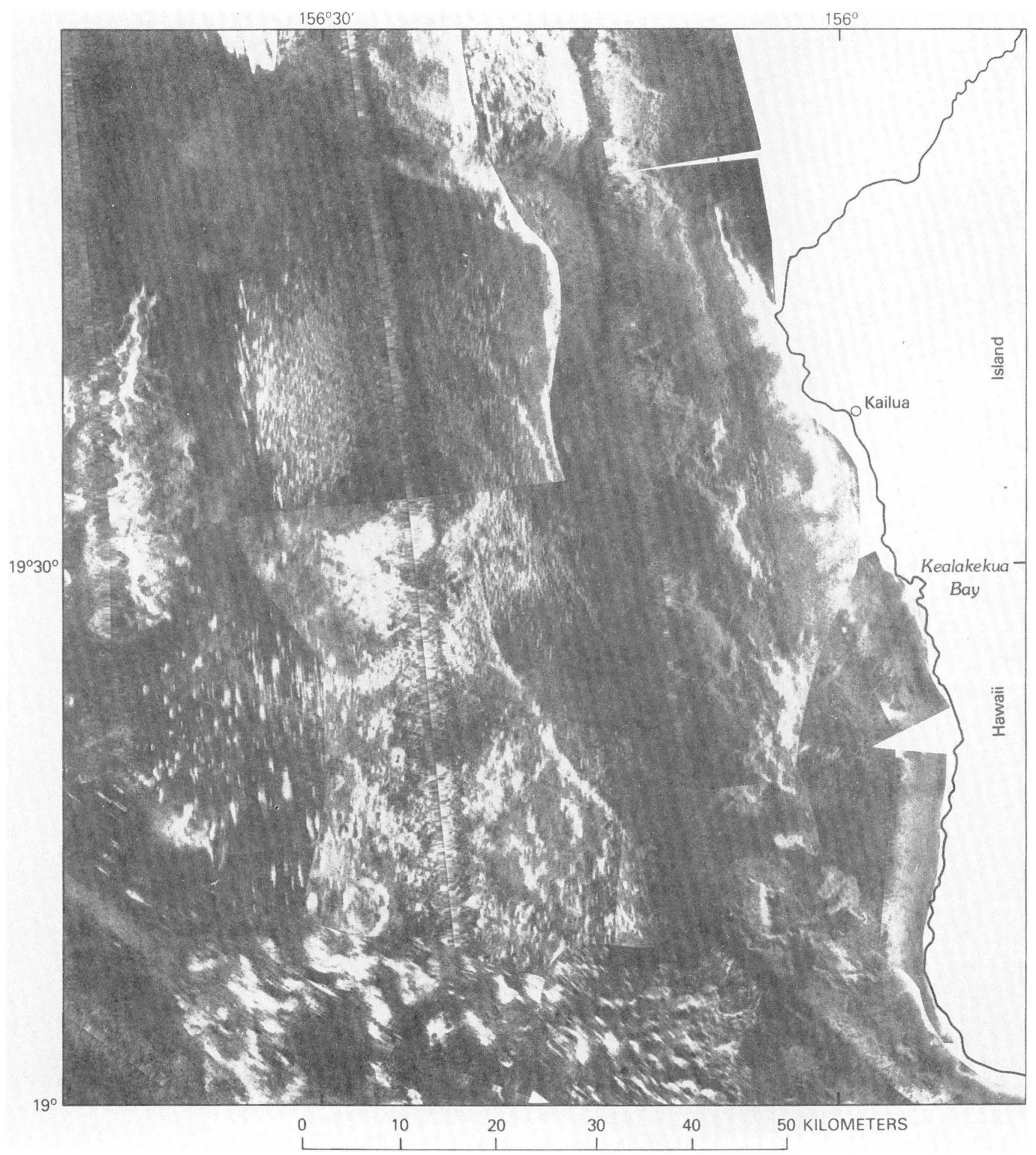

A

Figure 5. (A) Mosaic of GLORIA images with $(B)$ interpretation showing both phases of the Alika debris avalanche. Compare with the interpretation on figure 4 , which focuses on the debris lobe and leveed pathway for the Alika phase-2 event, and the mosaic of the Nuuanu and Wailau debris avalanche on figure 3 for explanation of the acoustic patterns. 


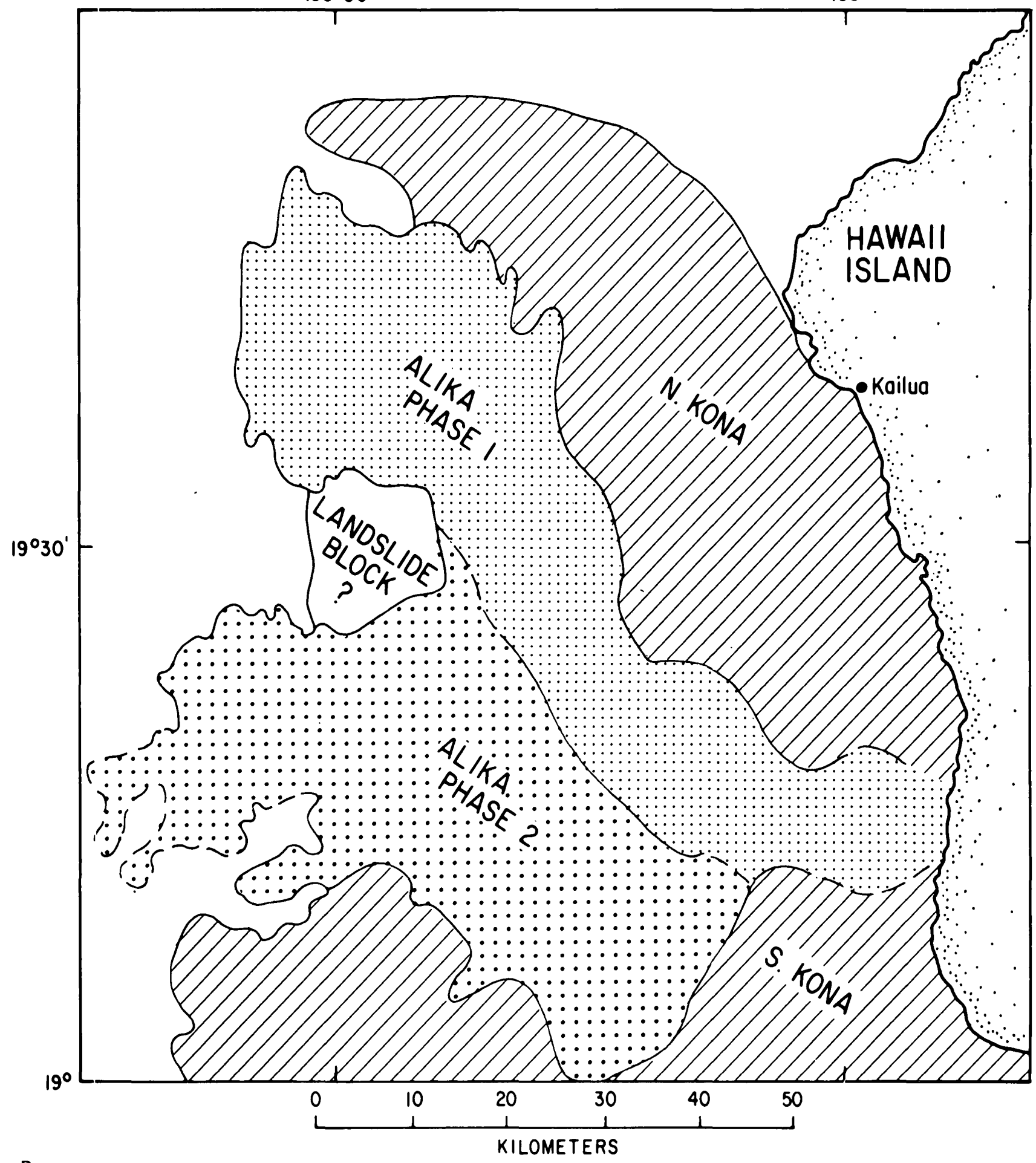

B

Figure 5.-Continued. 
slumps, such as that on the southeast side of St. Rogatien Bank, pond sediment as much as $25 \mathrm{~m}$ thick (Torresan and others, 1990). The GLORIA images adjacent to Necker Island show two debris avalanches on the north side of the Hawaiian Ridge that appear smaller and display apparently fewer blocks with a larger lower size limit and a smaller upper size limit than those observed in younger, more southeasterly debris avalanches depicted in figure 2 . These differences can all be attributed to more extensive postslide sediment cover.

Several lines of geologic evidence provide constraints on the absolute ages of the giant slumps and debris avalanches (table 1), but much careful study is needed to assign precise ages (Moore and others, 1989). Direct dating of the Hawaiian slope failures is difficult, and our main control on the periodicity of the failures comes from volcano growth rates. The current output of lava from the Hawaiian hot spot is about 0.1 cubic kilometers $\left(\mathrm{km}^{3}\right)$ per year (Swanson, 1972); hence, 10,000 years is required to produce the $1,000 \mathrm{~km}^{3}$ of the average large debris avalanche. Not all eruptive material can be involved in landsliding, however, or the volcanoes would never grow. We estimate that as much as 10 percent of the erupted material might be involved in the landslides. If correct, then this approximation suggests an average periodicity of 100,000 years for the major landslide events.

Most of the larger, older landslides that have been recognized seem to have occurred late in the shield-building phase of the host volcano (Moore and others, 1989). Hence, the ages of lavas (Clague and Dalrymple, 1987) of this phase of volcano development provide a rough estimate of ages of the youngest landslide. At the older volcanoes, northwest of Kauai, insufficient evidence exists to confirm whether landsliding occurred past the end of shield building. The most active volcanoes, Mauna Loa and Kilauea, which have not yet completed their shield-building phase, show ample evidence of major landslides; this indicates that slope failure is a common process through much of the history of volcano growth and is not restricted to the end of shield building.

In addition to the dating of the volcanic sequences that have become involved in landsliding, or that postdate landslides, constraints on landslide age can be deduced from the dating of coral reefs that appear to overlie landslides. Landslide ages also can be tied to dates of coral-reef fragments that apparently were deposited on subaerial slopes of adjacent islands by giant waves initiated by landslide movement. Moore and Moore (1984) report coral debris as high as $326 \mathrm{~m}$ above sea level on the island of Lanai that is probably related to the Alika phase-2 debris avalanche. Additional information on landslide ages may come from the deep-sea sedimentary record, both by examination of sediment atop the landslide debris and by identifying perturbations in the sediment stratigraphy beyond the landslide toes that may reflect currents initiated by the mass failures.

Because of the generally long recurrence interval for the giant landslides (perhaps 100,000 years), they are not considered to pose a serious threat despite the enormity of the tsunami (large sea waves) that might be produced (Moore and Moore, 1984) and the potential loss of land. Both small mass failures, however, such as those caused by the collapse of lava deltas formed where lava from sustained eruptions flows into the sea, and mid-size slope failures, such as the Papa'u and Loihi landslides (fig. 2), probably occur far more frequently than the giant ones. The collapse of the small lava deltas have produced waves as high as 20 $\mathrm{cm}$ that have been recorded on tide gauges several tens of kilometers away. The mid-size slope failures could produce tsunami of intermediate size; that is, far larger than the tsunami generated by earthquakes around the margins of the Pacific Ocean that have devastated Hawaiian coastal settlements in the recent past. Our knowledge of these nearshore, mid-size landslides is incomplete because the relatively shallow water on steep, highly irregular slopes has hamperèd detailed investigation.

\section{DESCRIPTIONS OF THREE DEBRIS AVALANCHES}

\section{Nuuanu Debris Avalanche}

The Nuuanu debris avalanche covers about 23,000 square kilometers $\left(\mathrm{km}^{2}\right)$ (the largest landslide mapped), on the northeast flank of Oahu (figs. 2 and 3). It extends about $230 \mathrm{~km}$ from its headwall at Nuuanu Pali on Oahu to its toe, which is found half-way up the southwest-sloping flank of the Hawaiian Arch.

The amphitheater above the Nuuanu debris avalanche deposits is defined by bathymetric contours that are deflected as much as $10 \mathrm{~km}$ shoreward from the projected original shape of the volcanic shield (Moore and others, 1989). The thickness of material removed to form this amphitheater is 700 to $1,100 \mathrm{~m}$. Below the amphitheater is a tongue-shaped mass studded with giant blocks that are tens of kilometers in maximum dimension (fig. 3) and rise 0.5 to $1.8 \mathrm{~km}$ above the regional slope. These blocks commonly have back-tilted flat summits; they originated in the amphitheater, and some have moved more than $50 \mathrm{~km}$ to their present position. The largest block, Tuscaloosa Seamount, $90 \mathrm{~km}$ northeast of Oahu, is $30 \mathrm{~km}$ long, $17 \mathrm{~km}$ wide and has a broad flat summit about $1.8 \mathrm{~km}$ above its base.

After crossing the axis of the Hawaiian Trough, the Nuuanu debris avalanche traveled uphill a distance of about $140 \mathrm{~km}$ from a present water depth of $4,600 \mathrm{~m}$ in the Trough to 4,300 m on the Hawaiian Arch where the debris avalanche ends. Thus, the upslope transport is at least 
$300 \mathrm{~m}$. The momentum necessary for the debris to ride up such a slope requires rapid movement. A fast-moving submarine landslide of this size would displace enormous volumes of sea water and probably produced large surface waves even more destructive than the wave recorded on Lanai (Moore and Moore, 1984) that was presumably caused by the smaller Alika phase- 2 event (table 1).

The distal $80 \mathrm{~km}$ of the Nuuanu debris-avalanche deposit, which lies on the Hawaiian Arch, is well defined on the GL.ORIA images as scattered blocks ranging up to about one kilometer in size (fig. 3). Insights on the thicknesses of debris avalanches are obtained by comparison of longitudinal profiles down the axis of the avalanche with parallel profiles to either side of it. These profiles suggest a minimum thickness of the central part of the avalanche of about $400 \mathrm{~m}$ and an average of perhaps $200 \mathrm{~m}$ over the entire landslide area. A conservative estimate of $200-\mathrm{m}$ thickness yields a volume of about $5,000 \mathrm{~km}^{3}$ for this debris-avalanche deposit.

Several submarine canyons incise the headwall area of the Nuuanu debris avalanche (figs. 2 and 3). These submarine canyons continue to supply sediment that is covering the blocky terrain of the upper landslide deposit. Because these submarine canyons are clearly associated with land canyons, Andrews and Bainbridge (1972) and Coulbourn and others (1974) concluded that the canyons were subaerially carved and subsequently drowned during subsidence: of the Hawaiian Ridge. This subsidence had been as much as $1,800 \mathrm{~m}$ because the canyon morphology is well-developed to that depth (Andrews and Bainbridge, 1972). Because the canyons are cut in the upper part of the slide scar, we infer that the Hawaiian Ridge stood at least $1,800 \mathrm{~m}$ higher at the time of slope failure.

\section{Wailau [lebris Avalanche}

The Wailau debris avalanche has removed the north part of East Molokai Volcano and left a well-defined, 40-km-wide amphitheater at its head. The debris avalanche apparently overrode the south side of the older Nuuanu debris avalanche an unknown distance. The largest block (Tuscaloosa Seamount) in this crossover zone, however, is not a part of the Wailau debris avalanche but rather belongs to the Nuuanu debris avalanche, on the basis of the composition of lava dredged from it.

A reggional terrace that abruptly steepens below 1,300 $m$ water depth provides some constraints on the age of the debris avalanche. This terrace extends completely across the headwall amphitheater of the Wailau landslide (Shepard and Dill, 1966). The nearly horizontal nature of the terrace indicates that it is probably a feature produced at or close to sea level (Mathewson, 1970) and that it postdates the Wailau debris avalanche. Thus, the slope failure occurred when the volcano stood at least $1,300 \mathrm{~m}$ higher than at present.

The 1,300-m-deep terrace is about $800 \mathrm{~m}$ deeper than a 500-m-deep terrace that formed about 850,000 years ago (Moore and Campbell, 1987). If the Molokai subsidence rate was comparable to that of northern Hawaii (2.5 millimeters per year $(\mathrm{mm} / \mathrm{yr})$ ) during the period between formation of the 1,300-m-deep terrace and the 500-m-deep terrace, then the estimated age of the 1,300-m-deep terrace is about 1.17 million years. Radiometric dating of lavas that mark the end of the shield-building stage of the East Molokai Volcano indicates an age of 1.50 million years (Clague and Dalrymple, 1987). Hence, the Wailau avalanche event cannot be much older than the 1,300-m-deep terrace ( 1.17 million years) and is younger than 1.50 million years old because postfailure volcano growth has been primarily limited to the small Kalaupapa volcano, which forms the small peninsula on the north side of Molokai and has been dated from radiometric dates of lavas at 570,000 to 340,000 years old (Clague and others, 1982). Kalaupapa volcano grew after both the landsliding and much of the observed subsidence (nearly 1,300 m) of the island of Molokai. Moore and others (1989) have, thus, estimated that the age of the Wailau debris avalanche is about 1.4 million years.

In the region where the Nuuanu debris avalanche and the neighboring Wailau avalanche meet (fig. 2), the major elongate blocks are more nearly normal to the long axis of the Nuuanu debris avalanche. Moore (1964) suggested that the Nuuanu debris avalanche was younger than the Wailau debris avalanche, because the long axes of landslide blocks are more commonly perpendicular to the movement direction of the Nuuanu debris avalanche. GLORIA images, however, (fig. 3) show a field of hummocky terrain typical of distal debris avalanche facies east of the upper Wailau debris avalanche. This material is probably not a part of the Wailau debris avalanche because of its location to the side and outside of a levee on the east side of the Wailau debris avalanche; hence, it is more likely a part of the great distal debris apron of the Nuuanui debris avalanche. If the Wailau debris avalanche was emplaced first, it is unlikely that finer material from the Nuuanu avalanche could have crossed it. For this reason, we consider the Wailau debris avalanche to be younger than the Nuuanu debris avalanche (table 1). The younger relative age inferred for the Wailau debris avalanche parallels the relative ages of the two volcanoes that spawned these slope failures.

\section{Alika Debris Avalanches}

The Alika debris avalanches are probably among Hawaii's youngest (table 1; Lipman and others, 1988). These two partly overlapping landslides, designated Alika phases 1 and 2, cover 2,300 and $1,700 \mathrm{~km}^{2}$, respectively 


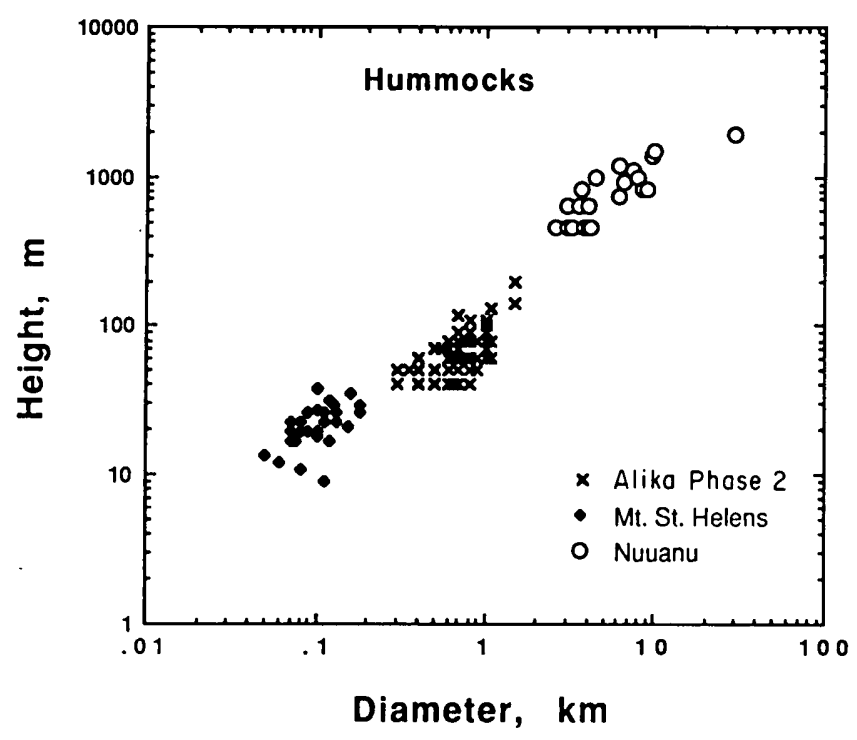

Figure 6. Comparison of diameter and height of hummocks (large blocks) in the Alika phase-2 debris-avalanche deposit with blocks from the submarine Nuuanu debrisavalanche deposit (number 5 in table 1) and the subaerial deposit from Mount St. Helens that was catastrophically formed in 1980 . The size relation forms a continuum for both submarine and subaerial mass movements (with scale varying by as much as two orders of magnitude). The submarine examples off Hawaii emphasize the tremendous energy associated with catastrophic, rapid downslope movement of these debris avalanches.

(figs. 2, 4, and 5). They extend nearly $100 \mathrm{~km}$ from their source near the present shoreline to depths of $4,800 \mathrm{~m}$ in the Hawaiian Trough. The estimated thickness of the debris avalanches is 50 to $200 \mathrm{~m}$ based on the size of the blocks and the height of natural levees that border the main transport paths. Volume estimates for both failures together range from 200 to $800 \mathrm{~km}^{3}$.

The lower part of the Alika debris-avalanches deposit, below about $4 \mathrm{~km}$ water depth, is marked by closely spaced hummocky mounds (figs. 4 and 5). The individual mounds are commonly a few hundred meters across and 25 to $75 \mathrm{~m}$ high, but some are several kilometers across and several hundred meters high (fig. 6). Over much of this terrain, the hummocks are closely spaced and similar in size and height, suggesting that they were all produced by the same processes in the same episode. Downslope from the zone of closely spaced hummocks is a fringing zone from 5 to $20 \mathrm{~km}$ wide of isolated blocks or mounds. Where this zone on the phase-2 Alika debris avalanche was examined with a high-resolution sidescan-sonar system and cameras towed near the sea floor, blocks and mounds are found that range from $500 \mathrm{~m}$ in diameter (large enough to identify on GLORIA images) to as small as cobble-size pieces. Toward the distal margin of this zone, the larger resolvable mounds on the GLORIA imagery are increasingly separated, commonly by $0.5-1 \mathrm{~km}$.
The hummocky topography and marginal levees of the Alika landslides resemble the 1980 Mount St. Helens subaerial debris avalanche and suggest that a similar high emplacement velocity prevailed for the Alika features (fig. 6). Rapid avalanching of rock volumes of this size could produce a large tsunami. The general youth and location of the Alika phase-2 debris avalanche (fig. 2) make this mass-movement event the most likely to have caused the extensive 105,000-year-old wave deposits that have been documented on Lanai and nearby islands up to heights of $326 \mathrm{~m}$ above sea level (Lipman and others, 1988; Moore and Moore, 1984, 1988).

\section{LANDSLIDING AND VOLCANO DEVELOPMENT}

Major landsliding has occurred throughout the growth of Hawaiian volcanoes, and may continue at a reduced rate long after dormancy. More than half the surface area of Loihi, the youngest volcano in the chain (fig. 2), is extensively modified by landsliding even though its summit is still $1 \mathrm{~km}$ below sea level and the volcano is perhaps a hundredth the size of a mature shield volcano (Moore and others, 1989). We expect the largest and most far traveled debris avalanches to occur during the final stages of the shield-building cycle when not only is the volcanic production still significant but also the volcanoes' stand is highest above sea level. Before and after that time, smaller landslides that travel shorter distances could be expected. Large-scale landsliding probably occurs, however, intermittently throughout most of the shield-building stage with the slope failure deposits being incorporated into the edifice as it grows so that little surface evidence for gliding remains.

The Nuuanu, Wailau, and Pololu debris avalanches, and the Waianae, Hilina, and South Kona slumps (figs. 1, 2 , and table 1) all head at, and have moved perpendicular to, the primary rift zones of their host volcanoes. Other slope failures, such as the Kaena debris avalanche and the Hana slump, head on the sides of long, shallow submarine ridges that apparently represent submerged rift zones. This rift-zone/slope-failure relationship is part of the cause-effect relation reflecting the gravitational instability of these volcanoes. Rift-zone trends can be strongly influenced by the position of tensional zones at the head of landslides, but landsliding can be induced by the lateral shoving caused by magma injection into the rift zones (Lipman and others, 1988).

\section{CONCLUSIONS}

A primary result of GLORIA sidescan-sonar surveys of the Hawaiian Exclusive Economic Zone was to document the enormous scale of submarine slope failure along the Hawaiian Ridge. Slumps and debris avalanches were found 
to cover nearly $100,000 \mathrm{~km}^{2}$ of the ridge and adjacent sea floor just within the segment from Kauai to Hawaii; $100,000 \mathrm{~km}^{2}$ represents an area more than 5 times the combined land areas of the islands. About 20 additional major lanidslides have been imaged from Kauai Island northwest to Kure Island on the Hawaiian Ridge. Some of the individual debris avalanches are more than $200 \mathrm{~km}$ long and about $5,000 \mathrm{~km}^{3}$ in volume, ranking them among the largest on Earth (Lipman and others, 1988). These slope failures begin early in the history of individual volcanoes when they are small submarine seamounts, culminate near the end of subaerial shield-building, and may continue long after dormancy. Thus, mass-movement deposits and structures are an important element in the composition and evolution of the volcanoes.

The landslides are of two general types: slumps and debris avalanches. Slumps are wide (up to $110 \mathrm{~km}$ ) and thick (about $10 \mathrm{~km}$ ) with transverse blocky ridges and steep toes. Debris avalanches are fast-moving, long (up to 230 $\mathrm{km}$ ) compared to their width (commonly less than $50 \mathrm{~km}$ wide in the proximal part but many produce broad depositional lobes more than $100 \mathrm{~km}$ in diameter at their distal reaches), and comparatively thin (0.05 to $2 \mathrm{~km})$; they commonly have well-defined amphitheaters at their heads and humnocky terrain in their lower parts.

Most of the landslides moved into, and locally across, the axis of the Hawaiian Trough, which flanks the Hawaiian Ridge (fig. 2). Thus, mass movement is a primary mechanism for filling the Trough and widening the base of the ridge. The eruptive behavior of the volcanoes can be modulated by landsliding, and the subaerial geometry of the slope failures is related to the structural features of the volcanoes including rift zones and fault systems. Water disturbances caused by the rapid movement of the debris avalanches probably produced the high waves responsible for elevated reef deposits on Lanai and adjacent islands. Most submarine canyons offshore of the Hawaiian volcanoes were carved subaerially in the upper amphitheaters of debris avalanches. Subaerial canyon cutting in these amphitheaters is probably enhanced by the resulting oversteepened slopes.

The: widespread development of landslides along the submarine slopes of the Hawaiian Ridge suggests that analogous slides should be present on other oceanic volcanoes constructed in deep water. Isle de la Reunion in the Indian Ocean, for example, has large-scale submarine landslides on the east flank of the active volcano, Piton de la Fournaise. The landslide was inferred by Duffield and others (1982), and recent SeaBeam bathymetric mapping, high-resolution sidescan-sonar imaging, sea-floor photography, and dredging along the submarine east flank of Piton de la Fournaise has confirmed the widespread presence of submarine: landslide material (Lenat and others, 1989). Hummocky terrain, similar to the Hawaiian debrisavalanche deposits, extends at least $40 \mathrm{~km}$ offshore to
2,500 m depth; the full dimensions of the large submarine slope failures on the east flank of La Reunion, however, have not yet been delimited. Steep submarine slopes along older parts of La Reunion (Piton de Neiges) that grade down into a broad gently sloping apron on the lower slopes suggest that mass failure is widespread around the entire island.

The recurrence interval of landslides on oceanic volcanoes is long, from 1 to 100 thousand years, in part being limited by the large ratio of landslide volume to annual eruptive volume especially for the largest failures. Because large landslides have also been identified at other oceanic volcanoes rising from abyssal depths, however, and because their effects can be catastrophic, a survey of landslide-prone oceanic volcanoes should be initiated.

\section{ACKNOWLEDGMENTS}

We are indebted to the crews and technical staffs of the R.V. Farnella for their outstanding work during the cruises in 1986 and 1988, and we have benefited from discussions with our colleagues of the U.K. Institute of Oceanographic Sciences, R. Belderson, J. Campbell, M. Harris, R.G. Rothwell, R.C. Searle, M.L. Somers, and J.B. Wilson. R.M. Carter, D.A. Clague, R.P. Denlinger, R.T. Holcomb, M.L. Holmes, P.W. Lipman, K. Hon, and A.N. Shor helped with the data collection and provided important geologic insights. We appreciate thoughtful reviews by D.E. Drake and D.W. Peterson.

\section{REFERENCES CITED}

Andrews, J.E., and Bainbridge, C., 1972, Submarine canyons off eastern Oahu: Pacific Science, v. 26, p. 108-113.

Borgia, A.J., Burr, J., Montero, W., Alvardo, G.E., and Morales, L.D., 1990, Fault-propagation folds induced by gravitational failure and slumping of the central Costa Rica volcanic range: implications for large terrestrial and Martian volcanic edifices: Journal of Geophysical Research, v. 95, p. 14,357-14,382.

Clague, D.A., and Dalrymple, G.B., 1987, The HawaiianEmperor volcanic chain, Part I: U.S. Geological Survey Professional Paper 1350, p. 5-54.

Clague, D.A., Dao-gong, C., Murnane, R., Beeson, M.H., Lanphere, M.A., Dalrymple, G.B., Friesen, W., and Holcomb, R.T., 1982, Age and petrology of the Kalaupapa basalt, Molokai, Hawaii: Pacific Science, v. 36, p. 411-420.

Coulbourn, W.T., Campbell, J.F., and Moberly, Ralph, 1974, Hawaiian submarine terraces, canyon, and Quaternary history evaluated by seismic-reflection profiling: Marine Geology, v. 17, p. 215-234.

Dana, J.D., 1890, Characteristics of volcanoes: University Press, John Wilson and Son, Cambridge, Mass., 399 p.

Duffield, W.A., Stieltjes, L., and Varet, J., 1982, Huge landslide blocks in the growth of Piton de la Fournaise, La Reunion, and Kilauea Volcano, Hawaii: Journal of Volcanology and Geothermal Research, v. 12, p. 147-160. 
Fornari, D.J., and Campbell, J.F., 1987, Submarine topography around the Hawaiian Islands: U.S. Geological Survey Professional Paper 1350, p. 109-124.

Hitchcock, C.H., 1900, The geology of Oahu: Geological Society of America Bulletin, v. 11, p. 23-35.

Lenat, J.F., Vincent, P., and Bachelery, P., 1989, The off-shore continuation of an active basaltic volcano: Piton de la Fournaise (Reunion Island, Indian Ocean): Journal of Volcanology and Geothermal Research, v. 36, p. 1-36.

Lipman, P.W., Lockwood, J.P., Okamura, R.T., Swanson, D.A., and Yamashita, K.M., 1985, Ground deformation associated with the 1975 magnitude-7.2 earthquake and resulting changes in activity of Kilauea volcano, Hawaii: U.S. Geological Survey Professional Paper 1276, 45 p.

Lipman, P.W., Normark, W.R., Moore, J.G., Wilson, J.B., and Gutmacher, C.E., 1988, The giant submarine Alika debris slide, Mauna Loa, Hawaii: Journal of Geophysical Research, v. 89 , p. $4279-4299$.

Macdonald, G.A., 1956, The structure of Hawaiian volcanoes: Koninklijk Nederlandsch Geologisch Mijnbbouwkundig Genootschap, v. 16, p. 174-295.

Macdonald, G.A., and Abbot, A.T., 1970, Volcanoes in the sea, the geology of Hawaii: University of Hawaii Press, Honolulu, Hawaii, 441 p.

Mathewson, C.C., 1970, Submarine canyons and the shelf along the north coast of Molokai Island, Hawaiian Ridge: Pacific Science, v. 24, p. 235-244.

Moore, G.W., and Moore, J.G., 1988, Large-scale bedforms in boulder gravel produced by giant waves in Hawaii: Geological Society of America Special Paper 229, p. 101-110.

Moore, J.G., 1964, Giant submarine landslides on the Hawaiian Ridge: U.S. Geological Survey Professional Paper 501-D, p. D95-D98.

Moore, J.G., and Campbell, J.F., 1987, Age of tilted reefs, Hawaii: Journal of Geophysical Research, v. 92, p. 26412646.

Moore, J.G., Clague, D.A., Holcomb, R.T., Lipman, P.W., Normark, W.R., and Torresan, M.E., 1989, Prodigious submarine landslides on the Hawaiian Ridge: Journal of Geophysical Research, v. 94, p. 17,465-17,484.

Moore, J.G., and Krivoy, H.L., 1964, The 1962 flank eruption of
Kilauea volcano and structure of the east rift zone: Journal of Geophysical Research, v. 69, p. 2033-2045.

Moore, J.G., and Moore, G.W., 1984, Deposit from a giant wave on the island of Lanai, Hawaii: Science, v. 226, p. 1312-1315.

Normark, W.R., Lipman, P.W., and Moore, J.G., 1979, Regional slump structures on the west flank of Mauna Loa volcano, Hawaii: Proceedings of Hawaii Symposium on Intraplate Volcanism and Submarine. Volcanism, International Association of Volcanology and Chemistry of the Earth's Interior, Hilo, Hawaii, p. 22.

Shepard, F.P., and Dill, R.F., 1966, Submarine canyons and other sea valleys: Rand McNally, Chicago, Ill, 381 p.

Somers, M.L., Carson, R.M., Revie, J.A., Edge, R.H., Barrow, B.J., and Andrews, A.G., 1978, GLORIA II-An improved long range sidescan sonar: Proceedings, IEEE/IERE Subconference on Ocean Instruments and Communication, Oceanology International, London, B.P.S. Publications Limited, p. 16-24.

Stearns, H.T., and Clark, W.O., 1930, Geology and water resources of the Kau District, Hawaii: U.S: Geological Survey Water-Supply Paper 616, 194 p.

Stearns, H.T., and Macdonald, G.A.; 1946, Geology and groundwater resources of the island of Hawaii: Hawaiian Division Hydrographic Bulletin, v. 9, 363 p.

Swanson, D.A., 1972, Magma supply rate at Kilauea Volcano, 1952-1971: Science, v. 175, p. 163-170.

Torresan, M.E., Clague, D.A., Jacobs, C.L., and Moore, J.G., 1990, Maturation of large-scale mass wasting along the Hawaiian Ridge: Circum-Pacific Energy and Mineral Resources Conference Abstracts Volume, Honolulu, Hawaii, p. $73-74$.

U.S. Naval Oceanographic Office, 1973, Bathymetric atlas of the North Pacific Ocean: Washington, D.C., 88 p.

Varnes, D.J., 1978, Slope movement types and processes, in Schuster, R.L., and Krizek, R.J., eds., Landslides, analysis and control: National Academy of Sciences, Special Report 176, Washington, D.C., p. 11-33.

Wentworth, C.K., 1927, Estimates of marine and fluvial erosion in Hawaii: Journal of Geology, v. 1, p. 117-133. 


\title{
Submarine Slope Failures Initiated by Hurricane Iwa, Kahe Point, Oahu, Hawaii
}

\author{
By W.R. Normark, Pat Wilde ${ }^{1}$, J.F. Campbell ${ }^{2}$, T.E. Chase, and Bruce Tsutsui ${ }^{3}$
}

\section{INTRODUCTION}

Real-time "monitoring" of submarine slope failure (or landslide) events has generally been limited to visual observation of the collapse of shoreline features into the ocean and associated destruction of manmade coastal structures and (or) the appearance of muddy turbulent surface waters in the shallow waters of fjords, off large deltas or in the heads of submarine canyons. In deeper water settings, temporal observations have generally been limited to a knowledge: of the time of disruption/destruction of manmade structures, especially submarine telecommunication cables (see: Menard, 1964, and Lee, 1989, for a review of the types of observations). The 1929 Grand Banks earthquake, which generated mass flows on the upper continental slope off eastern Canada, has long been a classic example of submarine slope failure and subsequent generation of turbidity currents. The timing of sediment movement and areal extent of the failure during the 1929 earthquake have been deduced from the sequential disruption of a series of submarine telecommunication cables. The limitation of this type of indirect observation of mass-movement events, however, has become evident as recent data from the Grand Banks margin, including high-resolution sidescan-sonar imagery and inspection of the sea floor using manned submersibles, have resulted in a substantial revision of our thinking about both the nature of the slope failure and the character of the sediment mass flows that were generated (Hughes Clarke, 1988; Hughes Clarke and others, 1990).

A series of sea-floor surveys and instrument deployments to monitor oceanographic conditions offshore from Kahe Point, Oahu, as part of a feasibility study for the Ocean Thermal Energy Conversion (OTEC) project (Noda, 1983; Tsutsui and others, 1987; Dengler and Wilde, 1987) provided a rare opportunity to observe mass movement of sediment on submarine slopes more directly. An array of self-contained current meters that were displaced during the passage of a major hurricane in 1982 provided measurements of the timing, velocity of movement, and change of water depth as sediment was displaced to deeper water. Detailed surveys of the sea floor in the area of the

\footnotetext{
' Marine Sciences Group, University of California, Berkeley, Calif.

${ }^{2}$ Seafloor Surveys International, Inc., Honolulu, Hawaii.

${ }^{3}$ School of Ocean and Earth Science and Technology, University of Hawaii, Honolulu, Hawaii.
}

current-meter array both before and after the hurricane provide additional constraints on the nature of the mass movement.

\section{GEOLOGIC SETTING}

The study area lies off Kahe Point, which is on the southwest coast of the island of Oahu (fig. 1). Immediately offshore from Kahe Point, the shelf is very narrow, slightly more than 1 kilometer $(\mathrm{km})$ wide, and a steep $\left(30^{\circ}\right.$ to $40^{\circ}$ average) upper slope drops abruptly to 350 meters (m) water depth (fig. 2). Farther seaward the slope gradually decreases, forming a broad terrace that terminates at about $1 ; 500 \mathrm{~m}$, where the sea-floor slope increases to about $20^{\circ}$. The section of narrow shelf corresponds to a reentrant in the upper slope that is about $4 \mathrm{~km}$ wide and matched directly downslope by a convex-seaward bulge in the outer edge of the terrace (figs. 2 and 3). These relations led Normark and others (1982) to suggest that this morphology might represent a small bedrock slump feature; such slumps and more catastrophic slope failures have since been documented offshore of all major volcanoes of the southeastern Hawaiian Ridge (Moore and others, 1989; Normark, Moore, and Torresan, this report).

A detailed, precision-navigated survey conducted in 1981 obtained both 3.5-kilohertz $(\mathrm{kHz})$ and minisparker seismic-reflection profiles along an orthogonal grid with 0.5 to $1 \mathrm{~km}$ line-spacings allowing Normark and others (1982) to prepare a map of estimated sediment character based on acoustic reflectivity. Irregular local topography, together with an internally chaotic or structureless subbottom character, were interpreted by them to indicate that much of the upper slope and inner terrace off Kahe Point is underlain by sediment that has undergone mass movement. The physical properties of carbonate sediment samples from the study area are consistent with this interpretation (Winters and Lee, 1982). Posthurricane surveys of the inner part of the study area using sidescan sonar and additional core data show direct evidence for downslope movement of sediment (Tsutsui and others, 1987).

\section{SEDIMENT MOVEMENT AND ASSOCIATED BOTTOM-WATER CURRENTS DURING HURRICANE IWA}

Hurricane Iwa passed just west of the island of Kauai on November 23, 1982, causing extensive damage on that 


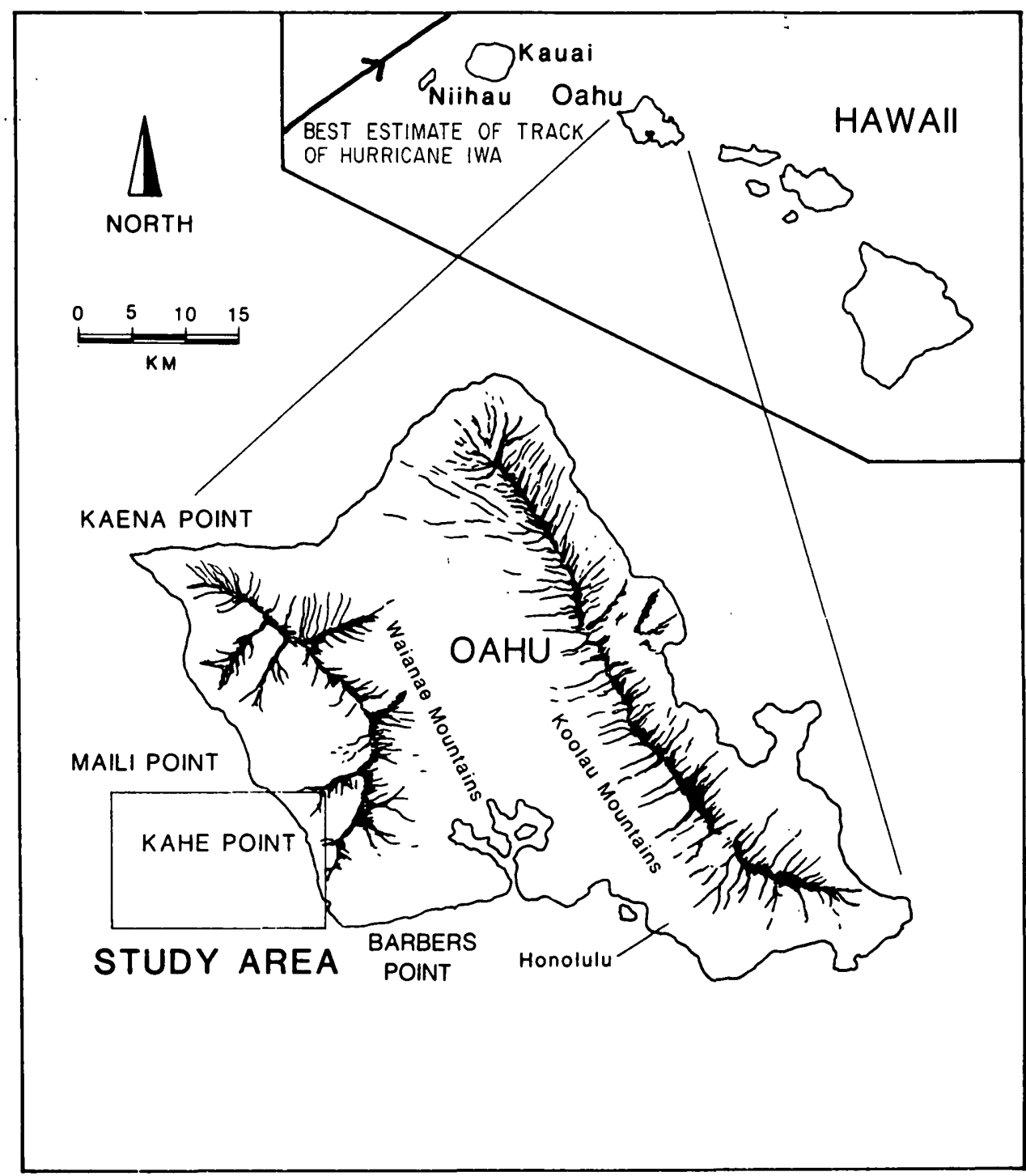

Figure 1. Location of the Kahe Point, Oahu, study area, showing the path of Hurricane Iwa west of the main Hawaiian Islands (modified from Tsutsui and others, 1987).

island and disrupting a series of telecommunication cables in water depths greater than $1,100 \mathrm{~m}$ between the islands of Oahu and Kauai (figs. 1 and 3; Chui and others, 1983; Noda, 1983). Additional temporal evidence for submarine mass movement was provided from disruption of an array of moored instruments that had been deployed west of Kahe Point (Noda, 1983; Dengler, Wilde, and others, 1984a; Dengler, Noda, and others, 1984b). These moorings included self-contained units that recorded water depth, temperature, and speed and direction of currents.

Figure 4 shows a smoothed bathymetric profile for the four moorings with current meters that could be recovered after the storm passed. The deduced downslope displacement of the recovered meters is as much as $2.4 \mathrm{~km}$ and is based on depth changes recorded by the meters assuming that movement was perpendicular to the isobaths, which are well determined from the prehurricane survey (Normark and others, 1982). The displacement of the current meters to deeper water occurred in a series of four episodes with recorded water-current speeds of as much as 220 centimeters per second $(\mathrm{cm} / \mathrm{sec})$. In general, downslope water flow during these episodes was in the range of 70 to $135 \mathrm{~cm} / \mathrm{sec}$ (Dengler, Wilde, and others, 1984a). The velocity of the flow front of one of the episodes was about $300 \mathrm{~cm} / \mathrm{sec}$; that is, the time of passage of the leading edge of the downslopemoving event between moorings was faster than the peak recorded water-current speeds within the main body of the event. The initiation of each displacement event of the meters corresponded with the occurrence of high-velocity water flow. The water temperatures recorded at the meters 


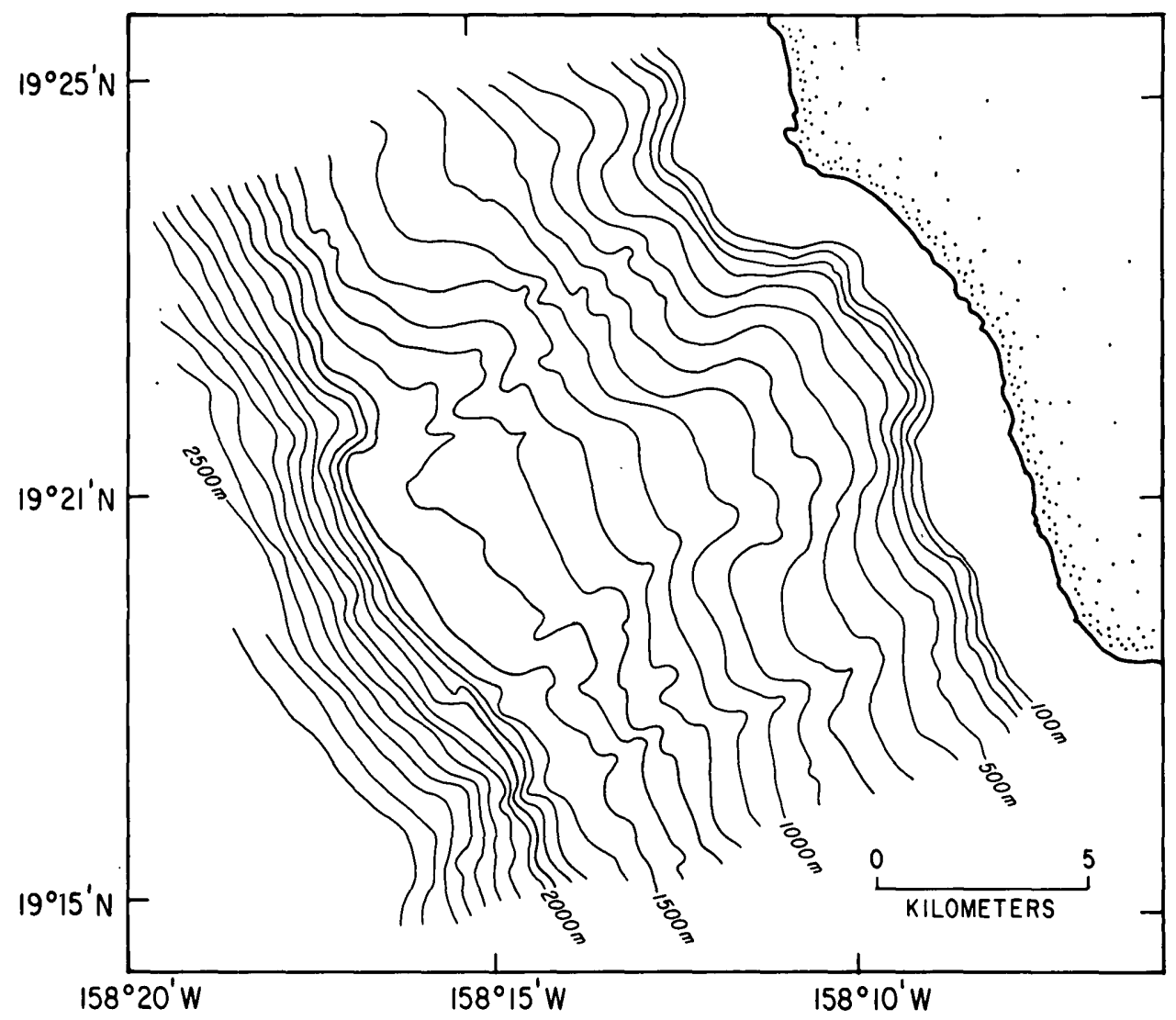

Figure 2. Bathymetry of the Oahu slope off Kahe Point (adapted from Normark and others, 1982). This bathymetry has been used to create the perspective relief map of figure 3.

during the episodes were generally $2^{\circ}$ to $4^{\circ} \mathrm{C}$ above the ambient temperature at the mooring site before displacement (Dengler, Wilde, and others, 1984a).

The data provided by the recovered current meters were supplemented by the following observations that provide important clues to the processes that displaced the moorings (Dengler, Wilde, and others, 1984a): (1) there were no significant differences between pre- and posthurricane bathymetry of the slope below the reef front indicated by later detailed surveys; (2) the shallowest mooring had two meters (fig. 4) and the upper meter showed onshore flow while the lower meter showed offshore (downslope) flow suggesting fluid-flow phenomena in addition to possible mass flow of the sediment at the mooring sites; and (3) both the float housings and flat surfaces on the currentmeter housings had accumulated significant amounts of sediment: something not observed in any moorings deployed in the Kahe Point area before and after those affected by Hurricane Iwa.

\section{POSTHIJRRICANE STUDIES}

A SeaMARC II sidescan-sonar mosaic of the upper slope and inner terrace provide good insight to slope processes during the passage of Hurricane Iwa (fig. 5; Tsutsui, 1987). Interpretation of the mosaic is augmented by analyses of 19 core samples collected in 1983 and 1984, sea-floor photographs, and by observations from a manned submersible (Fornari, 1983). The most striking patterns of the mosaic are

- the subparallel returns that follow the coastline shape representing individual scarps within the steep upperslope area. These are the fronts of a series of coral reefs drowned during sea-level changes over the past several hundred thousand years.

- the westward converging dendritic pattern of darker sinuous, and locally braided, high-backscatter returns that terminate upslope at the base of the upper-slope scarps. These sinuous features locally show positive relief and trend generally perpendicular to the isobaths.

A schematic interpretation of part of the sidescansonar mosaic (fig. 6) shows that the displaced current meters were deployed along a set of these sinuous features. A few core samples recovered from these features contained medium sand-sized material.

Tsutsui and others (1987) emphasize several large, broad swaths of uneven intermediate-to-high-backscatter 


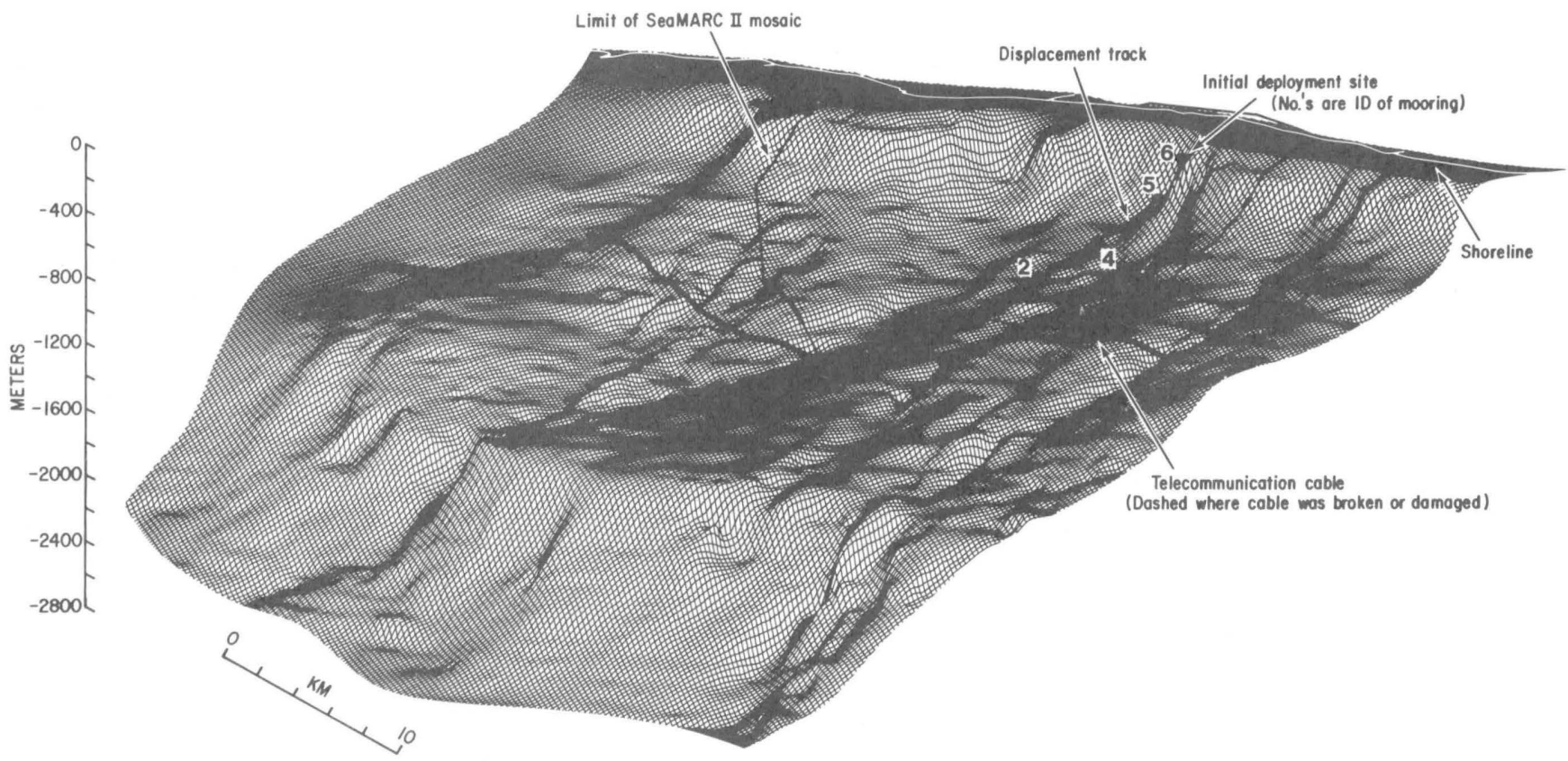

Figure 3. The upper slope off Kahe Point, Oahu, based on detailed bathymetry compiled by Normark and others (1982) prior to the mass movement events (fig. 2). The drawing is constructed from an elevation of $10^{\circ}$ and with a vertical exaggeration of about 12 . The initial mooring position (solid circle) and inferred displacement path of current-meter moorings (numbered 2, 4, 5, and 6) are

returns that are best expressed along the north side of the reentrant in the upper slope (for example, sand pattern in fig. 6 that terminates upslope from the cable break). These broad swaths also trend downslope, and core samples from the largest, northern example contain very poorly sorted, angular, coarse sand and gravel. A minimum thickness of $2.5 \mathrm{~m}$ of the coarse material is indicated from the available cores. There is a uniformly high percentage of shallow water benthic foraminifera in these samples as well.

Samples from much of the rest of the SeaMARC II image area (intermediate-to-low-backscatter background returns) are predominantly silt- and clay-sized sediment containing very high abundances of exclusively deep-water pelagic foraminifera. The sharp contrast in both the acoustic backscatter and in the grain size of sediment samples between this background pattern and the broad swaths and sinuous returns suggest that the latter features are zones of downslope sediment transport. Evidence for downslope transport of the sediment in these swaths is further supported by the common occurrence of displaced shallowwater foraminifera. Because the shallowest telecommunication cable was broken and partially buried in the area immediately downslope from these converging zones of coarser sediment (fig. 6), it is likely that some, or perhaps all, of this coarser sediment was emplaced during Hurricane Iwa. projected as solid lines. The shallowest telecommunication cable that was damaged as a result of sediment movement caused by Hurricane Iwa is shown as a dashed line with vertical tic marks in the section that was damaged. The irregular polygon (solid line) on the upper slope and inner terrace denotes the area covered by the SeaMARC II image of figure 5 .

\section{DISCUSSION}

The deep-water effects of the passage of Hurricane Iwa provided a rare opportunity to measure some of the sediment-transport parameters that can result from slope failure of submarine sediment. Such a glimpse at the processes of slope failure events is not possible for geologically old examples; that is, for most of those presented in this report. Despite the relative wealth of observations before, during, and after the slope failure episodes, however, it is still not possible to deduce unequivocally the cause and mechanism of failure, a fact that emphasizes the great handicap to scientific observation provided by the oblique nature of ocean water itself.

The available observations are consistent with several possible mechanisms that can explain downslope movement of both the near-bottom water and the slope sediment. Dengler, Wilde, and others (1984a) suggested that the most likely cause for movement of the current meters was a series of discrete turbidity-current flow episodes generated by successive sediment slope failures on the upper island slope and reef front. A turbidity current is a turbulent body of sediment and water that is pulled downslope by gravity because the density of the water/sediment mixture is slightly greater that the density of the surrounding seawater (Lee, Schwab, and Booth, this report). During Hurricane Iwa, 


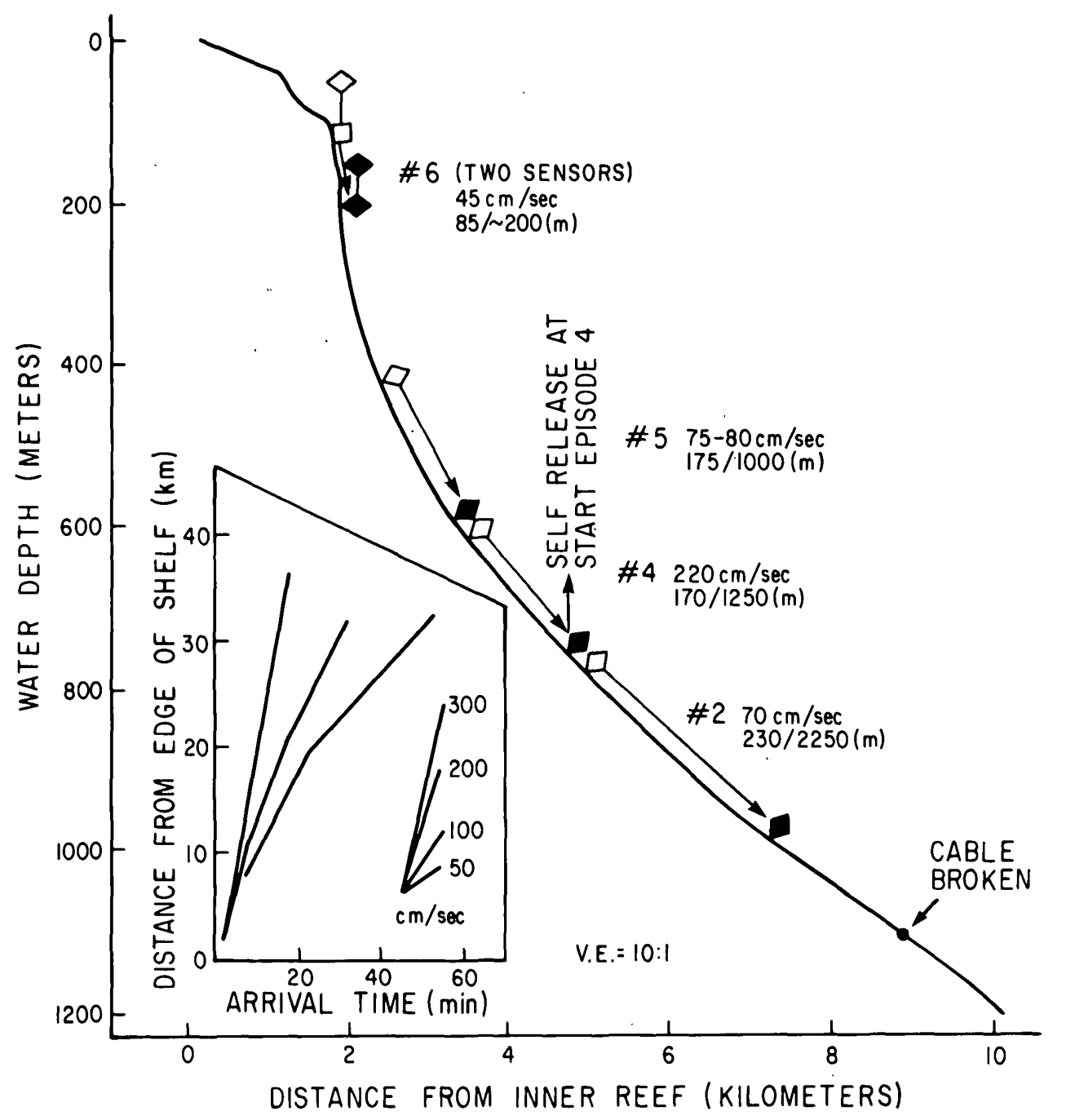

Figure 4. Summary of the displacement experienced by the four current-meter moorings that were recovered after the passage of Hurricane Iwa (from Normark and Piper, 1991). Smoothed profile along the line of the moorings constructed from the detailed bathymetry of Normark and others (1982) with initial (open symbols) and reconstructed final positions (blackened symbols) of the moorings. Peak recorded current speeds and ratio of total downslope/horizontal displacement given for each mooring. Inset shows frontal speed of three of the displacement episodes correlated between adjacent meters for the lower three moorings; numbers 2, 4, and 5 (based on Dengler, Wilde, and others, 1984a; Dengler, Noda, and others, 1984b).

current measurements show that warm (less dense) seawater was moving downslope; thus, the entrainment of sediment is the only plausible cause for the downslope flow (for producing denser water). The sediment found on the current meters, which were mounted $10 \mathrm{~m}$ above the sea floor on the moored cables, is good evidence that sediment-laden water in a mass flow at least $10 \mathrm{~m}$ thick moved past the meters.

The missing observation related to a turbidity-current mechanism, however, is how the sediment was mixed with the overlying seawater to form the turbidity current. Dengler, Noda, and others (1984b) extend their earlier interpre- tation by suggesting that the moorings could have been moved directly by successive sediment failures (that is, the anchors for the mooring rode downslope on sediment blocks in submarine slides or were carried with debris flows) that were accompanied by turbidity currents generated simultaneously with the slope failures and recorded by the current meters. A debris flow is generated as a sediment body involved in a submarine slope failure becomes disaggregated and mixed with seawater during downslope transport (Lee, Schwab, and Booth, this report). The sediment character of the coarser material sampled is consistent with debris flow transport that is locally channelized and could 


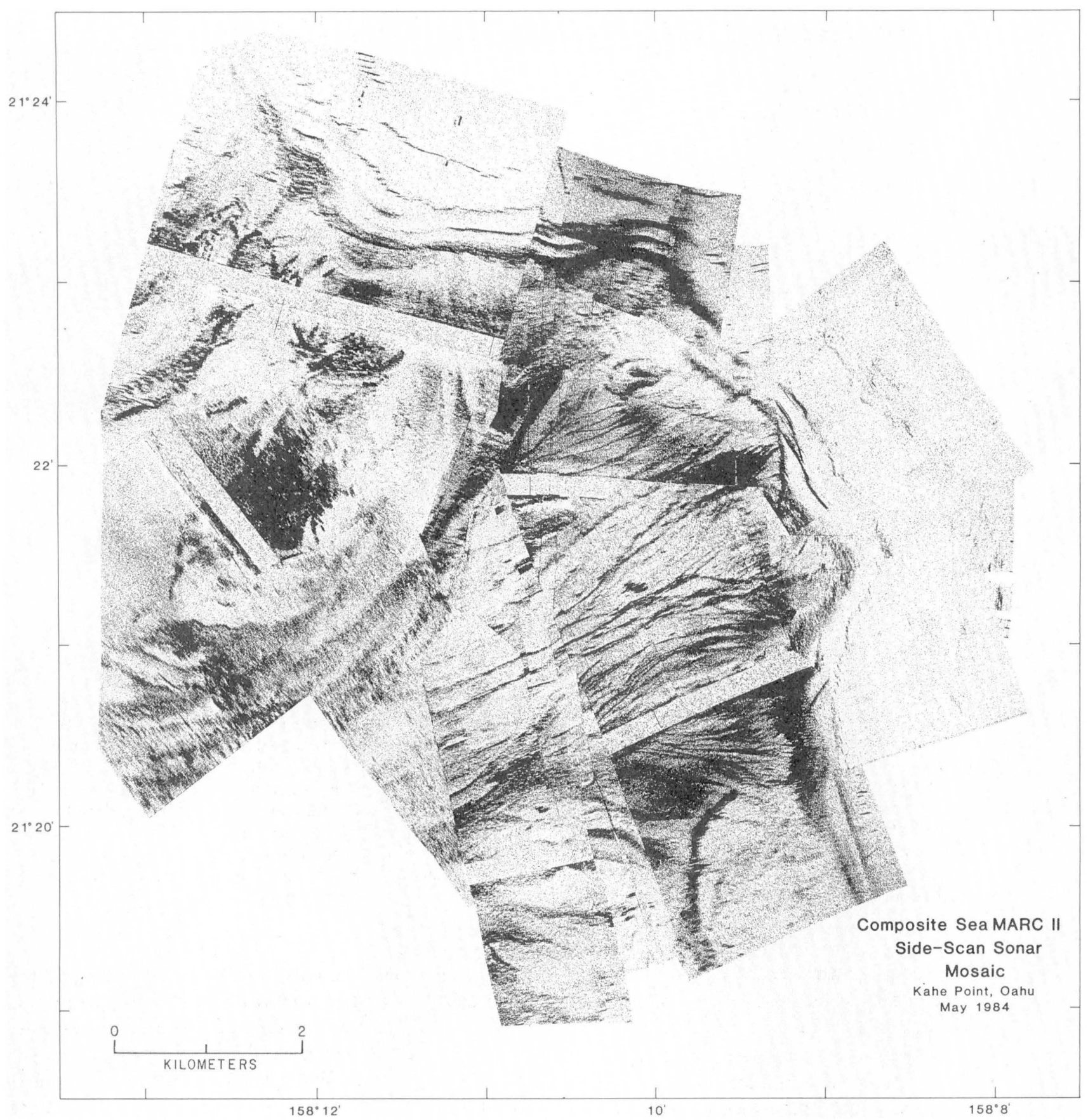

Figure 5. SeaMARC II sidescan-sonar imagery of the Kahe Point area. The darker tones on the imagery indicate a greater level of acoustic backscattering intensity, which is a function of slope, local surface texture, and sediment characteristics (see Lee, Schwab, and Booth, this report); refer to Tsutsui and others (1987) for detailed interpretation of the imagery. The areas of the sea floor with steeper gradients, more local roughness (such as unsedimented volcanic rock or piles of rubble from steep cliffs), and (or) coarser grain size of the sediment covering the sea floor all tend to produce higher backscatter (darker areas in the image). The lower backscatter (lighter gray) areas are thought to represent the undisturbed areas covered by fine-grained pelagic sediment. 


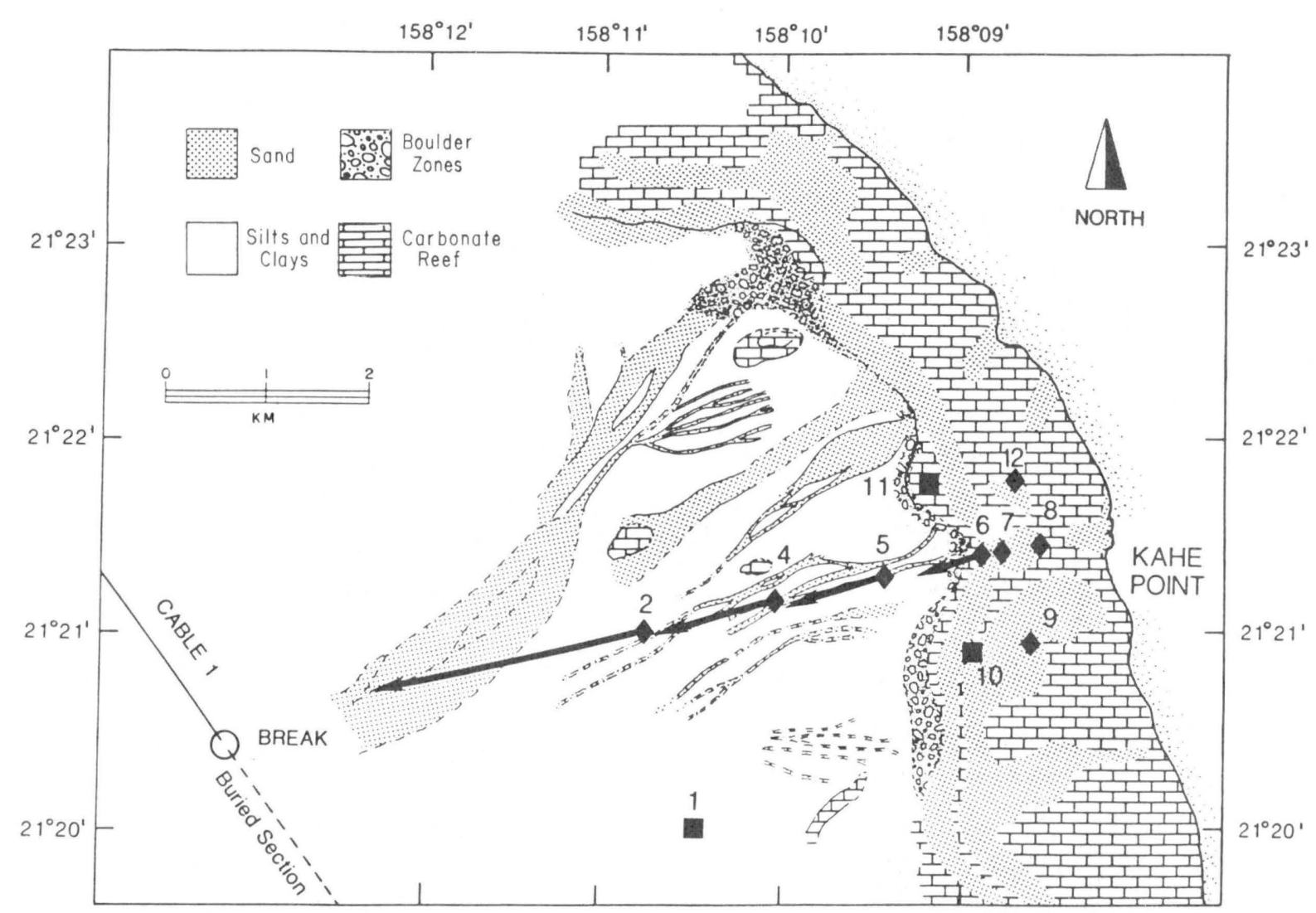

Figure 6. Interpretation of SeaMARC II imagery (fig. 5) showing sediment transport paths, superimposed with initial positions of the current-meter moorings and location of the shallowest telecommunication cable break (from Tsutsui and others, 1987). The wide sand swaths on the carbonate shelf represent sand-filled channels and sand bodies. The broad sand swaths perpendicular to the shelf are areas where the SeaMARC II images and core sampling indicate downslope transport of coarse-grained sediment. The darker, narrower, more sinuous bands recorded on the SeaMARC II image, shown here as narrow, braided or branching patterns, indicate other paths of downslope transport of sediment. Arrows represent inferred path and estimated displacement of moorings during Hurricane Iwa (after Noda, 1983). The numbered squares and diamonds are current-meter stations. produce the high-backscatter patterns observed on the SeaMARC II images (Tsutsui and others, 1987). If we accept slope failures as the ultimate cause of the displacement of the moorings (with or without the concurrent generation of turbidity currents), a key question remains: what caused the slope to fail? Rapid loading and unloading of the slope sediment as the large hurricane-induced storm waves moved through the area might have caused a loss of strength within the sediment and would also have generated downslope-directed forces to move the sediment (see Lee, Schwab, and Booth, this report). Noda (1983) calculated that minimum wave heights of $9 \mathrm{~m}$ were likely in the area offshore of Kahe Point.

The turbidity currents also could have resulted from storm-induced surges without significant associated slope failure (Dengler, Wilde, and others, 1984a; Dengler, Noda, and others, 1984b). Noda (1983) reconstructed the wind and wave conditions that probably existed off Kahe Point as Hurricane Iwa passed across the islands. His models sug- gest that strong currents across the reef resulting from seawater pushed shoreward from the advancing storm could have eroded and put into suspension sufficient sediment to generate a turbidity current directly.

Dengler and Wilde (1987) use the data from the current-meter array in a later analysis to suggest that a slope failure model based on snow avalanches adequately accounts for the available observations. For now, we will have to await an even more direct observation of modern slope failure to improve our understanding of the processes involved.

\section{CONCLUSIONS}

The reentrant in the upper slope and shelf contours off Kahe Point has helped to focus downslope sediment transport in this area. The focusing effect is reflected in both the general sediment structure and in the surficial relief and 
acoustic backscatter pattern observed on SeaMARC II images (Normark and others, 1982; Tsutsui and others, 1987). The main episodes of transport during the passage of Hurricane Iwa were of high velocity, suggesting that sediment slope failure by cyclic loading during storm surges is the probable triggering mechanism for these mass flow events. We cannot rule out, however, a mechanism that involves sediment suspension resulting from the downslope flow of water pushed onto the reef area by storm surges and the resultant formation of turbidity currents. Available core data suggest that substantial amounts of shelf sediment were transported to deeper water in several discrete episodes during the passage of the hurricane (Tsutsui and others, 1987). Much of the sediment traveled along well defined, relatively narrow pathways across the terrace before moving down the steeper flank of the volcano and disrupting the deeper water telecommunication cables.

\section{ACKNOWLEDGMENTS}

We thank Carolyn Degnan and Chris Gutmacher for their assistance in preparing figure 3 . The manuscript was improved by reviews by H.J. Lee and R.E. Hunter. This is contribution MSG 90-010 of the Marine Sciences Group, University of California, Berkeley.

\section{REFERENCES CITED}

Chui, A.N.L., Escalante, L.E., Mitchell, J.K., Perry, D.C., Schroeder, T.A., and Walton, T., 1983, Hurricane Iwa, Hawaii, November 23, 1982: National Academy Press, Washington, D.C., 68 p.

Dengler, A.T., Noda, E.K., Wilde, Pat, and Normark, W.R., 1984b, Slumping and related turbidity currents along proposed OTEC cold-water-pipe route resulting from Hurricane Iwa: Proceedings of the 1984 Offshore Technology Conference, Houston, Tex., OTC 4702, p. 475-480.

Dengler, A.T., and Wilde, Pat, 1987, Turbidity currents on steep slopes: Application of an avalanche-type numeric model for ocean thermal energy conversion design: Ocean Engineering, v. 14 , p. $409-433$.
Dengler, A.T., Wilde, Pat, Noda, E.K., and Normark, W.R., 1984a, Turbidity currents generated by Hurricane Iwa: GeoMarine Letters, v. 4, p. 5-11.

Fornari, D.J., 1983, Final report, DSV Turtle dives off Kahe Point, Oahu, Hawaii: Offshore Investigations Ltd., Chatham, N.Y., 39 p.

Hughes Clarke, J.E., 1988, The geological record of the 1929 "Grand Banks" earthquake and its relevance to deep-sea clastic sedimentation: Ph.D. Dissertation, Dalhousie University, Halifax, Nova Scotia, Canada, $171 \mathrm{p}$.

Hughes Clarke, J.E., Shor, A.N., Piper, D.J.W., and Mayer, L.A., 1990, Large-scale current-induced erosion and deposition in the path of the 1929 Grand Banks turbidity current: Sedimentology, v. 37, p. 613-629.

Lee, H.J., 1989, Undersea landslides: extent and significance in the Pacific Ocean, in Brabb, E.E., and Harrod, B.L., eds., Landslides: Extent and Economic Significance: Rotterdam, A.A. Balkema, p. 367-379.

Menard, H.W., 1964, Marine geology of the Pacific: New York, McGraw-Hill, 271 p.

Moore, J.G., Clague, D.A., Holcomb, R.T., Lipman, P.W., Normark, W.R., and Torresan, M.E., 1989, Prodigious submarine landslides on the Hawaiian Ridge: Journal of Geophysical Research, v. 94 , p. 17,465-17,484.

Noda, E.K., 1983, Effects of Hurricane Iwa, November 23, 1982, offshore of Kahe Point, Oahu: Technical Report for Research Corporation, University of Hawaii, Honolulu, Hawaii, 56 p.

Normark, W.R., Chase, T.E., Wilde, Pat, Hampton, M.A., Gutmacher, C.E., Seekins, B.A., and Johnson, K.H., 1982, Geologic report for OTEC site off Kahe Point, Oahu', Hawaii: U.S. Geological Survey Open-File Report 82-468A, 32 p.

Normark, W.R., and Piper, D.J.W., 1991, Initiation processes and flow evolution of turbidity currents: implications for the depositional record: in Osborne, R.H., ed., From Shoreline to Abyss: Contributions in Marine Geology in Honor of Francis Parker Shepard: Society of Economic Paleontologists and Mineralogists Special Publication No. 46, p. 207-230.

Tsutsui, Bruce, Campbell, J.F., and Coulbourn, W.T., 1987, Storm-generated episodic sediment movements off Kahe Point, Oahu, Hawaii: Marine Geology, v. 76, p. 281-299.

Winters, W.J., and Lee, H.J., 1982, Evaluation of geotechnical properties and slope stability of a calcareous ooze on the southwest slope of Oahu, Hawaii: U.S. Geological Survey Open-File Report 82-468B, 274 p. 